UNIVERSIDADE DE SÃO PAULO
INSTITUTO DE GEOCIENNCIAS

\title{
GEOLOGIA, PETROGRAFIA E METAMORFISMO DOS GRUPOS SERRA DO ITABERABA E ÃO ROQUE A NOROESTE DA CIDADE DE SÃO PAULO (SP)
}

MARCO AURÉLIO BONFÁ MARTIN

Orientador: Prof. Dr. Caetano Juliani

DISSERTAÇÃO DE MESTRADO

COMISSÃO JULGADORA
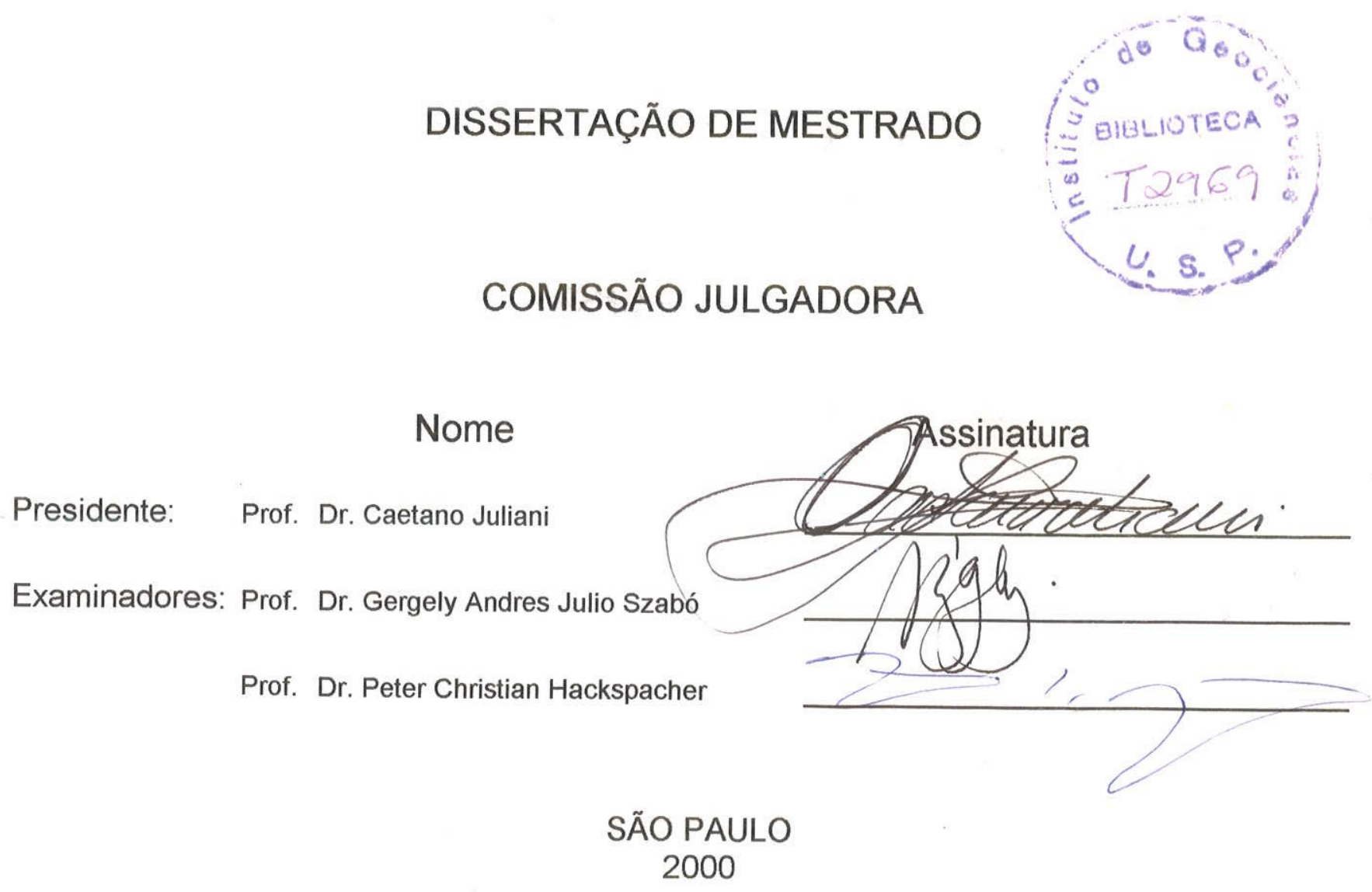


\title{
UNIVERSIDADE DE SÃO PAULO INSTITUTO DE GEOCIÊNCIAS
}

\section{GEOLOGIA, PETROGRAFIA E METAMORFISMO DOS GRUPOS SERRA DO ITABERABA E SÃO ROQUE A NOROESTE DA CIDADE DE SÃO PAULO (SP)}

\author{
Marco Aurélio Bonfá Martin
}

Orientador: Prof. Dr. Caetano Juliani

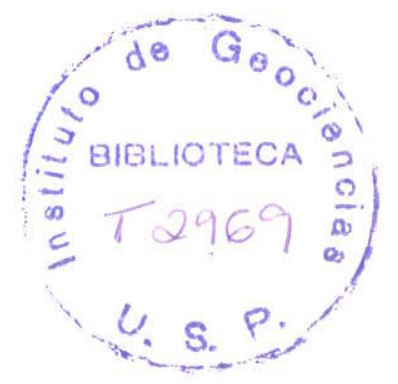

DISSERTAÇÃO DE MESTRADO

Programa de Pós-Graduação em Mineralogia e Petrologia

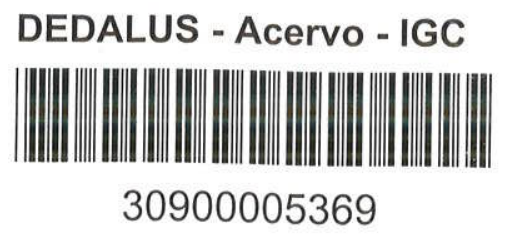


À Nena e aos meus pais, pelo tempo de convívio de que nos privamos para a confecção deste trabalho. 


\section{AGRADECIMENTOS}

A confecção desta dissertação tornou-se possível graças à ajuda de diversas pessoas e instituições, às quais quero expressar o meu agradecimento.

Primeiramente, devo reconhecer a atenção oferecida pelo orientador, Prof. Dr. Caetano Juliani, que nunca mediu esforços para a finalização desta empreitada, pela inestimável contribuição em várias etapas de campo e, principalmente, pela confecção final do mapa geológico aqui apresentado, do qual acabei por participar como colaborador. Agradeço ainda pelas críticas e sugestões, pela revisão final do texto e por tentar, quase sempre sem sucesso, organizar a minha desordem.

À cidade de Pirapora do Bom Jesus pela estada agradável. Quero agradecer principalmente ao Padre Godofredo, que nos acolheu no Museu do Seminário nas diversas etapas de campo.

Aos amigos geólogos que me ajudaram nesses anos, pelos quais tenho grande apreço. Ao Alexandre Patrício Chiarini (Xapa), pela companhia e discussões no início dos trabalhos de campo. Ao Silvano de Jesus Clarimundo (Ugah), na época bolsista de iniciação científica, pela disposição demonstrada nos levantamentos geológicos.

Ao Msc. Gelson Luis Fambrini (Sapo) e ao Renato Paes de Almeida (Ninguém), e às amigas Msc. Annabel Pérez-Aguilar (Coca) e Msc. Lena Monteiro (Barbosa), pela ajuda desinteressada ao me acompanharem por semanas no mapeamento. Devo agradacer novamente à Coca, pela revisão criteriosa do capítulo referente à petrografia.

Aos colegas de departamento Klaus Petersen Júnior, Fernando Freitas (Pobremah), Carmem Nunes (Xitah), Lucelene Martins (Vaudemar), Gaston Enrich (Edir Macedo), Dionísio Azevedo e Rosana Lopes, e aos guardiões do templo, Peter Davies, Gilson Guimarães e Iede Zolinger, pela companhia nos inúmeros finais de semana.

Não poderia deixar de mencionar os amigos que comigo conviveram nos últimos dois anos em nosso amplo escritório. Pelas discussões proveitosas e soluções oferecidas, tanto na geologia como em outros assuntos. Ao Gustavo Vilela (Troglô) por sua tranquiilidade. Ao Xapa, por sua amizade e momentos de descontração.

Ao Prof. Dr. Gergely Szabó, por elucidar algumas dúvidas no campo da petrografia e pelo convívio sempre agradável durante os vários meses de utilização do Laboratório de Óptica, comentário que deve ser extendido à Angélica Morente, funcionária do laboratório.

Ao Klaus sou muito grato pelo infinito esforço que envolveu a digitalização de toda a base topográfica e do mapa geológico e ainda por se mostrar sempre disposto a corrigir os inúmeros detalhes das várias revisões e em resolver os problemas relacionados à informática que apareceram no dia-a-dia.

Aos funcionários do Laboratório de Tratamento de Amostras (LTA) do antigo Departamento de Mineralogia e Petrologia e do atual Departamento de Mineralogia e Geotectônica, José Quirino da Silva, José Paulo Sertek e Roseane Damião da Silva, pela assistência na preparação das amostras de rocha para 
análise petrográfica.

Aos senhores Cláudio Hopp, Paulo Roberto Molinaro, Paulo Augusto Morgato e Luiz Clándio Nogueira do Setor de Laminação pela excelente confecção das mais de 350 secções delgadas.

Aos geólogos Dr. Edgard Santoro e Msc. Marcos Alves de Almeida por colocarem à disposição anotações pessoais de campo efetuadas em levantamentos geológicos nas folhas Santana de Parnaíba e Cabreúva de quando participavam dos projetos de mapeamento IPT - PRÓ-MINÉRIO. Ao Dr. Cláudio Ferreira pelo empréstimo de suas cadernetas de campo e mapas de pontos usados em sua dissertação. A essas pessoas e as suas valiosas informações que em muito acrescentaram na apresentação do mapa, meus sinceros agradecimentos.

Ao CNPq pela concessão da bolsa de mestrado (processo 134351/95 - 9), à FAPESP pelo suporte financeiro concedido através de Projeto de Pesquisa (proc. 964403/5) que permitiu dentre várias coisas, a realização dos trabalhos de campo e, à CAPES, pela aquisição de computadores, acessórios e programas de informática para as salas de pósugraduação do Programa de Pós-Graduação em Mineralogia e Petrologia, que em muito facilitaram a conclusão dessa dissertação.

Ao Prof. Dr. Excelso Ruperti, Coordenador do Programa, pelo apoio institucional e por encampar desde o início, a idéia dos computadores nas salas.

Às funcionárias da Biblioteca, Brenda Mascarenhas, Érica do Nascimento, Maristela Prestes Severino e Maria Aparecida Bezerra pela agradável atenção oferecida. Às secretárias da Secção de PósGraduação Ana Paula Cabanal e Magali Fernandes Rizzo pela cortesia e a preocupação em lembrar-me daquelas datas que teimo em esquecer. À Marta J. Silva, à Denise C. M. Cristovan, secretárias do antigo Departamento de Mineralogia e Petrologia, e à Sonia Costa Vieira e à Nícia Brandão Zalaf, do atual Departamento de Mineralogia e Geotectônica, pelo apoio no dia-a-dia nesses anos. Ao Tadeu Gaggiano, da Secretaria do Programa Mineralogia e Petrologia, por estar sempre solícito e pelos inúmeros quebra* galhos propiciados.

Ao pessoal da Gráfica, na figura dos senhores Dalton M. da Silva e Edmir de Oliveira, pela encadernação dos volumes finais dessa dissertação. Ao Jaime S. Marcos pela preparação de parte do material fotográfico.

À Irena Sparrenberger (Nena) e ao Troglô pelo Abstract.

Às pessoas que de uma forma ou de outra colaboraram neste trabalho e que, eventualmente, não tenham sido mencionadas, meus sinceros agradecimentos. Aos amigos de quem me furtei nos últimos tempos, obrigado por serem teimosos em me procurar.

À Nena, por tudo que representa. Ainda pelas críticas e sugestões nas primeiras versões e pela revisão final e ortográfica.

Aos meus pais, a quem devo tudo. Pelo empréstimo do Voyage utilizado em boa parte dos trabalhos de campo e, o mais importante, pela compreensão e afeto que nunca me faltaram e por tentarem entender nesses últimos anos a distância e a quase ausência. À Andréa, irmã e grande amiga. 


\section{RESUMO}

Esta dissertação teve como objetivo principal a petrografia dos grupos Serra do Itaberaba e São Roque a noroeste da cidade de São Paulo.

Os estudos petrográficos enfatizaram as relações de cristalização dos minerais com as foliações (análise microestrutural) acompanhados do estudo do metamorfismo para a caracterização litoestratigráfica dos grupos São Roque e Serra do Itaberaba.

Esses procedimentos permitiram demonstrar a existência do Grupo Serra do Itaberaba (Mesoproterozóico), que constitui a base das supracrustais e subdivide-se nas formações Morro da Pedra Preta, basal e vulcanossedimentar, Nhanguçu, representada por sedimentos manganesíferos e carbonáticos, e Pirucaia, composta por sedimentos clásticos mais quartzosos.

O Grupo São Roque (Neoproterozóico) foi caracterizado na região como posicionado discordantemente sobre o Grupo Serra do Itaberaba através de zonas de empurrão. Está representado por uma sequiência predominantemente metassedimentar onde foram individualizadas, na base, a Formação Morro Doce, contendo metarcóseos e metaconglomerados depositados em ambiente de leques aluviais, e a Formação Pirapora do Bom Jesus, de ambiente vulcanossedimentar e com contribuição cálcio-pelítica e carbonática. Segue a deposição da Formação Boturuna, que apresenta metarenitos feldspáticos e quartzitos depositados em ambiente litorâneo e que grada para depósitos de base de talude com metapelitos rítmicos mais grossos e proximais que constituem a Formação Estrada dos Romeiros, e de metapelitos mais finos e distais da Formação Piragibu, na porção superior.

Nas supracrustais verificou-se que não ocorre a gradaçâo do metamorfismo, sendo identificados dois conjuntos de rochas afetados por graus metamórficos e deformações distintas, quais sejam: os grupos Serra do Itaberaba e São Roque.

No Grupo Serra do Itaberaba, as rochas metabásicas têm paragêneses de grau médio, sendo que predominaram durante a $S_{1}$ condições de fácies anfibolito com variações para fácies epídoto-anfibolito, na porção sul da área, até anfibolito superior, subfácies almandina-anfibolito, na região do Stock Granítico Tico-Tico. A identificação de cianita sin-S do metamorfismo progressivo nos metapelitos e metapsamitos do grupo permitiu definir a pressão como intermediária em regime Barrowiano.

A foliação $S_{2}$ do Grupo Serra do Itaberaba é intensa e muitas vezes pode ser caracterizada como milonítica. $O$ metamorfismo na $S_{2}$ também se desenvolveu em fácies anfibolito, mas em pressão relativamente mais baixa, caracterizada devido à ausência de cianita nos metapelitos neste evento. Nas foliações $\mathrm{S}_{3}$ e $\mathrm{S}_{4}$, o Grupo Serra do Itaberaba sofreu retrometamorfismo em condições de fácies xistoverde, com cristalização de actinolita, epídoto, clorita e calcita nas rochas metabásicas, enquanto que nos metapelitos e metapsamitos se desenvolveram muscovita, clorita e quartzo e, mais raramente, biotita. 
O Grupo São Roque apresenta, nas rochas metabásicas, paragêneses típicas de fácies xisto-verde na foliação $S_{1}$, tanto na Formação Pirapora do Bom Jesus, base do grupo, como nas formações Estrada dos Romeiros e Piragibu, no topo, onde é comum ocorrer clinopiroxênio ígneo preservado. Na foliação $\mathrm{S}_{2}$ houve poucas variações das condições físicas, mas a cristalização mais forte de epídoto e clorita define o retrometamorfismo.

Durante o desenvolvimento da foliação $S_{1}$ nos metapsamitos das formações Morro Doce $e$ Boturuna e nos metapelitos e metarritmitos das formações Estrada dos Romeiros e Piragibu o grau metamórfico atingiu apenas a zona da clorita. A biotita somente está presente em metarcóseos ou em rochas ricas em feldspato potássico enquanto que nas intercalações de metapelitos há apenas clorita, indicando que a zona da biotita não foi alcançada nos litotipos do Grupo São Roque. Nas foliações $S_{2}$ e $S_{3}$ não foram constatadas mudanças significativas da condições físicas, sendo definido o retrometamorfismo com base na cristalização menos abundante de biotita $S_{2}$ na Formação Morro Doce e de sericita nas formações Estrada dos Romeiros e Piragibu. 
ABSTRACT

The main purpose of this work was the petrographic characterization of Serra do Itaberaba and São Roque groups, northwestern from São Paulo City.

Petrographic studies emphasized minerals and foliations relations (microstructural analysis) accompanied by metamorphism studies for lithostratigraphic characterization of São Roque and Serra do Itaberaba groups.

These procedures allowed to demonstrate the existence of Serra do Itaberaba Group (Mesoproterozoic), which is the supracrustals base and is formed by the Morro da Pedra Preta Formation, volcanosedimentary, on the bottom, Nhanguçu Formation, represented by carbonaceous and Mn-rich sediments, and Pirucaia Formation, composed by clastic sediments richer in quartz.

The São Roque Group (Neoproterozoic) overlaps the Serra do Itaberaba Group through thrurst shear zones and constitutes a Brasiliano geotectonic unit. It is represented by a metasedimentary sequence where were identified, on the bottom, the Morro Doce Formation which contains metarkoses and metaconglomerates deposited in alluvial fan environment, and the Pirapora do Bom Jesus Formation, volcanosedimentary with calcium-pelitic and carbonaceous contributions. After that occurred the Boturuna Formation deposition, with feldspathic metasandstones and quartzites deposited in coastal environment, that grades to continental slope base deposits with coarser and more proximal rhythmic metapelites (Estrada dos Romeiros Formation), besides finer and more distal metapelites of the Piragibu Formation, on the top.

The supracrustals do not show metamorphism gradation. Two groups affected by different metamorphic grades and deformation events where identified: the Serra do Itaberaba and the São Roque Groups.

The Serra do Itaberaba metabasic rocks present medium metamorphic grade parageneses with anfibolite varying to epidote-anfibolite facies predominating during $S_{1}$ in the southern portion of the area and superior anfibolite facies, almandine-anfibolite subfacies, in the Tico-Tico Granitic Stock region. The presence of kyanite syn- $S_{1}$ partially transformed to sillimanite during the progressive metamorphism evolution in metapelites and metapsamites of the group points to intermediate pressure in Barrowiano regime.

The Serra do Itaberaba Group $S_{2}$ foliation is intense and many times can be characterized as mylonitic. The $S_{2}$ metamorphism has also developed in anfibolite facies, but under relatively lower pressure as indicated by the absence of kyanite related to this event in the metapelites. During $S_{3}$ and $S_{4}$ deformations the group suffered retrograde metamorphism under greenschist facies conditions, with crystallization of actinolite, epidote, chlorite and calcite in metabasic rocks whereas in metapelites and metapsamites muscovite, chlorite, quartz and, rarely, biotite, developed.

The metabasic rocks of the São Roque Group present paragenesis typical of greenschist facies in 
$S_{1}$ foliation both in the Pirapora do Bom Jesus Formation, on the bottom, and in the Estrada dos Romeiros and Piragibu Formations, on the top, where the occurrence of preserved igneous clinopyroxene is common. During $\mathrm{S}_{2}$ deformation there were few changes in physical conditions, and the abundant epidote and chlorite crystallization defines the retrograde metamorphism.

Metamorphic grade achieved just the chlorite zone during the $S_{1}$ event in the metapsamites of Morro Doce and Boturuna Formations and in the metapelites and metarhythmites of Estrada dos Romeiros and Piragibu Formations. Biotite is present only in metarkoses or potash feldspar-rich rocks whereas there is just chlorite in the metapelites which alternate with them, indicating that the biotite zone was not reached in São Roque Group lithotypes. It were not identified significant changes in physical conditions in $S_{2}$ and $S_{3}$ foliations, and retrograde metamorphism was defined based on the lesser $S_{2}$ biotite and sericite abundances in Morro Doce Formation and Estrada dos Romeiros and Piragibu Formations, respectively. 


\section{SUMÁRIO}

\section{CAPÍTULO I INTRODUÇÃO}

1.1 Objetivos

1.2 Localização da Área e Acessos

1.3.1 Materiais Utilizados

1.3.1.1 Mapas-base

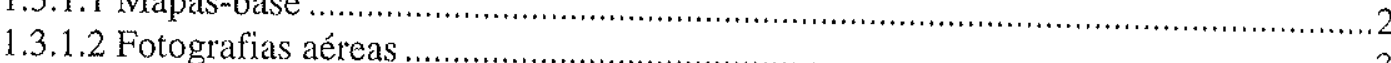

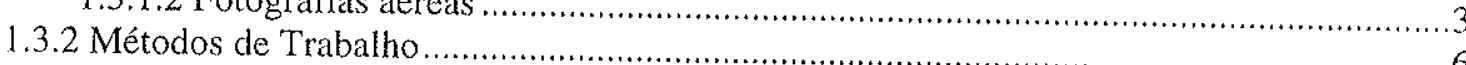

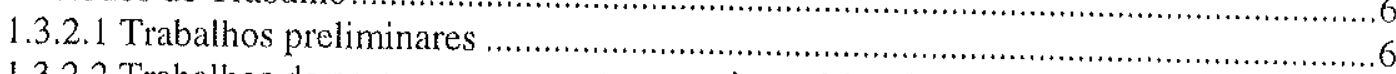

1.3.2.2 Trabalhos de campo com amostragem sistemática de rochas .................................6

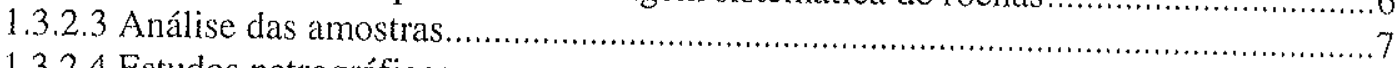

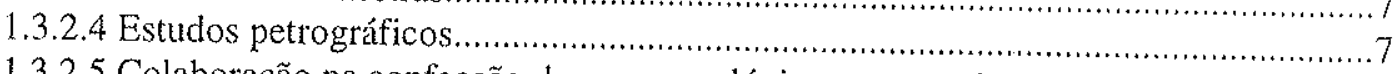

1.3.2.5 Colaboração na confeç̧ão do mapa geológico-estrutural ...................................

CAPÍTULO II TRABALHOS ANTERIORES

2.1 Revisão bibliográfica...

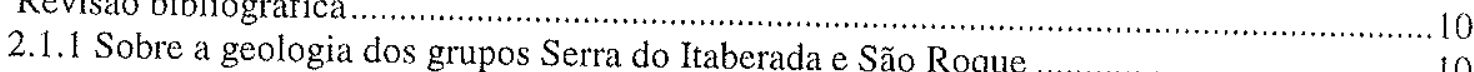

2.1.2 Sobre as rochas granitóides Serra do ltaberada e São Roque .................................. 10

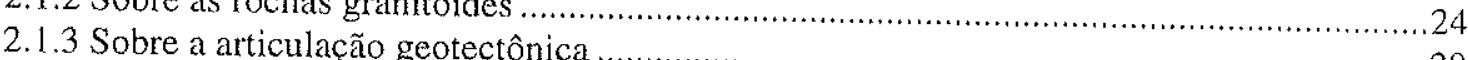

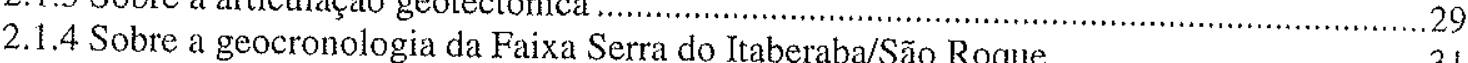

\section{CAPÍTULO III CONTEXTO GEOTECTONNICO, GEOLOGIA REGIONAL E
LITOESTRATIGRAFIA}

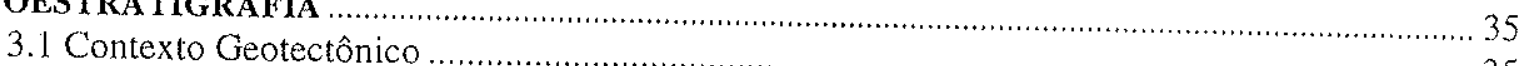

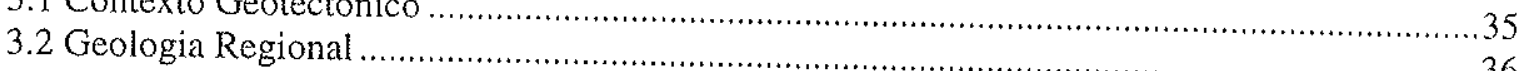

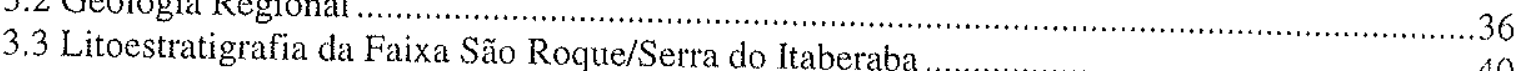

3.4 Litoestratigrafia da Faixa São Roque/Serra do Itaberaba a NW.................................40

CAPÍTULO IV GEOLOGIA E LITOESTRATIGRAFIA

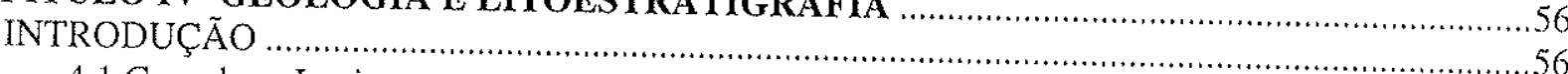

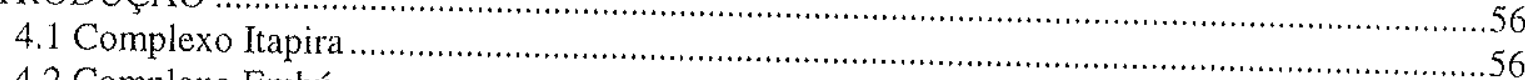

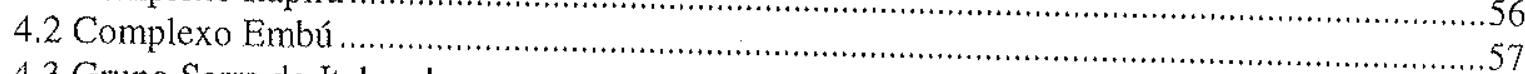

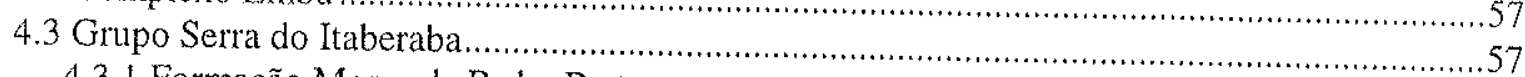

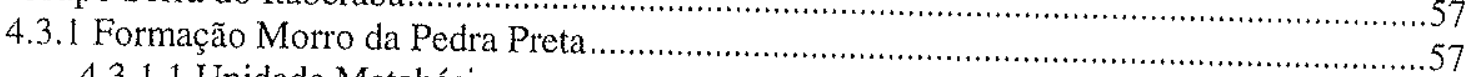

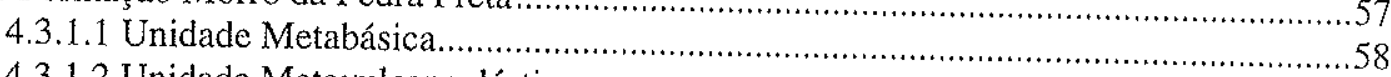

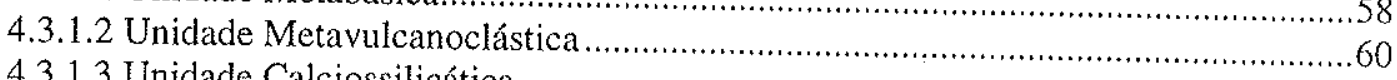

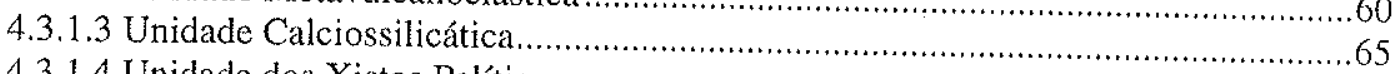

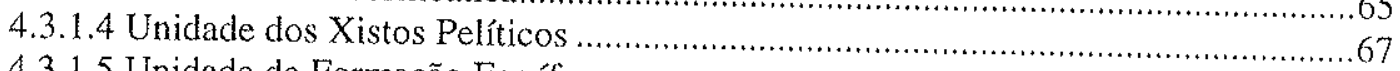

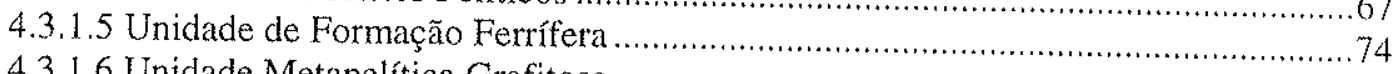

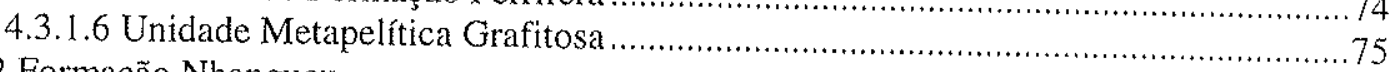

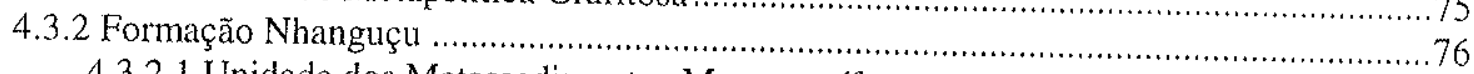

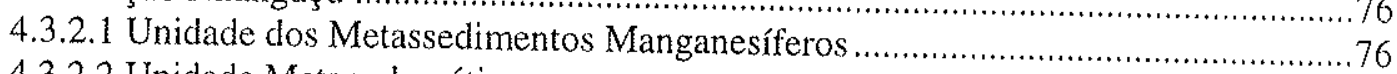

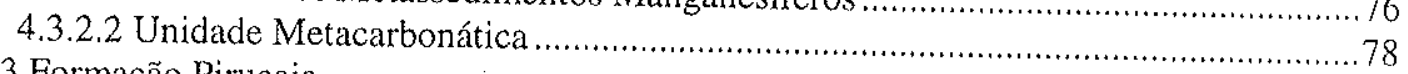

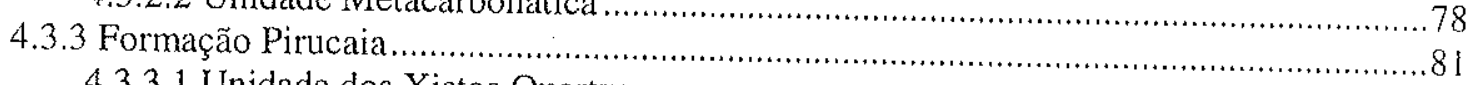

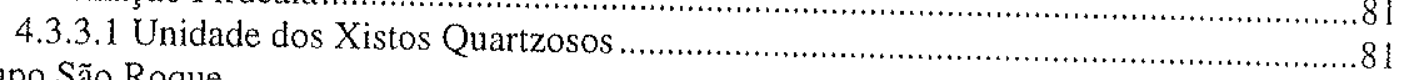

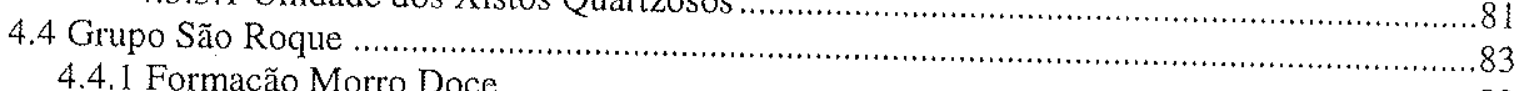

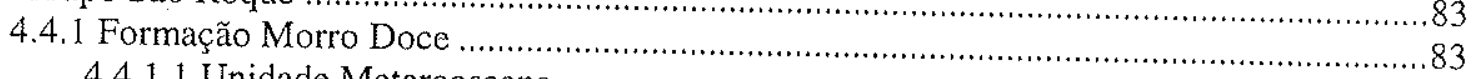

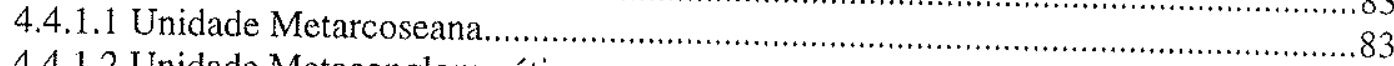

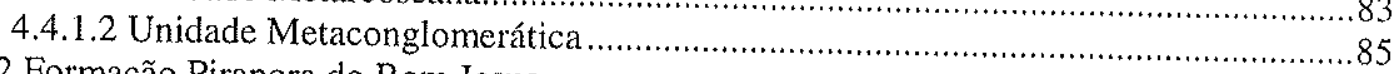

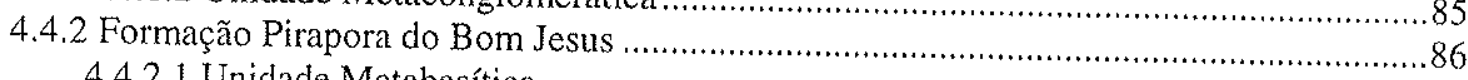

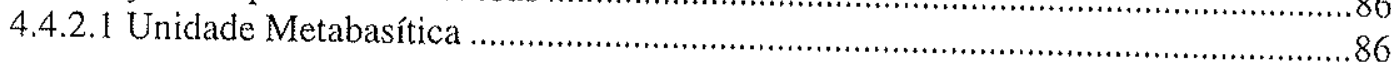


4.4.2.2 Unidade Metacálcio-pelítica

4.4.2.3 Unidade Metacarbonática

4.4.2.4 Unidade Metavulcanoclástica ...................................................................... 91

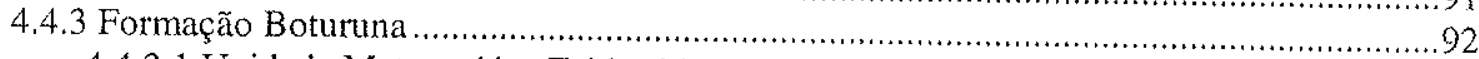

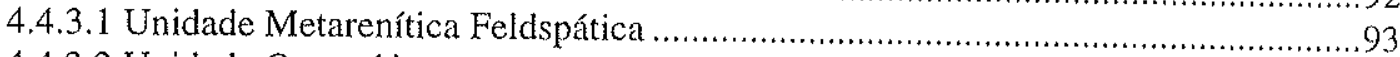

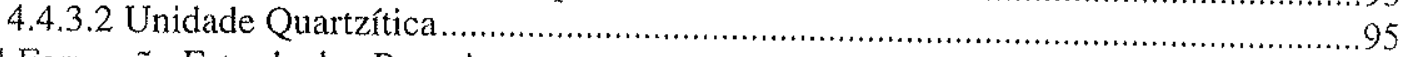

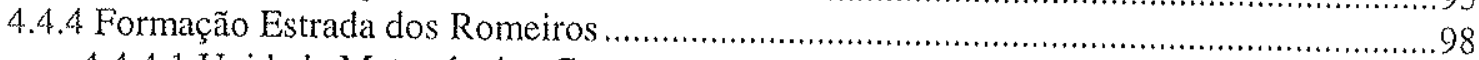

4.4.4.1 Unidade Metarrítmica Grossa ................................................................... 98

4.4.4.2 Unidade Metarenítica Feldspática .............................................................101

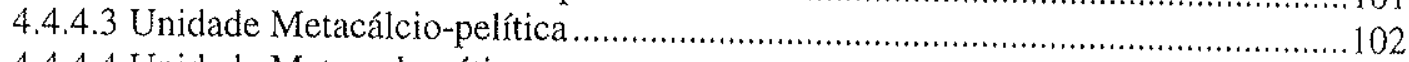

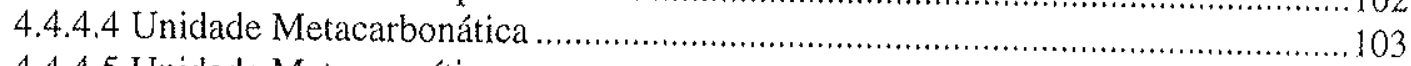

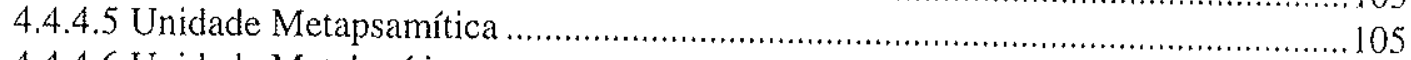

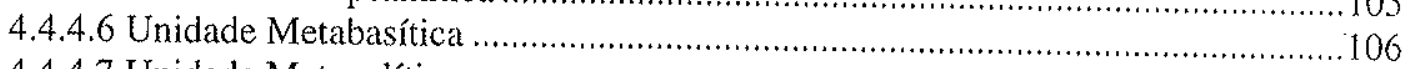

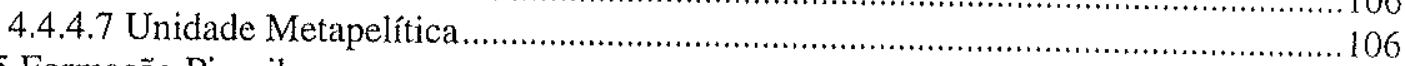

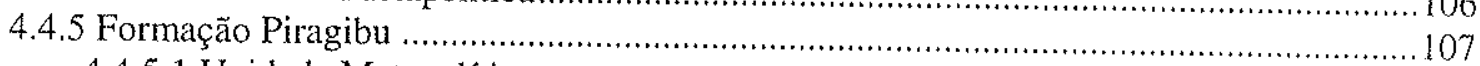

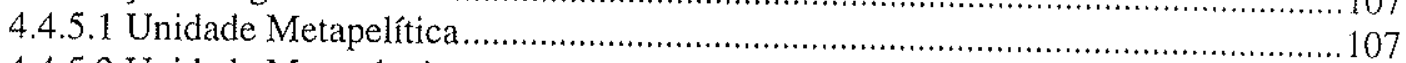

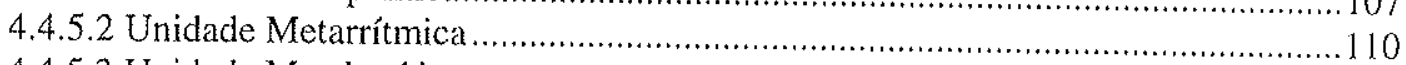

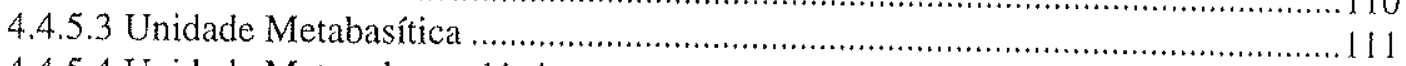

4.4.5.4 Unidade Metavulcanoclástica ..............................................................111

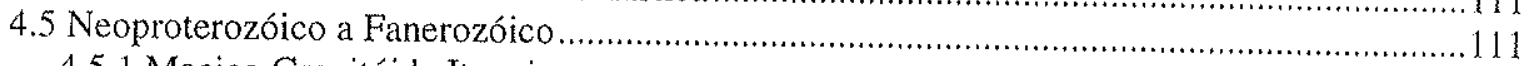

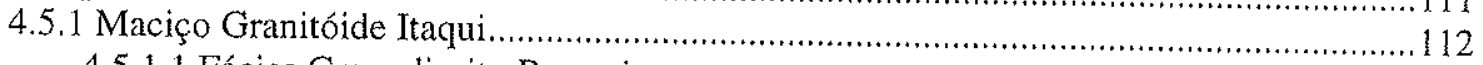

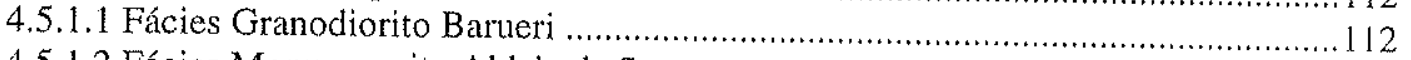

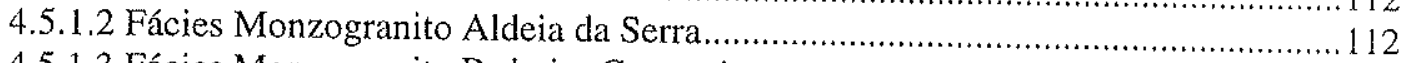

4.5.1.3 Fácies Monzogranito Pedreira Cantareira........................................................ 112

4.5.1.4 Fácies Monzogranito Mutinga .................................................................. 113

4.5.1.5 Fácies Monzogranito Suru ....................................................................... $1 / 3$

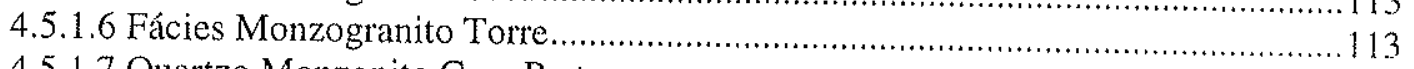

4.5.1.7 Quartzo Monzonito Cruz Preta ................................................................... 113

4.5.1.8 Dique Mesocrático Equigranular...................................................................... 113

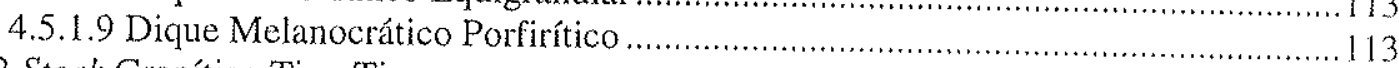

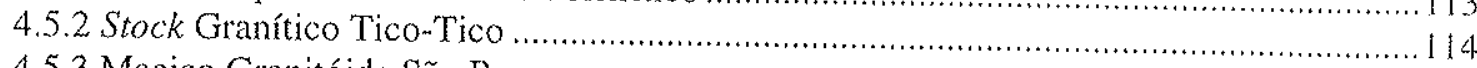

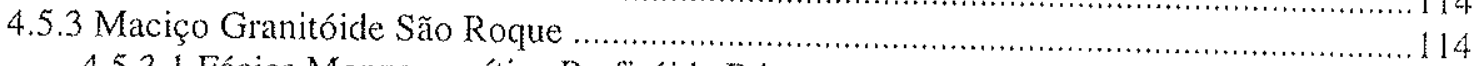

4.5.3.1 Fácies Monzogranítica Porfiróide Rósea ...................................................... 114

4.5.3.2 Fácies Monzogranítica Equi- a Inequigranular Média a Grossa..........................115

4.5.3.3 Fácies Monzogranítica Equigranular Média Rosada ...................................... 115

4.5.3.4 Fácies Sieno-Monzogranítica Gradacional .................................................. 115

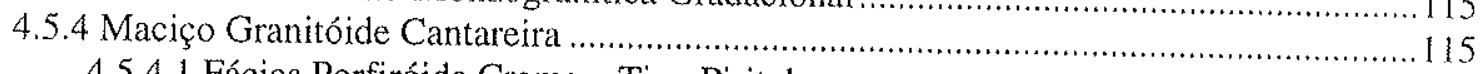

4.5.4.1 Fácies Porfiróide Creme - Tipo Pirituba ......................................................... 115

4.5.4.2 Fácies Porfiróide Rósea - Tipo Itaguassu...................................................... 116

4.5.4.3 Fácies Porfiróide Cinza Azulada - Tipo Canivete............................................... 116

4.5.4.4 Fácies Inequigranular Cinza - Tipo Hortolândia ............................................ 116

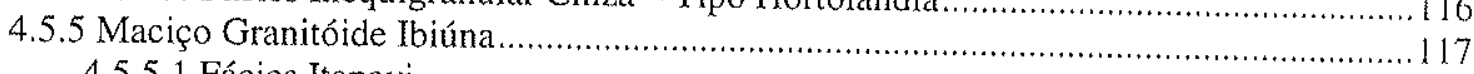

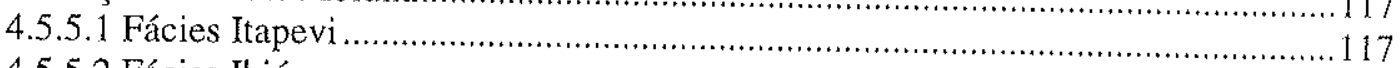

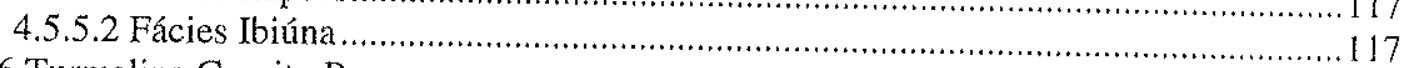

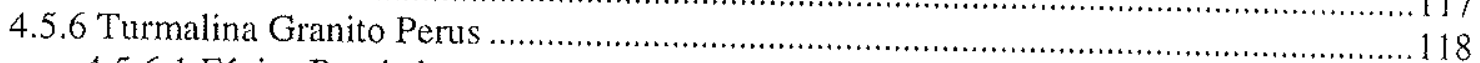

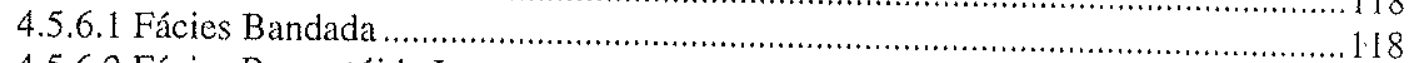

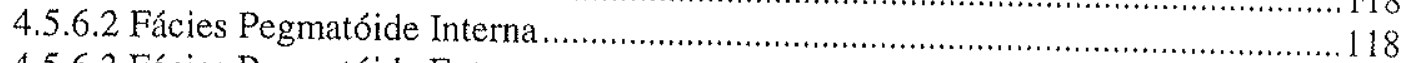

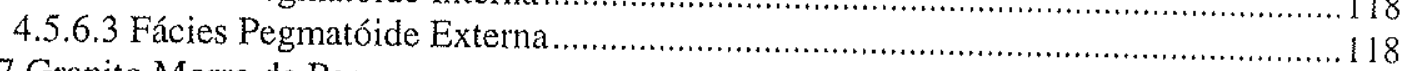

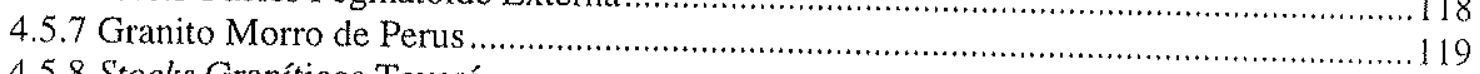

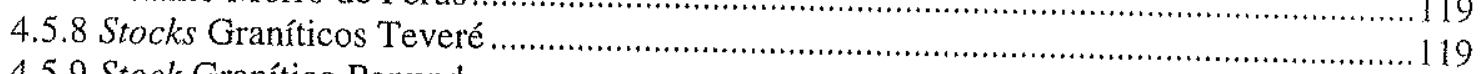

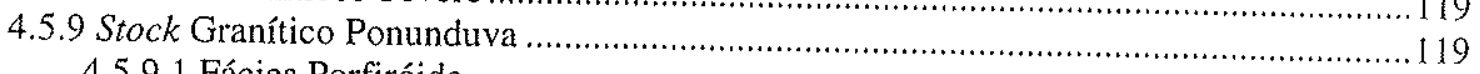

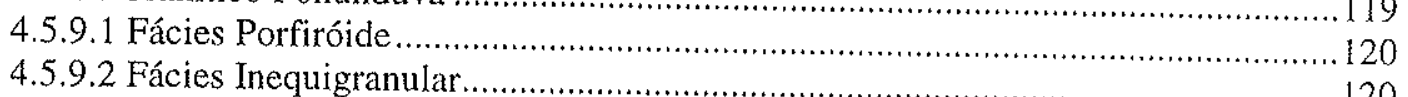

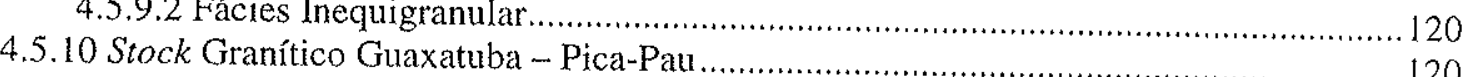

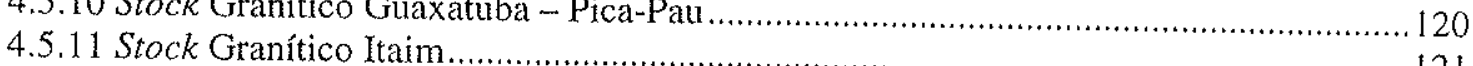




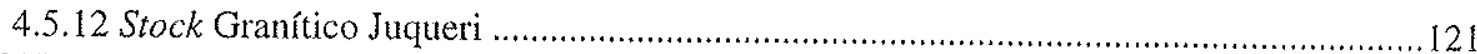

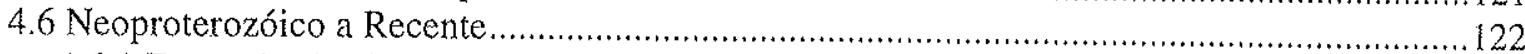

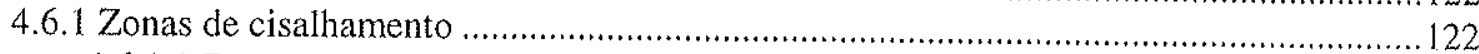

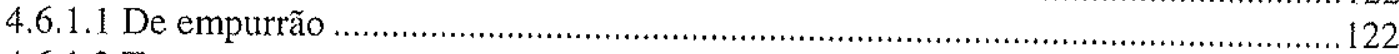

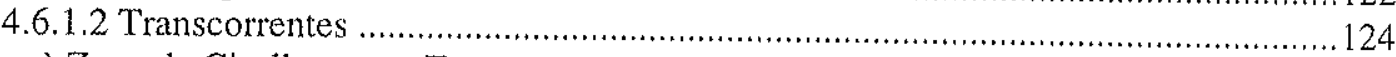

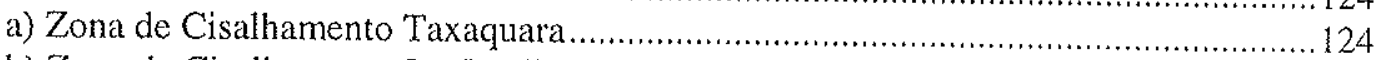

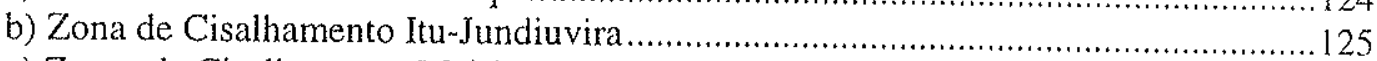

c) Zonas de Cisalhamento Mairinque e Moreiras ................................................... 125

d) Zona de Cisalhamento Araçariguama ................................................................. 126

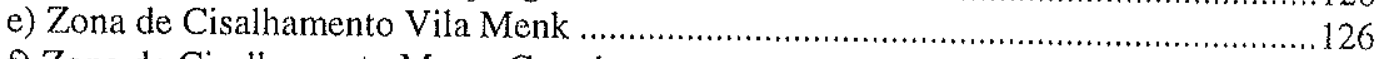

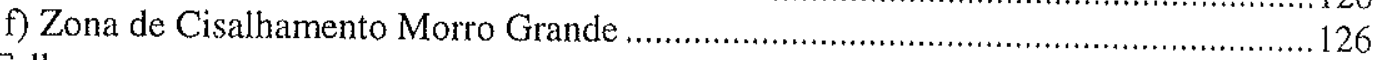

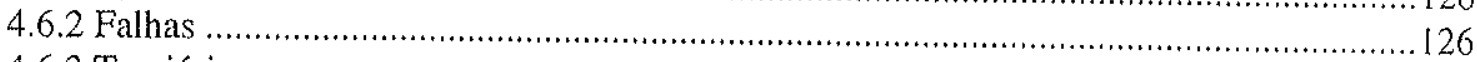

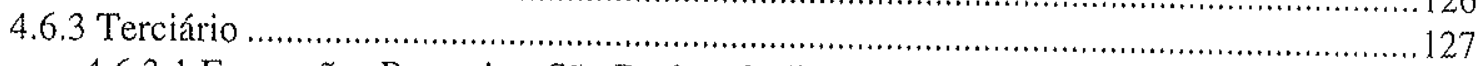

4.6.3.1 Formações Resende e São Paulo e Sedimentos Correlatos ................................. 127

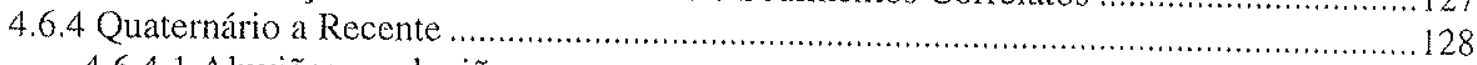

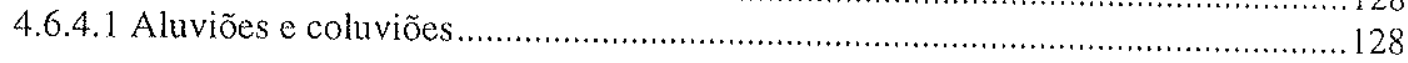

\section{CAPÍTULO V PETROGRAFIA}

5.1 Grupo Serra do Itaberaba.

5.1.1 Formação Morro da Pedra Preta....

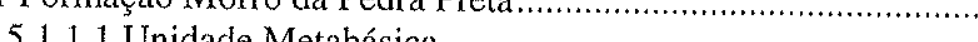

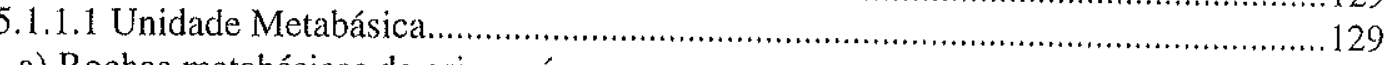

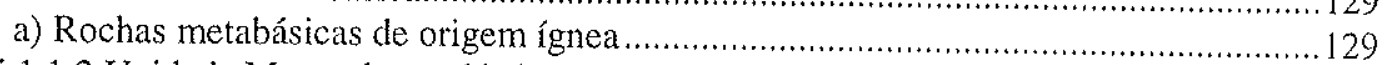

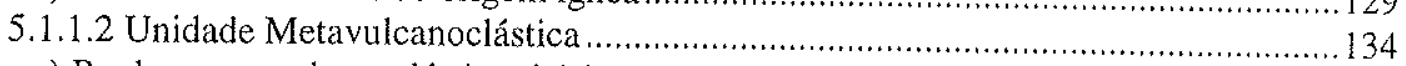

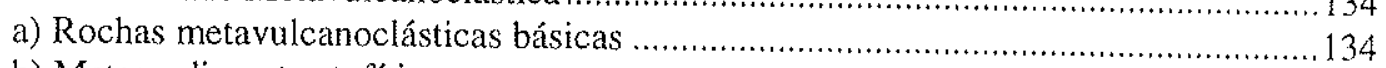

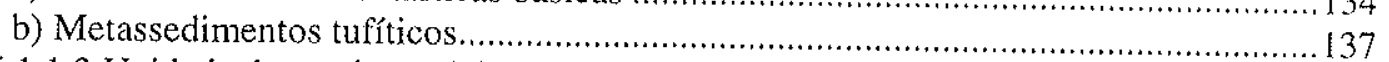

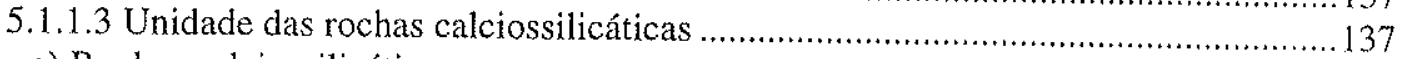

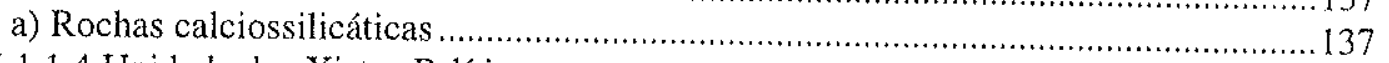

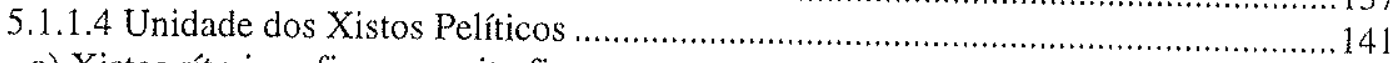

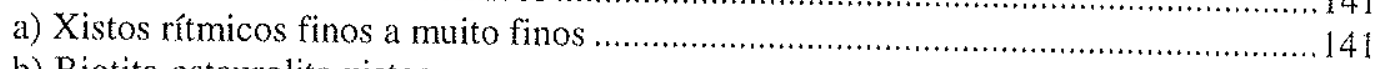

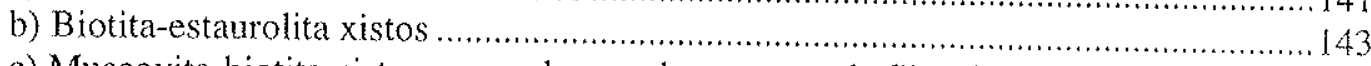

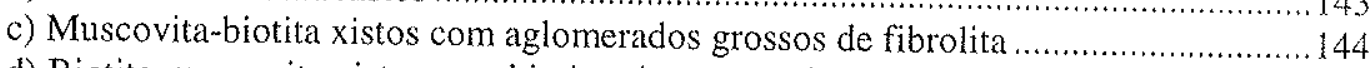

d) Biotita-muscovita xistos com biotita e/ou magnetita porfiroblásticas ........................ 148

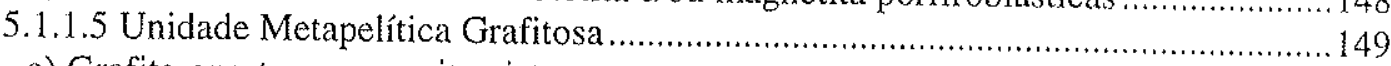

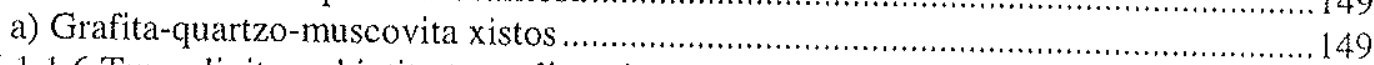

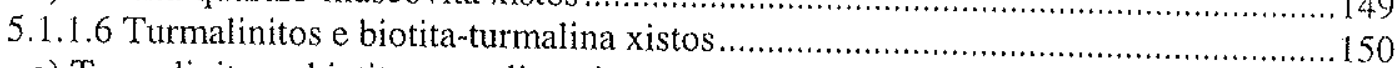

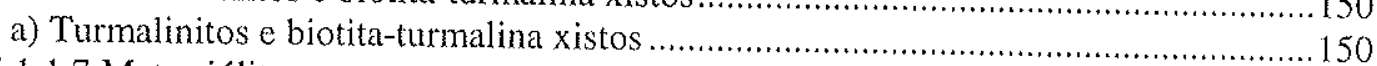

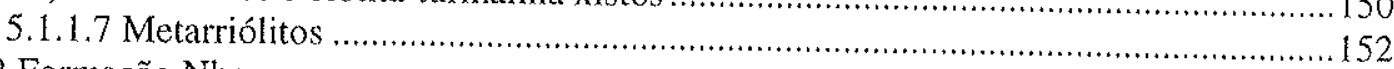

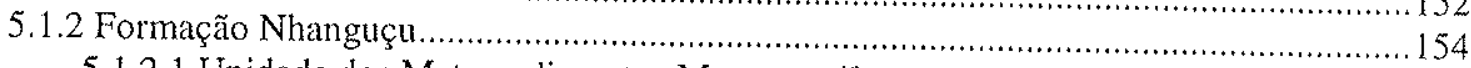

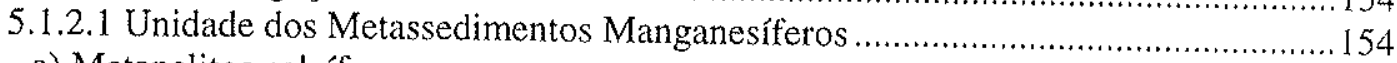

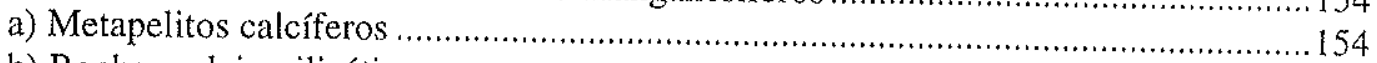

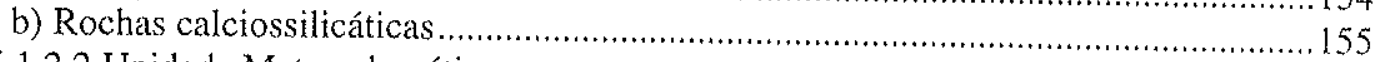

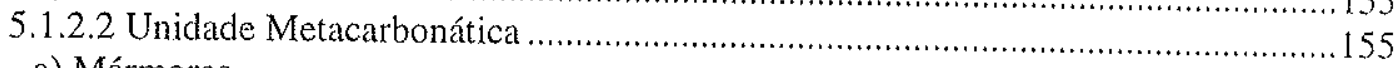

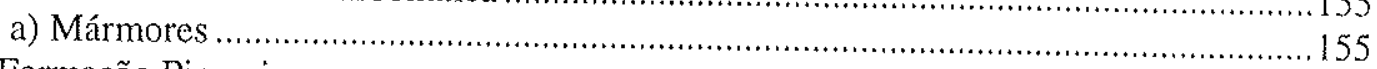

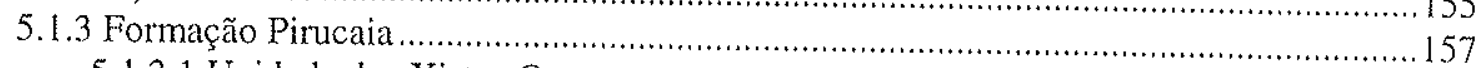

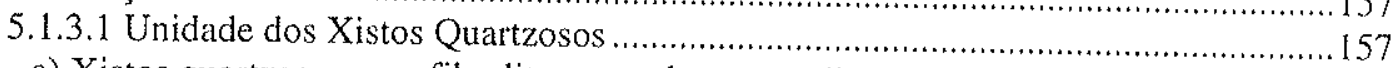

a) Xistos quartzosos com fibrolita, granada, estaurolita, silimanita e/ou cianita ...........157

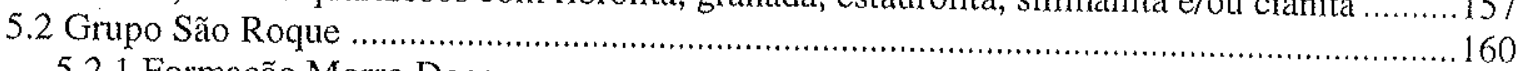

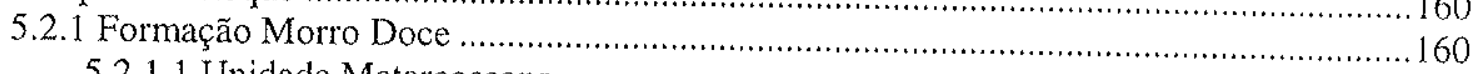

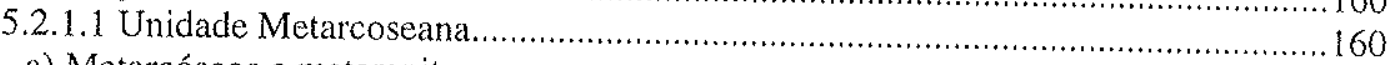

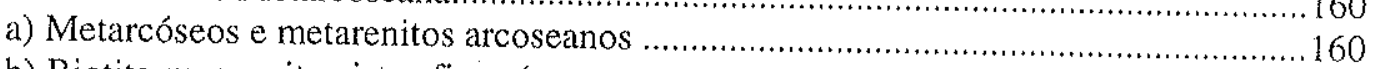

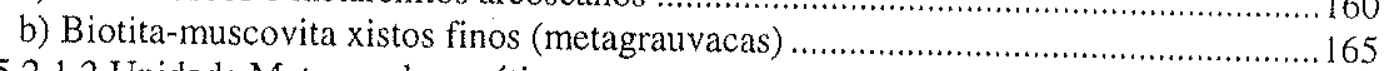

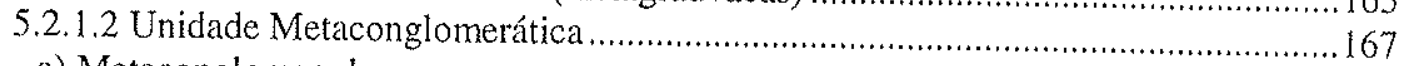

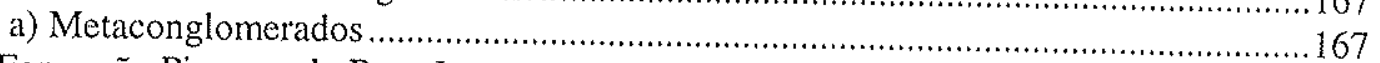

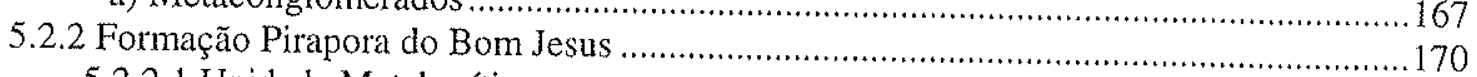

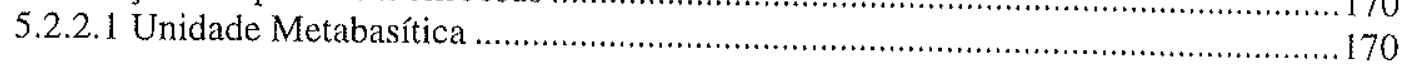


a) Rochas metabásicas

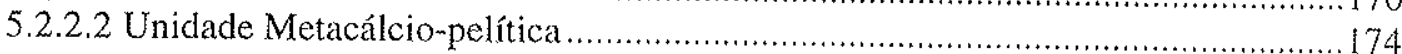

5.2.2.3 Unidade Metacarbonática ...................................................................... 174

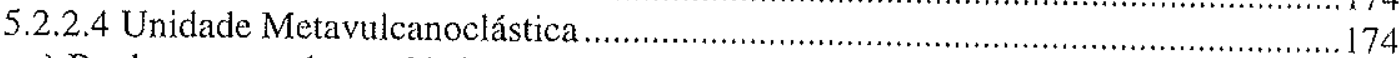

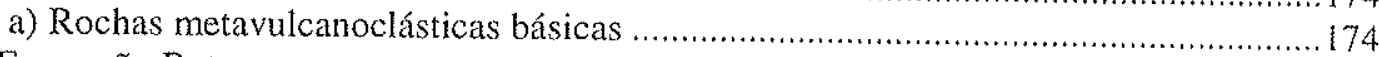

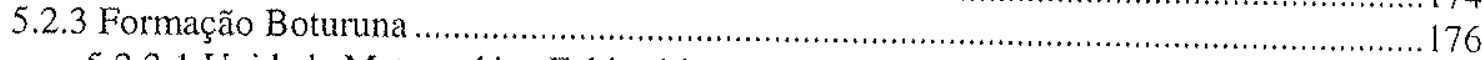

5.2.3.1 Unidade Metarenítica Feldspática ......................................................... 176

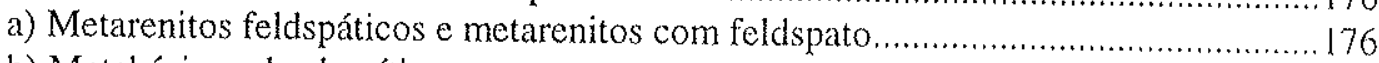

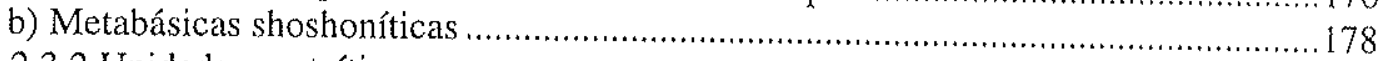

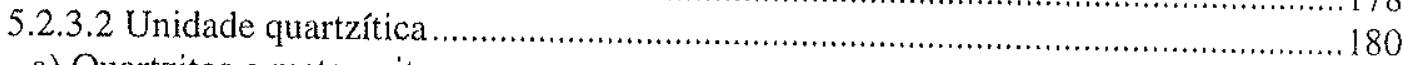

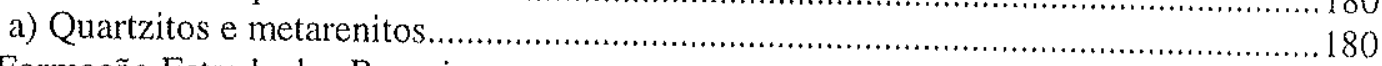

5.2.4 Formação Estrada dos Romeiros .................................................................. 181

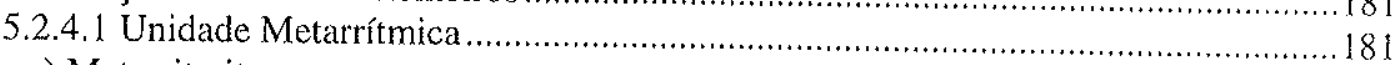

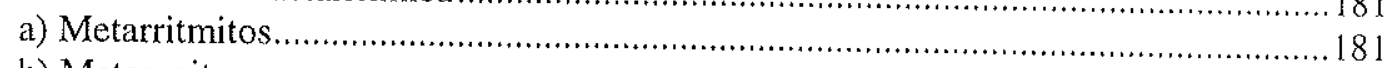

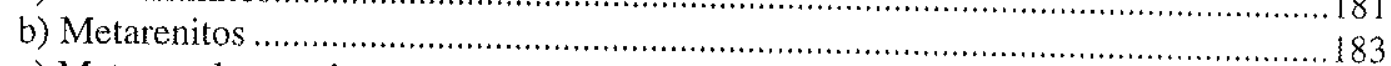

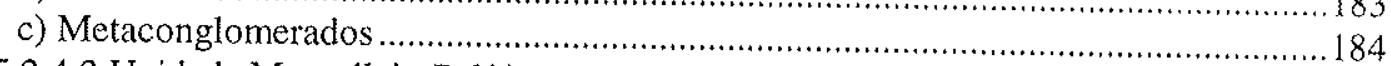

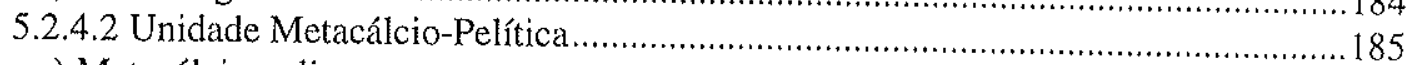

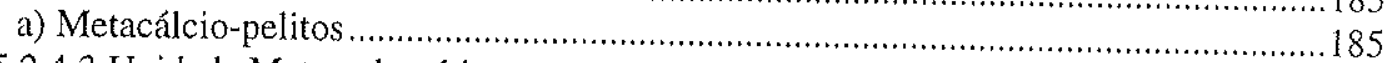

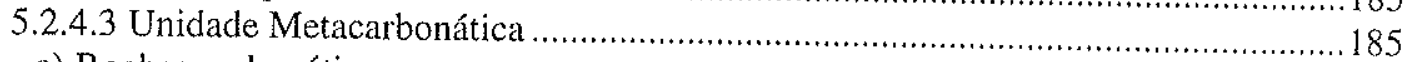

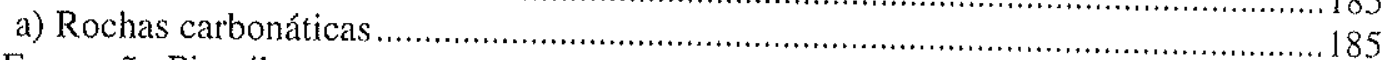

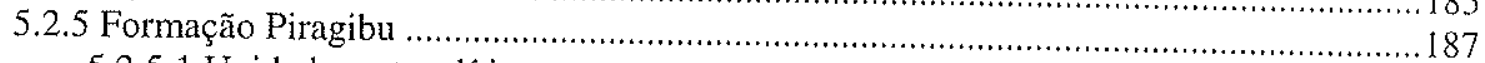

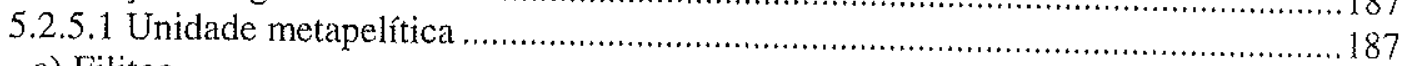

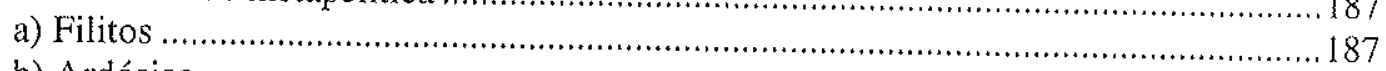

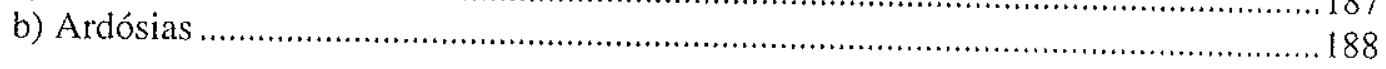

CAPÍTULO VI METAMORFISMO

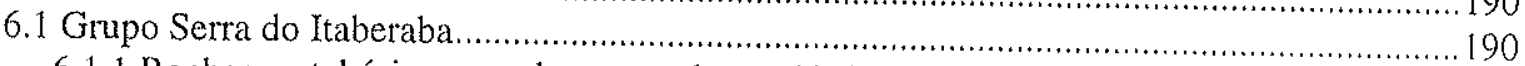

6.1.1 Rochas metabásicas e rochs metavulcanoclásticas básicas ......................................... 190

6.1.2 Metapelitos e metapsamitos das formações Morro da Pedra Preta e Pirucaia ................... 195

6.1.2.1 Xistos finos rítmicos ........................................................................... 195

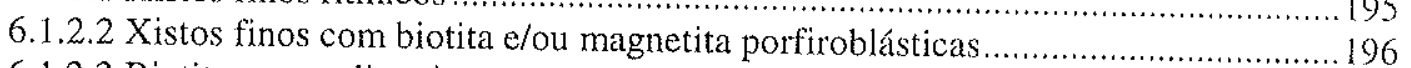

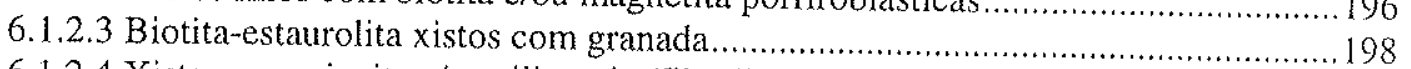

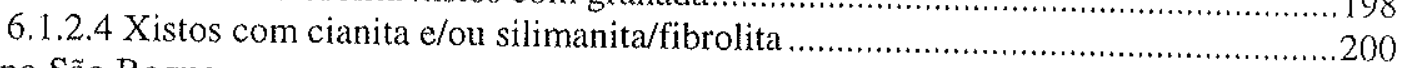

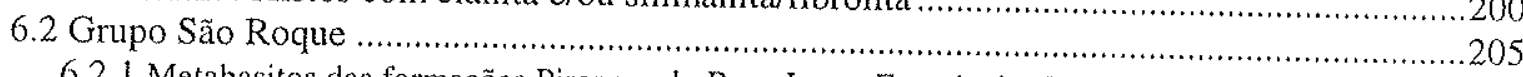

6.2.1 Metabasitos das formações Pirapora do Bom Jesus, Estrada dos Romeiros e Piragibu ...............205

6.2.2 Metapsamitos das formações Morro Doce e Boturuna ..............................................20 208

6.2.3 Metapelitos e metarritmitos das formações Estrada dos Romeiros e Piragibu..................209

6.3 Síntese do metamorfismo dos grupos Serra do Itaberaba e São Roque.................................210

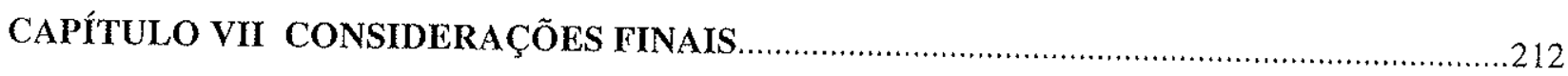

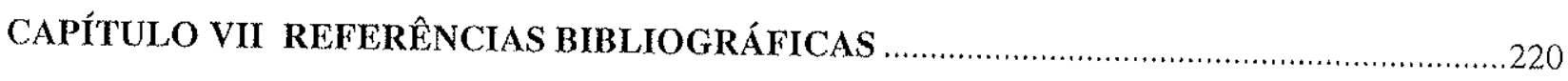

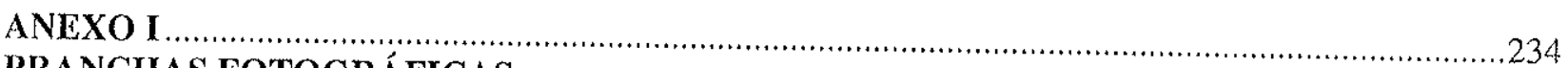

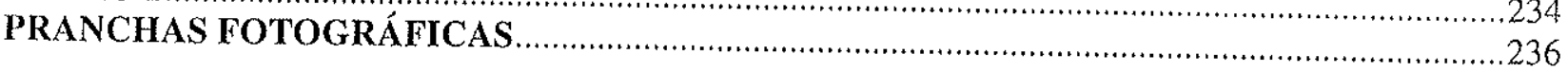

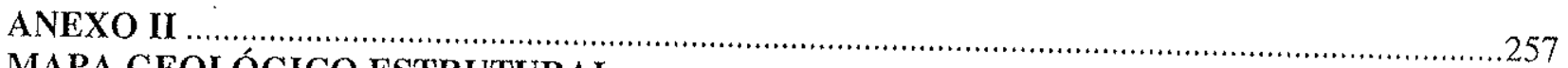

MAPA GEOLÓGICO ESTRUTURAL

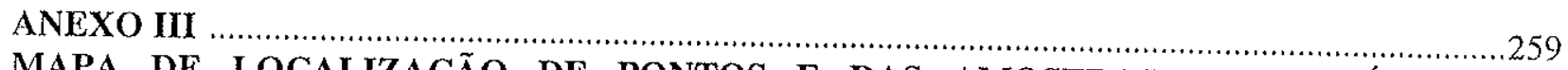

MAPA DE LOCALIZAÇÃO DE PONTOS E DAS AMOSTRAS COM ANÁLISE
PETROGRÁFICA 


\section{ÍNDICE DAS FIGURAS}

FIGURA 1.1 - Localização da área

FIGURA 1.2 - Articulação das folhas topográficas 1:10000, à esquerda, e localização nas folhas topográficas 1:50000 correspondentes, à direita. Projeto Região Metropolitana da Grande São Paulo, TERRAFOTO/EMPLASA $\left({ }^{*}\right)$ e Projeto Macro-Metrópole, TERRAFOTO/SEP $\left({ }^{*}\right)$................4

FIGURA 1.3 - Mapas compilados

FIGURA 3.1 - Contexto Geotectônico do sudeste brasileiro, incluindo a Faixa São Roque/Serra do Itaberaba. Onde (1) Maciço Mediano de Guaxupé, (2) Sistema de Dobramentos Sudeste/Ribeira, (3) Faixa de Dobramentos Brasília, (4) Bacia do Paraná, (5) Cráton do São Francisco, (6) Faixa São Roque/Serra do Itaberaba, e localização da área pesquisada em vermelho. Baseado em SCHOBBENHAUS FILHO et al. (1984)

FIGURA 3.2 - Cinturão de Cisalhamento Atlântico. Onde: (SCPS) - Sistema de Cisalhamento Paraíba do Sul; (ZCNI) - Zona de Cisalhamento Niterói; (ZCPCL) - Zona de Cisalhamento Paraíba do Sul-Cubatão-Lancinha; (ZCJFJT) - Zona de Cisalhamento Juiz, de Fora-JundiuviraTaxaquara. Modificado de MACHADO (1997)

FIGURA 3.3 - Contexto geológico regional da Faixa São Roque/Serra do Itaberaba. Modificado e simplificado a partir de BISTRICHI et al. (1981), JULIANI et al. (1986) e JULIANI \& BELJAVSKIS (1995).

FIGURA 3.4 - Colunas litoestratigráficas propostas para os grupos São Roque e Açungui (HASUI et al. 1976). As unidades Metapelitos, Metacarbonáticas, Quartzitos, Metaconglomerados e Metavulcânicas pertencem à Formação Boturuna

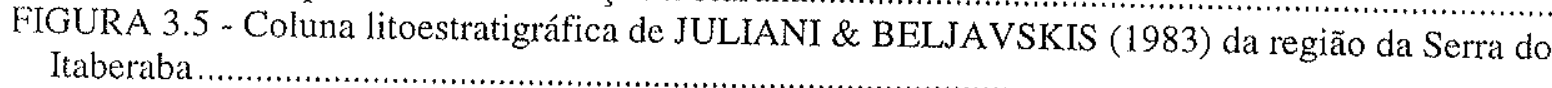

FIGURA 3.6 - Coluna litoestratigráfica da faixa entre o Pico do Jaragua...............................42 proposta por CARNEIRO (1983)

FIGURA 3.7 - Coluna litoestratigráfica proposta por CAMPOS NETO et al. $(1983 \ldots$ ) pa....................4. 43 a nordeste das Serras do Itaberaba e Pedra Branca

FIGURA 3.8 - Estratótipos das formações do Grupo São Roque proposta na subdivisão de BERGMANN (1988) para as regiões de Santana do Parnaíba e Pirapora do Bom Jesus. (A) Formação Pirapora no Corpo de Pirapora do Bom Jesus; (B) Formação Pirapora a leste de Santana do Parnaíba; (C) Formação Estrada dos Romeiros; (D) Formação Boturuna

FIGURA 3.9 - Coluna estratigráfica esquemática composta para o Grupo São Roque na Folha Guarulhos (DANTAS 1990)

FIGURA 3.10 - Coluna litoestratigráfica proposta para os grupos Serra do Itaberaba e São Roque na região das Serras do Itaberaba e Pedra Branca (JULIANI 1993)

FIGURA 3.11 - Litoestratigrafia dos grupos São Roque e Serra do Itaberaba extraída dos mapeamentos efetuados por HACKSPACHER et al. (1992b) na folha Pirapora (a), OLIVEIRA et al. (1992a) para a Folha Japi (b) e GODOY et al. (1996a) para a região de Sorocaba (c)......

FIGURA 3.12 - Síntese das correlações litoestratigráficas propostas por JULIANI \& BELJAVSKIS (1995) para a Faixa São Roque/Serra do Itaberaba. Onde (A): região das serras do Itaberaba e

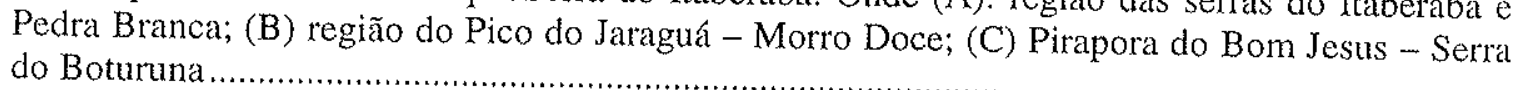

FIGURA 6.1 - Paragêneses metamórficas $(\mathrm{a}-\mathrm{c})$ e retrometamórficas (d-f) dos metabasitos do Grupo Serra do Itaberaba

FIGURA 6.2 - Paragêneses metamórficas $(a, b, c)$ e retrometamórficas $(d, e, f)$ dos metapelitos do Grupo Serra do Itaberaba

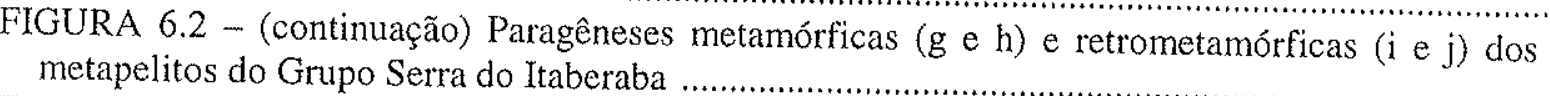

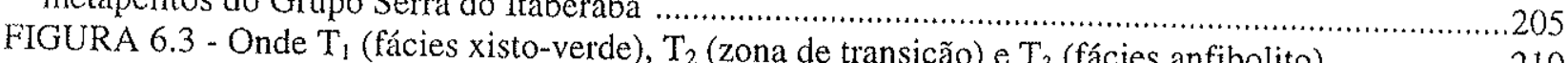

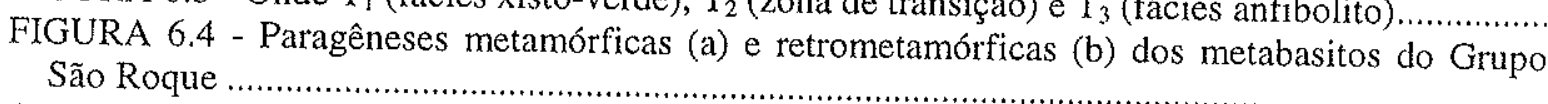

FIGURA 6.5 - Paragêneses metamórficas e retrometamórficas dos metapelitos, metarritmitos e rochas com K-feldspato detrítico (metarcóseos, metarenitos feldspáticos, matriz dos metaconglomerados) do Grupo São Roque 


\section{ÍNDICE DAS TABELAS}

TABELA 1.1 - Folhas topográficas na escala de 1:50000 4

TABELA 1.2 - Folhas topográficas 1:10000 utilizadas nos trabalhos de campo ..........................................5

TABELA 1.3 - Folhas topográficas $1: 25000$ usadas na digitalização e confecção do mapa geológico-estrutural......

TABELA 1.4 - Fotos aéreas utilizadas. Faixas I a VII (Vôos leste-oeste). Faixas FXs (Vôos nortesul).

TABELA 5.1 - Relações de cristalização dos minerais nos hornblenda-hornblenda/actinolita anfibolitos.

TABELA 5.2 - Relação de cristalização dos minerais nos hornblenda anfibolitos, hornblenda xistos e granada hornblenda anfibolitos

TABELA 5.3 - Relações de cristalização dos minerais nas rochas metavulcanoclásticas básicas............

TABELA 5.4 - Relações de cristalização dos minerais nos metassedimentos tufíticos (clorita xistos)

TABELA 5.5 - Relações de cristalização dos minerais nas rochas calciossilicáticas da Formação Morro da Pedra Preta

ABELA 5.6 - Relações de cristalização dos minerais nas rochas calciossilicáticas da Formação Morro da Pedra Preta afetadas por metamorfismo de contato

TABELA 5.7 - Relações de cristalização dos minerais dos xistos finos rítmicos.

TABELA 5.8 - Relações de cristalização dos minerais dos biotita-estaurolita xistos

TABELA 5.9 - Relações de cristalização dos minerais nos muscovita-biotita-quartzo xistos com aglomerados grossos de fibrolita.

TABELA 5.10 - Relações de cristalização dos minerais segundo as diferentes foliações nos biotitamuscovita xistos com biotita e/ou magnetita porfiroblásticas.

TABELA 5.11 - Relações de cristalização dos minerais segundo as foliações nos grafita-quartzomuscovita xistos

TABELA 5.12 - Relações de cristalização dos minerais nos turmalinitos e nos biotita-turmalina xistos .

TABELA 5.13 - Relações de cristalização dos minerais nos metarriólitos

TABELA 5.14 - Relações de cristalização dos minerais nos metapelitos calcíferos

TABELA 5.15 - Relações de cristalização dos minerais nas rochas calciossilicáticas da Formação Nhanguçu

TABELA 5.16 - Relações de cristalização dos minerais nas rochas carbonáticas do topo da Formação Nhanguçu

TABELA 5.17 - Relações de cristalização dos minerais nas rochas carbonáticas da base da Formação Nhanguçu

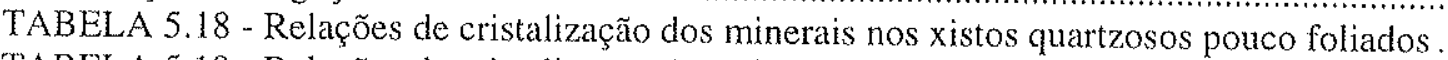

TABELA 5.19 - Relações de cristalização dos minerais nos metarcóseos e metarenitos arcoseanos

TABELA 5.20 - Relações de cristalização dos minerais nos biotita-muscovita xistos (metagrauvacas)

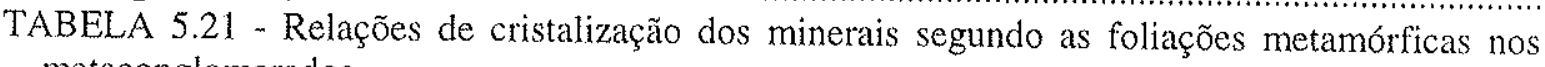
metaconglomerados

TABELA 5.22 - Relações de cristalização dos minerais nas rochas metabásicas do Grupo São Roque

TABELA 5.23 - Relações de cristalização dos minerais nas rochas metavulcanoclásticas básicas do Grupo São Roque

TABELA 5.24 - Relações de cristalização dos minerais nos metarenitos feldspáticos e metarenitos com feldspato

TABELA 5.25 - Relações de cristalização dos minerais nas tochas metabásicas shoshoníticas do Grupo São Roque

TABELA 5.26 - Relações de cristalização dos minerais segundo as diferentes foliações metamórficas nos quartzitos e metarenitos das formação Boturuna e Estrada dos Romeiros.

ABELA 5.27 - Relações de cristalização dos minerais com as foliações nos metarritmitos nas unidades Metarrítmica e Metacálcio-pelítica da Formação Estrada dos Romeiros e na Unidade Metarrítmica da Formação Piragibu. 
TABELA 5.28 - Relações de cristalização dos minerais segundo as foliações metamórficas nos metarenitos da Unidade Metarrítmica da Formação Estrada dos Romeiros

TABELA 5.29 - Relações de cristalização dos minerais nos metaconglomerados da Unidade Metarrítmica da Formação Estrada dos Romeiros

TABELA 5.30 - Relações de cristalização dos minerais com as foliações metamórficas nos metacálcio-pelitos das formações Pirapora do Bom Jesus e Estrada dos Romeiros

TABELA 5.31 - Relações de cristalização dos minerais com as foliações metamórficas nas rochas carbonáticas das formações Pirapora do Bom Jesus e Estrada dos Romeiros.

TABELA 5.32 - Relações de cristalização dos minerais com as foliações metamórficas nos filitos das unidades metapelíticas das formações Piragibu e Estrada dos Romeiros

TABELA 5.33 - Relações de cristalização dos minerais com as foliações metamórficas nas ardósias da Unidade Metapelítica da Formação Piragibu

\section{ÍNDICE DAS FOTOGRAFIAS}

\section{PRANCHA 01}

Foto A - Gnaisses do Complexo Itapira predominando porções xistosas com bandas graníticas brancas e anfibolítica ocre subordinadas. Notar bandas dobradas e por vezes rompidas no centro da foto, devido às falhas associadas à Zona da Cisalhamento de Itú-Jundiuvira. Banda anfibolítica com $6 \mathrm{~cm}$ de espessura. Afloramento do ponto MV 1036

Foto B - Xistos feldspáticos alterados e milonitizados do Complexo Embu apresentando intercalações graníticas derivadas da fusão parcial dos metassedimentos. A falha que desloca os litotipos associa-se ao sistema tardio de falhas conjugadas de direções NNW-SSE e NW-SE. Afloramento do ponto JA 996

Foto $\mathrm{C}$ - Leito de xisto conglomerático que ocorre intercalado com xistos arenosos e pelíticos com fibrolita sobrepostos a um corpo anfibolítico. Observar a riqueza de grânulos e pequenos seixos arredondados predominando os de quartzo de veio. Escala dada pela ponta da lapiseira.

Foto D - Metassedimentos tufíticos miloníticos da Formação Morro da Pedra Preta, intercalando lâminas e bandas roxo, vinho e vermelhas e brancas mais raras, afetados por falhas inversas associadas às zonas de cisalhamento de empurrão

Foto E-Milonito dos metassedimentos tufíticos na encosta nordeste do Pico do Jaraguá (PJ 1199). São laminados a variegados e com contribuição de material manganesífero indicado pela porções verdes-ocráceas. Notar foliação milonítica ondulada com sigmóides associados indicando transporte tectônico para N-NE marcado pela ponta da lapiseira

Foto F - Metapelitos que ocorrem intercalado aos metassedimentos tufíticos observado a SSE do Morro do Boturuna (CV 956). Estão representados por xistos finos róseo-claros de estrutura laminada a bandada. Notar a foliação milonítica S2 oblíqua ao bandamento e algumas falhas posteriores de rejeito centimétrico

Foto G - Metarriolito associado com metapelitos calcíferos e metassedimentos manganesíferos ocráceos que ocorrem no topo da Unidade Metavulcanoclástica da Formação Morro da Pedra Preta no afloramento do ponto BA 840. Altura do afloramento $\sim 5 \mathrm{~m}$. À esquerda o metarriolito está concordante com a foliação $\mathrm{S} 2$ dos metassedimentos e, para a direita, observa-se um provável xenólito.

Foto $\mathrm{H}$ - Intercalações de bandas de rochas calciossilicáticas ocre-amarelada a marrom com aspecto manchado dado pela percolação de manganês e leitos pretos com até $1 \mathrm{~cm}$ ricos em metapelitos manganesíferos e bandas mais largas e com cores mais vivas das rochas anfibolíticas ....235 


\section{PRANCHA 02}

Foto A - Xistos pelíticos porfiroblásticos com intercalações de bandas ricas em fibrolita branca orientada segundo a foliação S2 com mergulho subvertical e outras onde a fibrolita está quase ausente. À esquerda, pacote maciço de xistos mais arenosos

Foto B - Xistos pelíticos milonitizados do Grupo Serra do Itaberaba do ponto JD 961 próximo do contato com o Grupo São Roque, sendo observados veios de quartzo estirados e os pares S-C que mostram uma foliação milonítica associada com zonas de cisalhamento de empurrão

Foto C - Xistos pelíticos finos da Formação Morro da Pedra Preta ricos em porfiroblastos de estaurolita orientada segundo a foliação S2. Afloramento do ponto BA 844A

Foto D - Metassedimentos grafitosos laminados a bandados cinza da Formação Morro da Pedra Preta conrtendo intercalações de leitos brancos mais siltosos e outros esverdeados sugerindo contribuição de sedimentos manganesíferos

Foto E - Metassedimentos manganesíferos com estrutura laminada a finamente bandada intercalndo leitos ocre-claros e outros marrons. Afloramento do ponto CV 955 .

Foto $\mathrm{F}$ - Metassedimentos manganesíferos bandados a laminados intercalando finas laminações amarelo ocráceas de rocha calciossilicática exibindo dobras fechadas e paralelizando nos flancos a foliação S2 com o bandamento S1/S0. Afloramento do ponto BT 963

Foto $\mathrm{G}$ - Rochas carbonáticas do ponto PJ 879 exibindo estrutura laminada a bandada, com bandas castanho flogopíticas e esverdeadas com tremolita. Leitos mais claros em essência carbonáticos e mais escuros podem apresentar minerais opacos disseminados

Foto $\mathrm{H}$ - Porções mais finas dos xistos quartzosos da Formação Pirucaia com porções pouco milonitizadas exibindo os grânulos de quartzo arredondados no centro da fotografia. Afloramento do ponto PJ $944 \ldots$

\section{PRANCHA 03}

Foto A - Metarcóseos com porfuroclastos de feldspatos da Formação Morro Doce no Morro do Polvilho (BT 104) contendo intercalações de bandas com até $3,0 \mathrm{~cm}$ de espessura de metarenitos finos cinza-esverdeados escuros.

Foto B - Metaconglomerados milonitizados da Formação Morro Doce na região do Morro do Polvilho, no ponto BT 105, predominando seixos e calhaus de rochas granitóides e de quartzitos estirados pela foliação milonítica de alto ângulo. Matriz cinza-escura rica em biotita e magnetita. Topo do afloramento para direita.....

Foto C - Metabasitos da Formação Pirapora do Bom Jesus com estrutura tipo pillow lava parcialmente destruída por cisalhamento de baixo ângulo encaixado na descontinuidade do material interpillows. Afloramento do ponto RP 1225

Foto D - Rochas carbonáticas da Formação Pirapora do Bom Jesus contendo malaquita supérgena disseminada derivada da alteração de calcopirita. Afloramento VL 1063. Topo do afloramento para direita.

Foto E - Quartzitos da Formação Boturuna com estratificação cruzada tangencial na base e com veios de quartzo remolizados nos estratos. Topo em posição normal apontado pelo cabo do martelo. Afloramento do ponto CV 830.

Foto F - Quartzitos da base do Morro do Boturuna com estratificações plano-paralelas sobrepostas às estratificações cruzadas tipo espinha-de-peixe. Afloramento do ponto VL 785 .

Foto $\mathrm{G}$ - Nível do metapsamito grosso da Formação Boturuna contendo seixos angulosos de rocha filítica representando possíveis gretas de ressecação retrabalhadas ou nível de canibalismo com destruição de estratos argilosos. Afloramento do ponto CV 827B 
Foto H - Metaconglomerado da Unidade Metarrítmica da Formação da Estrada dos Romeiros apresentando matriz arenosa fina e exibindo seixos e calhaus angulosos de quartzo de veio e de metassedimentos manganesíferos marrom-escuros. Afloramento do ponto RP 1241 .......

\section{PRANCHA 04}

Foto A - Filitos com estrutura laminada a bandada da Unidade Metapelítica da Formação Piragibu com intercalações de leitos com até $1,5 \mathrm{~cm}$ escuros e grafitosos. Notar clivagem de fratura paralela à lapiseira com filmes mais escuros dado pela alteração de clorita. Afloramento do ponto CV 954

Foto B - Filitos bandados alterados ricos em clorita da Formação Piragibu com bandas de espessura decimétrica roxas e porções mais decompostas ocre-esverdeadas. Afloramento VL 1078 .

Foto $\mathrm{C}$ - Aspecto geral da fácies mais comum dos maciços granitóides que ocorrem na área. Amostra do Granodiorito Barueri dos arredores de Santana do Parnaíba. Ponto SP 826A

Foto D - Metarcóseos da base do Morro Doce milonitizados e associados às zonas de cisalhamento de empurrão de baixo a médio ângulo relacionadas à colocação do Grupo São Roque sobre o Grupo Serra do Itaberaba

Foto E - Xistos pelíticos da Formação Morro da Pedra Preta com dobras recumbentes e falhas de médio ângulo com venulações de quartzo associadas ao cisalhamento de empurrão. Ponto BT 569

Foto F - Milonitos do Maciço Granitóide Itaqui afetado pela Zona de Cisalhamento Taxaquara. Notar o mergulho suvertical e as estruturas S-C, mais comuns na porção inferior esquerda da foto. Afloramento do ponto JA 997

Foto G - Ultramilonitos da Fácies Itapevi do Maciço Granitóide Ibiúna exibindo foliação milonítica de baixo ângulo posterior a foliação milonítica associada à transcorrência. Ponto JA 995

Foto H - Sedimentos terciários correlatos às formações Resende e São Paulo expostos na altura do $\mathrm{km} 34$ da Rodovia dos Bandeirantes. Notar as flhas associadas que colocam lado a lado um pacote arenoso e outro de argilitos. Afloramento do ponto CB 1146

\section{PRANCHA 05}

Foto A - Textura blastofítica em hornblenda anfibolitos da Formação Morro da Pedra Preta (GSI). Observar inclusões de cristais de plagioclásio nos porfiroblastos de homblenda com a forma reliquiar ígnea preservada, mas recristalizados em grãos menores. Com analisador. Lado maior 2,8 mm. Amostra do afloramento PP 19

Foto B - Hornblenda-hornblenda/actinolita anfibolito pouco foliado da Formação Morro da Pedra Preta (GSI). Notar porfiroblasto de anfibólio com núcleo verde-claro (hornblenda-actinolita) e borda verdemescura (hornblenda). Sem analisador. Lado maior $\sim 1,4 \mathrm{~mm}$. Amostra do afloramento SP 643B, próximo ao Maçico Granitóide Itaqui.

Foto C - Hornblenda anfibolito da Formação Morro da Pedra Preta (GSI). Observar possível recristalização de hornblenda $\sin -S_{1}$ em aglomerados de cristais menores de hornblenda $\sin -S_{2}$. Notar subordinadamente a presença de biotita, ilmenita e titanita. Sem analisador. Lado maior $~$ $5.5 \mathrm{~mm}$. Amostra proveniente do afloramento TT 88

Foto D - Hornblenda-hornblenda/actinolita anfibolito da Formação Morro da Pedra Preta (GSI) próximo do Maciço Granitóide Itaqui. Notar granulação relativamente mais grossa e textura reliquiar intergranular (gabróica), onde estão preservados cristais de plagioclásio tabulares e geminados. Com analisador. Lado maior $\sim 2,8 \mathrm{~mm}$. Amostra do afloramento CV 766 
Foto E - Hornblenda xisto da Unidade Metabásica da Formação Morro da Pedra Preta (GSI), afetado por forte foliação milonítica. Notar cristais de hornblenda sin- $S_{1}$ um pouco maiores com disposição aproximada N-S rotacionados ou transpostos por cristais menores de hornblenda $\mathrm{S}_{2} / \mathrm{S}_{\mathrm{m}}$ orientados na direção $\mathrm{E}-\mathrm{W}$. Sem analisador. Lado maior $~ 5,5 \mathrm{~mm}$. Amostra do afloramento PP 142.

Foto F - Granada hornblenda anfibolito da Formação Morro da Pedra Preta (GSI), onde são vistos cristais subeuédricos de granada sin- a pós- $\mathrm{S}_{2}$ em equilíbrio com hornblenda. Amostra proveniente do ponto TT 79, próximo do contato com o Stock Granítico Tico-Tico. Notar núcleos poiquiloblásticos na granada com inclusões de ilmenita, quartzo e plagioclásio e bordas maciças associadas ao reequilíbrio pós- $\mathrm{S}_{2}$. Sem analisador. Lado maior $\sim 2,8 \mathrm{~mm}$

Foto G - Hornblenda anfibolito da Formação Morro da Pedra Preta (GSI). À direita, observar porfiroblasto de diopsídio $S_{1}$ instável e uma matriz composta por hornblenda $S_{2}$ e cristais menores recristalizados de plagioclásio $\mathrm{S}_{2}$. Com analisador. Lado maior $\sim 2,8 \mathrm{~mm}$. Amostra do afloramento PP 927, a sudoeste do Stock Granítico Tico-Tico.

Foto H - Hornblenda anfibolito da Formação Morro da Pedra Preta (GSI) dos arredores do Stock Granítico Tico-Tico. No centro, cristal de hornblenda $S_{1}$ (em secção basal) parcialmente envolvido por hornblenda $\sin -S_{2}$ orientada segundo essa foliação. Matriz composta essencialmente por cristais de plagioclásio menores e recristalizados. Sem analisador. Lado maior $\sim 2,8 \mathrm{~mm}$. Amostra do afloramento PP 514B

\section{PRANCHA 06}

Foto A - Hornblenda anfibolito da Formação Morro da Pedra Preta (GSI) afetado pela foliação milonítica $S_{\mathrm{m}}$. Notar bandamento composicional com intercalações de lâminas e finas bandas ricas em homblenda orientada e outras contendo plagioclásio recristalizado em cristais menores. Sem analisador. Lado maior 5,5 mm. Amostra do afloramento TT 568, próximo do Stock Granítico Tico-Tico

Foto B - Metatufo básico da Formação Morro da Pedra Preta (GSI), que petrograficamente correspondente a um hornblenda xisto Observar bandamento metamórfico $S_{2}$ com os cristais de hornblenda orientados paralelos à estrutura $S_{1} / S_{0}$. Estrutura marcada pela intercalação de finos leitos com variações da granulação e do volume de hornblenda, ora com cristais mais grossos e mais comuns, ora mais finos e mais raros. Com analisador. Lado maior $\sim 2,8 \mathrm{~mm}$. Amostra do afloramento PP 572

Foto C - Rocha metavulcanoclástica básica (da Unidade Metabásica) da Formação Morro da Pedra Preta (GSI) localizada próxima do Maciço Granitóide Cantareira. Notar cristais de hornblenda $S_{2}$ menores e fortemente orientados associados à milonitização que transpõe porfiroblastos de hornblenda-actinolita $S_{1}$ (núcleos verde-claros). Sem analisador. Lado maior 1,4 mm. Amostra do afloramento PJ 879 .....

Foto D - Clorita xisto presente nos metassedimentos tufíticos da Formação Morro da Pedra Preta (GSI). Notar que a clorita pouco pleocróica a incolor sugere composição magnesiana. Presença relativamente abundante de minerais opacos e raros cristais de quartzo. Observar foliação milonítica com feições tipo s-c onde finos cristais orientados de clorita $S_{2}$ transpõem uma foliação prévia $S_{1}$ constituída por cristais maiores de clorita. Sem analisadores. Lado maior $\sim 0,7 \mathrm{~mm}$. Amostra do afloramento SP 645

Foto E - Rochas calciossilicática da Formação Morro da Pedra Preta (GSI). No centro e à esquerda o amplo predomínio de cristais de tremolita-actinolita orientados segundo a $S_{2}$, além de um fino leito onde concentram-se cristais granulares de clinopiroxênio e outros de microclínio com geminação em grade. À direita, predomina flogopita $\sin -S_{2}$ e leitos formados na essência por clinozoizita. Com analisador. Lado maior $~ 2,8 \mathrm{~mm}$. Amostra do afloramento SP 620 
Foto F - Aspecto mais comum das rochas calciossilicáticas da Formação Morro da Pedra Preta (GSI) com intercalações de lâmina verde-escura (à direita) composta principalmente por biotita, mineral opaco e quartzo, com epídoto, tremolita e allanita subordinados, e lâmina verde-clara (à esquerda) contendo actinolita, epídoto e quartzo, além de hornblenda prismática, clinopiroxênio e clinozoizita. Sem analisador. Lado maior 5,5 mm. Amostra do afloramento PJ 109

Foto G - Rocha calciossilicática da Formação Morro da Pedra Preta (GSI). No centro ocorre um quartzo-flogopita xisto orientado segundo a foliação $S_{2}$ e estão presentes plagioclásio, clinozoizita e allanita subordinados. Notar na parte inferior, forte cristalização de diopsídio, titanita e cristais maiores de flogopita, todos de tendência granular e pouco orientados, sugerindo possível sobreposição de metamorfismo de contato pós- $S_{2}$. Com analisador. Lado maior $\sim 5,5 \mathrm{~mm}$. Amostra do ponto CV 761

Foto H - Muscovita-biotita xisto presente nos xistos finos a muito finos da Formação Morro da Pedra Preta (GSI). Observar o bandamento metamórfico $S_{2}$ marcado pela forte orientação dos cristais de biotita e pelos leitos ricos em quartzo dobrados intrafolialmente $\left(S_{2}\right.$ paralelo a $\left.S_{1} / S_{0}\right)$, posteriormente crenulados pela Coliação $S_{3}$. Com analisador. Lado maior $\sim 5,5 \mathrm{~mm}$. Amostra do afloramento PP 575

\section{PRANCHA 07}

Foto A - Porfiroblasto instável de andaluzita $\sin -S_{1}$ presente nos muscovita-biotita xistos (xistos finos rítmicos) da Formação Morro da Pedra Preta (GSI). Notar que o porfiroblasto está cortado e transformado nas bordas para cristais de sericita/muscovita fina orientados segundo a foliação $\mathrm{S}_{2} / \mathrm{S}_{\mathrm{m}}$. Com analisador. Lado maior 1,4 mm. Amostra do afloramento BT 691

Foto B - Biotita-estaurolita xisto com granada da Formação Morro da Pedra Preta (GSI). Notar os poiquiloblastos de granada e de estaurolita com inclusões orientadas sugerindo crescimento preferencial tardi- a pós- $S_{2}$, dispersos em uma matriz rica em quartzo e minerais micáceos orientados segundo a foliação $\mathrm{S}_{2} / \mathrm{S}_{\mathrm{m} 1}$. Sem analisador, Lado maior $\sim 5,5 \mathrm{~mm}$. Amostra do afloramento PP 22

Foto $\mathrm{C}$ - Aspecto comum da foliação $\mathrm{S}_{2} / \mathrm{S}_{\mathrm{m}}$ dos biotita-muscovita xistos com agregados grossos de fibrolita da Formação Morro da Pedra Preta (GSI). Observar pares Ss e Sc, formas sigmoidais e forte cristalização de fibrolita segundo a $S_{\mathrm{m}}$. Nos cristais de quartzo predominam bordas retilíneas devido à dissolução e recristalização. Com analisador. Lado maior $\sim 2,8 \mathrm{~mm}$. Amostra do afloramento PP 509

Foto D - Aspecto geral da clivagem de crenulação $S_{3}$ que afeta a foliação $S_{2} / S_{m}$ dos biotita-muscovita xistos com agregados grossos de fibrolita da Formação Morro da Pedra Preta (GSI), gerando dobras fechadas onde podem ser vistos arcos poligonais formados pelos minerais micáceos. Na porção inferior direita, observar porfiroblasto de fibrolita contido na foliação $S_{2}$. Com analisador. Lado maior 5,5 mm. Amostra do afloramento TT 85

Foto $\mathrm{E}$ - Aglomerados grossos de fibrolita $\sin -\mathrm{S}_{2}$ presentes em xistos pelíticos da Formação Morro da Pedra Preta (GSI). A fibrolita exibe hábito fibrorradiado a acicular e pode ser observado o crescimento epitáxico com biotita. Na porção inferior direita ocorrem cristais prismáticos finos de sillimanita caracterizados como $\sin -S_{1}$. Sem analisador. Lado maior $\sim 1,4 \mathrm{~mm}$. Amostra do afloramento PP 540

Foto F - Biotitamuscovita xisto com porfiroblastos de biotita e magnetita da Formação Morro da Pedra Preta (GSI). Na porção centro-esquerda, observa-se porfiroblasto de biotita $\sin -S_{\text {। }}$ e, na região superior direita, ocorre um agregado porfiroblástico de biotita e magnetita, ambos exibindo sombra de pressão, devido à sobreposição da xistosidade $S_{2}$ marcada pela matriz rica em quartzo e muscovita orientados. Sem analisador. Lado maior 5,5 mm. Amostra do ponto BT 717 . 
Foto G - Grafita-muscovita xisto da Formação Morro da Pedra Preta (GSI). Notar que o quartzo concentra-se em finos veios (metachert?) onde tem granulação relativamente mais grossa. Observar a orientação dos minerais micáceos segundo a foliação $S_{2}$ que está dobrada pela clivagem de crenulação $S_{3}$ gerando até dobras fechadas. Sem analisador. Lado maior $\sim 2,8 \mathrm{~mm}$. Amostra coletada em uma intercalação junto aos metassedimentos tufíticos no afloramento PP $570 \mathrm{~B}$

Foto H - Turmalinito da Formação Morro da Pedra Preta (GSI). Detalhe de um leito essencialmente turmalinítico onde a turmalina apresenta-se zonada em secção basal exibindo o centro verde e borda verde-acastanhada ou verde-escura. Cristais de quartzo e de mineral opaco estão presentes muito subordinadamente. Com analisador. Lado maior $~ 2,8 \mathrm{~mm}$. Amostra do afloramento PP $94 \ldots 247$

\section{PRANCHA 08}

Foto A - Biotita-turmalina xisto intercalado nos metassedimentos tufíticos e xistos pelíticos da Formação Morro da Pedra Preta (GSI). Nas porções superior e inferior observam-se leitos formados essencialmente por turmalina e biotita com quartzo subordinado. No leito central a turmalina se associa essencialmente ao quartzo. Sem analisador. Lado maior $\sim 5,5 \mathrm{~mm}$. Amostra do afloramento PP 593

Foto B - Metarriólito da Formação Morro da Pedra Preta (GSI). Observar fenocristais reliquiares de quartzo bipiramidais com faces retilíneas e/ou corroídas e preenchidas por matriz quartzomicácea. Alguns fenocristais estão recristalizados e se nota a extinção ondulante. A matriz, fina a muito fina, é composta por quartzo, feldspato potássico e plagioclásio recristalizados, além de minerais micáceos orientados segundo a foliação $S_{1}$. Com analisador. Lado maior $\sim 5,5 \mathrm{~mm}$. Amostra do ponto SP 643A.

Foto C - Metarriólito da Formação Morro da Pedra Preta (GSI) exibindo fenocristais de fedspato. O maior deles mostra uma textura granofírica devido ao intercrescimento de feldspato potássico e quartzo, indicando uma origem subvulcânica. Com analisador. Lado maior 5,5 mm. Amostra do ponto CV 818

Foto D - Metapelito calcífero da Formação Nhanguçu (GSI), formado principalmente por muscovita, flogopita, grafita \pm carbonato. Pode-se notar que os cristais de quartzo ocorrem subordinados e estão alongados segundo a foliação $S_{2}$. Na porção superior direita são vistos finos cristais de carbonato concentrados com os de quartzo. Sobrepõe-se à $S_{2}$ uma clivagem de crenulação $S_{3}$. Com analisador. Lado maior $\sim 2,8 \mathrm{~mm}$. Amostra do afloramento SP 484

Foto E - Metapelito calcífero da Formação Nhanguçu (GSI) rico em carbonato. Observam-se intercalações de leitos ricos em carbonato $\sin -\mathrm{S}_{2}$ e outros ricos em quartzo e flogopita também orientados na foliação $S_{2}$. Sem analisador. Lado maior 2,8 mm. Amostra da região central da área do afloramento SP 647 coletada em uma intercalação junto às rochas carbonáticas

Foto F - Rocha calciossilicática da Formação Nhanguçu (GSI). Notar na porção superior a presença de cristais de escapolita (com cores de interferência amarelo e cinza), gerados a partir da alteração do plagioclásio. Nas porções central e inferior ocorrem cristais de tremolita e de diopsídio (cor de interferência cinza). Com analisador. Lado maior 2,8 mm. Amostra do afloramento SP 632 .....

Foto G - Tremolita mármore da base da Formação Nhanguçu (GSI). Observar porfiroblastos de tremolita com forma tendendo a fibrorradiada dispersos em matriz carbonática. Com analisador. Lado maior 5,5 mm. Amostra coletada em um corpo lenticular imbricado tectonicamente na Unidade Metabásica da Formação Morro da Pedra Preta (GSI) no afloramento PJ 879

Foto H - Aspecto geral dos xistos quartzosos da Formação Pirucaia (GSI) formados principalmente por quartzo e biotita. Notar a presença de grãos e grânulos de quartzo com as formas clásticas preservadas porém recristalizados. A orientação da rocha é dada pela isorientação dos cristais mais finos de biotita da foliação $S_{2}$. Com analisador. Lado maior 5,5 mm. Amostra do afloramento TT $881 \mathrm{~B}$ 


\section{PRANCHA 09}

Foto A - Xisto quartzoso da Formação Pirucaia (GSI) formado por quartzo, biotita e muscovita. Notar na porção centro-inferior a foliação $S_{1}$ reconhecida pelo arranjo menos orientado dos cristais de biotita e de quartzo que também são maiores. Na região superior predomina a foliação $S_{2} / S_{m}$ que, mais intensa, trunca os cristais prévios e propicia a cristalização de muscovita, biotita e quartzo mais finos e fortemente orientados. Sem analisador. Lado maior 1,4 mm. Amostra do afloramento TT 526

Foto B - Detalhe dos xistos quartzosos da Formação Pirucaia (GSI), onde se observa biotita e um cristal euédrico de cianita, ambos $\sin -S_{1}$. Notar que a cianita possui uma provável inclusão de rutilo róseo no centro e de mineral opaco na borda. Sem analisador. Lado maior $\sim 0,7 \mathrm{~mm}$. Amostra do ponto TT $881 \mathrm{~B}$

Foto C - Metarcóseo da Formação Morro Doce (GSR). Notar no centro porfiroclasto de plagioclásio com a geminação múltipla preservada e fraturado pela foliação $S_{\mathrm{m}}$. $\grave{A}$ direita, porfiroclasto de feldspato potássico com faces retas indicando pouco transporte. Observar matriz intensamente recristalizada pela foliação milonítica $S_{1} / S_{m}$, onde predominam muscovita e biotita, além do quartzo e plagioclásio subordinados. Cristais maiores de biotita estão presentes junto ao plagioclásio porfiroclástico. São vistos ainda alguns clastos de quartzo. Com analisador. Lado maior 5,5 mm. Amostra do afloramento PJ 17D (região do Morro Doce) .

Foto D - Metarcóseo da Formação Morro Doce (GSR). Notar porfiroclastos euédricos de plagioclásio com a geminação múltipla preservada e fraturados pela foliação milonítica $S_{m}$. $A$ esquerda, observa-se outro porfiroclasto de plagioclásio subarredondado. Os porfiroclastos ocorrem dispersos em uma matriz fina a muito fina rica em biotita com muscovita e quartzo subordinados, orientados segundo a foliação $S_{1} / S_{m}$. Com analisador. Lado maior $\sim 5,5 \mathrm{~mm}$. Amostra do afloramento PJ $17 \mathrm{D}$ (região do Morro Doce).

Foto E - Metarcóseo da Formação Morro Doce (GSR) com porfiroclasto de feldspato potássico na porção superior parcialmente recristalizado em cristais menores nas bordas, mas sendo possível reconhecer a forma reliquiar. No centro, outro porfiroclasto exibe faces euédricas. Os porfiroclastos estão dispersos em uma matriz fina formada por biotita, quartzo (e feldspato recristalizado), muscovita, magnetita e epidoto. Com analisador. Lado maior 5,5 mm. Amostra do afloramento BT 104 (região do Morro do Polvilho)

Foto F - Metarcóseo da Formação Morro Doce (GSR) com porfiroclasto subeuédrico de feldspato (à esquerda) e com fragmento lítico de granitóide (à direita), dispersos em uma matriz fina parcialmente preservada da milonitização, constituída por quartzo e feldspatos recristalizados, com biotita, muscovita e epidoto subordinados. Com analisador, Lado maior $\sim 5,5 \mathrm{~mm}$. Amostra do afloramento BT 100 (região do Morro do Polvilho)

Foto G - Metaconglomerado da Formação Morro Doce (GSR). Obervar, à direita, um fragmento lítico de granitóide com cristais de feldspato semelhantes aos observados como porfiroclastos nos metarcóseos. Notar na porção inferior-esquerda que a matriz é rica em biotita e ocorrem dispersos pequenos clastos de feldspato e de quartzo. Com analisador. Lado maior $\sim 2,8 \mathrm{~mm}$. Amostra do afloramento BT 105 (região do Morro do Polvilho)

Foto H - Metaconglomerado da Formação Morro Doce (GSR). Notar no centro um fragmento lítico de rocha meta-intermediária, provavelmente um metandesito, rico em cristais ripiformes de plagioclásio. $\mathrm{Na}$ borda do fragmento há forte cristalização de epidoto. $\mathrm{Na}$ matriz do metaconglomerado, à direita, observam-se clastos euédricos de feldspato potássico e de plagioclásio. Com analisador. Lado maior $\sim 5,5 \mathrm{~mm}$. Amostra da base do Morro Doce (Túnel do Rodoanel, altura do $\mathrm{km} 22,5$ da Rodovia Anhangïera) 


\section{PRANCHA 10}

Foto A - Metaconglomerado da Formação Morro Doce (GSR) com porfiroclastos euédricos a subeuédricos de plagioclásio e de feldspato potássico, semelhantes àqueles presentes nos metarcóseos e metarenitos arcoseanos das regiões dos morros Doce e do Polvilho. Com analisador. Lado maior 5,5 mm. Amostra do ponto PJ 17A (região do Morro Doce).

Foto B - Clinopiroxênio-tremolita/actinolita da Formação Pirapora do Bom Jesus (GSR). Observar os cristais ripiformes de plagioclásio com geminação simples inclusos em fenocristal de clinopiroxênio denotando uma textura blastofítica. Com analisador. Lado maior $\sim 2,8 \mathrm{~mm}$. Amostra do ponto RP 894A.

Foto C - Aspecto comum dos tremolita/actinolita-clinopiroxênio anfibolitos das formações Estrada dos Romeiros e Piragibu (GSR), Observar restos instáveis de cristais de clinopiroxênio castanhoclaro dispersos em matriz fina constituída principalmente por agregados de cristais de epidoto e titanita. Sem analisador. Lado maior 2,8 mm. Amostra do afloramento CJ 285 (Formação Estrada dos Romeiros)

Foto D - Tremolita/actinolita anfibolito da Formação Estrada dos Romeiros (GSR). Observar porfiroblastos subeuédricos a anédricos de tremolita-actinolita com as extremidades esfiapadas. $\AA$ direita ocorrem cristais de plagioclásio com a forma tabular reliquiar e outros de epidoto granular. Na porção superior podem ser vistos cristais anédricos de titanita parcialmente leucoxenizada. Sem analisador. Lado maior 2,8 mm. Amostra do afloramento JD 152

Foto E - Tremolita/actinolita anfibolito da Formação Estrada dos Romeiros (GSR) contendo porfiroblastos de tremolita/actinolita $S_{1}$ parcialmente alterados para clorita retrometamórfica $S_{2}$. Observar à direita, cristais de plagioclásio não mais geminados inclusos nos porfiroblastos que estão reequilibrados para albita. Com analisador. Lado maior 1,4 mm. Amostra do afloramento $\mathrm{CV} 01$

Foto F - Tremolita/actinolita anfibolito com epidoto da Formação Pirapora do Bom Jesus (GSR) e que também ocorre nas Formações Estrada dos Romeiros e Piragibu. Observar a estrutura maciça e a textura blastosubofítica com cristais de plagioclásio ripiformes preservados. Notar a alteração dos cristais anédricos de tremolita/actinolita para epidoto granular no centro e à direita, e a presença de titanita anédrica. Sem analisador. Lado maior 5,5 $\mathrm{mm}$. Amostra do afloramento VS 412 .

Foto G - Tremolita/actinolita anfibolito (rocha metavulcanoclástica básica) da Formação Pirapora do Bom Jesus (GSR). No centro nota-se um fragmento de rocha (possivelmente intermediária) contendo prismas ripiformes de plagioclásio, em meio a uma matriz de granulação fina rica em cristais de tremolita-actinolita. À direita, ocorre um agregado constituído por clorita e com epidoto no centro, representando possível amígdala recristalizada. Sem analisador. Lado maior $\sim 2,8 \mathrm{~mm}$. Amostra do afloramento VS 373

Foto H - Metarenito feldspático da Formação Boturuna (GSR) formado principalmente por quartzo, feldspato e muscovita. Observar os grãos de quartzo e de feldspato recristalizados e um pouco orientados segundo a foliação $S_{1}$ (de direção NNE-SSW na foto) que também marca a isorientação dos cristais de muscovita. Os clastos de feldspato (cor de interferência cinza) são mais angulosos e concentram-se à esquerda e, um deles, preserva a geminação em grade. Com analisador. Lado maior $\sim 2,8 \mathrm{~mm}$. Amostra do afloramento CV 773 .

\section{PRANCHA 11}

Foto A - Rocha metabásica shoshonítica da Formação Boturuna (GSR). Petrograficamente corresponde a um biotita xisto. Observar aglomerados arredondados (amígdalas) ora preenchidos por quartzo (centro) ora formando uma espécie de corona com quartzo na borda e um núcleo ríco em biotita (esquerda). Notar que a amígdala à direita encontra-se adelgaçada pelas foliações $S_{1} / S_{2}$ superpostas. Com analisador. Lado maior $\sim 5,5 \mathrm{~mm}$. Amostra do afloramento PJ 920B (WSW do Pico do Jaraguá) 
Foto B - Aspecto geral dos quartzitos das formações Boturuna e Estrada dos Romeiros (GSR). Notar a estrutura orientada pela foliação $S_{m}$ que gerou nos cristais de quartzo, recristalização e estiramento. Clastos mais grossos exibem extinção ondulante e podem apresentar cominuição local. Com analisador. Lado maior 2,8 mm. Amostra do afloramento VS 376

Foto C - Aspecto geral dos metarritmitos da Formação Estrada dos Romeiros (GSR). Observar a intercalação de leitos ricos em sericita e que contém quartzo fino subordinado (porções superior e inferior) com leito arenoso contendo grãos arredondados de quartzo e uma matriz composta por quartzo, sericita e mineral opaco. Com analisador. Lado maior $\sim 5,5 \mathrm{~mm}$. Amostra do afloramento CJ 169, de uma intercalação dos metarritmitos na Unidade Metapelítica da Formação Piragibu

Foto D - Quartzonfilito presente nos metarritmitos da Formação Estrada dos Romeiros (GSR). Observar à esquerda, a clivagem de crenulação (de direção $N-S$ ) ortogonal à foliação $S_{1}$. (E-W) $\AA$ direita, a crenulação evolui para uma foliação de transposição $S_{\mathrm{m}}$ com o início da formação de um bandamento diferenciado com lâminas ricas em quartzo e outras ticas em sericita. Com analisador. Lado maior $~ 0.7 \mathrm{~mm}$. Amostra do ponto CJ 274

Foto E - Metarenitos presentes na Unidade Metarritmítica da Formação Estrada dos Romeiros (GSR). Observar a estrutura pouco orientada marcada pelo predomínio de cristais de quartzo com muscovita fina/sericita subordinada. Na parte superior ocorrem raros porfiroclastos de feldspato; no centro e a noroeste podem ser vistos porfiroblastos de clorita (cor de interferência anômala cinza-azulado escura). Com analisador. Lado maior 2,8 mm. Amostra do afloramento CJ $162 \ldots \ldots .255$

Foto F - Metaconglomerado da Unidade Metarrítmica da Formação Estrada dos Romeiros (GSR). Observar a estrutura clasto-suportada com fragmentos de rocha filítica (centro), de metarenito (à direita), de metarenito muito fino (à esquerda, no topo e na base) e de quartzito fino (à esquerda), além de grãos angulosos de quartzo. Matriz composta essencialmente por sericita e quartzo muito fino. Com analisador. Lado maior 5,5 mm. Amostra do afloramento JD 153

Foto G - Rocha metacarbonática da Formação Estrada dos Romeiros (GSR), formada essencialmente por carbonato com sericita e minerais opacos muito subordinados. Observar a foliação $S_{1}$ (direção NE-SW na foto) dada pela isorientação dos cristais de calcita e do mineral micáceo. Alguns porfiroblastos euédricos de pirita indicam crescimento pós- $S_{1}$. Com analisador. Lado maior $\sim 2,8$ mm. Amostra do afloramento VS $916 \mathrm{D}$, próximo do contato das unidades Metacarbonática e Metacálcio-pelítica

Foto H - Ardósia da Formação Piragibu (GSR) com matriz rica em cristais de clorita orientados segundo a foliação $S_{1}$ (NNE-WSW na foto). Notar a presença de grãos de biotita detrítica marrom rotacionados pela foliação $S_{1}$ e em parte reequilibrados para clorita $\sin -S_{1}$. À direita, porfiroclasto maior de muscovita com sombra de pressão parcialmente reequilibrado para clorita $\sin -S_{1}$. Sem analisador. Lado maior $\sim 1,4 \mathrm{~mm}$. Amostra do afloramento JD 20 


\section{CAPÍTULOI}

\section{INTRODUÇÃO}

A geologia dos arredores da cidade de São Paulo tem sido motivo de várias discussões, reflexo das informações colhidas em trabalhos sistemáticos efetuados na escala regional e outros de semi-detalhe realizados nas duas décadas anteriores e continuados, de maneira menos intensa, até os dias atuais. Uma das questões levantadas nesse período refere-se às supracrustais que afloram a NW de São Paulo, consideradas por vários autores como pertencentes ao Grupo São Roque (GSR) latu sensu. Outros, porém, têm admitido a existência de uma sequiência diferenciada quanto ao tipo e grau de metamorfismo, estilo estrutural e paleoambiente, e que seria, em essência, vulcano-sedimentar. Essa sequiência, individualizada do GSR e basal a ele, compreenderia o Grupo Serra do Itaberaba (GSI).

A compartimentação do GSR na região enfocada e do GSI a NE de São Paulo em formações, e as comparações entre suas várias subunidades litoestratigráficas continuam produzindo controvérsias. A possibilidade de individualização desses grupos e a correlação com as formações jấ conhecidas de ambos a partir de levantamentos de perfis regionais e do mapeamento de semidetalhe de algumas áreas, em conjunto com a reinterpretação dos dados existentes com relação à porção a NW de São Paulo, tem sido aventada há alguns anos, e foi motivo da confecção de um projeto de pesquisa enviado à Fapesp.

Essa dissertação é um dos resultados alcançados com a finalização do projeto. Apresenta as discussões litológicas e petrográficas e as algumas características metamórficas dos grupos São Roque e Serra do Itaberaba, além do mapa em escala reduzida confeccionado pelo orientador Prof. Cactano Juliani, em escala 1:25000 e no qual o autor deste trabalho participou como colaborador.

Para uma melhor contextualização da área, o capítulo de trabalhos anteriores inclui também uma revisão sobre as rochas granitóides da Faixa Serra do Itaberaba/São Roque, e que estão representadas no mapa geológico com suas fácies petrográficas individualizadas, resultado da compilação efetuada.

\subsection{OBJETIVOS}

O objetivo principal da dissertação foi separar e caracterizar os grupos Serra do Itaberaba e São Roque na região a NW da cidade de São Paulo, e compartimentar esses grupos, quando possível, em subunidades litoestratigráficas, correlacionando com aquelas já reconhecidas formalmente em ambos.

Para tanto, o trabalho foi precedido por uma revisão dos trabalhos publicados sobre a área (Capítulo II), seguida por uma discussão sobre a litoestratigrafia da Faixa São Roque/Serra do Itaberaba (Capítulo III). A partir do mapeamento efetuado, foram utilizadas as associações litológicas (Capítulo IV), petrográficas (Capítulo V) e metamórficas (Capítulo VI) para demonstrar esta separação. 


\subsection{LOCALIZAÇÃO DA ÁREA E ACESSOS}

A área está localizada na porção NW da região metropolitana da cidade de São Paulo, e se estende um pouco além dos limites da Grande São Paulo. Seu centro dista cerca de $35 \mathrm{~km}$ do centro da capital paulista. A área abrange Santana de Parnaíba e parte dos municípios de São Paulo, Barueri, Cajamar, Pirapora do Bom Jesus, Caieiras, Franco da Rocha, Jandira, Itapevi, Osasco, Carapicuiba, São Roque, Araçarigüama e Cabreúva (FIGURA 1.1). O polígono que delimita a área tem $807,6 \mathrm{~km}^{2}$ e está situado entre os paralelos $23^{\circ} 20^{\prime} 00^{\prime}$ 'S e $23^{\circ} 32^{\prime} 30^{\prime}$ 'S e os meridianos $46^{\circ} 41^{\prime} 15^{\prime \prime} \mathrm{W}$ e $47^{\circ} 03^{\prime} 45^{\prime \prime} \mathrm{W}$.

As principais vias de acesso, partindo de São Paulo, são as rodovias dos Bandeirantes e Anhanguiera, por onde se atinge as regiões centro-leste e norte-nordeste da área. Pela rodovia Castelo Branco tem-se acesso às porções sul e oeste. Das estradas secundárias, destaca-se a dos Romeiros, que liga a última rodovia ao extremo noroeste da área, passando por Barueri, Santana de Parnaíba e Pirapora do Bom Jesus. A Avenida Tenente Marques, a partir da via Anhangüera, corta a região central, serve os bairros do Polvilho e Várzea do Sousa, e atinge o município de Santana do Parnaíba. Outras vias secundárias e uma rede de estradas vicinais em condições regulares a boas recortam o interior da área.

\subsection{MATERIAIS E MÉTODOS}

\subsubsection{Materiais Utilizados}

\subsubsection{Mapas-base}

Foram utilizados nos levantamentos de campo os mapas topográficos em escala 1:10000 que recobrem toda a área, mas também foram usadas as folhas topográficas em 1:50000 para localização regional e reconhecimento das grandes estruturas geomorfológicas. A articulação das folhas nessas escalas pode ser observada na FIGURA 1.2 e nas TABELAS 1.1 e 1.2.

Apesar de estarem relativamente desatualizadas devido à intensa ocupação da região, essas cartas serviram de base para o levantamento dos perfis regionais e do mapeamento de semidetalhe de algumas porções da área e, pelo fato da boa qualidade de suas cópias e da escala em detalhe das últimas, tornou-se desnecessária a utilização de fotografias aéreas nos trabalhos de campo. Na base topográfica 1:10000 foram lançados os pontos descritos em campo.

A digitalização da base topográfica simplificada foi feita a partir das folhas topográficas em escala 1:25000 do Projeto Região Metropolitana da Grande São Paulo, elaborado pela EMPLASA em 1984 (TABELA 1.3). Na base digitalizada foram destacadas uma certa quantidade de cotas topográficas, as drenagens principais e várias menores, as principais vias de acesso, as cidades e algumas localidades. Para a faixa oeste, onde não se dispunha dessas reduções 1:25000, foram utilizadas fotocópias reduzidas das folhas 1:10000, o que implicou em algumas distorções da base topográfica.

O mapa geológico-estrutural foi em parte rascunhado em campo utilizando as plantas 1:10000, sendo posteriormente finalizado em uma fotocópia obtida da montagem das folhas 1:25000 e das reduções em 1:10000 efetuadas para a região oeste. Essa cópia foi usada na digitalização. 


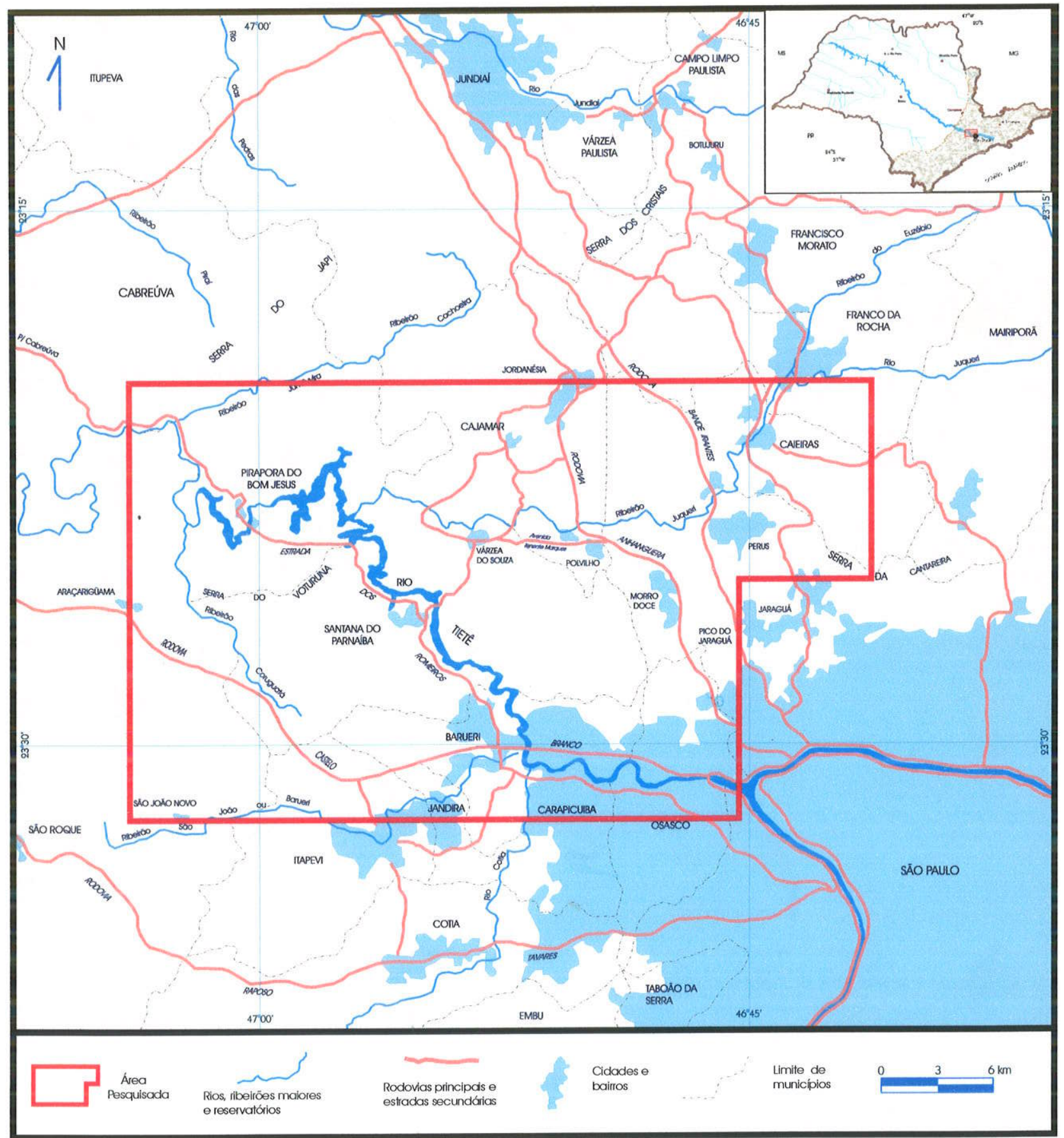

FIGURA 1.1 - Localização da área.

\subsubsection{Fotografias aéreas}

Os foto-pares utilizados pertencem ao levantamento em escala 1:25.000 do Instituto Agronômico da secretaria da Agricultura do Estado de São Paulo, levantados em 1963 pela Aerofoto Natividade Ltda, com sobrevôo leste-oeste. Os números e suas faixas estão listados na TABELA 1.4.

Devido à insuficiência de sobreposição do levantamento em uma faixa nas regiões de Pirapora do Bom Jesus e na Represa de Pirapora, também foram usados foto-pares de um sobrevôo de 1994 com direção norte-sul, executado por BASE Aerofotogrametria e Projetos S.A. (FX 09 e FX 10). 
As fotografias aéreas foram intensamente utilizadas na elaboração do mapa geológico-estrutural, após as reinterpretações dos mapas existentes em função da litologia e das estruturas tectônicas maiores detectadas neste trabalho. Seu uso permitiu correlações mais seguras entre perfis geológicos levantados em campo, por intermédio do uso das texturas, lineamentos de relevo e drenagem, assimetria de relevo e pela definição de zonas homólogas correlacionáveis a unidades geológicas redefinidas.

Essas informações foram muito úteis na separação das unidades metassedimentares do Grupo São Roque, especialmente das formações Piragibu e Estrada dos Romeiros, que podem apresentar afloramentos individuais com litotipos semelhantes. Também foram imprescindíveis na identificação de áreas isoladas de sedimentos terciários da Bacia de São Paulo e para interpretação de zonas de cisalhamento transcorrente e de empurrão, ou de falhas rúpteis mais tardias.

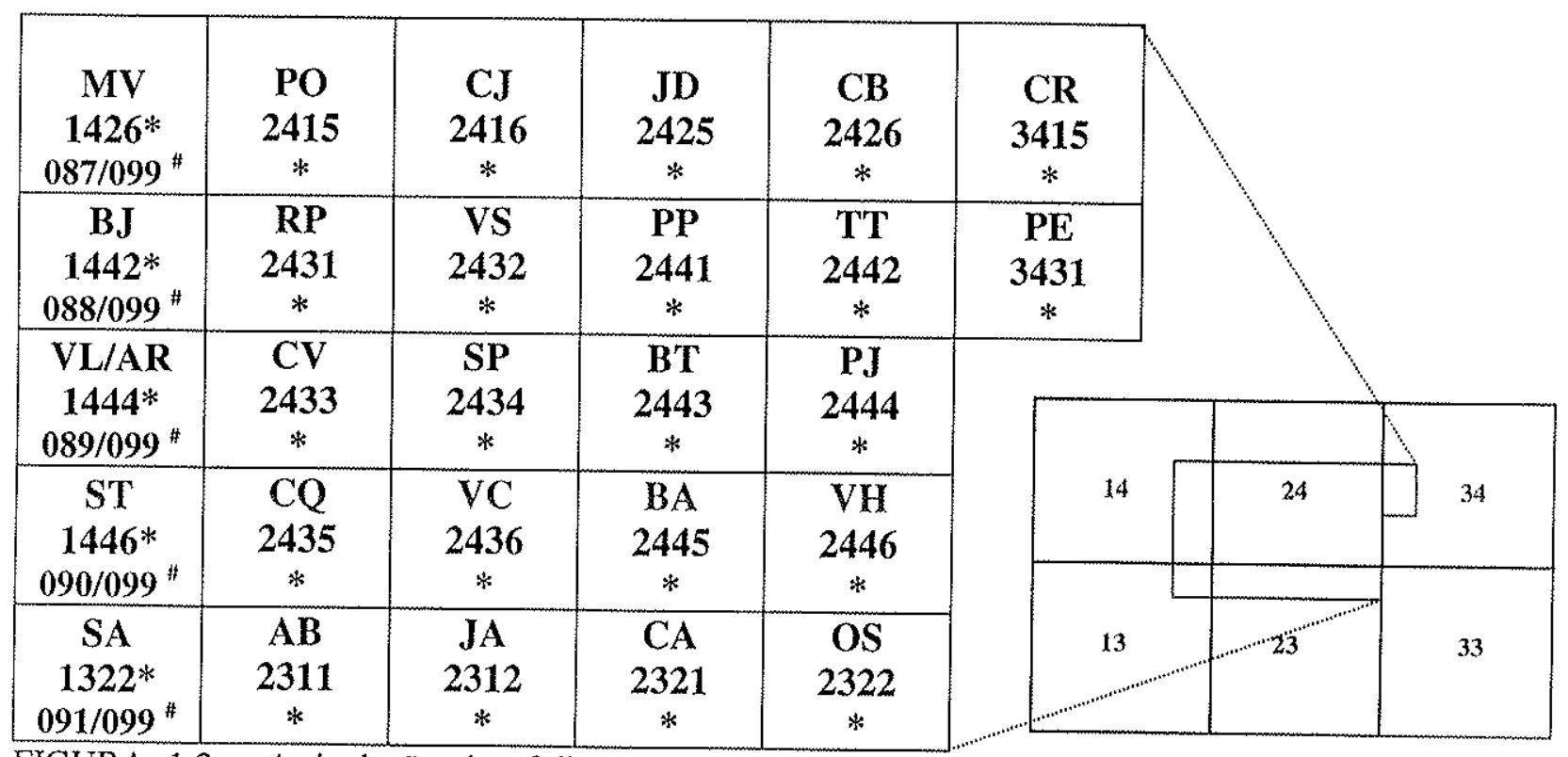

FIGURA 1.2 - Articulação das folhas topográficas 1:10000, à esquerda, e localização nas folhas topográficas 1:50000 correpondentes, à direita. Projeto Região Metropolitana da Grande São Paulo, TERRAFOTO/EMPLASA (*) e Projeto Macro-Metrópole, TERRAFOTO/SEP ( ${ }^{*}$ ).

TABELA 1.1 - Folhas topográficas na escala de 1:50000.

\begin{tabular}{|c|c|c|c|}
\hline Número & Nome & Código & Executor \\
\hline 13 & São Roque & $S F-23-Y-C-V-2$ & IGGSP \\
\hline 14 & Cabreúva & SF-23-Y-C-II-4 & IGGSP \\
\hline 23 & Itapecirica da Serra & SF-23-Y-C-VI-1 & IGGSP \\
\hline 24 & Santana do Parnaíba & SF-23-Y-C-III-3 & IGGSP \\
\hline 33 & São Paulo & SF-23-Y-C-VI-2 & IGGSP \\
\hline 34 & Guarulhos & SF-23-Y-C-III-4 & IGGSP \\
\hline
\end{tabular}

IGGSP - Instituto Geográfico e Geológico de São Paulo 
TABELA 1.2 - Folhas topográficas 1:10000 utilizadas nos trabalhos de campo.

\begin{tabular}{|c|c|c|c|c|}
\hline \multicolumn{5}{|c|}{ Projeto Macro-Metrópole } \\
\hline Número & Sigla & Nome da Folha & Nomenclatura & Executor \\
\hline $087 / 099$ & MV & Morro da Viúva & SF-23-Y-C-II-4-NE-F & TERRAFOTO/SEP \\
\hline $088 / 099$ & BJ & Pirapora do Bom Jesus & SF-23-Y-C-II-4-SE-B & TERRAFOTO/SEP \\
\hline $089 / 099$ & AR & Araçarigüama II & SF-23-Y-C-II-4-SE-D & TERRAFOTO/SEP \\
\hline $090 / 099$ & ST & Fazenda Santo Antônio & SF-23-Y-C-II-4-SE-F & TERRAFOTO/SEP \\
\hline $091 / 099$ & SA & Sabiá & SF-23-Y-C-V-2-NE-B & TERRAFOTO/SEP \\
\hline
\end{tabular}

\begin{tabular}{|c|c|c|c|c|}
\hline \multicolumn{5}{|c|}{ Projeto Grande São Paulo e Baixada Santista } \\
\hline Número & Sigla & Nome da Folha & Nomenclatura & Executor \\
\hline 1322 & SA & Sabiá & SF-23-Y-C-V-2-NE-B & TERRAFOTO/EMPLASA \\
\hline 1426 & MV & Morro da Viúva & SF-23-Y-C-II-4-NE-F & TERRAFOTO/EMPLASA \\
\hline 1442 & BJ & Pirapora do Bom Jesus & SF-23-Y-C-II-4-SE-B & TERRAFOTO/EMPLASA \\
\hline 1444 & $\mathrm{VL}$ & Vila Lolli & SF-23-Y-C-II-4-SE-D & TERRAFOTO/EMPLASA \\
\hline 1446 & ST & Fazenda Santo Antônio & SF-23-Y-C-II-4-SE-F & TERRAFOTO/EMPLASA \\
\hline 2311 & $\mathbf{A B}$ & Amador Bueno & SF-23-Y-C-II-1-NO-A & TERRAFOTO/EMPLASA \\
\hline 2312 & JA & Jandira & SF-23-Y-C-VI-1-NO-B & TERRAFOTO/EMPLASA \\
\hline 2321 & $\mathbf{C A}$ & Carapicuiba & SF-23-Y-C-VI-1-NE-A & TERRAFOTO/EMPLASA \\
\hline 2322 & OS & Osasco & SF-23-Y-C-VI-1-NE-B & TERRAFOTO/EMPLASA \\
\hline 2415 & PO & Ponunduva & SF-23-Y-C-III-3-NO-E & TERRAFOTO/EMPLASA \\
\hline 2416 & CJ & Cajamar & SF-23-Y-C-III-3-NO-F & TERRAFOTO/EMPLASA \\
\hline 2425 & JD & Jordanésia & SF-23-Y-C-III-3-NE-E & TERRAFOTO/EMPLASA \\
\hline 2426 & $\mathrm{CB}$ & Morro dos Cabelos Brancos & SF-23-Y-C-III-3-NE-F & TERRAFOTO/EMPLASA \\
\hline 2431 & RP & Represa de Pirapora & SF-23-Y-C-III-3-SO-A & TERRAFOTO/EMPLASA \\
\hline 2432 & VS & Várzea do Souza & SF-23-Y-C-III-3-SO-B & TERRAFOTO/EMPLASA \\
\hline 2433 & $\mathrm{CV}$ & Capela Velha & SF-23-Y-C-III-3-SO-C & TERRAFOTO/EMPLASA \\
\hline 2434 & SP & Santana do Parnaíba & $\mathrm{SF}-23-\mathrm{Y}-\mathrm{C}-\mathrm{III}-3-\mathrm{SO}-\mathrm{D}$ & TERRAFOTO/EMPLASA \\
\hline 2435 & $\mathrm{CQ}$ & Curuquara & SF-23-Y-C-III-3-SO-E & TERRAFOTO/EMPLASA \\
\hline 2436 & $\overrightarrow{\mathrm{VC}}$ & Vila Califórnia & SF-23-Y-C-III-3-SO-F & TERRAFOTO/EMPLASA \\
\hline 2441 & PP & Parque Panorama & SF-23-Y-C-III-3-SE-A & TERRAFOTO/EMPLASA \\
\hline 2442 & TT & Morro do Titico-Tico & SE-23-Y-C-III-3-SE-B & TERRAFOTO/EMPLASA \\
\hline 2443 & BT & Morro Botucavuru & SF-23-Y-C-III-3-SE-C & TERRAFOTO/EMPLASA \\
\hline 2444 & $\mathrm{PJ}$ & Pico do Jaraguá & SF-23-Y-C-III-3-SE-D & TERRAFOTO/EMPLASA \\
\hline 2445 & BA & Barueri & SF-23-Y-C-III-3-SE-E & TERRAFOTO/EMPLASA \\
\hline 2446 & $\mathrm{VH}$ & Vila Helena Maria & SF-23-Y-C-III-3-SE-F & TERRAFOTO/EMPLASA \\
\hline 3415 & CR & Caieiras & SF-23-Y-C-III-4-NO-E & TERRAFOTO/EMPLASA \\
\hline 3431 & PE & Perus & SF-23-Y-C-III-4-SO-A & TERRAFOTO/EMPLASA \\
\hline
\end{tabular}

TABELA 1.3 - Folhas topográficas 1:25000 usadas na digitalização e confecção do mapa geológico-estrutural.

\begin{tabular}{|c|c|c|c|c|c|}
\hline Número & Código & Executor \\
\hline 142 & SE-23-Y-C-II-4-NE & EMPLASA \\
\hline 144 & SF-23-Y-C-II-4-SE & EMPLASA \\
\hline 231 & SE-23-Y-C-VI-2-NO & EMPLASA \\
\hline 232 & SE-23-Y-C-VI-2-NE & EMPLASA \\
\hline 241 & SE-23-Y-C-III-3-NO & EMPLASA \\
\hline 242 & SE-23-Y-C-III-3-NE & EMPLASA \\
\hline 243 & SE-23-Y-CIII-3-SO & EMPLASA \\
\hline 244 & SE-23-Y-C-III-3-SE & EMPLASA \\
\hline 341 & SE-23-Y-C-III-4-NO & EMPLASA \\
\hline 343 & SE-23-Y-C-III-4-SO & EMPLASA \\
\hline
\end{tabular}


TABELA 1.4 - Fotos aéreas utilizadas. Faixas I a VII (Vôos leste-oeste). Faixas FXs (Vôos norte-sul).

\begin{tabular}{|c|c|c|}
\hline Faixa & Núnero das Fotos & Total \\
\hline I & 905 a 909 e 1720 a 1734 & 20 \\
\hline II & 8712 a 8719 e 1369 a 1357 & 21 \\
\hline III & 8774 a 8778 e 1772 a 1753 & 25 \\
\hline IV & 861 a 856 e 1832 a 1819 & 20 \\
\hline V & 834 a 837 e 1403 a 1394 & 14 \\
\hline
\end{tabular}

\begin{tabular}{|c|c|c|}
\hline Faixa & Número das Fotos & Total \\
\hline VI & 2911 a 2905 e 1776 a 1791 & 23 \\
\hline VII & 2961 a 2964 e 9225 a 9235 & 15 \\
\hline FX 09 & 05 a 09 & 05 \\
\hline FX 10 & 06 a 10 & 05 \\
\hline
\end{tabular}

\subsubsection{Métodos de Trabalho}

Os médotos aqui utilizados podem ser subdivididos em trabalhos preliminares, trabalhos de campo com amostragem sistemática de rochas, análises das amostras coletadas, estudos petrográficos e confecção do mapa geológico.

\subsubsection{Trabalhos preliminares}

Esta etapa contou com uma revisão bibliográfica sobre a geologia da área e arredores, envolvendo principalmente a Faixa São Roque/Serra do Itaberaba e reunindo os principais trabalhos desde o início da década de 1950 até o ano de 1992.

Neste período foram executadas as primeiras visitas à área para o reconhecimento das estruturas maiores e as unidades regionais, a coleta de algumas amostras e o início dos trabalhos petrográficos. Concomitantemente, foi efetuada a compilação dos mapas geológicos existentes da região, principalmente em escala de semidetalhe (FIGURA 1.3). Dessa compilação resultou um rascunho geológico da área, orientativo para a etapa seguinte.

Sempre que possível, foi feita a reinterpretação dos dados existentes para o desenho preliminar a partir do acesso aos originais dos trabalhos de mapeamento executados na região, como cadernetas de campo, fichas de pontos descritos, mapas de pontos, totalizando várias centenas de pontos compilados.

\subsubsection{Trabalhos de campo com amostragem sistemática de rochas}

A sistemática dos trabalhos de campo envolveu a descrição de afloramentos e sua correlação com a litoestratigrafia dos grupos, acompanhada de uma coleta sistemática de amostras frescas ou pouco alteradas para análise petrográfica e caracterização metamórfica.

Nesta fase, foram descritos 1365 pontos, e o total de amostras coletadas e tratadas, de acordo com as propostas formuladas, atingiu cerca de 700. A nomenclatura adotada para os afloramentos descritos foi a de números seqüenciados precedidos pela sigla da folha topográfica 1:10000 (TABELA 1.2). Concomitantemente os pontos compilados eram reavaliados com relação às descrições efetuadas neste trabalho, e as informações integradas transferidas para a base topográfica em escala 1:25000.

A descrição dos afloramentos envolveu a observação das estruturas maiores, como dobras, bandamento e acamamentos, e das foliações, lineações e sobreposição de fases deformacionais, além da caracterização de possíveis estruturas reliquiares, ígneas e sedimentares. Em continuidade, foram 
descritos os litotipos principais e a identificados seus constituintes minerais mais abundantes, bem como seus porfiroblastos.

Foi dada atenção especial à observação dos padrões de alteração dos litotipos, principalmente daqueles do Grupo Serra do Itaberaba, conforme os critérios utilizados por JULIANI (1993), pelo fato da alteração intempérica ser comum na área e estas correlações não serem descritas na região até então.

Ressalta-se que o projeto inicial previa a caracterização do metamorfismo regional dos grupos São Roque e Serra do Itaberaba, a partir da individualização desses grupos segundo perfis regionais. Porém, a dificuldade de integração dos dados prévios existentes e o reconhecimento de vários litotipos do Grupo Serra do Itaberaba na região, exigiu reformulação da hipótese inicial, sendo executado mapeamento com maior densidade de pontos.

\subsubsection{Análise das amostras}

No mesmo período dos trabalhos de campo, as amostras coletadas foram cerradas ortogonalmente à estrutura principal para observação mais detalhada, eventualmente seguida por visualização em lupa binocular CARL ZEISS. Esse tratamento prévio permitiu uma avaliação das estruturas e suas relações com a cristalização de alguns porfiroblastos, além de otimizar dentre amostras semelhantes a escolha da melhor porção para os estudos petrográficos.

\subsubsection{Estudos petrográficos}

Durante os trabalhos de petrografia foram descritas 360 secções delgadas. Com exceção de 14 lâminas referentes aos corpos granitóicles, e que mereceram uma sucinta caracterização, as demais envolvem amostras selecionadas de vários dos litotipos dos grupos São Roque e Serra do Itaberaba. Nessas lâminas, sempre que possível foram identificadas as relações temporais entre as foliações, suas características, os minerais metamórficos e os porfiroblastos, segundo os critérios de BORRAIDAILE et al. (1982), JULIANI (1993) e PASSCHIER \& TROUW (1996).

Para a análise petrográfica foi utilizado o microscópio ZEISS (Standart WL Research Microscope), e as fotomicrografias dessas secções obtidas através do equipamento ZEISS (Axioplan Pol). Foram consultados nos estudos petrográficos, os trabalhos de HIGGINS (1971), WINKLER (1977), TRÖGLER (1979), DEER et al. (1992), MACKENZIE \& GUILFORD (1980), MACKENZIE et al. (1991), YARDLEY et al. (1990) e JULIANI (1993).

\subsubsection{Colaboração na confeç̧ão do mapa geológico-estrutural}

O mapa geológico apresentado (ANEXO II) é uma redução do mapa geológico-estrutural (1:25000) confeccionado pelo Prof. Caetano Juliani e anexado como um dos resultados do Relatório Final do Projeto de Pesquisa enviado à FAPESP (processo 964403/5), sendo que o autor dessa dissertação participou como colaborador. O mapa contém os principais corpos granitóides da região com as fácies 
petrográficas individualizadas com base em informações integradas de diversos mapeamentos, as grandes estruturas já conhecidas e outras descritas durante os trabalhos de campo, e que separam ou afetam os grupos São Roque e Serra do Itaberaba.

O Grupo Serra do Itaberaba teve diversos de seus litotipos reconhecidos na região e, a partir das correlações com a área-tipo do Grupo, foi possivel cartografar várias unidades correlacionáveis às formações Morro da Pedra Preta, Nhanguçu e Pirucaia. No Grupo São Roque, suas formações foram em parte reinterpretadas, além de ser definida uma nova formação na sua base, denominada Morro Doce.

Encontram-se também cartografadas falhas tardias de direção NW-SE, em grande parte não mapeadas anteriormente, e que geram rejeitos de grandezas consideráveis.

No mapa de pontos apresentado (ANEXO III) constam os pontos estudados e os afloramentos com coletas de amostras onde foram efetuados estudos petrográficos. 


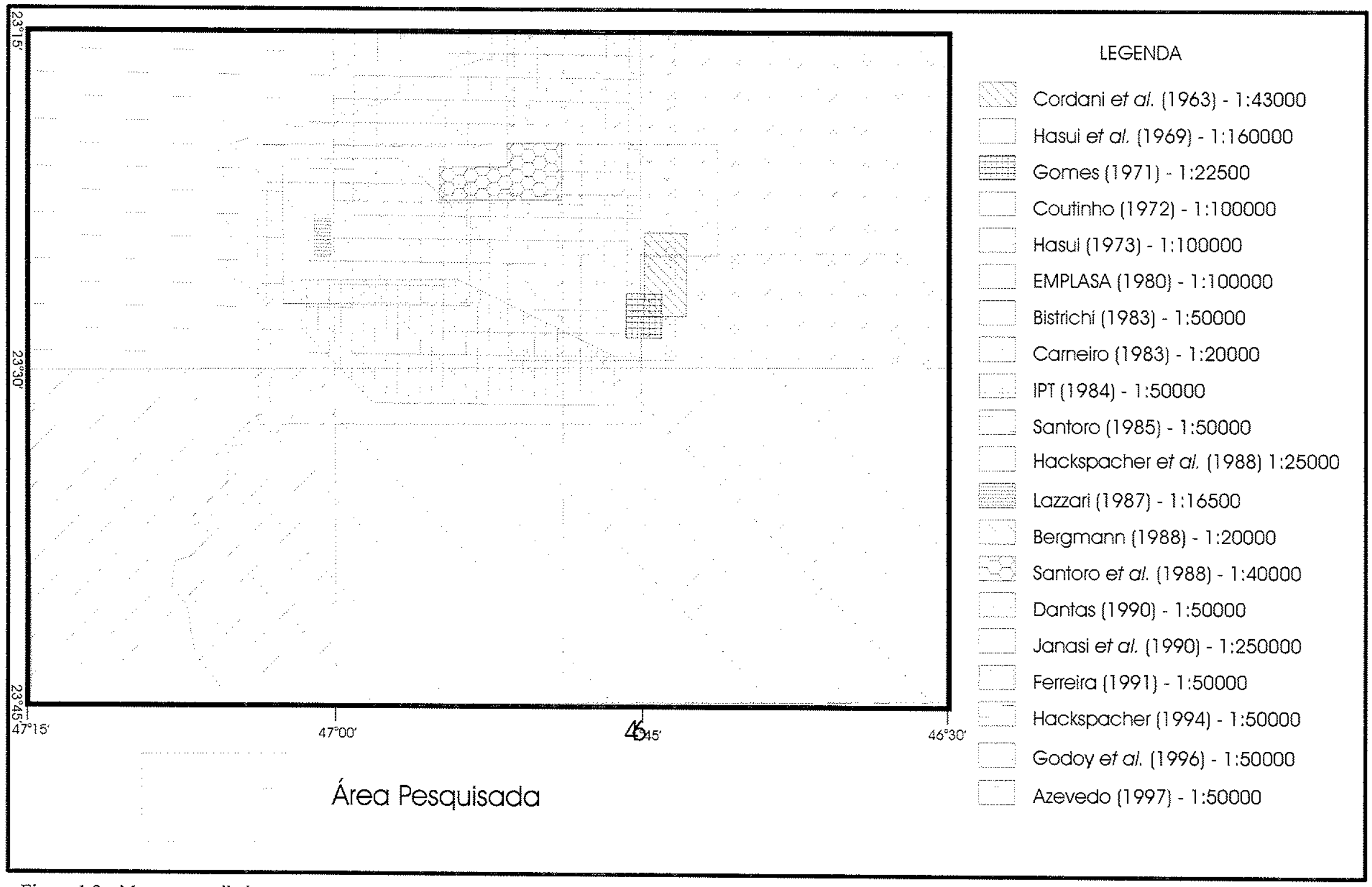

Figura 1.3 - Mapas compilados. 


\section{CAPÍTULO II}

\section{TRABALHOS ANTERIORES}

\subsection{Revisão Bibliográfica}

Algumas revisões das publicações sobre os arredores da cidade de São Paulo já foram feitas com o intuito de sistematizar os resultados de um grande número de pesquisas com enfoques diversos. Dentre elas, a geologia, deformação e estratigrafia dos grupos São Roque, Açungui e Serra do Itaberaba foram revisadas por HASUI et al. (1969), COUTINHO (1972), CARNEIRO (1983), JULIANI et al. (1986), JULIANI (1993) e JULIANI \& BELJAVSKIS (1995).

No que diz respeito às supracrustais, tanto o Grupo Açungui (MARINI et al. 1967), originalmente denominado Série Assunguy por OLIVEIRA (1916), como o Grupo São Roque (LEFEVRE et al. 1963), anteriormente designado Série de São Roque por OLIVEIRA (1925), têm sido objeto de muitos estudos.

Há décadas muitas discussões têm sido feitas sobre as correlações entre os grupos anteriores e, mais recentemente, estas têm se concentrado na separação da unidade vulcano-sedimentar inferior ao Grupo São Roque, denominada Grupo Serra do Itaberaba por JULIANI et al. (1986), e no estabelecimento das idades de deposição e metamorfismo.

Esta pesquisa visa à distinção dos grupos Serra do Itaberaba e São Roque na região noroeste da cidade de São Paulo. Desta forma, a revisão bibliográfica que se segue destacará as contribuições mais significativas para estes estudos.

\subsubsection{Sobre a geologia dos grupos Serra do Itaberaba e São Roque}

Um dos primeiros estudos sobre as rochas metamórficas da região deve-se a MORAES REGO (1930). Neste trabalho, reconheceu que a passagem entre xistos e filitos da então Série de São Roque era gradacional, assim como dos filitos para quartzitos. Posteriormente, reconheceu que os xistos transicionavam para rochas granitizadas e que os gnaisses correspondiam às rochas metassedimentares de mais alto grau metamórfico (MORAES REGO 1932). Considerou ainda que os anfibolitos seriam derivados de calcários.

A primeira identificação de felsitos no Morro do Rosário foi feita por MORAES REGO (1933), quando considerou que o grau metamórfico de metabásicas que gradavam lateralmente para calcários era mais alto e incompatível com o grau metamórfico dos filitos. Esta observação está em acordo com o verificado nesta pesquisa, onde zonas de cisalhamento separam metapelitos da fácies xisto-verde do Grupo São Roque das metabásicas e metatufos da fácies anfibolito do Grupo Serra do Itaberaba, que aflora a sul do Morro do Rosário.

O reconhecimento de estaurolita em xistos com biotita e granada da região de Perus, considerados como produzidos por metamorfismo de contato do granito Cantareira, deve-se a KNECHT 
(1943). Agregados fibrosos de silimanita dos arredores do granito Tico-Tico foram também considerados gerados por metamorfismo de contato por KNECHT (1944b).

Já as rochas metassedimentares dos arredores de São Roque foram caracterizadas como da fácies xisto-verde, zona da clorita, por COUTINHO $(1950,1953)$. A presença de diopsídio em rochas calcárias foi considerada consequiência de desequilíbrios locais causados pela falta de stress. Foram também descritas zonas métricas de hornfels cálcio-silicático feldspatizado.

Uma unidade significativa para individualização dos grupos Serra do Itaberaba e São Roque na região noroeste da cidade de São Paulo são os metaconglomerados que afloram na rodovia Anhangüera. Essa ocorrência foi descrita inicialmente por ODMAN (1955), COUTINHO (1955) e COUTINHO \& TAKEDA (1955). A sequiência estratigráfica foi descrita como composta por metaconglomerado na base que grada para metarcóseo, metagrauvaca com raros leitos de quartzito e fillito. No topo predominam filitos com intercalações de calcário, em seqüência muito semelhante à descrita por JULIANI (1992) no Morro Doce, situado mais a norte da ocorrência da Anhanguiera. Os xistos inferiores foram considerados como representantes de uma unidade mais antiga que os metaconglomerados, identificados como parte do Grupo Serra do Itaberaba por JULIANI et al. (1998). O conjunto sofreu metamorfismo regional na zona da biotita e de contato em grau um pouco mais elevado em auréola bastante restrita no contato com o granito Cantareira.

No corpo anfibolítico de Jaraguá, GOMES (1962) observou que o anfibólio e plagioclásio tornam-se respectivamente mais férricos e cálcicos nas proximidades do granito, tendências essas interpretadas como devidas ao metamorfismo regional da fácies almandina-anfibolito e de contato da fácies hornblenda hornfels.

As semelhanças químicas, texturais e mineralógicas dos anfibolitos do Jaraguá com os doleritos do Karroo levaram GOMES et al. (1964) a caracterizá-los como derivados de rochas ígneas toléticas, apesar da associação com rochas calciossilicáticas e calcários.

Complementando os estudos destas mesmas rochas, GOMES (1971, 1972), GOMES et al. (1972) e GOMES (1973b) concluíram que o plagioclásio teria composição mais sódica nas partes mais afastadas da intrusão granítica e mais cálcica nas proximidades do contato. No mesmo sentido, aumenta o teor de plagioclásio relativamente ao anfibólio. Próximo ao contato, o anfibólio de composição mais actinolítica foi gradativamente substituído por hornblenda zonada, com núcleo actinolítico, indicando que não foi alcançado o equilíbrio químico causado pelo aumento da temperatura. Retrometamorfismo na transição das fácies xisto-verde/anfibolito foi observado pela substituição das paragêneses de mais alta temperatura pela paragênese albita-epidoto-hornblenda. Esses trabalhos foram pioneiros na caracterização do quimismo dos minerais em função do metamorfismo, mas somente mais recentemente estudos semelhantes foram retomados (SOUZA et al. 1996a).

HENNIES et al. (1967) foram os primeiros pesquisadores a identificar as grandes falhas 
transcorrentes de Taxaquara e de Pirapora. Caracterizaram ainda cataclasitos de estrutura mortar, flasergranitos ou flaser-gnaisses, milonitos porfiroclásticos, filonitos e milonitos homogêneos.

O início dos estudos petrográficos do metamorfismo regional e de contato que afetam os litotipos da região é devido a COUTINHO (1968a), que caracterizou os metamorfitos da região de São Paulo como muito semelhantes aos da série facial de New Hampshire que, tipicamente, não apresentam cianita e a silimanita surge na zona da estaurolita, ou imediatamente após esta zona, e possui almandina associada.

COUTINHO (1971) considerou que, a norte da capital paulista, as rochas metassedimentares foram depositados da base para o topo como uma sequiência pré-flysch, com conglomerados, arcóseos e grauvacas seguidos por rocha básicas e por sequiência flysch, representada por arenitos e folhelhos, com uma fase deposicional em ambiente calmo, com argilas e calcários. Essa sequiência é, em essência, a mesma identificada nesta pesquisa, e corresponde às principais unidades sedimentares do Grupo São Roque sensu strictu (JULIANI 1992).

Os zoneamentos metamórficos regionais da área em estudo, incluindo as zonas da biotita, da almandina, da estaurolita e da silimanita, foram esboçados pela primeira vez por COUTINHO (1972). O autor constatou também que na auréola de contato do granito Tico-Tico as paragêneses indicam súbito aumento de temperatura, que teria aproximado e misturado as isógradas regionais junto à intrusiva. Em sedimentos de corrente, identificou a presença rara de cianita e de andaluzita, esta somente na auréola de contato, o que sugere a existência de metamorfismo barrowiano na região, posteriormente identificado como característico do Grupo Serra do Itaberaba por (JULIANI et al. 1986, JULIANI 1993).

Ao apresentar os resultados do mapeamento das folhas Pilar do Sul e São Roque, HASUI (1973) considerou que as rochas metassedimentares dos blocos Cotia e São Roque seriam análogas e com metamorfismo regional crescente de NW para SE. Nos blocos São Roque e Ituparanga, constatou que as rochas metassedimentares possuem o acamamento dobrado, com xistosidade plano-axial, enquanto que nos blocos Cotia e Juquitiba as mesmas dobras afetam o acamamento paralelizado a uma xistosidade. Mesmo admitindo evoluções estruturais distintas, considerou que os litototipos dos diversos blocos pertenceriam ao Grupo Açungui, abandonando a nomenclatura de Grupo São Roque para as supracrustais.

HASUI (1975a) reconsiderou algumas das conclusões anteriores ao admitir que as similaridades litológicas, geocronológica, metamórfica e magmática verificadas na região não eram argumentos suficientes para considerar os grupos São Roque e Açungui como uma mesma unidade litoestratigráfica. Assim, baseado nas evoluções estruturais distintas, definiu o Conjunto Paranapiacaba, que encerraria o Grupo Açungui, com uma fase de deformação primordial com dobras recumbentes cerradas que não ocorreriam no Conjunto São Roque. Nesse conjunto, retomou o uso do termo Grupo São Roque e admitiu a deposição das sequiências sedimentares em zonas diferentes ou mesmo em depressões distintas 
colocadas lado a lado por falhamentos posteriores.

Através de dados geológicos, petrológicos, geoquímicos e de Sr de calcários dos grupos Açungui e São Roque, BETTENCOURT \& WERNICK (1976) consideraram que, na região de Pirapora do Bom Jesus, a deposição ocorreu em ambiente litorâneo a nerítico, oxigenado, de profundidade variável.

A sedimentação terrígena inferior do Grupo São Roque, seguida por lentes mal desenvolvidas de rochas carbonatadas recobertas por outra seqüência terrígena, foi subdividida por HASUI et al. (1976) nas seguintes unidades: Formação Boturuna, com as melhores exposições entre Pirapora do Bom Jesus e Araçarigüama, composta por filitos e intercalações de quartzito na parte basal e rochas carbonatadas no topo; e Formação Piragibu, superior, de caráter flyschóide, que comporia uma sequiiência de filitos rítmicos ou alternâncias de filito e de quartzito, melhor caracterizada na região homônima ou às margens da represa de Pirapora do Bom Jesus.

FIGUEIREDO et al. (1982) descreveram a ocorrência de estruturas tipo pillow-lavas nos metabasitos de Pirapora do Bom Jesus, que indicaria a presença de uma sequiência vulcanomsedimentar com derrames submarinos no Grupo São Roque. Suas formas, com pedúnculo para baixo, e a pouca deformação superposta marcariam relações de topo e base em posição original.

BISTRICHI (1982) relacionou a estruturação do Sinclinório de Pirapora do Bom Jesus à segunda fase deformacional que afeta a região, representada por dobras com clivagem de crenulação plano-axial de eixos suborizontais, que afeta uma clivagem ardosiana anterior, subparalela ao acamamento reliquiar. A terceira fase teria flexionado o eixo do Sinclinório, com sua direção variando de N60E para E-W à medida que se desloca para leste, delineando uma macro-estrutura em arco com mergulho para o seu interior. Com relação à última fase, sugeriu relação com as intrusões dos maciços graníticos do Itaqui e São Roque e com falhas transcorrentes, como as de Araçariguiama, na borda oeste do Maciço São Roque, e do Morro Grande, que afeta a porção sudeste do stock do Ponunduva.

CARNEIRO (1983) e CARNEIRO et al. (1984a) definiram quatro grandes pacotes litológicos no Grupo São Roque a noroeste da cidade de São Paulo, constituídos por metapsamitos impuros, metapelitos, metamargas e prováveis metatufos, e metarenitos rítmicos. Das três fases principais de deformação identificadas, a primeira seria pouco freqüente e marcada por clivagem ardosiana ou xistosidade plano-axial, enquanto que a segunda teria levado ao desenvolvimento da maioria das mesoestruturas do grupo, produzindo clivagem de crenulação fina a microscópica, e a terceira seria responsável pelas amplas ondulações configuradas nos mapas geológicos. Descreveram ainda corpos descontínuos de metavulcânicas básicas amigdaloidais em meio aos metarcóseos da unidade de metapsamitos impuros, e a ocorrência de rochas metassubvulcânicas riodacíticas na região do Morro do Polvilho, reportando-as como atividade ígnea sin-tectônica.

BERGMANN \& FAIRCHILD $(1985$, 1986) caracterizaram as estruturas estromatolíticas da regiáo de Pirapora do Bom Jesus como bioermas grosseiramente estratificadas e como blocos e 
fragmentos em uma brecha dolomítica, interpretada como um tálus de recife estromatolítico. As bioermas associam-se com rochas básicas efusivas subaquáticas, em ambiente deposicional de águas rasas, mornas, agitadas e límpidas, com recifes estromatolíticos em torno de centros eruptivos.

A individualização do Grupo Serra do Itaberaba foi proposta por JULIANI et al. (1986) na região das serras do Itaberaba e da Pedra Branca, a nordeste da cidade de São Paulo. Foi posicionado no Ciclo Transamazônico, e o Grupo São Roque no Ciclo Brasiliano.

BERGMANN (1988) subdividiu o Grupo São Roque na região de Pirapora do Bom Jesus nas formações Pirapora, basal, composta por metabasitos com pillow-lavas e possíveis rochas piroclásticas básicas, além de um Membro Carbonático, com cálcio-filitos e metadolomitos; Estrada dos Romeiros, constituída por um Membro Arenoso e um Membro Pelítico superior; e Boturuna, sobreposta e em contato brusco a transicional com a formação anterior, formada por um Membro Arcoseano, dois membros vulcânicos e um Membro Ortoquartzítico.

Quanto aos ambientes geológicos, admitiu para a formação basal as propostas de BERGMANN \& FAIRCHILD (1986), enquanto que na Formação Estrada dos Romeiros as estruturas sedimentares como acamamento ondulado, lenticular e climbbings indicariam ambiente de sublitoral com águas rasas para os metarenitos. Para a ciclicidade dos dois membros da formação, com sedimentação desde grossa até fina, sugeriu proximidade de zona de transição, com ao menos um evento transgressivo generalizado. Na Formação Boturuna, o caráter vesiculado das rochas vulcânicas indicaria ambiente de águas rasas, corroborado pela presença de metarcóseos, de provável ambiente costeiro. Os ortoquartzitos poderiam representar sedimentação em uma barra de praia, mas não descartou a hipótese, menos provável, de transição para dunas costeiras.

BERGMANN (1991, 1992) redefiniu as formações propostas por BERGMANN (1988) em três uniclades litoestratigráficas. O Grupo São Roque seria composto pela Unidade Vulcano-sedimentar Basal, relacionada à Formação Pirapora, enquanto a Unidade Clástica Turbidítica Superior representaria a Formação Estrada dos Romeiros, no entanto depositada em um ambiente marinho profundo. A Formação Boturuna foi renomeada Unidade Clástica Alóctone, e essa cavalgaria a unidade turbidítica.

HACKSPACHER et al. (1991a) analisaram as estruturas dos grupos Itapira, São Roque (GSR), Embu e dos granitóides associados das folhas Cabreúva e São Roque, e concluíram que a tectônica dúctil que afetou os mátmores e metapelitos do Grupo São Roque correlaciona-se com $D_{n+3}$, e forma dobras com comprimento de onda e amplitudes métricas e intensa foliação de superfície axial $\left(S_{n+3}\right)$ subvertical e de direção NE. Lineações de intersecção $S_{0} \times S_{3}$ suborizontais de direção NE são freqüentes, enquanto que as lineações de estiramento mineral mostram-se paralelas e formadas a partir de alinhamento de cristais de carbonato em sombra de pressão de pirita. Analisaram ainda a tectônica rúptil-dúctil nos metarritmitos da Formação Estrada dos Romeiros, que apresentam estratificação gradacional verticalizada N-S, com topo para leste, e dobras verticais assimétricas formadas a partir de um sistema de clivagem de fratura, 
onde as estruturas predominantemente compressivas estariam relacionadas à fase $\mathrm{D}_{\mathrm{n}+3}$ em sua expressão progressiva tardia (história transcorrente), com transporte transcorrente horário. As dobras foram consideradas expressão de uma história transpressiva na qual os deslocamentos são heterogêneos ao longo da foliação vertical.

Os metabasitos do Pico do Jaraguá, Pirapora do Bom Jesus e Araçarigüama foram estudados por BATISTA et al. (1991), que identificaram características químicas limítrofes entre a cálcio-alcalina e toleíítica no diagrama AFM e com tendências komatíticas e de cadeias mesoceânicas. BATISTA (1991) considerou que os metabasitos de características komatíticas poderiam ter sido formados, em função do diagrama discriminante utilizado, em greenstone belt, arcos insulares ou em cadeia mesoceânica.

Ao analisar as seqüências metavulcano-sedimentares presentes em vários blocos geotectônicos dos arredores de São Paulo, separados por zonas de cisalhamento, JULIANI (1992) as considerou correlatas, mas expostas em níveis crustais variados. Essas sequiências, representadas a norte da Falha de Jundiuvira pelo Grupo Itapira e a sul da Falha de Taxaquara pelo Complexo Embu, compreendem litotipos de mais alto grau metamórfico que aqueles expostos no Grupo Serra do Itaberaba.

No Bloco Juquitiba, VIEIRA et al. (1992) verificaram que os "Xistos Santa Rita" e as rochas calciossilicáticas apresentam paragêneses indicativas da fácies anfibolito em pressão intermediária, situando-se entre $575-700^{\circ} \mathrm{C}$, a aproximadamente $5,5 \mathrm{kbar}$, sendo que o grau metamórfico diminuiria gradativamente em direção aos filitos rítmicos. A essa fase seguiu-se um evento metassomático que cristalizou muscovita, silimanita fibrosa e turmalina, relacionados com fluidos residuais magmáticos, e um evento retrógrado entre 300 e $600^{\circ} \mathrm{C}$, a pressões inferiores a 5,5 kbar. Toda essa evolução é muito semelhante à definida por JULIANI (1993) na Serra do Itaberaba, reforçando as correlações litoestratigráficas anteriormente feitas por JULIANI (1992).

HACKSPACHER et al. (1992a) apresentaram o mapearnento da porção oeste da Folha de Cabreúva em 1:25.000, onde aflora o Granito Subalcalino de Itu, intrusivo no Grupo Itapira, e os granitóides Sorocaba e São Roque, intrusivos no Grupo São Roque. As rochas metassedimentares que compõem este grupo são imaturas, com interestratificação entre filitos, metassiltitos e metarenitos feldspáticos impuros finos a grossos, localmente com seixos. Subordinadamente, ocorrem muscovitabiotita xistos a muscovita-quartzo xistos com ou sem granada, quartzitos pouco feldspáticos, rochas básicas (geralmente associadas ao domínio dos filitos), filitos grafitosos e hornfels de metarenitos e filitos com porfiroblastos de muscovita e biotita no contato do Granito São Roque, assim como andaluzita, cordierita, feldspato e coríndon. O Grupo Itapira é constituído por unidades de granada-biotita gnaisses e xistos, quartzitos, anfibolitos, ortognaisses e migmatitos. As rochas do Grupo São Roque foram metamorfizadas na fácies xisto-verde, zona da biotita, exceto a faixa de xistos a sul da Falha de Moreiras, que está na zona da granada, com o clímax $\sin -\mathrm{D}_{2}$, e o Grupo Itapira na fácies anfibolito alto, a pressão inferior a $7 \mathrm{kbar}$, como indicado pela presença de cordierita. $\mathrm{O}$ ambiente deposicional do Grupo 
Itapira foi considerado como marinho, com magmatismo inicial toleí́tico e cálcio-alcalino pré- a sintectônico, e seu metamorfismo deu-se, provavelmente no Proterozóico Inferior. No Grupo São Roque as estruturas sedimentares preservadas sugerem seqüências C, D, E de Bouma, mais típicas de turbiditos distais, e a intrusão dos granitóides associa-se ao evento deformacional $\mathrm{D}_{n+3 .+}$.

Na Folha Pirapora (1:25000), HACKSPACHER et al. (1992b) descreveram o Grupo Serra do Itaberaba como formado por mármores e xistos cálcio-silicáticos, que gradam para xistos com intercalações de metabasito e de quartzito metamorfizados na fácies xisto-verde, com biotita, granada e fibrolita. Detectaram ainda ao redor do Maciço Tévere uma auréola de metamorfismo de contato que afeta as rochas metassedimentares do Grupo Serra do Itaberaba.

Na Folha Japi (1:25.000), OLIVEIRA et al. (1992a) mapearam, a norte da Zona de Cisalhamento Itu-Jundiuvira, o Grupo Itapira, com as formações Ermida, composta por granada-biotita xistos, gonditos e anfibolitos parcialmente migmatizados; Japi, contendo predominantemente quartzitos feldspáticos e muscovita quartzitos, além de gnaisses, calciossilicáticas e anfibolitos; e Jundiuvira, no topo, com biotita-granada xistos e granada-biotita gnaisses. Reconheceram também o Grupo Serra do Itaberaba, constituído por metapelitos e metapsamitos com biotita, granada e fibrolita. No Grupo São Roque, aparentemente depositado em conformidade, observaram metassiltitos e metarritmitos pelíticos da Formação Estrada dos Romeiros.

Ao apresentar os dados do levantamento geológico da Folha São Roque (1:50.000), OLIVEIRA et al. (1992b) consideraram que o alojamento dos granitóides proterozóicos foi controlado tectonicamente e caracterizaram diversos tipos petrográficos, porfiróides, equi- a inequigranulares, de composições predominantemente monzo- a sienograníticas, como componentes dos maciços São Roque, Ibiúna e Caucaia. No Complexo Embu, observaram rochas metassedimentares migmatizadas com auge metamórfico em condições intermediárias da fácies anfibolito. O Grupo São Roque/Serra do Itaberaba foi representado como indiviso e formado por um pacote de rochas metavulcano-sedimentares metamorfizado na fácies xisto-verde (zonas da biotita e da granada), com predomínio de metarritmitos, metassiltitos, filitos, rochas calciossilicáticas e metabásicas.

A petrotrama de quartzo e feldspato ao longo da Zona de Cisalhamento Jundiuvira na folha Cabreúva foi estudada por HACKSPACHER et al. (1991b, 1993b). Amostras do Granito Itu e de quartzitos do Grupo Itapira mostraram a maioria das microestruturas com indicação de movimentação dextral. As temperaturas obtidas pelas texturas dos feldspatos estão entre 430 e $500^{\circ} \mathrm{C}$ e por volta de $290^{\circ} \mathrm{C}$ para o quartzo, devido à sua recristalização. Desta forma, o clímax da deformação dúctil desenvolveu-se sob condições semelhantes à da fácies xisto-verde (máx. $500^{\circ} \mathrm{C}$ ), em profundidades entre 12 e $15 \mathrm{~km}$, e a deformação rúptil a profundidades entre 4 e $6 \mathrm{~km}$.

O Grupo Serra do Itaberaba na sua área-tipo foi subdividido por JULIANI $(1993,1994,1997)$ nas formações Morro da Pedra Preta, vulcano-sedimentar e basal; Nhanguçu, com xistos manganesíferos, 
rochas calciossilicáticas e carbonáticas e xistos com andaluzita, com turmalinitos com texturas indicativas de meta-evaporitos, e; Pirucaia, essencialmente constituída por quartzito e xistos quartzosos. O Grupo São Roque, colocado tectonicamente sobre o Grupo anterior, está representado por metarritmitos da Formação Piragibu.

As supracrustais do Bloco São Roque foram consideradas por HACKSPACHER et al. (1993a) como evoluídas a partir da distensão de uma crosta transamazônica, com a sedimentação e vulcanismo do Grupo Serra do Itaberaba, seguida pela deposição de unidades rítmicas distais, siltosas a arenosas, com vulcânicas básicas a ácidas e margas do Grupo São Roque, ambos afetados por metamorfismo e deformação distintos, em razão dos níveis crustais de profundidades diferentes. Os dados estruturais sugerem a existência de dois pulsos durante o fechamento da bacia, sendo que no primeiro deles desenvolveram-se as fases $D_{n+1} /+2$ tangenciais, associadas ao início do processo colisional em níveis crustais diferenciados para os dois grupos, com maiores intensidades no Grupo Serra do Itaberaba, possivelmente em 1,3 Ga. Progressivamente foram formadas as estruturas $\mathrm{D}_{\mathrm{n}+3}$, associadas à colocação dos granitos São Roque e Sorocaba, sin-colisionais e sin-transcorrentes, que alçaram as isógradas de metamorfismo do grupo basal.

Lentes de marunditos associadas a anfibolitos com cordierita, granada e cummingtonita, rochas calciossilicáticas e turmalinitos da unidade vulcanomsedimentar inferior do Grupo Serra do Itaberaba foram descritos por MARTIN \& JULIANI (1994) e JULIANI et al. (1994). São rochas muito finas, compostas por coríndon, margaritamuscovita e rutilo, com relíquias de texturas sedimentares e vulcanoclásticas, consideradas como originadas pelo metamorfismo em grau médio de hidrotermalitos de rochas básicas a intermediárias enriquecidos em caulinita, pirofilita e andaluzita

Nas regiōes de Cabreúva e Sorocaba ocorrem rochas metassedimentares clásticas e carbonáticas pertencentes às formações Pirapora, Estrada dos Romeiros e Boturuna, com corpos de metabasitos associados aos xistos, que foram objeto de estudos por OLIVEIRA et al. (1994). Os metabasitos apresentam características químicas de basaltos de baixo Ti e $\mathrm{K}$ em alguns diagramas, e de toleítos subalcalinos em outros, que podem ter sido originados em margens de placas convergentes ou em fundo oceânico, em zonas divergentes.

HACKSPACHER et al. $(1994,1996)$ descreveram a geologia da Folha Cabreúva, onde o Complexo Itapira pôde ser subdividido nas formações Hermida, Japi e Jundiuvira, dispostas sobre ortognaisses graníticos a tonalíticos, migmatitos e raros anfibolitos. A sul da Zona de Cisalhamento ItuJundiuvira ocorrem os grupos Serra do Itaberaba e São Roque. O primeiro seria basal e composto por metapelitos, frequientemente grafitosos, metacalcários, metapsamitos e metabasitos de médio grau metamórfico, aflorantes entre os maciços granitóides São Roque e Itaqui. O Grupo São Roque é tectonicamente discordante do Complexo Itapira, tem baixo grau metamórfico e é constituído por uma seqüência metavulcano-sedimentar basicamente clástica e com menor porcentagem de químicos e 
intrusivas básicas. Os autores adotaram para o Grupo São Roque a subdivisão de BERGMANN (1988), com modificações na sucessão das formações, onde a Formação Estrada dos Romeiros seria basal e composta por metarritmitos, metarenitos, e metassiltitos, filitos e filitos grafitosos; a Formação Voturuna seria intermediária e composta por metassiltitos e quartzitos; e a Formação Pirapora estaria no topo e seria composta por metabásicas e metacalcários. Nos metassiltitos da Formação Voturuna, encaixados na parte central da Sinforma de Pirapora do Bom Jesus, observaram raras estratificações cruzadas com o topo em posição normal.

Na região de Sorocaba e arredores afloram rochas metassedimentares do Complexo Embu, metabásicas do Grupo Serra do Itaberaba, rochas metavulcano-sedimentares do Grupo São Roque, rochas granitóides dos maciços Sorocaba, São Francisco e Pirapora e rochas sedimentares da Bacia do Paraná (GODOY et al. 1994, 1996a). O Grupo Serra do Itaberaba sofreu metamorfismo sob condições de fácies anfibolito, enquanto que o Grupo São Roque atingiu a fácies xisto-verde, com clímax metamórfico alcançado na fase $D_{n+2}$ e retrometamorfismo na $D_{n+3}$. As formações do Grupo São Roque são correlatas às de BERGMANN (1988), mas a sequiência estratigráfica é distinta, com a Formação Estrada dos Romeiros na base (metarritmitos grossos e médios a finos, metarenitos, filitos, metassiltitos e metabasitos); a Formação Voturuna intercalada na anterior, e a Formação Pirapora no topo, com rochas metassedimentares pelito-psamíticas e metacalcários calcíticos, cálcio-filitos e rochas calciossilicáticas. A presença de calcários oolíticos, pisolíticos e oncolíticos indica sedimentação em águas salgadas quentes e relativamente agitadas de zonas de intermarés ou proximais. A evolução tectonometamórfica deu-se há $1300 \mathrm{Ma}$, com a deformação progressiva $D_{n+1 / 22}$, associada ao processo colisional, com transporte provável para SE e metamorfismo $M_{n+1 /+2}$ em fácies de xisto-verde baixa a média. De 800 a $500 \mathrm{Ma}$ a deformação foi contínua $\mathrm{D}_{\mathrm{n}+3}$, em início transtensiva, com ascensão magmática e associada à atual estruturação dos granitos brasilianos sin-colisionais, a transcorrente/transpressiva, com formação de dobras apertadas, foliação milonítica vertical de tectônica dúctil-rúptil (NE-SW) representada na área pela Zona de Cisalhamento Moreiras com movimentos basicamente horários. Para norte, devido à acomodação das rochas graníticas, o esforço é transpressivo, assumindo caráter dúctil com ondulações abertas a suaves e orientações principais NE-SW e tênue foliação subvertical em condições de fácies xisto-verde de caráter retrometamórfico. Nos maciços Sorocaba e São Francisco foram descritas auréolas de metamorfismo de contato com até 500 metros de espessura, onde afloram metarenito das fácies albita hornfels, homblenda hornfels e piroxênio hornfels, nas quais são comuns porfiroblastos de biotita, cordierita e andaluzita.

HACKSPACHER (1994) e GODOY et al. (1996b) também reconheceram no Grupo São Roque as formações definidas por BERGMANN (1988), contudo adotaram para a seqüência estratigráfica a Formação Estrada dos Romeiros na base, a Formação Boturuna intercalada à anterior, e a Formação Pirapora no topo. 


\section{CAPÍTULO III}

\subsection{Contexto Geotectônico}

As rochas supracrustais dos grupos São Roque e Serra do Itaberaba (JULIANI et al. 1986) inserem-se no contexto geotectônico dos Paraibides de EBERT (1967, 1971), denominado de Cinturão Ribeira por ALMEIDA et al. (1973). Essas supracrustais compõem, junto com o Grupo Açungui, o Sistema de Dobramento Apiaí (ALMEIDA et al. 1973) ou, respectivamente, as faixas de dobramentos São Roque e Açungui (HASUI et al. 1975, HASUI et al. 1978a), e situam-se, de acordo com ALMEIDA \& HASUI (1984) na Província Mantiqueira. Compreendem parte do Sistema de Dobramentos Sudeste (ALMEIDA et al. 1976, SCHOBBENHAUS FILHO et al. 1984), que limita-se, a norte-noroeste, com o Maciço Mediano de Guaxupé e o Cráton do São Francisco, a oeste, com as rochas sedimentares da Bacia do Paraná, e a leste é limitado pelo Oceano Atlântico (FIGURA 3.1).

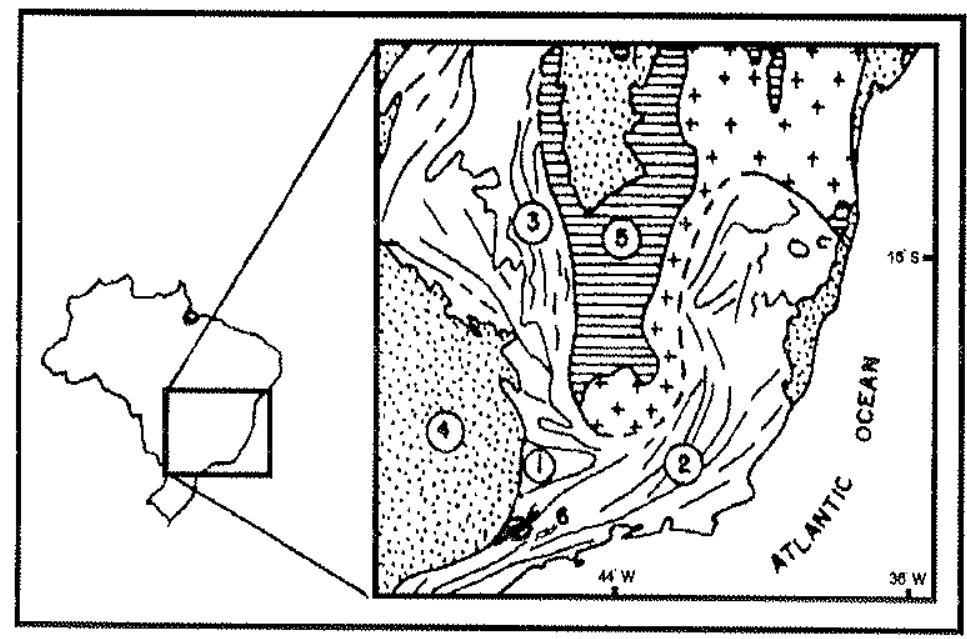

FIGURA 3.1 - Contexto Geotectônico do sudeste brasileiro, incluindo a Faixa São Roque/Serra do Itaberaba, Onde (1) Maciço Mediano de Guaxupé, (2) Sistema de Dobramentos Sudeste/Ribeira, (3) Faixa de Dobramentos Brasília, (4) Bacia do Paraná, (5) Cráton do São Francisco, (6) Faixa São Roque/Serra do Itaberaba, e localização da área pesquisada no círculo preto. Baseado em SCHOBBENHAUS FILHO et al. (1984).

Vários trabalhos compartimentam o Pré-Cambriano paulista em grandes blocos tectônicos, justapostos por zonas de cisalhamento transcorrentes com intensa movimentação horizontal, pressupondo histórias geológicas distintas. Neste contexto, as rochas dos grupos São Roque e Serra do Itaberaba, na área de estudo, integram o Bloco São Roque (HASUI et al. 1969) ou o Bloco Santana do Parnaíba do Conjunto São Roque (CAMPOS NETO \& BASEI 1983b).

O limite norte do Bloco São Roque faz-se através das zonas de cisalhamento de Itu (HASUI \& SADOWSKI 1976) e Jundiuvira (HASUI et al. 1969), onde encontra-se em contato com o Bloco Jundiaí, enquanto a sul é demarcado pelas zonas de cisalhamento de Taxaquara (HENNIES et al. 1967), Rio Jaguari e Monteiro Lobato (CAVALCANTE \& KAEFER 1974), justapondo-se com o Bloco Cotia.

Nos últimos anos, outros autores (HACKSPACHER et al. 1989, DANTAS 1990, JULIANI 1992) têm sugerido ou verificado continuidades litológicas, estruturais e estratigráficas, postulando uma 
MORALES et al. (1995a, b) estudaram os efeitos da Zona de Cisalhamento Taxaquara no Granito Mogi das Cruzes (ou Itapeti), associado às rochas metassedimentares do Complexo Embu. A análise da transcorrência dextral NE-SW mostra que a deformação do granito deu-se ao longo de planos subverticais e sua colocação foi sin-tectônica, como indicado pela trama linear e planar pré-cristalização total. Houve continuidade da deformação após a solidificação, gerando milonitos e estruturas distensivas NE-SW que indicam ambiente transtensivo pós- a tardi-consolidação.

JULIANI et al. $(1995,1996)$ descreveram metarriólitos encaixados nos filitos manganesíferos da Formação Nhanguçu do Grupo Serra do Itaberaba como formados por muscovita e quartzo muito finos e relíquias de fenocristais bipiramidais de quartzo, além de opacos e raros cristais de zircão. Essas rochas foram datadas por JULIANI et al. (1999) e apresentaram idade U-Pb em zircão brasiliana, sendo, desta forma, o magmatismo correlacionado ao Grupo São Roque.

Estudos sobre o metamorfismo do Grupo São Roque efetuados por SOUZA et al. (1996b) na Folha de Cabreúva indicaram que quanto mais próximo do contato com o Granito São Roque, maior o grau metamórfico dos metabasitos, que alcançam fácies anfibolito inferior a intermediária, e gradam para fácies xisto-verde à medida que aumenta a distância do corpo, com hornblenda substituída por actinolita. Devido à espessura do pacote de metabasitos de grau médio, consideraram ser mais provável que esses litotipos pertençam ao Grupo Serra do Itaberaba, não sendo produto de metamorfismo de contato. Os anfibolitos do Complexo Itapira mostram-se com mineralogia muito semelhante, compatível com a fácies anfibolito intermediária a superior e com paragêneses da fácies xisto-verde superpostas. Quimicamente, as rochas são muito homogêneas, apresentam afinidades com toleiítos subalcalinos e padrões de ETR pouco diferenciados (SOUZA et al. 1996a).

Uma análise mais completa destes dados, da geologia e do metamorfismo da região foi apresentada por SOUZA (1997) e SOUZA \& OLIVEIRA (1997). Através de estudos petrográficos, dividiram os anfibolitos em oito litotipos. Os litotipos I a IV pertenceriam ao Complexo Itapira; o Grupo São Roque englobaria os litotipos VI e VIII e o Grupo Serra do Itaberaba o litotipo VII; o litotipo V ocorreria nas três unidades (CI, GSI e GSR). Nos litotipos do Complexo Itapira, o pico de metamorfismo $\left(\mathrm{M}_{1}\right)$ atingiu a fácies anfibolito intermediária a superior com transição para fácies granulito, e o retrometamorfismo $\left(\mathrm{M}_{2}\right)$ tem associação da fácies xisto-verde-s baixa a intermediária, com a termobarometria indicando, respectivamente, $700^{\circ}$ e $860^{\circ} \mathrm{C}$ e 5 e 6 kbar. No Grupo Serra do Itaberaba, o pico metamórfico atingiu fácies anfibolito superior $\left(500^{\circ}\right.$ e $670^{\circ} \mathrm{C}$, pressão entre 8 e $\left.8,5 \mathrm{kbar}\right)$ tendo atingido, localmente, condições de $\mathrm{P}$ e T entre 737 a $790^{\circ} \mathrm{C}$ a 6 kbar (litotipo V). No Grupo São Roque, as paragêneses estariam na fácies xisto-verde superior e também teriam sofrido metamorfismo de contato (litotipo V) dos granitos Socorro e São Francisco, a $700^{\circ} \mathrm{C}$ e $1 \mathrm{kbar}$. Os dados químicos indicam tratar-se de prováveis basaltos de afinidade toleí́tica e subalcalina, embora alguns anfibolitos apresentem tendência andesítica no Grupo Serra do Itaberaba; andesitos de tendência cálcio-alcalina de baixo a 
médio potássio no Complexo Itapira e; andesitos de tendência cálcio-alcalina de médio a alto potássio no Grupo São Roque, protólitos originados a partir de suíte toleítica de arco de ilha (LKT) e andesitos originados a partir de suíte basáltica cálcio-alcalina (CAB).

PÉREZ AGUILAR \& JULIANI (1994), PÉREZ AGULLAR (1996) e PÉREZ AGUILAR et al. (1996) caracterizaram petrograficamente rochas básicas e intermediárias ígneas e vulcanoclásticas alteradas hidrotermalmente e metassomaticamente em intensidades variáveis, separados em zonas superpostas de concentração de ferro e magnésio, de carbonatizaçăo, de potassificação e de silicificação, todas de origem anterior ao metamorfismo. Os metabasitos não alterados (com hornblenda e plagioclásio essenciais) são gradativamente substituídos por rochas incipientemente alteradas (hornblenda anfibolitos com cordierita e cummingtonita), rochas da zona de transição (onde coexistem hornblenda e cummingtonita e/ou actinolita), rochas menos intensamente alteradas (cummingtonita anfibolitos, cordierita-cummingtonita anfibolitos e granada-cordierita-cummingtonita anfibolitos) e rochas mais intensamente alteradas (granada-cordierita-cumingtonita/antofilita anfibolitos). As rochas potassificadas são formadas por hornblenda-biotita anfibolitos, biotita-hornblenda anfibolitos e biotita-cummingtonita anfibolitos, as carbonatizadas por actinolita anfibolitos (menos alterados) a metabasitos cálcio-silicáticos, mais alterados, ricos em diopsídio, actinolita, epídotos e carbonatos. A identificação destes litotipos e de turmalinitos e marunditos, por associarem-se a metabasitos ricos em sulfetos, mineralizações de ouro e a anomalias geoquímicas de $\mathrm{Au}, \mathrm{Cu}, \mathrm{Zn}$ e As, foi considerada por JULIANI et al. (1996a) como indicadora de potencialidade metalogenética em sequiências metavulcano-sedimentares, úteis na orientação em trabalhos de prospecção mineral, especialmente para depósitos minerais com afinidade vulcanogênica.

Análise microestrutural e de petrotrama de eixos $c$ de quartzo feitos na junção das zonas de cisalhamento São Bento do Sapucaí, Sertãozinho e Jundiuvira por GARCIA (1996) e GARCIA \& CAMPOS NETO (1996) indicaram que as duas primeiras comporiam originalmente uma única zona sinistral e a última dextral, que corta as estruturas das demais. Observaram ainda neoformação de biotita e clorita a partir da granada e da biotita, retrometamorfismo de anfibólios, núcleos de silimanita prismática em agregados de fibrolita e biotita pós-cinemática, o que, indica, juntamente com a presença de quartzo poligonizado, estruturas manto-núcleo em feldspatos, mirmequitização e microclinização, e temperaturas de formação máximas ao redor de $450^{\circ} \mathrm{C}$.

FRASCÁ \& HACHIRO (1996) analisaram composições isotópicas de rochas carbonáticas dos grupos Açungui e São Roque, desse último nas regiões de Salto de Pirapora e de Pirapora do Bom Jesus. São rochas calcíticas ou dolomíticas de baixo grau metamórfico, e os resultados são concordantes com carbonatos marinhos pré-cambrianos. A maioria deles pode ser associado a ambientes restritos quanto ao $\delta^{13} \mathrm{C}$, enquanto as variações de $\delta^{18} \mathrm{O}$ devem-se, possivelmente, às variações de idades das diferentes unidades, uma vez que haveria nas rochas mais novas um progressivo enriquecimento em ${ }^{16} \mathrm{O}$. As rochas carbonáticas de ambos os grupos mostram predominância de dolomitos puros $(\mathrm{SiO} 2<25 \%$ e 
$\mathrm{MgO}>10,8 \%$ ) na Formação Itaiacoca e na região de Pirapora do Bom Jesus, respectivamente, segundo FRASCÁ \& COUTINHO (1998). A diferenciação entre dolomitos da região de Pirapora do Bom Jesus daqueles de Cajamar baseia-se na riqueza em Mn e Fe e pobreza em Ti e Sr, indicando processos de dolomitização dos sedimentos calcíticos por dissolução-reprecipitação. Os dolomitos da Formação Itaiacoca são pobres em Mn e Sr e teriam sido formados por deposição via protodolomítica, diferindo daqueles de Pirapora. Os calcários do Grupo São Roque são ricos em $\mathrm{Sr}$ e pobres em $\mathrm{Mn}$ e teriam sido formados por precipitação direta em assoalho oceânico, provavelmente em mar aberto, com a transformação da lama aragonítica, como indicado pelo Sr elevado, em calcita ou calcita magnesiana, via processos diagenéticos ou metamórficos.

SANTORO et al. (1997) verificaram que, no segmento alóctone da Faixa Ribeira, entre Santa Isabel e sul de Campos do Jordão, zonas de cisalhamento dúcteis de baixo ângulo com movimentação inversa, com orientação N60E/40SE, truncam a norte o Grupo São Roque, a Nappe de Socorro-Guaxupé e o Domínio Alóctone Inferior. A lineação de transporte tectônico de SE para NW está contida em torno da pendente máxima da foliação milonítica. Apresentaram ainda idades-modelo $\mathrm{Sm} / \mathrm{Nd}$ de paragnaisse migmatizado de 2,5 Ga., com melanossoma de 2,3 Ga. e leucossoma com 2,1 Ga, que seria uma aproximação da idade máxima de sedimentação.

JULIANI et al. (1997a) constataram passagens graduais entre os metaconglomerados do Morro do Polvilho e as rochas anteriormente consideradas como metarriodacitos, e verificaram haver nessas rochas texturas e estruturas sedimentares preservadas, idênticas às observadas nos metaconglomerados do Morro Doce, com as quais encontram-se em continuidade física, redefinindo-os como metarcóseos. Essas rochas gradam para quartzito feldspático e estão colocadas sobre a Formação Morro da Pedra Preta do Grupo Serra do Itaberaba, ali reconhecido. Conseqüentemente, a idade de 1,79 Ga obtida em zircão do metarcóseo por $\mathrm{U}-\mathrm{Pb}$ indica a idade máxima da sedimentação, não podendo ser interpretada para caracterizar o início da deposição da sequêencia vulcano-sedimentar, que situa-se na base do Grupo São Roque.

JULIANI et al. (1997b) concluíram, com base em estudos geotermobarométricos de pares e associações de minerais, que o metamorfismo registrado pelos minerais da $S_{1}$ das rochas do Grupo Serra do Itaberaba apresenta trajetória horária, variando da fácies xisto-verde superior a anfibolito, em pressão intermediária $\left(\sim 490-650^{\circ} \mathrm{C} \mathrm{e} \sim 4-7 \mathrm{kbar}\right)$. $\mathrm{Na} \mathrm{S}_{2}$, o metamorfismo registrado é também progressivo, da fáceis xisto-verde superior até anfibolito, mas deu-se em pressão mais baixa $\left(\sim 500-580^{\circ} \mathrm{C}\right.$ e $4-4,7$ kbar), também de sentido horário, que trunca a trajetória anterior, indicando tratar-se de dois eventos metamórficos e não apenas um progressivo seguido de evento retrometamórfico.

Ao estudar os turmalina granitos de Perus, AZEVEDO (1997) descreveu os xistos encaixantes como sendo do Grupo Serra do Itaberaba. Têm granulação fina a média, estruturas fortemente foliadas com pequenos porfiroblastos de granada e manchas esbranquiçadas compostas por silimanita e quartzo. 
Observa-se ainda um marcado bandeamento correspondente ao acamamento definido pela alternância de leitos ricos em biotita e muscovita com outros mais maciços e menos ricos em micas, representando camadas originalmente mais arenosas. Ocorrem intercaladas lentes de rochas calciossilicáticas com bandeamento composicional reliquiar encontradas em todas as pedreiras de turmalina granitos; bandas mais escuras ao microscópio têm diopsídio e flogopita e as mais claras estão enriquecidas em calcita e/ou quartzo e/ou tremolita. Anfibolitos foliados de granulação variada fina a grossa, apresentando ao microscópio predomínio de hornblenda e plagioclásio, completam as encaixantes desse grupo, todas com associações metamórficas de fácies anfibolito. Os turmalina granitos ocorrem como pequenas bossas e corpos menores (diques, veios e lentes) concordantes e discordantes nas rochas metamórficas encaixantes. São encontrados em pequenas áreas controlados por sistemas de cisalhamento - o principal, de direções NE, NW e E-W. Nas bossas, separou-se os turmalina granitos em quatro fácies: bandada, pegmatítica interna (mais importantes) e homogệnea, de distribuição muito restrita, enquanto que diques e veios são compostos de turmalina granitos bandados e de pegmatitos (fácies pegmatítica externa).

SILVA (1997a, b, 1998) considerou o ambiente de sedimentação do Grupo São Roque na região de Pilar do Sul e Votorantim como variando de marinho profundo até marinho restrito ou lagunar, refletindo um caráter regressivo inicial, que teria evoluído para transgressivo com a deposição de quatro conjuntos de litofácies formadas, da base para o topo, pelas associações siliciclástica basal, siliciclástica intermediária, clasto-química transicional e carbonática impura superior. Essas associações foram correlacionadas informalmente às formações Estrada dos Romeiros, Voturuna e Pirapora do Grupo São Roque, afetadas por três fases de deformação associadas ao metamorfismo regional da fácies xisto verde. A primeira fase, de baixo ângulo, com feições indicativas de cavalgamento NNW-SSE, seria responsável por inversões estratigráficas, expondo rochas metassedimentares de porções crustais mais profundas, como metapsamitos e metapelitos do Grupo Serra do Itaberaba e xistos e gnaisses anfibolíticos do Grupo Açungui. Após à primeira fase, desenvolveu-se uma cinemática de alto ângulo, que evoluiu de dobras e planos axiais em regime dúctil para zonas de cisalhamento lateral com foliação milonítica e lineação de estiramento mineral características de um regime dúctil-rúptil, favorecendo a colocação do Maciço Granítico São Francisco e produzindo rochas hornfélsicas por metamorfismo de contato em rochas inseridas na associação de litofácies clasto-química transicional,

O Grupo Serra do Itaberaba, na região de Cabreúva, tem xistos bandados porfiroblásticos, com bandeamento composicional e porfiroblastos de biotita, cordierita e andaluzita de crescimento sin- a tardi- $D_{n+2}$, muscovita-biotita xistos, anfibolitos e mármores, todos litotipos refletindo paragêneses em fácies anfibolito, localmente com formação de textura milonítica. O Grupo São Roque predomina na regiăo, e ocorre entre as zonas de cisalhamento Itu-Jundiuvira e Taxaquara, em discordância tectônica com as unidades do Complexo Itapira, sendo constituído por uma seqüência metavulcano-sedimentar basicamente clástica, com menor porcentagem de sedimentos químicos e intrusivas básicas 
(HACKSPACHER et al. 1997a). Corpos de quartzito com até $500 \mathrm{~m}$ de espessura circunscrevem a Sinforma de Pirapora e uma antiforma a nordeste do Maciço São Roque, ou ocorrem encaixados tectonicamente e verticalizados segundo zonas de cisalhamento, enquanto as metabásicas mostram-se discordantes das rochas metassedimentares da Formação Voturuna e dos metacalcários da Formação Pirapora, à qual pertencem.

JULIANI et al. (1998) sintetizaram a evolução dos grupos São Roque e Serra do Itaberaba a nordeste e noroeste da cidade de São Paulo. O contato entre os grupos é tectônico, a norte marcado por transcorrências e a sul por falhas de empurrão de baixo ângulo, com transporte para norte e truncadas por falhas em flor positivas. Metabasitos do Grupo Serra do Itaberaba teriam características oceânicas, com N-MORB bastante refratário na base, mostrando-se mais evoluídos para o topo, evidenciando cristalização fracionada de clinopiroxênio + plagioclásio \pm olivina. Os toleítos do Grupo São Roque, também apresentaram características de fundo ou de arcos oceânicos, porém sua evolução geoquímica seria a partir de magmas progenitores diferentes. Reavaliando dados de RAGATKY (1997), afirmaram que a média das idades modelo $\mathrm{Sm}-\mathrm{Nd}\left(\mathrm{T}_{\mathrm{DM}}\right)$ nos granitos encaixados no Grupo Serra do Itaberaba, de $1,78 \mathrm{Ga}$, é mais antiga que aquelas encontradas no Grupo São Roque, com média de 1,49 Ga, indicando uma crosta mais antiga para o Grupo Serra do Itaberaba, e sugeriram a evolução dos grupos em ciclos geotectônicos distintos.

MARTIN et al. (1998a) sustentaram que as mineralizações de ouro a NW da cidade de São Paulo, consideradas do Grupo São Roque, ocorreriam na transição entre metavulcanoclásticas básicas e metassedimentos tufíticos, correlacionáveis à Formação Morro da Pedra Preta do Grupo Serta do Itaberaba, com as antigas lavras situadas em zonas de cisalhamento de baixo ângulo. Modidificaram, assim, a concepção de que as mineralizações envolvem pequenos veios de quartzo discordantes associados aos granitos, e definiram uma extensa área mineralizada. Uma zona de cavalgamento teria colocado os quartzitos do Pico do Jaraguá, os metaconglomerados e os metarcóseos dos morros Doce e do Polvilho, pertencentes ao Grupo São Roque, sobre a sequiência metavulcano-sedimentar do Grupo Serra do Itaberaba.

A ocorrência de corpos métricos de metarriólito no Grupo Serra do Itaberaba na região de Santana do Parnaíba-Barueri foi reportada por MARTIN et al. (1998b). Apresentando caráter subvulcânico, estariam encaixados nas metavulcanoclásticas básicas da Formação Morro da Pedra Preta e nos filitos manganesíferos e metacálcio-pelitos da Formação Nhanguçu. Citando as ocorrências efusivas da região da Serra do Itaberaba (JULIANI et al. 1995, 1996b), julgaram o magmatismo ácido do grupo associado às unidades de topo da Formação Morro da Pedra Preta, e principalmente à Formação Nhanguçu.

Os anfibolitos da região de Hermida-Jundiaî, encaixados concordantemente em granada gnaisses migmatizados do Complexo Itapira, têm hornblenda pleocróica marrom, castanha-clara ou verde- 
acastanhada, plagioclásio zonado com andesina cálcica no núcleo e labradorita na borda, além de diopsídio salita, indicando pico metamórfico na fácies anfibolito intermediária a superior. Titanita, epídoto, opaco, quartzo, carbonato e actinolita seriam acessórios e, em parte, produtos das transformações retrometamórficas, cristalizados na fácies xisto-verde intermediária a superior. Análises químicas preliminares dos anfibolitos sugerem composiçôes basálticas de afinidade toleiítica em ambiente de arco de ilhas (SOUZA \& OLIVEIRA 1998).

OLIVEIRA et al. (1998) descreveram efeitos de metamorfismo de contato próximo às bordas do Maciço Granítico Rapakivi São Francisco, introduzido na sequêencia metavulcano-sedimentar do Grupo São Roque. Nos metapelitos, observaram paragêneses da fácies albita hornfels, hornblenda hornfels e estreitas faixas na fácies piroxênio hornfels, enquanto nas metabásicas a recristalização de hornblenda e plagioclásio cálcico indica fácies hornblenda hornfels. Tais paragêneses nas rochas carbonáticas, com metacalcários magnesianos impuros portando monticellita e periclásio pseudomórfico substituído por brucita, caracterizados como de contato de alto grau, e a presença de tremolita e diopsídio nas rochas calciossilicáticas, sugerem formação com pressão inferior a $1 \mathrm{~Kb}$ e temperaturas superiores a $800-850^{\circ}$ C, e indicariam uma colocação rasa do corpo granítico, ao redor de $3 \mathrm{Km}$.

\subsubsection{Sobre as rochas granitóides}

Neste tópico serão citadas as publicações mais recentes, principalmente as que se referem aos mapas compilados e aos períodos e estruturas de colocação das rochas graníticas.

FERREIRA (1991) e WERNICK \& FERREIRA (1991, 1993) identificaram indícios de associação espacial do Complexo Itaqui com a Zona de Cisalhamento Taxaquara, através da forma alongada geral e da presença de algumas unidades dentro do corpo que indicariam atividade magmática sin-movimentação, além de unidades circulares ocupando direções tensionais que surgem com a progressão do desenvolvimento da falha. As estruturas principais $\left(D_{2}\right)$ do Grupo São Roque amoldam-se em torno do Itaqui e localmente, nos contatos, são truncadas pelo corpo intrusivo, que seria afetado por arqueamentos da $D_{3}$ e pela foliação milonítica. O magmatismo teria ocorrido no intervalo tardi- $\mathrm{D}_{2}$ a pré$\mathrm{D}_{3}$. Seus limites são definidos pelas zonas de cisalhamento Vila Menk, a nordeste, e Taxaquara, a sul, que controlaram a colocação das intrusões, representadas por quatro grandes unidades: o Granodiorito Barueri e os monzogranitos Pedreira Cantareira, Aldeia da Serra e Mutinga, e pelos espessos corpos filonares dos monzogranitos Suru e Torre e do Quartzo Monzonito Cruz Preta, compondo cinco associações magmáticas.

WERNICK et al. (1992) classificaram os complexos granitóides de Mairiporã, Itaqui, Socorro e Sorocaba e os encraves microgranulares a eles associados como pertencentes à série crustal profunda cálcio-alcalina de baixa temperatura, cálcio-alcalina de alta temperatura/subalcalina potássica.

Complementando os estudos do Granito Itaqui, WERNICK et. al. (1993a) definiram séries 
cálcio-alcalinas, e dividiram o complexo em 10 unidades litológicas, agrupadas em 5 associações pertencentes a 4 fases magmáticas intrusivas. Os ciclos magmáticos I e II seriam separados no tempo por uma fase de diques mais básicos e seguidos por turmalina-muscovita aplitos, e cada um deles apresentaria subciclos (IA, IB, IIA e IIB), iniciados por rochas mais básicas que evoluem para tipos mais ácidos. Para WERNICK et al. (1994a), as composições médias do ciclo I caracterizam-se por teores crescentes de $\mathrm{Fe}$ e $\mathrm{Na}$, enquanto que no ciclo II a relação $\mathrm{Fe} / \mathrm{Fe}+\mathrm{Mg}$ permanece quase constante nos três primeiros pulsos, sugerindo que os mecanismos de fracionamento (estado líquido) foram distintos nos dois casos, e que poderiam também variar durante a fase de maturação magmática de um mesmo ciclo.

A deformação magmática do Granito Poli-Intrusivo Itaqui apresenta isolinhas paralelas ao contato nas porções $\mathrm{N}$ e W, e paralelas à Zona de Cisalhamento Taxaquara (E-W) na porção centro-sul. As rochas do Grupo São Roque e do Granodiorito Barueri tiveram comportamento reológico semelhante durante o emplacement da fácies e, na parte sul, a resistência do Granito Itapevi deformou o granodiorito Barueri e o monzogranito Pedreira Cantareira (FERREIRA \& WERNICK 1995). Na colocação dos stocks, as encaixantes metamórficas e parte das fácies magmáticas apresentam comportamento reológico distinto, resultando na deformação das unidades Barueri e Pedreira Cantareira.

Pertenceriam ao Ciclo I as unidades Barueri (BA), Pedreira Cantareira (PC), Torre e Aplitos; e ao Ciclo II, Cruz Preta (CP), Aldeia da Serra (AS), Mutinga (MU) e Suru (SU) (WERNICK et al. 1994a, FERREIRA \& WERNICK 1997b), separados por uma fase de colocação de diques de mela-quartzo mozonitos com Diques Máficos Porfiríticos (DMP) genericamente vinculados ao ciclo I, e Diques Máficos Equigranulares (DME) vinculados ao ciclo II. O Ciclo I apresenta saltos composicionais nos teores de máficos, álcalis e plagioclásio, indicando que unidades BA e PC sofreram diferenciação in situ. O Subciclo IIA, composto pelas unidades CP e AS, apresenta variação composicional gradacional e retilínea, principalmente dos máficos, álcalis e razão $\mathrm{Fe} / \mathrm{Mg}$. O Subciclo IIB, representado pelas unidades MU e SU, em continuidade com o Subciclo IIA, possui maiores valores de quartzo e menores de máficos, alta alcalinidade, riqueza em $\mathrm{Na}$, pobreza em Ca e alta relação $\mathrm{Fe} / \mathrm{Mg}$.

Devido à intensidade da deformação diminuir do interior do maciço para as encaixantes metamórficas e às isolinhas de deformação serem paralelas aos contatos, FERREIRA \& WERNICK (1996) consideraram que a intensidade e o padrão deformacional estariam relacionados à própria dinâmica magmática e não ao regime tectônico regional. Concluíram que o complexo teve sua colocação associada à Zona de Cisalhamento Taxaquara, que teria se desenvolvido, no início, em regime transpressivo com caráter press muito mais intenso que o caráter trans, produzindo deformação por achatamento, evoluindo com a modificação para um regime de transcorrência com deformação plana e atingindo, nos estágios finais, regime transtrativo com constrição (prolatos) e rochas miloníticas associadas (FERREIRA \& WERNICK 1997a).

Os complexos cálcio-alcalinos São Roque e Cantareira e os rapakivis de São Francisco, Sorocaba 
e Itu seriam formados pela coalescência de várias fases magmáticas definidas em precoce, principal, de acresção lateral inicial, de colocação de stocks e de intrusões circulares que cortam principalmente as rochas da fase principal, e de acresção final. Todos os maciços seriam formados por pelo menos dois ciclos magmáticos sucessivos, analisados com base em mecanismos de ascensão magmática, na existência de câmaras coletoras sucessivamente drenadas e recarregadas e reativação das falhas transcorrentes às quais as rochas graníticas se associam (WERNICK et al. 1993b).

Segundo ANDRADE (1993) e ANDRADE et al. (1994) o Complexo São Roque é composto por dez fácies agrupadas nos seguintes conjuntos litológicos: I) dioritos, II) granodioritos a monzogranitos porfiróides com hornblenda e biotita, III) monzogranitos e IV) turmalina monzogranitos. As relações do complexo com as zonas de cisalhamento sugerem que o magmatismo se deu concomitantemente ao tectonismo, provavelmente em estruturas pull-apart.

WERNICK et al. (1994b) verificaram, no Complexo São Roque e na intrusão Salto do Complexo Rapakivi Itu, que os líquidos fracionados (claros e escuros) mostram-se enriquecidos em minerais acessórios, expressos nos conteúdos de elementos traços específicos, como o $\mathrm{Rb}$, e nos espectros de ETR, como o $\mathrm{Zr}$, e que o conteúdo na matriz segregada estaria próximo ao do granito porfiróide no Complexo São Roque, e mostraria diferenças substanciais na intrusão Salto, refletindo um incremento de ETR pesados na matriz fracionada.

Os complexos graníticos São Francisco, Sorocaba e Itu definem três variações básicas para os plutons da Província Rapakivi Itu (GALEMBECK \& WERNICK 1998): variação de alcalinidade crescente na sequiência Sorocaba - São Francisco - Itu; ocorrência de corpos quimicamente expandidos com ampla variação no teor de sílica, como os corpos São Francisco, Sorocaba e o Plúton Cabreúva (Itu), e quimicamente restritos com elevados teores de sílica, caso dos plutons Salto e Indaiatuba; e estruturação variando em fases de acresção magmática observadas nos granitos São Francisco e Sorocaba, o último com cinco fases de acresção e ciclos.

Entre Piedade e Pilar do Sul destacam-se quatro maciços principais tardi-orogênicos (JANASI et al. 1994): Pilar do Sul e Serra do Lopes, constituídos principalmente por muscovita-biotita monzogranitos levemente peraluminosos; Piedade, aproximadamente circular com zoneamento petrográfico mais complexo, predominando, na borda, muscovita-biotita granodioritos a monzogranitos porfiríticos, sucedidos por biotita monzo- a sienogranitos inequigranulares e, no centro, biotita monzogranitos porfiríticos; e Serra da Bateia, composto principalmente de biotita-sienogranitos porfiríticos, e que invade o extremo sul-ocidental do maciço Piedade. Os dois últimos contrastam com os maciços Pilar do Sul e Serra do Lopes (teores menores de $\mathrm{Al}_{2} \mathrm{O}_{3}, \mathrm{Na}_{2} \mathrm{O}, \mathrm{Sr}$, Ba e maiores de $\mathrm{K}_{2} \mathrm{O}$ e $\mathrm{FeO}$ ), ressaltando composições sienograníticas (maior $\mathrm{K}_{2} \mathrm{O} / \mathrm{Na}_{2} \mathrm{O}$ ). As diversidades petrográfica e geoquímica poderiam ser atribuídas a variações nas condições físico-químicas de fusão e nas composições dos protólitos, predominantemente infracrustais. 
O Maciço Granítico de Piedade foi estudado por LEITE (1997) e LEITE et al. (1997), que identificaram foliação de origem magmática. É composto por várias unidades dispostas paralelamente ao contato, caracterizadas por pulsos magmáticos essencialmente graníticos, e constituindo uma intrusão forçada de caráter sin-orogênico (Rb-Sr: $654 \pm 24 \mathrm{Ma}$ ). Uma associação de rochas peraluminosas, com biotita-granodiorito a monzogranito porfirítico portadores de monazita, distingue-se da metaluminosa, formada por biotita-monzogranito com titanita + alanita como acessórios importantes.

O magmatismo Pirituba, representado pelo batólito Cantareira, pelo maciço Mairiporã e por intrusões menores, como as de Taipas, Morro do Perus e o turmalina granito Perus, intrusivos no Grupo São Roque, compreende intrusões polifásicas, e suas colocações devem-se às falhas transcorrentes Jundiuvira e Taxaquara (WERNICK \& TEUPPENHAYN 1996). O magma, com transição entre crustal e cálcio-alcalino de baixa temperatura, de pequena profundidade e com pouca participação de material mantélico, foi considerado gerado em dois estágios, iniciados pela fusão parcial da crosta inferior e pela assimilação de substanciais volumes de rochas do Grupo São Roque, ricas em boro, com a diferenciação posterior do magma segundo a sequência Mairiporã-Cantareira + Taipas-Morro do Perus-aplitos + pegmatitos + microgranitos-merus.

Datações U-Pb em zircão do granodiorito Cantareira e em xenotima do granito Perus indicam, respectivamente, idades de $572 \pm 9 \mathrm{Ma}$. e $566 \pm 6 \mathrm{Ma}$., enquanto que os dados de isótopos de $\mathrm{Sr}$ das rochas datadas lançados em diagrama de evolução permitem inferir que a separação do magma Perus do magma Cantareira ocorreu há cerca de $592 \mathrm{Ma}$. Os dados químicos, mineralógicos e de tipologia de zircão mostram que o magma Perus separou se do magma Cantareira quando este já tinha atingido um estágio magmático tardio (TEUPPENHAYN et al. 1995).

WERNICK et al. (1995) teceram comparações de ETR e tipologia de zircão entre granitos crustais (Anhangüera e Perus), transicionais crustais/cálcio-alcalinos (Cantareira, Mairiporã, Taipas, Morro do Perus) e cálcio-alcalinos de baixa (São Roque) e média (Itaqui) temperaturas. Os espectros dos granitos crustais apresentaram padrão típico "gaivota", simétrico (Perus) ou assimétrico, com maiores valores de ERTL (Anhanguera). Os granitóides transicionais teriam padrão tipo " $\mathrm{S}$ " achatados, deitados, o mesmo ocorrendo nos granitos cálcio-alcalinos com valores de $\mathrm{La}_{\mathrm{cn}}$ maiores. Os granitos turmaliníferos do granito São Roque e os fácies muito fracionados do granito Itaqui mostran espectros semelhantes aos do granito Anhanguera, com valores de $\mathrm{La} \mathrm{c}_{\mathrm{en}}$ entre 7 e 70.

Os maciços granitóides São Roque, Caucaia e Ibiúna ocupam, segundo (GODOY et al. 1996b), 3/4 da Folha São Roque (1:50.000). O primeiro tem contatos essencialmente tectônicos, a sul com os grupos Embu e São Roque, e a leste e oeste, com rochas dos grupos Serra do Itaberaba e São Roque. Compõe-se de cinco fácies petrográficas: monzogranitos porfiróides, raros equigranulares, dioritos, turmalinasienogranitos e veios e diques aplíticos. A classificação modal aponta para série cálcio-alcalina granodiorítica (médio K) a monzonítica (alto K), com um litotipo na série alcalina sódica, e a tipologia 
de zircão o classifica como cálcio alcalino de média profundidade, com fácies transicionais entre crustal e cálcio-alcalina rasa. Os maciços São Roque, Caucaia e Ibiúna enquadram-se na série cálcio-alcalina de alto potássio, com pequena tendência para a shoshonítica, e apresentam caráter peraluminoso e metaluminoso, com grau de saturação em alumina maior nas fácies tardias do Maciço São Roque e apenas localmente nos outros maciços. Do ponto de vista tectônico, os maciços São Roque e Caucaia são tardi-orogênicos, e o Ibiúna, mais complexo, tem tendências pré-, pós-colisionais e tardi-orogênicas, sendo considerados maciços orogênicos em dois possíveis ambientes: arco de ilhas e arco continental.

WERNICK (1997) vinculou a colocação dos corpos granitóides brasilianos na Faixa Ribeira e na cunha de Guaxupé a um regime tectônico geral transpressivo, com uma fase de intensa tectônica de cavalgamento, seguida por uma de transcorrência de longa duração com amainamento dos esforços, e a final transtensiva. Separou os corpos granitóides com estruturação relativamente simples e associados, em essência, a uma das fases tectônicas, daqueles com arquitetura magmática complexa, resultado de magmatismo policiclíco e/ou plurisserial, colocados durante duas ou mais das fases tectônicas, resultando em duas fases magmáticas principais. Uma, de idade inferior mínima ao redor de 630-660 Ma e superior por volta de $610 \mathrm{Ma}$, abrange as fases tectônicas iniciais, e está representada pelos granitos Tico-Tico, Nazaré Paulista e partes dos granitos Socorro, Morungaba, São Roque, Itaqui e Cantareira. A segunda, com idades entre 610 e $570 \mathrm{Ma}$, comporta as fases tectônicas de transcorrência e de transtensão, e engloba os granitos Itu, Perus, Pedra Branca e parte dos granitos Socorro, Morungaba, São Roque, Itaqui e Cantareira.

WERNICK \& TÖPFNER (1997) verificaram que os maciços granitóides Cantareira, Itaqui, São Roque, Sorocaba, São Francisco e Itu mostram natureza múltipla e arquitetura complexa, com cinco fases de colocação magmática vinculadas a sucessivos episódios de movimentação das falhas transcorrentes, e que granitóides brasilianos associados a cavalgamentos não são necessariamente mais antigos que os vinculados a falhas transcorrentes.

Segundo WERNICK (1998a), o estágio inicial, vinculado à convergência e colisão entre as placas envolvidas na geração do Cinturão Ribeira, situa-se entre 630-590 Ma, e inclui granitos cálcio-alcalinos tipo I-Cordilheirano, sob a forma de grandes batólitos múltiplos e compostos alongados segundo NE-SW (TIPO A), a peraluminosos do tipo 'S' com contribuições do embasamento ortognáissico (TIPO B). Ambos, quando afetados por zonas de cisalhamento ou anatexia, geraram ortognaisses ocelares (TIPO 1C), gnaisses bandados (TIPO ID) e migmatitos (TIPOS IF e 1G). O estágio final, com geração principal entre 600-580 Ma, reúne corpos afetados ou não por falhas transcorrentes relacionadas à fase tardia da colisão, e constitui o Sistema Magmático Plurisserial 590 (SMP-590), dominado por granitos álcalicálcicos com alto-K tipo I-Cordilheirano (TIPO 2A), tipo Rapakivi (TIPO 2B) em essência crustais, e granitóides alcalinos potássicos (TIPO 2C) e alcalinos sódicos (TIPO 2D), ambos mantélicos. 


\subsubsection{Sobre a articulação geotectônica}

O mapa Bouguer do Estado de São Paulo (HASUI et al., 1991) mostra anomalias de primeira ordem com pares de altos/baixos gravimétricos que indicam a existência de descontinuidades crustais separando domínios com fortes contrastes de massas, que correspondem às zonas de articulação de grandes blocos que se justapuseram tectonicamente no Pré-Cambriano. Os autores reconheceram porções dos blocos Vitória, Brasília, São Paulo e Paraná; devido à subduç̧ão de tipo A, relacionada a processos colisionais, de que resultaram as feições de cavalgamento complicadas por transcorrências tardias. Vários lineamentos estruturais representam anomalias de segunda ordem que introduziram complicações no quadro estrutural delineado pelas anomalias de primeira ordem, cruzam os blocos e seus limites deslocando porções por distâncias até apreciáveis, sendo interpretados como zonas de movimentação transcorrentes.

De acordo com EBERT et al. (1991), a colisão oblíqua dos blocos Vitória (leste) e São Paulo (oeste) envolveu uma etapa de cavalgamento seguida de outra transcorrente, resultando no Cinturão Transcorrente Rio Paraíba do Sul (CTRPS). Este, dextral e dúctil, possui zonas de cisalhamento que separaram frações rochosas lenticulares e sigmoidais, e que evoluíram, ao menos em parte, para duplexes direcionais ou estruturas em flor, onde as feições observadas indicariam a prevalência do regime transpressivo com vetor de transpressão em torno de WNW-ESE. O CTRPS poderia ser considerado transpressivo com eventuais subdomínios transtensivos também afetados durante as rotações por achatamento oblíquo. Para os autores, como a maioria das dobras empinadas com lineações direcionais estão associadas à tectônica direcional, juntamente com outros subprodutos, como imbricamentos, zonas reversas, crenulações, duplexes direcionais compressivos e estruturas em flor, ficaria comprometido o uso dos termos cinturão ou faixa de dobramentos Apiaí, São Roque, Rio Grande e Paraíba do Sul.

As zonas de cisalhamento de alto ângulo do Cinturão Ribeira foram consideradas por MACHADO \& ENDO (1993a, b) como de implantação precoce e responsáveis pela estruturação e evolução tectônica da região do Vale do Rio Paraíba do Sul, e a estrutura sinclinorial do vale entendida como uma mega-estrutura em flor positiva, resultante de uma tectônica transpressional dextral Brasiliana. O Cinturão Ribeira foi reinterpretado e denominado Cinturão de Cisalhamento Atlântico (CCA), composto em três zonas de cisalhamento principais: a Zona de Cisalhamento Juiz de Fora-JaguariTaxaquara (ZCJFJT), a Zona de Cisalhamento Além Paraíba-Cubatão-Lancinha (ZCPCL), e a Zona de Cisalhamento Niterói (ZCN), englobadas no Sistema de Cisalhamento Paraíba do Sul (SCPS). Duas fases de deformação principais e progressivas (F1 e F2) teriam sido afetadas pela $F 3$, de orientação axial paralela às anteriores, e pertenceriam a um sistema de zonas de cisalhamento com movimento coerente dextral. À F4, descontínua e de orientação variável de NW-SE a N-S, gerando freqüentemente padrão de interferência tipo domo e bacia, associar-se-iam discretas zonas de cisalhamento transversais ao CCA, 
com predomínio de movimento sinistral. A mega-estrutura em flor positiva seria balizada, a NW e a SE, respectivamente, pelas zonas de cisalhamento de ZCJFJT e ZCN, e na porção central da estrutura, a ZCPCL, compreenderia reativações de estruturas mais antigas, ao menos transamazônicas, e com atividade contínua até o Terciário.

Na revisão da Carta Geológica São Paulo (1:250.000), ALMEIDA et al. (1995) consideraram o Complexo Piaçagüera (Arqueano-Transamazônico) como composto por gnaisses, migmatitos e rochas granulíticas, e o Grupo Itapira (Proterozóico Médio) como supracrustal ao anterior e sobretudo com gnaisses e migmatitos, mas admitiram serem os conhecimentos insuficientes para delimitação das duas unidades na folha. O Complexo Embu (Proterozóico Médio) compreenderia mais extensa área do Supergrupo Açungui, com rochas localmente migmatizadas. A unidade Serra do Itaberaba foi delimitada, estando incluída no Grupo São Roque (Proterozóico Médio desde seu limite com Proterozóico Inferior).

$\mathrm{Na}$ integração geológica da Folha São Paulo 1:250.000, SACHS \& CAMPOS NETO (1996), consideraram a Nappe Socorro-Guaxupé formada por uma associação neoproterozóica com complexos granitóides, onde incluíram o Complexo Piracaia, e delimitaram os domínios Costeiro, São Roque, Embu e Açungui. O Domínio São Roque seria formado por granitos cálcio-alcalinos potássicos intrusivos em metassedimentos plataformais com rampas carbonáticas, complexos recifais, estruturas vulcanoplutônicas e vulcânicas de rochas básicas e fácies litorâneas (Grupo São Roque), e por uma sequiência metavulcano-sedimentar toleí́tica da fase rift (Grupo Serra do Itaberaba).

Na Folha Santos/Barra de Santos (MORAIS \& CAMPOS NETO 1996) os terrenos précambrianos estão representados pelos complexos Costeiro (Neoproterozóico III-Eocambriano), com 5 conjuntos principais de litotipos, predominando migmatitos e gnaisses diversos; Embu, com metassedimentos de baixo a alto grau metamórfico e rochas graníticas associadas; Rio Capivari (Arqueano-Paleoproterozóico), com biotita gnaisses possivelmente ortoderivados e migmatitos; e Piracaia (Neoproterozóico III), com xistos, gnaisses bandados, gnaisses migmatizados e hornblenda gnaisses. O Grupo São Roque compreende as unidades de filitos e metarenitos rítmicos, com xistos na base, e o Grupo Serra do Itaberaba foi considerado Paleoproterozóico-Mesoproterozóico, metavulcano* sedimentar e inferior ao grupo anterior.

Segundo SOARES \& ROSTIROLLA (1997), a organização final das porções sul e sudeste do Cinturão Ribeira resulta da amalgamação de blocos e terrenos acrescionários, com pico da tectônica transcorrente associada ao escape tardi-colisional estimado em cerca de $550 \mathrm{Ma}$. Esta estruturação foi posterior à principal fase de metamorfismo, ao cisalhamento dúctil de baixo ângulo e ao cavalgamento de 700 a $600 \mathrm{Ma}$ (relacionado ao espessamento do prisma acrescionário), e foi contemporânea à colocação dos grandes corpos de granitos rosados e anterior à fase dos granitos alcalinos e peralcalinos pósorogênicos $(530-490 \mathrm{Ma})$.

Ao Grupo Açungui (Domínio Apiaí), no Ciclo Brasiliano, estaria associado metamorfismo do 
tipo Barrowiano e extenso magmatismo granitóide cálcio-alcalino. No Neoproterozóico, o Domínio teria constituído um arco magmático continental do tipo cordilheirano em relação a uma provável zona de subducção de SE para NW (CAMPANHA \& SADOWSKI 1998). A evolução da bacia remontaria ao Paleo-Mesoproterozóico, ou por rifteamento e abertura de um oceano seguido de formação de arco-deilhas e colisão de um bloco continental contra o arco-de-ilhas, ou por abertura e fechamento de uma bacia marginal de retro-arco, seguida por intensa acresção, no Neoproterozóico, de entidades tectônicas distintas relacionadas ao sistema transcorrente dextral e à colisão oblíqua. Ressaltaram ainda que, dentre as várias questões não resolvidas, estaria a correlação entre o Supergrupo Açungui e os grupos São Roque/Serra do Itaberaba.

No segmento central da Faixa Ribeira, MORAIS et al. (1998) admitiram uma tectônica transcorrente com movimentação dextral e foliações de alto ângulo, e separaram os domínios Costeiro, Embu, São Roque e Açungui. O Domínio São Roque, com duas unidades vulcano-sedimentares, conteria os grupos Serra do Itaberaba, paleo- a mesoproterozóico com metamorfismo de fácies xisto-verde superior a anfibolito, e São Roque, no topo, constituído predominantemente por metassedimentos mesoproterozóicos com metamorfismo de fácies xisto-verde.

Baseados em experimentos desenvolvidos no Laboratório de Geotectônica e Tectônica Experimental do Setor de Tectônica do CENPES/Petrobrás, EBERT et al. (1995) concluíram que as bordas sul e sudeste do Cráton do São Francisco e da Cunha de Guaxupé seriam formadas por três blocos crustais separados por bacias que experimentaram colisão oblíqua por convergência E-W. As bacias estiveram interconectadas durante sua evolução de margem passiva para ativa e a partição da deformação resultou no Cinturão de Cisalhamento Rio Paraíba do Sul, com predominância de regime contracional e de vergência para W; Cinturão Transcorrente Ribeira, a sul, relacionado à convergência oblíqua de dois blocos móveis em regime transpressivo; Cinturão Transcorrente Campo do Meio, que afeta a Faixa Alto Rio Grande, apresentando deformação finita marcada por regime direcional transpressivo ao longo de extensas rampas laterais.

\subsubsection{Sobre a geocronologia da Faixa Serra do Itaberaba/São Roque}

Um dos primeiros reconhecimentos geocronológicos $\mathrm{K}$-Ar nas supracrustais dos grupos Açungui e São Roque é devido a CORDANI \& BITTENCOURT (1967a, b), quando consideraram que grande parte dos gnaisses do Complexo Migmatítico Indiferenciado e das rochas metassedimentares teriam sido formados por volta de 600 - $650 \mathrm{Ma}$, com sedimentação ainda no Pré-Cambriano Superior sobre um embasamento com idade mínima de 1,4 Ga, devido à idade de $1.360 \mathrm{Ma}$ obtida em amostra do epidiorito Penhinha. Constataram ainda que os granitos sin-tectônicos foram gerados a $590 \mathrm{Ma}$ e os pós-tectônicos entre 580 e $500 \mathrm{Ma}$. O plagioclásio do epidiorito apresentou idade Ar/Ar de $1.200 \mathrm{Ma}$, o anfibólio, 545 Ma e a biotita $515 \mathrm{Ma}$, segundo KINOSHITA (1976). 
HASUI \& HAMA $(1970,1972)$ interpretaram a idade $\mathrm{K}-\mathrm{Ar}$ de $714 \pm 30$ Ma obtida de um anfibolito de fácies xisto-verde com clinopiroxênio provavelmente reliquiar, e situado a norte do granito Tico-Tico, como a mais antiga para os metamorfitos do Grupo São Roque. Idade K-Ar de $1.036 \pm 45 \mathrm{Ma}$ foi obtida para o anfibolito de Ermida, do Bloco Jundiaí e, considerando conjuntamente a idade do epidiorito Penhinha no Bloco Cotia (CORDANI \& BITTENCOURT 1967a, b), estabeleceram esses blocos como mais antigos que o Grupo São Roque e remobilizados no Ciclo Brasiliano.

As idades Rb-Sr obtidas em isócronas de referência de rochas graníticas do Grupo Açungui feitas por CORDANI \& KAWASHITA (1971) sugeriram a existência de uma fase magmática tardi-tectônica ao redor de $610 \mathrm{Ma}$, representada na região pelo Maciço Cantareira, e outra pós-tectônica, em $540 \mathrm{Ma}$, correspondentes aos granitos São Francisco, Itu e Perus.

Ao revisarem as datações do Cinturão Ribeira, CORDANI \& TEIXEIRA (1979) concluíram que - Grupo São Roque seria formado por rochas metassedimentares epizonais brasilianas cortadas por granitos sin-tectônicos em $640 \mathrm{Ma}$, com $\mathrm{RI}=0.710$, que indicaria caráter ensiálico para o Cinturão.

Em rochas metabásicas do Grupo Serra do Itaberaba, SARAGIOTO et al. (1984) apresentaram idades $\mathrm{K}$-Ar de $530 \pm 31 \mathrm{Ma}$ e de $1.692 \pm 157 \mathrm{Ma}$, sendo a primeira proveniente das proximidades do Granito Pedra Branca. A idade mais antiga foi utilizada por JULIANI et al. (1986) para o posicionamento do Grupo Serra do Itaberaba no Mesoproterozóico ou até mesmo no Paleoproterozóico, enquanto o Grupo São Roque foi mantido no Neoproterozóico.

TASSINARl et al. (1985) dataram os seixos granito-gnáissicos e a matriz do metaconglomerado do Grupo São Roque nas proximidades do Pico do Jaraguá pelo método $\mathrm{Rb}-\mathrm{Sr}$, obtendo, respectivamente, as idades de $1200 \pm 100 \mathrm{Ma}$ e $\sim 800 \mathrm{Ma}$. A idade dos seixos foi interpretada como a idade máxima da sedimentação e a da matriz como devida ao metamorfismo. A biotita da matriz forneceu idades $\mathrm{K}-\mathrm{Ar}$ variando entre $628 \pm 11 \mathrm{Ma}$ e $615 \pm 11 \mathrm{Ma}$, correspondentes ao resfriamento regional.

VAN SCHMUS et al. (1986) obtiveram idade U-Pb de $1790 \pm 14 \mathrm{Ma}$ em zircão do metarriodacito do Morro do Polvilho, que seria intercalado na seqüência vulcano-sedimentar basal do Grupo São Roque. A idade foi interpretada como sendo da cristalização do vulcanismo, em desacordo com CARNEIRO (1983) e CARNEIRO et al. (1984b) que as definiram com intrusivas, implicando que a deposição do Grupo teria sido iniciada ao redor de 1,8 Ga. As idades $\mathrm{Rb}-\mathrm{Sr}$ indicaram rejuvenescimento ao redor de $550 \mathrm{Ma}$. Desta forma, não teria havido deposição de sedimentos do Grupo São Roque no Brasiliano. Entretanto, mapeamento e petrografia detalhados feitos na região anterior por JULIANI et al. (1997a) mostraram que o metarriodacito é em verdade um metarcóseo com intercalações de metaconglomerado, pertencentes às unidades basais do Grupo São Roque e posicionados sobre a sequiência metavulcano-sedimentar do Grupo Serra do Itaberaba. Os grãos de zircão mostram-se muitas vezes arredondados e, por serem detríticos, indicam a idade máxima da sedimentação do Grupo São Roque e não o início da formação do Grupo Serra do Itaberaba. 
TASSINARI et al. (1988) compartimentaram o embasamento do sudeste do Estado de São Paulo, de NW para SE, nos domínios Itapira-Amparo, Piracaia-Jundiá, São Roque, Embu e Costeiro, limitados por falhas transcorrentes e cavalgamentos. Observaram uma migração dos picos metamórficos, relacionada à orogenia brasiliana no Neoproterozóico, decrescente em idades do segundo domínio em direção ao Costeiro de $800 \mathrm{Ma}$ até $650 \mathrm{Ma}$, enquanto que nas rochas granitóides as idades aumentariam em direção a NW, com 550 Ma e 1000 Ma nos domínios Costeiro e Piracaia-Jundiaí, respectivamente. No Domínio São Roque, as rochas depositadas ao redor de $1.800 \mathrm{Ma}$ teriam sofrido um evento metamórfico principal em $1.300 \mathrm{Ma}$, acompanhado de atividades graníticas sin- a tardi-tectônicas, seguido por outro evento metamórfico entre 800 e $700 \mathrm{Ma}$. As intrusões graníticas principais foram consideradas como pós-tectônicas, distribuídas entre 700 e $520 \mathrm{Ma}$.

Os estudos geocronológicos de TASSINARI \& SATO (1996) incluem os complexos Costeiro (CC) e Embu (CE), Grupo São Roque (GSR), Nappe Socorro Guaxupé (NSG) e Maciço Itatins (MI), e indicam que as rochas metamórficas do CC foram formadas por volta de $600 \mathrm{Ma}$ e as do CE e GSR ao redor de $700 \mathrm{Ma}$. Suas composições isotópicas de $\mathrm{Sr}, \mathrm{Pb}$ e $\mathrm{Nd}$ indicam origem por retrabalhamento crustal. No $\mathrm{CC}$, as idades $\mathrm{T}_{\mathrm{DM}}$ entre 1,8 e 1,9 Ga indicariam a época de diferenciação da crosta continental primitiva e as situadas entre 1,2 e 1,4 Ga foram interpretadas como devidas à formação dos granitóides no Neoproterozóico por retrabalhamento das rochas preexistentes. No CE as rochas migmatíticas, orto- e paragnáissicas com idades entre 2,5 e 1,5 Ga apresentam $\mathrm{T}_{\mathrm{DM}}$ entre 2,9 e 3,3 Ga, indicando que a crosta continental formou-se no Mesoarqueano. Os migmatitos de Cunha têm $\mathrm{T}_{\mathrm{DM}}$ ao redor de 2,7 e 1,9 Ga, sugerindo idades mais jovens de diferenciação mantélica, incluindo materiais do Paleoproterozóico, assim como o granito Quebra Cangalha, com 2,2 Ga. Os paragnaisses do CE, com idades próximas a $700 \mathrm{Ma}$, têm $\mathrm{T}_{\mathrm{DM}}$ próximas a 1,4 Ga, interpretadas como devidas aos protólitos sedimentares oriundos de fontes diversas. No domínio GSR, os granitos analisados foram principalmente os pós-tectônicos, que apresentaram idades entre 2,1 e 1,7 Ga, o que indicaria o período de diferenciação mantélica do embasamento do Grupo São Roque. Na NSG foram obtidas idades entre 3,2 e 2,9 Ga e entre 2,0 e 1,8 Ga, evidenciando a existência de crosta arqueana na região de Amparo e Serra Negra e, mais a sul, de crosta continental transamazônica semelhante à do GSR. No MI foram obtidas $T_{D M}$ de 2,5 e de 1,3 Ga, sugerindo, respectivamente, crosta do Arqueano tardio e idade de mistura. Portanto, o sudeste de São Paulo é interpretado como constituído por terrenos formados em diferentes épocas e justapostos no Neoproterozóico.

RAGATKY (1997) apresentou um estudo e uma revisão dos dados geocronológicos das rochas graníticas brasilianas e de dois metabasitos da região, principalmente através dos métodos $\mathrm{Rb}-\mathrm{Sr}$, U-Pb e $\mathrm{Sm-Nd}$. Praticamente todas as datações pelos dois primeiros métodos apresentam grandes problemas, que não permitem sua utilização, provavelmente devido ao tratamento de rochas diferentes em um mesmo diagrama, como granitos, granodioritos e veios, bem como por problemas de alteração hidrotermal. 
Com base em dados geocronológicos, WERNICK \& TÖPFNER (1997), admitiram a seguinte evolução para o Cinturão Ribeira: a) rifteamento, com magmatismo básico de cabeça de pluma a 1000 $950 \mathrm{Ma}$; b) magmatismo sin-convergente mais antigo que $630 \mathrm{Ma}$ e, possivelmente, com idades de até $669 \mathrm{Ma}$; c) tectônica de cavalgamento NW-SE a 655 - $610 \mathrm{Ma}$, possivelmente até 669 - $610 \mathrm{Ma}$; d) tectônica transcorrente NE-SW transpressiva entre 624 - $595 \mathrm{Ma}$ e transtrativa a $583 \mathrm{Ma}$; e) magmatismo pós-cisalhamento a $590 \mathrm{Ma}$;) magmatismo filoniano a $566 \mathrm{Ma}$.

HACKSPACHER et al. (1998) constataram a existência de uma crosta paleoproterozóica na região de São Roque a partir de valores de $\mathrm{T}_{\mathrm{DM}}$ entre 1,8 e 2,0 Ga quantificados em granitos neoproterozóicos. A crosta, com núcleos preservados nos Blocos Jundiaí e Embu, seria fragmentada e rifteada para a deposição dos grupos São Roque e Serra do Itaberaba em 1,7 Ga, seguida de fechamento e colisão no Ciclo Brasiliano gerando deformações $D_{n+1}, D_{n+2}$ e $D_{n+3}$ progressivas, e metamorfismo +1 e +2 em fácies anfibolito no Grupo Serra do Itaberaba e xisto-verde no Grupo São Roque, com magmatismo cálcio-alcalino a alcalino associado. À última deformação, mais penetrativa, relacionaram zonas de cisalhamento transcorrente NE/SW iniciadas em regime transtrativo, com ascensão de magmas provocando formação de auréolas metamórfica e tectônica nas rochas metassedimentares dos grupos. O contínuo soerguimento crustal levaria à superposição do regime tectônico transcorrente e, no amainamento e evolução para transpressivo, à instalação de tectônica de blocos com deslocamentos verticais máximos, em que os blocos Jundiaí e Embu estruturar-se-iam como altos e o São Roque como baixo estrutural.

Datações mais recentes pelo método U-Pb em zircão de metabasito do Grupo São Roque têm indicado que a formação da sua bacia deposicional deu se no Neoproterozóico (HACKSPACHER et al. 1999, DANTAS et al. 1999), ao redor de $615 \mathrm{Ma}$.

No Grupo Serra do Itaberaba, o zircão de metandesito da Formação Morro da Pedra Preta (basal) apresentou idade $\mathrm{U}-\mathrm{Pb}$ de $1397 \pm 18 \mathrm{Ma}$, que indica a idade máxima da sedimentação dos pelitos que recobrem a unidade basáltica gerada em MORB. Os metarriólitos da Formação Nhanguçu apresentam duas populações de zircão: uma, com idade de $618 \pm 3 \mathrm{Ma}$, define o período de cristalização da rocha e outra, de $1449 \pm 3 \mathrm{Ma}$, interpretada como xenocristais herdados de litotipos do Grupo Serra do Itaberaba. O metarriólito foi afetado pela foliação $S_{2}$, gerada durante o evento metamórfico associado à evolução do Grupo São Roque, que retrabalhou a sequiência metavulcano-sedimentar do Proterozóico Médio, confirmando a evolução dos grupos em dois ciclos geotectônicos distintos. 


\section{CAPÍTULO III}

\subsection{Contexto Geotectônico}

As rochas supracrustais dos grupos São Roque e Serra do Itaberaba (JULIANI et al. 1986) inserem-se no contexto geotectônico dos Paraibides de EBERT $(1967,1971)$, denominado de Cinturão Ribeira por ALMEIDA et al. (1973). Essas supracrustais compõem, junto com o Grupo Açungui, o Sistema de Dobramento Apiaí (ALMEIDA et al. 1973) ou, respectivamente, as faixas de dobramentos São Roque e Açungui (HASUI et al. 1975, HASUI et al. 1978a), e situam-se, de acordo com ALMEIDA \& HASUI (1984) na Província Mantiqueira. Compreendem parte do Sistema de Dobramentos Sudeste (ALMEIDA et al. 1976, SCHOBBENHAUS FILHO et al. 1984), que limita-se, a norte-noroeste, com o Maciço Mediano de Guaxupé e o Cráton do São Francisco, a oeste, com as rochas sedimentares da Bacia do Paraná, e a leste é limitado pelo Oceano Atlântico (FIGURA 3.1).

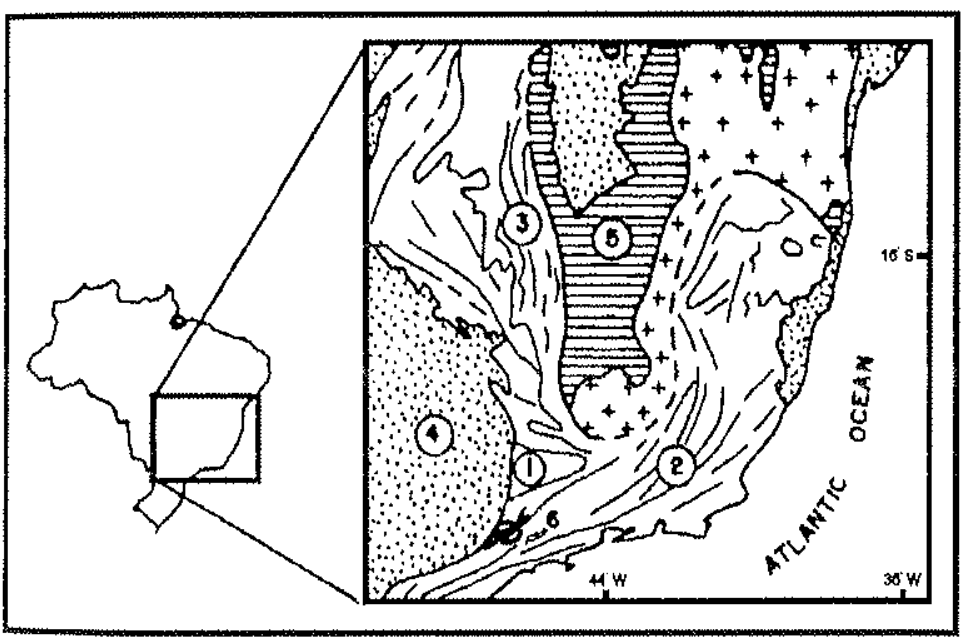

FIGURA 3.1 - Contexto Geotectônico do sudeste brasileiro, incluindo a Faixa São Roque/Serra do Itaberaba. Onde (1) Maciço Mediano de Guaxupé, (2) Sistema de Dobramentos Sudeste/Ribeira, (3) Faixa de Dobramentos Brasília, (4) Bacia do Paraná, (5) Cráton do São Francisco, (6) Faixa São Roque/Serra do Itaberaba, c localização da área pesquisada no círculo preto. Baseado em SCHOBBENHAUS FILHO et al. (1984).

Vários trabalhos compartimentam o Pré-Cambriano paulista em grandes blocos tectônicos, justapostos por zonas de cisalhamento transcorrentes com intensa movimentação horizontal, pressupondo histórias geológicas distintas. Neste contexto, as rochas dos grupos São Roque e Serra do Itaberaba, na área de estudo, integram o Bloco São Roque (HASUI et al. 1969) ou o Bloco Santana do Parnaíba do Conjunto São Roque (CAMPOS NETO \& BASEI 1983b).

O limite norte do Bloco São Roque faz-se através das zonas de cisalhamento de Itu (HASUI \& SADOWSKI 1976) e Jundiuvira (HASUI et al. 1969), onde encontra-se em contato com o Bloco Jundiaí, enquanto a sul é demarcado pelas zonas de cisalhamento de Taxaquara (HENNIES et al. 1967), Rio Jaguari e Monteiro Lobato (CAVALCANTE \& KAEFER 1974), justapondo-se com o Bloco Cotia.

Nos últimos anos, outros autores (HACKSPACHER et al. 1989, DANTAS 1990, JULIANI 1992) têm sugerido ou verificado continuidades litológicas, estruturais e estratigráficas, postulando uma 
estruturação em blocos posterior ao desenvolvimento das unidades litoestratigráficas (JULIANI 1992). HACKSPACHER (1994) considera os deslocamentos verticais mais importantes para a estruturação dos blocos em regimes transcorrentes, enquanto os horizontais seriam secundários.

No modelo de colisão continental com subducção da margem leste do Bloco Paraná proposto por SOARES (1988), o Grupo Serra do Itaberaba seria o resultado da abertura e separação crustal do final do Paleoproterozóico ou do início do Mesoproterozóico, enquanto que o Grupo São Roque representaria a transgressão que acompanhou o estiramento crustal de retro-arco na subducção do Neoproterozóico.

A área em que afloram as rochas da Faixa São Roque/Serra do Itaberaba (JULIANI \& BELJAVSKIS 1995) faz parte do Cinturão Transcorrente Rio Paraíba do Sul de EBERT et al. (1991). Neste contexto, HASUI et al. (1991, 1993) e EBERT et al. (1993a, b) entendem que a Faixa seria afetada por esse Cinturão, disposto entre os blocos São Paulo, a oeste, e Vitória, a leste, a partir de uma modelagem em colisão oblíqua com convergência $\mathrm{E}-\mathrm{W}$, que teria evoluído no Arqueano ou início do Paleoproterozóico. O Grupo Serra do Itaberaba, nesta abordagem, constitui parte do pacote metavulcanosedimentar Ribesita (HASUI et al. 1993).

De acordo com a modelagem proposta por MACHADO \& ENDO (1993a, b, 1994), ENDO \& MACHADO (1993) e MACHADO (1997) a Faixa São Roque/Serra do Itaberaba integra o Sistema de Cisalhamento Paraíba do Sul do Cinturão de Cisalhamento Atlântico (FIGURA 3.2), que comporta uma provável colisão continental oblíqua entre as placas do Congo e Amazonas, gerando uma tectônica transpressional neoproterozóica dividida em dois estágios: uma tectônica transpressional dextral com vetor compressivo $\mathrm{E}-\mathrm{W}$, e uma tectônica sinistral com vetor compressivo $\mathrm{N}-\mathrm{S}$.

A Faixa São Roque/Serra do Itaberaba insere-se no Domínio São Roque da Microplaca ApiaíGuaxupé do Sistema Orogênico Ribeira (CAMPOS NETO \& FIGUEIREDO 1992, 1995a, b, FIGUEIREDO \& CAMPOS NETO 1994, CAMPOS NETO \& CABY 1999), compreendendo estruturas em nappes ligadas ao transporte de terrenos no Neoproterozóico, através de sucessivos processos de convergência, que refletem a colagem de microplacas distintas.

\subsection{Geologia Regional}

As rochas supracrustais da Faixa São Roque/Serra do Itaberaba (JULIANI 1993, JULIANI \& BELJAVSKIS, 1995) e os granitóides nela intrusivos afloram por pouco mais de $180 \mathrm{~km}$ de comprimento, apresentando largura máxima ao redor de $40 \mathrm{~km}$ na porção ocidental e se afunilando para nordeste, desaparecendo nas cercanias de Monteiro Lobato (FIGURA 3.3). Os limites da Faixa fazem-se, a norte, através das zonas de cisalhamento de Itu (HASUI \& SADOWSKI 1976) e Jundiuvira (HASUI et al. 1969), com os complexos Amparo, Itapira e Paraíba do Sul e, a sul, com o Complexo Embu (HASUI 1973), junto à Zona de Cisalhamento Taxaquara (HENNIES et al. 1967).

O Grupo Amparo (EBERT 1967) foi dividido nas formações Hermida e Japi por HASUI et al. 
(1978c), e redefinido como Complexo Amparo, por BISTRICHI et al. (1981), sendo constituído predominantemente por gnaisses com granada, hornblenda e biotita, em parte migmatizados, além de quartzitos, xistos, anfibolitos, rochas calciossilicáticas, e granulitos subordinados (ALMEIDA et al. 1981). De acordo com CAMPOS NETO et al. (1984), representam os terrenos alóctones da Nappe de Cavalgamento de Socorro.

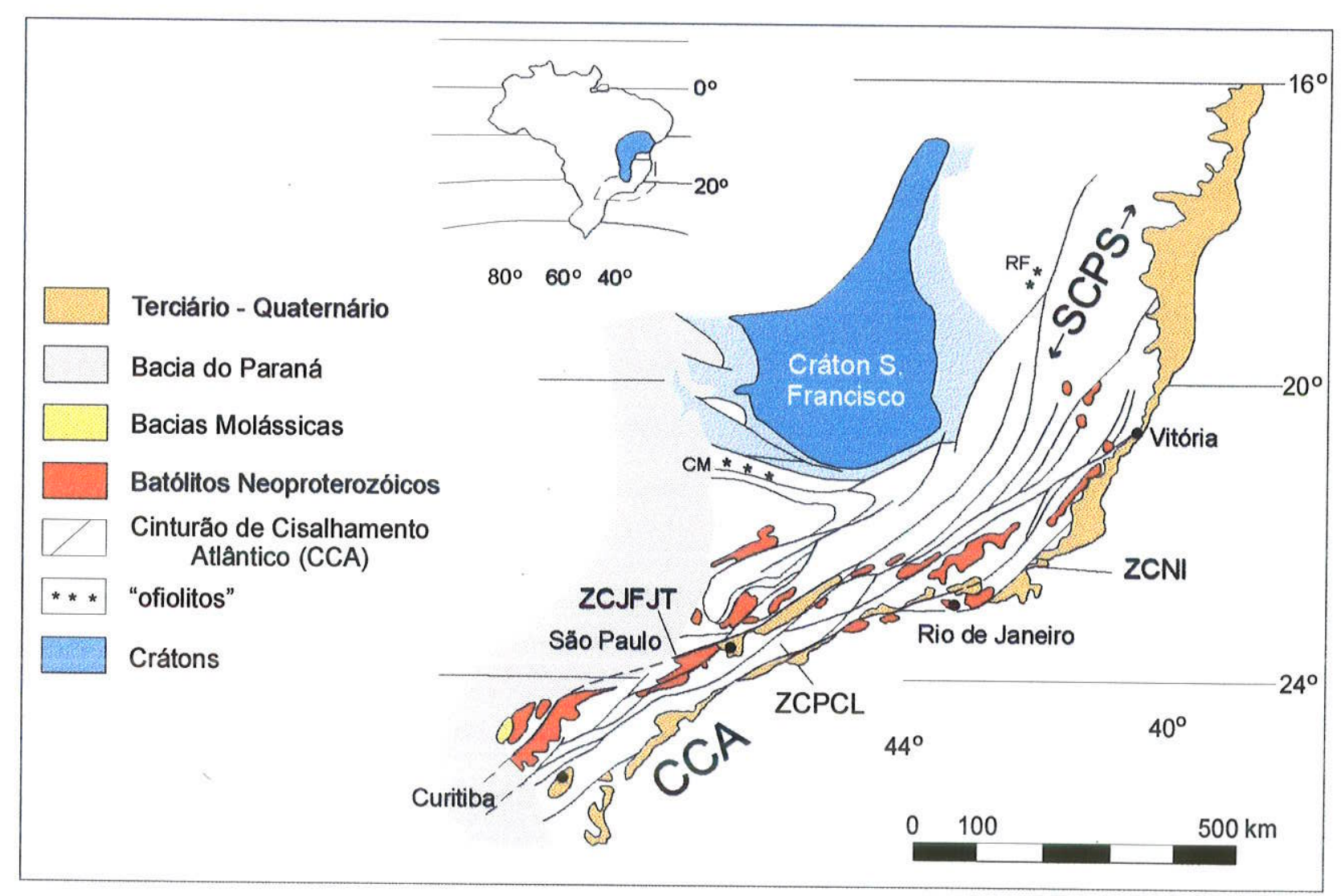

FIGURA 3.2 - Cinturão de Cisalhamento Atlântico. Onde: (SCPS) - Sistema de Cisalhamento Paraíba do Sul; (ZCNI) - Zona de Cisalhamento Niterói; (ZCPCL) - Zona de Cisalhamento Paraíba do Sul-Cubatão-Lancinha; (ZCJFJT) - Zona de Cisalhamento Juiz de Fora-Jundiuvira-Taxaquara. Modificado de MACHADO (1997).

A introdução do termo Grupo Paraíba deve-se a EBERT (1967). Segundo BISTRICHI et al. (1981), os litotipos do Complexo Paraíba do Sul (HASUI et al. 1981) ocorrem a leste-nordeste do Complexo Amparo, sendo constituídos predominantemente por gnaisses e migmatitos polifásicos com intercalações menores de granulitos, xistos, quartzitos, mármores e rochas calciossilicáticas.

DANTAS (1990, 1992) subdividiu o embasamento pré-São Roque, a norte da Zona de Cisalhamento de Jundiuvira, em migmatitos e ortognaisses, que correlacionou com o Complexo Amparo, enquanto que os xistos, gnaisses bandados, paragnaisses quartzosos e quartzitos alternados associou às supracrustais do Grupo Itapira. Ainda trabalhando a norte da referida zona de cisalhamento, CARNEIRO (1983) agrupou os gnaisses e migmatitos naquele Complexo, e SANTORO $(1984,1986)$ descreveu seus litotipos contendo incidência variável de migmatização. Quanto à unidade quartzítica das serras do Japi e Guaxatuba, o último autor considerou que, devido à posição estratigráfica indefinida, poderia pertencer 
àquele Complexo ou ao Grupo São Roque.

A definição de Grupo Itapira coube a EBERT (1968), sendo redefinido como Complexo Itapira por CAVALCANTE et al. (1979). Compreende rochas gnáissicas de composição variável, rochas calciossilicáticas e quartzo-dioríticas, com freqüentes intercalações anfibolíticas e migmatíticas, além de quartzitos, calcários e gonditos.

HACKSPACHER et al. (1992a, c) e HACKSPACHER (1994) mapearam as formações Hermida, Japi e Jundiuvira, além de migmatitos e gnaisses ortoderivados, a norte da Zona de Cisalhamento de Jundiuvira, e consideraram esses litotipos como pertencentes ao Complexo Itapira.

O Complexo Migmatítico Embu (HASUI 1975a, b) ou Complexo Embu (HASUI \& SADOWSKI 1976) conteria variedades estromáticas e oftalmíticas, correspondentes em grande parte aos gnaisses de COUTINHO (1972). Segundo BISTRICHI et al. (1981), seria constituído por migmatitos oftálmicos, nebulíticos e facoidais com inclusões menores irregulares de xistos, metabásicas, quartzitos e calciossilicáticas, além de conter núcleos reconhecidos por SADOWSKI (1974) como possivelmente mais antigos que os migmatitos brasilianos.

JANASI et al. (1990) caracterizaram diversas intrusões granitóides lenticulares enfeixadas no Complexo Embu e, na região de estudo, individualizaram as fácies petrográficas Itapevi e lbiúna.

A introdução do termo Série de São Roque é de OLIVEIRA (1925), sendo redefinida como Grupo São Roque nos trabalhos publicados referentes à cartografia do Mapa Geológico do Estado de São Paulo em escala 1:1.000.000 (IGG 1963, LEFEVRE et al. 1963, PAOLIELLO 1964).

A primeira tentativa de subdivisão estratigráfica do Grupo São Roque deve-se a HASUl et al. (1976). Compreenderia a Formação Boturuna, com filitos e intercalações de quartzito na parte basal e de rochas carbonatadas no topo, e a Formação Piragibu, superior e de caráter flyschóide, que comporia umà seqüência de filitos rítmicos ou altenâncias de filito e de quartzito.

Nova proposta foi efetuada por BERGMANN (1988), que definiu as formações Pirapora, com metabasitos com estruturas tipo pillow-lavas e possíveis rochas piroclásticas básicas, além de cálciofilitos e metadolomitos com bioermas estromatolíticas restritas; Estrada dos Romeiros, contendo um membro arenoso e outro pelítico; e Boturuna, que comportaria dois membros vulcânicos e dois arenosos.

Vários trabalhos abordando a Faixa São Roque/Serra do Itaberaba reconhecem a ocorrência de uma seqüência de rochas supracrustais possivelmente mais antigas que o Grupo São Roque (IGG 1947, COUTINHO 1955, COUTINHO \& TAKEDA 1955, ALMEIDA et al. 1981, HASUI et al. 1981). Essa sequiência constituir-se-ia, em grande parte, por xistos de mais alto grau metamórfico encontrados com frequiência nas proximidades de alguns dos maciços granitóides. Analisando essas supracrustais a nordeste da cidade de São Paulo, JULIANI \& BELJAVSKIS (1983) subdividiram o Grupo São Roque em uma unidade inferior, em essência metavulcano-sedimentar, e uma unidade superior, composta por litotipos associados a deposição clasto-química. Posteriormente, o pacote inferior foi definido por JULIANI et al. (1986) como o Grupo Serra do Itaberaba, sendo considerado o embasamento do Grupo 
São Roque striciu sensu, que então compreenderia apenas a unidade superior.

Segundo JULIANI (1993) e JULIANI \& BELJAVSKIS (1995), na Faixa São Roque/Serra do Itaberaba distinguem-se duas grandes unidades: o Grupo São Roque e o Grupo Serra do Itaberabá. No Grupo São Roque podem ser reconhecidas as formações Piragibu, metapelítica e portando lentes restritas de metaconglomerados e metavulcânicas; Pirapora do Bom Jesus, em essência metavulcânica/metavulcanoclástica, com cálcio-filitos e bioermas; Estrada dos Romeiros, contendo metapelitos e metarenitos rítmicos; e Boturuna, predominantemente metarenítica e arcoseana. O conjunto encontra-se afetado por metamorfismo de fácies xisto-verde de baixa pressão, localmente com grau metamórfico mais elevado pela ação termal de rochas granitóides.

O Grupo Serra do Itaberaba compreenderia as formações Morro da Pedra Preta, basal e metavulcano-sedimentar; Nhanguçu, superior, portando metapelitos com andaluzita ou manganesíferos, além de lentes menores de rochas carbonáticas e calciossilicáticas; Pirucaia, predominantemente quartzítica e possivelmente cronocorrelata à Formação Nhanguçu e, talvez, também à formação basal. Os litotipos estão metamorfizados na fácies xisto-verde superior a anfibolito, de pressão intermediária, e se observa a presença de cianita em diversas paragêneses minerais, indicando condições de pressão algo mais elevadas que aquelas vistas no Grupo São Roque.

Associações litoestratigráficas semelhantes têm sido verificadas a noroeste da cidade de São Paulo, onde o Grupo Serra do Itaberaba acha-se cartografado (HACKSPACHER et al. 1992a, b, c, OLIVEIRA et al. 1992a, b, HACKSPACHER 1994).

Diversos corpos granitóides de idade brasiliana intrudem extensas áreas da Faixa São Roque/Serra do Itaberaba. Compreendem várias fácies petrográficas, predominando os tipos porfiróides portadores de megacristais de feldspato potássico. Sua composição varia, predominantemente, de granítica a granodiorítica, e ocorrem tipos com características sin-, tardi- e pós-tectônicas (HASUI et al. 1978b, WERNICK \& GALEMBECK 1986, JANASI \& ULBRICH 1991).

WERNICK (1998a, b, c, d), distinguiu dois estágios para a colocação do magmatismo granitóide brasiliano. O inicial estaria associado ao caráter transpressivo do Cinturão Ribeira, situado entre 630. $590 \mathrm{Ma}$, resultando na colocação de batólitos maiores, múltiplos, compostos e plurisseriais com história evolutiva longa, entre 50 e $60 \mathrm{Ma}$, enquanto que o final, situado entre 600-580 $\mathrm{Ma}$, compreenderia granitóides alojados em zonas de fraqueza crustal, associados a flexuras ou arqueamentos, que poderiam estar ou não afetados pelas fases transcorrente final e transtrativa e por falhas normais tardias.

Na região ainda observam-se depósitos sedimentares terciários da Formação São Paulo e correlatos, às vezes afetados por reativações das zonas de cisalhamentos que recortam a área. 


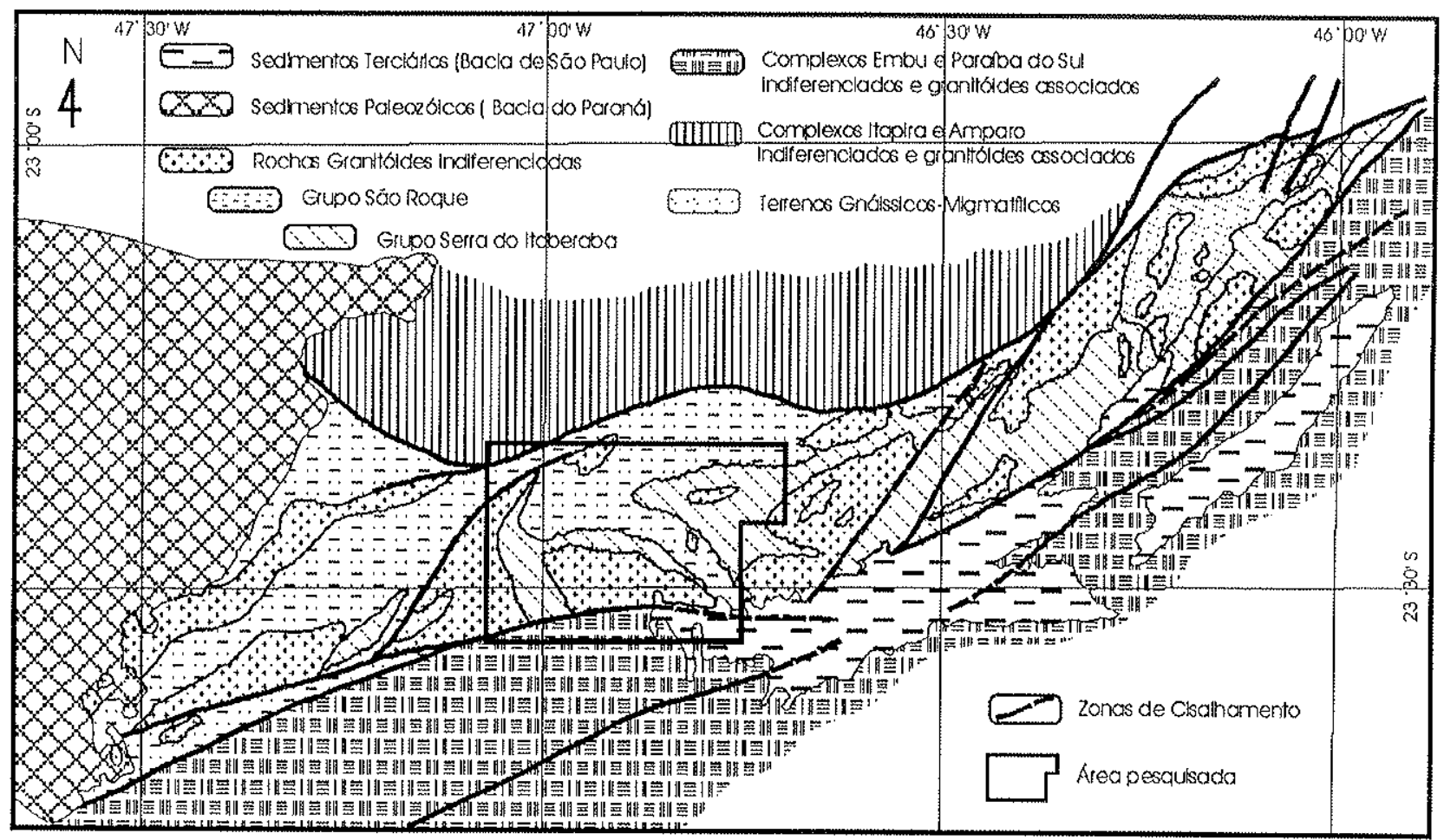

FIGURA 3.3 - Contexto geologico regional da Faixa São Roque/Serra do Itaberaba. Modificado e simplificado a partir de BISTRICHI et al. (1981), JULIANI et al. (1986) e JULIANI \& BELJAVSKIS (1995).

\subsection{Litoestratigrafia da Faixa São Roque/Serra do Itaberaba}

Diversas propostas litoestratigráficas foram elaboradas ao longo deste século para a Faixa São Roque/Serra do Itaberaba, e encontramıse compiladas em JULIANI (1993). As principais e as mais recentes são discutidas por JULIANI \& BELJAVSKIS (1995).

Coube a HASUI et al. (1976) a primeira subdivisão formal do Grupo São Roque, que compreenderia um pacote basal com predomínio de filitos e contendo intercalações de quartzito na parte inferior e de rochas carbonatadas no topo, denominada Formação Boturuna. A Formação Piragibu, superior, estaria representada por uma sequêencia de filitos rítmicos ou alternâncias de filito e de quartzito de caráter flyschóide. Tecendo comparações entre os grupos São Roque e Açungui, esses autores afirmaram que ambos teriam uma sedimentação terrígena inferior, seguida por lentes mal desenvolvidas de rochas carbonatadas recobertas por outra sequiência terrígena superior. Quanto aos metaconglomerados, às três ocorrências de metavulcânicas e aos metassedimentos de fácies anfibolito, aventaram a hipótese de pertencerem ao embasamento do Grupo São Roque. Esses litotipos também seriam identificados no Grupo Açungui (FIGURA 3.4).

HASUl et al. (1981) observaram no Grupo São Roque a passagem transicional entre os filitos e os xistos, mas admitiram que a maior parte das rochas de fácies anfibolito representariam uma unidade pré-São Roque, observada em zonas periféricas das intrusões graníticas, e resultante de um alçamento marginal. 
Na região da Serra do Itaberaba, COUTINHO et al. (1982) caracterizaram, para a porção basal do Grupo São Roque, um pacote com predomínio de vulcânicas ou subvulcânicas básicas e tufos associados, além de xistos finos com andaluzita, filitos derivados de sedimentos manganesíferos e xistos sericíticos diversos, denominada sequiência vulcano-sedimentar inferior. Os litotipos da seqüiencia superior seriam formados por ritmitos silto-argilosos com sedimentos carbonáticos associados, e corresponderiam a depósitos tipo flysch. Essas seqüências foram associadas respectivamente às formações Boturuna e Piragibu (HASUl et al. 1976).

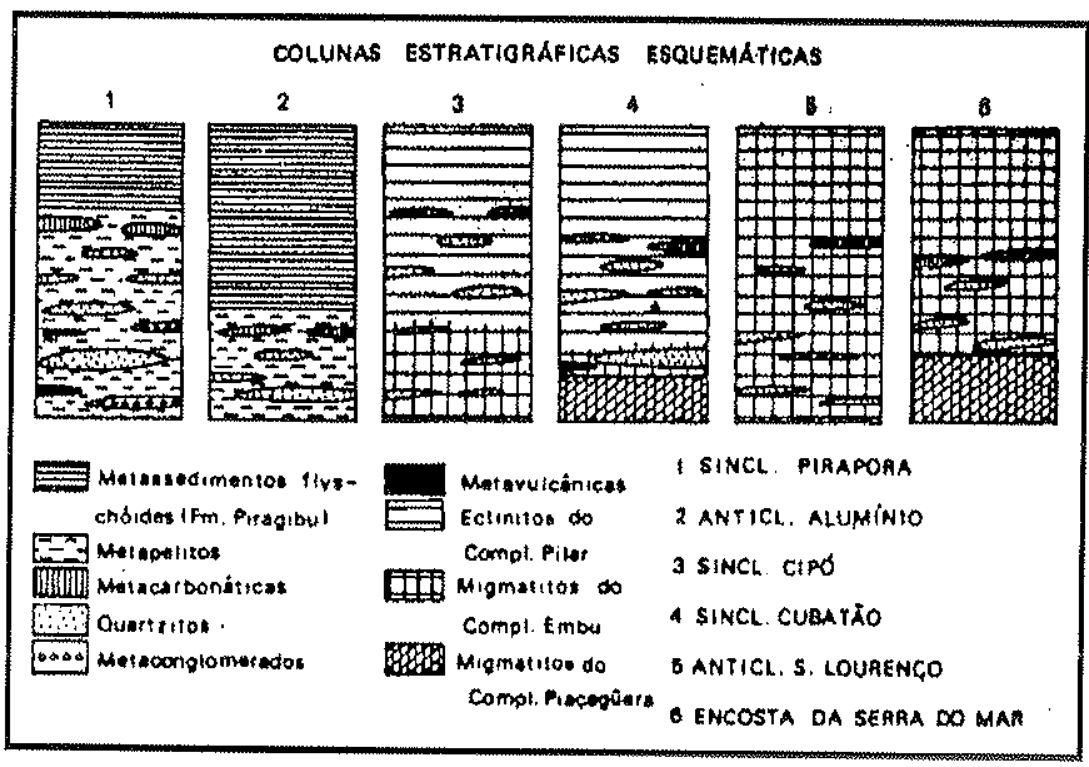

FIGURA 3.4 - Colunas litoestratigráficas propostas para os grupos São Roque e Açungui (HASUI et al. 1976). As unidades Metapelitos, Metacarbonáticas, Quartzitos, Metaconglomerados o Metavulcânicas pertencem à Formação Boturuna.

JULIANI \& BELJAVSKIS (1983) trouxeram novos dados à área discutida por COUTINHO et al. (1982), e subdividiram informalmente o Grupo São Roque na Sequiência Inferior, com depósitos clásticos e turbidíticos sedimentados nas partes mais profundas de uma bacia tafrogênica, associados com rochas vulcânicas extrusivas, intrusivas e vulcanoclásticas, rochas calciossilicáticas e produtos de atividades vulcano-exalativas, intercalados em eventos cíclicos por sedimentos terrígenos finos. Ainda individualizaram nessa sequêencia outros litotipos associados com atividades vulcano-exalativas, formados por filitos laminados a bandados ricos em óxidos e hidróxidos de ferro e manganês, e por fim mapearam sedimentos grossos e imaturos. A Seqüiencia Superior, com carbonatos, margas e sedimentos pelítico-aluminosos ou não, representaria depósitos clastomquímicos plataformais de águas menos profundas, correlacionada em parte à Formação Piragibu. (FIGURA 3.5).

Ao mapear a região a NNW do município de São Paulo, CARNEIRO (1983) considerou a presença de quatro grandes pacotes litológicos pertencentes ao Grupo São Roque que, por apresentarem passagens sempre gradacionais, teriam conotação estratigráfica. Da base para o topo ocorreriam: pacote de metapsamitos impuros, onde metarcóseos, metarenitos e metagrauvacas teriam intercalações de anfibolitos, metaconglomerados polimíticos e metavulcânicas básicas amigdaloidais, capeados provavelmente por quartzitos; pacote de metapelitos, englobando filitos laminados e xistos diversos, com intercalações de metapsamitos, além de anfibolitos restritos e rochas carbonáticas; pacote de metamargas 
e prováveis metatufos, que compreenderia as rochas calciossilicáticas com possível contribuição tufácea, e os anfibolitos bandados essencialmente eruptivos, sendo que as primeiras poderiam gradar para os calcários e dolomitos encontrados nas regiões de Cajamar e Pirapora do Bom Jesus; e o pacote de metapsamitos rítmicos, composto por metarenitos bandados e filitos, além de metarcóseos, metagrauvacas e quartzitos com possíveis níveis de metarcóseos e metaconglomerados basais (FIGURA. 3.6).

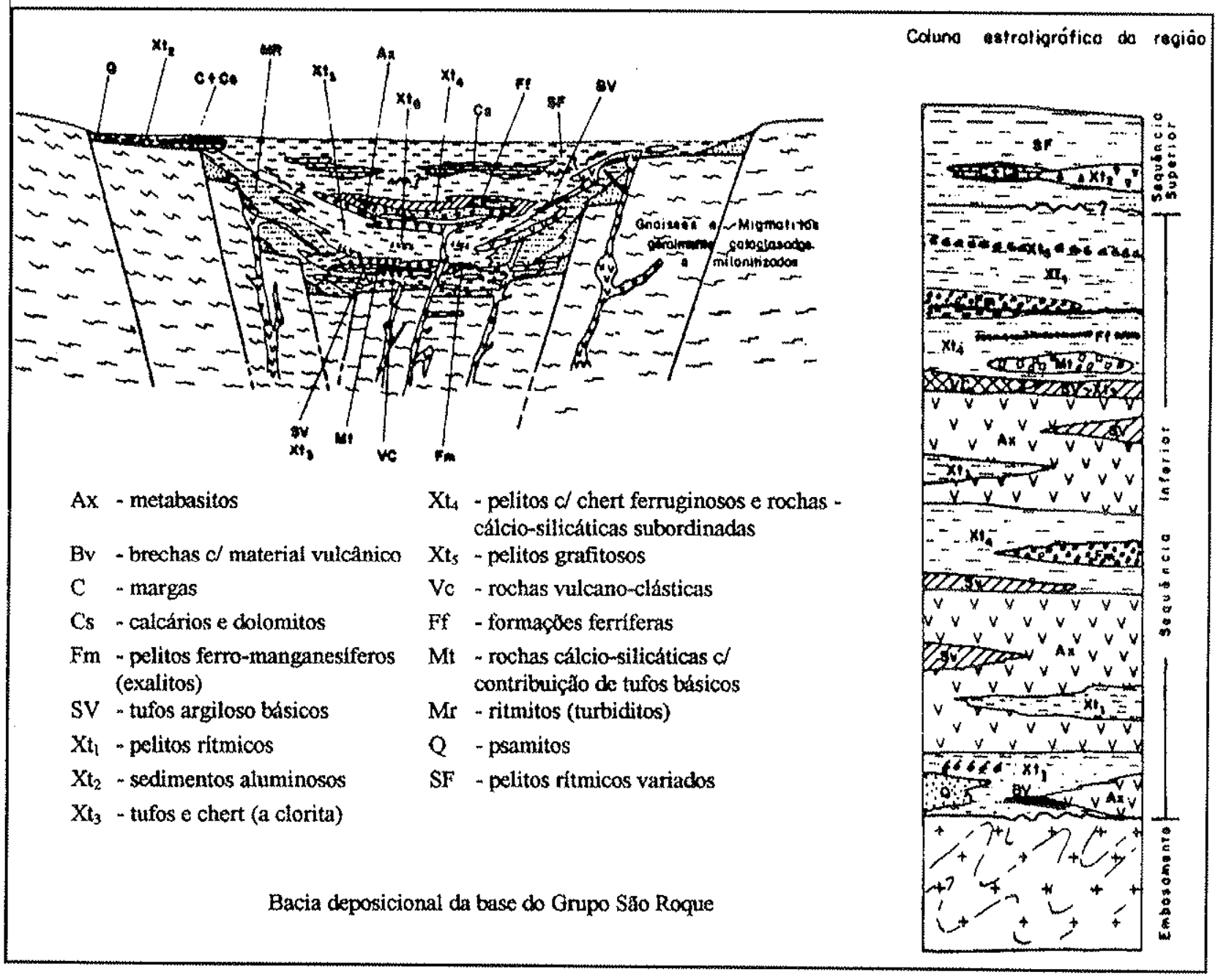

FIGURA 3.5 - Coluna litoestratigráfica de JULIANI \& BELJAVSKIS (1983) da região da Serra do Itaberaba.

CAMPOS NETO \& BASEI (1983a) propuseram para o Grupo São Roque, a NE da região discutida por COUTINHO et al. (1982) e JULIANI \& BELJAVSKIS (1983), a unidade vulcano. sedimentar basal, contendo anfibolitos na base, e metarritmitos com intercalações de hematita quartzitos, rochas calciossilicáticas e anfibolitos no topo, e a unidade metassedimentar rítmica, superior, composta de metarcóseos e metarenitos rítmicos, a unidade dos xistos e a unidade dos filitos, como se observa na FIGURA 3.7. As três primeiras unidades estariam metamorfizadas e gradariam, da base para o topo, da fácies anfibolito para xisto-verde, na zona da biotita, enquanto a unidade filítica ocorreria na fácies xistoverde, zona da clorita. 
Ao descrever o Sinclinório de Pirapora do Bom Jesus, BISTRICHI (1982) sugeriu um arcabouço estratigráfico semelhante às propostas formuladas por CARNEIRO (1983), e admitiu para os xistos de fácies anfibolito, embora não os tenha cartografado em mapa, origem a partir de auréolas de metamorfismo de contato de pequena expressão junto aos corpos graníticos maiores ou, como proposto por HASUI et al. (1981), a ascensão de rochas de níveis inferiores trazidas à superfície por intrusões graníticas.

TASSINARI et al. (1985) consideraram a idade de $1200 \pm 100 \mathrm{Ma}$ obtida pelo método $\mathrm{Rb}-\mathrm{Sr}$ para os seixos granito-gnáissicos do metaconglomerado da base do Grupo

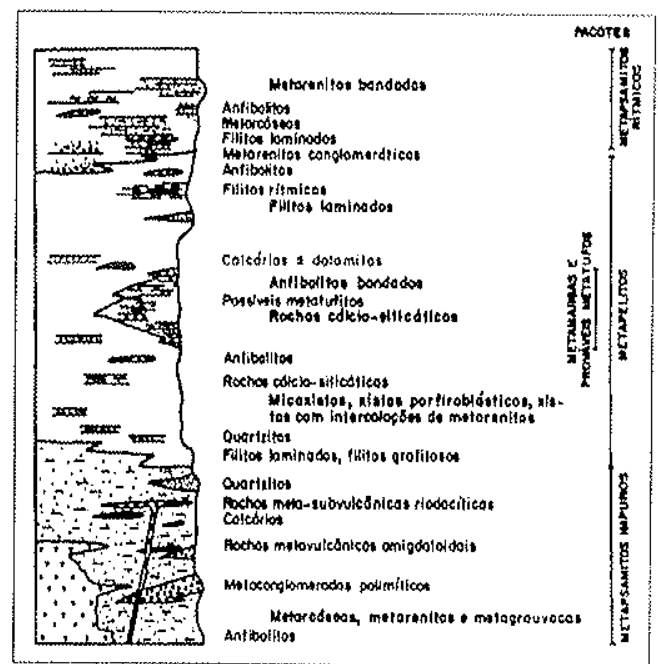

FIGURA 3.6 - Coluna litoestratigráfica da faixa entre o Pico do Jaraguá e a Serra do Cristais, proposta por CARNEIRO (1983).

São Roque, ou como a idade de formação da rocha geradora dos seixos, ou a do metamorfismo, concluindo por representar a idade máxima de deposição dos sedimentos do Grupo São Roque, enquanto a idade Rb-Sr, próxima a $800 \mathrm{Ma}$, obtida da matriz do metaconglomerado, relacionar-se-ia à fase principal de metamorfismo e à primeira fase de deformação do Grupo,

VAN SCHMUS et al. (1986), ao admitirem caráter vulcânico para o metarriodacito do Morro do Polvilho, intercalado no pacote inferior do Grupo São Roque e sotoposto aos metaconglomerados desse grupo, datado pelos mesmos em $1790 \pm 14 \mathrm{Ma}$ (método U.$\mathrm{Pb}$ em zircão), fizeram referência à deposição da sequiência vulcano-sedimentar da base do pacote inferior ao Paleoproterozóico, considerando a idade obtida como época de cristalização magmática dos riodacitos originais. Combinado com os dados de TASSINARI et al. (1985), sugeriram uma evolução policíclica para a sequiência inferior do grupo, que teria continuidade em episódios tectono-deformacionais durante o Neoproterozóico.

A designação formal do Grupo Serra do Itaberaba foi proposta por JULIANI et al. (1986), na região a NE da cidade de São Paulo, ao agrupar diversos litotipos antes

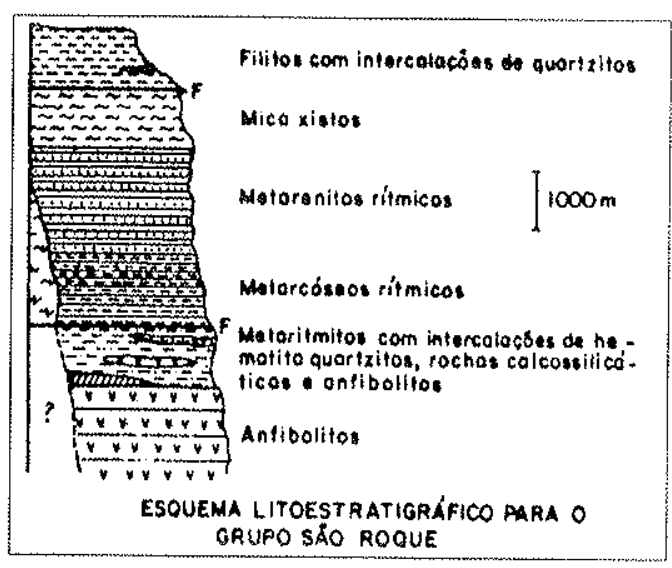

FIGURA 3.7 - Coluna litoestratigráfica proposta por CAMPOS NETO et al. (1983a) para a região a nordeste das Serras do Itaberaba e Pedra Branca. considerados como basais e pertencentes ao Grupo São Roque. As subdivisões são, em essência, as propostas por JULIANI \& BELJAVSKIS (1983).

O Grupo Serra do Itaberaba, com deposição em águas marinhas profundas acompanhada por intensa atividade ígnea, possuiria sequiências vulcano-sedimentares bem desenvolvidas, caracterizadas 
por extenso volume de magmatismo básico, e estaria alojado possivelmente em uma bacia do tipo rift, geotectonicamente situada em uma margem continental proximal ou mesmo marginal. Teria metamorfismo regional predominantemente em grau médio, com dobras intrafoliais dobrando uma xistosidade anterior, com evolução no Ciclo Transamazônico. O Grupo São Roque, redefinido, conteria sedimentos depositados em águas essencialmente rasas, possivelmente em uma bacia marinha epicontinental, sobreposta ao grupo anterior, predominando amplamente os clásticos com rochas carbonáticas subordinadas e rara atividade ígnea sin-sedimentar. Seriam afetados por grau metamórfico predominantemente mais baixo e também menos deformados. Pertenceria ao Ciclo Brasiliano. Os autores separaram outros possíveis locais de abrangência do grupo, destacando diversas semelhanças entre os litotipos da Serra do Itaberaba e os da faixa entre o Pico do Jaraguá e a Serra dos Cristais, e da região de Pirapora do Bom Jesus.

BERGMANN (1988) propôs uma subdivisão para o Grupo São Roque entre Santana do Parnaíba e Pirapora do Bom Jesus, da base para o topo, na Formação Pirapora, com metabasitos com estruturas tipo pillow-lavas e possíveis rochas piroclásticas básicas, e um Membro Carbonático, com cálcio-filitos e metadolomitos com bioermas estromatolíticos em exposições locais; na Formação Estrada dos Romeiros, que envolveria um Membro Arenoso com metarritmitos arenosos e microconglomerados intercalados gradando para metarenitos finos a médios, com intercalações subordinadas de metapelitos bandados, e um Membro Pelítico, superior, com metapelitos e metapsamitos rítmicos, finos a grossos, além de leitos microconglomeráticos; e na Formaçäo Boturuna, sobreposta, apresentando contato brusco a transicional com a formação anterior, contendo um Membro Arcoseano, dois membros vulcânicos, o primeiro de caráter básico e portando estruturas tipo pillow-lavas estiradas, e o segundo, ora de caráter básico, ora ácido, ocorrendo como bancos pouco espessos no pacote dos metarcóseos e geralmente rico em amígdalas, enquanto um Membro Ortoquartzítico capearia o pacote. Os contatos entre as formações seriam, em essência, gradacionais (FIGURA 3.8).

Ao mapear a Folha Guarulhos, DANTAS $(1990,1992)$ subdividiu o Grupo São Roque em duas unidades. A Unidade Inferior, composta por anfibolitos maciços e bandados com leitos de metatufitos e rochas calciossilicáticas na base, seguidos de quartzitos feldspáticos com intercalações de rochas subvulcânicas ácidas a intermediárias, metarcóseos e metaconglomerados, intercalações de filitos laminados e metassiltitos maciços, muscovita xistos e xistos porfiroblásticos e, no topo, filitos laminados e metarenitos, xistos finos alternados com metarenitos e raros níveis de rochas calciossilicáticas. A Unidade Superior portaria filitos bandados, metarritmitos intercalando filitos e metarenitos finos a grossos com níveis microconglomeráticos restritos e, no topo, metarenitos bandados de caráter subarcoseano com intercalações de filitos e níveis microconglomeráticos basais (FIGURA 3.9). 
BERGMANN (1991, 1992) renomeou as formações de BERGMANN (1988) nas unidades Vulcano Sedimentar Basal; Clástica Turbidítica Superior, depositada em um ambiente marinho profundo; e Clástica Alóctone, depositada em ambiente continental costeiro, gradando, no topo, para provável sedimentação de praia, capeados por um nível de ortoquartzitos também de ambiente continental costeiro, cavalgando a unidade turbidítica.
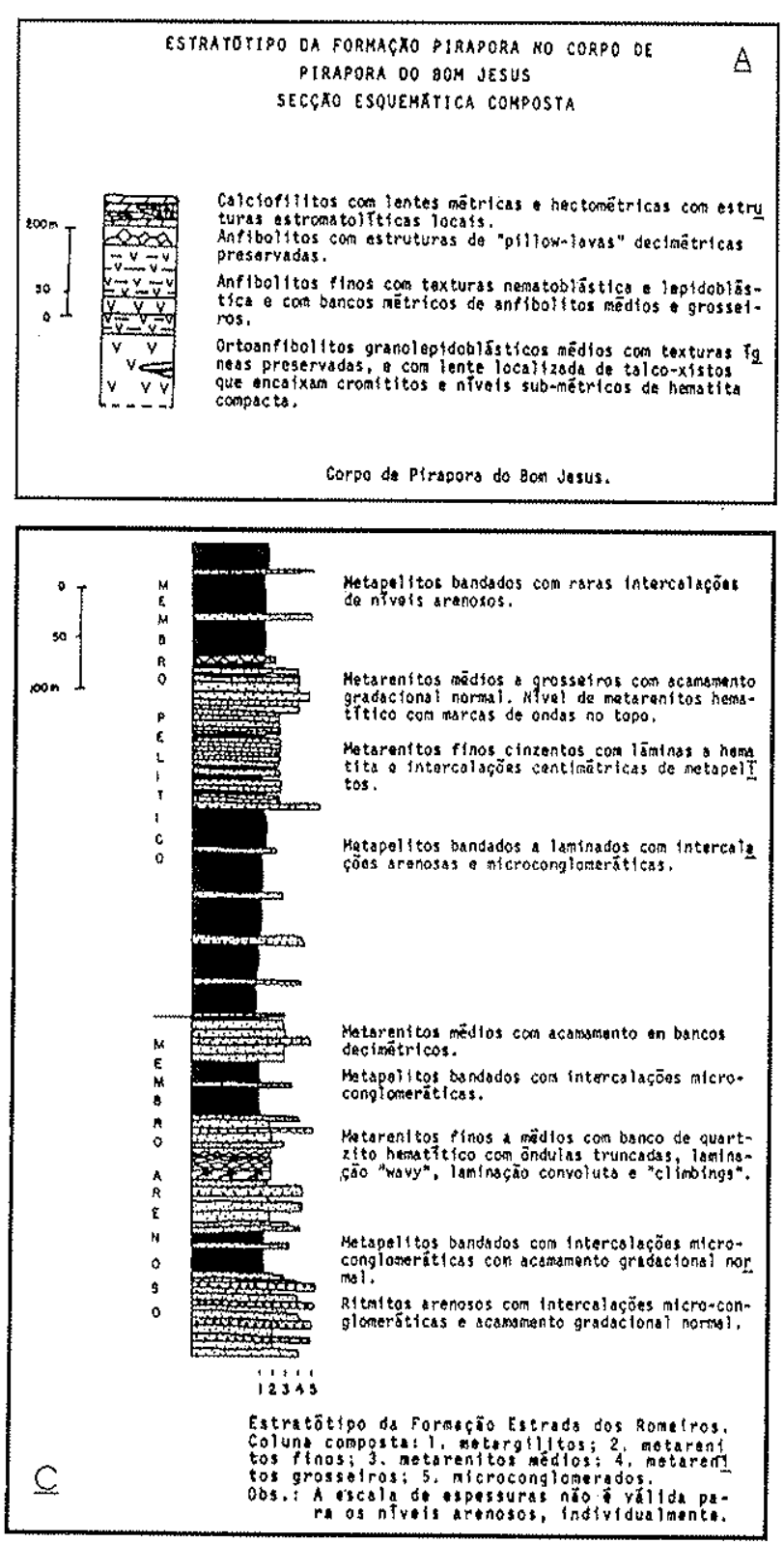

A ocorrência de três camadas de metaconglomerados cada vez menos espessas passando para metarcóseos no Morro Doce e os
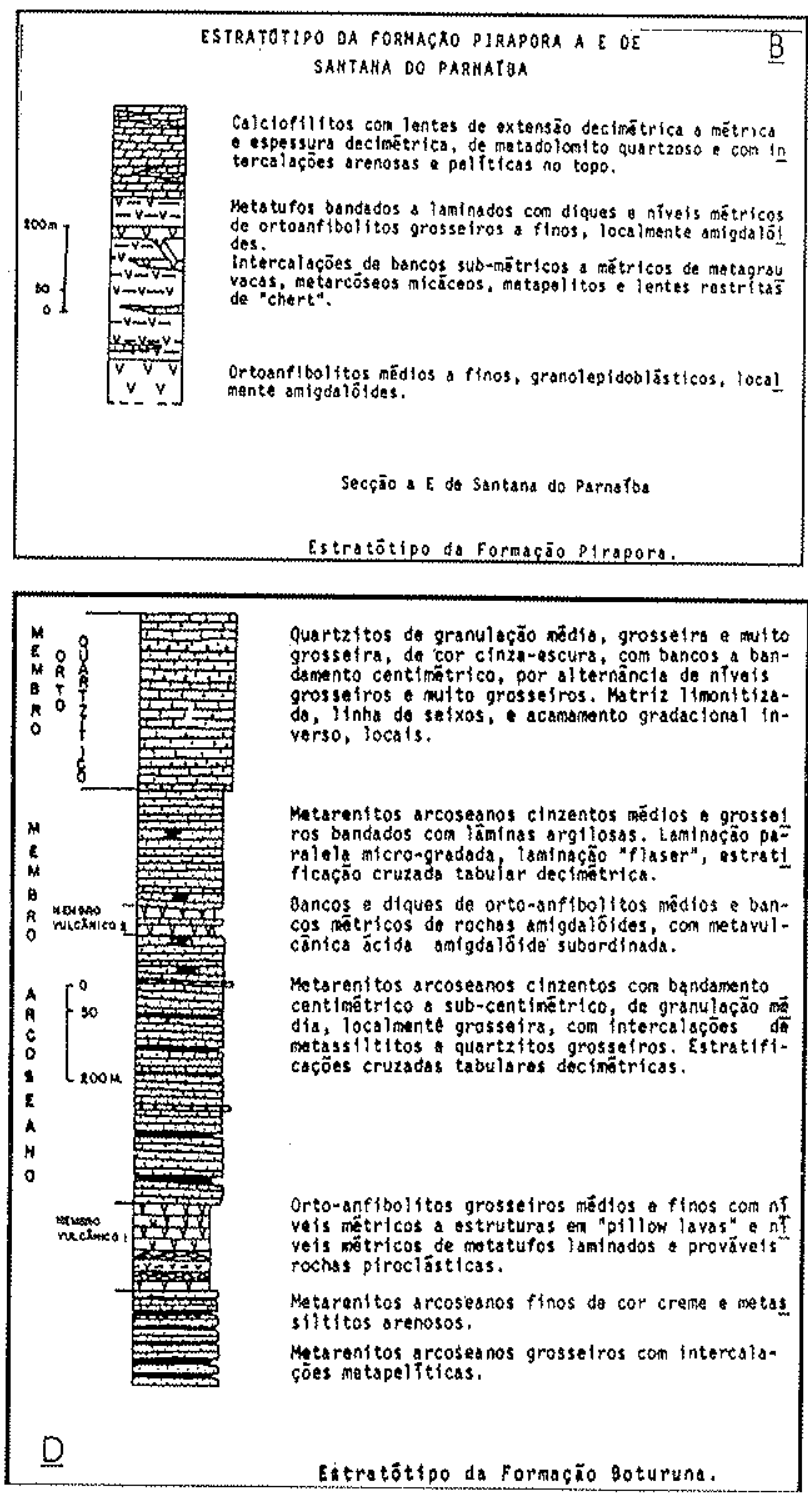

FIGURA 3.8 -.- Estratótipos das formaçôes do Grupo São Roque proposta na subdivisão de BERGMANN (1988) para as regiões de Santana do Parnaíba e Pirapora do Bom Jesus. (A) Formação Pirapora no Corpo de Pirapora do Bom Jesus; (B) Formação Pirapora a leste de Santana do Parnaíba; (C) Formação Estrada dos Romeiros; (D) Formação Boturuna. filitos róseos encontrados no topo do morro indicariam, de acordo com JULIANI (1992), a gradação para metapelitos rítmicos do Grupo São Roque, enquanto que a passagem para a seqüência vulcano- 
sedimentar, admitida como do Grupo Serra do Itaberaba, dado o incremento da transposição observado em direção ao possível contato, deduziu que seria por zona de cisalhamento.

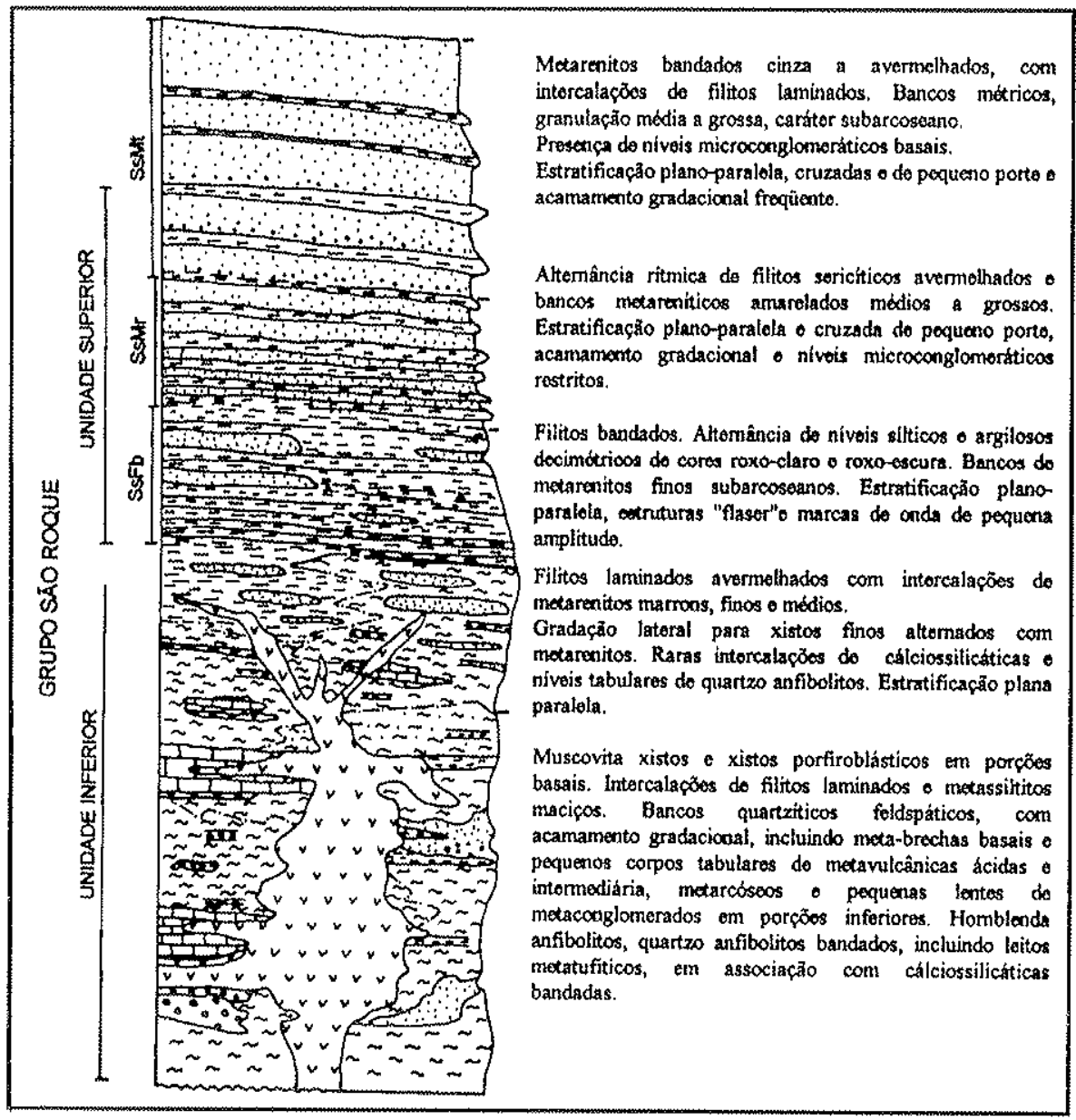

FIGURA 3.9 - Coluna estratigráfica esquemática composta para o Grupo São Roque na Folha Guarulhos (DANTAS 1990).

HACKSPACHER et al. (1992a) observaram estruturas sedimentares preservadas no Grupo São Roque e sugeriram tratarem-se de sequiências C, D e E de Bouma, mais típicas de turbiditos distais.

JULIANI (1993) subdividiu o Grupo Serra do Itaberaba nas formações Morro da Pedra Preta, vulcano-sedimentar e basal, constituída, em essência, por metabasitos e xistos diversos, metavulcanoclásticas, rochas calciossilicáticas, metassedimentos quartzosos e grafitosos, além de formações ferríferas, rochas metaígneas intermediárias a ácidas, metabasaltos e metatufos afetados por zonas de alterações hidrotermais-metassomáticas e marunditos subordinados; Nhanguçu, essencialmente clasto-química, com metapelitos ricos em óxidos e hidróxidos de ferro e manganês, rochas calciossilicáticas e carbonáticas e xistos peraluminosos com andaluzita, com turmalinitos com texturas indicativas de meta-evaporitos, além de corpos menores de metabasitos e metavulcanoclásticas; e Pirucaia, que contém essencialmente quartzitos e xistos quartzosos.

O Grupo São Roque, colocado tectonicamente sobre o grupo anterior, compreenderia a Formação Piragibu, constituída por metarritmitos, em parte arcoseanos, com quartzitos, metabasitos, rochas vulcanoclásticas subordinadas, e ainda, na base, metaconglomerados e metabrechas (FIGURA $3.10)$. 


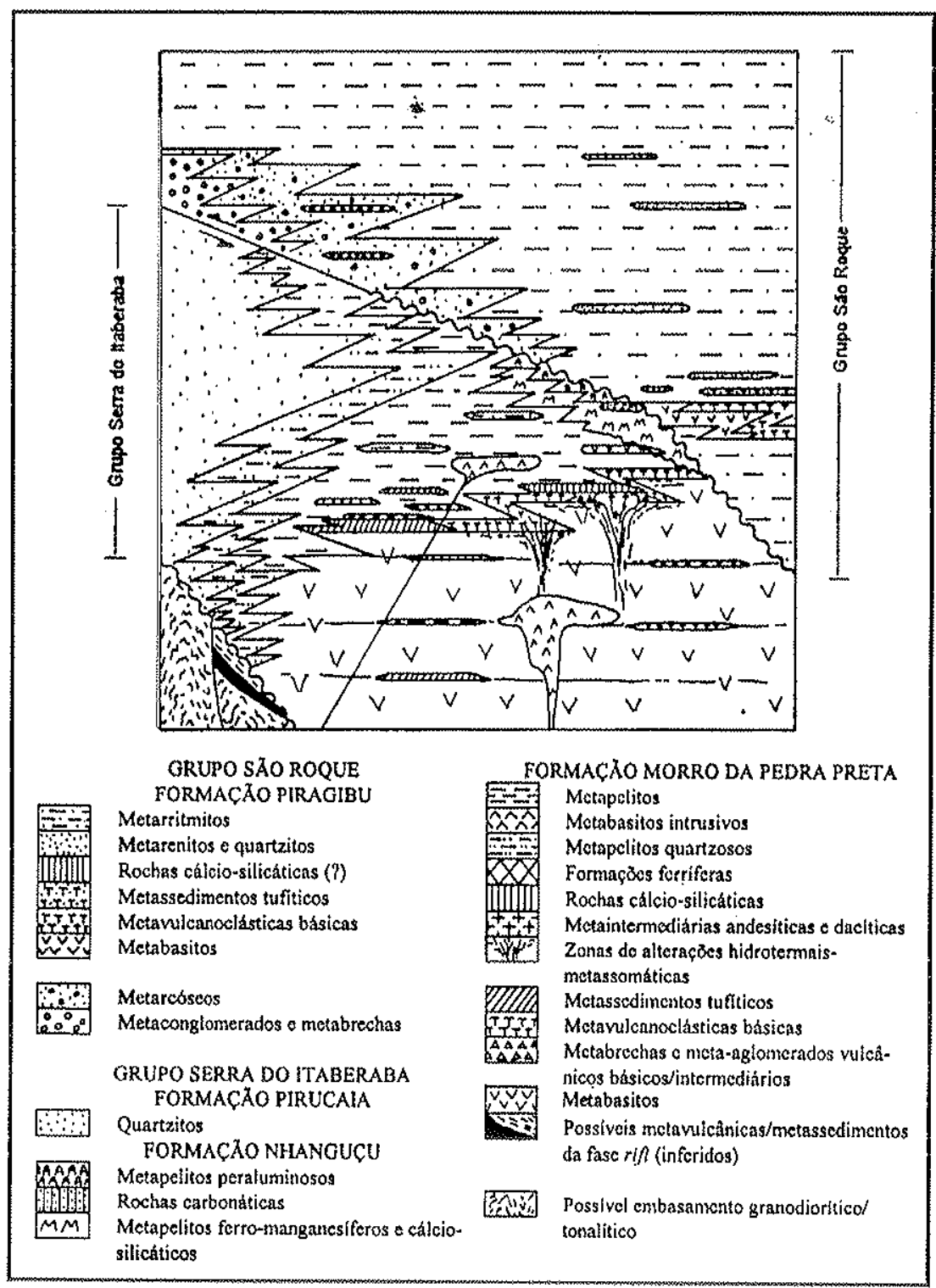

FIGURA 3.10 - Coluna litoestratigrafica proposta para os grupos Serra do Itaberaba e São Roque na região das Serras do Itaberaba e Pedra Branca (JULIANI 1993).

HACKSPACHER et al. (1993a) consideraram estas supracrustais como evoluídas a partir da distensão de uma crosta transamazônica, com a sedimentação e vulcanismo do Grupo Serra do Itaberaba, seguida por deposição de unidades rítmicas distais, siltosas a arenosas, com vulcânicas básicas a ácidas e margas do Grupo São Roque, ambos afetados por metamorfismo e deformação distintos, em razão dos níveis crustais de profundidades diferentes.

HACKSPACHER (1994) e HACKSPACHER et al. (1992a, b, 1994, 1996) descreveram o Grupo Serra do Itaberaba como composto por metapelitos, frequientemente grafitosos, metacalcários, metapsamitos e metabasitos de médio grau metamórfico. Quanto ao Grupo São Roque, adotaram a nomenclatura de BERGMANN (1988), com modificações estratigráficas, marcadas pela sucessão das formações Estrada dos Romeiros, basal, com metarritmitos, metarenitos, e metassiltitos, filitos e filitos grafitosos; Voturuna, composta por metassiltitos com raras estratificações cruzadas, com o topo em posição normal, e quartzitos, enquanto a Pirapora, colocada no topo, seria representada por metabásicas 
e metacalcários (FIGURA 3.11a).

OLIVEIRA et al. (1992b) utilizaram a mesma proposta litoestratigráfica de HACKSPACHER et al. (1992a) descrevendo, na Folha Japi, o Grupo Serra do Itaberaba como contendo xistos com intercalações de quartzitos e metabásicas, enquanto o Grupo São Roque estaria representado pelas formações Voturuna, no topo, e Estrada dos Romeiros, na base (FIGURA 3.11b).

GODOY et al. $(1994,1996$ a) analisaram a região de Sorocaba e subdividiram o Grupo São Roque na Formação Estrada dos Romeiros, basal, contendo metarritmitos grossos e médios a finos, metarenitos, filitos, metassiltitos e metabasitos; Formação Voturuna, intercalada na anterior; e Formação Pirapora, no topo, com metassedimentos pelito-psamíticos e metacalcários calcíticos, cálciofilitos e rochas calciossilicáticas. A presença de calcários oolíticos, pisolíticos e oncolíticos indicaria sedimentação em águas salgadas quentes e relativamente agitadas de zonas de intermarés ou proximais (FIGURA 3.11c). O Grupo Serra do Itaberaba seria representado pelos níveis crustais mais profundos, expostos a partir do soerguimento associado à fase de alojamento do Maciço Granitóide São Francisco. Consideraram que a estruturação da bacia deu-se no Paleo/Mesoproterozóico sobre um embasamento mais antigo, ocorrendo a deposição de sequêencias vulcano-sedimentares e unidades rítmicas distais rasas.

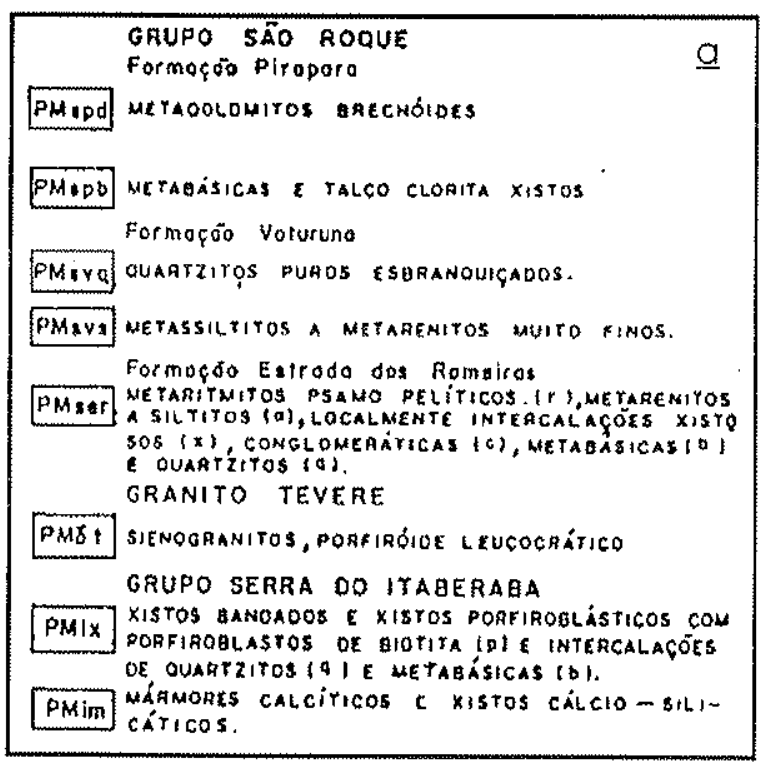

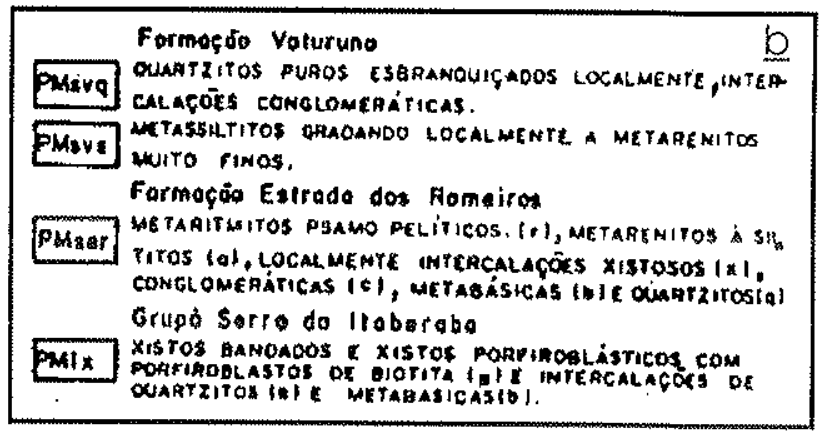

FIGURA 3.11 - Litoestratigrafia dos grupos São Roque e Serra do Itaberaba extraída dos mapeamentos efetuados por HACKSPACHER et al. (1992b) na folha Pirapora (a), OLIVEIRA et al. (1992b) para a Folha Japi (b) e GODOY et al. (1996a) para a região de Sorocaba (c).

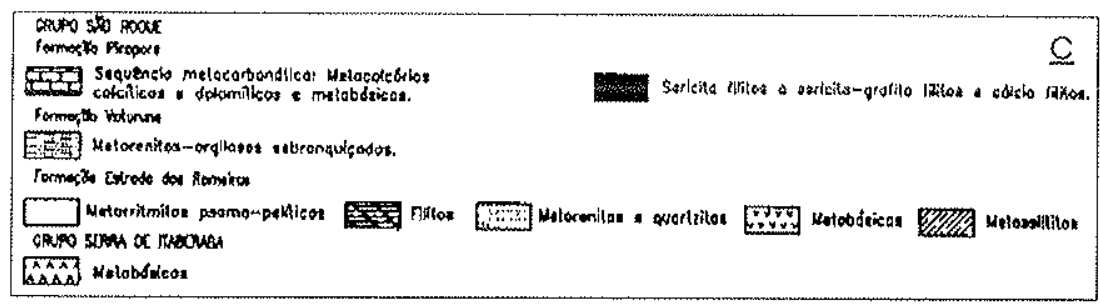

Com base em uma ampla revisão sobre a litoestratigrafia da Faixa São Roque/Serra do Itaberaba, JULIANI \& BELJAVSKIS (1995) mantiveram as subdivisões do Grupo Serra do Itaberaba propostas por JULIANI (1993). Quanto ao Grupo São Roque, reconheceram a Formação Piragibu, metapelítica, portando, na base, poucas lentes de metaconglomerados e de metavulcânicas. A Formação Pirapora 
(BERGMANN 1988) foi renomeada Formação Pirapora do Bom Jesus, contendo litotipos vulcânicos/vulcanoclásticos, além de rochas carbonáticas com bioermas e cálcio-filitos. Reconheceram também a Formação Estrada dos Romeiros, com metapelitos e metarenitos rítmicos; e a Formação Boturuna, com predomínio de metarenitos e metarcóseos.

Consideraram a Formação Piragibu basal nas regiões das Serras do Itaberaba e da Pedra Branca e do Morro Doce, enquanto a Formação Pirapora do Bom Jesus, possivelmente cronocorrelata, seria basal no Sinclinório homônimo e, nessa região, estaria recoberta pela Formação Estrada dos Romeiros, talvez interdigitada com a Formação Piragibu. Ambas seriam recobertas pela Formação Boturuna, de acordo com a proposta de BERGMANN (1988), como se verifica na FIGURA 3.12.

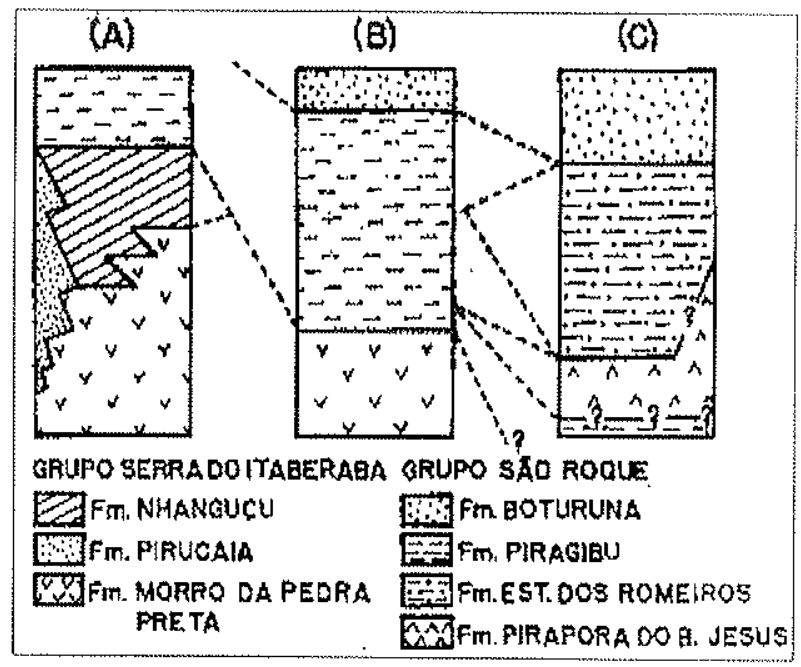

Mesmo considerando as diferenças metamórficas e tectônicas entre os grupos São Roque e Serra do Itaberaba, HACKSPACHER

Figura 3.12 - Síntese das correlações litoestratigráficas propostas por JULIANI \& BELJAVSKIS (1995) para a Faixa São Roque/Serra do Itaberaba. Onde (A): região das serras do Itaberaba e Pedra Branca; (B) região do Pico do Jaraguá - Morro Doce; (C) Pirapora (1994) admitiu para as supracrustais dos grupos idade de sedimentação em torno de 1,7 Ga, e que a história tectono-metamórfica estaria vinculada ao Ciclo Brasiliano.

A redefinição das rochas do Morro do Polvilho, anteriormente consideradas metarriodacitos, como metarcóseos (JULIANI et al. 1997a), como aqueles intercalados nos metaconglomerados do Morro Doce, indica que a idade máxima da sedimentação de 1,79 Ga (VAN SCHMUS et al.1986), obtida para os metarcóseos redefinidos, colocados tectonicamente sobre a Formação Morro da Pedra Preta do Grupo Serra do Itaberaba, ali reconhecida, não pode ser interpretada para caracterizar o início da deposição da sequiência vulcano-sedimentar, que situa-se na base do Grupo São Roque.

Segundo JULIANI et al. (1998), os dados reinterpretados de RAGATKY (1997) indicam que as idades modelo $\mathrm{Sm-Nd}\left(\mathrm{T}_{\mathrm{DM}}\right)$ dos granitos encaixados no GSI são sistematicamente mais antigas (média de $\sim 1,78 \mathrm{Ga}$ ) que as dos encaixados no GSR (média de $\sim 1,49 \mathrm{Ga}$ ), o que mostra que a crosta do GSI é mais antiga e que evolução dos grupos deu-se em ciclos geotectônicos diferentes. Os dados Rb-Sr da matriz dos metaconglomerados intercalados nos metarcóseos (TASSINARI et al. 1985) sugerem que a idade do metamorfismo e da aloctonia do GSR sobre o GSI é aproximadamente de $800 \mathrm{Ma}$.

JULIANI et al. (1995, 1996a) e MARTIN et al. (1998b) descreveram a ocorrência de metarriólito no Grupo Serra do Itaberaba, respectivamente nas regiões das serras do Itaberaba e Pedra Branca e entre Santana do Parnaíba e Barueri, sugerindo que o magmatismo ácido do grupo homônimo estaria associado às unidades de topo da Formação Morro da Pedra Preta e principalmente à Formação Nhanguçu. 


\subsection{Litoestratigrafia da Faixa São Roque/Serra do Itaberaba a NW da cidade de São Paulo}

O mapeamento da porção noroeste da região metropolitana de São Paulo permitiu identificar litotipos ou associações litológicas correlacionáveis às formações conhecidas nos grupos Serra do Itaberaba e São Roque, mas tornaram se necessárias algumas redefinições quanto às formações do último grupo, além de ser tentativamente definida uma nova formação.

Deste modo, para o Grupo Serra do Itaberaba e o Grupo São Roque foram reconhecidas nessa região as seguintes formações:

\section{Grupo Serra do Itaberaba}

\section{Formacão Morro da Pedra Preta}

Unidade Metabásica, onde predominam rochas metabásicas de origem ígnea e anfibolitos. Variam de finas a grossas, são cinzas a cinza-escuras e esverdeadas, maciças ou orientadas, inequigranulares a porfiroblásticas, e ocorrem com menos freqüência granada anfibolitos e anfibólio xistos. Esse conjunto apresenta comumente hornblenda/actinolita e plagioclásio (andesina a labradorita), mas também são observados diopsídio e granada.

Subordinadamente nessa unidade podem ser observados rochas metavulcanoclásticas básicas (metabrechas e metatufos), metassedimentos tufíticos com leitos pelíticos, grafitosos e manganesíferos, rochas calciossilicáticas, xistos pelíticos com estaurolita porfiroblástica ou com fíbrolita, além de xistos grafitosos, metapelitos calcíferos e xistos grossos granatíferos.

$\mathrm{Na}$ Unidade Metavulcanoclástica há o predomínio dos metassedimentos tufíticos frequientemente alterados, argilosos, laminados a bandados, contendo tipicamente intercalações de cores como ocre, vinho, vermelho, roxo e, menos comuns, amarelo, verde e cinza, além de delgadas lentes cauliníticas brancas. Ocorrem ainda não estruturados e variegados ou maciços, e intercalam-se metabrechas e metatufos básicos maciços, bandados ou laminados, marcados em geral pelo aumento ou redução do teor e da granulação dos cristais anfibólio entre os leitos.

Também estão presentes metapelitos com contribuição tufítica, identificados como xistos finos pobres em quartzo que às vezes pode conter biotita porfiroblástica). Intercalam-se ainda xistos pelíticos porfiroblásticos ou não e comumente grafitosos, metapelitos grafitosos, metapelitos ferro-manganesíferos e calcíferos, metabasitos, rochas calciossilicáticas, rochas metavulcanoclásticas quartzo-andesíticas a riolíticas, metachert, turmalinitos, metarriolitos, além de metassedimentos silto arenosos rítmicos por vezes com leitos microconglomeráticos.

Sobreposta ocorre a Unidade Calciossilicática constituída pela maior abundância das rochas calciossilicáticas que tipicamente ocorrem laminadas a bandadas, são finas a médias, e têm cores verdes, claras ou escuras ou cinzas a cinza-esverdeadas, com leitos mais claros ricos em diopsídio e/ou epídoto e os mais escuros em actinolita e/ou biotita/flogopita ou hornblenda. Ocasionalmente têm tendência maciça e são ricas em diopsídio. 
Subordinados na Unidade Calciossilicática foram descritos metassedimentos tufíticos, metatufos básicos, plagioclásio-biotita-quartzo xistos com porfiroblastos de biotita (possíveis metatufos riodacíticos silicificados), metapelitos manganesíferos, calcíferos e grafitosos, diopsídio mármore com tremolita, xistos finos granatíferos, flogopita-quuartzo xisto com epídoto e intercalações restritas de metacherts.

Na Unidade dos Xistos Pelíticos os xistos que predominam variam de foliados a miloníticos, finos a grossos, e podem ou não serem porfiroblásticos, ocorrendo porfiroblastos de fibrolita, granada e, mais raro, de estaurolita, andaluzita, silimanita, cianita e cordierita, além de, eventualmente serem observados agregados porfiroblásticos de muscovita+quartzo+biotita ou de muscovita.

Na base dessa unidade é comum a presença de xistos pelíticos finos a médios pobres em quartzo por vezes com biotita porfiroblástica e granada mais rara, semelhantes aos metapelitos com contribuição tufítica observados na unidade metavulcanoclástica. Também ocorrem próximos à base da unidade, os xistos médios a grossos de aspecto maciço com estaurolita, biotita e granada porfiroblásticas e, para o topo, foram identificados xistos finos a médios com biotita e magnetita porfiroblásticas.

Subordinadamente ocorrem metassedimentos tufíticos, xistos quartzosos com leitos conglomeráticos ou não, rochas metabásicas, rochas metavulcanoclásticas básicas, xistos turmaliníticos e xistos grafitosos e de metapelitos calcíferos. Raros leitos de turmalinitos, de rochas meta-intermediárias e de metarriolitos também foram identificados na unidade.

A Unidade de Formacão Ferrífera é constituída por leitos de metachert e ferríferos de espessura submétrica intercalados com metassedimento tufítico rico em turmalina, turmalinito, xistos grafitosos com pirita e xistos com estaurolita e granada. Metacherts finos e maciços apresentam quartzo fino sacaróide, sericita, hematita, antibólio verde, além de plagioclásio e granada, enquanto que as formações ferríferas têm hematita, magnetita, quartzo, sulfetos alterados e malaquita.

Na Unidade Metapelítica Grafitosa são observados xistos grafitosos finos a médios cinzaescuros com pirita disseminada, laminados e bandados e contém intercalações de leitos quartzosos e muscovíticos por vezes com andaluzita. Intercalam-se xistos pelíticos variados com grafita, muscovita e quartzo, xistos com estaurolita, formações ferríferas, turmalina xistos, turmalinitos e metapelitos com contribuições manganesíferas. Os metapelitos grafitosos interdigitam-se com xistos pelíticos e têm contato brusco com metabasitos/anfibolitos.

\section{Formacão Nhangucu}

Na Unidade dos Metassedimentos Manganesíferos predominam os metassedimentos manganesíferos alterados que ocorrem laminados a bandados e ricos em sericita. Frequientemente apresentam manchas e/ou planos pretos preenchidos por óxidos e hidróxidos de manganês. Seus leitos variam de verde-ocráceos, ocre-esverdeado escuros a marrons e, quando mais alterados, são marromescuros a pretos, sendo reconhecidos como filitos pó-de-café. 
Intercalam-se os metapelitos calcíferos alterados, também laminados a bandados, porém marcados por leitos ocre-esverdeados a ocre-amarelados e marrom-claros, e que apresentam aspecto áspero e/ou pulverulento, com gradações e intercalações de rochas carbonáticas. De forma subordinada ocorrem metassedimentos grafitosos e tufíticos, metapelitos com contribuição tufítica, rochas calciossilicáticas com escapolita e anfibolitos.

A Unidade das Rochas Carbonáticas contém rochas carbonáticas laminadas a bandadas, finas a médias, cinza-claras a escuras, por vezes pretas ou, brancas, grossas e de tendência maciça. Em getal essas variedades quando alteradas tornam-se marrom-escuras. Predominam termos dolomíticos e estão presentes tipos calcíticos. Pode ou não ocorrer tremolita e diopsídio nessas rochas. São comuns nessa unidade as intercalações de metapelitos calcíferos e de metassedimentos manganesíferos.

\section{Formacão Pirucaia}

As rochas dessa formação intercalam-se na base e estão sobrepostas aos xistos pelíticos da Formação Morro da Pedra Preta.

A formação é composta pela Unidade dos Xistos Quartzosos onde predominam xistos quartzosos e muscovitambiotita quartzitos com grânulos de quartzo dispersos. Essas rochas em geral são maciças e têm granulação variando de fina a média. Apresentam como porfiroblastos granada, fibrolita, estaurolita, e raros cristais de cianita, sillimanita e cordierita. São cinzas a cinza-esverdeados quando frescos. Intercalam-se comumente muscovita-biotita-quartzo xistos finos pouco foliados.

Xistos conglomeráticos oligomíticos e quartzitos puros podem ocorrer local e subordinadamente, e são frequientes, principalmente na base, as intercalações de xistos pelíticos porfiroblásticos ou não que, eventualmente, apresentam leitos muito restritos de metassedimentos tufíticos.

\section{Grupo São Roque}

\section{Formacão Morro Doce}

A Unidade Metarcoseana é constituída preferencialmente por metarcóseos cinzas a cinzaesverdeados maciços a foliados com porfitoclastos de feldspato potássico e de plagioclásio, e grânulos e pequenos seixos de quartzo, quartzito e, mais raros, de granitóides. Ocorrem frequientes gradações para subarcóseos e, de modo subordinado, observam-se lentes de metaconglomerados matriz suportados e com clastos relativamente mais finos, além de quartzitos e metarenitos feldspáticos, metarenitos finos, metagrauvacas (quartzo-biotita xistos finos com grânulos de feldspatos e quartzo) e filitos.

Na Unidade Metaconglomerática predominam metaconglomerados polimíticos orientados a miloníticos com matriz cinza-escura, ricos em seixos e calhaus, sendo mais comuns os de granitóides foliados ou não, além de pegmatitos, quartzitos, quartzo de veio, e clastos de feldspatos por vezes com as fases preservadas. 
Mais raramente observam-se clastos de xistos, de rochas metabásicas e de rochas de tendência andesítica. Raros calhaus com faces planas são sugestivos de retrabalhamento de depósitos glaciais em leques aluviais. Subordinadamente, ocorrem pacotes de metarcóseos, metarenitos feldspáticos ou não e filitos.

\section{Formacão Pirapora do Bom Jesus}

A Unidade Metabasítica contém rochas metabásicas verdes a verde-claras, maciças, equi- a inequigranulares médias, com actinolita e plagioclásio de composição albítica e, ocasionalmente, clinopiroxênio reliquiar. Observam-se estrutura tipo pillow-lava e texturas blastofítica e blastoporfirítical locais. Subordinadamente, ocorrem intercalações de metatufos básicos e de filitos manganesíferos e metacálcio-pelitos com leitos centimétricos de rochas carbonáticas, além de rocha metabásica amigdaloidal associada com metassedimento tufítico, rocha meta-ultrabásica e camadas de itabirito.

Na Unidade Metacálcio-Pelítica predominam metacálcio-pelitos alterados ocre-claros a escuros, laminados a bandados e localmente maciços. Raramente são frescos e cinza-azulados. São compostos por sericita, clorita e carbonato, e grafita e quartzo subordinados, óxidos e hidróxidos de manganês e níveis de sulfetos alterados. Ocorrem intercalações de filito sericítico, de filito grafitoso, de leitos carbonáticos e de filito manganesífero (filito pó-de-café) e, ocasionalmente, níveis restritos de metachert e de quartzitos ferruginosos.

A Unidade Metacarbonática é composta por rochas carbonáticas calcíticas e dolomíticas finas a muito finas, bandadas e laminadas e cinzas, ou de granulação média, maciças e brancas. Estruturas estromatolíticas ocorrem localmente. Subordinadamente, intercalam-se metacálcio-pelitos e metassedimentos manganesíferos.

$\mathrm{Na}$ Unidade Metavulcanoclástica predominam metabrechas e metatufos básicos foliados alterados e argilosos, com textura variegada e cores vermelha e vinho, ambas escuras. Raros são frescos, verde-claros e laminados, com actinolita e plagioclásio albítico. Intercalam-se rochas metabásicas finas, metassedimentos tufíticos, metapelitos e metarritmitos.

\section{Formacão Boturuna}

A Unidade Metarenítica Feldspática é formada preferencialmente por metarenitos feldspáticos maciços a foliados. Em geral são alterados, mostram-se verde-esbranquiçados a vermelho-claros e têm aspecto mosqueado contendo pontos vermelhos. Variam de finos a grossos com raros fragmentos de feldspatos e níveis ricos em grânulos de quartzo. Por vezes, observam-se acamamento, estratificações cruzadas e estratos plano-paralelos. Frescos são cinza-esverdeados a verde-claros.

Subordinadamente, ocorrem metarcóseos, metarenitos, metarritmitos, filitos sericíticos, quartzitos micáceos ou não, e metaconglomerados. Localmente são reconhecidas intercalações de rocha 
metavulcânica básica amigdaloidal shoshonítica rica em biotita, rocha metabásica maciça alterada com alofana, rocha metavulcânica intermediária a ácida amigdaloidal e metagrauvaca.

$\mathrm{Na}$ Unidade Quartzítica predominam quartzitos finos a grossos, brancos a branco-acinzentados, com grânulos de quartzo. Em geral são maciços e por vezes são miloníticos. Podem apresentar estratificações cruzadas tangenciais na base, acanaladas, plano-paralelas, tipo espinha-de-peixe, em geral de pequeno a médio portes, além de marcas onduladas.

Ocorrem subordinados metarenitos feldspáticos, metarcóseos, metaconglomerados oligomíticos matriz suportados, quartzitos micáceos, quartzo-muscovita xistos finos com biotita porfiroblástica, metarritmitos, filitos sericíticos e rocha meta-subvulcânica intermediária a ácida.

\section{Formacão Estrada dos Romeiros}

A Unidade Metarrítmica compreende a maior parte da Formação Estrada dos Romeiros, sendo constituída predominantemente por metarritmitos bandados e laminados compostos por metarenitos finos a médios, maciços, com grânulos e pequenos seixos de quartzo, metassiltitos micáceos ou não e quartzo filitos, litotipos esses que se intercalam com frequiência com filitos sericíticos em contato brusco. Ocorrem nos metarritmitos estratificação plano-paralela, estratificação cruzada de pequeno porte, laminação convoluta, climbbing ripple e marcas de sola.

De forma subordinada são reconhecidos metacálcio-pelitos com leitos grafitosos ou não, metarenitos com feldspatos, metaconglomerados clasto- ou matriz-suportados, metarenitos grossos e quartzitos. São comuns as intercalações até decamétricas de filitos sericíticos. Ocasionalmente, ocorrem metavulcanoclásticas básicas.

A Unidade Metarenítica Feldspática é formada predominantemente por metarenitos feldspáticos verde-claros, maciços, de granulação fina a média e que contém raros fragmentos de feldspatos. Subordinadamente ocorrem metarcóseos, metarenitos e metarritmitos.

$\mathrm{Na}$ Unidade Metacálcio-pelítica são comuns os metacálcio-pelitos alterados ocráceos, laminados a bandados a localmente maciços, que intercalam-se freqüentemente com metarritmitos de granulação mais fina e com filitos laminados a bandados. Esses filitos podem apresentar raros níveis de metarenito fino ferruginoso e leitos de formação ferrífera.

Ocorrem gradações para rochas carbonáticas. Subordinadamente, observam-se filitos bandados roxo-acinzentados e cremes com leitos carbonáticos, metapelitos manganesíferos, rochas calciossilicáticas bandadas, metarenitos feldspáticos e metagrauvacas.

$\mathrm{Na}$ Unidade Metacarbonática predominam rochas carbonáticas calcíticas finas a muito finas, com estrutura bandada a laminada. As rochas variam de cinza-claras a escuras, ou são pretas e grafitosas. Litotipos dolomíticos são subordinados. Ocorrem ainda rochas calciossilicáticas, quartzitos, metacálciopelitos, metarritmitos e fulitos sericíticos. 
A Unidade Metapsamítica é formada por metarenitos e quartzitos finos a grossos, maciços a miloníticos. Por vezes observam-se quartzitos conglomeráticos subordinados. Os litotipos que predominam podem transicionar para metarritmitos que contém metarenitos finos e metassiltitos intercalados.

Na Unidade Metabasítica predominam rochas metabásicas verde-claras, maciças, equi- a inequigranulares médias, com actinolita e plagioclásio de composição albítica com frequiente clinopiroxênio reliquiar e textura blastofítica. Intercalam-se metarritmitos e, de modo subordinado, metabrecha e metatufos básicos, além de metassedimentos tufíticos.

$\mathrm{Na}$ Unidade Metapelítica ocorrem filitos laminados a bandados alterados vinho- ou róseo-claros comumente intercalados com metarritmitos. Rochas metavulcanoclásticas básicas alteradas são observadas subordinadamente.

\section{Formacão Piragibu}

A formação é constituída em grande parte pela Unidade Metapelítica onde abundam os filitos sericíticos laminados a bandados alterados vinho- ou róseo-claros. Quando cloríticos variam de esverdeados a ocráceos. Frescos os filitos em geral são cinzas ou verdes. Por vezes são mais argilosos, mostram-se milimetricamente laminados e contêm leitos grafitosos. Ocasionalmente, observam-se fílonitos Ardósias constituem corpos menores e freqüentemente apresentam biotita e/ou muscovita detríticas.

Destacam-se intercalações até decamétricas de metarritmitos compostos por metarenitos finos, metassiltitos, quartzo filitos e leitos conglomeráticos, e outras intercalações de métricas de filitos grafitosos. Ocorrem gradações para metacálcio-pelitos, enquanto que as rochas metabásicas e metassedimentos tufíticos são restritos.

$\mathrm{Na}$ Unidade Metarrítmica predominam metarritmitos laminados a bandados compostos por metassiltitos, metarenitos finos a grossos com grânulos de quartzo e metaconglomerados de grânulos. Ocorrem intercalados bancos de filitos sericíticos.

A Unidade Metabasítica constitui pequenos corpos de rochas metabásicas verde-claras, maciças, de granulação média, com actinolita e plagioclásio de composição albítica, além de serem muito comuns o clinopiroxênio reliquiar e as texturas blastofítica e blasto-subofítica.

$\mathrm{Na}$ Unidade Metavulcanoclástica predominam metassedimentos tufíticos alterados, argilosos de textura variegada vermelho-escuros e vinho-escuros. Subordinadamente, também estão presentes rochas metabásicas e filitos sericíticos. 


\section{CAPÍTULO IV}

\section{GEOLOGIA E LITOESTRATIGRAFIA}

\section{INTRODUÇÃO}

O Grupo Serra do Itaberaba aflora na base do Grupo São Roque e ao redor do granito Tico-Tico, em uma janela estrutural. Seu contato com o Grupo São Roque é sempre tectônico, mas não se descarta que haja discordâncias erosivas locais.

Na porção sul do mapa, é nítida a presença de uma foliação milonítica de baixo ângulo, com transporte tectônico para norte, geralmente retrabalhada por falhamentos transcorrentes de direção geral E-W a ENE-WSW, muitas vezes constituindo falhas em flor positivas. Nas proximidades da rodovia Anhangüera, onde as direções gerais das camadas tendem a N-S, a zona de empurrão está melhor preservada, sendo constatado transporte para noroeste.

O mesmo tipo de contato é observado a norte, mas esse geralmente tende a falhas inversas, provavelmente devido a dobramentos ou aos efeitos das transcorrências. Zonas de empurrão säo frequientes internamente ao Grupo Serra do Itaberaba, e menos comuns no Grupo São Roque.

Com base nos litotipos e formações da área-tipo do Grupo Serra do Itaberaba, foi possivel sua separação em unidades correlacionáveis às formações Morro da Pedra Preta, Nhanguçu e Pirucaia, mas algumas variações faciológicas foram também observadas, e são discutidas adiante.

Já o Grupo São Roque teve suas formações reinterpretadas e redefinidas, face às novas informações obtidas neste trabalho, e passa a ser constituído, da base para o topo, pelas formações Morro Doce, Pirapora do Bom Jesus, Boturuna, Estrada dos Romeiros e Piragibu.

Além dos grupos citados, ocorrem ainda no extremo sul da área rochas do Maciço Granitóide Ibiúna, geralmente cisalhado, que inclui porções do Complexo Embu, e no extremo noroeste afloram alguns litotipos do Grupo Itapira.

O conjunto dos diversos maciços granitóides e suas fácies são descritos com base em compilações bibliográficas, bem como as zonas de cisalhamento e seus produtos, os sedimentos terciários e quaternários.

A seguir é descrita a geologia da área, segundo a cronoestratigrafia da região.

\subsection{COMPLEXO ITAPIRA (PPIT)}

No extremo noroeste da área ocorrem quartzitos feldspáticos finos e ultramiloníticos com os grãos de quartzo muito estirados, afetados pela Zona de Cisalhamento Itu-Jundiuvira e pertencentes à Formação Japi (PPITjpqz) desse complexo. Localmente, ocorrem metabasitos associados aos quartzitos nos quais, pelo menos em parte, podem ser reconhecidas ainda estruturas indicativas de antigas intrusões. 
Subordinadamente, especialmente na parte sul do complexo, afloram xistos de grau médio, intensamente milonitizados.

O contato sul desta unidade é feito com granitóides e gnaisses milonitizados com intercalações subordinadas de xistos e anfibolitos miloníticos (PPITmg) (Prancha 01/foto A). São bastante semelhantes à unidade ortoderivada descrita por HACKSPACHER et al. $(1992 \mathrm{a}, \mathrm{c})$ na região e, de modo geral, ocorrem imbricados com o Stock Granítico Guaxatuba - Pica-Pau.

\subsection{COMPLEXO EMBU (MPEBmg)}

Nos levamentos em campo feitos na parte meridional da área, a sul da Zona de Cisalhamento Taxaquara, foram descritos quase que exclusivamente rochas graníticas milonitizadas em intensidades variadas e poucos afloramentos de metassedimentos feldspáticos muito alterados e milonitizados (Prancha 01/foto B). Essa associação foi descrita por JANASI et al. (1990) como intrusões laminares em rochas metamórficas do Complexo Embu (HASUI 1973).

Associados aos granitóides já descritos ocorrem corpos com dezenas a poucos metros de espessura de milonitos de xistos feldspáticos com fibrolita, granada e, localmente, grafita. A foliação milonítica está dobrada, juntamente com os corpos de milonito de granito e de pegmatóides, que assemelham-se às descrições dos litotipos do Complexo Embu, com fusão parcial das rochas metassedimentares previamente à milonitização.

\subsection{GRUPO SERRA DO ITABERABA}

\subsubsection{Formação Morro da Pedra Preta}

Quando comparado à área-tipo definida por JULIANI (1993), esta formação mostra um volume significativamente menor de metabasitos e um maior predomínio de metassedimentos tufíticos e de metapelitos. Distingue-se ainda pela presença de metassedimentos silto-arenosos rítmicos, correspondentes a possíveis metaturbiditos, por vezes com leitos microconglomeráticos, não descritos na Serra do Itaberaba.

Essa associação indica que o ambiente deposicional do Grupo Serra do Itaberaba nesta região é relativamente mais proximal ao continente, distinguindo-se do ambiente de MORB dos metabasitos e metapelitos da Formação Morro da Pedra Preta na Serra do Itaberaba.

A cunha de supracrustais que inclui os grupos Serra do Itaberaba e São Roque apresenta nivel de erosão gradativamente mais profundo na direção sudoeste-nordeste, a partir do contato com os sedimentos da Bacia do Paraná, devido às movimentações relativas causadas pelas zonas de cisalhamento de Itu-Jundiuvira e Taxaquara-Rio Jaguari-Monteiro Lobato. Geralmente, o nível crustal é também relativamente mais profundo em direção às grandes massas graníticas, devido ao alçamento das unidades inferiores pelas intrusöes. 


\subsubsection{Unidade Metabásica (MPSIppmb)}

Esta unidade é composta predominantemente por metabasitos, com intercalações menores de metatufos básicos, metassedimentos tufíticos e metapelitos, por vezes com contribuição de metassedimentos silto-arenosos e microconglomeráticos. Sua maior exposição localizá-se a leste do Pico Jaraguá, parcialmente inclusa na área mapeada. Também ocorre como camadas nas bordas norte e sudoeste do Granito Itaqui, ou como intercalações menores nos metassedimentos tufíticos e, mais raramente, nos metapelitos superpostos. Os contatos com as encaixantes vulcanoclásticas podem ser gradacionais, mas são sempre bruscos com os metapelitos.

Com graus incipientes de alteração supérgena, os metabasitos são verdes, mas com o avanço do intemperismo adquirem cor ocre que passa a ocre-avermelhada homogênea e, como produto final da alteração, transformam-se em material argiloso e vermelho-escuro.

No corpo anfibolítico do Jaraguá os contatos são tectônicos, tanto com o Granito Cantareira como com as rochas metassedimentares do Grupo Serra do Itaberaba.

Para norte e noroeste desse corpo pode-se observar, apesar da milonitização, gradação dos metabasitos para metatufos e destes para metassedimentos tufíticos, e intercalações menores de rochas calciossilicáticas e carbonáticas associadas a milonitos. Os metassedimentos tufíticos possuem frequientes leitos pelíticos, grafitosos e manganesíferos milimétricos a centimétricos. Em partes milonitizadas, as estruturas $S$ - $C$ e dobras intrafoliais indicam transporte tectônico para norte nas zonas de empurrão.

$\mathrm{Na}$ borda norte do Maciço Granitóide Itaqui ocorrem vários corpos de metabasitos, por vezes lenticulares, com extensão quilométrica e até $200 \mathrm{~m}$ de espessura. Essão geralmente afetados pela Zona de Cisalhamento Vila Menk, que os transforma em anfibólio xistos com intensa foliação milonítica anastomosada, cortada por veios de quartzo decamétricos e com espessura superior a $30 \mathrm{~cm}$.

Quase sempre os metabasitos estão intercalados nas unidades de metassedimentos tufíticos, constituindo corpos métricos maciços, geralmente tendo metatufos e metapelitos associados. Nesses corpos são comuns intercalações de leitos decimétricos alterados argilosos, de cor vinho avermelhada, interpretados como metatufos finos interderrames. Xistos finos com porfiroblastos de estaurolita e corpos menores de metacálcio-pelitos podem ocorrer nas porções mais distais.

Intercalações de metabasitos de granulação grossa, derivados de tufos a brechas finas, que gradam para metassedimentos tufíticos e destes para xistos com contribuição de argilas vulcânicas, são comuns na área, podendo ser exemplificados pelo afloramento BA 871.

O corpo situado a sudoeste do Granito Itaqui encontra-se bastante milonitizado pela zona de cisalhamento que acompanha o traçado geral da Rodovia Castelo Branco. Associam-se lentes de rochas calciossilicáticas e de metassedimentos tufíticos, em arranjo estratigráfico análogo ao descrito na Serra do Itaberaba por JULIANI (1993). A lente vulcânica/vulcanoclástica está intercalada em granada-biotita xisto grosso com leitos centimétricos de xistos arenosos, e está em contato com metassedimentos manganesíferos semelhantes aos da Formação Nhanguçu, descritos adiante. 
A sudeste do Granito Tico-Tico afloram algumas lentes associadas a leitos menores de metassedimentos tufíticos e uma maior em meio a xistos granatíferos com contribuição frequiente de metatufos básicos e intercalações decamétricas de xistos finos grafitosos, às vezes, com porfiroblastos de andaluzita.

A associação destes diversos litotipos pode ser observada na Rodovia dos Bandeirantes, nas proximidades do $\mathrm{km} 28$, onde ocorre um corpo de anfibolito de grã grossa, com 25 metros de espessura, em contato brusco com xisto com porfiroblastos de fibrolita e com intercalações métricas de xistos arenosos finos, com leitos de xistos conglomeráticos com seixos e grânulos de quartzo locais (Prancha 01/Foto C). Para norte, o anfibolito está em contato com xisto grafitoso que grada para xisto pelítico com fibrolita e, novamente, intercalam-se leitos decimétricos de xistos arenosos, localmente com fibrolita, milonitizados, com foliação E-W subvertical.

Os metabasitos desta unidade são em geral facilmente distinguíveis dos metabasitos do Grupo São Roque em campo, pela sua cor preta a verde-escura ou cinza-esverdeada-escura, granulação mais grossa, predominando tipos médios com cristais de anfibólio com até $2,5 \mathrm{~cm}$, e texturas tipicamente metamórficas, xistosa ou granoblástica. Raramente preservam relíquias de texturas ígneas, como a blasto* subofítica, mais visível no ponto CQ 924, a blastofítica e a blastoporfirítica. As vulcanoclásticas são ainda mais raras.

Predominam rochas maciças ou levemente foliadas, que podem gradar para anfibólio xistos em um mesmo afloramento. Em alguns afloramentos, como no TT 88 e TT 880 , há estruturas muito deformadas sugestivas de antigas pillow-lavas.

A textura é geralmente nematoblástica ou granonematoblástica, às vezes porfiroblástica, muito embora não faltem tipos granoblásticos, com cristais maiores de anfibólio e de plagioclásio mais finos dispostos entre os anteriores. Nas rochas foliadas pode ser observado que uma foliação prévia está quase que totalmente transposta pela $S_{2}$ ou paralelizada a essa, mas preservada como dobras intrafoliais. Dois eventos de crenulação são evidentes mas, devido à reologia do litotipo, mostram-se muito menos intensos que nos metapelitos.

São comuns tipos inequigranulares a porfiroblásticos subordinados, contendo cristais prismáticos maiores de anfibólio verde-escuros dispersos na matriz. Ocasionalmente, esses cristais ou porfiroblastos tendem a arranjos radiados ( $A B$ 1124), notadamente nas proximidades de antigas lavras de ouro. Essas texturas são muito sugestivas de alterações hidrotermais pré-metamótficas, como descrito por PérezAguilar (1996) na Serra do Itaberaba.

São compostos por anfibólio e plagioclásio e, ocasionalmente, observa-se biotita, granada ou clinopiroxênio, enquanto que quartzo, clinozoizita, titanita, epídoto e carbonato são subordinados, e os dois últimos associam-se, de preferência, às fraturas. Litotipos contendo pirita e calcopirita ocorrem nas proximidades de antigas lavras de ouro, em situação idêntica a observada na Serra do Itaberaba. 


\subsubsection{Unidade Metavulcanoclástica (MPSIppmv)}

Esta é a principal unidade do Grupo Serra do Itaberaba na área, e é composta predominantemente por metassedimento tufítico (derivado da mistura de pelitos e argilas vulcânicas e/ou tufos muito finos em proporções muito variáveis metamorfizados). Subordinadamente, ocorrem intercalações de metavulcânica, metabrecha e metatufo básicos, rochas calciossilicáticas, formações ferríferas, xistos, comumente grafitosos, sulfetados ou ferro-manganesíferos e raros leitos de turmalinito.

O corpo principal tem início no contato nordeste-norte do Granito Itaqui, e estende-se até os arredores da rodovia Anhangüera, constituindo uma grande estrutura dobrada parcialmente recoberta pelo Grupo São Roque. Nas proximidades do Pico do Jaraguá, as camadas têm direção N-NNW, mas na direção norte inflexionam-se na direção $\mathrm{E}-\mathrm{W}$, onde são cortadas por intensa foliação milonítica, de atitude média E-W subvertical. Esta foliação trunca uma outra foliação milonítica de baixo ângulo, vinculada ao empurrão do Grupo São Roque sobre o Grupo Serra do Itaberaba, e as atitudes dos planos indicam tratarse de uma zona transcorrente com estrutura em flor positiva.

A maior parte desse corpo foi mapeado por CARNEIRO (1983) como rochas calciossilicáticas, mas as observações em campo e petrográficas não permitem essa conclusão.

Na porção central do corpo são muito comuns pares $S$ - $C$ em milonitos de baixo a médio ângulos de mergulho e pequenas falhas de empurrão mais tardias, que indicam transporte tectônico para NNE, subordinadamente para NE ou N-NW (Prancha 01/fotos D e E). Essas estruturas indicam que, no Grupo Serra do Itaberaba, as unidades vulcanoclásticas estão colocadas tectonicamente sobre os metapelitos, sugerindo inversão da estratigrafia. Por afetar também litotipos do Grupo São Roque e rochas graníticas, o período principal de empurrão deve ser relacionado ao final do metamorfismo desse grupo e associado a parte dos eventos de magmatismo granítico, conclusão esta que está de acordo com o observado por HACKSPACHER et al. (1993a) e WERNICK et al. (1993b). Entretanto, os movimentos associados às transcorrências que sucederam o empurrão contribuíram para a estruturação observada, não somente pelas transpressões, como também pela reativação dos planos de empurrão.

Os contatos com os metapelitos superpostos, quando não cisalhados, são gradacionais e interdigitados, mas com litotipos do Grupo São Roque são claramente tectônicos, como na região do Pico do Jaraguá e do Morro Doce. Camadas menos espessas, mas muito extensas, ocorrem intercaladas nos metapelitos, mas não se associam aos corpos maiores dos metassedimentos psamo-pelíticos da Formação Pirucaia.

Corpos maiores afloram também a sudoeste do Granito Itaqui, até serem truncados a oeste pelo Granito São Roque. Nessa região também estão em contato gradacional com xistos e têm intercalaçôes de metabasitos e rochas calciossilicáticas.

O arranjo característico das fácies vulcano-sedimentares é a interdigitação e repetição rítmica dos diversos litotipos, com uma gradação lateral e em direção ao topo de metatufo básico fino, metassedimento tufítico, e metassedimento tufítico com muita contribuição de pelitos e metassedimentos. 
Estas rochas mostram-se quase sempre intensamente intemperizadas, devido à abundância de sulfetos presentes na rocha fresca, constituindo materiais argilosos de cor variegada, vermelho, vinho ou arroxeada. São comuns fragmentos clásticos cauliníticos subcentimétricos e angulosos, que se destacam pela cor branca, e pequenas manchas de hidróxidos de manganês. Esses produtos de alteração são bastante distintos dos observados nas rochas calciossilicáticas, que apresentam cor amarelo-esverdeadapálida e aspecto arenoso, devido aos restos de anfibólios, epidoto e quartzo. Distinguem-se também pelos minerais residuais, especialmente pela abundância de magnetita e limonita nas vulcanoclásticas.

Metabrecha e metatufo básicos estão bem expostos junto ao corpo anfibolítico que aflora a leste do Pico do Jaraguá e nas cercanias de Santana do Parnaíba, onde são observados alguns núcleos frescos de anfibolito grosso, inequigranular, com agregados ovóides de hornblenda distribuídos em matriz fina com anfibólio, plagioclásio e quartzo, muito semelhantes aos metatufos descritos na Serra do Itaberaba.

Às vezes, como nas proximidades da Rodovia Anhangüera, ponto PJ 1173, metabasitos alterados de granulação média a grossa da Unidade Metabásica apresentam estruturas ovaladas com cerca de $40 \mathrm{~cm}$ de diâmetro envolvidas por anfibolito alterado fino marrom-escuro, sugerindo tratar-se de pillow-lavas' e material vulcanoclástico interpillows. Essas rochas de derrames gradam para anfibolitos grossos maciços, muito alterados e vermelho-escuros, com leitos de alguns centímetros de espessura de metassedimentos tufíticos bandados a laminados, que permitem interpretá-los como metatufos.

Mesmo quando afetados por forte recristalização metamórfica, localmente pode ser observada estrutura bandada nestes litotipos, marcada por aumento ou redução do teor de anfibólio. Frecüentemente, ocorrem também como leitos de poucos centímetros a decímetros de espessura de anfibolitos grossos em meio a metassedimentos tufíticos alterados, como na altura do $\mathrm{km} 28$ da Rodovia dos Bandeirantes ou no acesso de Santana do Parnaíba para o bairro Alphaville (SP 633).

Metatufos mais finos são comuns, como os que ocorrem próximo ao Granito Itaqui, na Fazenda Tamboré (BA 844B). Constituem um banco fresco com um metro de espessura inserido em metassedimento tufítico alterado, maciço, de cor ocre-amarelado a verde-esbranquiçado.

A mineralogia das rochas metavulcanoclásticas básicas é muito semelhante à das metavulcânicas, com hornblenda verde-escura geralmente perfazendo entre $45 \%$ e $55 \%$ em volume mas alcançando, em alguns leitos, $90 \%$. O complemento é dado basicamente por plagioclásio mais fino, com epídoto, clorita, biotita, quartzo, turmalina, carbonatos, titanita, magnetita e sulfetos subordinados.

Epídoto é muito freqüente nos planos da foliação, inclusive milonítica, ou como venulações tardias relacionadas ao retrometamorfismo associado à $S_{3}$, juntamente com quartzo, carbonatos, clorita e biotita. Em alguns afloramentos ocorrem finas lâminas ou pequenas lentes de quartzo com sulfetos disseminados, derivados da recristaliação de níveis de chert ou de silicificação pré-/sin-metamórfica.

Os metassedimentos tufíticos são rochas tipicamente bandadas ou laminadas e muito raramente são encontrados afloramentos pouco alterados, quando apresentam cores esverdeadas-escuras e riqueza em sulfetos ou magnetita. São comuns intercalações métricas de filitos ocre-esverdeados com fílitos 
grafitosos subordinados e filitos manganesíferos (p.ex., PJ 1138), como os descritos na Formação Nhanguçu, indicando que a passagem entre ambos é gradacional e dá-se pela gradativa redução da atividade vulcanoclástica em favor da deposição de pelitos misturados com exalitos ferro-manganesíferos, manganesíferos e carbonáticos.

Apresentam intercalações de lâminas e bandas de cor ocre, vinho, vermelha, roxa e, menos comumente, amarela, verde e cinza, além de delgadas lentes cauliníticas brancas (Prancha 01/foto E). Quando as lâminas muito finas predominam, são roxos ou arroxeados. Caracteristicamente, possuem muito pouco quartzo de granulação muito fina, diferindo dos metapelitos, que, mesmo quando têm cores semelhantes, são bastante enriquecidos em quartzo.

Não raramente apresentam fragmentos milimétricos, angulosos, brancos e cauliníticos que, quando menos deformados, podem ser identificados como cristais de hábito triclínico, provavelmente de plagioclásio, como no afloramento VS 959. Estas texturas são interpretadas como derivadas de tufos de cristais, que comporiam parte dos metassedimentos tufíticos.

Ocasionalmente, são encontrados bancos maciços de cor róseo-clara a creme, ocre-amareladaclara ou ocre a branco-azulada, mais enriquecidos em quartzo fino, que parecem ser derivados de metavulcânicas ou, mais provavelmente, de metavulcanoclásticas quartzo andesíticas a riolíticas, como nos afloramentos BT 896, TT 943, TT 946A e PJ 938.

Frequientemente, ocorrem bancos de espessura métrica de rocha alterada, maciça, de brilho sedoso, muito argilosa e quase sem quartzo. Podem apresentar cor roxo-avermelhada ou vinho-clara, com porções ocráceas subordinadas. Raras amostras frescas foram encontradas, como no afloramento SP 645 . Trata-se de um clorita xisto fino a muito fino, densamente foliado, milonítico. A clorita compõe cerca de $95 \%$ em volume da rocha, com quartzo, hematita, minerais opacos e, possivelmente, flogopita. No afloramento PP 572 a rocha fresca possui granulação menor que $0,4 \mathrm{~mm}$ e estrutura finamente laminada, dada pela intercalação de leitos mais ricos em plagioclásio e com anfibólio mais fino, com outras com anfibólio mais grosso e em maior volume. Essa mineralogia é idêntica à das rochas frescas descritas na Serra do Itaberaba por JULIANI (1993),

Em vários afloramentos (SP 653, PJ 937A, SA 1108) ocorrem bandas com até 2,0 cm de espessura compostas predominantente por quartzo fino branco, cinza ou cinzarazulado, fortemente recristalizado e, por vezes, com aspecto brechado, caracterizados como metachert. Com freqüência estão boudinados e estirados e podem conter magnetita, hematita e sulfetos disseminados. Localmente, é possível notar leitos brancos dobrados intrafolialmente e são observadas dobras rompidas, evidenciando forte transposição do bandamento associada à foliação $S_{2}$.

Nas zonas de cisalhamento são comuns veios de quartzo boudinados e cisalhados, com espessuras variando de decímetros a $3 \mathrm{~m}$, chegando excepcionalmente a $12 \mathrm{~m}$ (SP 652). Nas porções muito milonitizadas torna-se difícil a distinção entre os veios de quartzo e leitos de metachert. Essas foram as principais zonas lavradas para ouro no Período Colonial. 
Venulações de quartzo são comuns e podem indicar remobilizações hidrotermais prévias ou refletir os processos deformadores superpostos que remobilizam o quartzo. Cisalhamentos locais podem produzir eventuais concentrações de turmalina. A alteração rósea observada em alguns leitos turmaliníticos pode indicar a presença de sulfetos alterados para sulfatos supérgenos, ou representar eventuais cristais de feldspato também alterados.

Turmalinitos formam raras intercalações de espessura subdecimétrica nos metassedimentos tufíticos, por vezes associados com leitos de metachert, como pode ser observado no afloramento do ponto (TT 937B). São semelhantes aos descritos por JULIANI (1993) na região da Serra do Itaberaba que, face às frequientes associações com BIFs, foram correlacionados a uma possível variação da fácies silicática das formações ferríferas. São pretos ou cinza-escuros, laminados a localmente bandados, e têm leitos escuros com até $2,0 \mathrm{~mm}$ de espessura onde a turmalina ocupa até $90 \%$ do volume da rocha, o quartzo é acessório subordinado, e a magnetita cúbica parcialmente limonitizada pode atingir $1 \%$. Leitos brancos ou cinza esbranquiçados intercalados exibem o quartzo relativamente mais grosso e abundante, ainda que submilimétrico que, por vezes, constitui mais de $90 \%$ do conteúdo, sendo que turmalina é acessória disseminada ou pode marcar leitos descontínuos, e a sericita e a magnetita ocorrem muito subordinadas.

Ocorrem também alguns corpos menores de metapelitos calciossilicáticos ocre-esverdeados, por vezes contendo porfiroblastos alterados ocre-escuros (pirita limonitizada?) associados aos metapelitos manganesíferos, como nos afloramentos SP 480 e SP 584.

Rochas calciossilicáticas laminadas a bandadas ocorrem localmente em meio aos metassedimentos tufíticos, constituindo camadas de alguns decímetros até alguns metros, como visto no ponto PJ 535, geralmente com sedimentos manganesíferos associados. Esse tipo de ocorrência provavelmente levou CARNEIRO (1983) a interpretar os saprolitos dos metassedimentos tufíticos como resultado da alteração das rochas calciossilicáticas.

Nas fácies mais distais da Unidade Vulcanoclástica e em direção ao contato com os xistos, como nas regiões do bairro Várzea do Souza, em parte do contato com o Granito Itaqui (BA 841 A, BA 844C, BA 849), a sul do Morro do Boturuna e na Rodovia Castelo Branco, diminuem as intercalações e espessura dos corpos de metassedimento tufítico no metapelito. O metassedimento tufítico tornarse também relativamente mais claro, indicando menor contribuição de sedimentos vulcânicos. Essas variações faciológicas são devidas à redução da atividade vulcânica-vulcanoclástica na bacía deposicional.

Essas rochas metassedimentares estão representados por xistos finos a muito finos, pobres em quartzo, de cor róseo-clara a vermelha, quando a contribuição de argilas vulcânicas foi maior. Em geral, são foliados, bandados, por vezes possuem porfiroblastos de biotita, e possuem intercalações de espessuras centimétricas a métricas de metassedimentos tufíticos argilosos, bandados ou maciços e variegados (Prancha 01/Foto F). 
Nesses xistos, ocasionalmente, podem ser observados leitos turmaliníticos e níveis grafitosos de espessura centimétrica, como no ponto (BT 674). Turmalina xistos laminados podem formar intercalações de poucas dezenas de metros de extensão e até $2,0 \mathrm{~m}$ de espessura, como observado no afloramento do ponto (PP 144), onde se destacam devido à maior resistência aos processos intempéricos.

Vários corpos de alterito branco caulinítico com matriz foliada, onde destacam se fenocristais bipiramidados de quartzo, ocorrem na unidade metavulcanoclástica. Essas rochas também afloram, de modo subordinado, nas unidades metabásica, dos xistos pelíticos, e na unidade dos metassedimentos manganesíferos da Formação Nhanguçu. São caracterizados como de metarriólitos. As ocorrências principais, algumas menores, sem evidências de relações de contato, e outros possíveis corpos muito decompostos, encontram-se assinalados no mapa geológico.

Nas proximidades de Santana do Parnaíba, associados às rochas metavulcanoclásticas básicas (SP 478B) e aos metassedimentos tufíticos (SP 91) da unidade metavulcanoclástica, exibem contatos subconcordantes e apófises centimétricas, e contêm as foliações $S_{2}$ e $S_{3}$ análogas às das encaixantes, o que permite supor que são subvulcânicos intrusivos.

Nas regiões da Fazenda Tamboré (BA 840) e central da área (SP 481), os corpos de metarriólito ocorrem no topo da unidade metavulcanoclástica, junto aos pacotes de metapelitos calcíferos com metassedimentos manganesíferos e grafitosos associados, como os descritos na Formação Nhanguçu (Prancha 01/Foto G). Esses litotipos estão intercalados aos metassedimentos tufíticos e aos metapelitos com contribuição tufítica e, eventualmente, a xistos finos com estaurolita, como ocorre no ponto (BA 888B).

Na Fazenda Tamboré, essas rochas ácidas formam corpos lenticulares de até $4 \mathrm{~m}$ de espessura, subconcordantes ao bandamento e que exibem xenólitos de metapelito manganesífero. Nota-se, também, a foliação $S_{2}$ dobrando um bandamento prévio, com a $S_{1}$ subparalela ao acamamento, e as estruturas estão preservadas tanto na encaixante como na subvulcânica ácida, como reportado por MARTIN et. al. (1998b). Na região central do mapa geológico, o metarriólito tem $1 \mathrm{~m}$ de espessura e a foliação $S_{2}$ é subparalela ao bandamento. Por vezes, apesar da transposição local, é possível recuperar o contato concordante entre o metarriólito e esses metapelitos.

A situação sugere, além do caráter subvulcânico, ocorrências efusivas na transição da Formação Morro da Pedra Preta para a Formação Nhanguçu, semelhantes às reportadas por JULIANI et. al. (1995) na Formação Nhanguçu na Serra do Ttaberaba.

O litotipo não alterado foi descrito a partir de blocos até decimétricos encontrados em afloramento de metavulcanoclásticas básicas da unidade metabásica (SP 643). São maciços ou contêm moderada foliação, e têm uma matriz muito fina creme-esbraquiçada ou branca.

A análise petrográfica indica constituintes minerais menores que $0,1 \mathrm{~mm}$ ocupando ao redor de 85 $\%$ do volume da rocha. Predomina o quartzo, com feldspato potássico e plagioclásio subordinados, enquanto muscovita é acessório comum e torna-se o constituinte principal quando as subvulcânicas estão 
milonitizadas. Biotita, epídoto, clinozoizita, magnetita e sulfetos são traços. Destacam-se fenocristais vítreos, predominando os de quartzo, por vezes preservando o hábito bipiramidado, sendo possível observar suas faces e feições de corrosão com lupa. Feldspato potássico é comum, e o plagioclásio é mais raro e menor. Os fenocristais somados podem ser traços mas, eventualmente, atingem $20 \%$ do volume da rocha. Em lâmina observa-se, ocasionalmente, textura granofírica com intercrescimento de quartzo e feldspato alcalino (CV 818), o que reforça a hipótese do caráter subvulcânico.

Um outro afloramento de rocha muito semelhante, porém com fenocristais maiores de quartzo bipiramidado de até 4,0 mm, ocorre a NW de Santana do Parnaíba (SP 602A). Tem caráter intrusivo e corta ortogonalmente uma seqüiência de metapelitos grafitosos da unidade metapelítica da Formação Piragibu do Grupo São Roque.

BERGMANN (1988) descreveu, nas cercanias da cidade, rochas ora quartzosas muito finas, ora de matriz caulinítica contendo quartzo bipiramidal, consideradas como graníticas equigranulares finas a médias intrusivas na forma de diques e sills nas rochas metabásicas e nos metapelitos, e associadas ao Maciço Granítóide Itaqui. HACKSPACHER et. al. (1994, 1996) referem-se a rochas micrograníticas porfiríticas de caráter subvulcânico relacinadas à intrusão.

Os metarriólitos podem, eventualmente, devido à proximidade da maioria dos corpos com o Maciço Granitóide Itaqui, à dificuldade na caracterização do contato, e às foliações impressas nas pequenas exposições, ser confundidos com os microgranitos porfiríticos.

\subsubsection{Unidade Calciossilicática (MPSIppes)}

As rochas calciossilicáticas da região de Perus têm sido objeto de vários estudos e, por estarem em contato com granitos e apresentarem paragêneses de grau considerado mais alto que as encaixantes, foram geralmente consideradas como hornfels (CORDANI et al. 1963; CARNEIRO 1983) derivados de calcários magnesianos impuros intercalados nos xistos. Entretanto COUTINHO (1972), ao encontrar ocorrências muito afastadas dos granitos, considerou que nem todos os corpos poderiam ter sido gerados por metamorfismo de contato.

A caracterização desses litotipos como gerados predominantemente por metamorfismo regional, e de suas relações estratigráficas com metabasaltos, metatufos e metassedimentos tufíticos, foi estabelecida por COUTINHO et al. (1982) e JULIANI (1993). Os mesmos critérios foram aplicados neste estudo, o que resultou em reinterpretação do enorme corpo de rochas calciossilicáticas de CARNEIRO (1983) como sendo formado predominantemente por metavulcanoclásticas.

Em geral, do corpo mapeado por CARNEIRO (1983) restaram poucas lentes de rochas comprovadamente calciossilicáticas. Essas lentes possuem, em planta, largura ao redor ou inferior a 125 metros e comprimentos entre 500 e 1.250 metros, exceção feita ao corpo de formato semi-elíptico que aflora na Rodovia dos Bandeirantes, que possui cerca 250 metros de largura.

A principal ocorrência das rochas calciossilicáticas localiza-se entre os granitos São Roque e Itaqui, onde compõem três lentes alongadas segundo a direção NNW, com comprimentos variando entre 
300 e 3.750 metros. Outros corpos afloram próximos de Santana do Parnaíba e a SSE do Morro do Boturuna, na região da Capela Velha-Estrada do Suru.

Os contatos com os litotipos das unidades dos Xistos Pelíticos e Metavulcanoclástica da Formação Morro da Pedra Preta são gradacionais e interdigitados, bem como com metacálcio-pelitos, metapelitos manganesíferos e grafitosos da Formação Nhanguçu. Os contatos com os litotipos da Unidade Metabásica são geralmente bruscos e concordantes com as metavulcânicas, mas podem ser gradacionais quando metatufos intercalam-se entre ambos, possivelmente devido à carbonatização das rochas básicas previamente ao metamorfismo e pelas reações químicas associadas ao metamorfismo.

Estas rochas têm cores verdes, claras ou escuras, ou cinzas a cinza-esverdeadas, e são tipicamente bandadas ou laminadas, com leitos de diferentes composicões mineralógicas. Leitos mais claros são normalmente mais ricos em epídoto ou diopsídio, e nos mais escuros predomina actinolita ou hornblenda. Normalmente, têm granulação finna, raramente média e, em geral, as bandas variam entre 1,0 e $3,0 \mathrm{~cm}$ de espessura, podendo, localmente ter $5,0 \mathrm{~cm}$.

Comumente são observadas dobras intrafoliais que afetam uma xistosidade, com a foliação planoaxial identificada como $S_{2}$ paralelizada ao acamamento. Em outros afloramentos, há dobras $D_{2}$ são recumbentes com eixos pouco inclinados. Nessas, nota-se vergência para norte.

As rochas calciossilicáticas são compostas por clinopiroxênio, tremolita-actinolita, epídoto, biotita-flogopita, hornblenda, titanita, plagioclásio, quartzo, carbonatos, alanita, zircão, microclínio, escapolitat, titanita, leucoxênio, ortoclásio pertítico, granada, clorita magnesiana e turmalina em porcentagens muito variadas em diferentes litotipos, ou em bandas ou lâminas de uma mesma rocha. Às vezes ocorrem prismas mais grossos de actinolita em arranjo radiado.

Ocasionalmente, compreendem lâminas constituídas essencialmente por actinolita ou hornblenda, às vezes com plagioclásio subordinado, como se observa a sul do Morro do Boturuna no afloramento do ponto (CV 808), sugerindo contribuição de tufos básicos ou carbonatação de metatufos, como descrito por JULIANI (1993) e PÉREZ-AGUILAR (1996) na Serra do Itaberaba.

Quando intemperizadas, as rochas calciossilicáticas adquirem inicialmente cor verde amarelada que passa para amarela-clara e, nas porções mais alteradas, mostram-se tipicamente ocre-amareladoclaras ou ocre-esverdeado-claras, num padrão de alteração muito distinto daquele das metavulcanoclásticas (Prancha 01/foto H). O solo residual é vermelho-escuro, argiloso, e diferencia-se dos derivados dos metabasitos e metassedimentos tufíticos pela abundância com que esses apresentam minerais opacos.

Em vários dos afloramentos observam-se pontos, manchas dendríticas milimétricas e fraturas percoladas por óxidos e hidróxidos de manganês. Localmente, há grande volume desses óxidos e hidróxidos, conferindo à alteração aspecto terroso de cor de pó de café. Nestas rochas normalmente ocorrem leitos de carbonatos com até $5,0 \mathrm{~mm}$. Epidotização geralmente está associada à $\mathrm{S}_{3}$, às foliações miloníticas e aos planos de pequenas falhas. 
As rochas podem apresentar uma foliação cerrada e estrutura lamindada, com leitos ricos em clinopiroxênio \pm microclínio alternados com outros formados essencialmente por tremolita-actinolita, além de lâminas verdes subordinadas ricas em flogopita. Alguns leitos são mais escuros devido à disseminação de finíssimos cristais placóides, possivelmente de hematita, ou grafita em outros leitos.

Localmente, as rochas calciossilicáticas possuem intercalações decimétricas de xisto e, em zonas miloníticas, podem apresentar lâminas branco-esverdeadas com escapolita, tremolita, diopsídio e clinozoizita.

Na Estrada do Suru, a NNW do Granito Itaqui (CV 761), algumas rochas calciossilicáticas diferenciam-se pelo aspecto maciço, granulação média e pela riqueza em diopsídio, além de flogopita, titanita e clinozoizita subordinados. Apresentam ainda bandas e porções lenticulares castanhas formadas por flogopita-quartzo xisto com epídoto.

Plagioclásio-biotita-quartzo xistos com porfiroblastos de biotita são encontrados intercalados nas rochas calciossilicáticas que afloram na Rodovia Castelo Branco (CQ 924 B). Se assemelham aos observados em Santana do Parnaíba (SP 621), e que também ocorrem a SSW do Morro do Boturuna intercalados nos metassedimentos tufíticos (CV 745) e nos xistos pelíticos na região da Fazenda Itaybe (BT 715). Esses podem representar metatufos riodacíticos silificados, em analogia às ocorrências descritas na Serra do Itaberaba. Delgados leitos de quartzo recristalizados, interpretados como metachert, estão também presentes nessas rochas.

Metapelitos carbonáticos ocráceos e cinzas, laminados ou com bandas até decimétricas de filitos grafitoso e manganesífero e xistos finos granatíferos podem intercalar-se também na rochas calciossilicáticas, como no afloramento do ponto PJ 953.

\subsubsection{Unidade dos Xistos Pelíticos (MPSIppmp)}

Os xistos pelíticos afloram em três regiões. Na porção centro-nordeste do mapa geológico, na área de maior exposição, envolvem o Stock Granítico Tico-Tico, e se estendem para W no sentido do Bairro Várzea do Souza, e para SE, até o Maciço Granitóide Cantareira. Na região sudoeste, ocorrem entre os maciços granitóides Itaqui e São Roque, e acompanham o contorno da última intrusão até os arredores do rio Tietê. A norte do Granito Itaqui, encontram-se freqüentemente intercalados aos litotipos da unidade metavulcanoclástica e apresentam contato tectônico com as formações Piragibu, Estrada dos Romeiros e Morro Doce do Grupo São Roque.

$\mathrm{Na}$ primeira área de exposição, predominam como extensos pacotes, e para $\mathrm{S}$ do Granito TicoTico intercalam com maior frequiência corpos lenticulares de rochas metabásicas, xistos quartzosos, litotipos da unidade metavulcanoclástica e xistos grafitosos, que podem se estender por dezenas de metros.

Em direção ao Pico do Jaraguá, os xistos pelíticos passam a ocorrer intercalados com os metassedimentos tufíticos até se tornarem corpos lenticulares restritos, e são também mais comuns as 
lentes de metassedimentos grafitosos, como a do ponto (PJ 1182B). Para ENE do Granito Tico-Tico os xistos quartzosos, semelhantes aos observados na Formação Pirucaia, estão presentes como pacotes lenticulares de espessura até métrica entre o Maciço Granitóide Cantareira e o Grupo São Roque.

O limite setentrional dos xistos pelíticos faz-se com unidades do Grupo São Roque através de extensa zona milonitizada de direção predominante E-W que, às vezes, enfeixa e intercala litotipos cataclasados das unidades limites, ocorrendo desde o limite nordeste do mapa geológico até o centro da área, onde a zona sofre inflexão para sudoeste.

Xistos de moderada foliação com estaurolita e biotita porfiroblásticas parecem formar um pacote restrito de espessura até decamétrica a sul do Stock Granítico Tico-Tico marcando, possivelmente, um nível estratigráfico (PP 22, PP 28, PP 473, PP 893, PP 942). Estão em contato brusco, interdigitado on tectônico com os metassedimentos tufíticos, o que sugere, mesmo que localmente, que o contato basal da unidade dos xistos pelíticos pode ocorrer através dos biotita-estaurolita xistos com essas metavulcanoclásticas.

Esses xistos têm aspecto maciço a moderadamente foliado e exibem textura lepidogranoblástica e granoblástica-poiquiloblástica. Contêm porfiroblastos-poiquiloblastos de estaurolita e de biotita, além da granada subordinada. Uma certa orientação é dada pelo arranjo dos cristais de biotita.

Frescos, exibem matriz cinza a cinza-esverdeada, e destacam-se cristais amarelados de estaurolita, pretos de biotita e vermelhos de granada, como pode ser vistos no afloramento do ponto (TT 942). Alterados, tornam-se verdes, com placas de biotita vermiculitizada dourada, e são vinho-avermelhadoescuros na alteração pronunciada. A granulação é média a grossa, com os cristais de biotita tendo ao redor de 3,0 mm, os de estaurolita atingindo até $8,0 \mathrm{~mm}$, enquanto que os de granada podem ter 5,0 mm.

A estaurolita ocupa até $60 \%$ do volume da rocha em alguns leitos maciços. Biotita predomina como cristais maiores distribuídos randomicamente, e atinge até $25 \%$ do volume, ou ocorre como cristais menores na matriz orientados na foliação $S_{n}$, apresentando, às vezes, feições $S-C$. Quartzo é um constituinte essencial e a muscovita um acessório subordinado, estando orientada. Granada, em grande parte limonitizada, ocupa até $2,0 \%$, enquanto que turmalina e magnetita euédricas variam de traços a acessórios e zircão é raro.

Nas proximidades do oleoduto que corta o Bairro do Polvilho (PP 22), os biotita-estaurolita xistos estão em contato tectônico com metassedimentos tufíticos argilosos, laminados a bandados, que exibem cores diversas e que são cortados por veios de quartzo de até $20 \mathrm{~cm}$ de espessura, subconcordantes ou ortogonais ao bandeamento. Ambos os litotipos têm uma foliação milonítica verticalizada.

Na estrada de acesso de Cajamar para o bairro do Polvilho, esses xistos apresentam intercalações de até $10,0 \mathrm{~cm}$ de espessura de rochas básicas alteradas que, para sul, tornam-se mais frequientes e portam laminações argilosas brancas. Para norte, os biotita-estaurolita xistos dão lugar a biotita-xistos com estaurolita, grafita-granada-estaurolita-biotita xistos, e esses últimos gradam para os xistos pelíticos.

Ocasionalmente, estão em contato brusco e concordante com metassedimentos tufíticos contendo 
intercalações de xistos argilosos vermelhos com granada e fubrolita porfiroblásticas e leitos de xistos grafitosos. Localmente, observa-se uma intercalação decimétrica de turmalinito (PP 94).

Esses litotipos gradam para os xistos pelíticos ricos em fibrolita porfiroblástica, como se observa no acesso ao bairro do Polvilho na Rodovia Anhangüera (PP 28). Nesse afloramento, ambas as rochas estão sobrepostas aos metassedimentos tufíticos e, para norte, os biotita-estaurolita xistos são raros e passam a predominar os xistos pelíticos.

Os xistos pelíticos ricos em fibrolita porfiroblástica predominam na região do Stock Granítico Tico-Tico. Encontram-se quase sempre intensamente foliados ou milonitizados. Como variações, observam-se tipos com estaurolita associada (TT 883A), ou a fibrolita está ausente e com estaurolita cristaliza granada (PP 569). Junto à fibrolita pode ocorrer granada, e a estaurolita ser intersticial e anédrica (PE 979).

Quando frescos, são cinza-médios e destacam-se cristais fibrosos a fibrorradiados brancos de fibrolita, amendoados ou estirados. Apesar da grande área de abrangência, as poucas amostras frescas foram obtidas nas drenagens a sul do Stock Granítico Tico-Tico (TT 75, TT 85, TT 90, TT 564). Uma delas é do Bairro Perus (PE 979), próximo do contato com o Maciço Granitóide Cantareira.

Se incipientemente intemperizados, são cinza-esverdeados escuros ou verde-dourados devido à alteração da biotita. A continuidade do processo gera tipos vinho-escuros a vinho-avermelhados com típicas manchas brancas. Mais alterados, tendem a róseo-claros.

Caracterizam-se por uma estrutura $S_{2}$ que varia de uma forte xistosidade a uma foliação milonítica, dada pela orientação dos minerais micáceos e pelo caráter assimétrico dos porfíroblastos de fibrolita (PP 509). A recristalização de grãos de quartzo maiores, que estão estirados pela $S_{2}$, e de prováveis leitos granoblásticos isolados e adelgaçados em meio ao bandamento micáceo, pode gerar uma estrutura anastomosada.

A $S_{2}$ em geral é paralela ao bandeamento, e a foliação prévia $S_{1} / S_{0}$ está dobrada intrafolialmente, com os minerais micáceos formando arcos poligonais isolados pela transposição associada à estrutura $S_{2}$, como se observa no afloramento do ponto (PP 145). Uma clivagem de crenulação $S_{3}$ superposta ondula e pode gerar dobras fechadas na foliação principal, como ocorre nos arredores do afloramento TT 85 , ou a transpõe. A clivagem de crenulação $S_{4}$ é mais rara, produzindo suaves ondulações nas estruturas prévias, e é mais fácil de ser observada na análise petrográfica, onde se nota a recristalização do quartzo e a presença de alguns cristais de muscovita ortogonais à $S_{3}$.

Esses xistos têm granulação média, com os cristais da matriz entre 1,0 e 3,0 mm, por vezes com os minerais micáceos atingindo 5,0 mm. Tipos grossos são subordinados, com predomínio de cristais maiores e porfiroblastos de fibrolita ou de agregados porfiroblásticos de muscovita que podem atingir até $1,2 \mathrm{~cm}($ TT 564).

Predomina a textura granolepidoblástica porfiroblástica, mas é frequiente a granolepidoblástica, enquanto a lepidogranoblástica e lepidogranoblástica porfiroblástica são incomuns. O quartzo é o mineral 
comum da matriz, que completa-se com muscovita e biotita, sendo que esses micáceos, amiúde, permutam-se como o segundo mineral mais frequiente.

Dentre os xistos contendo fibrolita porfiroblástica, predominam muscovita-biotita-quartzo xisto e biotita-muscovita-quartzo xisto, seguidos por biotita-quartzo-muscovita xisto, além de biotita-quartzoxisto com muscovita e quartzo-muscovita-xisto com biotita.

Os porfiroblastos de fibrolita variam de traço até $25 \%$ do volume da rocha. Podem apresentar inclusões milimétricas limonitizadas, de mineral opaco e, mais raro, de granada.

Granada em cristais relativamente maiores é acessório ou traço, enquanto que plagioclásio é muito raro ou acessório acidental, sendo descrito apenas em lâminas dos pontos PJ 75, TT 85 e PE 979. Turmalina e zircão são freqüentes, como acessórios subordinados ou como traços, e a clorita é acessório ocasional em raros leitos.

Andaluzita em parte retrometamorfizada para sericita/pirofilita, e estaurolita como cristais maiores ou porfiroblastos, ou retrometamorfizada para agregados de muscovita (TT 941), são incomuns. A magnetita predomina como acessório ou traço frequiente e ilmenita/hematita é acidental. Agregados porfiroblásticos com muscovita, quartzo e biotita, ou só portando muscovita, ocorrem eventualmente (TT 564), enquanto que relíquias de cristais de cianita e, possivelmente, de silimanita, são bem raros (TT 85).

Nos afloramentos maiores das rodovias Anhangüera (PP 145, PP 146), dos Bandeirantes (TT 85, TT 883, CB 989) e no acesso ao Parque Anhangüera (TT 946A, TT 946B), esses xistos dispõem-se em pacotes métricos a decamétricos intercalando litotipos desde finos até grossos. A fibrolita pode abundar em um pacote e nos seguintes ser um acessório ou estar ausente (Prancha 02/foto A). Não são raras as intercalações de espessura até decimétrica de xistos quartzosos com granada ou com fibrolita, além de pacotes de metassedimentos tufíticos subordinados.

Nos arredores do Stock Granítico Tico-Tico são comuns os veios ou até corpos pegmatóides de composição granítica e ricos em turmalina, com extensão de alguns metros. Suas espessuras variam de decimétrica até 5 metros, como no ponto TT 946B. A maioria das ocorrências acompanham o bandeamento metamórfico. Porém, em outros afloramentos, os veios claramente cortam a foliação milonítica $\mathrm{S}_{2}$, como a sudeste do stock (TT 883A).

A N do Pico do Jaraguá, esses xistos tornam-se mais finos e os porfiroblastos de fíbrolita são raros ou estão ausentes, e passam a ser muito freqüentes as contribuições de metassedimentos tufíticos, que podem formar pacotes de espessura até métrica.

Nas proximidades de Caieiras, são comuns intercalações de xistos quartzosos de espessura até métrica e leitos de xisto grafitoso, como no ponto CA 971. Os xistos pelíticos estão milonitizados e as estruturas sigmóides indicam movimentação para leste. São posteriormente cortados por novo cisalhamento de alto ângulo.

Se dirigindo para sul, no afloramento $C A 981 B$, os xistos exibem pares $S-C$ indicando movimentação dextral. A xistosidade grada para a foliação milonítica com falhas inversas associadas e, 
essa foliação rotaciona os porfiroblastos de granada e fibrolita, sugerindo que a estrutura $S_{2}$ está relacionada à transpressão, responsável pela colocação do Grupo São Roque sobre o Grupo Serra do Itaberaba. O mesmo ocorre no Bairro Perus, nas proximidades do Maciço Granitóide Cantareira. Em um afloramento com extensão ao redor de 30 metros, a foliação $S_{2}$ também rotaciona e estira os mesmos porfiroblastos, indicando que o aparecimento desses não está relacionado com o metamorfismo de contato gerado pelas intrusões graníticas, e sim que as intrusões apenas alçaram as isógradas do Grupo Serra do Itaberaba.

Como observado, o alojamento do Stock Granítico Tico-Tico é posterior a esta foliação $\mathrm{S}_{2} / \mathrm{S}_{\mathrm{m}}$, pois seus veios pegmatóides cortam-na ortogonalmente. Datações mais recentes pelo método U-Pb em zircão indicam que os corpos intrusivos da região são contemporâneos, com o stock apresentando idade de $626 \pm 21$ Ma e $625 \pm 18 \mathrm{Ma}$ (respectivamente, TEUPPENHAYN (1994), TÖPFNER (1996), em AZEVEDO, 1997) enquanto que o Maciço Granitóide Cantareira tem idade de $630 \pm 8 \mathrm{Ma}$ (TÖPFNER 1996, em AZEVEDO 1997).

A oeste do Stock Granítico Tico-Tico, na estrada do Bairro de Polvilho para Cajamar, os xistos em geral são mais finos e exibem com freqüência estaurolita porfiroblástica que, às vezes, atinge até $4,0 \mathrm{~cm}$ (PP 471). Estão laminados ou bandados e intercalam-se camadas de xistos quartzosos e níveis subordinados de quartzitos finos, o que permite observar que o bandeamento está dobrado intrafolialmente, como visto nos pontos JD 349 e PP 359.

Mais próximo do contato com o Grupo São Roque, os xistos adquirem intensa foliação milonítica e têm bandamento tectônico milimétrico (Prancha 02/foto B). São comuns pares $S-C$ e, nos veios de quartzo boudinados com $6,0 \mathrm{~cm}$ de comprimento, ocorre biotita. Nas falhas inversas associadas, os grãos de quartzo exibem lineação de estiramento mineral com indicação de transporte de massa para NNW. Esse transporte relacionamse à extensa estrutura de cisalhamento associada com zonas de empurrão, que põe em contato os grupos Serra do Itaberaba e São Roque.

Na Rodovia do Bandeirantes, no afloramento do ponto TT 1157, ocorre por até $25 \mathrm{~m}$ de extensão uma rocha maciça verde-clara onde predominam cristais brancos ripiformes de plagioclásio, sugerindo a presença de rochas metaintermediárias intercaladas nos xistos.

Nas proximidades do Stock Granítico Tico-Tico ocorre um turmalina-muscovita-biotita-quartzo xisto com granada de estrutura laminada a bandada, que contém lâminas turmalino-biotíticas e outras essencialmente turmaliníticas (PP 593). Essa situação sugere, segundo PENALVA \& HASUI (1970), enriquecimento do mineral através de fluidos associados à intrusão granítica, produzindo mica-xistos turmalinizados. Porém, mesmo ocorrendo disseminada nesses xistos, a turmalina pode marcar leitos bem definidos, o que parece indicar gênese por deposição química ou detrítica, não relacionados a fluidos pneumatolíticos.

Na porção SW do mapa geológico, os xistos limitam-se com o Maciço Granitóide São Roque através da Zona de Cisalhamento Araçarigüama, e o contato sul é feito com milonitos do Maciço 
Granitóide Ibiúna na Zona de Cisalhamento Taxaquara. Com a unidade metavulcanoclástica ocorrem passagens transicionais, marcadas pela diminuição da espessura e da frequiência dos leitos de metassedimentos tufíticos nos xistos.

Para o topo, apesar da pouca exposição, o contato com a unidade dos filitos manganesíferos da Formação Nhanguçu também parece em posição normal. A partir do predomínio dos xistos e continuando para SW, passa a ocorrer uma rocha alterada e bandada amarelo-ocrácea e, no colúvio, observam-se plaquetas de óxido de manganês em um afloramento de filito manganesífero alterado com possível contribuição de rochas calciossilicáticas (ST 1091), e ocorrem intercalações centimétricas até decimétricas de xistos pelíticos.

Na região de Araçariguiama, os xistos apresentam intercalações freqüentes de xistos quartzosos e, localmente, ocorrem leitos conglomeráticos contendo seixos de quartzo estirados devido à milonitização (VL 1075). Um desses leitos atinge 0,5 metro de espessura. Mais a oeste, no contato com a unidade metabásica e com o corpo granítico lenticular, os xistos estão intensamente milonitizados, têm intercalações freqüentes de veios de quartzo e corpos decimétricos dobrados de composição granítica. Os litotipos mostram-se lenticularizados, indicando estarem afetados pela Zona de Cisalhamento Araçarigüama.

Para sul, exceção feita a alguns afloramentos de xistos grossos com porfiroblastos de estaurolita (AB 1119) ou de fibrolita (SA 1100, SA 1101), os xistos pelíticos são finos e têm biotita porfiroblástica, e a granada, subordinada, ocorre nas intercalações mais arenosas. Em geral são também mais pobres em quartzo, exibem cores vermelho-claro-arroxeadas ou róseo-claras, e são comuns as contribuições de metassedimentos tufíticos em intercalações até métricas (ST 1085), e de leitos grafitosos até decimétricos (SA 1096), O mesmo pode ser observado no perfil entre a Rodovia Castelo Branco até a região da Mina Santa Rita e da mina em direção ao distrito de São João Novo (ST 1094 a SA 1095).

As intercalações de xistos mais arenosos podem ter espessura métrica nos xistos pelíticos e conter inúmeros veios de quartzo cisalhados, além de interposições de metassedimentos manganesíferos e tufíticos milonitizados e localmente lenticularizados, sugerindo, também, contato tectônico local com a unidade dos filitos manganesíferos., como pode ser visto no afloramento ST 1089.

A terceira área de exposição dos xistos pelíticos ocorre além do contorno setentrional do Maciço Granitóide Itaqui. Constituem corpos mais espessos a NNW, frequientemente com mais de 400 metros de espessura e mais de $2 \mathrm{~km}$ de extensão. A NNE da intrusão, formam corpos lenticulares de extensão quilométrica com até $200 \mathrm{~m}$ de espessura, dobrados e subordinados na unidade metavulcanoclástica.

Mais a NE, aflora um corpo grossseiramente triangular com ao menos $2 \mathrm{~km}$ de lado, e outras lentes com espessura entre 350 e 700 metros. Esses xistos estão em contato tectônico e cavalgados por litotipos das formações Piragibu e Estrada dos Romeiros do Grupo São Roque.

Predominam os tipos alterados róseo-claros a vermelho-claros que, quando mais preservados, são vinho-esverdeado-escuros. Quando frescos, são verde-acizentados. Têm granulação fina, sendo locais os 
tipos médios e incomuns os grossos. Exibem biotita porfiroblástica com até 3,0 mm e, por vezes, ocorrem porfiroblastos de estaurolita com até $2,0 \mathrm{~cm}$ ocupando até $15 \%$ do volume da rocha (Prancha 02/Foto C). A ocorrência a fibrolita é rara.

Na região das fazendas Itayhe e Tamboré, os xistos pelíticos são mais ricos em quartzo e muscovita, enquanto que biotita e grafita ocorrem como acessórios subordinados. Têm, caracteristicamente, biotita e magnetita porfiroblásticas disseminadas e muitas vezes associadas, que podem atingir até $2,0 \mathrm{~mm}$ (BT 717). A biotita pode formar agregados porfiroblásticos com três ou quatro cristais que, em grande parte, substituem a magnetita. Turmalina é traço constante, clorita e andaluzita são raras. Nesses xistos, a estaurolita é menos frequiente ou rara, e observada como porfiroblasto no ponto BT 933.

As cores de alteração intempérica diferenciam se, variando do verde-ocráceo ao verde-claroacastanhado. Mais decompostos, são vinho-avermelhados com biotita vermiculitizada e magnetita limonitizada. Planos locais com percolação de óxidos e hidróxidos de manganês não são raros.

Xistos semelhantes foram descritos em um afloramento na porção SW do mapa geológico (CQ 1005). Nesse ponto, os porfiroblastos de biotita exibem várias plaquetas em forma de livro e parecem relacionados ao metamorfismo de contato gerado pela colocação do Maciço Granitóide Itaqui. Contudo, onde a foliação $S_{2}$ é milonítica nota-se a orientação e o estiramento desses porfiroblastos, o que decarta a possibilidade anterior, pois a intrusão trunca essa foliação.

A estrutura comum é um bandeamento composicional com intercalações de lâminas lenticularizadas, isolando as mais quartzosas de outras micáceas. Nestes xistos, eventualmente, pode ser observada a crenulação, ocorrendo ondulaçōes no bandeamento. Localmente, a clivagem de crenulação pode evoluir para uma crenulação zonal ou produzir transposição do bandamento prévio.

Nas cercanias de Santana do Parnaíba e para oeste, o contato meridional é feito com as fácies Barueri, Suru e Pedreira Cantareira, com a intrusão truncando a foliação $S_{2}$ dos xistos, como visto no ponto CV 811. A norte, o contato é tectônico com a Unidade Metapelítica da Formação Piragibu. Na região da Estrada do Suru, mostra-se concordante, e os xistos pelíticos superpõem-se aos metassedimentos tufíticos e calciossilicáticas.

Nas proximidades do contato com o Maciço Granitóide Cantareira, os xistos pelíticos encerram intercalações métricas a decamétricas de xistos mais arenosos e leitos decimétricos de metacálcio-pelitos alterados ocráceos. Para sul, esses últimos litotipos transicionam para a unidade metavulcanoclástica.

Nas fazendas Itayhe e Tamboré, os xistos podem estar milonitizados e exibir bandeamento tectônico com feições anastomosadas. Alternammse lenticularizações esbranquiçadas com até 2,0 mm de espessura contendo quartzo muito recristalizado, e filmes submilimétricos portando muscovita com biotita como acessório subordinado.

Estão presentes leitos grafitosos cinzas a cinza-escuros e, localmente, ocorrem pacotes de espessura subdecamétrica de xistos grafitosos laminados portando leitos milimétricos cinza-claros con 
quartzo essencial e grafita subordinada, e outros cinza-escuros com grafita abundante, como no afloramento do ponto BT 722. Subordinadamente, observam-se intercalações de alguns decímetros de espessura de metassedimentos tufíticos maciços.

A SW do Morro do Polvilho observam-se metapelitos formados por xistos finos a muito finos que tendem a ser mais pobres em quartzo, sendo observados quase sempre alterados e avermelhados ou vinho-escuros, como nos afloramentos dos pontos BT 580 e BT 691 e arredores. Os litotipos são muito foliados ou milonitizados, têm um forte bandeamento composicional, e também podem apresentar biotita porfiroblástica, além de andaluzita rara.

Tornam-se frequientes as interdigitações de metassedimentos tufíticos argilosos vermelho-escuros, ou maciços e variegados, sugerindo influência de atividade vulcanoclástica com aporte de material mais fino e mais distante do centro vulcânico. São os mesmos xistos finos identificados para o topo da unidade metavulcanoclástica, e que ocorrem associados aos metassedimentos tufíticos.

\subsubsection{Unidade de Formação Ferrífera (MPSIppff)}

$\mathrm{Na}$ área ocorrem diversos corpos não mapeáveis, ou delgados leitos, de metachert ferruginoso e de formações ferríferas com hematita e magnetita, geralmente intercalados nos metassedimentos tufíticos ou associados às metavulcânicas.

Uma ocorrência desses litotipos foi descrita por KNECHT (1944a) no bairro Várzea do Souza, onde um corpo de rocha magnetítica parcialmente hematitizada está situado sobre epídoto-hornblenda xisto e capeado por xisto grafitoso com pirita disseminada.

Uma faixa com abundantes leitos de metachert e ferríferos foi delimitada no mapa geológico, situada na porção central da área, a nordeste do bairro mencionado, constituindo esta unidade. Possui largura máxima em planta menor que 100 metros, e tem comprimento ao redor de 1.500 metros.

A unidade é capeada por xistos grafitosos ou pelíticos e está superposta a xistos pelíticos com leitos de metachert de espessura decimétrica até métrica. Em direção ao topo, as intercalações de xisto grafitoso tornam-se mais freqüentes e os corpos tornam-se lenticulares, ocorrendo leitos quartzosos friáveis, de granulação fina, com veios de quartzo associados ricos em hematita e em cavidades com formas que sugerem sulfetos lixiviados, incrustadas por material argiloso amarelo a ocráceo. Essa associação é interpretada como leitos de metachert deformados, com remobilização hidrotermal de quartzo e óxidos de ferro.

Em algumas partes, há predomínio de leitos de metachert intercalados em metassedimento tufítico rico em turmalina e com leitos pretos com alguns centímetros de espessura de turmalinito (PP 404). Ocorrem associadas camadas decimétricas de metachert ferruginoso ou não, e de formação ferríferá magnetítica com veios de quartzo com sulfetos alterados e malaquita. Alguns dos leitos de metachert observados no afloramento PP 405 possuem granada rósea, plagioclásio, anfibólio e clorita muito subordinados.

Intercalações de muscovita-biotita xisto com porfiroblastos de estaurolita e granada de cor verde- 
acinzentada e com leitos grafitosos são freqüentes.

\subsubsection{Unidade Metapelítica Grafitosa (MPSIppmg)}

Os metassedimentos grafitosos estão amplamente distribuídos na área, principalmente como intercalações menores nos metassedimentos tufíticos e como lentes sobre as metavulcânicas e metatufos básicos.

Algumas lentes maiores foram individualizadas na parte central da área, alcançando mais de 100 metros de espessura e até 1.500 metros de comprimento. Os corpos situados a sul de Cajamar inserem-se nos xistos pelíticos, assim como algumas das lentes que ocorrem a sul do Granito Tico-Tíco que, apesar. de desmembradas, parecem compor um nível estratigráfico. Um dos corpos, entretanto, está em contato com metabasitos, e lentes menores afloram nas proximidades da Rodovia dos Bandeirantes e junto à Rodovia Anhanguiera, dentre outros, inseridas nos metassedimentos tufíticos.

O contato dos metassedimentos grafitosos com os xistos pelíticos é gradacional e interdigitado. A partir dos corpos rítmicos fortemente grafitosos, a passagem para os metapelitos se dá com a redução do teor de grafita, da espessura e da frequência dos leitos grafitosos até seu completo desaparecimento, geralmente após algumas interposições cíclicas. Com os metabasitos o contato é sempre brusco e concordante.

Os xistos grafitosos são bandados a laminados e apresentam cor cinza-escura a clara, comumente com leitos esbranquiçados, de cor creme ou esverdeada (Prancha 02/foto D). Podem ocorrer intercalações com até 2 metros de espessura de metassedimentos mais siltosos, de cor creme-amarelada, e xistos finos com estaurolita, de até $1,5 \mathrm{~cm}$, e granada em alguns afloramentos, bem como formações ferríferas, turmalina xistos e turmalinitos, indicando ambiente deposicional sob influência de atividades exalativas vulcanogênicas. Quase sempre possuem pirita disseminada, que pode ser muito abundante em alguns leitos.

Em algumas lentes há predomínio de muscovita-grafita xisto, grafita-muscovita xisto e grafitaquartzo-muscovita xisto, finos a médios, cinzas a cinza-claros, com delgados leitos cinza-escuros fortemente grafitosos, como no afloramento PP 542, que correspondem a ambientes um pouco menos redutores, provavelmente marginais aos centros com ambiente mais redutor, que vinculam-se predominantemente aos centros vulcânicos e exalativos submarinos.

Localmente, ocorrem pacotes métricos de metapelito ocremamarelado com leitos subordinados e pontos milimétricos cauliníticos em contato brusco com os metassedimentos grafitosos, sugerindo possível contribuição de metassedimentos manganesíferos na unidade dos metassedimentos grafitosos (PP 40).

Quando intemperizados, preservam a cor cinza, mas alguns leitos vermelho-escuros estão presentes em alguns litotipos. 


\subsubsection{Formação Nhanguçu}

\subsubsection{Unidade dos Metassedimentos Manganesíferos (MPSInhmn)}

Dentre os litotipos da unidade predominam os metassedimentos manganesíferos como os descritos por JULIANI (1993) na região da Serra do Itaberaba. São também freqüentes os metapelitos calcíferos e ocorrem corpos menores de rochas calciossilicáticas, metassedimentos grafitosos, tufíticos e pelíticos. Rochas carbonáticas podem aflorar isoladamente e tornam-se mais comuns nas proximidades da unidade carbonática, enquanto que as rochas metabásicas têm ocorrência restrita.

A unidade está exposta na forma de vários corpos lenticulares. O maior deles, delimitado a SW no mapa geológico, tem direção NW-SE com extensão próxima de $6 \mathrm{~km}$ e espessura máxima ao redor de 750 metros. Os demais geralmente são menos extensos e mais delgados, distribuindo-se na região central da área, a norte do Maciço Granitóide Itaqui, e compreendendo sete corpos lenticulares por vezes dobrados. Dois outros pequenos corpos afloram, respectivamente, $2 \mathrm{~km}$ a S e $3,5 \mathrm{~km}$ a W do Stock Granítico TicoTico.

Excetuando o corpo de direção E-W na região central da área que estende-se por até $7 \mathrm{Km}$, e o que envolve lentes de rochas carbonáticas e atinge até $700 \mathrm{~m}$ de espessura, as demais lentes variam entre 2 e $4 \mathrm{Km}$ de comprimento e têm menos de $350 \mathrm{~m}$ de espessura.

O contato basal da Formação Nhanguçu e da Unidade dos Metassedimentos Manganesíferos ocorre preferencialmente com a unidade metavulcanoclástica, sendo em geral brusco e através de intercalações bem marcadas entre os metassedimentos tufíticos e os metapelitos manganesíferos e calcíferos.

Nas regiões do acesso do Bairro de Polvilho para Cajamar (PP 474 até PP 475), a W do Morro do Polvilho (BT 576), e a SW desse Morro (BT 967), podem ser observadas camadas métricas de metassedimentos tufíticos intercaladas em pacotes métricos a decamétricos de metapelitos calcíferos contendo leitos subordinados até camadas de espessura métrica de metassedimentos manganesíferos.

Localmente, também é sugestivo a ocorrência do contato gradacional entre as unidades. Em um dos afloramentos a SW do Morro do Polvilho (BT 577), ainda na unidade metavulcanoclástica, próximo do contato, são frequientes os leitos de filito manganesífero intercalados nos metassedimentos tufíticos. Contudo, ocorrem bandas e porções esverdeadas ou ocráceas que, quando mais alteradas, exibem percolação de óxidos e hidróxidos de manganês em fraturas ou disseminados, indicando contribuições manganesíferas nos metassedimentos tufíticos.

O contato com a unidade dos xistos pelíticos deve ser brusco, porém não foi confirmado. Em alguns afloramentos, observam-se blocos muito foliados desses xistos junto aos metapelitos calcíferos e nos metassedimentos manganesíferos (SP 669). Na região a SW do mapa, o contato, além de brusco, parece inderdigitado, com frequientes repetições de leitos até decimétricos de xistos róseos ricos em quartzo intercalados aos metassedimentos manganesf́feros e às rochas com contribuição calciossilicática.

Com o Grupo São Roque, o contato, quando verificado, é tectônico. A SE do Morro do Boturuna, 
- contato meridional da unidade ocorre com a unidade metapelítica da Formação Piragibu, sendo observado o truncamento da foliação $S_{2}$ dos metapelitos calcíferos, manganesíferos e grafitosos da Formação Nhanguçu por uma zona de falha de alguns metros muito transposta, e a partir de onde passam a aflorar os metarritmitos do Grupo São Roque (CV 955).

A S do Morro do Polvilho, os metassedimentos manganesíferos (BT 09B) limitam-se, através de uma zona de cisalhamento, com metaconglomerados intensamente transpostos da unidade metarcoseana (BT 09A), sendo que os seixos podem formar pseudobandas com até $1 \mathrm{~m}$ de comprimento e $3 \mathrm{~cm}$ de espessura.

Os metassedimentos manganesíferos estão alterados ou muito decompostos. Raras porções um pouco preservadas são verdes a verde-ocráceas. Variam de laminados até bandados com bandas de poucos centímetros, alternando leitos ocres, ocre-esverdeado-escuros e marrons, ou marrom-acinzentados, e lâminas brancas subcentimétricas. São ricos em sericita e exibem, com frequiência, manchas escuras de aspecto mosqueado e diversos planos marrom-escuros ou pretos, indicando precipitação de óxidos e hidróxidos de manganês, como observado no ponto SA 1092 (Prancha 02/fotos E e F).

Quando mais alterados, seus leitos tornam-se marrom-escuros ou pretos, e não é raro observar nos saprolitos pacotes de poucos centímetros que podem atingir até 1 metro de espessura muito decompostos, com material maciço e terroso de cor pó-de-café. A decomposição produz um colúvio que caracteristicamente contém plaquetas detríticas angulosas com até $2,0 \mathrm{~cm}$ ricas em hidróxidos de manganês, como as descritas por JULIANI (1993), e que são observadas em vários afloramentos.

Os metapelitos calcíferos exibem padrões de alteração que se assemelham aos dos metassedimentos manganesíferos mas, em geral, as cores dos saprolitos são mais claras. Têm uma certa aspereza ao tato, resultado das cavidades deixadas pela lixiviação dos minerais carbonáticos, ou devido à presença destes e, mais alterados, podem ser pulverulentos.

São finos e têm estrutura em lâminas até bandas de poucos centímetros de espessura, com leitos ocres, ocre-esverdeados, ocre-amarelados, cremes e creme-acastanhados. Quando mais alterados, são marrom-claros (Prancha 01/foto G). Exibem forte orientação e compreendem, além de quartzo, clorita e muscovita, carbonatos e, eventualmente, porfiroblastos de até 1,0 mm de magnetita euédrica disseminada. Percolações dendríticas de hidróxidos de manganês em planos preferenciais estão menos presentes.

São freqüentes as intercalações com os metassedimentos manganesíferos, como indicado pela ocorrência de leitos marrom-escuros ou ocre-escuros com forte percolação de manganês, o que sugere que esses litotipos podem representar gradações locais ou misturas de contribuições exalativas em regiões mais distais do centro vulcânico associadas com deposição química de carbonatos.

Intercalações locais de espessura até métrica de rochas carbonáticas e a gradação dessas rochas para os metapelitos calcíferos, como nos afloramentos SP 92 e BT 677, não são raras. Corpos maiores foram individualizados a SW do mapa geológico, nas cercanias e a nordeste de Santana do Parnaíba, e constituem a Unidade Carbonática, descrita adiante. 
Junto aos metassedimentos manganesíferos ocorrem, por vezes, lâminas até bandas de metapelitos grafitosos, que podem formar pacotes de até alguns metros de espessura, como no ponto BT 681 e nas proximidades de Santana do Parnaíba (SP 628), onde estão estruturados em lâminas cinzaescuras de até 4,0 mm e outras brancas e cauliníticas com espessura de até 1,0 mm.

Rochas calciossilicáticas podem formar alternâncias de espessura até decimétrica nos metassedimentos manganesíferos e nos metapelitos calcíferos. Em geral, estão alteradas e intercalam leitos ocre-amarelados, amarelos a esverdeados, e outros maciços, grossos e ocráceos, com manchas escuras dos hidróxidos precipitados, como nos afloramentos dos pontos BT 901 e ST 1092.

Um corpo maior dessas rochas ocorre na lente de Santana do Parnaíba, exibindo efeitos de milonitização (SP 632). A rocha calciossilicática apresenta manchas dendríticas marrons e lâminas entre 2,0 $\mathrm{mm}$ e 8,0 $\mathrm{mm}$ onde alternam-se leitos brancos portando tremolita, escapolita e clinozoizita, e outros verde-claros mais espessos, ricos em escapolita, tremolita, diopsídio, além de plagioclásio, clinozoizita, titanita, flogopita e microclínio. Lâminas subordinadas cinza-claras têm clinopiroxênio e plagioclásio essenciais. Intercalam-se às rochas calciossilicáticas bandas de poucos decímetros de espessura compostas por um xisto esverdeado rico em flogopita.

Alternâncias de metassedimentos tufíticos são comuns, e se destacam nos pacotes mais espessos de pelitos manganesíferos marcando leitos subordinados vinho-avermelhados ou vinho-arroxeados, como nos pontos TT 536 e BT 967 , dentre outros. Localmente, podem constituir leitos maciços vinho-claros com até $5,0 \mathrm{~cm}$ de espessura.

Metapelitos com contribuições de sedimentos tufíticos, como os das unidades metavulcanoclástica e dos xistos pelíticos, podem constituir delgados leitos alterados de poucos centímetros, arroxeados ou róseos, intercalados aos metassedimentos manganesíferos e, por vezes, associados com metapelitos grafitosos (CV 955, BT 964). Localmente, têm granulação média, forte foliação, são sedosos e ricos em clorita, como nos pontos SP 658A, SP 658B.

Pacotes com até 4 metros de espessura de xistos finos verdes pouco alterados e com aspecto fosco são descritos em meio aos metassedimentos manganesíferos no afloramento BT 576, onde também aflora, na drenagem, um corpo de rocha metabásica de estrutura maciça. Esses xistos são semelhantes aos metapelitos intercalados aos metassedimentos tufíticos que ocorrem dezenas de metros a norte, na unidade metavulcanoclástica, caracterizados em lâmina delgada como um quartzo-biotita-muscovita xisto com turmalina.

A WSW do Morro do Polvilho, no afloramento BT 99, as rochas metabásicas da unidade dos metassedimentos manganesíferos constituem um anfibólio xisto com planos de percolação de hidróxidos de manganês. A região, milonitizada, marca o contato tectônico da Formação Nhanguçu com a Unidade Metarcoseana do Grupo São Roque.

\subsubsection{Unidade Metacarbonática (MPSInhed)}

As rochas carbonáticas compreendem o topo da Formação Nhanguçu, ocorrendo superpostas aos 
metassedimentos manganesíferos e aos metapelitos calcíferos,

A NE de Santana do Parnaíba, passam a ser frequientes as intercalações de metassedimentos manganesíferos e de metapelitos calcíferos nos metassedimentos tufíticos, como ocorre no afloramento do ponto SP 591. Na continuidade do perfil para nordeste, esses litotipos passam a predominar, exibindo metassedimentos tufíticos subordinados, e intercalam-se nos metapelitos calcíferos leitos subdecimétricos de rochas carbonáticas que, localmente, apresentam, no topo, deposição dos metapelitos calcíferos em contato brusco.

Tanto a norte (SP 484) como a sul (SP 585, SP 586), devido, possivelmente, a alternâncias entre os litotipos ou a dobras, afloram corpos métricos de rochas calcáreas, os metapelitos calcíferos tornam-se mais raros e os litotipos básicos desaparecem, indicando a deposição das rochas carbonáticas em direção e no topo da Formação Nhanguçu.

Em geral, os corpos da unidade encontram-se individualizados no interior da unidade dos metassedimentos manganesíferos. O mais espesso ocorre na porção SW do mapa geológico, na região da Mina Santa Rita (SA 917), apresentando cerca de 1250 metros de extensão e até 350 metros de espessura. Outros doze corpos de dimensóes menores afloram nas cercanias de Santana do Parnába e, cerca de $3 \mathrm{~km}$ a NE, constituem oito lentes com até 175 metros de espessura que se prolongam por 250 até 750 metros. Na região SE da área, duas ocorrências, com 30 e 50 metros de espessura, estão expostas na Rodovia dos Bandeirantes imbricadas em metabasitos do corpo anfibolítico do Jaraguá.

Na região central da área, as rochas carbonáticas ocorrem como blocos frescos de até $4 \mathrm{~m}$ de diâmetro intercalados aos pacotes mais extensos e alterados dos metapelitos calcíferos e dos metassedimentos manganesíferos. Podem formar afloramentos de 25 metros de extensão com até 10 metros de altura e, eventualmente, sustentam encostas de 50 metros por 25 metros de altura, como no ponto SP 648. Nessa região, predominam os calcários dolomíticos (SP 585, SP 664), mas ocorrem também os litotipos calcíticos (SP 586, SP 647).

São laminados a bandados, com bandas de até $3,0 \mathrm{~cm}$, e a granulação é fina a localmente média, com cristais de carbonatos atingindo $3,0 \mathrm{~mm}$. Por vezes, têm leitos difusos e descontínuos devido às diferenças composicionais, texturais e granulométricas, que produzem altemâncias de tons e cores, e que podem ser ressaltados pela lixiviação diferenciada.

Excepcionalmente, nos afloramentos maiores, as bandas podem atingir até $30 \mathrm{~cm}$, e exibem granulação muito fina, textura granoblástica e aspecto maciço, mas ainda são recuperadas algumas laminações internas ao redor de $1,0 \mathrm{~mm}$ de espessura, o que parece indicar apenas uma recristalização mais intensa sobre essas rochas, que oblitera as estruturas sedimentares.

Venulações brancas de poucos milímetros ou fraturas preenchidas com remobilização e precipitaç̃̃o de calcita são comuns nos litotipos dolomíticos e calcíticos. Contudo, em algumas rochas as venulações não efervescem ao ataque do ácido clorídrico, sugerindo composição bastante pobre em $\mathrm{CaO}$.

As rochas carbonáticas variam de cinza-claras até escuras e, localmente, são pretas, devido à 
grafita associada, ou cinzanesverdeadas quando têm minerais micáceos subordinados. Não são raros os leitos brancos. Em grau incipiente de alteração intempérica são marrom-ocráceas; se mais decompostas têm aspecto áspero ou pulverulento e cor marrom-escura.

Algumas análises petrográficas efetuadas nos corpos centrais indicam a presença de rochas carbonáticas quase puras, com o quartzo atingindo apenas $1 \%$ e os demais constituintes ocorrendo como traços. Em outras, os constituintes carbonáticos variam entre $70 \%$ e $80 \%$, o quartzo ocorre como grãos finos mas também constitui grânulos e pequenos seixos que, somados, ocupam entre $15 \%$ e $20 \%$ do volume da rocha, enquanto que a muscovita subordinada pode atingir localmente $10 \%$. Como acessórios acidentais ou traços ocorrem flogopita-biotita, clorita, grafita, pirita e, possivelmente, rutilo.

A pirita ocorre disseminada ou concentra em certas porções. Com freqüência, está limonitizada. Os cristais maiores podem atingir $3,0 \mathrm{~mm}$. Caracteristicamente, precipita em fraturas, em regiões cisalhadas, ou em venulações associada à calcita, sendo também identificada pela precipitação de sulfatos amarelados ao seu redor, como no ponto SP 648.

Os litotipos carbonáticos da região central têm uma clivagem de crenulação ou de fratura que ondula o bandeamento, muitas vezes de baixo mergulho ou suborizontal, gerando dobras espaçadas e abertas. Ao penetrar nos metapelitos calcíferos e nos metassedimentos manganesíferos associados, essa estrutura transforma-se em uma foliação de transposição de alto mergulho.

Localmente, estruturas muito delgadas representando possíveis laminações ou finas venulações estão dobradas intrafolialmente, o que sugere que o bandeamento descrito acima representa a foliação $S_{2}$ paralela ao acamamento original, que posteriormente foi ondulado pela clivagem $S_{3}$. Essa clivagem pode evoluir para uma foliação de transposição que oblitera o bandeamento.

Os corpos que ocorrem na Rodovia dos Bandeirantes são lenticulares e os contatos, quando observados, sẫo tectônicos e ocorrem com rochas metabásicas milonitizadas. A lente meridional apresenta três intercalações de 4 a 5 metros de espessura entre porções decompostas.

Nessas intercalações, também são comuns os litotipos calcíticos maciços ou com leitos difusos brancos e cinza-claros ricos em calcita. Quando laminados a bandados, exibem porções castanhas flogopíticas, e outras cinza-médias a escuras com mineral opaco disseminado (Prancha 02/foto G). A granulação varia de fina a média, mas podem ocorrer tipos grossos.

Nas lâminas analisadas, tremolita é o mineral comum após os carbonatos, variando de $25 \%$ a 40 $\%$ do volume da rocha, sendo rotineiros os porfiroblastos fibrorradiados. Cristais de tremolita associados às venulações tardias subparalelas à foliação milonítica podem atingir até $1,0 \mathrm{~cm}$. Em alguns leitos de granulação mais fina o quartzo é um acessório raro, enquanto que, ocasionalmente, observam-se níveis ricos em pirita e calcopirita/bornita, e cristais muito finos, aparentemente de rutilo.

$\mathrm{Na}$ análise de uma amostra da região SW, os carbonatos ocupam mais de $90 \%$ do volume da rocha, o quartzo atinge, em alguns níveis, até $5 \%$, por vezes como grãos maiores arreclondados, e a biotita é um acessório mais raro. Clorita, muscovita, pirita, turmalina e titanita são traços. 


\subsubsection{Formação Pirucaia}

\subsubsection{Unidade dos Xistos Quartzosos (MPSIpcxq)}

São comuns na unidade os litotipos de tendência metapsamítica, que estão representados preferencialmente por muscovita-biotita-quartzo xistos, muscovita-biotita quartzitos e xistos quartzosos. O último litotipo predomina, sendo assim denominado quando o conteúdo de quartzo ocupa entre 60 e 80 $\%$ do volume da rocha.

A unidade está exposta ao redor do Stock Granítico Tico-Tico como corpos lenticulares subordinados à unidade dos xistos pelíticos. Esses corpos tornam-se mais espessos na região NE, atingindo até 1000 metros de espessura e $7,5 \mathrm{~km}$ de comprimento. Por sofrerem menos os efeitos da erosão que os metapelitos, sustentam as elevações intermediárias, como pode ser observado no perfil entre os pontos TT 113 e TT $881 \mathrm{~B}$. Algumas lentes delgadas foram delimitadas a partir da identificação, nos foto-pares, do padrão de relevo ressaltado, tendo menos de 100 metros de espessura e até $1 \mathrm{~km}$ de extensão.

O contato basal da Unidade dos Xistos Quartzosos é feito com os xistos pelíticos da Formação Morro da Pedra Preta, como pode ser observado nas rodovias Anhangüera (PP 528 até PP 530) e dos Bandeirantes (PJ 112 até PJ 1141). Nestes perfis afloram extensos pacotes de xistos pelíticos, que passam a apresentar intercalações cada vez mais frequientes de leitos centimétricos até bancos métricos de muscovita-biotitanquartzo xistos, onde são observadas passagens gradacionais que se caracterizam pelo aumento do conteúdo de quartzo.

Entre os muscovita-biotita-quartzo xistos tornam-se freqüentes as camadas e bancos subordinados de xistos quartzosos e de muscovita-biotita quartzitos que apresentam, em geral, contato brusco com os bancos mais pelíticos. Os metapsamitos passam a predominar por algumas dezenas ou centenas de metros até, novamente, se tornarem raros ou desaparecerem junto aos metapelitos.

Quando frescos, os metapsamitos são cinzas a cinza-esverdeados, enquanto que alterados tomamse esverdeados, e são vinho-claros ou avermelhados quando o intemperismo foi mais intenso. Em geral, os litotipos são finos a raramente médios, e têm estrutura maciça. Exibem, eventualmente, uma incipiente orientação.

Nos xistos quartzosos e nos muscovita-biotita quartzitos, o quartzo ocupa entre 60 e $90 \%$, sendo que grãos maiores e grânulos do mineral são observados com certa frequiência dispersos na matriz. A biotita varia de 10 até $35 \%$, enquanto que a muscovita pode ser traço ou atingir $10 \%$ do volume da rocha e, em rochas com foliação marcante, compreende até $25 \%$.

Como acessórios subordinados e traços, foram identificados turmalina, zircão, agulhas de fibrolita, e minerais opacos, ora caracterizados como magnetita, ora ocorrendo como finas inclusões não identificadas nos porfiroblastos. Clorita é ocasional. A granada, alterada e vermelha, é mais comum que nos xistos pelíticos, exibindo até $3,0 \mathrm{~mm}$ e atingindo até $3 \%$. 
Porfiroblastos de fibrolita com até 4,0 mm têm a forma externa amendoada, sendo mais comuns nos tipos micáceos intercalados mas podendo ocorrer também nos tipos arenosos. A estaurolita em geral é rara, mas pode tornar-se um porfiroblasto comum, como no ponto PJ 73. Quando poiquiloblástica, é frequiente estar parcial ou totalmente retrometamorfizada para agregados porfiroblásticos de muscovita, como nos afloramentos TT 948 e TTT 113.

Raros cristais de cianita muito finos ocorrem nos xistos quartzosos, sendo observados apenas na análise petrográfica. Em outras lâminas, parece estar presente silimanita prismática em parte transformada para fibrolita. A presença de agulhas de fibrolita crescendo sobre agregados granoblásticos sugere a presença de cristais de cordierita. Outros agregados granoblásticos semelhantes, aos quais também se associam agulhas de fibrolita, consistem de cristais de quartzo.

Os xistos quartzosos podem apresentar uma foliação milonítica pouco desenvolvida, com os minerais micáceos amoldando-se ao redor dos gxãos e grânulos dispersos de quartzo. Essa foliação tornase mais acentuada quando os xistos quartzosos estão subordinados entre bancos mais espessos de xistos pelíticos também milonitizados, como pode ser visto no afloramento do ponto PP 489.

Veios de quartzo de espessura até decimétrica são freqüentes nos litotipos mais arenosos, apresentando alguns metros de extensão. Podem estar paralelizados à foliação $S_{2} / S_{m}$ ou ser transpostos por essa estrutura, como no afloramento do ponto PP 472. Apófises pegmatóides de composição granítica podem ter até $1 \mathrm{~m}$ de espessura nas mediações do Stock Granítico do Tico-Tico, e cortam a foliação $S_{2}$, como no ponto PP 537.

Os xistos pelíticos intercalados, porfiroblásticos ou não, como os descritos na Formação Morro da Pedra Preta, também exibem uma forte foliação $S_{2}$, que comumente é milonítica. Não raro, estão ondulados por uma clivagem de crenulação $S_{3}$ que pode, localmente, transpor a foliação prévia.

Xistos conglomeráticos oligomíticos, como os que foram identificados nas unidades metavulcanoclástica e dos xistos pelíticos, também ocorrem nos xistos quartzosos na Rodovia dos Bandeirantes, nos afloramentos dos pontos PJ 112 e PJ 1141. Constituem raras intercalações de espessura até métrica exibindo matriz arenosa ou com forte contribuição pelítica. Em ambos os casos contêm, essencialmente, seixos de quartzo-de-veio angulosos a subarredondados que podem atingir até $2,0 \mathrm{~cm}$.

Nos arredores do Parque Anhangïera (PJ 944), os pacotes mais arenosos associados aos xistos quartzosos estão milonitizados. Porém, nas porções preservadas, observam-se níveis conglomeráticos de grânulos e seixos de quartzo subarredondados com até 5,0 mm que ocorrem dispersos (Prancha 02/foto H). Nessa região também ocorrem raros leitos de metassedimentos tufíticos de espessura subdecimétrica associados aos xistos pelíticos.

Considerando as freqüientes interposições de xistos pelíticos na Unidade dos Xistos Quartzosos, e a ocorrência de quartzitos puros, xistos conglomeráticos e metassedimentos tufíticos apenas como raros leitos, existe uma variação deposicional em relação à Formação Pirucaia da região da Serra do Itaberaba onde, segundo JULIANI (1993), predominam quartzitos quase puros em contatos locais gradacionais a 
relativamente bruscos com metassedimentos quartzosos, e que têm passagem por granodecrescência para metassiltitos com contribuição pelítica.

A Formação Pirucaia pode ser correlacionada com os xistos quartzosos descritos por DANTAS $(1990,1992)$ no topo da unidade inferior do Grupo São Roque. Contudo, não se observam intercalações de rochas calciossilicáticas e de metabásicas, e as ocorrências de filitos descritas pelo autor parecem representar intercalações tectônicas, como ocorre na porção NE do mapa geológico, onde existem metarritmitos da Formação Estrada dos Romeiros imbricados nos xistos pelíticos do Grupo Serra do ltaberaba.

\subsection{GRUPO SÃO ROQUE}

\subsubsection{Formação Morro Doce}

\subsubsection{Unidade Metarcoseana (NPSRmdac)}

A unidade aflora principalmente nos arredores do Morro Doce e da Fazenda Itayhe, onde constitui um extenso corpo em contato transicional ou tectônico com a unidade metaconglomerática, com os metarritmitos da Formação Estrada dos Romeiros, com os metarenitos feldspáticos da Formação Boturuna e com litotipos do Grupo Serra do Itaberaba, aos quais está superposta através de uma zona de empurrão que aflora na meia encosta do Morro Doce.

O corpo tem orientação NNW e inflexiona-se para W na localidade de Maria Trindade, adelgaçando-se nas proximidades do Morro do Polvilho. Nesse local, os litotipos apresentam forte foliação milonítica de alto ângulo e estão lenticularizados e encaixados tectonicamente nas unidades metavulcanoclástica (NPSIppmvc) e dos metassedimentos manganesíferos (NPSInhmn). Mais a oeste, afloram descontinuamente até a porção central da área, formando corpos geralmente intercalados nos metarenitos feldspáticos, que gradam para quartzitos com leitos de ardósia subordinados da Unidade Metarenítica Feldspática da Formação Boturuna.

Esse corpo tem continuidade para SSE da área, onde está em contato tectônico com os maciços granitóides Itaqui, através da Zona de Cisalhamento Vila Menk, e Cantareira, por cavalgamentos/falhas de empurrão. A leste do Pico do Jaraguá, a unidade associa-se aos metarenitos feldspáticos com lentes de quartzito.

O principal litotipo que compóe esta unidade foi definido como metarcóseo devido ao conteúdo de feldspatos, como relíquias de clastos e como constituintes da matriz, atingir no mínimo $20 \%$ do volume da rocha. A granulação é geralmente média, mas podem ocorrer termos finos e grossos, por vezes conglomeráticos, com clastos do tamanho de grânulos ou de seixos de até $6,0 \mathrm{~mm}$ de comprimento. Gradações para subarcóseos são comuns.

Em geral, litotipos semelhantes têm sido descritos como metagrauvacas (COUTINHO 1955, CARNEIRO 1983, BERGMANN 1988) devido ao conteúdo de micas superior a $15 \%$ do volume da rocha. Constituem quartzo-biotita xistos finos, miloníticos ou não, com grânulos de quartzo e de 
feldspato, que ocorrem como corpos menores lenticulares muito subordinados e intercalados principalmente nos metarcóseos, representando deposições locais mais pelíticas na Unidade Metarcoseana, como pode ser observado a SSE do Morro Doce (VH 919A).

Quando frescos, os metarcóseos têm cor cinza a cinza-esverdeada, com fragmentos de feldspatos brancos ou levemente amarelados, predominando feldspato potássico sobre o plagioclásio. Alterados, apresentam cor vinho-escura a avermelhada, quando possuem maior teor de biotita, ou exibem cor amarelo-acastanhada, amarelo-esverdeada ou vermelho-clara, quando tendem a composições subarcoseanas ou quando são pobres em biotita.

A estrutura comumente é maciça ou incipientemente orientada, mas não faltam tipos bandados, com leitos mais síticos ou pelíticos, ou com forte xistosidade, além de protomiloníticos e miloníticos. Uma clivagem de crenulação superposta pode ser localmente observada.

As texturas observadas no metarcóseo são granoblásticas a lepidogranoblásticas porfiroclásticas, devido à presença dos feldspatos mais grossos. Textura lepidoblástica ocorre em delgados e raros leitos com composição mais micácea ou em rochas blastomiloníticas.

São compostos por quartzo, feldspato potássico, plagioclásio, biotita e muscovita, além de magnetita, epídoto, clinozoizita, carbonato, alanita, apatita, zircão, titanita, leucoxênio, rutilo, turmalina e clorita. Grânulos de quartzo e quartzito, e raros de granitóides, completam os fragmentos clásticos. Os leitos mais pelíticos/grauváquicos são compostos por quartzo-biotita xisto fino com grânulos de quartzo e de feldspato.

Destacam-se também freqüentes intercalações com espessura métrica de metaconglomerado fino, matriz suportado, como nos afloramentos BT 09A e VH 66, bem como de metarenito feldspático, de metarenito fino, como no ponto BT 104 (Prancha 03/foto A), e de filito.

No Morro do Polvilho, CARNEIRO (1983) e CARNEIRO et al. (1984b) descreveram intercalações de metarriodacito subvulcânico, com fenocristais (ou fenoblastos) de plagioclásio e de feldspato potássico imersos em matriz afanítica ou fina, composta por quartzo, feldspato, biotita e minerais opacos. VAN SCHMUS et al. (1986) admitiram caráter vulcânico para este corpo, que estaria intercalado na sequiência vulcano-sedimentar basal do Grupo São Roque, e grãos de zircão desse litotipo resultaram em idade U.Pb de $1790 \pm 14 \mathrm{Ma}$, interpretada como sendo da cristalização do magma, o que implicaria que a deposição do Grupo São Roque teria sido iniciada ao redor de $1,8 \mathrm{Ga}$. O metamorfismo teria ocorrido provavelmente ao redor de 1,2 Ga, e as idades $\mathrm{Rb}$-Sr indicaram rejuvenescimento ao redor de $550 \mathrm{Ma}$. Dessa forma, não teria havido deposição de sedimentos do Grupo São Roque no Brasiliano.

Mapeamento detalhado feito por JULIANI et al. (1997a) na região do Morro do Polvilho evidenciou passagens graduais entre o suposto metarriodacito e corpos de metaconglomerado semelhantes aos que afloram no Morro Doce, além de contatos por cisalhamento com litotipos do Grupo Serra do Itaberaba. Também foram observadas naquelas rochas estruturas sedimentares e fragmentos clásticos idênticos aos encontrados nos metarcóseos do Morro Doce, e gradação para quartzito feldspático. Os 
estudos petrográficos revelaram grăos de zircão de vários tipos, muitas vezes arredondados, e fragmentos de rochas graníticas, indicando que o "metarriodacito" é, em verdade, um metarcóseo com intercalações de metaconglomerado. Dessa forma, por serem detríticos, os cristais de zircão indicam a idade máxima da sedimentação do Grupo São Roque e não o início da formação do Grupo Serra do Itaberaba, como interpretado pelos autores supracitados.

\subsubsection{Unidade Metaconglomerática (NPSRmdcg)}

As principais ocorrências desta unidade afloram na encosta leste do Morro Doce, onde constituem pelo menos três lentes principais intercaladas nos metarcóseos e quartzitos feldspáticos (JULIANI 1992). Essas apresentam dezenas de metros de espessura, adelgaçando-se em direção ao topo da seqüência e no sentido noroeste, até alcançarem pouco mais de um metro no Morro do Polvilho. Nos corpos de metaconglomerado, intercalam-se camadas menores de metarcóseo, variando de decímetros a mais de uma dezena de metros de espessura e, mais raramente, em direção ao topo do Morro Doce, observam-se pacotes de metarenitos, feldspáticos ou não, e blocos de filito sericítico vinho-claro no cume.

O conjunto caracteriza uma gradação rítmica dos litotipos da Formação Morro Doce, que constituem a base do pacote sedimentar, para rochas mais finas das formações Boturuna e Piragibu, no topo (COUTINHO 1968a, 1972; JULIANI 1992).

Nos afloramentos e nos testemunhos de sondagem das regiões do Morro Doce e da Fazenda Itayhe, os metaconglomerados apresentam-se comumente milonitizados (PJ 696) em baixo ângulo, comumente subconcordante com o acamamento, devido a zonas de empurrão com movimentação para leste.

Localmente, ocorrem clastos de epidotito, que podem predominar em alguns trechos e em testemunhos de sondagens, compondo, aparentemente uma quarta lente, a mais inferior de todas, onde são frequientes fragmentos de rochas básicas semelhantes às do Grupo Serra do Itaberaba e zonas com forte carbonatização. Seixos de rochas metavulcânicas de composição tendendo à andesítica não são raros nesses testemunhos de sondagem, e contêm, na matriz, uma quantidade relativamente maior de carbonato e epídoto. Esta lente mais basal parece indicar que a área-fonte dos metaconglomerados é parcialmente composta pela sequiência vulcano-sedimentar do Grupo Serra do Itaberaba.

Frequientemente, o metaconglomerado apresenta intenso estiramento dos seixos e calhaus, principalmente quando intercalado aos metarcóseos, onde se observa uma relação entre os eixos desses seixos ao redor de 20 para 1 , notadamente no Morro do Polvilho.

Os metaconglomerados também afloram no trevo do $\mathrm{km} 18$ da Rodovia Anhangüera (VH 14), ocorrência esta estudada por COUTINHO (1955), COUTINHO \& TAKEDA (1955), CARNEIRO (1983) e TASSINARI et al. (1986). Algumas lentes menores afloram intercaladas nos metarcóseos das proximidades do contato do Maciço Granitóide Itaqui, onde estão fortemente milonitizadas pela Zona de Cisalhamento Vila Menk.

A unidade é composta predominantemente por metaconglomerado polimítico geralmente bem 
foliado e frequientemente milonítico, com a matriz micácea orientada e clastos alongados e tendendo a elípticos (Prancha 03/foto B). Na base da unidade, os metaconglomerados têm proporçöes semelhantes entre a matriz e seus clastos, que podem atingir $30 \mathrm{~cm}$ e, em direção ao topo, predominam litotipos matriz-suportados com fragmentos clásticos menores e cada vez menos comuns.

Quando frescos, apresentam matriz cinza-escura composta por quartzo, feldspato potássico, plagioclásio, biotita, magnetita, muscovita e epídoto. Frequientemente, ocorrem ainda alanita, apatita, zircão, rutilo, clinozoizita, clorita, carbonato e titanita.

Os fragmentos clásticos são brancos, cremes ou cinza-esbranquiçados, predominando os de granitóides, miloníticos ou não, de pegmatito, ambos com bom arredondamento, e os de quartzito e de quartzo-de-veio, mais angulosos, e feldspatos subcentimétricos. Clastos de xisto, de metabásica e de epidotito são mais raros.

Os metaconglomerados alterados são avermelhados ou róseo-claros, destacando-se em relevo na matriz os seixos mais resistentes à alteração, principalmente os de quartzo-de-veio, de quartzito e de granitóides. Nas variações do litotipo, onde a matriz biotítica predomina, são vermelho escuros.

No Morro Doce, alguns calhaus mostram-se com faces planas o que, juntamente com reduzidíssima contribuição de metapelitos, sugere possível origem por retrabalhamento de depósitos glaciais em leques aluviais (JULIANI, comunicação verbal).

\subsubsection{Formação Pirapora do Bom Jesus}

BERGMANN (1988) denominou de Formação Pirapora a unidade basal do Grupo São Roque, composta por metabasito com pillow-lavas e anfibolitos bandados representando possíveis metapiroclásticas básicas. Comporia ainda a formação um Membro Carbonático, com cálcio-filitos e metadolomitos, onde recifes carbonáticos com bioermas estromatolíticas teriam exposições locais, além de possíveis rochas ultrabásicas, prováveis metatufos com tufos de cristais associados, e corpos métricos de metarcóseos, metagrauvacas e metapelitos intercalados nos anfibolitos bandados.

Esta formação foi renomeada por JULIANI \& BELJAVSKIS (1995) como Pirapora do Bom Jesus por ser esta a toponímia e devido à existência de outra unidade litoestratigráfica com a mesma denominação.

O Membro Carbonático restringe-se, neste trabalho, aos corpos de rochas carbonáticas e de cálcio-filitos associados ao corpo metabasítico de Pirapora do Bom Jesus. Os demais corpos que afloram das proximidades de Pirapora do Bom Jesus até a região de Cajamar-Jordanésia foram excluídos desta formação por não estarem em contato ou associados a rochas metabásicas, e compõem, assim, parte da Formação Estrada dos Romeiros.

Desta forma, a Formação Pirapora do Bom Jesus passa a ser constituída pelas unidades Metabasítica, Metacálcio-pelítica, Metacarbonática e Metavulcanoclástica, descritas a seguir:

\subsubsection{Unidade Metabasítica (NPSRpjmb)}

Vários corpos da unidade foram cartografados, podendo alcançar cerca de $10 \mathrm{~km}$ de comprimento 
e espessura entre 1000-1500 metros. Apresentam contatos gradacionais com metatufos e concordantes com os metapsamitos e metacálcio-pelitos superpostos. Filitos manganesíferos e com leitos centimétricos de rochas carbonáticas estão frequientemente associados aos metatufos.

Contatos tectônicos com os metassedimentos, através de zonas de transcorrência, ocorrem na borda meridional do corpo maior onde, por vezes, formam extensas zonas de milonitos.

No corpo de Pirapora do Bom Jesus, no topo, as metavulcânicas estão em contato em posição normal com metacálcio-pelitos com bancos métricos de metatufos básicos ou com filitos manganesíferos. Mais raramente, estão capeadas por metapsamitos ou por metassedimentos laminados alterados, com leitos brancos e ocres, ricos em quartzo e, possivelmente, sulfetos, que gradam para filitos manganesíferos.

A unidade é composta por metabasitos predominantemente maciços, localmente foliados e miloníticos, de cor verde-clara a escura quando frescos. Os tons mais claros, com porções esbranquiçadas, são mais comuns em rochas com onde o clinopiroxênio é um constituinte importante, e os mais escuros são devidos ao enriquecimento em clorita.

Em campo, os metabasitos do Grupo São Roque são distintos daqueles do Grupo Serra do Itaberaba, tanto pelas cores das rochas frescas e alteradas quanto pelas estruturas e intensidade da deformação. Se incipientemente intemperizados, os metabasitos exibem cores ocre-esverdeadas a ocreamareladas, como se observa nos arredores de Pirapora do Bom Jesus (BJ 1217 a BJ 1221), e são comuns fraturas preenchidas por óxidos e hidróxidos de manganês. Às vezes, destacam-se pseudomorfos de cristais milimétricos de plagioclásio transformados em caulim. Com a intensificação da alteração, tomamse amarelos, vermetho-escuros ou vinhos, e argilosos.

A ocorrência de pillow-lavas no corpo metabasítico de Pirapora do Bom Jesus é comum (LAZZARI 1987), como pôde ser visto em perfil realizado na Estrada dos Romeiros (BJ 1217 a RP 1222), e em alguns afloramentos isolados, como no RP 1225 (Prancha 03/foto C). Essas estruturas também foram descritas na Estrada dos Romeiros por BERGMANN (1988), sendo observadas à cerca de $4 \mathrm{~km}$ a NW de Santana do Parnaíba, no afloramento CV 1268.

O diâmetro na maioria das estruturas almofadadas encontra-se entre 30 e $50 \mathrm{~cm}$. Às vezes, estão delimitadas nas bordas por uma estreita faixa, com 1 a $3 \mathrm{~cm}$ de espessura, de rocha alterada muito fina e argilosa, marrom-avermelhada, considerada como possível material interpillows, com vesículas alongadas em arranjo radiado que acompanham as bordas das estruturas (FIGUEIREDO et al. 1982; LAZZARI 1987), indicando efusões em águas relativamente rasas.

Em alguns afloramentos próximos a Pirapora do Bom Jesus, a xistosidade e milonitização deformam e obliteram as estruturas mas, em porções mais preservadas, pode-se observar a granulação mais grossa no centro das almofadas e bordas muito finas, provavelmente derivadas de rochas mais ticas em vidro vulcânico, assim como o material interpillow. Entre as almofadas, são comuns porções silicificadas, carbonatizadas, cloritizadas e mais enriquecidas em sulfetos. Não raramente, são observados 
afloramentos de rochas com esfoliação esferoidal, dificultando o reconhecimento das pillow-lavas.

Vesículas com formas ovóides e até quase $1 \mathrm{~cm}$ de comprimento, preenchidas com quartzo, carbonato, epídoto, clorita e óxidos de manganês, às vezes em arranjos radiados, estão presentes em alguns afloramentos (p.ex., BJ 1216). Quando muito foliados, esses metabasitos tornam-se enriquecidos em clorita e adquirem aspecto de metaconglomerado fino, mas quase não possuem quartzo na matriz. Comumente, esses litotipos têm corpos de metassedimentos tufíticos ou tufos finos alterados associados.

Nos demais corpos da unidade, as exposições contínuas são mais raras, a alteração supérgena é mais acentuada, e não mais se observam pillow-lavas, sugerindo que os litotipos observados podem, eventualmente, ser derivados do metamorfismo de derrames maciços ou de sills ou diques de rochas básicas.

São muito comuns intercalações de litotipos intensamente alterados, argilosos, variegados a vermelhos ou vinho-escuros, por vezes bandados, interpretados como metavulcanoclásticas básicas, com contribuição de pelitos ou não, como se observa no afloramento do ponto BJ 1218 . Comumente, estão fortemente foliados e preferencialmente em contato com metabasitos com pillow-lavas ou com rochas da Unidade Metacálcio-pelítica (BJ 1219, RP 1227), ou ainda com lentes menores de metacálcio-pelitos, como observado no afloramento do ponto RP 50. Às vezes, contêm intercalações de leitos limoníticos, possivelmente derivados da alteração supérgena de sulfetos (RP 1222). Localmente, formam corpos maiores, compondo a Unidade Metavulcanoclástica (NPSRpjmv).

A sul do km 55 da Estrada dos Romeiros, as intercalações de metatufos básicos de granulação fina com raros corpos menores de filitos laminados e bandados são freqüentes nos metabasitos (RP 1249 a RP 1250). Este corpo deve corresponder às fácies distais do corpo metabasítico com pillow lavas (CV 1268) que a aflora a $N$ de Santana do Parnaíba, o que sugere deposição contemporânea entre os derrames e tufos básicos subaquáticos com os metapelitos da Formação Piragibu.

Na continuidade leste do corpo metabasítico da Vila Lolli, na região do contato entre os metarenitos feldspáticos e os quartzitos da Formação Boturuna (VL 791), ocorre uma lente imbricada com 20 metros de espessura aparente de uma rocha milonitizada alterada ocre-clara, maciça e de granulação média. É composta por clorita magnesiana ( 90\% do volume), possivelmente cromita, flogopita, e biotita subordinada, tratando-se, provavelmente, de um pequeno corpo de rocha metaultrabásica. Na mesma região KNECHT (1950) desreveu minério de ferro e BERGMANN (1988) metaultrabásicas com talco e cromita na porção sul do corpo metabasítico de Pirapora do Bom Jesus.

Nesta mesma região, HASUl et al. (1969) e LAZZARI (1987) descreveram gradações de filito para camadas de itabirito alterado, formados por leitos subcentimétricos de cor castanho-avermelhada a amarelada intercalados com outros com hematita e quartzo.

A textura dos metabasitos em geral é nematoblástica, e varia de equi- a inequigranular. Às vezes, pode ser porfiroblástica ou ainda granonematoblástica, quando a recristalização é mais intensa. Ocasionalmente, podem ser observadas texturas blastofítica e blastoporfirítica macroscopicamente, como 
no ponto VS 154

A granulação é predominantemente média, variando entre 3 e $4 \mathrm{~mm}$, mas não são incomuns amostras de granulação grossa ou fina a muito fina, típica de metabasaltos, e são ricos em minerais do grupo do epídoto e clorita. Raramente apresentam-se mais foliados e com leitos essencialmente cloríticos representando, provavelmente, antigos tufos finos que, em raras amostras, exibem um fino bandeamento.

Em essência, são compostos por actinolita, plagioclásio sódico, epídoto/clinozoizita e clorita e, não raramente, estão presentes relíquias de clinopiroxênio e plagioclásio ígneos, esse comumente saussuritizado. O quartzo geralmente ocorre de modo subordinado, assim como titanita, leucoxênio, ilmenita, titanomagnetita, calcita, biotita, hornblenda, turmalina, sulfetos, apatita e rutilo. Em algumas faixas cisalhadas, próximas aos corpos carbonáticos, foi identificada calcopirita nos metabasitos.

\subsubsection{Unidade Metacálcio-pelítica (NPSRpjcp)}

Em contato com a unidade metabasítica da Formação Pirapora do Bom Jesus ocorrem rochas pelíticas ricas em carbonato, manganês e, possivelmente, em sulfetos, e que por vezes possuem níveis restritos de metachert e de quartzitos finos ferruginosos. Correspondem, em parte, aos cálcio-filitos do Membro Carbonático da Formação Pirapora (BERGMANN 1988).

$\mathrm{Na}$ base da encosta norte do Morro do Boturuna, três pequenas lentes da unidade metacálciopelítica da Formação Pirapora do Bom Jesus estão estiradas entre as unidades quartzítica e metarenítica feldspática da Formação Boturuna, representando, possivelmente, a continuidade dos metacálcio-pelitos que ocorrem associados ao corpo metabasítico da Vila Lolli, que estão, atualmente, desmembrados e enfeixados tectonicamente nessas unidades. Junto às lentes cálcio-pelíticas, foram individualizados corpos de rochas carbonáticas.

Para ENE, em direção a Cajamar, os metacálcio-pelitos apresentam-se intercalados com, e em geral transicionam para, a unidade metarrítmica da Formação Estrada dos Romeiros, constituindo uma outra unidade sobreposta pertencente a essa formação, e que está descrita adiante. Também ocorrem em contato com a unidade metapelítica da Formação Piragibu.

Nos arredores da cidade de Pirapora do Bom Jesus, a unidade metacálcio-pelítica novamente faz contato com o corpo metabasítico da Formação Pirapora do Bom Jesus, delimitando praticamente todo o seu envoltório e margeando pequenas lentes da unidade carbonática. Apresenta contato em posição normal com metassedimentos tufíticos intercalados em um pacote de rochas metabásicas onde estão presentes metatufos básicos da unidade metabasítica, como se observa no afloramento BJ 1219 .

Localmente, grada para filitos com intercalações freqüentes de metassiltitos e metarenitos finos da unidade metarrítmica da Formação Estrada dos Romeiros, como pode ser acompanhado no perfil entre os pontos RP 1227 e RP 1243.

Quando frescos, os metacálcio pelitos são cinza-azulado-claros. Contudo, ocorrem quase sempre alterados, variando de ocre-claros até escuros, com estrutura bandada e/on laminada marcada pelos diversos tons ocráceos. Podem formar bancos mais espessos, tendendo ao maciço, ou se apresentar 
milimetricamente intercalados com filitos sericíticos, filitos grafitosos e leitos carbonáticos. A granulação é fina ou muito fina.

São também ricos em sericita, contêm clorita, e a grafita é um acessório comum, enquanto que o quartzo ocorre como um constituinte secundário. Ocasionalmente, têm porfiroblastos de pirita limonitizados, ou notam-se níveis pulverulentos ocráceos a esverdeados com cristais de pirita milimétricos, o que sugere níveis ticos em sulfetos afetados pela alteração intempérica (BJ 1057). Os cristais de carbonato ocorrem muito alterados e, assim, não efervescem ao ataque do ácido clorídrico.

Por vezes, observam-se intercalações de lâminas marrom-claras ricas em quartzo muito fino e mineral opaco, e outras lâminas ocres com minerais carbonáticos e possivelmente sulfetos estão alteradas.

São muito frequientes nos metacálcio-pelitos as intercalações de metapelito grafitoso, que, de forma geral, constituem pacotes com cerca de 1 metro de espessura que, eventualmente, podem atingir até 5,0 metros, como no afloramento do ponto BJ 1219.

Metapelitos manganesíferos, semelhantes aos caracterizados por JULIANI (1993) e que ocorrem frequientemente na Formação Nhanguçu do Grupo Serra do Itaberaba na região deste trabalho, formam poucas intercalações nos metacálcio-pelitos da Formação Pirapora do Bom Jesus. Litotipos semelhantes foram descritos em trabalhos na região como filito pó-de-café (HACKSPACHER et al. 1986, BERGMANN 1988). Raramente é possível observar níveis cinza-azulados pouco alterados com até 4,0 cm de espessura.

\subsubsection{Unidade Metacarbonática (NPSRpjed)}

As rochas carbonáticas, dolomíticas ou calcíticas desta unidade foram reconhecidas em campo usando como critério o controle pontual, verificando a presença ou ausência de efervescência quando atacadas por ácido clorídrico, razão pela qual a separação desses litotipos não se encontra efetuada no mapa geológico.

HASUI et al. (1976) posicionaram as rochas carbonáticas no topo da Formação Boturuna, encerradas entre filitos. BERGMANN (1988) incluiu essas rochas no Membro Carbonático da Formação Pirapora, base do Grupo São Roque, enquanto que HACKSPACHER et al. (1992a), ao mapearem a Folha Cabreúva, integraram os corpos calcários na Formação Pirapora mas, invertendo a coluna estratigráfica de BERGMANN (1988), colocaram essa formação no topo do Grupo São Roque.

Excetuando o pequeno corpo delimitado a NNE de Pirapora do Bom Jesus, considerado pertencente à Formação Estrada dos Romeiros, foram individualizadas doze lentes no interior dos metacálcio-pelitos que margeiam os corpos metabasíticos Pirapora do Bom Jesus e Vila Lolli e naqueles que estão estirados na base da encosta norte do Morro do Boturuna.

Os poucos corpos carbonáticos observados têm contato em posição normal com metacálciopelitos e com metassedimentos manganesíferos, e esses estão sobrepostos às rochas metabásicas e a metatufos, como pôde ser observado em perfil efetuado na Estrada dos Romeiros e na ligação entre Pirapora do Bom Jesus e Araçarigüama, sendo considerados em posição estratigráfica próxima à base da 
Bacia São Roque, conforme BERGMANN (1988). A autora também reportou a existência de lentes carbonáticas com estruturas estromatolíticas contornando parcialmente os corpos metabasíticos, e sugeriu a ocorrência de recifes calcários biogênicos margeando centros eruptivos.

Algumas lentes foram, em parte, delimitadas com base em trabalhos anteriores (KNECHT 1950, BISTRICHI 1982, BERGMANN 1988) e na observação de feições cársticas obtidas por fotointerpretação. A maior delas aflora nas cercanias da cidade de Pirapora do Bom Jesus, com 175 metros de largura e cerca de 700 metros de extensão.

Nas poucas lavras visitadas na região da Vila Lolli predominam pacotes homogêneos, maciços e brancos, podendo ocorrer variações para tipos cremes. Parecem predominar litotipos preferencialmente dolomíticos. Calcopirita foi identificada localmente no afloramento do ponto VL 52. Próximo do contato com a unidade metabasítica, ocorre malaquita supérgena disseminada (Prancha 03/foto D), possivelmente derivada da alteração de calcopirita, como já descrito por KNECHT (1950).

Nessa região, as rochas cabonáticas podem constituir lentes nas proximidades ou na borda do corpo metabasítico e, ao menos localmente, o contato é tectônico com as rochas carbonáticas e metabásicas, em parte milonitizadas.

\subsubsection{Unidade Metavulcanoclástica (NPSRpjmv)}

A principal ocorrência situa-se a norte do Bairro Várzea do Souza, onde as rochas desta unidade estão em contato gradacional com metabasitos de granulação fina. $O$ corpo é formado por metavulcanoclásticas quase sempre alteradas para materiais muito argilosos, variegados, com tons vermelho-escuros, vinho-escuros, amarelos, ocres, brancos, marrons ou esverdeados, com metabasitos intercalados nas proximidades do contato.

As rochas são mais foliadas que os metabasitos e, às vezes, ainda preservam estrutura bandada. Localmente, ocorrem leitos brancos a amarelados, ou películas de possíveis sulfatos branco-amarelados recobrindo parte dos afloramentos alterados, sugerindo alteração de níveis sulfetados.

Quando frescos (VS 373), têm cor verde-escura, estrutura laminada, e são compostos predominantemente por actinolita, plagioclásio albítico, epídoto e clorita, sem relíquias de texturas ígneas e contêm fragmentos de granulação mais grossa que sugerem tratar-se de basalto recristalizado, além de amigdalas preenchidas por clorita e epidoto. São muito semelhantes aos metatufos básicos ricos em amígdalas descritos por BERGMANN (1988) na mesma região. A granulação, fragmentos observados, mineralogia e a estrutura laminada permitem interpretar esta unidade como formada por metabrecha $\mathrm{e}$ metatufo básico.

Estes litotipos gradam para os metarritmitos da Formação Estrada dos Romeiros, apresentando intercalações com contados bruscos e gradacionais de metapelitos e metarritmitos, e têm contato tectônico com os quartzitos da formação supracitada. 


\subsubsection{Formação Boturuna}

Na definição da Formação Boturuna, HASUI et al. (1976) consideraram-na a unidade inferior do Grupo São Roque, em que ocorreriam intercalações de quartzito em meio a filitos próximo à base. CARNEIRO (1983) descreveu um pacote de metapsamitos impuros provavelmente capeado por quartzitos na base do grupo, nas regiões do Morro Doce e do Pico do Jaraguá.

BERGMANN (1988) situou a Formação Boturuna, na região de Pirapora do Bom Jesus, no topo do Grupo São Roque, individualizando um membro arcoseano, dois vulcânicos e um ortoquartzítico que estaria intercalado e capeado pelos metarcóseos, sugerindo transição entre esses membros. Admitiu a passagem gradacional a partir do membro pelítico da Formação Estrada dos Romeiros, considerada sotoposta, para os metarcóseos. Entretanto, BERGMANN (1991,1992) afirmou que o contato entre os membros pelítico e arcoseano seria por falhamento, sendo a Formação Boturuna considerada uma unidade alóctone.

HACKSPACHER et al. (1992a, b) admitiram, em parte, as definições de BERGMANN (1988), com a Formação Boturuna sobreposta à Formação Estrada dos Romeiros, porém não observaram os membros arcoseano e vulcânicos, mas apenas quartzitos com leitos conglomeráticos locais.

Neste trabalho, pôde ser observado que no Morro do Boturuna, no Pico da Jaraguá e a SSW do Morro Doce o conteúdo de feldspatos detríticos raramente atinge $15 \%$, bem inferior ao que se observa nos litotipos que predominam na região dos morros Doce e do Polvilho, caracterizados como metarcóseos e agrupados na Unidade Metarcoseana da Formação Morro Doce.

Nas primeiras regiões, são freqüentes as possantes lentes de metarenitos feldspáticos, sendo raros e de pequena espessura os corpos de metarcóseos, e nota-se o contato gradacional em posição normal dos metarenitos feldspáticos para os quartzitos, que passam a ocorrer a partir da meia encosta do Pico do Jaraguá, onde compreendem corpos lenticulares delgados que predominam amplamente no Morro do Boturuna, formando um extenso corpo.

A SSW do Morro Doce, os metárcoseos com lentes de metaconglomerados transicionam para os metarenitos feldspáticos, e a mesma situação é observada a $\mathrm{E}$ do Pico do Jaraguá, sugerindo a passagem normal dos litotipos da Formação Morro Doce para os metarenitos feldspáticos e destes para quartzitos, aqui agrupados na Formação Boturuna que, redefinida, passa a ser composta pela Unidade Metarenítica Feldspática e pela Unidade Quartzítica, que apresentam ainda alguns litotipos subordinados ou de ocorrência restrita.

Assim, o pacote de metapsamitos impuros de CARNEIRO (1983), se não forem considerados os litotipos pertencentes ao Grupo Serra do Itaberaba, pode ser desmembrado nas unidades Metaconglomerática e Metarcoseana que compõem a Formação Morro Doce, basal, e que são seguidas pelas unidades Metarenítica Feldspática e Quartzítica da Formação Boturuna, a partir de uma seqüência com passagem normal.

O membro arcoseano descrito por BERGMANN (1988) no Morro do Boturuna parece composto, 
na maioria dos casos, por metarenitos feldspáticos como aqueles da região sudeste da área aqui pesquisada, e que são capeados pelos quartzitos em contato gradacional. Os metarenitos feldspáticos transicionam, na base, para metarritmitos da Formação Estrada dos Romeiros e, a SSW de Pirapora do Bom Jesus, estão em contato brusco e e em posição normal com as unidades metabasítica e metacálciopelítica da Formação Pirapora do Bom Jesus.

Nos perfis efetuados, não foram observados contatos por falha, o que sugere que, nessa região, a deposição dos metarenitos feldspáticos pode ter sido, em parte, contemporânea à dos metarritmitos em ambiente com menor aporte de sedimentos grossos e imaturos, sendo que rapidamente passam a predominar os quartzitos.

Na porção sudeste da área mápeada, a Formação Boturuna estaria depositada em posição mais proximal da área fonte, diretamente sobre a calha da Bacia São Roque, primeiramente entulhada pelos metarcóseos e metaconglomerados, o que estaria de acordo com a presença mais frequiente dos metarenitos feldspáticos com lentes de metarcóseos, enquanto que os quartzitos ocorrem subordinados.

\subsubsection{Unidade Metarenítica Feldspática (NPSRbtaf)}

A unidade aflora a sudeste da área, em contato com o Maciço Granitóide Itaqui, com formas lenticulares que podem atingir quase $2 \mathrm{~km}$ de espessura e até $6 \mathrm{~km}$ de comprimento, e no Pico do Jaraguá, onde forma um corpo com 2,5 km largura por até $4,5 \mathrm{~km}$ de extensão, que pode ser observado em afloramentos na rodovia Anhangüera (VH 128, PJ 548). Esses corpos limitam-se com as unidades metarcoseana e metarrítmica do Grupo São Roque e têm contato tectônico com a unidade metavulcanoclástica do Grupo Serra do Itaberaba.

Na porção oeste da área, a unidade envolve os quartzitos do Morro do Boturuna como extensas lentes com até $10 \mathrm{~km}$ e de direção aproximada $\mathrm{E}_{\sim} \mathrm{W}$, e que atingem cerca de 1200 metros de espessura no Sinclinório de Pirapora do Bom Jesus, onde capeiam a unidade metabasítica.

A partir da represa da Fazenda Itayhe indo para $S$, nota-se a passagem de metarcóseos grossos com níveis conglomeráticos para metarcóseos médios, como ocorre no afloramento do ponto PJ 738 . Continuando o perfil, esses litotipos transicionam para metarenitos feldspáticos mais finos com intercalações de bancos de até $10 \mathrm{~cm}$ de espessura de metarenitos médios, quartzo filito e filito sericítico, como no ponto VH 742.

Os metarenitos feldspáticos passam a predominar amplamente (VH 835) mas, seguindo para W, essas rochas dão lugar para os metarritmitos da Formação Estrada dos Romeiros, como pode ser observado entre os pontos VH 839B e VH 839A, com o metarenito feldspático grosso com grânulos de quartzo passando para um metarritmito com laminações mais arenosas e outras mais micáceas, o litotipo mais comum para norte.

Este perfil demonstra a passagem gradacional e interdigitada dos metarenitos feldspáticos, que ocorrem sobrepostos aos metarcóseos com lentes de metaconglomerados, típicos da unidade metarcoseana da Formação Morro Doce, e o contato normal com os metarritmitos da Formação Estrada 
dos Romeiros. Nesta região, os quartzitos ocorrem como lentes muito delgadas não individualizadas.

Predominam os metarenitos feldspáticos com estrutura maciça e granulação fina até raramente grossa. Têm textura granoblástica e raros porfiroclastos de feldspato que, em geral, formam grãos subangulosos maiores que os de quartzo e ocupam até $5 \%$ da rocha, sendo que litotipos com $15 \%$ do volume da rocha constituído por feldspatos são raros. Às vezes, em tipos mais micáceos e que também são mais finos, observa-se uma foliação bem marcada.

Quando frescos, são cinza-esverdeado-claros ou verde-claros, e quando em grau de alteração intempérica incipiente, tendem ao verde mais claro com porções amareladas. Bem alterados, constituem pacotes verde-esbranquiçados, outros quase brancos, finos e cauliníticos, ou ainda, creme-amarelados. Por vezes, porções róseo-claras podem exibir aspecto mosqueado, onde pontos avermelhados mais escuros revelam a alteração supérgena de biotita e/ou de magnetita.

A matriz é rica em quartzo e pobre em feldspato, predominando o plagioclásio e, ocasionalmente, o feldspato potássico. Complementam a mineralogia como acessórios comuns muscovita branca ou verdepálida e biotita, além de epídoto, carbonato, alanita, apatita e zircão. A magnetita é menos comum que nos litotipos da Formação Morro Doce. Clorita, titanita, leucoxênio, turmalina e rutilo são mais raros.

Por vezes podem preservar estrutura sedimentar, com estratos entre 5 e $20 \mathrm{~cm}$ internamente laminados (CV 753), ou níveis mais grossos com grânulos de quartzo. Na base do Pico do Jaraguá, observam-se estratificações cruzadas acanaladas de porte métrico e tangenciais na base nos metarenitos feldspáticos e, no topo, estratos plano-paralelos de 2 a $6 \mathrm{~cm}$ de espessura constituídos por metarenito mais fino (PJ 920A).

São comuns intercalações subordinadas de espessura até métrica de metarenitos finos, maciços ou bandados, e de metarritmitos semelhantes aos da Formação Estrada dos Romeiros. Os metarcóseos dispõem-se como bancos nas proximidades do contato com a unidade metarcoseana e desaparecem bruscamente. Níveis de metaconglomerados são muito subordinados. Eventualmente, podem exibir intercalações de quartzitos micáceos próximo do contato com a unidade quartzítica, como ocorre na encosta sul do Morro do Boturuna, entre os pontos CV 771 e CV 772.

Os metarritmitos como aqueles que predominam na Formação Estrada do Romeiros em geral formam pacotes com até $40 \mathrm{~cm}$, sendo locais algumas intercalações de espessura métrica, como no ponto PJ 546. Mostram-se laminados ou com bandas ao redor de $3 \mathrm{~cm}$ ocupadas por metarenitos finos, metassiltitos, quartzo filito e filito sericítico.

Um pacote com ao menos 10 metros de espessura de quartzo-biotita-muscovita xisto fino ocorre no ponto VH 743, sendo bastante semelhante às metagrauvacas descritas na unidade metarcoseana da Formação Morro Doce.

Corpos de rocha metabásica de espessura até decamétrica foram identificados a NNE do Pico do Jaraguá (PJ 922). São maciços, finos e cinza-esverdeados. Alterados, tornam-se ocre-amarelados a ocreavermelhados. A análise petrográfica indicou intensa substituição dos cristais de plagioclásio por alofana. 
Um outro possível corpo de rocha metabásica, descrito como clorita xisto vinho-escuro muito alterado ocorre no afloramento do ponto VH 837. Em ambas as ocorrências, ora devido à alteração intempérica dos litotipos, ora pela presença de colúvios associados, não se observam as relações de contato.

Rochas contendo amígdalas ocorrem a oeste do Pico do Jaraguá, junto aos metarenitos feldspáticos, isoladas em alguns afloramentos (PJ 921) ou como grandes blocos, não sendo recuperadas as relações de contato. Também afloram na altura do $\mathrm{km} 21$ da Rodovia Anhangüera (VH 127B), nas proximidades do contato com a unidade metarcoseana da Formação Morro Doce. São cinza-escuras, finas, com textura lepidoblástica, e contêm amígdalas milimétricas, que por vezes atingem $3,0 \mathrm{~cm}$, ocorrendo dispersas e com formas elípticas ou alongadas devidas à forte foliação que, localmente, tornase milonítica.

A matriz é composta por biotita e quartzo freqüentes, com feldspato muito subordinado. Magnetita, muscovita e epídoto são os acessórios em ordem decrescente de importância, enquanto que alanita, zircão e clinozoizita são mais raros. As amígdalas podem estar inteiramente preenchidas por quartzo, ou conter quartzo na borda enquanto cristais de biotita ocupam o centro.

Rochas metavulcânicas básicas amigdaloidais foram descritas por CARNEIRO (1983) e CARNEIRO et al. (1984b) na região, onde observaram uma passagem transicional para metpsamitos finos. Devido à presença de amígdalas e à alta porcentagem de biotita no conteúdo, são aqui consideradas como metabásicas shoshoníticas em parte milonitizadas, derivadas de prováveis rochas vulcânicas básicas potassificadas.

Na estrada que liga Pirapora do Bom Jesus a Araçarigüama, ocorre um extenso afloramento (BJ 1065) de uma rocha alterada ocre-clara a marrom-clara contendo amígdalas, na forma de um banco com aproximadamente 10 metros de espessura, intercalada nos metarenitos fedspáticos.

Vários níveis de rochas metavulcânicas intermediárias a ácidas, ocasionalmente constituindo pacotes de até 20 metros de espessura, foram descritos por BERGMANN (1988) e BERGMANN \& MAcREATH (1992) no Morro do Boturuna. Apresentam sericita essencial com ilmenita e quartzo acessórios, e as amígdalas elipsoidais variam de milimétricas até $1,3 \mathrm{~cm}$. A rocha do afloramento citado no parágrafo anterior, apesar de decomposta, parece análoga às descrições daqueles autores, sendo considerada como mais um pacote dessas rochas metavulcânicas intercaladas nos metarenitos feldspáticos.

\subsubsection{Unidade Quartzítica (NPSRbtqz)}

Na região do Morro do Boturuna, é possível observar, da base em direção à meia encosta, um contínuo empobrecimento de feldspato nas amostras que, alteradas, tornam-se cada vez menos cauliníticas, e passam a ocorrer com mais freqüência as intercalações de quartzitos. As estratificações cruzadas tangenciais na base preservadas nesses litotipos indicam topo em posição normal e confirmam a deposição dos quartzitos sobre a unidade dos metarenitos feldspáticos.

$\mathrm{Na}$ unidade predominam os quartzitos, formando desde corpos mais delgados até possantes 
pacotes, como o que aflora no Morro do Boturuna, onde sustenta o relevo por aproximadamente $8 \mathrm{~km} \mathrm{e}$ chega a atingir ao redor de $2 \mathrm{~km}$ de espessura, enquanto que na região do Pico do Jaraguá constituem corpos lenticulares envolvidos pelos metarenitos feldspáticos.

A NW da área, sustentam a Serra do Sapoca e o Morro da Viúva por ao menos $10 \mathrm{~km}$, onde exibem, com frequiência, contatos tectônicos com os metarritmitos da Formação Estrada dos Romeiros. Contudo, HACKSPACHER et al. (1986) observaram contato transicional entre os litotipos a ESE da Serra. A N de Santana do Parnaíba foi individualizada outra lente em contato com esses metarritmitos.

Os quartzitos frescos são branco-acinzentado-claros. Tornam-se creme-amarelados ou brancos e friáveis quando alterados intempericamente. A granulação varia desde fina a grossa, mas predomina a última. São compostos por grãos de quartzo com incipiente a forte recristalização, enquanto que muscovita e clorita acessótias evidenciam a orientação. Cristais de microclínio e de plagioclásio detríticos, epídoto, magnetita, finos porfiroblastos de pirita, turmalina, rutilo e zircão complementam a mineralogia. Metapsamitos mais grossos têm comumente grânulos de quartzo dispersos.

Os quartzitos na região do Morro do Boturuna com freqüência exibem estruturas sedimentares preservadas. São comuns os pacotes de grande porte lenticularizados contendo estratificações planoparalelas que se estendem por dezenas de metros. Das estruturas menores, ocorrem a estratificação cruzada tabular, com mergulho entre os estratos variando de $10^{\circ}$ a $20^{\circ}$ (VL. 785), a estratificação cruzada tangencial na base (Prancha 03/foto E), e a estratificação plano-paralela, todas de pequeno a médio porte constituindo até pacotes métricos. Os estratos variam de 1 a $2 \mathrm{~cm}$ e podem atingir $20 \mathrm{~cm}$ de espessura quando os litotipos têm granulação mais grossa.

Marcas onduladas são mais raras. Podem ser simétricas ou ter cristas tendendo à retilínea, com comprimento de onda entre 3 e $6 \mathrm{~cm}$ e amplitude ao redor de $1 \mathrm{~cm}$ (VL 790). Observa-se ainda deposição rítmica e granodecrescente para o topo, como no ponto $\mathrm{CV} 784 \mathrm{~B}$, e estratificação cruzada tipo espinhade-peixe (Prancha 03/foto F).

Leitos decimétricos ricos em minerais pesados (hematita?) disseminados ou constituindo laminações cinza-escuras no metapsamito parecem ainda mais raros, sendo observados no ponto $\mathrm{CV}$ 827B. No mesmo local também ocorre um banco com alguns decímetros de metarenito grosso contendo seixos angulosos de rocha filítica (Prancha 03/foto G), sugerindo possíveis gretas de ressecação retrabalhadas ou um nível de canibalismo, com o aporte de areia grossa destruindo delgados estratos argilosos.

Essas estruturas são mais comuns em ambiente costeiro a marinho raso, em zona de planície de maré a intermaré com possível influência de ondas. Contudo, em algumas escarpas ocorrem megaestratificações cruzadas tangenciais com 3 a 5 metros de altura e ao menos 30 metros de extensão, o que permite considerar também a possibilidade de condições eólicas para a deposição de parte dos quartzitos.

A partir das medidas das estruturas feitas no Morro do Boturuna em bancos de metapsamitos mais 
micáceos, foi possível observar que a foliação $S_{1}$ está disposta paralela a um pouco oblíqua ao $S_{0}$ e que ambas têm mergulhos semelhantes. Os estratos cruzados e os plano-paralelos indicam que o acamamento tem uma direção com variações da ordem de $\mathrm{N} 40-85 \mathrm{E}$ e mergulho de $30^{\circ}$ até $65^{\circ}$ para NW, sendo mais comuns mergulhos entre $40^{\circ}$ e $55^{\circ}$.

Os milonitos da unidade nesse morro parecem ter um caráter local, mas ocorrem nas encostas e tornam se mais freqüentes nas proximidades e no cume. Constituem lentes métricas nos quartzitos, sendo acompanháveis por vários metros a forte orientação e o estiramento dos grãos que compõem o litotipo, e associam-se, nas porções milonitizadas, veios de quartzo que atingem até a espessura decimétrica. A foliação milonítica corta as estruturas prévias e encontra-se verticalizada, com mergulhos para NW ou para SE.

A unidade apresenta intercalações subordinadas muitas vezes centimétricas, mas que podem atingir até a espessura decamétrica. Na base da unidade, na região do Morro do Boturuna, são mais freqüentes os metarenitos feldspáticos, quartzitos micáceos e quartzo-muscovita xistos finos, os dois últimos, às vezes, com biotita porfiroblástica. Localmente, são encontrados metarritmitos, com lâminas interpondo filitos sericíticos a finos estratos de quartzo filito, metassiltito e metarenito fino.

Os quartzitos do Pico do Jaraguá são mais foliados e recristalizados. As estruturas sedimentares estão menos preservadas, e não é raro observar pacotes boudinados e estirados ou mesmo cisalhados, como ocorre no afloramento do ponto PJ 903. Nesse ponto, as formas sigmoidais dos veios de quartzo associados ao cisalhamento indicam transporte para NNE, em concordância com as estruturas que ocorrem nas metavulcanoclásticas do Grupo Serra do Itaberaba.

Quando mais preservados, os quartzitos demostram ser quase puros, com textura sacaróide, ocorrendo em bancos métricos marcados pela estratificação plano-paralela. São observadas intercalações de quartzitos micáceos ora ricos em sericita ora em clorita e biotita. Próximo do contato com a unidade dos metarenitos feldspáticos na região do Pico do Jaraguá, ocorrem intercalações lenticulares de metarenitos feldspáticos e, com menor frequiência, de metarcóseos, de metaconglomerados e de filitos sericíticos.

Leitos de metaconglomerado matriz-suportado são muito subordinados e exibem espessura até decimétrica. Predominam os grânulos, na matriz, e os seixos subarredondados a arredondados de quartzito ou de quartzo-de-veio, que constituem até $10 \%$ do volume da rocha e ocasionalmente atingem $6,0 \mathrm{~cm}$ de diâmetro ou de eixo maior, como no afloramento do ponto BA 803 .

Um metarritmito com espessura de $15 \mathrm{~cm}$ e ao menos 15 metros de extensão está encaixado concordantemente nos quartzitos no topo do Morro Boturuna (CV 829). Está fresco, é cinza-azulado-claro e exibe laminação, intercalando um filito composto por sericita essencial e minerais opacos (ilmenita e magnetita) que marcam leitos de pesados que contêm ainda quartzo e zircão como traços. O filito grada para a um nível onde o quartzo torna-se um acessório mais frequiente, e esse nível passa abruptamente para um metapsamito micáceo fino milonítico contendo grãos de quartzo estirados. 
A porção filítica assemelha-se às rochas metavulcânicas intermediárias a ácidas amigdaloidais descritas por BERGMANN (1990) e BERGMANN \& MAcREATH (1992) que, em direção ao topo do Morro Boturuna, teriam amígdalas cada vez menores e mais raras, tornando difícil a separação entre níveis vulcânicos não amigdaloidais e os pelitos. Contudo, essas rochas metavulcânicas não foram identificadas nos quartzitos.

Essa possível ocorrência (CV 829) e um corpo maior alterado que ocorre na porção W no Morro do Boturuna (VL 1064), intercalado nos quartzitos e semelhante àquele descrito na unidade metarenítica feldspática poucas dezenas de metros a sul, sugerem que essas rochas metassubvulcânicas também ocorrem com certa frequiência na unidade quartzítica.

\subsubsection{Formação Estrada dos Romeiros}

Segundo BERGMANN (1988), a Formação Estrada dos Romeiros tem, na base, um Membro Arenoso, com metarritmitos arenosos e microconglomerados intercalados que gradam para metarenitos finos a médios, com intercalações subordinadas de metapelitos bandados e, no topo, um Membro Pelítico, que pode ser correlacionado, em grande parte, aos filitos rítmicos de caráter flyschóide da Formação Piragibu (HASUI et al. 1976).

Na região de Cajamar-Jordanésia observam-se, com frequêencia, pacotes onde predominam metarritmitos representados por interposições de metarenitos finos a médios, metassiltitos e quartzofilitos, por vezes com leitos subordinados conglomeráticos nos quais comumente intercalam se e passam a predominar localmente bancos de filitos laminados e bandados. No sentido de Cajamar-Jordanésia e nas cercanias, passam a predominar metassedimentos mais finos, contudo o caráter rítmico ainda está bem marcado.

Aparentemente, a associação representa um processo de sedimentação mais distal comparado às deposições que ocorrem na região de Pirapora do Bom Jesus, de carâter relativamente mais grosso, e confirma a hipótese de JULIANI \& BELJAVSKIS (1995) de que as formações Estrada dos Romeiros e Piragibu poderiam representar apenas diferentes fácies de ambiente deposicional. A Formação Estrada dos Romeiros, reinterpretada, está representada em grande parte da área pela Unidade Metarrítmica, constituída por pacotes predominantemente arenosos, com litotipos clásticos grossos e finos subordinados.

Outros litotipos predominam localmente na formação, constituindo, em geral, corpos lenticulares intercalados e envolvidos pelos metarritmitos. Estão individualizados nas unidades Metarenítica Feldspática, Metacálcio-pelítica, Metacarbonática, Metapsamítica, Metabasítica e Metapelítica.

\subsubsection{Unidade Metarrítmica Grossa (NPSRermr)}

A unidade ocorre principalmente na porção setentrional da área, aflorando como um extenso corpo desde os arredores de Pirapora do Bom Jesus até as proximidades do Ribeirão Juqueri, a nordeste. A partir da região central, o limite meridional da unidade em geral é feito através de contato tectônico, de 
empurrão ou por cisalhamento com mergulho de alto ângulo, com os xistos pelíticos do Grupo Serra do Itaberaba.

Em outros locais constitui corpos lenticulares, como a NW na região da Serra da Sapoca e do Morro da Viúva, a S do Morro do Boturuna e a $\mathrm{N}$ de Santana do Parnába, ocorrendo em contato com os metarenitos feldspáticos e com os quartzitos da Formação Boturuna e gradando para os metapelitos da Formação Piragibu. Seus litotipos também ocorrem enfeixados no Stock Granítico Ponunduva.

Dois corpos da unidade metarrítmica foram delimitados entre o Morro Doce e o Maciço Granitóide Itaqui, atingindo espessura de até $1,5 \mathrm{~km}$ e se estendendo por alguns quilômetros. Apresentam transição para outras unidades do Grupo São Roque e estão colocados tectonicamente sobre as unidades metavulcanoclástica e dos xistos pelíticos do Grupo Serra do Itaberaba.

Na porção SE da área, nas cercanias da Fazenda Itayhe, observa-se a gradação de um metarenito feldspático grosso com grânulos de quartzo para um metarritmito com laminações mais arenosas e outras mais micáceas, e que passam a apresentar várias intercalações de filitos laminados e bandados, marcando o contato dos metarenitos feldspáticos da Formação Boturuna para a unidade metarrítmica da Formação Estrada dos Romeiros. Mais a norte, devido possivelmente às variações laterais que ocorreram durante a sedimentação, os metarritmitos encontram-se em contato com a unidade metarcoseana da Formação Morro Doce. Nos arredores do Morro do Boturuna os metarritmitos também estão intercalados aos metarenitos feldspáticos e, em direção a $\mathrm{N}$, tornam-se mais comuns.

$\mathrm{Na}$ região $\mathrm{W}$, os metarritmitos gradam a partir dos metacálcio-pelitos que envolvem o corpo metabasítico de Pirapora do Bom Jesus, como se observa entre os pontos RP 1227 e RP 1243, passando a ocorrer intercalações de filitos, metassiltitos e metarenitos finos que estão depositados sobre os metacálcio-pelitos. Nessa região, mais a nordeste, também são observados metaconglomerados formados por matriz arenosa fina contendo seixos e calhaus angulosos de quartzo-de-veio e de metassedimentos manganesíferos (Prancha 03/foto $\mathbf{H}$ ), indicando que a deposição dos metarritmitos foi posterior à unidade metacálcio-pelítica da Formação Pirapora do Bom Jesus.

As relações de contato com a unidade metabásica da Formação Estrada dos Romeiros não foram observadas nos perfis efetuados, devido à intensa alteração das rochas daquela unidade. Contudo, no corpo menor de metabásica que aflora a sul, a partir do ponto CV 01 , notanse a passagem brusca para os metarritmitos do afloramento CV 1269.

O contato entre a unidade metarrítmica e a unidade metapelítica da Formação Piragibu geralmente é gradacional e pode se estender por algumas dezenas de metros. Com relativa freqüência, como entre os pontos CJ 283 e CJ 293, a unidade metarrítmica compreende metassiltitos e quartzo filitos com metarenitos finos subordinados, e os bancos de filito sericítico tornam-se comuns.

Essa relação pode ser observada no perfil efetuado no oleoduto que passa a $W$ do Bairro Jordanésia e que corta ortogonalmente a estrutura regional. De sul para norte, entre os pontos JD 340 e JD 330, afloram metarritmitos com alguns bancos filíticos que passam a se intercalar cada vez com maior 
frequiência. A seguir, torna-se amplo o predomínio de filitos entre metarritmitos em afloramentos mais extensos, e os metapsamitos estão presentes como raros pacotes de espessura subdecimétrica, para então praticamente desaparecerem, como se observa mais a norte, entre os pontos JD 262 e JD 264, indicando a transição para a Formação Piragibu.

As faixas milonitizadas podem concentrar-se no interior de uma das unidades, porém não são raras as vezes em que dispõem-se na transição entre os metarritmitos e os filitos, obliterando as relações de contato, como ocorre entre os pontos CJ 278 a CJ 282, e caracterizando um contato tectônico.

A unidade metarrítmica apresenta como litotipo comum os metarritmitos bandados, por vezes laminados, onde intercalam-se freqüentemente metarenitos em geral maciços e metassiltitos maciços ou laminados, além de interposições bruscas de filitos como laminações e bandas, evidenciando ainda mais a seqüência rítmica. Estruturas sedimentares são comuns, destacando-se laminações e finos estratos planoparalelos, laminações convolutas e climbbing ripple, como já destacado por BERGMANN (1988), além de efeitos de pressão deposicional de clastos maiores sobre delgadas laminações, indicando topo e base, e leitos de minerais opacos marcando o acamamento original.

São comuns as intercalações de bancos métricos a decamétricos de metarenitos finos, apresentando estratificações cruzadas de pequeno porte com até $40 \mathrm{~cm}$ de altura, internamente marcadas por estratos maciços ao redor de $3 \mathrm{~cm}$, em contato brusco com bancos de metassiltitos.

A granulação dos metarenitos tende a ser fina, com os grãos em geral menores que $0,1 \mathrm{~mm}$. Metarenitos e metassiltitos frescos têm cor verde-clara; quando alterados, tornam-se amarelos a cremes ou vinho-avermelhado-claros ou escuros. Os metarenitos mais grossos alterados tendem ao amarelo ou branco (RP 04).

A orientação dos metarenitos finos e de metassiltitos de modo geral é incipiente. Quando ricos em minerais micáceos, desenvolvem moderada foliação e, em regiões onde a milonitização está concentrada, os grãos, grânulos e pequenos seixos de quartzo, que são mais comuns nos metarenitos, podem estar amendoados e estirados, e são ressaltados pela alteração intempérica, destacando-se em relevo da matriz.

O principal mineral desses litotipos é o quartzo, que em geral ocupa mais de $60 \%$ do volume da rocha e atinge, em algumas amostras, quase o conteúdo total. Dos minerais micáceos, predomina a muscovita que, junto à clorita, em leitos mais raros, soma até 30\%. O plagioclásio é um acessório ocasional ou traço, e por vezes preserva a geminação múltipla. Mineral opaco varia de acessório a traço freqüente, e foi reconhecido como magnetita fina comumente limonitizada. Turmalina e zircão são traços e muitas vezes detríticos, enquanto que o epídoto é muito raro. Óxidos de ferro, possivelmente goethita, distribuem-se nas amostras mais alteradas.

Duas foliações são observadas nas intercalações filíticas entre os metapsamitos. A $S_{1}$ caracteriza uma clivagem ardosiana bem desenvolvida ou uma clivagem de fratura, sendo observada na maioria dos afloramentos em posição oblíqua ao acamamento, ou está colocada paralelamente. O bandeamento $\mathrm{S}_{0} / \mathrm{S}_{1}$ está ondulado pela foliação $S_{2}$, que também é densa, e varia de uma clivagem de crenulação discreta a 
zonal. Essa crenulação, às vezes, evolui, no mesmo afloramento, para uma foliação milonítica com formas anastomosadas, em geral oblíqua às estruturas anteriores, e que pode transpor o bandeamento, obliterando as feições pretéritas, como é comum nas proximidades de Cajamar-Jordanésia. Nesse caso, a foliação anterior é recuperada apenas quando observados os arcos poligonais, como ocorre na amostra CJ $274 \mathrm{e}$.

Nos pacotes arenosos mais finos, são comuns as venulações e finos veios de quartzo geralmente com menos de $2,0 \mathrm{~cm}$ de espessura e que podem se estender por alguns metros, como ocorre na exposição do ponto ID 265, sugerindo remobilizações nos eventos deformacionais $S_{1}$ e $S_{2}$. Eventualmente, estão relacionados às fraturas e falhas tardias de direção NW-SE que cortam a foliação $S_{2}$. Essas remobilizações em geral estão ausentes nos pacotes micáceos intercalados.

Intercalações de metarenitos com feldspatos contendo lentes subordinadas de metarenitos finos com possíveis marcas de sola e com leitos de até $30 \mathrm{~cm}$ de espessura de metarenitos grossos e metaconglomerados matriz-suportados com grânulos e pequenos seixos ocorrem a $\mathrm{N}$ de Pirapora do Bom Jesus, entre os pontos RP 03 e RP 04.

Os metarritmitos podem apresentar entre os metarenitos e, principalmente, nos metassiltitos ricos em minerais micáceos, um litotipo com conteúdo de quartzo em geral superior à metade do volume da rocha, e que exibe granulação muito fina, designado quartzo filito. Quando desenvolvem uma conspícua foliação, por vezes milonítica, tornam-se muito parecidos com os filitos sericíticos, como pode ser observado nos afloramentos CJ 274 e CJ 280.

Os metaconglomerados ocorrem subordinados como leitos intercalados de espessura decimétrica. Em geral são amarelados ou esbranquiçados. Localmente, encontram-se milonitizados e em parte enfeixados entre bancos de metarenitos finos com filitos subordinados. O metaconglomerado, nesse caso, é vermelho, clasto-suportado, com a matriz muscovítica orientada ocupando cerca de $10 \%$ da rocha. Predominam, entre os clastos, grânulos e seixos subcentimétricos arredondados a subarredondados de metassiltitos, metarenitos finos, quartzitos, quartzo-de-veio e grânulos angulosos de filito sericítico (JD 153).

Junto às intercalações filíticas no afloramento do ponto CJ 174 foram observados leitos de metacálcio-pelitos associados. Leitos grafitosos também podem ocorrer ocasionalmente nessas intercalações.

Rochas metavulcanoclásticas básicas com cores variegadas e caráter argiloso podem constituir níveis de espessura até métrica no metarritmitos, como ocorre no ponto CJ 283. Lentes de quartzitos intercalados são comuns nos metarritmitos, como pode ser observado a $\mathrm{N}$ do Bairro Várzea do Souza, no perfil entre os pontos VS 419 e VS 420.

\subsubsection{Unidade Metarenítica Feldspática (NPSReraf)}

A W do Morro Doce foram individualizadas cinco lentes em que são frequientes os metarenitos feldspáticos, localmente predominantes em meio aos espessos pacotes de metarritmitos, como pode ser 
observado entre os pontos VH 739 e PJ 740. A estrutura, a textura, a mineralogia essencial e tipo de alteração são como as que ocorrem nos litotipos descritos na Formação Boturuna. Constituem corpos entre 50 e 150 metros de espessura e podem atingir até $1500 \mathrm{~m}$ de comprimento. Subordinadamente, ocorrem leitos de espessura decimétrica de metarcóseos, e observam-se também intercalações de metarenitos e dos metarritmitos.

\subsubsection{Unidade Metacálcio-pelítica (NPSRercp)}

A unidade ocorre preferencialmente na porção centro-setentrional da área, na região de CajamarJordanésia. Os corpos, com formas lenticulares, podem atingir até $11 \mathrm{~km}$ de extensão e ter até 700 metros de espessura em planta. Predominam na unidade os metacálciompelitos muito semelhantes àqueles descritos na Formação Pirapora do Bom Jesus, que correspondem aos filitos calcíferos observados por CARNEIRO (1983) nessa região.

De modo geral, estão em contato com metarritmitos da Formação Estrada dos Romeiros, e com os metapelitos da Formação Piragibu, como pode ser observado nas proximidades da Pedreira do Pires (CJ 296), junto à antiga Pedreira Beneducci (CJ 462 a CJ 466), e nos arredores da Pedreira Geocal (VS 904 a VS 910) até, aparentemente, a região da Metalúrgica Mamoré (RP 50), onde os metacálcio-pelitos transicionam a $\mathrm{S}$ para os filitos e, a $\mathrm{N}$, para os metarritmitos.

Gradam com frequiência para litotipos carbonáticos, como ocorre a $W$ de Cajamar e na região do Morro do Rosário (por ex. CJ 222 a CJ 223). Uma outra lente da unidade está delimitada a NE de Pirapora do Born Jesus, envolvida pelos metarritmitos da Formação Estrada dos Romeiros.

Assim como na Formação Pirapora do Bom Jesus, estão sempre bem alterados intempericamente, exibindo bandas e lâminas com variações de tons ocráceos. Sua granulação varia de muito fina até fina. Contêm sericita, clorita, grafita, e o quartzo ocorre subordinado mas freqüente. Observarse pirita por vezes limonitizada e cristais de carbonato alterados, e que, devido à lixiviação, praticamente não são reconhecidos. Em algumas amostras, entretanto, sua presença é sugerida pelas cavidades com formas romboédricas e que podem atingir até $4,0 \mathrm{~mm}$, como ocorre a sul do afloramento CJ 150. Por vezes, interpõem-se bancos métricos de metacálcio-pelitos ricos em magnetita disseminada, como pode ser observado no afloramento do ponto VS 426.

Nas poucas lâminas analisadas observa-se uma mistura de uma massa carbonática, por vezes pouco recristalizada, e de finíssimos cristais de sericita com tênue orientação, mas a granulação menor que $0,01 \mathrm{~mm}$ dificulta a distinção da sericita dos minerais carbonáticos, como pode ser visto em leitos menores do litotipo descritos em intercalação com rochas carbonáticas no ponto VS 328. Os minerais opacos são frequientes, mas de difícil identificação.

Pacotes de filito sericítico são muito comuns e, por vezes, até mesmo predominam em vários afloramentos da Unidade Metacálcio-pelítica. Não é raro atingirem espessura até decamétrica, como no ponto (JD 365), principalmente quando próximos das unidades metapelíticas. Eventualmente, intercalamse nesses filitos níveis subcentimétricos de metarenito fino ferruginoso (JD 297), e delgados leitos de 
possíveis formações ferriferas foram observados nos níveis fillíticos na região da Pedreira Beneducci, particularmente nos pontos CJ $460 \mathrm{e}$ CJ 461 .

Também foram descritas rochas filíticas bandadas com intercalações de bandas com até $2,0 \mathrm{~cm}$ roxo-acinzentadas internamente laminadas, ricas em sericita, minerais opacos e grafita, com outras bandas cremes ou brancas, também sericíticas e com quartzo, contudo pobres nos demais minerais. Essas rochas filíticas ocorrem em contato com delgadas lentes de rochas carbonáticas finas cinza-escuras que, eventualmente, podem ter até 1 metro de espessura, como ocorre entre os pontos CJ 230 e CJ 231 .

Intercalações subordinadas de metapelitos manganesíferos em bandas de espessura até decimétrica junto aos cálcio-filitos são vistas ocasionalmente. Consistem de uma rocha muito alterada, maciça, fina, e marrom-escura, como pode ser visto no afloramento do ponto CJ 223.

As intercalações estão presentes com relativa frequiência, e variam desde laminações até estratos com espessuras de uma dezena de metros, mas são comumente métricas. Predominam aquelas de metarritmitos contendo sericita filito vinho-claro em bandas centimétricas marcadas por contatos nítidos com outras bandas de metassiltito creme e laminações de filito grafitoso.

Nas proximidades do contato com as rochas metacarbonáticas, os metacálcio-pelitos podem apresentar lentes de espessura até métrica de rocha calciossilicática fina, bandada e verde-clara, níveis de filitos manganesíferos e leitos carbonáticos, como está exposto no afloramento do ponto VS 904 na Pedreira Geocal.

Na mesma região, os metacálcio-pelitos por vezes estão milonitizados e exibem uma densá foliação de direção ENE-WSW, que mergulha entre $65-75^{\circ}$ para NW. Enfeixado na unidade ocorre um pacote de espessura decamétrica de metagrauvacas e de metarenitos feldspáticos alterados verdeavermelhado-claros que, dado à milonitização, apresentam cristais de plagioclásio saussuritizados, granulação fina e estrutura xistosa (VS 916).

\subsubsection{Unidade Metacarbonática (NPSRercd)}

Essa unidade metacarbonática, assim como a descrita na Formação Pirapora do Bom Jesus, apresenta corpos alongados em contato e geralmente envolvidos por metacálcio-pelitos. As rochas da unidade afloram na porção centro-setentrional da área, desde as proximidades da Metalúrgica Mamoré passando pelo Bairro Várzea do Souza até a região de Cajamar-Jordanésia, onde são mais abundantes. Os corpos, em geral, têm direção aproximada NNE-WSW e constituem um mesmo horizonte estratigráfico.

Para CARNEIRO (1983) as rochas carbonáticas dessa região seriam correlacionadas às de Pirapora do Bom Jesus, e estariam situadas no meio de um pacote francamente pelítico, com posicionamento estratigráfico semelhante ao adotado por HASUI et al. (1976).

Contudo, a quase ausência de rochas metabásicas associadas e a frequiente passagem da unidade metacálcio-pelítica para metarritmitos e metapelitos da Formação Estrada dos Romeiros parece indicar a deposição dessas rochas em ambientes mais distais dos centros vulcânicos e relacionados às porções da bacia onde foi maior o aporte de sedimentos detríticos. Essa hipótese é reforçada pela rápida gradação 
local dos metarritmitos e dos metacálcio-pelitos ou de litotipos carbonáticos para delgados pacotes de quartzitos, como ocorre na Pedreira Geocal (VS 368, VS 371), nas antigas lavras da Pedreira Vau Velho e arredores (VS 425 a VS 434), na região do Morro do Rosário (JD 184 a JD 185) e do Gato Preto (JD 177 a JD 179).

A unidade metacarbonática da Formação Estrada dos Romeiros é constituída de corpos mais expressivos, sendo reconhecidas vinte e duas lentes onde predominam os litotipos carbonáticos. São frequientes na região de Cajamar, destacando-se pelas várias lavras em atividade. Os maiores são observados nas pedreiras Geocal, a W do Bairro Várzea do Souza, e Pires (CJ 296), onde atinge 350 metros de espessura e tem por volta de $1 \mathrm{~km}$ de extensão.

Quando frescos, distinguem-se em duas variedades mais comuns. São predominantemente calcíticos e cinzas desde claros até escuros, a localmente pretos e grafitosos, ou são brancos ou cremes, e em geral também calcíticos. Rochas dolomíticas ocorrem de forma mais restrita. Litotipos esverdeados estão presentes na região da Várzea do Souza, devido às composições de tendência calciossilicática com presença de minerais acessórios não carbonáticos.

Alterados intempericamente, variam para o ocre-claro a alaranjado; com o aumento da alteração, essas cores mostram-se mais homogêneas e escuras. Amostras grafitosas alteradas são ocre-escuras ou marrom-escuras.

Os litotipos carbonáticos são quase puros, e constitúdos em essência por calcita e/ou dolomita. Como acessórios ocorrem quartzo, muscovita e uma variedade desse micáceo levemente pleocróica e esverdeada, além de clorita. Flogopita pode estar presente em alguns leitos cálcio-pelíticos intercalados, como em uma amostra do ponto VS 328. Nas rochas carbonáticas grafitosas observam-se com frequiência porfiroblastos de pirita com até $4,0 \mathrm{~mm}$.

Nas lavras de Cajamar-Jordanésia nota-se a estrutura bandada, com bandas decimétricas a métricas onde intercalam-se camadas cinza-claras e outras escuras, como ocorre na cava do ponto JD 294. Internamente, formam lâminas com até $6,0 \mathrm{~mm}$, enquanto que as bandas com até $2,0 \mathrm{~cm}$ de espessura são maciças e granoblásticas. Essas estruturas são visíveis graças às diferenças de tonalidade, que refletem pequenas variações composicionais e granulométricas e que estão ressaltadas por efeito do intemperismo diferenciado.

A textura granoblástica e o aspecto maciço predomina em amostras mesoscópicas, enquanto que nos estratos ricos em minerais micáceos e nas porções grafitosas predominam tipos lepidogranoblásticos orientados.

Os litotipos em geral são finos ou muito finos, mas podem ter granulação média e, nesse caso, também são impuros e exibem com mais freqüência os grãos de quartzo e minerais micáceos disseminados. Quando afetados pela deformação, são comuns venulações com até $3,0 \mathrm{~mm}$ com calcita recristalizada mais grossa e, em amostras brechadas, notam-se inúmeras venulações com várias orientações. 
Rochas calciossilicáticas podem formar intercalaçôes de espessura até métrica ná unidade metacarbonática. São esverdeadas, com bandas centimétricas contendo minerais carbonáticos e outras mais espessas constituídas por flogopita e carbonato essenciais, enquanto que pirita e quartzo estão disseminados. Por vezes, são maciças e estão dobradas junto com intercalações de quartzitos finos em meio às rochas carbonáticas, como ocorre na frente de lavra da Pedreira do Pires (JD 296).

Os metacálcio-pelitos podem ocorrer ocasionalmente. Na antiga lavra de calcário do Morro do Rosário, formam intercalações métricas no talude norte. Estão fortemente orientados, têm aspecto filítico e, quando mais alterados, tornam-se ocre-escuros e pulverulentos.

Filitos sericíticos, como os que ocorrem na unidade metapelítica da Formação Piragibu, e metarritimitos, como aqueles da Formação Estrada dos Romeiros, podem ser observados com certa freqüência em direção às bordas dos corpos carbonáticos e na transição para os metacálcio-pelitos.

\subsubsection{Unidade Metapsamítica (NPSRerpm)}

Diversos corpos lenticulares de metapsamitos foram individualizados na Formação Estrada dos Romeiros. Nas proximidades de Pirapora do Bom Jesus, ocorre o maior da unidade, com quase $6 \mathrm{~km}$ de comprimento e exibindo espessura máxima ao redor de 600 metros, e contendo quartzitos com leitos conglomeráticos, como se observa no perfil entre os pontos RP 1231 e RP 1235.

A E do Stock Granítico Ponunduva e a partir do Morro do Rosário e indo para leste, até as proximidades do Ribeirão Juqueri, ocorrem diversas lentes com espessura entre 100 e 500 metros que se estendem por ao menos $2,5 \mathrm{~km}$. Inúmeros corpos ainda mais delgados de metapsamitos também foram delimitados entre os metarritmitos, como aqueles que possuem quartzitos e quartzitos conglomeráticos e que ocorrem nos pontos CJ 315, CJ 317 e CJ 347, próximos à Cajamar.

Os metapsamitos com frequiência fazem contato com os metarritmitos e por vezes gradam rapidamente a partir da unidade metacálcio-pelítica, como observado nos arredores da Pedreira Geocal. Ocasionalmente, algumas lentes menores dos metapsamitos mais finos têm contato com os filitos e com as rochas carbonáticas e, a NNW do Bairro Várzea do Souza, limitam-se tectonicamente com a unidade metabásica da Formação Pirapora do Bom Jesus.

Quando apresentaram fraca recristalização e pouca deformação, e foi possível o reconhecimento de algumas estruturas sedimentares ou texturas clásticas, tais como a forma do grãos, os metapsamitos foram descritos como metarenitos. Esses litotipos podem exibir granulação fina até grossa. Em outros locais, como no afloramento VS 376 e nos arredores, a recristalização e o estiramento dos grãos são intensos, sendo classificados como quartzitos. Nesses litotipos, muitas vezes, associam-se feições de milonitização.

Nos afloramentos descritos na região do Vau Novo, como no VS 440, podem ocorrer intercalações de bancos métricos de metarritmitos, em geral mais psamíticos, representados por leitos de metarenitos finos e de metassiltitos.

Em perfil efetuado em uma drenagem a SW do afloramento anterior, em direção à mointante, os 
quartzitos são finos e constituem pacotes até decamétricos. Ocorrem intercalados na unidade metarrítmica, onde predominam metassiltitos e metarenitos finos por vezes contendo leitos de metacálcio-.pelitos e de filitos grafitosos, além de bancos métricos de filitos sericíticos. Nota-se a presença de finos porfiroblastos limonitizados disseminados nos vários litotipos, cuja forma octaédrica sugere tratarem-se de magnetita.

Em direção ao topo da drenagem os metapsamitos tornam-se comuns, a granulação varia de média a fina e passam a ser observados leitos ou delgados pacotes de quartzito grosso, indicando a transição do unidade metarrítmica para a unidade metapsamítica.

\subsubsection{Unidade Metabasítica (NPSRermb)}

As rochas metabásicas da Formação Estrada do Romeiros têm, de modo geral, as mesmas características das que ocorrem na Formação Pirapora do Bom Jesus. Diferenciam-se pelo tamanho dos seus corpos, com formas lenticulares que variam entre 750 a 1600 metros de extensão e atingem no máximo 300 metros de espessura.

São reconhecidas cinco ocorrências da unidade, uma delas a $W$ de Pirapora do Bom Jesus e as demais na porção centro-setentrional da área. A que ocorre mais a leste faz contato tectônico, através de zonas de empurrão, com os xistos pelíticos do Grupo Serra do Itaberaba.

Em comparação com as rochas metabásicas da Formação Pirapora do Bom Jesus, é mais comum apresentarem texturas ígneas preservadas, como a blastofítica, e clinopiroxênio reliquiar como um dos principais minerais, como se observa no afloramento CJ 284. Nesse caso, as rochas metabásicas exibem cor verde-clara. Os minerais opacos são raros e com freqüência mostram-se leucoxenizados, da mesma forma que a titanita.

Nessa região dos pontos CJ 283 a CJ 292 passam a ocorrer alguns blocos de rocha metabásica em meio aos metarritmitos, como no ponto CJ 288. A partir daí, predomina um corpo mais contínuo de rochas metabásicas, tanto para WNW como para N. Nestes perfis ainda ocorrem intercalações menores dos metarritmitos, sugerindo uma possível contemporaneidade, mas não se observam as relações de contato.

Neste mesmo corpo foram descritos alguns blocos de metabrecha básica intercalada entre metatufos grossos e metassedimentos tufíticos bandados, ambos bastante alterados (CJ 286). A metabrecha apresenta fragmentos angulosos de rocha básica com até $2 \mathrm{~cm}$ dispersos em matriz de composição também básica. Considerando ainda que as direções gerais da rochas metabásicas e dos metarritmitos são semelhantes, parece menos provável a hipótese de intrusão de diques pretéritos.

\subsubsection{Unidade Metapelítica (NPSRermp)}

São comuns as interposições filíticas entre os metarritmitos. Dois corpos onde os metapelitos predominam foram individualizados na Formação Estrada dos Romeiros. Têm formato lenticular com até 250 metros de espessura e se prolongam por até $4 \mathrm{~km}$. O primeiro ocorre a SE do corpo metabasítico de Pirapora do Bom Jesus (RP 1251), e o segundo foi cartografado na região centro-setentrional, nas 
proximidades da antiga Pedreira Beneducci (CJ 455, CJ 467).

Os filitos desses corpos, além de manter contato com os metarritmitos, limitam-se com metacálcio-pelitos, rochas metabásicas e rochas carbonáticas e, como pode ser visto no ponto CJ 454 , comportam intercalações de rochas metavulcanoclásticas básicas alteradas com cores variegadas e caráter argiloso.

\subsubsection{Formação Piragibu}

Segundo HASUI et al. (1976), a Formação Piragibu ocorre no topo do Grupo São Roque, sendo composta por uma seqüência de filitos rítmicos ou alternâncias de filito e de quartzito, de caráter flyschóide. BERGMANN (1988) considerou os cortes da Estrada dos Romeiros para a caracterização do Membro Pelítico, no topo da formação homônima, uma das referências para a definição da Formação Piragibu de HASUI et al. (1976), que citam a grande exposição às margens da Represa de Pirapora do Bom Jesus.

O Membro Pelítico de BERGMANN (1988) é composto por dois pacotes contendo metapelitos bandados a laminados com intercalações subordinadas arenosas e microcoglomeráticas, e ocorre entre os pacotes um banco de metarenitos desde finos até grossos.

Na Formação Boturuna (HASUI et al. 1976) foram descritos filitos e intercalações de quartzitos na parte basal e rochas carbonatadas no topo, a partir do perfil realizado entre Pirapora do Bom Jesus e Araçariguiama. Os autores reportaram a existência de outro extenso pacote metapelítico na estrada de Pirapora do Bom Jesus para Cabreúva.

JULIANI \& BELJAVSKIS (1995) admitiram possíveis correlações entre as formações Piragibu e Estrada dos Romeiros, que representariam apenas diferentes fácies deposicionais.

Neste trabalho, foi possivel observar que esses metapelitos sofrem forte adelgaçamento a SW de Pirapora do Bom Jesus, e desaparecem a S do Morro do Boturuna, mas voltam a aflorar a NW de Santana do Parnaíba e na Estrada dos Romeiros, onde foram definidos os filitos da Formação Piragibu (HASUI et al. 1976) e o Membro Pelítico da Formação Estrada dos Romeiros (BERGMANN 1988), sugerindo tratarem-se do mesmo nível estratigráfico.

A Formação Piragibu redefinida engloba os metassedimentos de caráter flyschóide da Formação Piragibu, os filitos da Formação Boturuna (HASUl et al. 1976), e o Membro Pelítico da Formação Estrada dos Romeiros (BERGMANN 1988). Também foram agrupados na formação os filitos laminados da unidade dos metassedimentos detríticos com predomínio de metapelitos, descritos por CARNEIRO (1983) na região de Cajamar-Jordanésia, e os filitos bandados do Pacote Superior do Grupo São Roque (DANTAS 1990, 1992), que afloram na extremidade nordeste do mapa geológico.

\subsubsection{Unidade Metapelítica (NPSRpgmp)}

As denominações anteriores aplicadas às rochas da unidade metapelítica demonstram uma certa variação da estrutura, do aspecto rítmico, e dos minerais principais, constituindo uma extensa exposição 
de filitos variados. De modo geral, seus litotipos resultam de uma sedimentação pelítica, rítmica e distal, representando o topo do Grupo São Roque.

Contudo, alguns corpos desses metapelitos, delimitados entre Santana do Parnaíba e Pirapora do Bom Jesus, estão em contato com litotipos que ocupam posições mais basais no Grupo São Roque, como rochas metabásicas, metacálcio-pelitos e metarenitos feldspáticos, parecendo indicar uma variação lateral de fácies dentro da Bacia São Roque, ou ainda, que os filitos podem ter sido depositados, de modo subordinado, desde a início da instalação da bacia.

Os metapelitos afloram nas regiões NW e NNE da área, onde constituem extensos pacotes com espessura variando entre 1 e $2,5 \mathrm{~km}$ e que podem se estender por quase $20 \mathrm{~km}$, como o que desenha o Sinclinório de Pirapora do Bom Jesus. Para NNE, atingem até $3 \mathrm{~km}$ de espessura e ainda afloram além dos limites da área. Uma lente menor foi delimitada na regiăo $\mathrm{SE}$, com até 600 metros de espessura e que se prolonga por $5,5 \mathrm{~km}$.

Os metapelitos são vistos em grandes afloramentos nas rodovias dos Bandeirantes e Anhangüera, na ligação entre Cajamar e o Bairro de Jordanésia, na Estrada dos Romeiros, entre Santana do Parnaíba e Pirapora do Bom Jesus, e daí para NW em direção à Cabreúva, e para WSW, na ligação para Araçarigüama.

Na porção NNE da área, o contato meridional da unidade em geral é tectônico com os xistos pelíticos do Grupo Serra do Itaberaba, através de uma zona de cisalhamento de alto ângulo e direção aproximada $\mathrm{E}_{-} \mathrm{W}$, onde ambos os litotipos ocorrem milonitizados, como se observa nos perfis entre os pontos CB 1145 e CB 1146 na Rodovia dos Bandeirantes, e CA 982A e CA 982B, nos arredores de Caieiras.

A unidade exibe contato frequiente com a Formação Estrada dos Romeiros, apresentando transição para os metarritmitos e, por vezes, gradando para os metacálcio-pelitos. Na estrada que liga Pirapora do Bom Jesus a Araçarigüama, pode ser observado seu contato gradacional com os metarritmitos, no perfil entre o ponto VL 1080 até VL 1078, sendo que nesse último os metapelitos já predominam amplamente. A W e a $S$ desse perfil, estão em contato tectônico com os xistos pelíticos do Grupo Serra do Itaberaba, situação que volta a se repetir a NNW de Santana do Parnaíba.

Em direção à Cabreúva, o contato é milonítico com o Maciço Granitóide São Roque segundo a Zona de Cisalhamento Araçarigüama, como se observa entre os pontos VL 1147 e MV 1148 e, para ENE, limitam-se com frequiência e também tectonicamente com o Stock Granítico Ponunduva.

Os filitos predominam na unidade metapelítica. Têm estrutura laminada a bandada com bandas de espessura até decimétrica. Essas, eventualmente, podem estar laminadas, refletindo possîveis oscilações das condições da energia durante a sedimentação, o que também modifica a proporção dos constituintes minerais mais comuns e, por vezes, da granulação, produzindo variação de cores entre bandas (Prancha $04 /$ foto A). A granulação é fina a muito fina, em geral menor que $0,1 \mathrm{~mm}$. Ocasionalmente são observadas estruturas de marcas de sola (CV 954). 
Comumente ocorrem alterados, apresentam aspecto sedoso, e são vinho-claros e róseo-claros ou ainda arroxeados. Quando ainda mais alterados, tornam-se mais claros, amarelados ou cremes. Frescos, mostram-se cinzas ou verdes, exibindo intercalações mais claras e outras mais escuras.

Nas laminações com texturas lepidoblásticas e granolepidoblásticas predomina a sericita branca ou levemente esverdeada, enquanto que a clorita em geral ocorre subordinada, e ambas dispõem-se isorientadas. Em alguns afloramentos a clorita torna-se o mineral mais abundante, marcando bandas até decimétricas verdes a verde-ocráceas, como ocorre no ponto BJ 1025. O pacotes cloríticos alterados intempericamente tornam-se roxos e mais decompostos tendem ao ocre-esverdeado (Prancha 04/foto B). O quartzo também é comum, ocorrendo disperso ou concentrando em leitos. Eventualmente, os filitos apresentam leitos contendo grafita acessória.

Cristais de muscovita e biotita maiores são raros e anédricos, sugerindo serem detríticos. Mineral opaco é traço a acessório, às vezes concentra-se em leitos e marca o acamamento, sendo ocasionalmente identificado pelo hábito cúbico e a cor preta como magnetita, mas em geral está em parte ou totalmente transformado por intemperismo para agregados microgranulares de limonita/goethita.

Por vezes os minerais opacos são porfiroblásticos e atingem até 2,0 mm (PO 57), mas devido à forte alteração supérgena não foi possível caracterizá-los. Zircão e turmalina são traços raros e detríticos, e carbonato é um constituinte acidental.

Localmente, o litotipo é mais fino, argiloso, e aparenta estrutura maciça, mas mostra-se milimetricamente laminado (CB 35, CB 1149), e tornam-se mais comuns os leitos subcentimétricos de filitos grafitosos, como pode ser visto no afloramento CB 985 .

A conspícua foliação dos filitos relaciona-se à $S_{1}$ do Grupo São Roque, sendo observadas dobras abertas até fechadas e localmente isoclinais, com planos axiais tendendo a verticais, às quais associam-se geralmente uma foliação filítica penetrativa ou uma clivagem ardosiana que, quando mais densa, pode ser paralela ao $S_{0}$, produzindo um bandeamento metamórfico.

Quando a deformação é mais suave, a clivagem ardosiana pode gradar para uma clivagem de fratura, como se observa na rodovia Estrada dos Romeiros no perfil entre os pontos SP 1272 e SP 1274 . Na região de Cajamar-Jordanésia, a $S_{1}$ foi caracterizada como uma forte foliação filítica, sendo difícil recuperar sua posição em relação ao acamamento sedimentar. Sua direção principal média é N70-95E, mergulhando de preferência para SE e mais raramente para NW, com predomínio de mergulhos acima de $65^{\circ}$ até subverticais.

Essa foliação por vezes parece evoluir para uma foliação milonítica, que transpõe e oblitera as estruturas originais, gerando feições anastomosadas ou lenticularizadas, que associadas à cominuição dos minerais, transformam os fillitos laminados em filonitos. Esses filonitos estão distribuídos como porções subordinadas, mas podem ser reconhecidos por toda região onde aflora a unidade metapelítica. Dentre outros afloramentos, os filonitos podem ser observados nos pontos CA 982B, MV 1044, JD 1151 e RP $1261 \mathrm{~A}$. 
Uma segunda foliação $S_{2}$ caracteriza-se como uma clivagem de fratura a ardosiana mais espaçada que, às vezes, e em escala de afloramento, crenula o bandeamento $S_{1} / S_{0}$, gerando uma clivagem de crenulação discreta. Localmente, pode tornar-se mais densa e predominar, como ocorre no afloramento do ponto RP 1270, produzindo transposição da estrutura prévia, sendo observados arcos poligonais de minerais micáceos e estiramento de grãos de quartzo.

Como litotipos subordinados na unidade destacam-se os metarritmitos perfazendo bancos de espessura métrica a raramente decamétrica em meio aos filitos. Uma boa exposição do litotipo é o afloramento do ponto CJ 169 , onde os metarritmitos constituem intercalações subcentimétricas a decimétricas intercalando filitos, quartzo filitos, metassiltitos e metarenitos finos de composições e granulações variadas, além de restritos leitos de metaconglomerados de grânulos e de metarenitos ferruginosos.

Metassittitos e quartzo filitos intercalam-se nos filitos como leitos subcentimétricos cremeamarelados ou formando pacotes de espessura até métrica. São laminados a finamente bandados e menos orientados, predominando as texturas granoblástica a lepidogranoblástica, como visto nas amostras do afloramento JD 226.

Intercalações de filitos grafitosos são freqüentes na unidade, como no ponto RP 789. Localmente predominam, constituindo pacotes que se estendem por alguns metros, exibindo bandas cinzas com até $4,0 \mathrm{~cm}$ de espessura onde a grafita predomina que ocorrem intercaladas com bandas brancas (SP 602).

Ocasionalmente, a S de Jordanésia (JD 20), ocorrem ardósias com granulação menor que 0,05 mm portando incipiente cristalização dos minerais metamórficos. Quando frescas são verde-claras, mas alteradas torna-se difícil diferenciá-las dos filitos. A análise petrográfica mostra uma matriz rica em quartzo, sericita e clorita, com leitos ricos em mineral opaco detrítico. O conteúdo de clorita pode aumentar em algumas laminações de granulação relativamente mais grossa, e a biotita, rara, é detrítica, e os grãos observados estão em grande parte reequilibrados para clorita.

Na Rodovia Anhangüera (JD 234) observa-se um litotipo muito alterado com textura variegada e com forte foliação milonítica em meio aos metapelitos. As relações de contato não foram recuperadas, mas o litotipo pode ser uma rocha metabásica milonitizada ou uma ocorrência subordinada de metatufos básicos.

No ponto CJ 316 ocorrem metassedimentos tufíticos alterados de aspecto variegado, com níveis milimétricos argilosos brancos, e associados com metacálcio-pelitos. Restritos leitos quartzosos de granulação fina com veios de quartzo associados e com hematita disseminada constituem um possível nível de metachert no afloramento do ponto JD 227.

\subsubsection{Unidade Metarrítmica (NPSRpgmr)}

A W de Jordanésia e na extremidade nordeste da área, intercalados aos metapelitos, são observados com relativa freqüência bancos métricos até decamétricos de metarritmitos como aqueles descritos na Formação Estradas dos Romeiros. 
Ocasionalmente, os metarritmitos predominam por dezenas até centenas de metros, enquanto que os filitos ocorrem de forma subordinada, sendo possível individualizar cinco corpos lenticulares desta unidade que variam de 150 a 600 metros de espessura e podem atingir até $6 \mathrm{~km}$ na extremidade $\mathrm{NE}$ da área.

No oleoduto que passa nos arredores de Jordanésia, essas interposições ocorrem várias vezes entre os pontos JD 262 e JD 268, sendo observados pacotes de metassiltitos, de metarenitos finos a grossos com grânulos de quartzo, de metaconglomerados compostos por grânulos angulosos de feldspatos caulinizados e de quartzo, e também estão presentes entre esses litotipos os bancos de filitos sericíticos.

Novamente, nos pacotes mais psamíticos, são comuns os veios de quartzo como os descritos na unidade metarrítmica da Formação Estrada dos Romeiros.

\subsubsection{Unidade Metabasítica (NPSRpgmb)}

A W do Bairro Jordanésia ocorrem alguns afloramentos de rochas metabásicas (JD 195, JD 196). Os litotipos observados são muito semelhantes aos descritos na Formação Estradas dos Romeiros e, do mesmo modo, as relações de contato também não são claras. As texturas reliquiares estão mais preservadas, as rochas tendem a verde-claras quando frescas e têm clinopiroxênio ígneo e opaco leucoxenizado.

O corpo delimitado apresenta direção aproximada NNW-SSE, com cerca de 200 metros de espessura e $1 \mathrm{~km}$ de extensão. Intempericamente alteradas, como ocorre entre os pontos JD 194 e JD 206 , exibem cor amarelo-ocrácea com manchas cauliníticas, se em grau incipiente, ou configuram um colúvio vermelho-sangue, como produto final da decomposição.

\subsubsection{Unidade Metavulcanoclástica (NPSRpgmv)}

Intercalado à unidade metapelítica da Formação Piragibu, foi observado um corpo com cerca de 100 metros de espessura a NW, na Estrada dos Romeiros, afloramento do ponto MV 1044, onde predominam metassedimentos tufíticos muito alterados e por vezes variegados, semelhantes aos que ocorrem na Formação Pirapora do Bom Jesus, junto às rochas metabásicas e aos filitos subordinados, sugerindo que, mesmo em direção ao topo do Grupo São Roque, ainda pode existir atividade vulcanoclástica.

\subsection{Neoproterozóico a Fanerozóico}

A grande maioria dos granitóides intrusivos nas supracrustais Serra do Itaberaba e São Roque tem idade variando entre 700 e $520 \mathrm{Ma}$ (TASSINARI et al. 1988), ou entre 669 e $566 \mathrm{Ma}$ para os granitos sin-colisionais e filonianos pós-transcorrência, respectivamente (WERNICK \& TÖPFNER 1997).

Nesta pesquisa não foram feitos levantamentos sistemáticos em campo no interior dos maciços graníticos, e sim apenas nos seus contatos, visando à delimitação da área de ocorrência das supracrustais. Poucos estudos petrográficos foram conduzidos nestes litotipos, sendo utilizados apenas para observação 
das feições gerais. Desta forma, as informações apresentadas a seguir são quase que totalmente derivadas dos artigos e, principalmente, das teses e dissertações compilados.

São os seguintes os principais corpos de granito que ocorrem na área mapeada:

\subsubsection{Maciço Granitóide Itaqui}

Os dados sobre este maciço foram compilados de FERREIRA (1991), que gentilmente emprestou suas cadernetas de campo e a base topográfica original em escala 1:10.000. Novas observações de campo feitas pelo autor na preparação de sua Tese de Doutoramento (FERREIRA 1996) foram incorporadas, produzindo pequenas alterações no mapa original.

Os dados compilados foram confrontados com os dados de campo levantados neste trabalho, o que permitiu um refinamento do traçado do contato, em especial da borda norte do maciço com as rochas metamórficas encaixantes, em grande parte reinterpretadas como pertencentes ao Grupo Serra do Itaberaba. O mesmo foi feito com a distribuição das fácies do maciço, baseado na fotointerpretação efetuada e em zonas de cisalhamento detectadas.

FERREIRA (1991) distinguiu nove subunidades litotípicas mapeáveis na escala 1:50.000, além dos corpos de aplito, pegmatito e encrave máfico, quais sejam:

\subsubsection{Fácies Granodiorito Barueri (NP yitb)}

É a fácies de maior expressão, compreendendo preferencialmente o centro setentrional do maciço, e estende-se até o extremo leste. Ocorre também na forma de corpos menores lenticulares, a oeste, a sudoeste e a sul. É constituída predominantemente por rocha mesocrática porfirítica, com a matriz variando de média a grossa, onde os megacristais de feldspato potássico róseo ocupam ao redor de $12 \%$ do volume, com dimensões de 1,5 até $8,0 \mathrm{~cm}$ de comprimento (Prancha 04/foto $\mathrm{C}$ ). É isótropo, mas pode estar levemente foliado na região da Zona de Cisalhamento Vila Menk, e as intrusões da região sul são afetadas pela Zona de Cisalhamento Taxaquara.

\subsubsection{Fácies Monzogranito Aldeia da Serra (NPyita)}

Constitui um grande corpo na região sul-sudoeste do maciço, com forma aproximadamente alongada na direção E-W. É também uma fácies porfirítica de rochas mesocráticas, porém com índice de máficos menor que a fácies anterior, inequigranular seriada de matriz média. Os megacristais de feldspato róseo variam de 1 a $2 \mathrm{~cm}$ de comprimento e compõem cerca de $3 \%$ do volume da rocha.

\subsubsection{Fácies Monzogranito Pedreira Cantareira (NPyitp)}

Distribui-se no centro-sul do maciço, onde forma um corpo alongado segundo NW, quase que totalmente envolvido pela fácies Aldeia da Serra, e na porção noroeste, onde apresenta contato predominante com a fácies Barueri. Predominam rochas leucocráticas inequigranulares seriadas a porfiríticas, de granulação média a grossa. Os megacristais de feldspato potássico róseo têm comprimentos variando de 1,5 a 7,0 $\mathrm{cm}$ e perfazem ao redor de $3 \%$ do volume da rocha. 


\subsubsection{Fácies Monzogranito Mutinga (NP yitm)}

Esta fácies foi individualizada na parte leste do maciço e suas rochas são caracteristicamente leucocráticas, equigranulares a inequigranulares seriadas de granulação média. Raramente possuem megacristais de feldspato potássico róseo, com eixo maior entre 1,5 e $3,5 \mathrm{~cm}$.

\subsubsection{Fácies Monzogranito Suru (NP $\gamma$ its)}

Aflora no extremo norte-noroeste do maciço, constituindo um corpo alongado aparentemente truncado pelo Granodiorito Barueri, e como uma pequena intrusão circular nas supracrustais do Grupo Serra do Itaberaba a nordeste do maciço. A fácies é constituída por rochas hololeucocráticas com textura xenomórfica equigranular média, alto teor de quartzo, com biotita como cristais isolados e com feldspato potássico cinza-esbranquiçado, que a diferencia das demais fácies.

\subsubsection{Fácies Monzogranito Torre (NP $\gamma \mathrm{itt})$}

Ocorre como diques cortando o granodiorito Barueri na porção centro-noroeste do maciço. A rocha é leucocrática, tem estrutura levemente anisótropa, textura equigranular fina a média, sendo muito raros os cristais de feldspato potássico róseo, que variam de 0,5 a $1 \mathrm{~cm}$. Encontra-se em geral semialterada, o que lhe confere cor cinza-clara a cinza-rosada, porém quando fresca é cinza-escura. Apresenta estrutura de fluxo ígneo, encraves e diques e, na zona de contato das maiores intrusões no granodiorito Barueri, forma uma rede de diques de espessura centimétrica, que divide o granodiorito em blocos retangulares angulosos.

\subsubsection{Quartzo Monzonito Cruz Preta (NP yitc)}

Ocorre como um conjunto de diques nas proximidades do $\mathrm{km} 30$ da Rodovia Castelo Branco, intrusivos no Granito Pedreira Cantareira e, mais raramente, no granodiorito Barueri A fácies é caracterizada por rocha mesocrática com textura porfirítica, com matriz fina a média e megacristais de feldspato potássico ao redor de $13 \%$ do volume, com dimensões maiores entre 0,5 e 1,5 cm.

\subsubsection{Dique Mesocrático Equigranular (NPyitd)}

O corpo tem largura máxima aflorante ao redor de 100 metros e ocorre na região centro-sul, nas frentes de lavra das pedreiras Cantareira e Barueri, encaixado na fácies Pedreira Cantareira e truncado pelo Quartzo Monzonito Cruz Preta. É constituído por quartzo monzonito equigranular, fino a médio e mesocrático.

\subsubsection{Dique Melanocrático Porfirítico (NPritdp)}

Ocorre na mesma região da fácies anterior. A fácies compreende um enxame de encraves de quartzo monzonito com matriz fina e megacristais de feldspato potássico com aproximadamente $0,5 \mathrm{~cm}$ em teores muito variáveis. O índice de cor situa-se ao redor de 36. 


\subsubsection{Stock Granítico Tico-Tico (NP $\gamma \mathrm{tt})$}

O corpo granítico do Tico-Tico aflora na região centro-leste da área, exibindo forma elíptica com eixo maior ao redor de $7 \mathrm{~km}$, orientado aproximadamente segundo NNE.

Dentre as rochas que compõem o stock, predominam sienogranito a monzogranito leuco- a hololeucocráticos com textura fanerítica inequigranular média a grossa, localmente porfirítica. Quando frescos, são branco-acinzentados ou cinza-claros e, devido ao intemperismo, tornam-se creme-amarelados ou avermelhados.

Nas partes internas do corpo predominam rochas maciças, que tornam-se mais finas e foliadas nas bordas, segundo a orientação dos xistos ou milonitos encaixantes. Veios pegmatóides de espessura submétrica freqüentemente cortam os granitos e encaixantes.

Segundo PENALVA \& HASUI (1970), têm ortoclásio pertítico, quartzo e albita como constituintes principais, e biotita, muscovita, granada, apatita e zircão acessórios. Turmalina foi caracterizada como mineral pós-magmático e cristalizado a expensas da biotita ou do feldspato.

A idade U-Pb em zircão das rochas é de aproximadamente 625 Ma (TEUPPENHAYN 1994 e TÖPFNER 1996, em AZEVEDO, 1997). Uma vez que o granito é intrusivo pelo menos na $S_{2}$ do Grupo Serra do Itaberaba, que corresponde à $S_{1}$ do Grupo São Roque, pode-se interpretar que o metamorfismo do último grupo deve ser mais novo que esta idade. A idade das transcorrências pós-cavalgamento do Grupo São Roque que afetam o stock são, conseqüentemente, posteriores a $625 \mathrm{Ma}$.

\subsubsection{Maciço Granitóide São Roque}

Aflora no extremo oeste da área e é completamente limitado por zonas de cisalhamento. A leste e a oeste está em contato com as supracrustais através das zonas de cisalhamento Araçarigüama (HACKSPACHER et al. 1992b) e Mairinque (OLIVEIRA et al. 1992a), respectivamente. A sul é cortado pela Zona de Cisalhamento Taxaquara (HENNIES et al. 1967), que o coloca em contato com o granito Ibiúna e com metassedimentos do Complexo Embu.

HACKSPACHER et al. (1992b, 1996) e GODOY et al. (1996b) individualizaram no maciço cinco fácies petrográficas, sendo que quatro delas ocorrem na região mapeada. Predomina a Monzogranítica Porfiróide Rósea, que compõe a quase totalidade das rochas que afloram na área, enquanto que as outras três estão circunscritas no interior do batólito.

\subsubsection{Fácies Monzogranítica Porfiróide Rósea (NP $\gamma \mathrm{srp}$ )}

Constitui o arcabouço do maciço, apresentando estrutura predominante maciça, ocorrendo orientada até milonitizada em direção às bordas ou nas zonas de cisalhamento internas. As rochas têm granulação média a grossa, textura porfirítica, com cerca de $20 \%$ a $25 \%$ do volume de megacristais róseos de feldspato potássico de granulação variando de 2,0 a $5,0 \mathrm{~cm}$ dispersos em matriz cinza quatzofeldspática, com biotita e hornblenda. 


\subsubsection{Fácies Monzogranítica Equi- a Inequigranular Média a Grossa (NP $\gamma s r c)$}

Encontra-se delimitada na região norte do batólito como um corpo elíptico circunscrito por rochas da fácies anterior. O litotipo caraterístico tem cor cinza, estrutura predominantemente maciça, com orientação incipiente na direção NE-SW e com biotita e/ou anfibólio e, por vezes, muscovita.

\subsubsection{Fácies Monzogranítica Equigranular Média Rosada (NP $\gamma s r e)$}

Os litotipos que compõem esta fácies distribuem-se na área de ocorrência da fácies NP $\gamma$ src. E descrita como constituindo um pequeno corpo de tendência circular e diâmetro ao redor de 500 metros. A composição mineralógica é semelhante à das rochas da fácies anterior, das quais diferencia-se por conter turmalina e muscovita na matriz.

\subsubsection{Fácies Sieno-Monzogranítica Gradacional (NP $\gamma \mathrm{srg}$ )}

Ocorre na porção sul do batólito como um corpo alongado com direção NNW-SSW. A fácies é inequigranular média a grossa com alta concentração de feldspato potássico, além de quartzo, plagioclásio e mineral micáceo, e os cristais de biotita mostram orientação NE-SW. Exibe passagem gradacional para a fácies principal por meio da diminuição do teor e da granulação do feldspato potássico, variando para composições monzograníticas e para os termos porfiróides.

\subsubsection{Maciço Granitóide Cantareira}

Apenas a extremidade sudoeste do maciço aflora no lado leste da área.

O maciço foi detalhadamente mapeado por DANTAS (1990), que o caracterizou como constituído predominantemente por rochas da Fácies Porfiróide Creme - Tipo Pirituba. Próximo à Caieiras, na área deste trabalho, predominam rochas desta fácies e ocorrem, de modo subordinado, rochas das fácies Porfiróide Rósea - Tipo Itaguassu, Fácies Porfiróide Cinza-Azulada - Tipo Canivete e Fácies Inequigranular Cinza - Tipo Hortolândia.

A análise das aerofotos indica claramente diversas estruturas concêntricas superpostas e alguns contatos que parecem limitar algumas das fácies. Entretanto, a correspondência destas estruturas com os corpos individualizados por DANTAS (1990) é bastante grosseira ou até mesmo inexistente, especialmente com relação às estruturas concêntricas. Dessa forma, os corpos tiveram seus limites redefinidos em função da fotointerpretação e dos afloramentos compilados, mas nem todas estruturas puderam ser correlacionadas com os afloramentos.

Assim, o mapa apresentado é o reinterpretado, mas as distribuições das fácies não foram estudadas em campo, por não ser este o objetivo da pesquisa.

Segundo DANTAS (1990), as características das fácies são as seguintes:

\subsection{4 .1 Fácies Porfiróide Creme - Tipo Pirituba (NP $\gamma \mathrm{cp})$}

Corresponde à Fácies Cantareira de CARNEIRO (1983), e seu contato com as encaixantes se dá através de zona cisalhamento sinistral. Segundo CARNEIRO (1983), nas proximidades do contato os 
litotipos geralmente estão foliados e há transição de tipos equigranulares para porfiróides. Encraves anfibolíticos, xenólitos gnáissicos e anfibolíticos são comuns.

As rochas são cinzas a cinza-claras, podendo ser cinza-escuras devido à abundância local de minerais máficos. De modo geral, as estruturas são predominantemente maciças, com megacristais de microclínio creme a esbranquiçado dispersos aleatoriamente na matriz, que localmente podem exibir orientação. Predomina biotita monzogranito, ocorrendo subordinados monzogranito e quartzo monzodiorito. Além do plagioclásio, microclínio, quartzo e biotita como constituintes principais, ocorrem minerais opacos, titanita, apatita e zircão como acessórios e clorita, epídoto e sericita deutéricos.

Essas rochas possuem idade U-Pb em zircão de $630 \pm 8 \mathrm{Ma}$ (TÖPFNER 1996, em AZEVEDO 1997).

\subsubsection{Fácies Porfiróide Rósea - Tipo Itaguassu (PS $\gamma c i)$}

Ocorre como uma lente de direção ENE-WSW inserida quase que totalmente em rochas da Fácies Pirituba e exibe contatos bruscos ou transicionais com as demais fácies do Maciço Cantareira.

Os litotipos desta fácies são caracterizados por sua matriz cinza-esverdeada, megacristais de microclínio róseo, feldspatos potássicos esbranquiçados dispersos na matriz ou inclusos nos megacristais, sulfetos abundantes em planos de fratura, intensa epidotização e forte alteração deutérica, com saussuritização, sericitização, cloritização, carbonatação e zeolitização.

As rochas têm composição predominante monzogranítica a granodionítica e, subordinadamente, ocorrem monzodiorito, granodiorito, quartzo-diorito, quartzo-monzonito e sienogranito, por vezes enriquecidos em biotita monzogranito. Como acessórios estão presentes minerais opacos, titanita, apatita, zircão e alanita, os dois últimos presentes no monzogranito.

\subsubsection{Fácies Porfiróide Cinza Azulada - Tipo Canivete (NPycc)}

A ocorrência das rochas desta fácies restringem-se à borda noroeste do Maciço Cantareira, que está delimitada na terminação nordeste do mapa geológico, onde ocorrem em contato brusco a transicional com as fácies Hortolândia e Pirituba e são intrusivas nas rochas supracrustais do Grupo Serra do Itaberaba, sendo que, mais a nordeste, o contato é tectônico.

As rochas são maciças e têm megacristais de microclínio cinza-azulado a cinzawclaro aleatoriamente distribuídos. Predomina monzogranito e granodiorito é subordinado, mas também ocorrem variações para tonalito, quartzo monzodiorito e sienogranito. O plagioclásio tem, freqüentemente, composição albítica, e a biotita é um constituinte importante. Como acessórios ocorrem titanita, minerais opacos, alanita, apatita e zircão.

\subsubsection{Fácies Inequigranular Cinza - Tipo Hortolândia (NP $\gamma \mathrm{ch})$}

Essa fácies aflora como um corpo delgado, em forma de "V", e representa, possivelmente, fácies de borda de intrusões menores.

Os litotipos têm cor cinza-clara a média, textura inequigranular orientada, granulação média a 
grossa e podem, às vezes, possuir raros megacristais de microclínio. Esses tornam-se mais frequientes nas proximidades com os tipos porfiróides, indicando contatos transicionais.

Os litotipos principais são monzogranitos e granodioritos, ambos ricos em biotita, com tonalito e quartzo monzodiorito subordinados. Caracteristicamente, apresentam plagioclásio mais cálcico, geralmente com composição de andesina. Possuem ainda epídoto, minerais opacos, titanita, apatita, zircão e alanita.

\subsubsection{Maciço Granitóide Ibiúna}

Aflora no extremo sul da área, a partir do início da Zona de Cisalhamento Taxaquara, e está interdigitado tectonicamente com rochas metamórficas do Complexo Embu. A individualização de fácies na escala 1:250.000 deverse a JANASI et al. (1990).

Na região de estudo afloram as fácies Itapevi e Ibiúna (ou Santa Isabel) sob a forma de corpos alongados segundo ENE-WSW devido ao intenso cisalhamento, que fez com que a maior parte das rochas se transformassem em milonitos.

Suas principais características são:

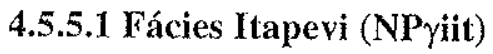

É constituída por rochas cinzas, foliadas, equi- a inequigranulares e de granulação média a fina, comumente muito deformadas. Ocorrem tipicamente como corpos laminares de espessura decamétrica introduzidos nos xistos e gnaisses migmatíticos do Complexo Embu.

A composição predominante é monzogranítica e tem biotita como único máfico. Titanita e alanita são abundantes e, como acessórios, estão presentes minerais opacos, apatita e zircão, além de epídoto e fluorita como minerais hidrotermais.

FERREIRA (1991) descreveu litotipos desta fácies com textura porfirítica, com matriz escura de granulação fina a muito fina foliada, e com biotita, quartzo e feldspato esverdeado. Os cristais de feldspato potássico rosa subeuedrais geralmente variam entre 3 e $5 \mathrm{~mm}$, raramente atingindo $20 \mathrm{~mm}$, e são comuns veios e diques pegmatíticos com espessura máxima de $20 \mathrm{~cm}$.

\subsubsection{Fácies Ibiúna (NPriib)}

Aflora em toda porção sul da área e está parcialmente recoberta pelos sedimentos da Bacia de São Paulo. Foram feitos poucos levantamentos em campo nessa região, e os mapas existentes estão em escala pequena, incompatível com a escala do mapa do ANEXO V. Desta forma, é muito provável que outros litotipos também ocorram associados, especialmente migmatitos, gnaisses e xistos do Complexo Embu.

As rochas típicas desta fácies são biotita-hornblenda granodiorito e monzogranito porfiríticos, com megacristais de feldspato potássico frequientemente alcançando mais de $5 \mathrm{~cm}$ de comprimento. A estrutura varia de maciça a porfiroclástica com matriz protomilonítica, e podem ocorrer enchaves microgranulares e corpos dioríticos subordinados. O feldspato potássico é pertítico e apresenta inclusões de plagioclásio e biotita, e a matriz é equigranular, de granulação média a grossa. O plagioclásio tem 
composição de andesina-oligoclásio, a hornblenda predomina nos litotipos maciços e a biotita aumenta sua concentração nos tipos mais deformados e com maior índice de cor. Como minerais acessórios, estão presentes titanita, alanita, magnetita, apatita e zircão. Epídoto e clorita são abundantes em amostras mais deformadas.

\subsubsection{Turmalina Granito Perus}

O Turmalina Granito Perus constitui pelo menos treze pequenas bossas intrusivas nos xistos pelíticos do Grupo Serra do Itaberaba, distribuídas no bairro homônimo. As dimensões do corpo maior estão ao redor de 300 metros de diâmetro.

Das fácies distinguidas por AZEVEDO (1997), três delas afloram e foram individualizadas no mapa geológico, predominando amplamente a fácies bandada, quais sejam:

\subsubsection{Fácies Bandada (NPytpb)}

É composta por rochas com bandeamento bem definido, dado pela alternância rítmica de leitos claros e escuros, com espessura entre 1 e $10 \mathrm{~cm}$, gradacionais, quartzo-feldspáticos e ricos em turmalina. São comuns sistemas de dobras complexos.

As rochas têm composição predominantemente granodiorítica, com variações para tonalito e quartzo-monzodiorito. São leuco- a hololeucocráticas, equigranulares finas a grossas, com turmalina negra sempre presente que pode alcançar $15 \%$ do volume. Granada e apatita são acessórios frequientes.

\subsubsection{Fácies Pegmatóide Interna (NP $\gamma$ tpi).}

Ocorre como bolsões até decamétricos, veios ou corpos irregulares, ou ainda como diques e sills nas intrusões onde predominam os litotipos bandados. Restringem-se aos corpos delimitados a sul do Morro de Perus.

É composta por turmalina pegmatito leucogranito de granulação grossa a muito grossa, com plagioclásio ausente ou muito subordinado. Granada e apatita podem estar presentes como acessórios. Variam para sienogranitos a álcali-feldspato granitos, com o plagioclásio gradativamente mais raro nos litotipos mais grossos.

As rochas desta fácies distinguem-se das demais por apresentarem turmalina verde e rósea. Em fraturas e em pequenos bolsões é comum a ocorrência de minerais secundários, como argilominerais e minerais uraníferos (ATENCIO \& HYPÓLITO 1994).

\subsubsection{Fácies Pegmatóide Externa (NP $\gamma$ tpe)}

É formada por veios e diques em corpos da Fácies Bandada ou nos xistos pelíticos do Grupo Serra do Itaberaba. Têm espessura decamétrica e podem atingir até 150 metros de comprimento, parecendo controlados por falhas de direções NE-SW e NW-SE. As rochas são homogêneas e maciças, apresentam textura inequi- a equigranular e são constituídas por quartzo, feldspatos, turmalina, granada, muscovita e apatita. 


\subsubsection{Granito Morro de Perus (NP $\gamma \mathrm{mp})$}

Aflora como matacões no morro homônimo, onde ocupa uma área com cerca 300 metros de diâmetro.

As rochas são maciças, com tipos porfiróides nas bordas e inequi- a equigranulares no centro, onde mostram granulação média a grossa (DANTAS 1990).

É composto pelas fácies Porfiróide Creme, constituída por leucogranito semelhante ao Tipo Pirituba, Inequigranular Mosqueada, formada por leucomonzogranito fino a médio, Equigranular Mosqueada, também com composição leucomonzogranítica, porém de granulação grossa e com característicos agregados esparsos de biotita, e Aplítica, que ocorre sob a forma de bolsões irregulares e vênulas centimétricas.

São compostos por quartzo, microclínio e plagioclásio, além de granada, apatita, zircão, magnetita, ilmenita e hematita acessórios. Tipicamente, possuem pirita, pirrotita e calcopirita relativamente abundantes.

\subsubsection{Stocks Graníticos 'Teveré (NP $\gamma \mathrm{t})$}

Afloram a norte da Rodovia Castelo Branco nas proximidades de Araçarigüama, e foram descritos por HACKSPACHER et al. (1992b, 1996) como intrusivos no contato entre os xistos do Grupo Serra do Itaberaba e os metarritmitos da Formação Estrada dos Romeiros e cortados pela Falha Doninhas.

BERGMANN (1988) já havia descrito parte destas rochas muito foliadas, e as considerou como granitos e gnaisses com texturas proto- a ultramiloníticas. Parte da rochas preservam ainda relíquias de texturas ígneas, sendo classificadas como gnaisse blastomilonítico com muscovita e biotita xistos intercalados, além de biotita granito porfiroclástico de granulação média. HACKSPACHER et al. (1996) verificaram ainda rochas com composição sienogranítica com biotita subordinada.

Neste trabalho, o corpo foi verificado como composto por três stocks elípticos menores, com eixos maiores entre 1000 e 1500 metros, intrusivos na Unidade dos Xistos Pelíticos da Formação Morro da Pedra Preta. A norte, são afetados pela Falha Doninhas, que separa o Grupo Serra do Itaberaba do Grupo São Roque.

\subsubsection{Stock Granítico Ponunduva}

Parte do stock foi cartografada na porção NNW da área, onde apresenta cerca de $3 \mathrm{~km}$ de largura e de onde ramifica-se para sudoeste em dois corpos com larguras de 750 e 1500 metros separados pela Unidade Metapelítica da Formaçẫo Piragibu.

Sua colocação parece ser controlada por zonas de cisalhamento, como sugerido por seu formato alongado (HASUI et al. 1969, NASCIMENTO \& RUEGGER 1986, BERGMANN 1988), e é afetado por ramos secundários das zonas de cisalhamento de Mairinque, Araçarigüama e Morro Grande.

Os contatos com as encaixantes, quando não tectônicos, são discordantes e intrusivos. Duas fácies 
foram individualizadas por NASCIMENTO \& RUEGGER (1986) e ALMEIDA \& MOYA (1986), quais sejam:

\subsubsection{Fácies Porfiróide (NP $\gamma p p)$}

Ocorre na porção sudeste do stock e nas partes mais poupadas pela milonitização. As rochas são semelhantes às do Tipo Pirituba. Possuem megacristais de feldspato potássico com até $2 \mathrm{~cm}$ de comprimento que podem perfazer $30 \%$ do volume dispersos em matriz inequigranular média a grossa, em geral esverdeada devido à epidotização.

Os litotipos são leucocráticos e maciços, mas mais comumente possuem estruturas cataclásticas e miloníticas na borda sudeste do corpo (PO 63, RP 1256), onde ocorrem protomilonitos porfiróides, localmente ocelares, que gradam para ultramilonitos, por vezes tão recristalizados que geram filonitos que podem ser confundidos com os milonitos de metassedimentos, como no ponto PO 07.

Predominam monzogranito e sienogranito, mas granodiorito também ocorre subordinadamente, todos com megacristais de microclínio, às vezes pertítico, com inclusões de plagioclásio. Na matriz os teores de plagioclásio e de feldspato potássico são semelhantes, o quartzo compõe menor volume e também estão presentes biotita e, mais raramente, muscovita primária. Os feldspatos estão intensamente saussuritizados ou sericitizados devido ao hidrotermalismo associado ao cisalhamento. Em rochas fortemente milonitizadas, a muscovita pode tornar-se o principal constituinte, tendo clorita e epídoto associados. Como acessórios, foram verificados magnetita e pirita (freqüentemente limonitizados), titanita, zircão e, ocasionalmente, alanita.

\subsubsection{Fácies Inequigranular (NP $\gamma$ pi)}

Aflora nas regiões noroeste e central do stock, e foi caracterizada como posterior à Fácies Porfiróide por NASCIMENTO \& RUEGGER (1986).

É constituída por granitóides leucocráticos amarelo-esbranquiçados, inequigranulares e de granulação média a grossa, maciços a incipientemente orientados até pronunciadamente foliados nas proximidades de zonas de cisalhamento. As composições são semelhantes às rochas da Fácies Porfiróide, predominando monzo- a sienogranitos com termos granodioríticos menos comuns. O quartzo predomina nas porções milonitizadas e é subordinado nos litotipos isótropos, indicando silicificação e/ou lixiviação seletiva de álcalis pelos fluidos hidrotermais associados ao cisalhamento. Minerais opacos, apatita, titanita, zircão e turmalina são acessórios e biotita primária pode estar ocasionalmente presente. Epídoto, clorita e sericita/muscovita são freqüentes em rochas milonitizadas ou cataclasadas, sendo que a última pode constituir até $20 \%$ do volume em rochas mais deformadas.

\subsubsection{Stock Granítico Guaxatuba - Pica-Pau (PS $\gamma \mathrm{g}$ )}

Ocorre na extremidade noroeste da área, onde constitui uma faixa de litotipos intensamente foliados embutidos na Zona de Cisalhamento Itu-Jundiuvira. A sul, está em contato tectônico com os 
metapelitos da Formação Piragibu, através da Zona de Cisalhamento Moreiras e, a norte, com quartzitos feldspáticos da Formação Japi do Complexo Itapira.

A denominação Guaxatuba é devida a HASUY et al. (1969), mas OLIVEIRA et al. (1992b), ao relatarem a existência do corpo granitóide presente no contato entre as zonas de cisalhamento ItuJundiuvira e Moreiras, o denominaram Granito Pica-Pau. Aparentemente, trata-se do mesmo corpó, razão pela qual foi aqui denominado de Guaxatuba - Pica-Pau.

Quando não cataclasados, têm composição sienogranítica, são róseos, equigranulares a inequigranulares, com granulação média e estrutura maciça.

Comumente são protomilonitos cinza-esverdeados de granulação média, com porfiroclastos ocelares de feldspato potássico centimétrico (MV 1033), mas não faltam ultramilonitos fïnos cinzas com porfiroclastos menores e mais raros fortemente estirados, ou cataclasitos cinzas. São compostos por feldspato potássico pertítico, oligoclásio e biotita, além de sericita, epídoto e clorita.

A semelhança destas rochas com as dos maciços São Roque e Itaqui fez que HACKSPACHER et al. (1992a, 1992b) os interpretassem como contemporâneos.

\subsubsection{Stock Granútico Itaim (NP $\gamma \mathrm{i})$}

Constitui um pequeno corpo intrusivo nas unidades Metaconglomerática e Metarcoseana da Formação Morro Doce nas proximidades da sede da Fazenda Itayhe.

COUTINHO (1972) considerou o stock como composto por granito porfirítico Tipo Pirituba e CARNEIRO (1984) o associou à Fácies Cantareira.

É formado por biotita granodiorito porfirítico cinza-esbranquiçado, com matriz inequigranular média a grossa tenuemente orientada. Os megacristais de microclínio têm cor creme a rosada, são comumente pertíticos, atingem até $3 \mathrm{~cm}$ de comprimento e contêm inclusões de biotita. Na matriz predomina plagioclásio, com feldspato potássico e quartzo subordinados. A biotita é verde, ocupa ao redor de $10 \%$ do volume da rocha, e está contida na foliação dos litotipos orientados. Titanita e mineral opaco cúbico ocorrem como acessórios comuns, enquanto que alanita, apatita e zircão são mais raros. Como minerais deutéricos, ocorrem epídoto e sericita.

\subsubsection{Stock Granítico Juqueri (NP $\gamma \mathbf{j})$}

Forma uma pequena intrusão ovalada situada na terminação nordeste da área, em Franco da Rocha, seccionada pela Falha Juqueri. A rochas possuem estrutura maciça na região central do corpo e tornam-se gradativamente foliadas e cataclasadas nas bordas em contato com os filitos do Grupo São Roque.

Predomina monzogranito cinza-claro inequigranular e de granulação fina a média. De acordo com DANTAS (1990), tem como constituintes principais quartzo, microclínio e plagioclásio em teores 
semelhantes, e biotita em quantidade bem subordinada. Minerais opacos, alanita e apatita são os acessórios principais, enquanto que epídoto, clorita e sericita são hidrotermais.

\subsection{Neoproterozóico a Recente}

Muito embora deva haver zonas de cisalhamento na área com evolução que remonte a períodos mais antigos, a principal movimentação tectônica ocorreu na transição Neoproterozóico/Fanerozóico, com reflexos até os dias de hoje. Por este motivo, optou-se pelo título anterior.

\subsubsection{Zonas de cisalhamento}

As zonas de cisalhamento foram aqui consideradas como sendo estruturas que compreendem um grande número de falhas concentradas em feixes, produzindo milonitização e cataclase em uma faixa relativamente larga.

Diversas zonas de cisalhamento têm sido mapeadas na porção noroeste da cidade de São Paulo, podendo-se destacar os trabalhos de HACKSPACHER et al. (1988, 1992a, b), DANTAS (1990), FERREIRA (1991) e JULIANI (1993).

As zonas de cisalhamento observadas na região concentram-se preferencialmente no contato entre os maciços granitóides com as rochas supracrustais. Isso é devido, inicialmente, ao fato de as zonás de cisalhamento constituírem sítios preferenciais de colocação de magma, ainda quando ativas (HACKSPACHER et al. 1993a, WERNICK et al. 1993b). Posteriormente, a continuidade das movimentações concentra a deformação nas bordas das massas graníticas consolidadas, que acabam por se constituírem em blocos rígidos, contra os quais são comprimidas as supracrustais, ocasionando alívio das tensões através de zonas de empurrão e de transcorrências.

Por outro lado, os produtos do cisalhamento de rochas graníticas são, geralmente, relativamente menos afetados pelo intemperismo que os de metassedimentos, tornando seus afloramentos proporcionalmente mais freqüentes. São também mais facilmente identificáveis macroscopicamente que os filitos, facilitando sua caracterização em campo, razão pela qual há uma tendência de predominância de zonas de cisalhamento e de falhas nas rochas que compõem os maciços graníticos.

As zonas de cisalhamento identificadas na área são agrupadas segundo suas características de movimentação relativa, quais sejam:

\subsubsection{De empurrão}

Estas são identificadas pela primeira vez nesta pesquisa como estruturas extensas e importantes na região. De modo geral, são semelhantes às zonas de empurrão descritas por JULIANI (1993) na região da Serra do Itaberaba, onde, de modo análogo, são parcialmente responsáveis pela colocação do Grupo São Roque sobre o Grupo Serra do Ttaberaba.

As zonas de empurrão são melhor observáveis em afloramentos e em testemunhos de sondagens da base do Morro Doce, como porções preservadas pela transcorrência superposta nos flancos do Morro 
do Polvilho e na base do Morro Doce (Prancha 04/foto D), em xistos da região do bairro Várzea do Souza, na base de metarcóseos e de metarritimitos na Fazenda Itayhe, na base leste do Pico do Jaraguá, na Rodovia dos Bandeirantes, e em diversos afloramentos do contato norte do Grupo Serra do Itaberaba com - Grupo São Roque (Prancha 02/foto B). Internamente aos grupos, mais especialmente no Grupo Serra do Itaberaba, são também comuns zonas mais ou menos extensas. Em outros locais, foram inferidas por fotointerpretação e por nítidas descontinuidades nas atitudes das camadas superpostas e sotopostas.

Constituem zonas heterogêneas, com forte variação na intensidade da deformação, com espessuras usualmente superiores a 100 metros e geometria anastomosada. Com o afastamento das regiões mais deformadas, as zonas milonitizadas tornam-se menos espessas e menos freqüentes, até restarem como zonas com poucos centímetros de espessura e com formas ramificadas.

As atitudes apresentam pouca variação e os mergulhos variam de baixo a médio, comumente para quadrantes opostos, indicando dobramento aberto superposto ou, mais provavelmente, ondulações causadas pelos movimentos finais associados ao próprio esforço tectônico. Atitudes suborizontais são comuns e, mais raramente, ocorrem mergulhos mais altos, especialmente em zonas afetadas pelas transcorrências superpostas.

No contato norte, onde as transcorrências são muito intensas, predominam falhas inversas, com lineaçôes minerais e de estiramento de quartzo indicando movimento geral para norte com variações para nordeste e noroeste. Localmente, verificam-se tendências de baixo ângulo na lineação, indicando forte componente transcorrente no movimento final, ou basculamentos, uma vez que afloramentos próximos mostram-se suborizontalizados.

Nos flancos do Morro do Polvilho, esta foliação preserva-se dentro de milonitos associados às transpressões relacionadas a transcorrências, que geram falhas em flor positivas. Nos xistos menos afetados são comuns dobras recumbentes com o flanco inverso rompido (Prancha 04/foto E), e dobras intrafoliais cortadas por milonitos de baixo ângulo, com características mais rúpteis, onde são freqüentes as estruturas $S$ - $C$ indicativas de deslocamentos para norte.

Grandes afloramentos de filonitos dobrados de baixo ângulo de mergulho foram observados cortados pelos milonitos da Zona de Cisalhamento Taxaquara.

A rocha típica é um filonito comumente laminado, constituído por lentes estiradas de diversos litotipos e de quartzo-de-veio, com paragêneses compatíveis com a fácies xisto-verde. Esses filonitos estão quase sempre muito alterados, e podem ser confundidos com filitos do Grupo São Roque, dos quais se distinguem pela presença de restos de estaurolita e silimanita. Podem apresentar dobras intrafoliais pequenas, com eixo um pouco deformado, que parecem gradar para dobras em bainha, e estão freqüentemente afetados por dobras assimétricas abertas, com um fraca crenulação ou clivagem de fratura associada, com indicação de movimentação no mesmo sentido das estruturas do filonito. Muito comumente verifica-se truncamento do filonito por milonito de menor espessura, com atitudes um pouco diferenciadas. Esses milonitos foram verificados praticamente em todos os litotipos, mas parecem 
predominar nos metassedimentos tufíticos que, por apresentarem comportamento muito plástico, podem ter concentrado as deformações (Prancha 01/foto $\mathbf{E}$ ).

No contato norte entre os grupos Serra do Itaberaba e São Roque ocorre uma extensa zona de filonitos geralmente verticalizados pelas transcorrências, embora ainda sejam encontradas porções de baixo ângulo com indicadores cinemáticos que caracterizam o empurrão, que encaixam lentes com vários metros de espessura de milonito de granitos.

A estrutura geral da zona de empurrão permite interpretar a principal área de ocorrência do Grupo Serra do Itaberaba ao redor do Granito Tico-Tico como uma janela estrutural, mas as zonas de empurrão tem continuidade mais a sul do Granito Itaqui, podendo constituir-se em uma estrutura tectônica importante no Pré-Cambriano dos arredores de São Paulo.

Localmente, foram observadas falhas de empurrão com espessura decimétrica cortando os milonitos das transcorrências, que devem estar associadas aos movimentos transpressivos fanerozóicos ou até mesmo cenozóicos.

\subsubsection{Transcorrentes}

\section{a) Zona de Cisalhamento Taxaquara (ZCT)}

A Falha Transcorrente de Taxaquara, situada no extremo sul da área, foi definida por HENNIES et al. (1967) e redefinida como zona de cisalhamento por HACKSPACHER et al. (1988). Possui direção geral E-W, secciona os granitos São Roque, Ibiúna e Itaqui, litotipos do Grupo Serra do Itaberaba e do Complexo Embu, e é parcialmente recoberta pelos aluviões do rio Tietê a leste.

Caracteristicamente ocorrem várias fases de deformação, evidenciadas por milonitos subverticais que cortam os milonitos anteriores (Prancha 04/foto F). As lineações de estiramento são suborizontais ou com mergulhos suaves a médios nos milonitos mais antigos, e tendem à reta de maior mergulho nos mais tardios, indicando fortes escapes de massa nos últimos eventos ou reativações.

Na porção SW da área, nas proximidades do bairro São João Novo (SA 1111 até SA 1114), os litotipos do Maciço Granitóide Ibiúna foram transformados em protomilonito e milonito, com os megacristais de feldspato potássico fortemente estirados, conferindo às rochas textura porfiroclástica. No contato dos granitos com as supracrustais é comum verificar-se milonitos ou ultramilonitos bandados ou laminados, com intercalações de leitos micáceos, tufíticos ou grafitosos alternados aos félsicos com quartzo, feldspatos e muscovita.

Entre as cidades de Osasco e Barueri e na Rodovia Castelo Branco os milonitos dos granitóides Ibiúna e Itaqui são muito foliados, com porfiroclastos de feldspato potássico rotacionados, por vezes amendoados. Ultramilonitos estão sempre associados e têm granulação muito fina a fina, são ricos em clorita e possuem porfiroclastos de feldspatos muito estirados. Os planos de falhas estão freqüentemente epidotizados.

No trevo de Carapicuíba para Barueri (CA 994A) os conglomerados da Formação São Paulo encontram-se localmente milonitizados no contato com o Maciço Ibiúna e, eventualmente, ocorrem 
imbricados no granitóide fino e milonitizado da fácies Itapevi, rico em biotita e muscovita, e que exibe cristais estirados de feldspato de até $1 \mathrm{~cm}$ de comprimento, indicando atividade da ZCT pelo menos até o Terciário. Rochas ultramiloníticas das proximidades possuem falhas inversas e de baixo ângulo que cortam a foliação milonítica, com indicadores cinemáticos que mostram transporte de massa para NNE (Prancha 04/foto G).

\section{b) Zona de Cisalhamento Itu-Jundiuvira (ZCIJ)}

A Zona de Cisalhamento Itu-Jundiuvira foi assim denominada por HACKSPACHER et al. (1988), incluindo o Falhamento de Itu (HASUI \& SADOWSKI 1973) e o Falhamento de Jundiuvira (HASUI et al. 1969). Aflora na região NW da área, onde apresenta direção ENE-WSW e afeta os metassedimentos do Grupo São Roque, rochas do Complexo Itapira e do Stock Granítico Guaxatuba Pica-Pau.

Nos quartzitos feldspáticos do Complexo Itapira nota-se forte estiramento dos grãos de quartzo, enquanto que nos filitos do Grupo São Roque as feições de cataclase são difíceis de serem observadas, mas esses apresentam-se laminados e dobrados intrafolialmente, com transposição.

As rochas variam de cataclasitos a ultramilonitos, mas predominam milonitos de rochas graníticas e quartzíticas e filonitos de xistos, com estiramento e lineações predominantemente suborizontalizadas. A deformação é muito heterogênea, com feições anastomosadas, e falhas mais tardias, normais, inversas e transcorrentes são freqüentes. Outra estrutura relativamente comum é definida por zonas de empurrão menores, por vezes muito pouco recristalizadas.

\section{c) Zonas de Cisalhamento Mairinque (ZCMa) e Moreiras (ZCMo)}

A Zona de Cisalhamento Mairinque compreende estreita faixa milonitizada junto à borda ocidental do Maciço Granitóide São Roque. Essa faixa junta-se, fora dos limites da área, à Zona de Cisalhamento Moreiras (HACKSPACHER et al. 1992b), definida por SANTORO (1984), conferindo ao conjunto caráter geométrico anastomosado.

A continuidade nordeste da ZCMo adentra a área e deforma intensamente o Stock Granítico Guaxatuba - Pica-Pau, produzindo protomilonitos de matriz equigranular média a fina epidotizada e com venulações de epídoto, da qual destacam-se porfiroclastos de feldspato amendoados. Em intervalo de poucos metros o granitóide protomilonítico transforma-se em ultramilonito de aspecto filítico portando uma massa ainda mais fina e epidotizada, e os raros porfiroclastos de feldspato potássico presentes estão muito estirados. Estendendo-se pela Serra da Guaxatuba, imbrica-se com a ZCIJ.

Segundo HACKSPACHER (1994), a ZCMa afeta a borda do Maciço Granitóide São Roque, mas sua expressão diminui consideravelmente a sudoeste do rio Tietê. Na Estrada dos Romeiros, no contato norte do corpo granítico, seus efeitos ainda são observados, onde um quartzito fino milonitizado está em contato com filonito de granitóide que aflora por aproximadamente 15 metros, e esse torna-se milonítico por uma dezena de metros antes de passar para tipos cataclasados por outros metros, até a rocha mostrarse mais isótropa (MV 1045). 


\section{d) Zona de Cisalhamento Araçarigüama (ZCA)}

A Falha Araçarigüama foi definida por BISTRICHI (1982) e redefinida como a Zona de Cisalhamento Araçarigüama por HACKSPACHER et al. (1992b) e OLIVEIRA (1992a). Situa-se na borda oriental do Maciço Granitóide São Roque.

Nesta pesquisa verificou-se que a zona de cisalhamento se distribui por toda extensão entre os maciços Itaqui e São Roque, e inicia como uma ramificação NW da Zona de Cisalhamento Taxaquara (ZCT). Entretanto, nas proximidades do Granito São Roque parece ser truncada pela mesma zona, sugerindo que a ZCA pode ser relativamente mais antiga e reativada durante o desenvolvimento da ZCT. Devido à aproximação dos maciços São Roque e Itaqui, causada pelo movimento transcorrente do par ZCT e ZCII, o escape das supracrustais pode ter se dado por componente de empurrão sobre o Maciço São Roque, mas poucos dados em campo foram obtidos para confirmação dessa hipótese.

A ZCA deforma os granitóides, produzindo protomilonitos verde-escuros intensamente orientados, por vezes epidotizados, com porfiroclastos de feldspatos estirados. Entretanto, os últimos podem ainda manter as formas euédricas em faixas menos deformadas, com fraca rotação. Os xistos pelíticos do Grupo Serra do Itaberaba de modo geral têm, como produtos do cisalhamento, filonitos, especialmente nas proximidades do contato com a intrusão.

Na borda oriental do Maciço Granítico São Roque ocorre um pequeno stock granítico alongado e cataclasado e que grada, em direção às porções mais foliadas, para filonito. Anfibolitos milonitizados das encaixantes apresentam alto teor de biotita.

\section{e) Zona de Cisalhamento Vila Menk (ZCVM)}

Situa-se no limite NE do Maciço Granitóide Itaqui e compreende um conjunto de falhas transcorrentes que afeta as rochas granitóides e, preferencialmente, as rochas encaixantes (FERREIRA 1991). Aflora na Rodovia Anhangüera, onde gera protomilonitos nas rochas graníticas, com orientação dos megacristais de feldspato potássico e delgadas zonas mais internamente deformadas.

Em litotipos do Grupo Serra do Itaberaba ocorrem extensas faixas de filonitos com dobras intrafoliais e zonas menos deformadas que podem estar brechadas.

\section{f) Zona de Cisalhamento Morro Grande (ZCMG)}

Esta estrutura ocorre na borda SE do Stock Granítico Ponunduva. Foi descrita por HASUI et al. (1969) e NASCIMENTO \& RUEGGER (1986), e denominada por BERGMANN (1988) Falha do Morro Grande. A fácies porfiróide do stock na região mais tectonizada é finamente foliada, tem cor verde, é rica em epídoto e apresenta porfiroclastos de feldspato potássico ocelares. Localmente, estão brechados e epidotizados.

\subsubsection{Falhas}

Diversas falhas maiores foram compiladas, merecendo destaque Romeiros (BERGMANN 1988), Morro da Viúva (OLIVEIRA et al. 1992a) e Doninhas (HACKSPACHER et al. 1992b). Uma grande quantidade de falhas menores foram identificadas ou inferidas através da observação do deslocamento de 
unidades ou por fotointerpretação.

Dentre as falhas, um conjugado de direção NW-SE e NNW-SSE constitui um grande número de falhas. Em campo não se observam deslocamentos significativos em um único plano, e sim zonas relativamente extensas, com fraturas cerradas, que chegam a causar deslocamentos gradativos de centenas de metros nos contatos entre unidades. Em alguns afloramentos as falhas deste conjugado mostram planos estriados, geralmente com clorita, carbonatos e epídoto, que indicam forte componente transcorrente com direção de esforço NW-SE.

Grande parte destas falhas são normais ou inversas e, raramente, ocorrem milonitos associados, especialmente nas falhas maiores, citadas anteriormente.

\subsubsection{Terciário}

\subsubsection{Formações Resende e São Paulo (TQs) e Sedimentos Correlatos (TQsc)}

A Formação São Paulo aflora na porção SSE da área, a sul da Zona de Cisalhamento Taxaquara, e seus depósitos tornam-se mais esparsos em direção a Barueri. Usualmente, ocorrem como coberturas pouco espessas no topo das elevações de milonitos e gnaisses.

Nos poucos afloramentos descritos constituem arenitos grossos a muito grossos com níveis de siltitos argilosos arroxeados e leitos conglomeráticos ricos em grânulos de quartzo, quase sempre suborizontais. Foram depositados por leques aluviais e retrabalhados por sistemas fluviais, o que permite caracterizá-los como pertencentes à Formação Resende, segundo RICCOMINI (1989). Entretanto, parte dos sedimentos pode pertencer à Formação São Paulo.

Nos arredores do trevo de Barueri para Jandira (CA 994) os sedimentos foram depositados diretamente sobre milonitos do Granito Ibiúna, mas encontram-se afetados por diversas falhas. No contato estão presentes blocos angulosos do milonito e, localmente, o conglomerado está imbricado com o milonito, caracterizando reativações recentes da zona de cisalhamento.

Várias áreas pequenas com sedimentos semelhantes aos da Bacia de São Paulo foram identificados em campo ou por meio de fotointerpretação sobre a parte sul do Granito Itaqui, a leste da Rodovia dos Bandeirantes e a sul da Estrada dos Romeiros, nas proximidades do Granito Itaqui, dentre outros corpos menores.

Estas coberturas sedimentares pouco espessas e situadas nas partes do topo de elevações de rochas pré-cambrianas podem ser correlacionadas aos sedimentos da Bacia São Paulo, sugerindo que a área da bacia foi maior que a atual. Entretanto, parte delas pode pertencer aos depósitos colúvio eluvionares definidos por CARNEIRO (1983), que foram assim considerados devido à insuficiência de estruturas sedimentares, pouca consolidação e pequena similaridade com os depósitos típicos da Formação São Paulo. A distribuição dos corpos e a litologia parece não sustentar essa hipótese, mas o tema, por não ter sido objeto deste estudo, não será aqui discutido. 
Notam-se ainda nestas coberturas, em aerofotos, basculamentos, por vezes relativamente fortes, em direções variadas, e fortes desníveis entre ocorrências próximas, indicando que o principal fator para preservação destas áreas deve ter sido tectônico, condicionado pela movimentação relativa de blocos menores entre as falhas.

Localmente, os sedimentos encontram-se com alto ângulo de mergulho e afetados por falhas, como no afloramento RP 1245, onde conglomerados e lamitos de leque aluvial estão sobrepostos aos metassedimentos da Formação Estrada dos Romeiros, sendo cataclasados por falha de alto ângulo oblíqua à Falha de Romeiros.

No afloramento $\mathrm{CB} 1146$ os sedimentos estão colocados sobre filitos milonitizados e brechados do Grupo São Roque, nas proximidades do contato com o Grupo Serra do Itaberaba. Predominam argilitos brancos, cinzas, vermelhos e róseos, comumente dobrados e, por vezes, com o acamamento deslocado por falhas conjugadas (Prancha 04/foto $\mathbf{H}$ ), e ocorrem fatias do filito encaixadas tectonicamente nos sedimentos.

\subsubsection{Quaternário a Recente}

\subsubsection{Aluviões e coluviões (Qa)}

Os aluviões foram cartografados com o uso de fotografias aéreas, não tendo sido descritos, usualmente, nos trabalhos de campo. Nas bordas dos aluviões observam-se colúvios superpostos, especialmente nos vales mais fechados, geralmente incluídos nesta unidade.

Estão associados às calhas dos rios e ribeirões, e os depósitos maiores estão geralmente vinculados às principais zonas de cisalhamento, como a Taxaquara e a Jundiuvira e, principalmente, no limite norte da Bacia de São Paulo, com as rochas pré-cambrianas intensamente cisalhadas na calha do rio Tietê. Também formam corpos extensos associados aos rios Barueri e Cotia, enquanto que na altura do córrego do Itaqui e na confluência desse com o rio Tietê, os depósitos quaternários diminuem muito em tamanho, devido à topografia mais elevada do Granito Itaqui.

Na parte nordeste da área, depósitos relativamente extensos associam-se ao rio Juqueri, entre Caieiras e Franco da Rocha, e repetem-se na porção central, no bairro de Várzea do Souza, onde o rio recebe as águas do ribeirão dos Cristais, que a NNE, nas proximidades do bairro Jordanésia, também possui grandes depósitos. Outros aluviões de dimensões consideráveis ocorrem junto ao ribeirão Jundiuvira, na região NW.

Em fotografias aéreas observam-se, muito freqüentemente, níveis de paleoterraços parcialmente erodidos, evidenciando movimentações tectônicas recentes.

A neotectônica aparentemente provocou movimentações diferenciais entre vários blocos limitados por falhas, propiciando a formação de depósitos maiores em determinadas áreas. 


\section{CAPÍTULO V}

\section{PETROGRAFIA}

\subsection{GRUPO SERRA DO ITABERABA}

\subsubsection{Formação Morro da Pedra Preta}

\subsubsection{Unidade Metabásica (MPSIppmb)}

\section{a) Rochas metabásicas de origem ígnea}

Estão representadas em essência por rochas cuja granulação varia de fina a média, sendo raras as amostras de granulação fina ou grossa. São constituídas por hornblenda/actinolita e/ou homblenda variando de 40 a $70 \%$ do volume da rocha, com predomínio de composições entre 50 e $60 \%$, e plagioclásio (30 a 45\%). Como acessórios podem estar presentes epídoto (traço a $3 \%$ ), clinozoizita (até $5 \%$ ), quartzo ( 5\%, raramente $20 \%$ ), tremolita/actinolita, titanita, minerais opacos, esses representados por titanomagnetita, magnetita e ilmenita (somando até $4 \%$ ), apatita $(<1 \%$, raramente $2 \%$ ), biotita (ausente até raramente 10\%), clorita (traço a $2 \%$ ) e carbonato (traço a acessório ocasional), além de zircão, rutilo, turmalina, cummingtonita e sulfeto (pirita) eventuais, e limonita/goethita relacionada à alteração supérgena.

Localmente observam-se rochas de composição mais intermediária, onde o anfibólio ocupa entre 25 a $40 \%$ do volume da rocha e o plagioclásio atinge aproximadamente $60 \%$. Em raros exemplares há presença de granada (5 a 15\%) ou de clinopiroxênio. Estão representadas por homblendahomblenda/actinolita anfibolitos, hornblenda anfibolitos e, subordinadamente, hornblenda xistos e granada-hornblenda anfibolitos.

Essas rochas são formadas por porfiroblastos de anfibólio dispersos em matriz constituída essencialmente por plagioclásio com anfibólio subordinado. Os porfiroblastos variam entre 1 e $2,5 \mathrm{~mm}$ podendo atingir até $3,5 \mathrm{~mm}$, sendo que relíquias de plagioclásio ígneo podem variar de 0,5 até $3,0 \mathrm{~mm}$. Predomina, no entanto, o plagioclásio recristalizado como pequenos cristais granulares que medem entre 0,1 e $0,5 \mathrm{~mm}$. Em alguns exemplares de granulação grossa os cristais de anfibólio têm até 7,0 mm.

Nesta unidade foram incluídas todas as rochas metabásicas de origem ́́gnea, sendo que coexistem rochas pouco deformadas, onde, por vezes, são recuperadas as texturas blastofítica e basto-subofítica (Prancha 05/Fotos A e B), com aquelas que sofreram intensa recristalização e deformação, em que restam ocasionalmente apenas os pseudomorfos dos antigos fenocristais de anfibólio e/ou de piroxênio, os quais foram substituídos por aglomerados de cristais de anfibólio (Prancha 05/Foto $\mathrm{C}$ ). Muitas vezes a origem ígnea só pôde ser estabelecida pelo controle efetuado em campo.

Nas rochas onde são recuperados restos de texturas ígneas, pode ser observado, por exemplo, o plagioclásio ígneo prismático em contato com anfibólio em textura intergranular (Prancha 05/Foto D) ou 
a forma reliquiar do mesmo, que sofreu recristalização para cristais menores (Prancha 05/Foto A). Nessas amostras predomina a estrutura maciça e, de forma subordinada, alguns exemplares podem exibir uma orientação preferencial dos minerais.

As formas dos porfiroblastos de anfibólio variam de euedrais a subeuedrais, sendo alguns cristais anédricos. Geralmente têm as extremidades mal formadas a esfiapadas e apresentam-se caracteristicamente manchados, com um núcleo pouco pleocróico de hornblenda/actinolita e as bordas e alguns planos de clivagens formadas por hornblenda (Prancha 05/Foto B). Nos núcleos de hornblenda/actinolita podem estar presentes pequenas inclusões de plagioclásio, quartzo, minerais opacos que, por vezes, estão alterados para leucoxênio, enquanto que na borda há ausência de inclusões.

A matriz dessas rochas é constituída por plagioclásio recristalizado gxanular não geminado e, subordinadamente, por prismas menores e por pequenos cristais subeuédricos a anédricos de hornblenda. Coexistem cristais de plagioclásio límpidos ou com aspecto "sujo", devido principalmente à presença de minúsculos cristais de clinozoizita, que apresentam contatos irregulares, suturados e, mais comumente, retilineos a poligonizados. No último caso estão ausentes ou são menos frequientes as inclusões.

Os raros exemplares de granulação fina ou grossa são também aproximadamente equigranulares, e os últimos podem preservar alguma textura ígnea, sendo observado a intergranular (gabróica).

Entre as rochas menos deformadas predominam hornblenda-hornblenda/actinolita anfibolitos, que afloram principalmente nas proximidades dos maciços granitóides Itaqui e Cantareira e, de forma subordinada, nos arredores do Stock Granítico Tico-Tico.

Observa-se uma gradação das rochas metabásicas com texturas dos protólitos preservadas para aquelas onde houve intensa recristalização e a hornblenda/actinolita foi completamente substituída por hornblenda. Na transição ainda podem ser observados raros cristais zonados com o núcleo de hornblenda/actinolita. Quanto mais intenso o processo de recristalização e de deformação das rochas metabásicas ígneas, menor é a quantidade presente de porfiroblastos de anfibólio, os quais recristalizaram em prismas menores de hormblenda (Prancha 05/Foto E). Nessas rochas predomina a textura nematoblástica dada pela orientação dos anfibólios.

Alguns exemplares dessas rochas podem apresentar granada subeuédrica (Prancha 05/Foto $\mathrm{F}$ ) ou restos instáveis de clinopiroxênio que provavelmente correspondem a diopsídio cristalizado na foliação $S_{\text {, }}$ (Prancha 05/Foto G). Quando o plagioclásio ocorre no interior de raros cristais de clinopiroxênio possivelmente ígneo, pode preservar parte da geminação e, talvez, da composição original. Alguns desses cristais de plagioclásio mostram uma outra geminação associada à múltipla, geralmente oblíqua a perpendicular a essa, sugerindo ser a geminação da periclina.

Estas rochas mais recristalizadas estão predominantemente representadas por hornblenda anfibolitos e, de modo subordinado, por hornblenda xistos e granada-hornblenda anfibolitos distribuídos nos arredores do Stock Granítico Tico-Tico, mas também podem ocorrer próximos ao Maciço Granitóide Cantareira. 
Nas rochas desta unidade há evidências de quatro eventos deformacionais, o segundo deles associado a uma intensa recristalização que pode evoluir para um evento milonítico caracterizado por uma foliação milonítica. Na TABELA 5.1 podem ser vistas as relações de cristalização dos minerais com as respectivas foliações metamórficas para os hornblenda-hornblenda/actinolita anfibolitos, e na TABELA 5.2 para os hornblenda anfibolitos, homblenda xistos e granada-hornblenda anfibolitos.

A foliação $S_{2}$, quando milonítica, é responsável pela reorientação, rotação ou envergamento/arqueamento de porfiroblastos de anfibólio pré- $S_{1}$ segundo o plano axial da $S_{2}$ (Prancha 05/Foto E). Raramente, observam-se porfiroblastos de anfibólio da foliação $S_{1}$ em secções basais parcialmente envolvidos pelos porfiroblastos de hornblenda orientada e relacionada à foliação $S_{2}$ (Prancha 05/Foto H). A $S_{2}$ foi responsável pela recristalização dos porfiroblastos de anfibólio e pelo reequilíbrio dos cristais de plagioclásio, possivelmente de composições próximas à labradorita ou até um pouco mais cálcicas da foliação prévia para oligoclásio-andesina na foliação $S_{2}$. Contudo, também foram observados cristais de labradorita relacionada ao evento $S_{2}$.

As foliações $\mathrm{S}_{3}$ e $\mathrm{S}_{4}$ ocorrem de forma restrita e associam-se aos eventos retrometamórficos, sendo caracterizadas pela cristalização de tremolita/actinolita, epídoto, clinozoizita, clorita, albita e quartzo, além de carbonato e leucoxênio.

Nos hornblenda-homblenda/actinolita anfibolitos as porções mais escuras dos porfiroblastos marcam o reequilíbrio na foliação $S_{2}$ em condições de fácies anfibolito algo mais elevadas, enquanto que os núcleos mais claros podem representar condições iniciais menos drásticas do evento $\mathrm{S}_{2}$, com o aumento do grau metamórfico denunciado nas bordas.

Nos hornblenda anfibolitos o clinopiroxênio pode ocorrer como cristais anédricos inclusos em porfiroblastos de anfibólio, tratando-se ou de fenocristais não totalmente consumidos nos eventos metamórficos ou, mais provavelmente, de relíquias de clinopiroxênio do primeiro evento metamórfico preservadas no interior dos porfiroblastos de anfibólio cristalizados durante a $S_{2}$.

Nos granada-hornblenda anfibolitos observa-se granada euédrica a subeuédrica, a qual possui uma parte central poiquiloblástica $\sin -\mathrm{S}_{2}$ rica em inclusões de quartzo, plagioclásio e ilmenita e bordas mais maciças mostrando um crescimento pós- $S_{2}$ (Prancha 05/Foto F).

Nos hornblenda xistos os cristais menores de hornblenda estão orientados segundo a $\mathrm{S}_{\mathrm{m}}$, e chegam a ocorrer concentrados em finos leitos acompanhados de outros ricos em plagioclásio (Prancha 06/Foto A).

Nos hornblenda-hornblenda/actinolita anfibolitos ocorrem feições cataclásticas locais associadas com deslocamentos tardios sobre porções anteriormente milonitizadas, talvez, devido à colocação do Maciço Granitóide Itaqui nas proximidades, ou ainda, a reativações da Zona de Cisalhamento Vila Menk em níveis mais raros. Os porfiroblastos de anfibólio estão fraturados e podem ocorrer rejeitos nos cristais com venulações milimétricas associadas e que são preenchidas por epídoto.

O quartzo, em geral, ocorre como cristais mais límpidos e maiores se comparados aos cristais de 
plagioclásio recristalizados. Comumente tem extinção ondulante e seus contatos variam de irregulares até poligonizados com os cristais de plagioclásio, sendo que pode ocorrer também nos interstícios dos porfiroblastos de anfibólio. Raramente atinge $20 \%$ da matriz. Onde a foliação é mais intensa ou milonítica, o quartzo recristaliza com forte extinção ondulante em formas granulares alongadas até elipsoidais e paralelizadas à $\mathrm{S}_{\mathrm{m}}$.

Nas amostras onde a cominuição do plagioclásio é mais intensa, é comum a presença de quartzo e clinozoizita e, subordinadamente, de epídoto e raros cristais de carbonatos. Nessa situação, os cristais de plagioclásio tendem a apresentar caráter biaxial positivo, contatos mais difusos e irregulares, e o índice de refração é inferior ao do quartzo, sendo caracterizados como cristais que se reequilibraram para albita associados à foliação $S_{3}$. Localmente é observada a cristalização de albita em venulações tardias, possivelmente relacionada ao evento $S_{4}$.

Por vezes podem ser vistos agregados de biotita nas rochas desta unidade. O mineral é pleocróico do castanho-escuro ao vermelho, sugerindo incorporação de titânio (Prancha 05/Foto C). Pode também formar cristais alongados e associar-se com mineral opaco, provavelmente ilmenita, enquanto que em outros exemplares está presente em venulações tardias. Localmente está associado à turmalina euédrica e possíveis cristais de cummingtonita.

A clinozoizita ocorre na forma de agregados microcristalinos, como finos cristais anédricos disseminados ou como agregados granulares maiores, relacionados com a foliação $S_{2}$, geralmente nos estágios tardi- e pós-deformacionais e, mais comumente, na $S_{3}$. Cristaliza principalmente a expensas do plagioclásio, substituindo esse mineral por vezes quase que totalmente.

O epídoto em geral é mais comum que a clinozoizita, mas eventualmente ocorre subordinado. Está presente na forma de cristais subeuédricos a euédricos com pleocroísmo variando preferencialmente do amarelo-pálido/incolor ao amarelo-esverdeado, ou formando agregados maiores que aqueles de clinozoizita. Cristaliza principalmente a partir dos porfiroblastos de anfibólio. Pode estar relacionado aos estágios tardios da foliação $S_{2}$, porém ocorre predominantemente onde a foliação $S_{3}$ retrometamórfica é mais atuante, sendo que em uma das lâminas ocupa, em associação com a clinozoizita, até $40 \%$ da matriz. Pode, ocasionalmente, cristalizar-se junto às bordas de minerais opacos.

A clorita é retrometamórfica e cristaliza na $S_{3}$, em paragênese com quartzo e epídoto, na borda de porfiroblastos de anfibólio ou na matriz. Mais raramente, ocorre junto com carbonato e, eventualmente, associa-se a eventos cataclásticos tardios, preenchendo fraturas de rejeitos milimétricos presentes nos anfibólios. O carbonato cristaliza a partir do plagioclásio e pode, ocasionalmente, envolver cristais de epídoto, configurando textura poiquiloblástica. Ocupa até $5 \%$ da rocha.

Os minerais opacos compreendem possivelmente a magnetita/titanomagnetita, quando caracterizado o hábito octaédrico, e a ilmenita, quando ocorre como cristais subeuédricos a euédricos tabulares, por vezes alongados ou com formas esqueléticas. Em algumas amostras os minerais opacos estão associados a sulfetos. 
TABELA 5.1 - Relações de cristalização dos minerais nos hornblenda-hornblenda/actinolita antibolitos.

\begin{tabular}{|c|c|c|c|c|c|c|c|c|}
\hline Minerais & $R$. & Foliacão $S_{L}$ & $P \delta s-S_{i}$ & Foliacão $S_{2}$ & $P 6 s w S_{2}$ & Foliacão $S_{3}$ & $P o s w S_{3}$ & Foliacão $S_{4}$ \\
\hline Hornblenda/actinolita & & $\ldots$ & & …- & & & & \\
\hline Hornblenda (borda) & & $\ldots$ & & $\ldots$ & $\ldots$ & -- ? & & \\
\hline Hornblenda matriz & & & & $\ldots .$. & & & & \\
\hline Tremolita - Actinolita & & & & & & $\ldots \ldots$ & & \\
\hline Tremolita & & & & & & & & $\cdots$ \\
\hline Olig.-Andes.a Labrad. &.$? \cdot$ & 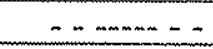 & $=$ & $-\ldots$ & & & & \\
\hline Albita & & & & & & $--\cdots \cdots$ & & $\ldots$. \\
\hline Clinopiroxênio & $? ?$ & $\cdots$ & & & & & & \\
\hline Clinozoizita & & & & $\sim$ & - & $-\cdots$ & - & \\
\hline Epídoto & & & & $\ldots$ & $\ldots$ & $\ldots \ldots$ & $=-$ & $\cdots$ \\
\hline Quartzo & & $\cdots$ & & $\ldots$ & - & $\cdots \cdots \cdots$ & 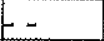 & $\cdots \cdots$ \\
\hline Clorita & & & & & & $-\cdots \cdots$ & - & $\ldots$ \\
\hline Carbonato (calcita) & & & & & & $-\cdots-\cdots$ & & $\cdots ?$ \\
\hline Biotita & & & & $\cdots \cdots$ & & & & \\
\hline Titanita & & & & $\ldots$ & - - & $\ldots$ & & \\
\hline Mineral opaco & & $\ldots$ & - & $\cdots \cdots$ & - & & & \\
\hline Sulfeto (pirita) & & & & $\ldots$ & & & & \\
\hline Apatita & & $-?-$ & & - ? & - & $\cdots$ & $=$ & - \\
\hline Zircão & $-?-$ & $-?-$ & & & & & & \\
\hline Rutilo & $-?-$ & $-?-$ & & & & & & \\
\hline Turmalina & & & & & & $\cdots$ & - & \\
\hline Cummingtonita & & & & $\cdots \cdots$ & & & & \\
\hline Leucoxênio & & & & & & $\cdots$ & & $\cdots$ \\
\hline Fácies Metamórfica & & anfibolito & & anfibolito & & xisto-verde & & xisto-verde \\
\hline
\end{tabular}

TABELA 5.2 - Relação de cristalização dos minerais nos hornblenda anfíbolitos, homblenda xistos e granada hornblenda anfibolitos.

\begin{tabular}{|c|c|c|c|c|c|c|c|c|}
\hline Minerais & $R$. & Foliação $S_{L}$ & $P o ́ s \cdot S_{2}$ & Foliação $S_{2}$ & $P o s-S_{2}$ & Foliacãao $S_{3}$ & $P \delta s-S_{3}$ & Foliacão $S_{4}$ \\
\hline Fe-actinolita-Hornblenda & & $\ldots-$ & & $\cdots \cdots$ & & $\ldots$ & & \\
\hline Hornblenda & & $\cdots \cdots \cdots$ & $-\infty$ & - & $\infty$ & $-\ldots$ & & \\
\hline Tremolita - Actinolita & & & & & & $\ldots \ldots$ & & $\cdots \cdots ?$ \\
\hline Olig./Andes. a Labrad. & 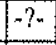 & $\ldots \ldots$ & $\ldots$ & $-1-2-1-$ & & & & \\
\hline Albita & & & & & & $-\cdots$ & & $\ldots$ \\
\hline Clinopiroxênio (diopsídio) & & $---?$ & & & & & & \\
\hline Granada & & - . - & $-\infty$ & $-\cdots$ & $-\infty$ & & & \\
\hline Clinozoizita & & - & - ? & - & -- & $\ldots \ldots$ & 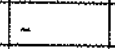 & $\cdots$ \\
\hline Epídoto & & -- & m & - & - & $\ldots$ & - & $\cdots$ \\
\hline Quartzo & & $\cdots \cdots$ & - - & $\ldots \ldots$ & - & -0 & $-\ldots$ & $\ldots$ \\
\hline Clorita & & & & & & $-\cdots$ & & $\cdots+?$ \\
\hline Carbonato (calcita) & & & & & & $\cdots$ & & \\
\hline Biotita & & $\cdots$ & & - & - & $-\cdots$ & $-?-$ & \\
\hline Titanita & & $\cdots$ & & $-\ldots \ldots$ & $-\cdots$ & $\ldots \ldots$ & & \\
\hline Mineral opaco & & …n- & & 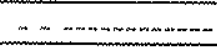 & $-\cdots$ & 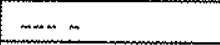 & & \\
\hline Sulfeto (pirita) & & --- & & $\ldots$ & & $\cdots$ ? & & \\
\hline Apatita & & & & $-\ldots$ & -. & & - & \\
\hline Rutilo & $-?^{-*}$ & -? & & & & & & \\
\hline Turmalina & & & & & & $\ldots$ & E- & \\
\hline Leucoxênio & & & & & & $\ldots$ & & $\cdots$ \\
\hline Fácies Metamórfica & & anfibolito & & alm. anfibol. & & xisto-verde & & xisto-verde \\
\hline
\end{tabular}

A ilmenita pode estar presente como inclusões no ou em contato com o anfibólio porfiroblástico, associada com titanita, ora predominando, ora sendo subordinada (Prancha 05/Fotos B e C), ou ainda como pequenas inclusões na granada. Em alguns exemplares, os minerais opacos podem estar associados 
a agregados microcristalinos de titanita, mineral esse que também pode ocorrer sobre ou nas bordas dos porfiroblastos de anfibólio formando finos cristais anédricos ou cristais maiores euédricos.

Apatita cristaliza como prismas euédricos na matriz granoblástica. A tremolita pode estar presente na borda de alguns porfiroblastos de anfíbólio, e o seu crescimento relaciona-se à foliações retrometamórficas $\mathrm{S}_{3}$ e $\mathrm{S}_{4}$. Pode cristalizar associada à actinolita, preenchendo microfraturas.

\subsubsection{Unidade Metavulcanoclástica (MPSIppmv)}

\section{a) Rochas metavulcanoclásticas básicas}

Composicionalmente assemelham-se às rochas da unidade anteriror. Têm granulação fina a média, predominando aquelas de granulação fina, e como minerais essenciais ocorrem hornblenda e plagioclásio. A hornblenda ocupa entre 55 e $65 \%$ do volume da rocha, mas pode atingir $75 \%$ ou, mais raramente, até $90 \%$, enquanto que o plagioclásio compreende entre 35 e $45 \%$ do volume da rocha, sendo que localmente pode constituir apenas $5 \%$. Como minerais acessórios comuns predominam epídoto (traço até 3\%), clinozoizita (traço até 2\%), quartzo (traço até 10\%), minerais opacos (3 até 6\%), titanita (até $1 \%$ ), e tremolita (ausente até $2 \%$ ). Em menor abundância e com conteúdo em ordem decrescente tem-se apatita, carbonato, clorita e sulfeto. Mais rara é a presença de rutilo, zircão, alanita, biotita, turmalina e cummingtonita. Correspondem a actinolita-hornblenda anfibolitos, hornblenda anfibolitos e hornblenda xistos.

A definição da origem vulcanoclástica destas rochas básicas muitas vezes baseou-se nas observações de campo, sendo que algumas feições estruturais e texturais que denotam esse caráter foram recuperadas em algumas lâminas. Constituem rochas bandadas, finamente laminadas ou maciças. Com exceção das maciças, apresentam alternância de leitos com espessuras variando de alguns milímetros até $2 \mathrm{~cm}$ dada por variação composicional e granulométrica. Em alguns exemplares notam-se intercalações de leitos ricos em plagioclásio e outros constituídos em essência por anfibólio.

Predominam cristais maiores de hornblenda em relação aos de plagioclásio, os primeiros medindo entre 0,5 e 2,0 $\mathrm{mm}$ enquanto que os de plagioclásio são menores que $1,0 \mathrm{~mm}$, predominando aqueles entre 0,05 e $0,2 \mathrm{~mm}$. Nestas rochas a textura nematoblástica é dada pela orientação dos cristais de hornblenda.

Dentre essas rochas, aquelas de granulação menor que $0,4 \mathrm{~mm}$ finamente laminadas, por vezes mostrando um bandeamento composicional e granulométrico, puderam ser identificadas como metatufos (Prancha 06/Foto B), sendo que alguns exemplares são formados essencialmente por hornblenda (Prancha 06/Foto C).

Nas rochas de granulação mais grossa foram identificados alguns cristais maiores isolados e aglomerados de hornblenda que sugerem a presença de antigos cristais de anfibólio ou litoclastos de composição básica recristalizados, admitindo que essas rochas sofreram deformação e recristalização suficientes para obliterar as principais feições vulcanoclásticas do protólito. Dado o tamanho dos aglomerados, algumas podem ser classificadas como metabrechas. 
A intercalação de raros leitos ricos em quartzo, principalmente dentro dos metatufos, pode indicar fïnas deposições de origem química correspondentes a cherts.

As foliações são, em essência, as mesmas descritas nas rochas metabásicas de origem ígnea. A orientação preferencial dos minerais também é dada pelo segundo evento deformacional, que localmente pode evoluir para uma foliação milonítica $S_{\mathrm{m}}$. A $S_{1}$ por vezes é recuperada como dobras intrafoliais formadas por finos prismas de anfibólios isolados e transpostos pela $S_{2}$ (Prancha 06/Foto C). Localmente foi possível caracterizar uma clivagem de crenulação $S_{3}$ nos exemplares mais ricos em hornblenda. As relações de cristalização dos minerais segundo as foliações metamófficas podem ser vistas na TABELA 5.3 .

$\mathrm{Na}$ maioria dos exemplares destacam-se porfiroblastos de hornblenda em matriz fina a muito fina constituída por plagioclásio recristalizado com formas granulares e, subordinadamente, por hornblenda, que pode ocupar até $15 \%$. Os cristais de hornblenda variam de euédricos a subeuédricos. Em algumas amostras o seu índice de refração maior, comparado com o do quartzo, parece indicar o seu reequilíbrio para uma composição próxima do limite andesina-labradorita associada ao segundo evento deformacional. Raramente os cristais de plagioclásio são vistos com a geminação múltipla. Nota-se, com freqüência, o início de saussuritização do plagioclásio associada aos eventos retrometamórficos $S_{3}$ e $S_{4}$, representada pela cristalização incipiente de sericita, clinozoizita, carbonato e epídoto. Nessa situação, em geral o plagioclásio está em parte reequilibrado para albita.

Coexistem minerais opacos maiores $(\sim 0,7 \mathrm{~mm})$ com aqueles de granulação muito fina $\mathrm{e}$ anédricos. Alguns dos cristais maiores têm formas octaédricas/romboédricas, correspondendo à magnetita, enquanto que outros com formas tabulares provavelmente são de ilmenita. Alguns destes minerais opacos maiores mostram uma incipiente orientação segundo a foliação $S_{2}$. Os menores ocorrem disseminados e, ocasionalmente, formam finos leitos ou lentes descontínuas orientadas preferencialmente segundo a $S_{2}$. Por vezes, constituem finíssimas inclusões $\sin -S_{1}$ e $\sin -S_{2}$ observadas no interior dos cristais de hornblenda.

Nessas rochas, o epídoto é mais comum que a clinozoizita e, por vezes, concentrações de epícloto granular podem constituir finos leitos. Cristais de epídoto presentes junto à hornblenda são subeuédricos a euédricos. Quando derivado da alteração do plagioclásio, ocorre como agregados microcristalinos. Pode também estar presente em venulaçốes tardias relacionadas ao evento retrometamórfico da foliação $S_{3}$ constituindo cristais euédricos maiores, e em microfraturas de rejeito milimétrico onde precipita junto com carbonato.

Clinozoizita cristaliza principalmente a partir do plagioclásio na forma de minúsculos cristais agregados, podendo, por vezes, substituí-lo completamente. Pode estar associada a cristais de titanita, è alteração de alanita. Eventualmente perfaz até $15 \%$ do volume da rocha. A sua cristalizaçâo está relacionada tanto à fase final do evento principal $S_{2}$ como aos eventos retrometamórficos posteriores, em especial ao terceiro. 
O quartzo, quando presente, em geral é anguloso, límpido, e pode apresentar extinção ondulante. Em alguns exemplares, esse mineral forma venulações subconcordantes com a $S_{\mathfrak{m}}$, cristaliza preenchendo fraturas, ou apresenta desenvolvimento local de textura mortar relacionada aos eventos cataclásticos finais.

Titanita, quando presente, predomina na forma de pequenos cristais anédricos, e pode se cristalizar envolvendo o mineral opaco prévio na forma de uma franja, sugerindo reequilíbrio retrometamórfico. A tremolita é ausente na maioria das amostras porém, quando observada, associa-se de preferência ao evento retrometamórfico $S_{3}$, cristalizando na borda dos cristais de hornblenda ou como constituinte da matriz, onde compreende primas finos euédricos a subeuédricos, cristalizados também a expensas da hornblenda.

A presença de clorita, apatita e rutilo é rara. Clorita, quando observada, está relacionada ao evento $\mathrm{S}_{3}$. Apatita está presente como pequenos cristais euédricos, enquanto que o rutilo avermelhado varia de subeuédrico a anédrico.

Biotita ocorre como raros porfiroblastos, podendo ser derivada de processos metassomáticos relacionados à intrusão do Maciço Granitóide Itaqui, o que também parece ocorrer com a turmalina. O crescimento local de anfibólio incolor em prismas radiados e com geminação múltipla sugere a presença de cummingtonita tardi- a pós- $\mathrm{S}_{2}$.

TABELA 5.3-Relações de cristalização dos minerais nas rochas metavulcanoclásticas básicas.

\begin{tabular}{|c|c|c|c|c|c|c|c|c|}
\hline Minerais & $R$. & Foliacão $S_{l}$ & $P O S-S_{L}$ & Foliacão $S_{2}$ & $P 6 s-S_{2}$ & Foliacão $S_{3}$ & $P 6 s-S_{3}$ & Foliacão $S_{4}$ \\
\hline Hornblenda porf. (borda) & & $\ldots-\cdots$ & & $-\ldots$ & & & & \\
\hline Hornblenda matriz & & & & 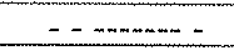 & 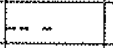 & & & \\
\hline Tremolita - Actinolita & & & & & $\ldots$ & - $-\cdots$ & & \\
\hline Tremolita & & & & & & $\ldots \ldots$ & $\ldots$ & $-?-$ \\
\hline Olig./Andes. a Labrad. & $-?-$ & $\ldots$ & & 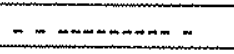 & & & & \\
\hline Albita & & & & & & $m--\cdots m m-\cdots$ & & $-?-$ \\
\hline Pertita & & & & & & -- & - & \\
\hline Clinozoizita & & & & $\cdots \cdots$ & $\ldots$ & $\ldots \ldots \ldots$ & & \\
\hline Epídoto & & & & $-\cdots$ & -- & - & & $-\cdots$ \\
\hline Quartzo & & $\ldots$ & - & $\ldots \ldots$ & 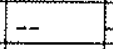 & $\ldots \ldots$ & $F$ & $\ldots$ \\
\hline Clorita (peninita) & & & & & & $\ldots \ldots$ & & $-?-$ \\
\hline Carbonato (calcita) & & & & $\sim$ & -- & $\ldots \ldots$ & & $-?-$ \\
\hline Biotita & & & & $\ldots$ & - & & & \\
\hline Titanita & & & & $\ldots \ldots$ & 5 & $\ldots-n \ldots$ & & \\
\hline Mineral opaco & & $\ldots$ & & 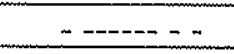 & $-\cdots$ & $\ldots$ & & \\
\hline Sulfeto (pirita) & & $\ldots$ & & $\ldots$ & & $\therefore-m$ & & \\
\hline Apatita & & & & $\ldots$ & & $\ldots$ & & \\
\hline Zircão & & $-?-$ & & - & & & & \\
\hline Rutilo & & $-?-$ & & & & & & \\
\hline Turmalina & & & & --- & - & & & \\
\hline Cummingtonita & & & & -- & 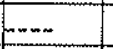 & & & \\
\hline Leucoxênio & & & & & & $\cdots$ & & \\
\hline Sericita & & & & & & $-?-$ & & \\
\hline Fácies Metamórfica & & anfibolito & & anfibolito & & xisto-verde & & xisto-verde \\
\hline
\end{tabular}




\section{b) Metassedimentos tufiticos}

Os metassedimentos tufíticos encontram-se interdigitados com as rochas metavulcanoclásticas básicas. Afloram quase que exclusivamente como rochas intensamente intemperizadas, motivo pelo qual foi encontrado apenas um afloramento de rocha fresca. Dentro do pacote dessas rochas também ocorrem metatufos básicos frescos, já descritos acima.

A amostra dos metassedimentos tufíticos compreende uma rocha de granulação fina, composta principalmente por clorita $(\sim 94 \%)$ e, subordinadamente, por quartzo $(2 \%)$, plagioclásio $(2 \%)$, minerais opacos (2\%), flogopita e epídoto (Prancha 06/Foto D). Petrograficamente corresponde a um clorita xisto.

No exemplar pode ser observada uma foliação milonítica bem desenvolvida, com frequientes feições do tipo $S-C$ formadas pelo arranjo das palhetas de clorita em cristais menores que $0,3 \mathrm{~mm}$. A clorita é quase incolor, sugerindo composição rica em magnésio. No quartzo e no plagioclásio predominam formas irregulares, com alguns cristais mostrando formas lenticulares orientadas segundo a foliação milonítica $S_{2}\left(S_{m}\right)$. As relações de cristalização dos minerais com as respectivas foliações podem ser vistas na TABELA 5.4.

Dos minerais opacos, predominam aqueles com formas tabulares, constituindo prováveis cristais de hematita. Alguns desses cristais exibem a borda avermelhada, indicando a sua transformação para óxidos e hidróxidos de ferro (limonita/goethita).

TABELA 5.4-Relações de cristalização dos minerais nos metassedimentos tufíticos (clorita xistos).

\begin{tabular}{|c|c|c|c|c|c|c|c|c|}
\hline Minerais & $R$. & Foliacão $S_{I}$ & $P \sigma s-S_{l}$ & Foliacão $S_{2}$ & $P O S-S_{2}$ & Foliacão $S_{3}$ & $P O S-S_{3}$ & Foliacão $\mathrm{S}_{4}$ \\
\hline Clorita (magnesiana) & & $--?$ & & - & & $-\cdots$ & & \\
\hline Quartzo & & $\cdots$ & & $\sim-\cdots+\cdots$ & & $\ldots \ldots \ldots$ & & \\
\hline Plagioclásio & & $\ldots$ & & $\ldots$ & & & & \\
\hline Mineral opaco (hematita) & & $-?-$ & & $\ldots \ldots$ & & & & \\
\hline Epídoto & & & & & & $\ldots-$ & & \\
\hline Biotita/flogopita & & & & 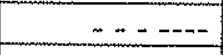 & - & & & \\
\hline Limonita/goethita & & & & & & $\ldots$ & & \\
\hline Leucoxênio (?) & & & & & & $\ldots$ & & \\
\hline Fácies Metamórfica & & xisto-verde & & xisto-verde & & xisto-verde & & \\
\hline
\end{tabular}

\subsubsection{Unidade das rochas calciossilicáticas (MPSIppes)}

\section{a) Rochas calciossilicáticas}

Predominam rochas cuja granulação varia de muito fina a média. Dentre os principais constituintes minerais ocorrem, com maior ou menor frequiência, diopsídio, anfibólio com composições desde tremolítica até actinolítica, e são menos comuns hornblenda, quartzo, epídoto, clinozoizita, flogopita e biotita. Turmalina, alanita, zircão, microclínio, titanita, leucoxênio, feldspato alcalino pertítico, plagioclásio, clorita magnesiana, carbonato e granada são observados ocasionalmente.

O tamanho dos minerais varia de 0,3 a $0,6 \mathrm{~mm}$, sendo que raros porfiroblastos de clinopiroxênio ou de epídoto podem atingir até $1,2 \mathrm{~mm}$. As rochas em geral apresentam alternância de lâminas até bandas, sendo que essas últimas raramente ultrapassam $2,0 \mathrm{~cm}$ de espessura. Internamente, as camadas podem estar foliadas ou prevalecer um arranjo maciço. Muitas vezes o limite dessas estruturas é mal 
definido, observando-se lâminas e bandas descontínuas, que eventualmente também podem estar interrompidas por outras com granulação e mineralogia distintas, refletindo as variações herdadas do protólito.

Nestas rochas puderam ser recuperados três eventos deformacionais, sendo que o principal deles corresponde à $\mathrm{S}_{2}$. As relações de cristalização dos minerais com os eventos deformacionais encontram-se na TABELA 5.5 .

As variações mineralógicas e a disposição dos minerais se refletem na textura, que pode mudar bruscamente entre as camadas. Dentre as mais freqüentes, predominam as texturas granoblástica a nematoblástica, devidas aos arranjos de cristais granulares de clinopiroxênio e de epídoto distribuídos sem orientação preferencial, no primeiro caso, e à orientação dos mesmos, no segundo. Em outras bandas e lâminas ocorre a textura nematoblástica essencial, marcada pela orientação dos cristais de anfibólio, enquanto que nas camadas onde há orientação dos minerais micáceos observa-se a textura lepidoblástica. Naquelas onde coexistem anfibólios e minerais micáceos orientados a textura é nematolepidoblástica.

Essas intercalações de diversas lâminas e bandas com composições mineralógicas tão variadas em uma única rocha poderiam ser descritas como litotipos independendes.

Em algumas amostras observa-se a alternância de camadas onde predomina actinolita e outras onde o diopsídio é mais comum. Nas primeiras ocorre, subordinadamente, clinopiroxênio parcialmente alterado para epídoto, enquanto que naquelas onde o diopsídio é mais frequiente microclínio, quartzo e clinozoizita aparecem subordinados, e como minerais acessórios tem-se epídoto e titanita, leucoxênio, flogopita, carbonato e alanita. Nessas amostras podem ocorrer lâminas formadas por hornblenda, feldspato, clinozoizita e raros cristais de flogopita e níveis finos ricos em quartzo e minerais opacos.

Em outras amostras estão intercaladas camadas ricas em flogopita, tremolita ou clinopiroxênio. Naquelas onde a flogopita é mais comum ocorrem, subordinadamente, microclínio com relíquias da geminação em grade, clinozoizita e relíquias de pequenos cristais de alanita substituída por clinozoizita+epídoto. Nessas camadas, a clinozoizita pode estar disseminada ou marcar níveis mais finos (Prancha 06/Foto E). Nas camadas onde predomina a tremolita associam-se também plagioclásio, flogopita e, mais raramente, clinopiroxênio e clinozoizita. Naquelas ricas em clinopiroxênio, o mineral está em parte transformado para tremolita ou para actinolita, e observam-se venulações pós $-S_{2}$ portando carbonato e clinozoizita.

Na amostra PJ 109a observam-se lâminas formadas por biotita, mineral opaco e quartzo e, subordinadamente, epídoto, turmalina, apatita e alanita intercaladas com outras formadas por actinolita, epídoto, quartzo e pequenas quantidades de clinopiroxênio e clinozoizita (Prancha 06/Foto F).

Em outras amostras coexistem camadas com mineralogias diversas. Podem ser vistas lâminas compostas essencialmente por cristais ou relíquias de tremolita/actinolita alteradas parcialmente para clinozoizita fina intercrescida com leucoxênio, epídoto e carbonato, e notam-se cristais de alanita relativamente preservados. Em leitos de granulação mais grossa predomina epídoto em cristais granulares 
associados com titanita euédrica, aguthas de tremolita/actinolita e cristais de clinopiroxênio e leucoxênio. Em algumas camadas podem ser vistos pequenos porfiroblastos de plagioclásio anédrico com geminação parcialmente preservada ou recristalizado em cristais menores com clinozoizita associada, que ocorrem dispersos em uma matriz rica em actinolita, cristais microgranulares de epídoto+leucoxênio, anfibólio anédrico e relíquias de clinopiroxênio.

Com relação ao mineral micáceo, em algumas camadas tem-se o predomínio de biotita em detrimento da flogopita, e ambas cristalizam na $S_{2}$ freqüentemente associadas com cristais de epídoto ricos em inclusões. Em várias camadas pode-se observar a presença de calcita. Inclusões sólidas podem ocorrer ocasionalmente nos maiores cristais de clinopiroxênio, e foram caracterizadas como de microclínio, de quartzo e de plagioclásio.

Localmente, podem intercalar-se rochas metavulcanoclásticas básicas finas, metapelitos e leitos de metachert às rochas calciossilicáticas. As primeiras são formadas essencialmente por hornblenda $(90 \%)$ e plagioclásio $(\sim 5 \%)$, com pequenas quantidades de clinozoizita e quartzo. O metapelito corresponde a um plagioclásio-biotita-quartzo xisto com agregados de biotita porfiroblástica envolvendo magnetita.

As rochas calciossilicáticas que ocorrem intercaladas às rochas metavulcanoclásticas básicas têm como minerais essenciais clinopiroxênio, quartzo, tremolita/actinolita e, subordinadamente, feldspatos (microclínio e plagioclásio), flogopita e clorita. Por vezes o clinopiroxênio porta lamelas de ortopiroxênio e cristaliza na foliação $S_{1}$, tendo sido parcialmente transformado para flogopita e tremolita durante o evento $S_{2}$. O microclínio com geminação em grade ocorre às vezes preservado no interior do clinopiroxênio. Clorita retrometamórfica $S_{3}$ cristaliza a partir da flogopita.

Quando intercaladas entre os plagioclásiombiotitamquartzo xistos, as rochas calciossilicáticas exibem porfiroblastos de diopsídio, cristais finos de actinolita, flogopita, titanita fina e clinozoizita, sendo rara a presença de quartzo, plagioclásio e feldspato potássico. Como minerais traços podem estar presentes turmalina, zircão, carbonato porfiroblástico e cristais euédricos de granada.

Em algumas amostras da unidade localizadas próximas do contato com o Maciço Granitóide Itaqui, há evidências da sobreposição de um evento de metamorfismo de contato. Duas amostras obtidas foram caracterizadas como flogopita-quartzo xisto com clinopiroxênio, plagioclásio, epídoto, clinozoizita e titanita subordinadas, a titanita e a flogopita formando cristais maiores (Prancha 06/Foto G). Há predomínio de clinozoizita em lugar do epídoto, o plagioclásio é uma andesina cálcica em contato poligonizado com o diopsídio, que por vezes apresenta-se reequilibrado para actinolita possivelmente associada à foliação $S_{3}$, ou pode estar envolvido por epídoto cristalizado pós- $S_{2}$. A flogopita às vezes encontra-se retrometamorfizada para clorita magnesiana.

Algumas camadas ricas em tremolita/actinolita apresentam textura decussada, enquanto que alguns cristais de diopsídio associados deixam dúvidas se estão ou não relacionados ao metamorfismo de contato gerado na intrusão do Maciço Granitóide Itaqui (SP 624a $)$. A cristalização de porfíoblastos de 
turmalina subeuédrica nessas amostras sugere relação com o evento de metamorfismo de contato.

As relações de cristalização dos minerais nas rochas afetadas por metamorfismo de contato encontram-se na TABELA 5.6.

TABELA 5.5 - Relações de cristalização dos minerais nas rochas calciossilicáticas da Formação Morro da Pedra Preta.

\begin{tabular}{|c|c|c|c|c|c|c|c|c|}
\hline Minerais & R. & Foliacão $S_{l}$ & $P O S-S_{I}$ & Foliacão $S_{2}$ & $P 6 s-S_{2}$ & Foliacão $S_{3}$ & $P \sigma s-S_{3}$ & Foliacão $S_{4}$ \\
\hline Diopsídio & & $\ldots \ldots$ & & 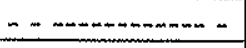 & -- & & & \\
\hline Tremolita/actinolita & & & & $\ldots \ldots \ldots$ & & $\ldots$ & & \\
\hline Tremolita & & & & 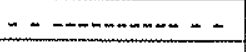 & & $\ldots \ldots$ & & \\
\hline Epídoto & & & & $\ldots \ldots \ldots+\cdots$ & $-\ldots$ & $\ldots \ldots \ldots$ & $\cdots$ & \\
\hline Flogopita & & & & $--\cdots$ & & $-\cdots$ & & \\
\hline Clinozoizita & & & & $\ldots \ldots \ldots$ & $-\cdots$ & $\ldots$ & & \\
\hline Titanita & & 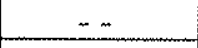 & & $\ldots \ldots$ & - & & & \\
\hline Leucoxênio & & & & & & $\cdots \cdots$ & & \\
\hline Plagioclásio geminado & & 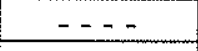 & & 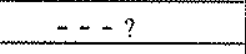 & & & & \\
\hline Plagioclásio (And. cálcica) & & & & $\ldots \ldots \ldots$ & & & & \\
\hline Fe-actinolita-Hornblenda & & --- & & $\ldots \ldots \ldots$ & - & & & \\
\hline Quartzo & & $\ldots$ & & $\cdots \cdots$ & & $-\cdots$ & & \\
\hline Microclínio & & 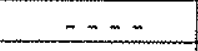 & & $-\cdots-?$ & & & & \\
\hline K-Feldspato nâo geminado & & & & $\ldots$ & & $\cdots$ & & \\
\hline Plagioclásio não geminado & & & & $--?$ & & $\ldots$ & & \\
\hline Biotita & & $\cdots \cdots$ & & $\ldots \ldots \ldots$ & $=-$ & & & \\
\hline Carbonato & & & & $\ldots$ & $\ldots$ & $\ldots-\cdots$ & & \\
\hline Mineral opaco (magnetita) & & $\cdots$ & & $\ldots \ldots$ & - & & & \\
\hline Ortoclásio pertítico & & $\ldots$ & & $--?$ & & & & \\
\hline Clorita (magnesiana) & & & & & & $\cdots \cdots$ & & \\
\hline Turmalina & & & & - & $\ldots$ & & & \\
\hline Augita (?) hosp. c/ Ortopirox. & & $\cdots$ & & & & & & \\
\hline Zircão & -4 & $\ldots$ & & & & & & \\
\hline Granada & & & & $\cdots$ & - & & & \\
\hline Alanita & - & $---?$ & & & & & & \\
\hline Apatita & & & & - & - & & $F$ & \\
\hline Limonita/Goethita & & & & & & & & $\rightarrow$ \\
\hline Fácies metamórfica & & anfibolito & & anfibolito & & xisto-verde & & \\
\hline
\end{tabular}

TABELA 5.6 - Relações de cristalização dos minerais nas rochas calciossilicáticas da Formação Morro da Pedra Preta afetadas por metamorfismo de contato.

\begin{tabular}{|c|c|c|c|c|c|c|c|}
\hline Minerais & $R$. & Foliacão $S_{\perp}$ & $P o ́ s \cdot S_{1}$ & Foliação $S_{2}$ & Metam. de Contato & Foliação $S_{3}$ & Pós-S $S_{3}$ \\
\hline Flogopita & & & & $\ldots \ldots$ & & & \\
\hline Quartzo & & $-\cdots ?$ & & 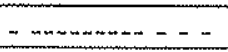 & $\cdots$ & - & \\
\hline Clinozoizita & & & & $\cdots \cdots$ & $\cdots-\cdots$ & & \\
\hline Epídoto & & & & $\cdots \cdots$ & & $\cdots$ & \\
\hline Plagioclásio & & $---?$ & & $\ldots \ldots$ & & & \\
\hline Titanita & & & & $\ldots \ldots$ & $\cdots \cdots$ & & \\
\hline Leucoxênio & & & & & & $\ldots$ & \\
\hline Clinopiroxênio (diopsídio) & & & & $\ldots$ & - & & \\
\hline Plagioclásio (And. cálcica) & & & & -- & $\ldots \cdots \cdots$ & & \\
\hline Microclínio & & & & & $\ldots \ldots$ & & \\
\hline Plagioclásio não geminado & & & & & & $\ldots \ldots$ & \\
\hline Fe-actinolita & & & & & & $\ldots$ & \\
\hline Clorita & & & & & & $\cdots$ & \\
\hline Turmalina & & & & & $\cdots$ & & \\
\hline Fácies metamórfica & & & & anfibolito & & xisto-verde & \\
\hline
\end{tabular}




\subsubsection{Unidade dos Xistos Pelíticos (MPSIppmp)}

Nesta unidade estão agrupados os xistos rítmicos finos a muito finos que comumente estão intercalados com os metassedimentos tufíticos. Também em contato e sobrepostos aos metassedimentos tufíticos ocorrem biotita-estaurolita xistos. Esses dois litotipos freqüentemente gradam para os xistos pelíticos com aglomerados grossios de fibrolita. Na região das fazendas Itayhe e Tamboré observam-se biotita-muscovita-quartzo xistos com biotita e/ou magnetita porfiroblásticas dispostos no topo dessa unidade. Estas variedades de xistos pelíticos são descritas a seguir.

\section{a) Xistos rítmicos finos a muito finos}

São rochas de granulação fina a muito fina compostas em essência por biotita (30 até $80 \%$ ), quartzo $(\sim 10$ até $35 \%)$ e muscovita $(<30 \%$ ou entre 45 e $50 \%)$. Como minerais acessórios, podem estar presentes mineral opaco (até 3\%), turmalina $(<1 \%$ ), grafita $(<1 \%$ ), andaluzita e epídoto e, mais raramente, zircão, alanita e rutilo. Goethita/limonita ocorre com freqüência como mineral de alteração. Há predominância modal de cristais entre 0,1 e $0,2 \mathrm{~mm}$, sendo raros os com $0,4 \mathrm{~mm}$.

A estrutura mais comum é a foliação $S_{2}$ à qual se sobrepõe uma clivagem de crenulação $S_{3}$ (Prancha 06/Foto H), sendo que o segundo evento deformacional $\left(S_{2}\right)$ pode evoluir para uma foliação milonítica, gerando rochas com uma forte orientação mineral segundo a $S_{m}$. Por vezes, essa foliação gera cominuição dos minerais, transposição e um bandeamento tectônico paralelo ou oblíquo à $S_{1} / S_{0}$. A foliação $S_{1}$ pode ser recuperada pela presença de alguns cristais relativamente maiores de minerais micáceos anédricos que estäo reorientados ou transpostos pela $S_{2}$, ou ainda pela identificação de leitos quartzosos contendo minerais micáceos orientados, e que ocorrem dobrados intrafolialmente com os flancos adelgaçados ou rompidos pela foliação milonítica. Na $S_{3}$ cristalizaram principalmente minerais micáceos e quartzo. As relações de cristalização dos minerais segundo as diferentes foliações metamórficas podem ser vistas na TABELA 5.7.

Nestas rochas observa-se caracteristicamente a alternância de finas lâminas ou lentes constituídas essencialmente por biotita e/ou muscovita e aquelas formadas quase exclusivamente por quartzo (Prancha 06/Foto H). Predomina a textura lepidoblástica dada pela orientação da biotita e da muscovita, sendo que onde $S_{2} / S_{m}$ é mais intensa cristais de quartzo alongados são freqüentes.

Observam-se cristais subeuédricos de biotita com pleocroísmo variando do marrom-amarelado ao amarelo ou verde que estão orientados principalmente segundo a foliação $S_{2} / S_{\mathrm{m}}$ e, subordinadamente, segundo a $S_{3}$. No último caso, os cristais são enédricos e maiores.

Eventualmente, observam-se também cristais de biotita maiores $\sin -S_{1}$, anédricos, com pleocroísmo variando do castanho ao amarelomesverdeado, ou agregados de biotita menores também sin$S_{1}$. Em ambos os casos, mostram-se parcialmente reorientados e, por vezes, são cortados por minerais micáceos da foliação $S_{2} / S_{\mathrm{m}}$.

Muscovita predomina associada à foliação $\mathrm{S}_{2}$, constituindo cristais mais finos clo que aqueles de biotita $\sin -S_{2} / S_{\mathfrak{m}}$. Geralmente está presente em concentrações menores do que a última. Localmente, 
ocorrem cristais de muscovita $\sin -S_{1}$ reorientados, formando dobras intrafoliais isoladas no interior da $S_{2}$, ou sendo parcialmente transpostos ou destruídos pela foliação $S_{m}$. São raros os cristais euédricos de muscovita $\sin -\mathrm{S}_{3}$.

O quartzo pode variar quanto ao conteúdo e às características texturais nos diferentes leitos. Nas rochas afetadas pela $S_{m}$, está alongado segundo essa foliação, podendo apresentar extinção ondulante; raramente exibe hábito fitado ou está cristalizado segundo os pares $S-C$ da foliação milonítica. Nas outras rochas predomina como cristais granulares angulosos pouco orientados. Eventualmente, associa-se aos cristais anédricos de biotita $\sin -\mathrm{S}$, formando agregados de cristais com formas amendoadas ao redor dos quais ocorrem muscovita e biotita $\sin -S_{\mathrm{m}}$.

Os minerais opacos maiores estão disseminados pela rocha como cristais anédricos com formas que lembram antigos cristais de magnetita, ou constituem pequenos porfiroblastos de até $3,0 \mathrm{~mm}$ associados aos cristais de biotita $\sin -S_{1}$. Cristais menores estão preferencialmente orientados segundo a $S_{2} / S_{m}$ e, secundariamente, segundo a $S_{1}$. Outros podem estar dobrados pela $S_{3}$.

Em raros exemplares ocorrem porfiroblastos de andaluzita e, em outros, de epídoto. O epídoto está presente como pequenos porfiroblastos prismáticos subeuédricos a euédricos de até $1,2 \mathrm{~mm}$. Podem estar aleatoriamente distribuídos ou mostrar-se orientados segundo a foliação $S_{2}$, sendo localmente dobrados pela foliação $S_{3}$, sugerindo cristalização nos estágios tardi- e pós- $S_{2}$. Porfiroblastos corroídos e instáveis de andaluzita $\sin -\mathrm{S}_{1}$, de até $1,2 \mathrm{~mm}$, foram observados parcialmente cortados e alterados para sericita/muscovita fina $\sin -\mathrm{S}_{2}$ (Prancha 07/Foto $\left.\mathrm{A}\right)$.

Pequenos cristais de turmalina euédrica podem estar zonados, mostrando o centro verde-escuro e a borda verde-clara. Aparentemente, cristalizaram nos estágios tardi- a pós- $\mathrm{S}_{2}$.

Zircão ocorre eventualmente, enquanto que raros cristais vermelhos de alto relevo com geminação em cotovelo indicam a presença de rutilo. Alanita e apatita foram observados apenas na amostra BT 925. TABELA 5.7 - Relações de cristalização dos minerais dos xistos finos rítmicos.

\begin{tabular}{|c|c|c|c|c|c|c|c|c|}
\hline Minerais & $R$. & Foliacão $S_{L}$ & Poss-S $S_{I}$ & Foliacão $S_{2}$ & $P \sigma s=S_{2}$ & Foliacão $S_{1}$ & $P 6 s-S_{3}$ & Foliacão $S_{4}$ \\
\hline Biotita & & $\ldots \cdots$ & $-?-$ & $-\ldots$ & & $\ldots \ldots$ & & \\
\hline Quartzo & & $\ldots \ldots$ & & $\cdots \cdots$ & & $\ldots$ & & \\
\hline Muscovita fina / sericita & & $\cdots \cdots$ & & a. & & $\cdots$ & & \\
\hline Grafita & & $\cdots$ & & $\cdots \cdots$ & & & & \\
\hline Epídoto & & $-\cdots$ & $m-$ & $-?-$ & & & & \\
\hline Turmalina & & & & $-\cdots$ & .. & & & \\
\hline Mineral opaco (magnetita) & & $\cdots \cdots$ & - & $\cdots \cdots$ & & --2 & & \\
\hline Andaluzita & & - & $-\infty$ & & & & & \\
\hline Zircão & $-?-$ & $-?-$ & & & & & & \\
\hline Alanita & & & & -. & & & & \\
\hline Rutilo & - & & & & & & & \\
\hline Apatita & & & & - & . & & & \\
\hline Limonita / goethita & & & & & & & & \\
\hline Fácies Metamórfica & & xisto"verde & & xisto-verde & & xisto-verde & & \\
\hline
\end{tabular}




\section{b) Biotita-estaurolita xistos}

Constituem rochas de granulação fina a média que têm como minerais principais estaurolita (15 até $60 \%$ ), quartzo (35 a $55 \%$ ) e biotita (15 a 25\%), enquanto que muscovita (até $5 \%$ ), granada (ausente a $5 \%$ ), turmalina (traço até $2 \%$ ), magnetita ( 1\%) e zircão (traço raro) constituem os minerais acessórios. Petrograficamente, correspondem a biotita-estaurolita xistos, por vezes com granada e/ou muscovita. Afloram como um possível corpo lenticular à sul do Stock Granítico Tico-Tico.

São formados por porfiroblastos de estaurolita, de biotita e, por vezes, de granada (Prancha 07/Foto B), que ocorrem dispersos em matriz fina constituída essencialmente por quartzo e biotita. Os cristais de estaurolita variam de 0,7 a $3,5 \mathrm{~mm}$, os de quartzo de 0,4 a $0,8 \mathrm{~mm}$, os de biotita de 0,3 a 0,8 mm e os de muscovita de 0,3 a $0,5 \mathrm{~mm}$.

Nessas rochas se recupera uma foliação milonítica correlacionável à $S_{2}$ (Prancha 07/Foto B), ainda que macroscopicamente o tamanho e a abundância dos cristais maiores de estaurolita e de biotita sugiram textura maciça. Alguns cristais de quartzo e de biotita da matriz relacionados a uma foliação prévia são cortados pela $S_{m}$, e ainda, por vezes, truncados pelos cristais maiores de estaurolita e de biotita. A foliação $S_{3}$ é responsável por dobras suaves da foliação milonítica, havendo fraca recristalização mineral associada a esse evento deformacional. As relações de cristalização dos minerais segundo os diferentes eventos deformacionais estão exibidas na TABELA 5.8.

A estaurolita constitui em geral cristais poiquiloblásticos $\sin -S_{2}$, sendo que o volume das inclusões de quartzo e, secundariamente, de finíssimos cristais de opacos ocupa, em alguns casos, até a metade deles. Ocasionalmente, essas inclusôes marcam uma foliação interna $S_{\mathrm{i}}$ correlacionada à $S_{1}$. Parte dos poiquiloblastos pode apresentar porções mais maciças, e outros exibem bordas subeuedrais a euedrais pós-S $S_{2}$ pobres ou isentas de inclusões. A possibilidade dessas bordas terem cristalizado por efeito de um evento de metamorfismo de contato poss- $\mathrm{S}_{2}$ é sugestiva, dada a proximidade do Stock Granítico Tico-Tico.

Os porfiroblastos de biotita são em geral bem menores do que os poiquiloblastos de estaurolita, podendo ser ricos em inclusões de quartzo e opacos. Predominam como cristais castanho-avermelhados por vezes distribuídos aleatoriamente pela matriz na forma de placas subeuédricas curtas. Eventualmente, estão parcialmente alterados para agregados microgranulares vermelhos sugestivos da precipitação de limonita/goethita.

A granada, quando presente, ocorre como pequenos poiquiloblastos $\sin -S_{\mathrm{m}} / \mathrm{S}_{2}$ ricos em inclusões de quartzo, biotita e opacos com porções mais maciças, frequientemente associadas às bordas que indicam crescimento tardi- a pós- $\mathrm{S}_{2}$. Em outros cristais de granada, as inclusões de quartzo que ocorrem no centro têm formas elipsóides e estão dispostas obliquamente à foliação $S_{2}$, sugerindo também a presença de granada cristalizada no estágio pós-S. Se modo geral, os cristais de granada encontram-se intemperizados e limonitizados.

Predomina uma matriz de textura lepidoblástica com cristais de quartzo e minerais micáceos estirados segundo a foliação principal. Em amostras menos deformadas, observam-se porções de matriz. 
lepidogranoblásticas ou mesmo granoblásticas, devido a ausência de orientação do quartzo e da biotita.

Na matriz, é comum a presença de quartzo com forma granular e com contato poligonizado podendo apresentar extinção ondulante, ou exibindo forma alongada segundo a foliação $S_{2}$. A biotita da matriz está formada por cristais bem menores orientados em essência segundo a foliação $S_{2} / S_{m}$, crescendo às vezes nos pares $S$ - $C$ dessa foliação milonítica. A muscovita também mostra-se orientada de acordo com a foliação principal, sendo, por vezes, observadas inclusões euédricas desse mineral nos cristais de biotita.

Turmalina ocorre como cristais euédricos menores que $0,1 \mathrm{~mm}$ distribuídos pela matriz e, ocasionalmente, está inclusa na biotita ou na estaurolita. Os minerais opacos ocorrem subordinados na matriz exibindo formas euédricas e hábito octaédrico, sendo caracterizados como de magnetita, ou têm formas tabulares e podem estar presentes como finas inclusões na estaurolita, na granada e nos cristais maiores de biotita. Pequenos cristais de zircão são observados raramente junto ao quartzo na matriz ou como inclusões na biotita.

TABELA 5.8 - Relação de cristalização dos minerais dos biotita-estaurolita xistos.

\begin{tabular}{|c|c|c|c|c|c|c|c|}
\hline Minerais & Foliação $S_{l}$ & $P o s-S_{l}$ & Foliação $S_{2}$ & $\begin{array}{c}\begin{array}{c}\text { Pós- } S_{2} / o u \\
\text { contato }\end{array} \\
\end{array}$ & Foliação $S_{3}$ & $P 6 s * S_{3}$ & Foliação $S_{4}$ \\
\hline Estaurolita porfiroblástica & $\ldots$ & -- & $\ldots \ldots$ & \begin{tabular}{|l|}
$\ldots \ldots \ldots$ \\
\end{tabular} & & & \\
\hline Biotita & 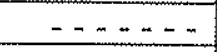 & & 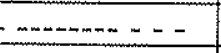 & & $\cdots$ & & \\
\hline Biotita porfiroblástica & & & $\ldots \ldots$ & $-\cdots-\cdots$ & & & \\
\hline Quartzo & $\cdots \cdots$ & & $\ldots \ldots$ & $\cdots$ & $\cdots$ & & \\
\hline Muscovita & $-?-$ & & $-\cdots$ & -- & $\ldots$ & & \\
\hline Granada & - & $\cdots$ & $-\cdots-$ & -- & & & \\
\hline Turmalina & & & $\cdots$ & - & & & \\
\hline Minerais opacos & $\cdots$ & & $\cdots \cdots$ & & $\cdots$ & & \\
\hline Zircão & - & & -- & & & & \\
\hline Fácies Metamórfica & anfibolito & & anfibolito & & xisto-yerde & & \\
\hline
\end{tabular}

\section{c) Muscovita-biotita xistos com aglomerados grossos de fibrolita}

Estas rochas são formadas por aglomerados grossos de fibrolita $(\sim 15 \%$, por vezes atê $30 \%)$, de muscovita, ou de muscovita, quartzo e biotita, que podem perfazer de 15 a $20 \%$ e, eventualmente, até $50 \%$ do volume da rocha. Mais raramente, ocorrem porfiroblastos de andaluzita, estaurolita ou cordierita dispersos em matriz fina constituída essencialmente por quartzo, biotita e muscovita.

As amostras apresentam uma variação nos teores de quartzo, biotita e muscovita da matriz mas, de modo geral, seus conteúdos decrescem nessa ordem. O quartzo ocupa de 20 a $60 \%$ do volume da rocha, a biotita constitui entre 10 e $30 \%$, podendo atingir até $50 \%$, enquanto que a muscovita compreende, em geral, teores inferiores a $20 \%$, mas é o mineral que exibe maior oscilação, podendo ocupar $2 \%$ ou atingir até $60 \%$ nas porções mais milonitizadas. Ainda são observados na matriz minerais opacos (traço a acessório ocasional), turmalina ( 1\% até ocasionalmente $3 \%$ ), zircão (traço comum), clorita (acessório ocasional em raros leitos), plagioclásio (ausente até raramente 5\%), granada (ausente até $2 \%$ ) e cordierita. Petrograficamente, correspondem a muscovita-biotita xistos com agregados grossos de fibrolita, 
Na matriz, os cristais de quartzo, biotita e muscovita em geral variam entre 0,2 a $0,8 \mathrm{~mm}$, sendo raros os que atingem 1,2 $\mathrm{mm}$. O tamanho dos aglomerados varia de 0,8 até $3,5 \mathrm{~mm}$, sendo que os de fibrolita podem medir até $7,0 \mathrm{~mm}$. Por vezes, observam-se aglomerados de muscovita, quartzo e biotita que atingem até $1,5 \mathrm{~cm}$, sendo formados por cristais maiores de muscovita com até $2,0 \mathrm{~mm}$.

A estrutura principal dessas rochas corresponde à foliação $S_{2}$ mas, em alguns locais, a $S_{3}$ predomina. $\mathrm{A} \mathrm{S}_{2}$ é marcada por uma intensa xistosidade que, não raro, evolui para uma foliação milonítica (Prancha 07/Foto $C$ ) por vezes com bandeamento diferencial associado. Essa foliação $S_{m}$ mostra aspecto ondulado a anastomosado e amolda-se aos agregados de muscovita, biotita e quartzo, de muscovita e de fibrolita, evidenciando o caráter milonítico. A foliação $S_{1}$ é recuperada ocasionalmente pela presença de cristais maiores de quartzo e de biotita associados que são truncados e estão isolados em lenticularizações geradas pela transposição da foliação principal, $S_{2} / S_{m}$. Nas amostras onde o terceiro evento foi mais intenso, a $S_{3}$ gera dobras apertadas plano-axiais (Prancha 07/Foto D) com arcos poligonais formados pelos minerais micáceos e, quando menos intenso, ocorre apenas uma ondulação da foliação anterior. As relações de cristalização metamórfica com as foliações estão na TABELA 5.9.

Alguns dos cristais maiores de muscovita apresentam kink bands que podem estar associadas à foliação $S_{2}$, mas é mais comum relacionarem-se à $S_{3}$, principalmente quando os cristais são menores e a $\mathrm{S}_{3}$ mostra-se mais efetiva.

Predomina na matriz a textura lepidogranoblástica dada pela orientação dos minerais micáceos e a não orientação dos cristais granulares de quartzo. Quando a foliação $S_{2}$ torna-se mais intensa ou milonítica, aumenta a cristalização de minerais micáceos e os de quartzo ocorrem estirados, produzindo uma textura lepidoblástica.

A fibrolita exibe hábito fibroso a acicular, sendo às vezes reconhecidas pequenas formas prismáticas ou granulares de silimanita no meio dos agregados, além do crescimento epitáxico com biotita (Prancha 07/Foto E). A forma externa dos aglomerados de fibrolita é predominantemente amendoada. Em geral é incolor ou tem porções marrom-claras a castanho-claras. Sua cristalização mais efetiva é sincinemática à foliação $S_{2}$, predominando nos locais onde a $S_{2}$ evolui para milonítica, podendo crescer, nesses casos, segundo os pares $S-C$ da milonitização. Raramente a fibrolita parece ter cristalizado a expensas de andaluzita e, em outras amostras, a partir de cristais de cianita da foliação $S_{1}$. No interior desses aglomerados podem ser vistos finos cristais de minerais opacos, quartzo e biotita e, por vezes, observa-se, na sua parte central, inclusão de granada parcialmente limonitizada relacionada à foliação $S_{\downarrow}$.

Nos agregados grossos formados por muscovita, biotita e quartzo, predomina a muscovita na forma de cristais maiores a porfiroblásticos. Esses agregados podem apresentar alguns cristais de fibrolita. Já nas bordas dos agregados grossos formados essencialmente por muscovita, não são raros os cristais de fibrolita. Nesses agregados predominam as formas lenticulares, sendo que alguns deles mostram uma forte recristalização de muscovita e/ou biotita em cristais menores orientados segundo o evento deformacional $S_{2}$ nas suas bordas, o que levou a caracterizar os agregados como relíquias da foliação $S_{1}$. 
Alguns dos cristais maiores de muscovita que fazem parte dos agregados grossos podem ser ricos em inclusões de quartzo na forma de gota ou, mais raramente, de granada. Em geral, os aglomerados formados por muscovita, biotita e quartzo ou só por muscovita ocorrem de forma subordinada aos agregados de fibrolita, mas, ocasionalmente, podem constituir até metade do volume da rocha.

Os agregados portando muscovita, quartzo e biotita ou essencialmente muscovita podem constituir arranjos pouco ou não orientados ou apresentar formas amendoadas ou lenticulares orientadas segundo a foliação principal.

Em alguns exemplares ainda é possível identificar restos de estaurolita porfiroblástica quase totalmente retrometamorfizada e transformada em um agregado de muscovita, por vezes restando apenas o núcleo submilimétrico de estaurolita.

Ocasionalmente, notam-se porfiroblastos de andaluzita alterados ou cortados parcialmente por cristais mais finos de fibrolita, indicando uma cristalização desses porfiroblastos em evento prévio à foliação $S_{2}$. A ocorrência de pseudomorfos de andaluzita também é sugerida pela presença de formas reliquiares prismáticas curtas e euedrais, que estão em grande parte substituídas por sericita e/ou pirofilitá muito finas distribuídas randomicamente sobre o provável pseudomorfo. A andaluzita pode também cristalizar-se em venulações tardias, provavelmente pós- $S_{2}$, que cortam o bandeamento tectônico.

$\mathrm{Na}$ maioria das amostras a matriz é constituída predominantemente por quartzo e, subordinadamente, pelos minerais micáceos. O quartzo recristalizado pode mostrar bordas variando de irregulares a retilíneas. Onde a foliação milonítica predomina, geralmente o quartzo ocorre subordinado aos minerais micáceos, e mostra formas estiradas com as extremidades angulosas a pontiagudas, sendo comum a extinção ondulante e o contato retilíneo com os minerais micáceos. Eventualmente, são observados finos cristais com formas sigmoidais. Por vezes finos cristais de quartzo ocorrem associados a sombras de pressão formadas ao redor de agregados de fibrolita. Nas chameiras das dobras $\mathrm{D}_{2}$ podem ser vistas concentrações de quartzo e, onde o terceiro evento deformacional foi mais intenso, houve maior recristalização de quartzo $\sin -\mathrm{S}_{3}$.

Nestas rochas são comuns as intercalações mais arenosas formando finos leitos ricos em quartzo paralelos ao acamamento original, onde também podem ser encontradas pequenas quantidades de muscovita e biotita.

Biotita predomina como palhetas subeuédricas curtas castanho-avermelhadas cristalizadas de preferência na foliação $S_{2}$. Concentra-se também nas bordas de agregados grossos de muscovita e em pequenas lentes onde concentrou a milonitização. Nas amostras mais ricas em quartzo e menos deformadas, cristaliza amoldando-se nos espaços entre os cristais granulares de quartzo, marcando uma incipiente foliação $\mathrm{S}_{2}$.

Localmente, observam-se cristais de quartzo e de biotita anédricos e relativamente maiores, se comparados com os outros minerais da matriz, francamente orientados segundo a foliaçấo $S_{2}$ e que, por vezes, truncam e rotacionam parcialmente os demais, que foram, portanto, caracterizados como cristais 
preservados da foliação $S_{1}$.

A muscovita em geral ocorre de forma subordinada em relação à biotita, tem granulação mais fina, compreendendo cristais subeuédricos a euédricos predominantemente orientados segundo a $S_{2}$ e, subordinadamente, segundo a $S_{3}$, consistindo, nesse caso, de placas mais finas ortogonais à $S_{2}$ quando a crenulação é suave. Quando a $S_{3}$ é mais intensa, ocorre de preferência próxima às charneiras das dobras $\mathrm{D}_{3}$. Nos xistos mais foliados ou miloníticos seu conteúdo é maior, podendo constituir o micáceo predominante ou mesmo a fase mineral principal da rocha.

Feldspato potássico e plagioclásio estão quase ausentes e, devido à recristalização metamórfica, torna-se difícil sua caracterização. Às vezes são reconhecidos por apresentarem, além do caráter óptico biaxial, finíssimas inclusões de sericita indicando início da saussuritização, principalmente no plagioclásio. Em outras situações, sua presença é sugerida pelo fato de os cristais apresentarem extinção concêntrica. Finos cristais de cordierita dispersos na matriz são observados em algumas amostras.

Finos cristais euédricos a subeuédricos de granada sin- a pós- $\mathrm{S}_{2}$ ocorrem dispersos na matriz, sendo raros os que atingem $0,8 \mathrm{~mm}$. Eventualmente, a granada ocorre inclusa nos agregados grossos de minerais micáceos e nos aglomerados de fibrolita. Encontra-se em grande parte alterada e limonitizada mas, quando observada mais fresca, é possível distinguir no seu núcleo finíssimas inclusões, principalmente de mineral opaco e quartzo, além de biotita orientada segundo uma foliação interna $S_{\mathrm{i}}$ correlacionada à foliação $S_{1}$. As bordas isentas de inclusões indicam um crescimento pós- $S_{2}$. Por vezes, também pode ocorrer um certo alongamento de alguns cristais orientados segundo a foliação $S_{m}$.

TABELAA 5.9 - Relações de cristalização dos minerais nos muscovitambiotita xistos com aglomerados grossos de fibrolita.

\begin{tabular}{|c|c|c|c|c|c|c|c|c|}
\hline Minerais & $R$. & Foliacão $S_{1}$ & $P O s \cdot S_{1}$ & Foliacão $S_{2}$ & $P \delta s-S_{2}$ & Foliacão $S_{2}$ & $P O S-S_{3}$ & Foliacão $S_{4}$ \\
\hline Biotita & & $\ldots \ldots$ & $\ldots$ & $-\ldots$ & $\cdots$ & $\ldots$ & & \\
\hline Quartzo & & $\cdots \cdots$ & - & rnw & $-\cdots$ & $\ldots \ldots$ & & $\cdots$ \\
\hline Muscovita & & $\ldots$ & - & (2n-1- & -- & $-\cdots \cdots$ & & $\ldots$ \\
\hline Aglomerados de Fibrolita & & $\ldots$ & & man- & & & & \\
\hline Fibrolita & & & & $\ldots$ & & & & \\
\hline Muscovita porfiroblástica & & $\ldots$ & - & & $=-\ldots$ & & & \\
\hline Agregados de Muscovita & & $-\ldots \operatorname{man}-1$ & & $-\cdots$ & & & & \\
\hline Agreg. de Musc+Bt+Qtz & & $-\cdots+\cdots-\cdots$ & $\ldots$ & $--?$ & & & & \\
\hline Granada & & -- & $\ldots$ & -- & $m-$ & & & \\
\hline Plagioclásio (andesina?) & & $m$ & & $-\cdots$ & & & & \\
\hline Feldspato potássico & & $-\cdots$ & & & & & & \\
\hline Turmalina & & & & 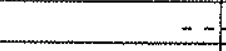 & -- & - & & \\
\hline Mineral opaco & & $--?$ & & 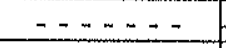 & $\ldots$ & & & \\
\hline Zircão & $\sim$ & $\ldots$ & & $\cdots$ & & & & \\
\hline Clorita & & & & $\ldots$ & & $\cdots$ & & - \\
\hline Estaurolita (porf. reliq.) & & $\ldots$ & & & & & & \\
\hline Cordierita & & & & $\cdots-$ & - & & & \\
\hline Silimanita & & $\cdots$ & & & & & & \\
\hline Cianita & & $=$ & & & & & & \\
\hline Andaluzita & & $\ldots$ & - & & $-?$ & & $-?$ & \\
\hline Sericita / pirofilita & & & & & & $\ldots$ & $E$ & \\
\hline Fácies Metamórfica & & anfibolito & & anfibolito & & xisto-verde & & xisto-verde \\
\hline
\end{tabular}


A turmalina apresenta-se em finos cristais euédricos com secção basal menor que $0,1 \mathrm{~mm}$ que exibem o núcleo verde e a borda tendendo ao amarelo, cristalizados principalmente nos estágios tardi- a pós $S_{2}$, sendo, por vezes, parcialmente dobrada e fraturada pela foliação $S_{3}$.

Coexistem minerais opacos de forma cúbica/octaédrica, caracterizados como cristais de magnetita, com aqueles que exibem forma tabular e são mal formados, tratandomse, possivelmente, de ilmenita e/ou hematita. De modo geral, os minerais opacos são menores que $0,1 \mathrm{~mm}$, estando orientados segundo a $S_{2}$ e cristalizados também no evento pós $S_{2}$. Podem ocorrer ainda, secundariamente, nos estágios tardios da foliação $S_{3}$.

Cristais muito finos de zircão, medindo ao redor de $0,01 \mathrm{~mm}$, ocorrem associados aos cristais granulares de quartzo ou inclusos na biotita $\sin -S_{1}$ e $\sin -S_{2}$. Na matriz, também podem ser vistas finas agulhas de fibrolita sin- $S_{2}$. Localmente, foram descritas venulações tardias subconcordantes e posteriores à foliação $S_{2}$, onde cristalizam quartzo e muscovita de granulação média.

\section{d) Biotita-muscovita xistos com biotita e/ou magnetita porfiroblásticas}

Estas rochas são constituídas por porfiroblastos de biotita e de magnetita dispersos em matriz fina, de granulação em geral menor que 0,2 mm, composta por quartzo ( 50 até 55\%), muscovita (40 até $50 \%$ ), biotita $(\sim 5-7 \%)$ e minerais opacos (até $4 \%$ ). Como minerais acessórios, podem ocorrer estaurolita, turmalina, clorita e grafita. Estes xistos afloram na região das fazendas Itayhe e Tamboré e, petrograficamente, correspondem a biotita-muscovita xistos com porfiroblastos de biotita e/ou de magnetita.

A foliação principal também está representada nesses xistos pela $S_{2}$ que pode evoluir para uma foliação milonítica, e predomina a textura lepidoblástica dada pela orientação dos minerais micáceos.

Os porfiroblastos castanho-avermelhados de biotita podem medir até $1,2 \mathrm{~mm}$ e têrn formas alongadas a arredondadas onde predominam bordas irregulares. São freqüientes sombras de pressão ao redor deles, formadas principalmente por cristais de quartzo maiores do que aqueles presentes na matriz, indicando que esses porfiroblastos cristalizaram no evento deformacional $S_{1}$ (Prancha 07/Foto F).

Os porfiroblastos de magnetita são menores, atingindo até $0,4 \mathrm{~mm}$, e têm forma octaédrica. Podem coexistir cristais com bordas retilíneas e outras corroídas.

Não raro, são observados agregados de formas irregulares formados por finos cristais de biotita, porfiroblastos de magnetita e diminutos minerais opacos menores que $0,05 \mathrm{~mm}$, que parecem também corresponder à magnetita. Os agregados estão orientados segundo a $S_{2}$, enquanto que as formas euédricas a subeuédricas dos opacos maiores mostram crescimento pós- $\mathrm{S}_{2}$. Estes agregados podem atingir até 1,2 $\mathrm{mm}$, e provavelmente compreendem antigos porfiroblastos de biotita $\sin -S_{1}$ que recristalizaram na foliação principal, pois também se observa a presença de sombras de pressão nos agregados (Prancha 07/Foto F).

Localmente, há estaurolita porfiroblástica cristalizada essencialmente no estágio $\sin -\mathrm{S}_{2}$, mas 
também são observadas texturas indicativas de cristalização ao menos tardi- $S_{1}$, como o truncamento dos minerais micáceos da foliação $S_{2}$ que recortam o porfiroblasto. A recristalização de bordas enédricas a subeuédricas e isentas de inclusões possivelmente relaciona-se ao estágio pós- $S_{2}$.

O quartzo encontra-se, com freqüência, recristalizado em grãos menores que possuem bordas irregulares e mais raramente retilíneas, podendo possuir extinção ondulante. Nas rochas onde a foliação milonítica foi mais atuante, os minerais de quartzo da matriz apresentam formas alongadas.

A muscovita constitui finas placas alongadas menores que $0,1 \mathrm{~mm}$. A magnetita forma porfiroblastos euédricos pós $-S_{2}$, sendo que cristais menores de contornos arredondados são $\sin -S_{1}$ e, mais raramente, cristaliza segundo a foliação $S_{3}$.

Turmalina é frequiente como cristais euédricos verdes, e a grafita predomina como cristais disseminados, sendo menos comum a sua ocorrência na forma de finos leitos.

As relações de cristalização dos minerais com as respectivas foliações metamórficas podem ser observadas na TABELA 5.10.

TABELA 5.10 - Relações de cristalização dos minerais segundo as diferentes foliações nos biotita-muscovita xistos com biotita e/ou magnetita porfiroblásticas.

\begin{tabular}{|c|c|c|c|c|c|c|c|c|}
\hline Minerais & $R$. & Foliacão $S_{l}$ & $P \delta s-S_{t}$ & Foliacão $S_{2}$ & $P \sigma s-S_{2}$ & Foliacão $S_{3}$ & $P o s-S_{3}$ & Foliacão $S_{t}$ \\
\hline Biotita & & $\ldots \ldots$ & & $\ldots \ldots \ldots$ & & & & \\
\hline Biotita porfiroblástica & & $-\cdots$ & - & & & & & \\
\hline Quartzo & & $\ldots \ldots$ & & $-\cdots$ & & $-\cdots$ & & \\
\hline Muscovita & & $\ldots$ & & $-\ldots-n+\ldots-n-1$ & & $\ldots \ldots$ & & \\
\hline Magnetita & & $\ldots$ & & $\ldots$ & & $\ldots$ & & \\
\hline Magnetita porfiroblástica & & $\ldots \ldots$ & 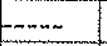 & $\ldots$ & $---m$. & & & \\
\hline Turmalina & & & & - & - & & & \\
\hline Clorita & & & & & & $--?$ & & \\
\hline Grafita & & $-\cdots$ & & $\cdots \cdots$ & & & & \\
\hline Estaurolita & & & $?-$ & $\ldots$ & -- & & & \\
\hline Fácies Metamórfica & & anfibolito & & anfibolito & & xisto-verde & & \\
\hline
\end{tabular}

\subsubsection{Unidade Metapelítica Grafitosa (MPSIppmg)}

\section{a) Grafita quartzo-muscovita xistos}

Devido à alteração intempérica, a descrição petrográfica da unidade baseia-se em amostras do litotipo parcialmente preservado e encontrado intercalado nas unidades dos metassedimentos tufíticos (PP 570B) e dos xistos pelíticos (TT 89).

São xistos finos a muito finos constituídos por muscovita (50 a 60\%), quartzo (5 a $25 \%$ ), grafita (10 a $15 \%$ ) e turmalina (traço até $4 \%$ ). Como minerais acessórios podem estar presentes andaluzita, zircão e rutilo. Petrograficamente, correspondem a grafita-quartzo-muscovita xistos.

Nos exemplares da unidade raramente observam-se porfiroblastos de muscovita com até $0,8 \mathrm{~mm}$, estando excepcionalmente presentes porfiroblastos de andaluzita de até 7,0 mm. A matriz apresenta granulação menor que $0,1 \mathrm{~mm}$.

Estas rochas mostram intercalações de leitos mais claros de granulação relativamente mais grossa, ricos em muscovita e onde a grafita e quartzo ocorrem de forma subordinada, e de lâminas cinza-escuras 
de granulação relativamente mais fina, por vezes formando finos níveis ou lentes constituídas principalmente por grafita. Nessas amostras, o quartzo geralmente ocorre em pequenas quantidades, sendo que concentrações maiores do mineral associam-se à presença de finos veios de quartzo paralelos ou sub-paralelos à $S_{2}$, formados por grãos maiores do que aqueles presentes na matriz (Prancha 07/Foto G).

A foliação mais comum relaciona-se ao segundo evento deformacional, sendo marcada por uma forte xistosidade $S_{2}$ comumente afetada pela clivagem de crenulação $S_{3}$, que pode, localmente, gerar dobras fechadas e arcos poligonais (Prancha 07/Foto G). Predomina a textura lepidoblástica dada pela orientação da muscovita $\sin -\mathrm{S}_{2}$, com os cristais alongados de quartzo e de grafita dispostos em essência segundo a mesma foliação, que pode evoluir para uma foliação milonítica e gerar um bandeamento tectônico paralelo à $S_{1} / S_{0}$. Um quarto evento deformacional é responsável pela ondulação das estruturas anteriores e pela cristalização de muscovita euédrica $\sin -S_{4}$.

$\mathrm{Na}$ amostra TT $89 \mathrm{~b}$ observam-se porfiroblastos de andaluzita em parte recortados e transformados para fibrolita cristalizada durante o evento deformacional $S_{2}$, o que sugere que os porfiroblastos são reliquiares e relacionados ao evento $S 1$.

Localmente, ocorrem agregados porfiroblásticos portando quartzo, muscovita e mineral opaco, os quais encontram-se amendoados e estirados pela foliação $S_{2} / S_{m}$, representando relíquias da foliação prévia. Finos cristais de turmalina apresentam-se zonados, com centro verde e borda amarelada, e cristalizam sobre a foliação $S_{2}$, sendo considerados como pós- $S_{2}$.

As relações de cristalização dos minerais com as foliações podem ser vistas na TABELA S.I1.

TABELA 5.11 - Relações de cristalização dos minerais segundo as foliações nos grafita-quartzo-muscovita xistos.

\begin{tabular}{|c|c|c|c|c|c|c|c|c|}
\hline Minerais & $R$. & Foliacão $S_{L}$ & $P O S-S_{l}$ & Foliacão $S_{2}$ & $P \sigma s-S_{2}$ & Foliacão $S_{3}$ & $P O S-S_{3}$ & Foliacãoo $S_{4}$ \\
\hline Quartzo & & 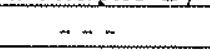 & & $-\cdots-\operatorname{cosmm-\infty }--$ & & 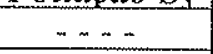 & & $\ldots$ \\
\hline Muscovita fina / sericita & & $\ldots$ & & $\ldots \ldots$ & & $\ldots \ldots \ldots$ & $-\infty$ & $\ldots \ldots$ \\
\hline Fibrolita & & & & $-\ldots \ldots$ & & & & \\
\hline Grafita & & $-\ldots$ & & $\ldots \ldots \ldots$ & & $\ldots-\cdots$ & & \\
\hline Turmalina & & & & $\ldots$ & - & & & \\
\hline Mineral opaco & & $\ldots$ & & $\cdots \cdots \cdots$ & & & & \\
\hline Andaluzita & & 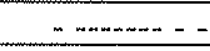 & - & & & & & \\
\hline Zircão & & - & & & & & & \\
\hline Rutilo & & $\sim$ & & & & & & \\
\hline Fácies Metamórfica & & xisto-verde? & & anfibolito & & xisto-verde & & xisto-verde \\
\hline
\end{tabular}

\subsubsection{Turmalinitos e biotita-turmalina xistos}

Estas rochas foram observadas intercaladas em alguns litotipos que ocupam posições estratigráficas diferenciadas, motivo pelo qual estão individualizadas neste subitem. Os seus posicionamentos estratigráficos e suas descrições são comentados a seguir.

\section{a) Turmalinitos e biotita-turmalina xistos}

A descrição petrográfica dos turmalinitos refere-se às amostras coletadas a partir de pequenos leitos de espessura até decimétrica que ocorrem intercalados nos metassedimentos tufíticos e também nos 
biotita-estaurolita xistos anteriormente descritos. Localmente, junto aos xistos pelíticos com aglomerados grossos de fibrolita, ocorrem intercalações de leitos de xistos que exibem maior concentração de turmalina. Essas rochas foram caracterizadas como biotita-turmalina xistos.

Os turmalinitos são rochas de granulação fina onde observamse a alternância de laminações descontínuas ou não, com espessura menor que $2,0 \mathrm{~mm}$, ora constituídas essencialmente por turmalina (20 até 98\%) e, subordinadamente, quarzo e mineral opaco, ora contendo principalmente quartzo (85 a $90 \%$ ), com turmalina e sericita ocorrendo subordinadas, e com espessura de até 4,0 mm (Prancha 07/Foto $\mathrm{H})$.

Nos leitos ricos em turmalina, esse mineral ocupa ao menos $20 \%$ volume da rocha mas, não raro, corresponde a mais de $60 \%$ do conteúdo, podendo perfazer de 90 até $98 \%$ em alguns leitos. Os cristais são euédricos e prismáticos, apresentando um núcleo verde a verde azulado que em direção à borda tornase verde-amarelado, verde-acastanhado ou castanho-esverdeado. As secções basais de turmalina podem atingir até $0,2 \mathrm{~mm}$, enquanto que os cristais de quartzo têm ao redor de $0,5 \mathrm{~mm}$, exibem formas granulares e contatos suturados e irregulares, sendo comum apresentarem extinção ondulante.

Nas lâminas um pouco mais espessas intercaladas, os cristais de quartzo chegam a constituir mais de $90 \%$ do conteúdo, sugerindo representarem níveis de metacherts onde podem estar presentes pequenas quantidades de turmalina, sericita e mineral opaco. A sericita ocorre disseminada entre os cristais de quartzo, ou marca uma incipiente foliação paralela ao bandeamento composicional, enquanto que o mineral opaco, também disseminado, tem hábito tendendo ao cúbico ou ocorre como poiquiloblasto rico em inclusões de quartzo, tratandorse, possivelmente, de magnetita e/ou de pseudomorfo desse mineral.

Os biotita-turmalina xistos são compostos essencialmente por quartzo $(35-40 \%)$, turmalina (30 $35 \%)$, biotita (15-20\%), e quantidades menores de muscovita (3-10\%), minerais opacos ( 2\%), apatita ( $1 \%$ ), zircão (traço) e granada (traço). Correspondem, petrograficamente, a um muscovita-biotitaturmalina-quartzo xisto.

São rochas de granulação fina, com os cristais em geral variando entre 0,2 a $1,0 \mathrm{~mm}$, que foram afetadas pelos mesmos eventos deformacionais que atuaram sobre os xistos pelíticos.

A estrutura mostra-se orientada e marcada por uma xistosidade, mas ainda é recuperada a intercalação de lâminas e finos estratos. A concentração de turmalina varia bastante: pode ocorrer disseminada, concentrar-se ainda mais em certas laminações associada à biotita ou ao quartzo, ou compreender leitos mais finos essencialmente turmaliníticos (Prancha 08/Foto A).

A textura varia de granolepidoblástica a lepidoblástica devido, respectivamente, à menor e à maior presença dos minerais micáceos orientados, enquanto que o quartzo pode ser granular ou exibir forte orientação e estiramento. Alguns leitos são granoblásticos, com o quartzo, a turmalina e a muscovita não apresentando orientação.

As relações de cristalização dos minerais com as respectivas foliações metamórficas nos turmalinitos e nos biotita-turmalina xistos podem ser observadas na TABELA 5.12. 
TABELA 5.12 - Relações de cristalização dos minerais nos turmalinitos e nos biotita-turmalina xistos.

\begin{tabular}{|c|c|c|c|c|c|c|c|c|}
\hline Minerais & $R$. & Foliacão $S_{1}$ & $P \sigma s w S_{l}$ & Foliacão $S_{2}$ & $P o s-S_{2}$ & Foliacâo $S_{3}$ & \begin{tabular}{|l|} 
Posw $S_{3}$ \\
\end{tabular} & Foliacão $S_{4}$ \\
\hline Quartzo & & $\ldots$ & $\ldots$ & $\ldots \ldots$ & $\ldots$ & & & \\
\hline Biotita & & $\ldots$ & & $\ldots-\ldots$ & & & & \\
\hline Turmalina & - & $\ldots$ & $\ldots$ & $-\ldots . . \cdots \ldots$ & - & & & \\
\hline Muscovita fina / sericita & & $\ldots$ & & $\ldots \ldots$ & $\ldots$ & & & \\
\hline Mineral opaco (magnetifa) & & $\cdots$ & & $\cdots$ & $-\ldots$ & & & \\
\hline Zircâo & - & & & & & & & \\
\hline Granada & & $--(?)$ & & - & - & & & \\
\hline Limonita / goethita & & & & & & $\rightarrow$ & & \\
\hline Fácies Metamórfica & & xisto-verde & & xisto-yerde & & & & \\
\hline
\end{tabular}

\subsubsection{Metarriólitos}

Estas rochas foram observadas preferencialmente na unidade metavulcanoclástica apresentando frequientemente caráter subvulcânico. Ocorrem intercaladas com as rochas metavulcanoclásticas básicas, com os metassedimentos tufíticos, com metapelitos calcíferos e metassedimentos manganesíferos dispostos no topo da unidade metavulcanoclástica e, ocasionalmente, estão presentes na unidade dos xistos pelíticos associados com os xistos finos rítmicos.

Predominam litotipos relativamente maciços que podem ser confundidos, devido à proximidade, com uma fácies de microgranitos porfiríticos relacionadas ao Maciço Granitóide Itaqui.

Caracteristicamente, apresentam relíquias de fenocristais de quartzo bipiramidado que podem ocupar até 15\% (Prancha 08/Foto B), de feldspato potássico (5 a 10\%) e de plagioclásio $(<5 \%$ ) que ocorrem dispersos e que se destacam em uma matriz fina a muito fina, sendo caracterizados como riólitos metamorfizados. Os porfiroclastos presentes constituem entre 1 a $20 \%$ do volume da rocha.

A matriz ocupa, em geral, de 80 a $90 \%$ do conteúdo da rocha, e é formada por quartzo (40 a $50 \%$ ), muscovita (10 a 80\%), feldspato potássico ( 20\%), plagioclásio (5 a 10\%), podendo estar presentes, como minerais accessórios, biotita em cristais anédricos, epídoto, clinozoizita e minerais opacos, em geral menores que $0,05 \mathrm{~mm}$.

Os fenocristais bipiramidados de quartzo podem estar bem preservados, e também é comum observar texturas reliquiares como uma ou várias das faces corroídas. Em geral, preservam a forma original, mas estão recristalizados em grãos menores, quando exibem extinção ondulante (Prancha 08/Foto B). Ocasionalmente, têm formas anedrais. As formas reliquiares medem entre $0,5 \mathrm{~mm}$ e $3,0 \mathrm{~mm}$ de diâmetro.

Entre os maiores fenocristais feldspáticos, que atingem até $3,5 \mathrm{~mm}$, é comum a presença de ortoclásio e, mais raramente, de microclínio, ocorrendo ambos como prismas curtos subeuédricos, podendo alguns deles apresentar inclusões de plagioclásio saussuritizado. Em alguns desses fenocristais, destaca-se a textura granofírica, com intercrescimento de feldspato potássico e quartzo (Prancha 08/Foto C). Ocasionalmente, observam-se fenocristais de plagioclásio que, em geral, têm ao redor de 1,0 mm, exibem tendência anédrica mas, não raro, preservam a geminação múltipla reliquiar. Podem estar parcialmente reequilibrados para albita e, nesse caso, ocorre cristalização de muscovita e clinozoizita 
associada. Aqueles que permitiram caracterizar sua composição variam de oligoclásio $\left(\mathrm{An}_{28}\right)$ a andesina $\left(\mathrm{An}_{38}\right)$.

Por vezes, os fenocristais de feldspato podem ocorrer como pseudomorfos e estar alterados para cristais menores de muscovita, ou ainda apresentar as bordas recristalizadas.

A matriz ocupa em média $85 \%$ e compreende, predominantemente, cristais granulares de quartzo e de feldspatos subordinados, sendo que entre os últimos é mais comum o feldspato potássico que o plagioclásio. A granulação dos minerais félsicos é menor que $0,1 \mathrm{~mm}$. Mostra-se bem recristalizada, com os grãos exibindo contatos desde irregulares até retilíneos ou poligonizados, sendo que em alguns cristais de plagioclásio ainda se reconhece a relíquia da geminação múltipla mas, de modo geral, o mineral está reequilibrado para albita e não mais se observa a geminação.

Os minerais micáceos presentes na matriz são maiores que os félsicos e alguns de biotita atingem até $0,3 \mathrm{~mm}$. Podem exibir distribuição randômica, ou se dispõem orientados. Cristais de minerais micáceos menores foram caracterizados como de muscovita ou de sericita.

Na matriz predomina a textura granoblástica, mostrando, eventualmente, uma incipiente foliação dada pelos minerais micáceos. No entanto, algumas amostras mais ricas em sericita podem apresentar uma foliação milonítica $S_{\mathrm{m}}$ bem desenvolvida que foi correlacionada com a $S_{2}$, onde os minerais micáceos formam pequenos sigmóides e o quartzo apresenta formas lenticulares alongadas e tem extinção ondulante. Por vezes, devido à milonitização responsável pela transformação parcial ou total do feldspato potássico presente na rocha, os minerais micáceos atingem até $80 \%$. As relações de cristalização dos minerais com as foliações estão na TABELA 5.13.

Venulações tardias subconcordantes ou não com a foliação apresentam remobilização de quartzo e cristalização de epídoto com muscovita associada. Amostras mais alteradas favorecem a cristalização supérgena de agregados finos avermelhados caracterizados como de limonita/goethita.

TABELA 5.13 - Relações de cristalização dos minerais nos metarriólitos.

\begin{tabular}{|c|c|c|c|c|c|c|c|}
\hline Minerais & Reliquiar & Foliacão $S_{L}$ & $P \delta s-S_{1}$ & Foliacão $S_{2}$ & $P \delta s-S_{2}$ & Foliacão $S_{3}$ & Pós- $S_{3}$ \\
\hline Quartzo fino granoblástico & -- & $\ldots \ldots$ & - & $\cdots$ & $\ldots$ & & \\
\hline Quartzo (bipiramidado) & $\ldots \ldots$ & & & & & & \\
\hline K-feldspato / Microclínio & & $\ldots \ldots$ & & $--1 ? 2$ & & & \\
\hline Plagioclásio (albita) & & $\ldots$ & & & & & \\
\hline K-Feldspato / Pertítico & $\cdots$ & & & & & & \\
\hline Plagioclásio (Fenocristal) & $\ldots$ & & & & & & \\
\hline Muscovita & & $\ldots$ & $\cdots$ & $\cdots$ & $\cdots$ & & \\
\hline Sericita & & & & & & $\rightarrow$ & \\
\hline Biotita & $\ldots$ & $-(?)$ & & & & & \\
\hline Epídoto & & $\ldots$ & & & $\ldots$ & & \\
\hline Clinozoizita & & $\ldots$ & & & & & \\
\hline Minerais opacos & $\ldots$ & $\ldots$ & & & & & \\
\hline Sulfeto & $\ldots$ & & & & & & \\
\hline Fácies Metamórfica & & xisto-verde & & xisto-yerde & & & \\
\hline
\end{tabular}




\subsubsection{Formação Nhanguçu}

\subsubsection{Unidade dos Metassedimentos Manganesíferos (MPSInhmn)}

Os metassedimentos manganesíferos afloram como rochas muito intemperizadas. Assim sendo, foram encontradas nesta unidade somente raras amostras pouco alteradas dos metapelitos calcíferos e das rochas calciossilicáticas que permitiram a análise petrográfica, descritas a seguir.

\section{a) Metapelitos calcíferos}

São rochas de granulação fina, laminadas, e que apresentam forte variação composicional conforme a lâmina. São formadas em essência por muscovita (10 até $80 \%$ ), carbonato (5 até $60 \%$ ), quartzo ( 10 até $35 \%$ ), grafita (traço até $55 \%$ ) e alguma flogopita.

Observa-se alternância de leitos de composições e cores diferentes, com espessuras em geral menores que 2,0 mm. Alguns são brancos, outros cinzas e, por vezes, exibem cor castanho-acinzentada. $O$ segundo evento deformacional está representado por uma intensa foliação $S_{2}$ paralela ao $S_{1} / S_{0}$. A $S_{3}$ está evidenciada por uma clivagem de crenulação discreta que localmente evolui para uma clivagem de crenulação zonal. As relações de cristalização dos minerais com as diferentes foliações estão expostas na TABELA 5.14.

A textura é essencialmente lepidoblástica nos leitos onde há presença de muscovita ou flogopita (Prancha 08/Foto D), enquanto que em outros ricos em carbonato e com quartzo subordinado ocorre a textura granoblástica.

A muscovita predomina como finas palhetas brancas orientadas segundo a $S_{2}$, com raros cristais maiores atingindo até $0,3 \mathrm{~mm}$. Cristaliza também associada à clivagem de crenulação $S_{3}$, e pode ser o mineral predominante em alguns leitos (Prancha 08/Foto D). Cristais de flogopita mostram-se pouco pleocróicos, variando de incolor ao marrom-claro-amarelado, e parecem cristalizados em essência na $S_{2}$.

O carbonato está presente nos leitos mais espessos, junto com quartzo, flogopita e alguns minerais opacos. Apesar do hábito granular, seus cristais muitas vezes estão alongados, indicando recristalização segundo a $S_{2}$ (Prancha 08/Foto E).

TABELA 5.14 - Relações de cristalização dos minerais nos metapelitos calcíferos.

\begin{tabular}{|c|c|c|c|c|c|c|c|}
\hline Minerais & Reliquiar & Foliacão $S_{l}$ & $P 6 s-S_{1}$ & Foliacão $S_{2}$ & $P O S w S_{2}$ & Foliacão $S_{3}$ & $P \operatorname{ses} S_{3}$ \\
\hline Muscovita & & & & $-\cdots$ & - & $\ldots$ & \\
\hline Grafita & & & & $\ldots \ldots$ & & $\ldots \ldots$ & \\
\hline Carbonato & & $-(?)$ & & $\ldots \ldots$ & $\sim$ & $\cdots(?)$ & \\
\hline Quartzo & & $-(?)$ & & $\cdots \cdots$ & & $\ldots$ & \\
\hline Flogopita & & & & $\ldots$ & & & \\
\hline Fácies Metamórfica & & & & xisto-verde & & xisto-yerde & \\
\hline
\end{tabular}

O quartzo pode ser o constituinte essencial em alguns leitos submilimétricos, e constituir lentes descontímuas e finas. Em ambos os casos, seus cristais estão orientados segundo a foliação principal, exibindo ainda contatos retilíneos e extinção ondulante em leitos mais micáceos, indicando cristalização na foliação $S_{2}$. Eventualmente, podem estar parcialmente reorientados pela $S_{3}$, sugerindo também moderada recristalização durante o terceiro evento deformacional (Prancha 08/Fotos D e E). 
Grafita ocorre de modo subordinado como cristais mais finos, anédricos, cinza-escuros ou pretos. Em alguns leitos pode ser o principal constituinte mineral. Também cristaliza nas foliações $S_{2}$ e $S_{3}$.

\section{b) Rochas calciossilicáticas}

Estas rochas são compostas por diopsídio ( 50\%), tremolita (25 a 30\%), escapolita (10 a 15\%), flogopita (1 a 10\%), plagioclásio (até 5\%), clinozoizita (até 2\%) e microclínio (traço), além de pequenas quantidades de titanita e turmalina.

São rochas laminadas a bandadas que apresentam orientação preferencial dos minerais segundo a $S_{2}$, sendo localmente observada a ruptura de bandas. A textura é nematoblástica nos leitos onde há orientação dos cristais de diopsídio, mineral que também pode se apresentar não orientado. Lâminas com textura lepidoblástica evidenciam uma forte cristalização de flogopita orientada.

Como acontece nas rochas calciossilicáticas da Formação Morro da Pedra Preta, observa-se uma grande variação composicional nos diferentes leitos. Alguns são ricos em diopsídio na forma de cristais euédricos ou subeuédricos, que podem estar parcialmente alterados para tremolita, que cristalizada às suas custas produz leitos poiquiloblásticos, enquanto que outros leitos são ricos em flogopita, e esse mineral também ocorre preenchendo microfraturas, sugerindo remobilizações tardias possivelmente tardi- a pós$\mathrm{S}_{3}$.

Em certas porções ocorre a destruição de plagioclásio e a cristalização de escapolita, possivelmente de composição mais próxima à marialita (Prancha 08/Foto $\mathbf{F}$ ), e ainda é possível observar alguns cristais de turmalina. A clinozoizita é retrometamórfica, consumindo parte do plagioclásio e, mais raro, parece precipitar a expensas do clinopiroxênio e da escapolita. Microclínio cristaliza possivelmente na foliação $S_{1}$, sendo em grande parte destruído pelos reequilíbrios associados às foliações superpostas.

As relações de cristalização dos minerais com as foliações metamórficas estão na TABELA 5.15.

TABELA 5.15 - Relações de cristalização dos minerais nas rochas calciossilicáticas da Formação Nhanguçu.

\begin{tabular}{|c|c|c|c|c|c|c|c|}
\hline Minerais & Reliquiar & Foliacão $S_{1}$ & $P o s=S_{I}$ & Foliacão $S_{2}$ & $P O s-S_{2}$ & Foliacão $S_{3}$ & $P O s_{-} S_{3}$ \\
\hline Diopsídio & & - & $\ldots$ & $\cdots \cdots \cdots$ & & & \\
\hline Tremolita & & & & $\ldots \ldots$ & $\ldots$ & & \\
\hline Escapolita (marialita) & & & & $\ldots . . . \cdots n+m-n$ & $\cdots$ & & \\
\hline Plagioclásio & $\cdots$ & $\cdots \cdots \cdot$ & & $\ldots \ldots$ & & & \\
\hline Clinozoizita & & & & & & $\ldots .$. & \\
\hline Titanita & & & & $\ldots$ & & & \\
\hline Flogopita & & & & $\cdots-(?)$ & & $\ldots \ldots . .$. & $\cdots$ \\
\hline Microclínio & & $\cdots$ & & & & & \\
\hline Turmalina & & & & $\ldots$ & $\ldots$ & & \\
\hline Fácies Metamórfica & & anfibolito & & anfibolito & & xisto-verde & \\
\hline
\end{tabular}

\subsubsection{Unidade Metacarbonática (MPSInhcd)}

\section{a) Mármores}

Estas rochas estão localizadas preferencialmente no topo da Formação Nhanguçu. Sua granulação varia de fina a média, predominando os mármores dolomíticos que, por vezes, podem também ser ricos 
em calcita. São formadas principalmente por dolomita e/ou calcita que ocupam de 55 até $95 \%$ do volume das rochas. Em quantidades variáveis, estăo presentes quartzo (desde 1 até ocasionalmente 20\%), flogopita (traço até 10\%) e tremolita (acessório até 10\%), podendo também ocorrer pequenas quantidades de biotita (até 3\%), diopsídio, clorita, muscovita, minerais opacos, rutilo e titanita. Petrograficamente, correspondem a mármores.

Exibem uma estrutura laminada a bandada, onde se observa a intercalação de leitos de composições diferentes com espessuras variando de alguns milímetros até poucos centímetros. Alguns podem ser essencialmente compostos por carbonato, outros podem ser ricos em tremolita ou em flogopita, havendo, às vezes, intercalações de leitos ricos em quartzo

Em algumas amostras observam-se porfiroblastos de tremolita e/ou diopsídio de até 4,0 mm, mas predominam aquelas de granulação menor que $0,6 \mathrm{~mm}$, e nessas os cristais de carbonato têm em geral menos de $0,2 \mathrm{~mm}$. Podem ocorrer cristais ou agregados de quartzo de até $1,5 \mathrm{~mm}$.

Predomina a textura granoblástica, dada pelo arranjo dos cristais não orientados de carbonato e de quartzo, e observam-se, de forma subordinada, as texturas nematogranoblástica e lepidogranoblástica, essencialmente nos leitos ricos em tremolita e/ou flogopita. Em alguns leitos ocorre a textura decussada, marcada pela disposição dos cristais de tremolita.

Outras amostras apresentam estrutura maciça e a recristalização intensa do carbonato $\sin -\mathrm{S}_{2}$ dificultam a reconstituição dos eventos deformacionais e a caracterização das foliações. Contudo, foi possível reconhecer, ocasionalmente, uma foliação prévia paralela ao acamamento sedimentar e caracterizada como $S_{1}$, sendo cortada pela $S_{2}$.

Nessas rochas predominam minerais de carbonato como cristais granulares com contatos retilíneos sendo que, nos exemplares onde a foliação $S_{2}$ é mais intensa, podem estar presentes como cristais levemente alongados. O carbonato também está remobilizado em venulações, como cristais maiores com até $7,0 \mathrm{~mm}$.

O quartzo ocorre disperso ou marcando leitos descontínuos. Podem-se observar cristais alongados segundo a $S_{2}$, cristais subangulosos a arredondados que provavelmente refletem as formas clásticas originais, e outros com extinção ondulante ou recristalizados em agregados com contatos poligonizados, representando, provavelmente, seixos de metarenito metamorfizados.

A tremolita, comum em algumas amostras, compreende cristais maiores dispersos na matriz carbonática ou constitui mineral essencial em lâminas restritas (Prancha 08/Foto G). É anédrica com tendência a cristalizar em feixes fibrorradiados. Pode relacionar-se às venulações tardias, ocorrendo como porfiroblastos (PJ 879c), ou estar ausente (SP 647, SP 666 e SA 917).

Raramente observam-se porfiroblastos anédricos de diopsídio, sendo alguns deles poiquiloblásticos, muito ricos em inclusões de carbonato. A sua cristalização aparentemente está relacionada aos efeitos do metamorfísmo de contato do Maciço Granitóide Itaqui.

A flogopita compreende palhetas curtas ou alongadas que variam de subeuédricas a euédricas. 
Localmente, parece apresentar inclusões de grafita, e está em parte retrometamorfizada para clorita na borda.

Nessas amostras podem ocorrer pequenas quantidades de muscovita, biotita e clorita. Cristais menores de muscovita estão em essência orientados na foliação $S_{2}$, predomina biotita distribuída de forma aleatória, e observam-se cristais de clorita $\sin -S_{3}$ incolores, refletindo composiçōes magnesianas. A clorita também pode estar presente em venulações tardias ricas em quartzo.

Dentre os minerais opacos ocorre a pirita, ocasionalmente como microporfiroblastos euédricos, além de prováveis cristais de magnetita. Ambas são euédricas, podem ocupar até $1 \%$, e têm as bordas limonitizadas, sendo que o óxido, em geral, apresenta-se mais fino. Também ocorrem dispersos e mal formados.

Rutilo constitui traço frequente apresentando finas estrias e geminação em cotovelo. Por vezes é anédrico ou mesmo arredondado, sugerindo tratar-se de relíquias detríticas. Raramente apresenta sinal ótico negativo, o que poderia indicar alterações tardias para anatásio (SP 647c), ou ainda, não ser clara sua distinção da goethita. Titanita é rara e, quando observada, pode estar em parte leucoxenizada.

A análise petrográfica das rochas carbonáticas sugere uma subdivisão em dois litotipos predominantes. O primeiro envolve amostras da região nordeste da cidade de Santana do Parnaíba, apresentando mármores mais finos onde tremolita e diopsídio estão ausentes (SP 647 e SP 666b), e parece representar o topo da Formação Nhanguçu.

Em amostras obtidas da região da Mina Santa Rita (SA 917), o anfibólio e o clinopiroxênio também não ocorrem, e observa-se biotita como acessório disperso e titanita como traço, sugerindo posicionamento estratigráfico e condições metamórficas semelhantes.

Amostras enfeixadas na unidade metabásica da Formação Morro da Pedra Preta na Rodovia dos Bandeirantes, nos pontos VH 876 e PJ 879, têm tremolita (Prancha 08/Foto G), e a pequena lente junto às rochas calciossilicáticas na região urbana de Santana do Parnaíba contém diopsídio e tremolita (SP 610). Esses litotipos parecem relacionar-se às porções mais basais da Formação Nhanguçu, por vezes enfeixados tectonicamente na Formação Morro da Pedra Preta e afetados por grau metamórfico mais alto, sendo que a última ocorrência parece também sofrer influência de metamorfismo de contato.

As relações de cristalização dos minerais com as foliaçōes estão nas TABELAS 5.16 e 5.17.

\subsubsection{Formação Pirucaia}

\subsubsection{Unidade dos Xistos Quartzosos (MPSIpcxq)}

\section{a) Xistos quartzosos com fibrolita, granada, estaurolita, silimanita elou cianita}

São rochas de granulação variando de fina a grossa, com aglomerados de fibrolita (traço até $2 \%$ ), cristais mais grossos de granada (traço a $2 \%$ ), porfiroblastos de estaurolita (traço), e agregados grossos de muscovita com biotita subordinada (traço), que ocorrem dispersos em matriz formada por quartzo (60 a $85 \%$ ), biotita ( $10 \%$ a $35 \%$ ) e muscovita ( 2 a $10 \%$, eventualmente $25 \%$ ), com turmalina, minerais opacos, 
zircão, agulhas de fibrolita, clorita, silimanita, cianita e cordierita subordinados.

Os porfiroblastos de fibrolita atingem até $4,0 \mathrm{~mm}$, sendo que alguns porfiroblastos de estaurolita podem medir até $1,3 \mathrm{~cm}$. Predomina a granulação fina na matriz, menor que $1,0 \mathrm{~mm}$, sendo que normalmente os grãos de quartzo têm menos de $0,6 \mathrm{~mm}$ e, localmente, os cristais de muscovita podem medir até 2,0 mm. Grânulos de quartzo não são raros (Prancha 08/Foto H).

Nessas rochas predomina estrutura maciça ou pouco orientada, sendo raras as porções onde aumenta a cristalização de minerais micáceos entre os cristais de quartzo, marcando a foliação $S_{2}$ (Prancha 08/Foto H). Eventualmente, essa foliação pode evoluir para uma foliação milonítica $S_{\mathrm{m}}$.

Por vezes, ainda se recupera a foliação prévia $S_{1}$, que geralmente está cortada pela foliação principal (Prancha 09/Foto A). Cristais anédricos de biotita, de granada e, raramente, de cianita cristalizaram segundo a $S_{1}$. Às foliações retrometamórficas $S_{3}$ e $S_{4}$ pode-se associar, de forma subordinada, cristalização de muscovita, clorita e quartzo. As relações de cristalização dos minerais com as diferentes foliações metamórficas podem ser visualizadas na TABELA 5.18.

Predomina a textura lepidogranoblástica, onde são francamente mais abundantes os cristais granulares de quartzo, com minerais micáceos subordinados orientados, essencialmente biotita e, secundariamente, muscovita. Nas amostras mais afetadas pelo evento milonítico, predominam cristais de quartzo alongados segundo a $S_{m}$.

Os aglomerados formados por cristais de fibrolita sin- $\mathrm{S}_{2}$ estão dispersos na matriz e têm forma amendoada. Podem apresentar inclusões de mineral opaco fino, de granada euédrica limonitizada, e exibir crescimento epitáxico com biotita. Em alguns dos porfiroblastos nota-se a presença subordinada de finos cristais prismáticos de silimanita. Nas bordas desses aglomerados pode ser observada a forte cristalização de muscovita tardi- $S_{2}$ ou $\sin -S_{3}$.

Frequientemente, ao redor de poiquiloblastos reliquiares de estaurolita ocorrem agregados pseudomórficos formados principalmente por cristais de muscovita não orientados e maiores do que os observados na matriz e, subordinadamente, por granada anédrica limonitizada e finíssimos cristais de quartzo. Na borda desses agregados pseudomórficos observa-se crescimento de muscovita e biotita. As texturas sugerem crescimento da estaurolita pós- $S_{1}$ ou pós- $S_{2}$, sendo posteriormente retrometamorfizada. Nos restos da estaurolita podem ser vistas inclusões de biotita.

A cristalização dos agregados de muscovita associados com a estaurolita pode estar relacionada aos eventos retrometamórficos ou com o metamorfismo de contato pós- $\mathrm{S}_{2}$ gerado pelo Stock Granítico Tico-Tico. Contudo, esses agregados são muitos semelhantes aos observados nos xistos com aglomerados grossos de fibrolita, que estão estirados pela foliação $S_{2} / S_{m}$ e podem ser truncados nas bordas pelos minerais micáceos da foliação milonítica, sendo claramente relacionados à $S_{1}$. Possivelmente, em algumas porções nos xistos quartzosos, a foliação $S_{2}$ não foi intensa o bastante para reorientar ou mesmo estirar os agregados.

Observam-se cristais euédricos a subeuédricos de granada, geralmente limonitizada, de até 0,7 
mm, onde, normalmente, há um núcleo rico em inclusōes de quartzo orientadas segundo uma $S_{1}$ oblíquá à $S_{2}$ e que pode ser correlacionada à $S_{1}$. A borda está recristalizada e não contém inclusões, parecendo indicar crescimento pós- $S_{2}$. Em alguns cristais de granada observa-se a ocorrência de textura em atol, com cristais de biotita retrometamórfica $S_{3}$ crescendo no interior e às custas da granada.

Na matriz, o quartzo predomina como cristais granulares angulosos pouco orientados ou com formas alongadas paralelas à foliação milonítica, podendo apresentar extinção ondulante.

Eventualmente, ainda são observados cristais de biotita sin- $S_{1}$ anédricos e marromavermelhados, mas predominam aqueles euédricos a subeuédricos orientados e cristalizados segundo a foliação $S_{2} / S_{m}$ (Prancha 09/Foto A). Muscovita cristaliza como plaquetas finas $\sin -S_{2}$ ou $\sin$ - a tardi- $S_{m}$. As rochas mais afetadas pelo evento milonítico geralmente são mais ricas em muscovita.

A clorita ocorre de preferência na matriz, sendo também observada no núcleo de alguns porfiroblastos de fibrolita. A sua presença pode estar relacionada às variações composicionais do litotipo, pois parece coexistir com muscovita e com finos agregados de grafita.

Minerais opacos com formas cúbica e octaédrica, menores que $0,1 \mathrm{~mm}$, e que mostram por vezes bordas limonitizadas, foram caracterizados como magnetita, estando os cristais incipientemente orientados segundo a foliação $S_{2}$. Minerais opacos muito finos, geralmente anédricos, podem ocorrer como inclusões na granada e nos agregados grossos de fibrolita.

Turmalina verde, fina e etédrica, cristaliza predominantemente nos estágios tardi- a pós- $S_{2}$. Localmente, a sua cristalização parece estar relacionada ao evento milonítico, sendo observado o aumento da sua cristalizaçăo em amostras onde predomina a $S_{m}$

Raros cristais de cianita sin-S, estão presentes nas porções mais quartzosas com dimensões próximas às do quartzo (Prancha 09/Foto B). Às vezes, apresentam incipiente cristalização de fibrolita $\sin -S_{2}$ na borda. Eventuais pequenos cristais biaxiais incolores dispersos na matriz sugerem a presença de cordierita.

TABELA 5.16 - Relações de cristalização dos minerais nas rochas carbonáticas do topo da Formação Nhanguçu.

\begin{tabular}{|c|c|c|c|c|c|c|c|}
\hline Minerais & Reliquiar & Foliacão $S_{\perp}$ & $P 6 s w S_{t}$ & Foliacão $S_{2}$ & $P \delta s-S_{2}$ & Foliaçâo $S_{3}$ & Pós-S \\
\hline Carbonato & & $\ldots$ & & $\ldots$ & $\ldots$ & $\ldots . .$. & \\
\hline Quartzo & & $\ldots$ & & $\cdots \cdots$ & - & $\ldots \ldots$ & 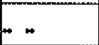 \\
\hline Muscovita & & & & $\ldots \ldots$ & & & \\
\hline Tlogopita & & & & $\cdots \cdots \cdots$ & $\cdots$ & $\cdots$ & \\
\hline Grafita & & & & $\ldots$ & & & \\
\hline Biotita & & & & $\ldots$. & & & \\
\hline Clorita & & & & & & $\ldots$ & - \\
\hline Mineral opaco (magnetita) & $\cdots$ & & & $\ldots$ & & & \\
\hline Sulfeto & & & & $\ldots$ & $\ldots$ & & \\
\hline Rutilo & 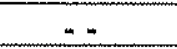 & & & & & & \\
\hline Titanita & & & & $\ldots$ & & & \\
\hline Turmalina & & & & $\ldots$ & $-(?)$ & & \\
\hline Limonita / goethita & & & & & & & \\
\hline Fácies Metamórfica & & xisto-verde & & xisto-verde & & xisto-verde & \\
\hline
\end{tabular}


TABELA 5.17 - Relações de cristalização dos minerais nas rochas carbonaticas da base da Formação Nhanguçu.

\begin{tabular}{|c|c|c|c|c|c|c|c|}
\hline Minerais & Reliquiar & Foliacão $S_{L}$ & $P \delta s-S_{1}$ & Foliacão $S_{2}$ & $P \delta s \omega S_{2}$ & Foliacão $S_{3}$ & $P 6 s^{-} S_{3}$ \\
\hline Carbonato & & $\ldots \ldots$ & $n$ & 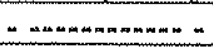 & $\ldots$ & $-n$ & \\
\hline Tremolita & & $m--(?)$ & & $m \ldots \ldots$ & $\ldots$ & & \\
\hline Flogopita & & & & $\ldots$ & & & \\
\hline Quartzo & & $-\cdots$ & & $\ldots \ldots$ & & & \\
\hline Muscovita & & & & $\ldots$ & & & \\
\hline Diopsídio & & $\because(?)$ & & $\cdots \cdots$ & & & \\
\hline Clorita & & & & & & $\cdots$ & \\
\hline Titanita & & & & $m$ & & & \\
\hline Sulfeto (pirita) & & $\ldots$ & $-(?)$ & $\ldots$ & $--(?)$ & & \\
\hline \multicolumn{8}{|l|}{ Rutilo } \\
\hline Leucoxênio & & & & & & $\cdots$ & \\
\hline Fácies Metamórfica & & anfibolito & & anfibolito & & xisto-yerde & \\
\hline
\end{tabular}

TABELA 5.18 - Relações de cristalização dos minerais nos xistos quartzosos pouco foliados.

\begin{tabular}{|c|c|c|c|c|c|c|c|c|}
\hline Minerais & $R$. & Foliacão $S_{\ell}$ & $P \delta s-S_{l}$ & Foliacão $S_{2}$ & $P o s-S_{2}$ & Foliacão $S_{3}$ & $P \delta s-S_{3}$ & Foliacão $S_{4}$ \\
\hline Biotita & & $\ldots \ldots \cdots$ & & $\ldots \ldots \ldots$ & $\ldots$ & $\ldots$ & & \\
\hline Quartzo & & $-\cdots$ & & - & $\ldots$ & $\ldots \ldots$ & & $m$ \\
\hline Muscovita & & $\ldots$ & - & $\cdots \cdots$ & & 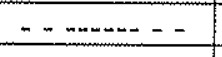 & & $\ldots$ \\
\hline Fibrolita & & $\ldots$ & & $-m-m-\cdots$ & & & & \\
\hline Muscovita (agreg. porf.) & & $-\cdots$ & $\ldots$ & & 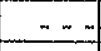 & $\ldots$ & & \\
\hline Granada & & $\ldots-\cdots$ & $m$ & $-\cdots-$ & $-\cdots$ & & & \\
\hline Turmalina & & & & $-\cdots$ & $\ldots$ & $-?-$ & & \\
\hline Mineral opaco (magnetita) & &.-- & & $\ldots-\cdots$ & & - & & \\
\hline Zircão & & -- & & $\ldots$ & & & & \\
\hline Clorita & & & & 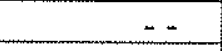 & & $\cdots$ & & \\
\hline Grafita & & & & -- & & & & \\
\hline Estaurolita (porf. reliq.) & & $\ldots$ & - & $m-$ & - & & & \\
\hline Cordierita & & $--?$ & & $--?-$ & & & & \\
\hline Silimanita & & $\ldots$ & & $-?-$ & & & & \\
\hline Cianita & & $\ldots$ & & & & & & \\
\hline Fácies Metamórfica & & anfibolito & & anfibolito & & xisto-verde & & xisto-verde \\
\hline
\end{tabular}

\subsection{GRUPO SÃO ROQUE}

Considerando que litotipos muito semelhantes afloram em duas ou três formações como, por exemplo, as rochas carbonáticas que ocorrem nas formações Pirapora do Bom Jesus e Estrada dos Romeiros, os quartzitos e metarenitos das Formações Boturuna e Estrada dos Romeiros e as rochas metabásicas descritas nas unidades metabasíticas das formaçôes Pirapora do Bom Jesus, Estrada dos Romeiros e Piragibu, como pode ser apreciado no Capítulo IV, e que alguns litotipos afloram geralmente muitos alterados, permitindo a coleta de poucas ou de nenhuma amostra fresca em algumas unidades, optou-se pela apresentação integrada das descrições petrográficas, ora de exemplares semelhantes de diferentes formações, ora das poucas amostras que puderam ser coletadas de rochas frequientemente alteradas, contudo representativas do litotipo.

\subsubsection{Formação Morro Doce}

\subsubsection{Unidade Metarcoseana (NPSRmdac)}

a) Metarcóseos e metarenitos arcoseanos 
As amostras foram coletadas nas regióes dos morros Doce e do Polvilho, da Fazenda Itayhe e da base do Pico do Jaraguá.

Nestas rochas destacammse os porfiroclastos de feldspato (Prancha 09/Fotos C, D e E) e de quartzo e fragmentos líticos de granitóides (Prancha 09/Foto F) dispersos em uma matriz fina a muito fina, com granulação menor que $0,1 \mathrm{~mm}$, comumente ao redor de $0,05 \mathrm{~mm}$, composta por quartzo (50$60 \%$ ), feldspato potássico (até 25\%), plagioclásio (10 15\%), biotita (até 10\%, ocasionalmente 40\%), minerais opacos (entre 2 e $5 \%$ ), epídoto (até 3\%) e carbonato (até 1\%). Como minerais menos frequientes podem ocorrer muscovita, alanita, apatita e zircão, sendo rara a presença de titanita, leucoxênio, rutilo, clinozoizita e clorita (excepcionalmente até 2\%). Petrograficamente, correspondem a metarcóseos e metarenitos arcoseanos.

Predomina a estrutura maciça, mas pode ocorrer uma orientação incipiente dos minerais, sendo que alguns exemplares mostram-se finamente foliados devido ao primeiro evento deformacional (Prancha 09/Fotos C, E e F), evento esse que pode evoluir para protomilonítico ou milonítico marcado pela foliação $S_{m}$ (Prancha 09/Foto D). A $S_{1} / S_{m}$ dispõe-se paralela ou obliquamente ao acamamento. A $S_{2}$ dessas rochas é caracterizada por uma clivagem de crenulação que corta de forma aproximadamente ortogonal a foliação $S_{1}$. As relações de cristalização dos minerais com as diferentes foliações metamórficas podem ser visualizadas na TABELA 5.19.

As rochas milonitizadas apresentam, com frequiência, leitos rompidos e bandeamento tectônico. Em algumas amostras intercalam-se leitos mais ricos em minerais micáceos intensamente foliados, onde predomina a textura lepicloblástica, com aqueles mais ricos em quartzo e feldspato, em que é mais comum a textura granoblástica, sendo que as porções das rochas mais foliadas podem corresponder tanto a camadas mais pelíticas metamorfizadas quanto ser o resultado da milonitização sobre essas rochas, que teria favorecido a cristalização dos minerais micáceos orientados.

Destacam-se porfiroclastos de feldspatos, predominando amplamente os de plagioclásio (Prancha 09/Foto D) e sendo mais rara a ocorrência de ortoclásio (Prancha 09/Foto E) e microclínio. Dentre os porfiroclastos de feldspato potássico, também são freqüentes os pertíticos. Esses porfiroclastos podem medir entre 0,4 e 2,0 mm, predominando aqueles entre 1,0 e 1,25 mm.

Em geral, preservam suas formas e parecem muito pouco afetados pelas transformações metamórficas que atingem o restante da rocha e, dessa forma, foram denominados porfiroclastos. Em outras ocasiões, esses cristais maiores, originalmente detríticos, podem estar metamorfizados, mesmo que mantenham a forma clástica original, sendo considerados porfiroblastos.

Predominam cristais euédricos que ocupam geralmente de 10 a $15 \%$ do conteúdo da rocha, podendo raramente constituir 5 ou $30 \%$ do volume da mesma. Os porfiroclastos de feldspato têm hábito prismático curto e, em geral, mantêm uma relação entre os eixos maior e menor de 2:1 a 3:1, sendo que, ocasionalmente, essa relação pode atingir 7:1. O predomínio de cristais euédricos evidencia o pouco transporte com relação à área fonte. Ocorrem ainda como fragmentos de cristais, por vezes subangulosos 
e, mais raramente, subarredondados.

Devido ao evento milonítico em algumas amostras, e em leitos mais ricos em minerais micáceos, os porfiroclastos podem estar levemente estirados ou apresentar formas amendoadas e estar envolvidos por minerais micáceos, enquanto que em outros leitos esses cristais detríticos estão quebrados, podendo, em algumas porções, estar deslocados ou rotacionados pela $S_{m}$ (Prancha 09/Foto D). Nessas rochas podem-se observar sombras de pressão associadas aos porfiroclastos.

A maioria dos porfiroclastos de plagioclásio têm aspecto manchado, não apresentam geminação e, com frequiência, encontram-se reequilibrados em cristais menores de albita com contatos internos suturados e retilíneos, enquanto que outros apresentam somente as bordas reequilibradas. Os cristais de plagioclásio podem estar fraturados devido ao evento milonítico.

Esses porfiroclastos por vezes estão alterados essencialmente para epídoto e, secundariamente, para muscovita e carbonato. A composição dos porfiroclastos que preservaram parcial ou totalmente a geminação múltipla corresponde, em geral, à de andesina e de oligoclásio.

Os porfiroclastos de feldspato potássico são mais raros e, de forma geral, foram menos afetados pelas transformações metamórficas. Podem ser observadas pertitas, mesopertitas e micropertitas com segregação de feldspato sódico em fïletes e, mais raramente, em gotas. São comuns cristais com geminação Carlsbad, sugerindo a ocorrência de ortoclásio preservado. Localmente, em um cristal euédrico de microclínio com a geminação em grade preservada, notam-se inclusões de plagioclásio e crístalização de carbonato granular na borda.

Fragmentos clásticos de granitóides, de quartzitos e de quartzo-de-veio săo menos comuns, mas não deixam de ocorrer em várias amostras. De modo geral, são mais raros de serem observados nas descrições petrográficas referentes ao Morro do Polvilho.

Porfiroclastos de quartzo e clastos de quartzito variam preferencialmente de subangulosos a subarredondados. Mostram uma forte cominuição dos antigos cristais, os quais recristalizaram em vários grãos mais finos, porém ainda maiores que os observados na matriz, estando o contorno clástico delimitado de modo difuso. Nas amostras onde foi mais intenso o evento milonítico, podem apresentar extinção ondulante e, eventualmente, ocorrem clastos de quartzito alongados segundo a $S_{m}$, normalmente em rochas onde há grande cristalização de muscovita $\sin -S_{m}$.

Na matriz, devido à granulação fina e à forte recristalização superposta, toma-se difícil a quantificação do conteúdo de feldspatos, e assim, confirmar se as amostras correspondem a metarenitos arcoseanos ou a metarcóseos fortemente recristalizados.

O quartzo predomina na matriz. É límpido, granular, anguloso, com contatos variando desde irregulares até retilíneos, mostrando localmente textura em mosaico com outros cristais de quartzo e de feldspatos. Pode estar um pouco orientado exibindo extinção ondulante e, nos leitos mais ricos em minerais micáceos, eventualmente exibe formas alongadas segundo a $S_{1} / S_{m}$.

Os cristais de plagioclásio e de feldspato potássico da matriz encontram-se bem recristalizados, 
predominando os de plagioclásio com geminação ausente ou difusa. Com frequiência, grande parte dos cristais de plagioclásio estão reequilibrados em albita.

Devido à ausência de geminação e de alteraçôes, o conteúdo de feldspato potássico pode ser subestimado. De modo geral, entretanto, parece ser mais raro. Ocasionalmente tem aspecto "sujo", estando parcialmente alterado para cristais muito finos de epídoto e sericita, o que facilita a sua identificação, ao passo que os cristais maiores dispersos na matriz parecem preservar a forma clástica original, subangulosa a subarredondada.

A biotita cristaliza na forma de finas palhetas curtas subeuédricas, ocorrendo de forma subordinada nas porções ricas em feldspatos e quartzo. Pode estar aleatoriamente distribuída ou orientada, marcando uma foliação $S_{1}$ incipiente. Limonita/goethita em geral relaciona-se à alteração supérgena da biotita.

A cristalização de biotita como cristais maiores associa-se à transformação parcial dos porfiroclastos de feldspato, podendo também formar agregados junto com o mineral opaco. Por vezes, está presente na forma de palhetas curtas e grossas marrom-esverdeadas que têm, na borda, finos cristais do mesmo mineral micáceo cristalizados na foliação $S_{1}$, o que parece indicar a existência de restos de biotita detrítica.

A presença de cristais maiores de biotita distribuídos de forma aleatória, sugere cristalização associada a um evento de metamorfismo de contato da intrusão do Maciço Granitóide Cantareira.

A muscovita predomina como cristais incolores, sendo observados alguns verde-pálidos que ocorrem, em geral, como grãos mais finos. Forma cristais subeuédricos a euédricos comumente orientados segundo a $S_{1} / S_{m}$ e, onde a foliação milonítica está mais desenvolvida, ocorre associada ao epídoto e pode constituir o mineral micáceo predominante, ambos tendo cristalizado às custas do feldspato mais fino da matriz ou da borda de porfiroclastos. Localmente, pode estar ausente ou ser muito rara, mesmo em amostras parcialmente milonitizadas. Os leitos mais foliados são essencialmente constituídos pelos minerais micáceos que, por vezes, podem formar pequenas lentes devido à foliação milonítica.

Observa-se magnetita subeuédrica com forma cúbica/octaédrica compreendendo cristais disseminados em várias amostras, sendo que, eventualmente, constitui pequenos porfiroblastos ou poiquiloblastos de até $0,3 \mathrm{~mm}$, por vezes limonitizados ou transformados em leucoxênio e/ou titanita. Os poiquiloblastos são ricos em inclusões de quartzo e epídoto.

Epídoto em geral ocorre na forma de agregados contendo inúmeros cristais granulares fínos e anédricos, sendo que alguns leitos são constituídos essencialmente por esse mineral. Cristais euédricos maiores ocorrem disseminados nas porções ou leitos mais ricos em quartzo e feldspato. Ocasionalmente, cristaliza na borda da alanita detrítica, ou ainda junto aos agregados anédricos de mineral opaco. Pode também ser visto substituindo parcial ou totalmente alguns porfiroclastos de plagioclásio.

$\mathrm{O}$ carbonato em geral compreende cristais granulares finos. Localmente, cristaliza de forma 
incipiente na borda de cristais de plagioclásio, podendo, em alguns casos, substituir completamente esse mineral e ser considerado como calcita. $O$ carbonato por vezes está disseminado na matriz em paragênese com epídoto, muscovita e biotita $\sin -S_{1}$ e, mais raramente, encontra-se remobilizado em venulações tardias.

Ocasionalmente, ocorre clorita cristalizada de forma aleatória ou encontra-se orientada e em contato com biotita na matriz, enquanto que cristais maiores estão presentes nas bordas dos porfiroclastos de feldspato ou cristalizam associados ao mineral opaco. Na amostra BT $100 \mathrm{~b}$ ocorre como porfiroblastos com cor de interferência anômala azul-violeta, se tratando, provavelmente, de peninita.

Quando presente, a titanita mostra formas variando de subeuedrais a anedrais e cristaliza a partir do mineral opaco, sendo que, com frequiência, está parcialmente substituída por leucoxênio. Apatita forma cristais prismáticos euédricos cristalizados tardiamente em relação aos eventos deformacionais.

Zircão é fino e, por vezes, constitui cristais bem arredondados e metamíticos, sugerindo tratar-se de grãos detríticos, ao passo que em outras situações é euédrico. Eventualmente pode estar zonado, o que sugere recristalização metamórfica.

Raramente observam-se grãos de alanita detrítica quase totalmente destruídos, parcialmente substituídos por epídoto. Em alguns leitos observam-se maiores concentrações de rutilo muito fino associado ao mineral opaco.

A origem sedimentar dos litotipos descritos no Morro do Polvilho, antes considerados metarriodacitos (CARNEIRO 1983, CARNEIRO et al. 1984b), é denunciada pela frequiência com que intercalam-se lentes de metaconglomerados em contatos não tectônicos, e pelo fato de serem, em campo e petrograficamente, muito semelhantes aos metarcóseos do Morro Doce, diferenciando-se apenas pela presença mais comum de porfiroclastos de feldspatos e pela ocorrência mais restrita de fragmentos líticos na região do Morro do Polvilho. Adicionalmente, observam-se intercalações centimétricas de quartzitos feldspáticos ricos em epídoto que mostram contatos bruscos com camadas dos metarcóseos no Morro do Polvilho

Nos metarcóseos do Morro Doce (Prancha 09/Fotos C e D) podem ser observados porfiroclastos arredondados de plagioclásio e subeuédricos de feldspato potássico dispersos em matriz fina formada essencialmente por biotita + muscovita \pm quartzo \pm plagioclásio (Foto $\mathrm{C}$ ), ou ainda, porfïroclastos fraturados e deformados de plagioclásio em matriz constituída principalmente por biotita + muscovita $上$ quartzo, orientados segundo a $S_{\mathrm{m}}$ (Foto D).

Essas amostras são muito semelhantes àquelas de metarcóseos do Morro do Polvilho (antigos metarriodacitos), que apresentam uma matriz fina a muito fina composta principalmente por muscovita + biotita \pm epídoto \pm quartzo (Prancha 09/Fotos E e F) e onde ocorrem porfiroclastos de feldspato potássico idênticos ao descritos nos metarcóseos do Morro Doce (Prancha 09/Foto D) e, de forma mais restrita, fragmentos líticos de granitóide (Foto $\mathbf{F}$ ). 
TABELA 5.19 - Relações de cristalização dos minerais nos metarcóseos e metarenitos arcoseanos.

\begin{tabular}{|c|c|c|c|c|c|c|c|}
\hline Minerais & Reliquiar & Foliacão $S_{L}$ & $P o ́ s-S_{L}$ & Foliacão $S_{2}$ & $P o ́ s-S_{2}$ & Foliacão $S_{3}$ & $P O ́ s-S_{3}$ \\
\hline Quartzo & $\ldots$ & _....... & $\ldots$ & $\ldots \ldots \ldots$ & $\ldots$ & & \\
\hline Plagioclásio (albita) & & $\ldots \ldots \ldots$ & & $\ldots$ & & & \\
\hline FK (microclínio) & & 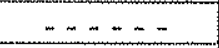 & & $--?$ & & & \\
\hline Biotita & $\ldots$ & $-\cdots$ & n-m.n.m.n.m & $\ldots-\cdots \cdots$ & - - - - - & & \\
\hline Muscovita & & 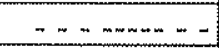 & & $\ldots \ldots \ldots$ & & & \\
\hline Plag. Andesina/Olig. & $\ldots \ldots$ & & & & & & \\
\hline Plag, reeq. (Albita porf.) & & 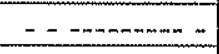 & & & & & \\
\hline Pertitas & $\cdots \cdots$ & & & & & & \\
\hline Ortoclásio (porfiroclasto) & $\ldots$ & $\ldots$ ? & & & & & \\
\hline Microclínio (porfiroclasto) & $\ldots$ & $\ldots \ldots$ & & & & & \\
\hline Quartzo (grânulos) & $\ldots$ & $\ldots$ & & & & & \\
\hline Fragmentos líticos & $-\cdots$ & & & & & & \\
\hline Mineral opaco (magnetita) & $\ldots$ & $\cdots \cdots \cdots \cdots-$ & $\ldots$ & - & $\omega \ldots$ & & \\
\hline Epídoto & & $\ldots-n \operatorname{mon} \cdots$ & $\ldots$ & $\ldots$ & $-\cdots \cdots$ & $--?$ & \\
\hline Carbonato (calcita) & & $\ldots \ldots$ & & $\ldots \ldots \ldots$ & $\ldots \ldots$ & & \\
\hline Alanita & $\cdots$ & & & & & & \\
\hline Apatita & & $-*$ & $\sim \ldots$ & - & $\ldots$ & & \\
\hline Zircão & $\cdots$ & $\cdots$ & - & $--?$ & & & \\
\hline Titanita & & $\ldots$ & & --1 & & & \\
\hline Leucoxênio & & & & - & & $--?$ & \\
\hline Clinozoizita & & -- & & $\therefore$ & & & \\
\hline Rutilo & $\ldots$ & & & & & & \\
\hline Clorita & & $\cdots$ & & $\ldots \ldots$ & & & \\
\hline Sericita & & & & & & $--?$ & $\rightarrow$ \\
\hline Fácies Metamórfica & & xisto-verde & & xisto-verde & & xisto-verde & \\
\hline
\end{tabular}

\section{b) Biotita-muscovita xistos finos (metagrauvacas)}

Estas rochas ocorrem como pequenos corpos intercalados nos metarcóseos e metarenitos arcoseanos, diferenciando-se por serem ricas em minerais micáceos e por conterem, ainda que de forma subordinada, porfiroclastos de feldspato e fragmentos líticos de quartzito e de granitóides. Essas metagrauvacas também ocorrem na Unidade dos Metarenitos Feldspáticos, mas são descritas conjuntamente neste item.

Na constituição mineralógica da matriz geralmente prevalece a muscovita (15 até $80 \%)$, estando também presentes quartzo $(\sim 20$ até $55 \%)$, biotita (ausente até $45 \%)$ e pequenas quantidades de feldspato potássico e plagioclásio (raros a até $10 \%$ ), minerais opacos $(<1 \%$ ) e epídoto (até $1 \%$ ). Ocasionalmente ocorre apatita. Petrograficamente, correspondem a biotita-muscovita xistos ou, ainda, a muscovita-biotita xistos.

A granulação da matriz é fina, com os cristais dos minerais micáceos menores que $0,3 \mathrm{~mm}$ e os de quartzo menores que 1,0 $\mathrm{mm}$. Os porfiroclastos de feldspatos atingem até $1,25 \mathrm{~mm}$.

Predomina nessas rochas a textura lepidoblástica, dada pela orientação da muscovita e da biotita quando ocorre. Estão presentes as mesmas foliações descritas nos metarcóseos e metarenitos arcoseanos. Caracteristicamente, apresentam uma forte foliação $S_{1}$, que em algumas amostras pode estar representada por uma foliação milonítica que transpõe localmente o acamamento. Rochas mais ricas em quartzo e 
feldspato e com composições mais próximas dos metarenitos arcoseanos podem apresentar uma orientação incipiente de minerais segundo a $S_{1} / S_{m}$. As relações de cristalização dos minerais segundo as diferentes foliações metamórficas podem ser observadas na TABELA 5.20.

Também são mais frequientes os porfiroclastos de plagioclásio do que os de feldspato potássico, e os primeiros podem mostrar relíquias da geminação múltipla e formas variando de subeuédrica a anédrica, sendo que alguns exibem formas arredondadas. Freqüentemente encontram-se saussuritizados.

A muscovita ocorre como finos cristais predominantemente orientados segundo a $S_{1} / S_{\mathrm{m}}$ e, subordinadamente, segundo a $S_{2}$. Por vezes, é o mineral mais abundante, enquanto que em outras ocasiôes está subordinada à biotita.

Biotita também cristaliza principalmente na foliação $S_{1}$ como cristais subeuédricos a euédricos. Apresenta-se pleocróica, variando, em alguns exemplares, do verde ao verde-claro e, em outros, do verde ao castanho. Ocasionalmente, cristais anédricos de biotita são cortados por cristais menores do mesmo mineral que cristalizaram segundo a $S_{1}$, sugerindo a presença de possíveis cristais detríticos de biotita.

O quartzo em geral está presente como cristais angulosos e alongados segundo a $S_{1} / S_{m}$, podendo exibir extinção ondulante. Por vezes tem forma granular arredondada parecendo preservar a sua forma clástica original.

Na matriz o plagioclásio é mais abundante que o feldspato potássico, ocorrendo geralmente como cristais não geminados reequilibrados para composições mais sódicas, denunciados pelo relevo mais baixo ou próximo ao do quartzo. Raramente observam-se grãos de microclínio com geminação em grade, sugerindo tratar-se cristais detríticos com composição preservada.

Epídoto cristaliza como cristais euédricos maiores tardi- a pós- $S_{1}$ e, mais raro, na $S_{2}$, compreendendo agregados finos dispostos ao redor dos cristais prévios. Os minerais opacos ocorrem preferencialmente orientados segundo a $S_{1}$ e, localmente, encontram-se dobrados pela clivagem de crenulação $S_{2}$. Eventualmente, parecem recristalizados a partir de grãos detríticos de minerais opacos. Alguns possuem formas cúbicas, correspondendo a magnetita, e outros formas tabulares.

TABELA 5.20 - Relações de cristalização dos minerais nos biotita-muscovita xistos finos (metagrauvacas).

\begin{tabular}{|c|c|c|c|c|c|c|c|}
\hline Minerais & Reliquiar & Foliacão $S_{l}$ & Pós-S & Foliacão $S_{2}$ & Pós-S $S_{2}$ & Foliacão $S_{3}$ & Pós-S 3 \\
\hline Muscovita & & - …....... & & $\ldots \ldots \ldots$ & & & \\
\hline Quartzo & $\cdots$ & $\ldots \ldots$ & & $\ldots$ & & & \\
\hline Biotita & $--?$ & $\ldots \ldots$ & & & & & \\
\hline Plagioclásio geminado & - & & & & & & \\
\hline Plagioclásio (albita) & & $\cdots$ & & & & & \\
\hline Feldspato potássico & - & $m m$ & & $-m$ ? & & & \\
\hline Epídoto & & $\ldots \ldots$ & $\ldots$ & $\ldots$ & & & \\
\hline Mineral opaco (magnetita) & -- ? & $\ldots$ & & & & & \\
\hline Apatita & $--?$ & $m$ & - & & - & & \\
\hline Sericita & & & & - & & & \\
\hline Fácies Metamórfica & & xisto-verde & & xisto-verde & & & \\
\hline
\end{tabular}




\subsubsection{Unidade Metaconglomerática (NPSRmolcg)}

\section{a) Metaconglomerados}

A descrição destas rochas envolveu preferencialmente a matriz dos metaconglomerados e os seus fragmentos clásticos menores, para fins de comparação com aqueles observados nos metarcóseos.

São rochas formadas por fragmentos líticos de granitóide, quartzito, metabásica, metaintermediária, epidotitos, xistos e quartzo-de-veio, e por porfiroclastos (10 a $15 \%)$ de plagioclásio, feldspato potássico e quartzo, dispersos em matriz fina constituída principalmente por quartzo (40 a $60 \%$ ), biotita $(\sim 2$ até $15 \%)$, muscovita/sericita (traço até $5 \%$ ), feldspato potássico e plagioclásio (ambos com menos de 5\%), epídoto (traço até 3\%) e mineral opaco (traço até 1\%). Como minerais acessórios podem estar presentes alanita, apatita, zircão e, raramente, rutilo, clinozoizita, clorita, carbonato e titanita.

Na matriz dessas rochas ocorrem estruturas e texturas muito semelhantes às descritas nos metarcóseos e metarenitos arcoseanos. Predomina, em geral, a textura lepidogranoblástica, dada pelo arranjo dos cristais granulares de quartzo, feldspato potássico e plagioclásio associados com os minerais micáceos orientados. Quando a foliação milonítica é mais intensa, prevalece a textura lepidoblástica. As relações de cristalização dos minerais com as diferentes foliações podem ser observadas na TABELA 5.21 .

Os fragmentos líticos estão dispersos na rocha e sua granulação varia de areia grossa a seixo. São subarredondados a subangulosos, predominando os de granitóide (Prancha 09/Foto G), com os de quartzito, de quartzito feldspático e de quartzo-de-veio subordinados, sendo raramente vistos fragmentos de rocha metabásica, meta-intermediária (Prancha 09/Foto $\mathbf{H}$ ) e de xisto. Nos fragmentos de quartzito, quartzito feldspático e quartzo-de-veio observa-se, por vezes, uma orientação dos minerais anterior à $S_{1}$ e caracterizada como herdada dos protólitos.

Os fragmentos menores de granitóide podem estar relativamente orientados segundo a foliação protomilonítica/milonítica, sendo que os seus cristais de feldspato e de plagioclásio assemelham-se aos porfiroclastos destes minerais observados na matriz dos metaconglomerados. É comum a presença de alanita, e podem coexistir cristais de biotita menos pleocróicos semelhantes àqueles presentes na matriz do metaconglomerado. Porém, alguns são castanho-avermelhado-escuros, o que sugere tratarem-se de minerais micáceos ígneos não reequilibrados.

Amostras de testemunhos de sondagem da região do Morro Doce e da Fazenda Itayhe revelaram a presença de grânulos e seixos de epidotitos, de rochas metabásicas, e de rochas vulcânicas a subvulcânicas de tendência andesítica (Prancha 09/Foto H) nos metaconglomerados. Os fragmentos de rochas metabásicas e meta-intermediárias podem estar parcial ou totalmente alterados para agregados de cristais granulares de epídoto, ou exibir apenas uma borda de reação formada principalmente por esse mineral (Prancha 09/Foto H). Aparentemente, quando totalmente alterados para epícloto passam a constituir fragmentos líticos de epidotito. Eventualmente, alguns metaconglomerados mais finos diferenciam-se por conterem apenas grânulos e seixos de quartzo. 
Na matriz dos metaconglomerados predominam os porfiroclastos de feldspatos, ocorrendo de forma subordinada os de quartzo, com tamanhos variando geralmente entre $0,4 \mathrm{~mm}$ a $2,5 \mathrm{~mm}$, mas predominantemente ao redor de $1,0 \mathrm{~mm}$, sendo por vezes observados cristais com até $6,5 \mathrm{~mm}$. Ocasionalmente ocorrem leitos subordinados clasto-suportados. Os porfiroclastos de feldspato são semelhantes àqueles presentes nos metarcóseos e metarenitos arcoseanos, predominando os de plagioclásio. São comuns os cristais euédricos a subarredondados alongados segundo a $S_{1}$.

Como conseqüência do evento $S_{1} / S_{m}$ observam-se, em alguns porfiroclastos, kink bands, deslocamentos, rotação, microfraturas e sombras de pressão, estando geralmente a borda reequilibrada em diversos cristais menores de tendência granular. Localmente, devido ao mesmo evento, ocorrem pseudomorfos dos porfiroclastos de feldspatos parcial ou totalmente alterados para finos cristais de sericita, carbonato e epídoto, ou recristalizados em grãos menores que conferem à matriz textura granoblástica local.

Os porfiroclastos de plagioclásio podem preservar intacta a sua geminação múltipla, sendo em alguns casos determinada a sua composição como correspondendo a oligoclásio. Porfiroclastos de plagioclásio que perderam a sua geminação encontram-se reequilibrados em grande parte ou totalmente para albita.

É frequiente também a presença de porfiroclastos de feldspatos alcalinos com texturas pertíticas, meso- e micropertíticas. A presença de cristais euédricos desses feldspatos e de plagioclásio comprova a proximidade da área fonte (Prancha 10/Foto $\mathrm{A}$ ).

Porfiroclastos e fragmentos de quartzo em geral são menores se comparados com os de feldspato e, apesar de terem sido recristalizados em grãos menores que muitas vezes também apresentam extinção ondulante, a sua origem clástica evidencia-se nas suas formas externas subarredondadas a subangulosas.

Nessas rochas, o tamanho dos cristais da matriz varia entre $0,05 \mathrm{~mm}$ e $0,1 \mathrm{~mm}$, atingindo $0,4 \mathrm{~mm}$ nas porções mais grossas. Em geral o quartzo predomina, ocorrendo como cristais granulares com formas variando de irregulares a angulosas com contatos suturados, podendo localmente mostrar textura em mosaico com contatos retilíneos entre seus cristais e os de feldspatos. Comumente, têm forma amendoada e extinção ondulante, estando alongados segundo a $S_{1} / S_{m}$. Localmente, são reconhecidas relíçuias de grãos detríticos maiores e arredondados de quartzo que podem ter se recristalizado em vários cristais menores, formando pequenos aglomerados. Eventualmente estão presentes associados às sombras de pressão de alguns dos porfiroclastos de feldspato.

O reconhecimento de plagioclásio e de feldspato potássico na matriz é dificultado devido à recristalização e aos reequilíbrios associados ao primeiro evento deformacional. Raramente observam-se cristais de plagioclásio com geminação polissindética e de K-feldspato com geminação em grade ou Carlsbad.. Os feldspatos da matriz podem mostrar saussuritização incipiente a moderada, à qual associase, essencialmente, cristalização de sericita. Alguns cristais de plagioclásio exibem relevo mais baixo que o do quartzo, sendo caracterizados como albita. Os feldspatos da matriz por vezes estão orientados 
segundo a $S_{1}$ e, mais raro, pela $S_{2}$. Podem ainda constituir cristais granulares com contatos poligonizados.

Biotita é o mineral micáceo mais frequiente da matriz e pode apresentar uma certa variação no seu pleocró́smo, sendo que nas regiões dos morros Doce e do Polvilho predominam cristais que variam do verde ao verde-acastanhado, enquanto que nos pacotes basais são mais freqüentes os que variam do verde-acastanhado ao marrom ou castanho-avermelhado-escuro. A magnetita parece favorecer a cristalização desse mineral micáceo, pois onde a biotita abunda o mineral opaco torna-se menor, mais raro e anédrico.

Cristais maiores de biotita são anédricos e estão distribuídos aleatoriamente pela amostra. Localmente, formam agregados, orientados ou não, junto aos quais pode ocorrer mineral opaco. Cristais menores estão principalmente orientados segundo a $S_{l} / S_{m}$ constituindo, por vezes, finos leitos anastomosados que podem isolar pequenas lentes com textura granoblástica ou envolver os porfiroclastos de feldspato. Segundo a clivagem de crenulação $S_{2}$ são observados grãos ainda menores.

Muscovita cristaliza preferencialmente como palhetas subeuédricas finas orientadas principalmente na foliação $S_{1} / S_{m}$, sendo menos comum que a biotita. É incolor, mas foi observada em algumas porções com um leve pleocroísmo verde-claro.

Em alguns leitos onde predominam os minerais micáceos e a foliação $S_{\mathrm{m}}$ está bem desenvolvida, a muscovita pode tornar-se mais comum que a biotita. Localmente, ocorre nas bordas de porfiroclastos de feldspato ou cristaliza em microfraturas que cortam esses cristais maiores. Eventualmente, está distribuída de forma aleatória pela rocha como cristais ainda maiores que os cristais anédricos de biotita, sugerindo crescimento posterior aos eventos deformacionais possivelmente relacionado aos efeitos do metamorfismo de contato gerado pelo Maciço Granitóide Cantareira.

Observam-se cristais subeuédricos a euédricos maiores de epídoto que podem medir até $0,2 \mathrm{~mm}$. Em raras porções micáceas dessas rochas pode atingir até $10 \%$ do volume, constituindo, nesse caso, pequenos porfiroblastos pós- $S_{1}$ cristalizados sobre biotita e magnetita. No entanto, predominam cristais granulares de epídoto muito finos, e que podem estar presentes em alguns leitos associados à magnetita, ou ainda, na borda de alanita detrítica. Na foliação $S_{1}$ pode estar em paragênese com cristais menores de albita que recristalizaram nas bordas dos porfiroclastos de plagioclásio e, na $S_{2}$, eventualmente encontrase em paragênese com muscovita.

Alguns minerais opacos mostram formas variando de cúbicas a octaédricas, sendo caracterizados como magnetita. Pode estar orientada e alongada segundo a foliação $S_{1}$ e, nos leitos onde é mais abundante, observa-se também maior cristalização de biotita. Ocasionalmente, foi observada junto a cristais de rutilo.

Outros minerais opacos formam agregados ou cristais poiquiloblásticos com até $0,3 \mathrm{~mm}$ que, não raro, encontram-se parcial ou quase totalmente transformados em titanita. A última cristaliza, por vezes, na forma de franjas a partir do mineral opaco, o que sugere que esse pode corresponder à titanomagnetita.

Zircão é um mineral traço frequiente, sendo observado tanto na matriz como nos fragmentos 
líticos, geralmente ocorrendo com tamanho inferior a $0,05 \mathrm{~mm}$. Assim como nos metarcóseos, pode constituir grãos detríticos subarredondados e metamíticos que, eventualmente, apresentam sobrecrescimento/recristalização nas bordas, chegando a exibir faces euédricas. Também está presente como cristais límpidos euédricos, sendo por vezes reconhecidas suas secções basais tetragonais.

Alanita ocorre como cristais detríticos subarredondados ou, quando mais preservados, como prismas euédricos. Em geral, encontram-se alterados, mostrando porções metamíticas, enquanto que porções menos alteradas exibem cor laranja-claro. Geralmente apresentam uma borda reequilibrada para epídoto, e muitos podem estar presentes como pseudomorfos. Raros cristais exibem um halo pleocróico.

É comum observar pequenos cristais de apatita e titanita, estando o último mineral frequientemente associado a opacos. Carbonato cristaliza principalmente a partir da alteração do plagioclásio porfiroclástico e do plagioclásio presente nos fragmentos líticos de granitóides. Clinozoizita é rara e constitui finos cristais euédricos. A clorita, apesar de ocorrer ocasionalmente, pode tornar-se o mineral micáceo predominante em alguns leitos, estando em paragênese com epídoto abundante.

É notória a semelhança entre os metarcóseos e metarenitos arcoseanos e a matriz dos metaconclomerados. Ambos possuem fragmentos líticos e porfiroclastos de feldspato (Prancha 09/Fotos $\mathbf{C}$ até $\mathbf{H}$ ). Além disso, as matrizes dessas rochas são compostas essencialmente por quartzo, feldspato e minerais micáceos com pequena variação no conteúdo de cada fase mineral e nas suas feições texturais, ressaltando-se a presença de porfïroclastos euédricos tanto de plagioclásio como de feldspato potássico na matriz dos metaconglomerados (Prancha 10/Foto A), fato esse por vezes utilizado anteriormente para caracterizar esses cristais maiores como fenocristais e sugerir origem vulcânica ou subvulcânica.

\subsubsection{Formação Pirapora do Bom Jesus}

\subsubsection{Unidade Metabasítica (NPSRpjmb)}

As rochas metabásicas da Formação Pirapora do Bom Jesus são semelhantes às rochas metabásicas que ocorrem nas formações Estrada dos Romeiros e Piragibu, sendo portanto descritas conjuntamente neste item.

\section{a) Rochas metabásicas}

Diferenciam-se das rochas metabásicas do Grupo Serra do Itaberaba pelo fato de ser comum a presença de texturas ígneas bem preservadas, como a blastofítica, a blasto-subofítica e blaston poiquilofítica (Prancha 10/Foto B). Freqüentemente ocorrem cristais de plagioclásio ígneo e fenocristais de clinopiroxênio ou restos dos mesmos (Prancha 10/Foto C).

Os constituintes essenciais são tremolita/actinolita (30 até 45\%) e plagioclásio (15 até 55\%), enquanto que foram identificados clinopiroxênio (ausente até 30\%), quartzo (até 5\%), epídoto (5 até $10 \%$ ), clinozoizita $(\sim 5 \%)$, clorita (até $10 \%)$, titanita (1 até $4 \%$ ), leucoxênio $(\sim 1 \%$ ) e minerais opacos (ausente até $1 \%$ ) como minerais acessórios comuns. Raramente, encontram-se calcita, biotita, hornblenda, sericita, turmalina, sulfetos, apatita e rutilo. Relacionados à alteração supérgena, observam-se alofana e 
limonita/goethita. Petrograficamente, são principalmente representados por tremolita/actinolita anfibolitos e, subordinadamente, por clinopiroxênio-tremolita/actinolita anfibolitos e tremolitalactinolita. clinopiroxênio anfibolitos.

TABELA 5.21 - Relações de cristalização dos minerais segundo as foliações metamórficas nos metaconglomerados.

\begin{tabular}{|c|c|c|c|c|c|c|c|}
\hline Minerais & Reliquiar & Foliacão $S_{t}$ & $P o ́ s-S_{l}$ & Foliacão $S_{2}$ & Pós- $S_{2}$ & Foliacão $S_{3}$ & Pós- $S_{3}$ \\
\hline Quartzo & $\ldots$ & (1) & $-\ldots-$ & $\ldots .$. & & & \\
\hline Plagioclásio & $\ldots$ & 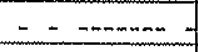 & & & & & \\
\hline Plagioclásio (albita) & & $\cdots \cdots$ & & $-\ldots$ ? & & & \\
\hline Feldspato potássico & $\cdots$ & & & & & & \\
\hline FK (microclínio) & & $\ldots \ldots$ & & & & & \\
\hline Biotita & & - & $\cdots$ & $\cdots \cdots \cdots$ & & & \\
\hline Muscovita & & $\ldots-\cdots$ & $-n$ & $\cdots \cdots \cdots$ & $\cdots$ & & \\
\hline Plag. porfiroclástico & $\cdots$ & & & & & & \\
\hline Plag. reeq. (Albita porf.) & & 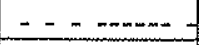 & & - -? & & & \\
\hline Feldspato Pertítico & $\cdots$ & $-?$ & & & & & \\
\hline Ortoclásio (porfiroclasto) & $\cdots$ & & & & & & \\
\hline Microclínio (porfiroclasto) & $\ldots$ & -- ? & & & & & \\
\hline Quartzo (grânulos) & $\ldots$ & $\ldots \ldots$ & & $\cdots$ & & & \\
\hline Fragmentos líticos & $\cdots$ & & & & & & \\
\hline Epídoto & & - ………n- & $\ldots$ & $\cdots \cdots$ & & & \\
\hline Mineral opaco (magnetita) & - & $\ldots \ldots$ & & $--?$ & & & \\
\hline Alanita & $\ldots$ & & & & & & \\
\hline Apatita & & & - & & $\ldots$ & & \\
\hline Zircão & - & - & & $-?$ & & & \\
\hline Carbonato (calcita) & & $\cdots$ & & & & $-\cdots ?$ & $\rightarrow$ \\
\hline Titanita & & $\ldots$ & 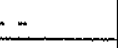 & $-\cdots$ & - & & \\
\hline Clinozoizita & & & $m$ & & & & \\
\hline Rutilo & $\cdots$ & & & & & & \\
\hline Clorita & & & & $\cdots$ & & & \\
\hline Sericita & & $\cdots$ & & $\ldots$ & & $---?$ & $\rightarrow$ \\
\hline Fácies Metamórfica & & xisto-verde & & xisto-verde & & xisto-verde & \\
\hline
\end{tabular}

Essas rochas metabásicas possuem granulação variável de fina a raramente grossa, predominando as amostras inequigranulares finas a médias constituídas por porfiroblastos de anfibólios, cristais reliquiares de clinopiroxênio e cristais maiores de plagioclásio com tamanhos que variam entre 2,0 e 4,0 $\mathrm{mm}$, dispersos em uma matriz com granulação entre 0,1 a $0,4 \mathrm{~mm}$. São mais comuns as rochas com estrutura maciça, sendo raras as pouco foliadas, as últimas podendo apresentar textura granonematoblástica.

Por serem quase sempre maciças, as relações de cristalização dos minerais com as diferentes foliações metamórficas são obtidas, em geral, a partir de recristalizações observadas nas bordas dos porfiroblastos de tremolita/actinolita e da orientação dos cristais da matriz, sendo sugestivo que as condições metamórficas alcançadas nos eventos deformacionais $S_{1}$ e $S_{2}$ encontram-se próximas. O evento $\mathrm{S}_{3}$ é local e de pouca intensidade. As relações de cristalização dos minerais com as respectivas foliações metamórficas podem ser observadas na TABELA 5.22

O anfibólio porfiroblástico foi caracterizado como sendo uma tremolita/actinolita, cujo pleocroísmo variável do verde ao verde-claro segundo os eixos z e y indica composição mais próxima da 
actinolita. Predominam os porfiroblastos subeuedrais onde geralmente podem ser vistas extremidades esfiapadas (Prancha 10/Foto D), ocorrendo de forma subordinada aqueles com formas euédrica ou anédrica. Podem estar incipiente ou intensamente substituídos por clorita, restando muitas vezes só fragmentos do antigo porfiroblasto, entre os quais observa-se intensa cristalização desse mineral micáceo (Prancha 10/Foto E).

Podem ser observados alguns fenocristais de clinopiroxênio parcial ou totalmente preservados que exibem relevo maior que o da tremolita/actinolita, fraco pleocroísmo variando de incolor a castanho-claro e $2 \mathrm{~V}$ ao redor de $50^{\circ}$. Esses fenocristais eventualmente se alteram para tremolita/actinolita, sendo que geralmente o anfibólio cristaliza primeiro nas bordas do piroxênio podendo, por vezes, substitú-lo quase completamente, restando apenas inclusões reliquiares do último na tremolita/actinolita. A constante presença de titanita nas amostras, ocorrendo por vezes associada aos cristais de clinopiroxênio em parte transformados para actinolita, sugere que esse clinopiroxênio é da série da augita - ferro-augita.

Localmente, observam-se fenocristais de clinopiroxênio alterados para um anfibólio com pleocroísmo mais intenso, correspondente ao da hornblenda. Eventualmente, restos do clinopiroxênio inclusos na hornblenda podem exibir uma borda de reação onde ocorre tremolita/actinolita, o que sugere, adicionalmente, uma cristalização tardia desse último mineral, ao menos pós-S $S_{1}$.

Na região de Pirapora do Bom Jesus, na formação homônima, o clinopiroxênio é mais raro, enquanto que em direção à Cajamar e proximidades, nas formações Estrada dos Romeiros e Piragibu, pode tomar-se um dos constituintes minerais principais das rochas metabásicas (Prancha 10/Fotos B e C).

A matriz das rochas metabásicas é constituída essencialmente por plagioclásio e prismas menores de tremolita/actinolita e, subordinadamente, por epídoto, clinozoizita, quartzo, tremolita, clorita, biotita e carbonato. Cristais maiores de plagioclásio preservam muitas vezes as suas formas ígneas ripiformes e tabulares observando-se, frequientemente, cristais com geminação múltipla e, mais raramente, com a da Albita-Carlsbad. Com o avanço da transformação metamórfica, os limites das maclas tornam-se difusos. Variam de euédricos a anédricos.

Os cristais de plagioclásio ígneo que não se reequilibraram mostram composições que variam desde oligoclásio até andesina cálcica, com teores de anortita entre $\mathrm{An}_{28}$ e $\mathrm{An}_{32}$. Alguns cristais de plagioclásio mais sódicos têm composição próxima à $\mathrm{Ab}_{78} \mathrm{An}_{22}$, enquanto que cristais com teores mais elevados de anortita $\left(\mathrm{An}_{38}\right)$ ocorrem em amostras do contato milonítico entre o corpo metabasítico da Vila Lolli e rochas carbonáticas, podendo refletir uma incipiente carbonatização das rochas metabásicas a partir das rochas carbonáticas.

Alguns dos cristais maiores de plagioclásio perdem a geminação nas suas bordas, que mostram-se recristalizadas em cristais menores granulares com extinção concêntrica. Freqüentemente, observam-se apenas as formas reliquiares dos plagioclásio ígneo, tendo esse se recristalizado em finos cristais de albita ou de albita + clinozoizita \pm epídoto. São abundantes os cristais menores de plagioclásio recristalizados, 
predominando cristais granulares não geminados de bordas irregulares a suturadas com relevo menor que o do quartzo, sendo caracterizados como albita.

Cristais menores de tremolita/actinolita $\sin -\mathrm{S}_{2}$ podem cristalizar como franjas ou agulhas nas bordas dos fenocristais de clinopiroxênio ou dos porfiroblastos de tremolita/actinolita $\sin -\mathrm{S}_{1}$. Por vezes, são observados pequenos prismas de um anfibólio incolor $\sin -S_{2}$ de provável composição tremolítica que geralmente estão associados aos cristais de clorita $\sin -S_{2}$.

O epídoto exibe pleocroísmo variável do amarelo ao amarelo-claro/incolor, ocorrendo na forma de pequenos cristais granulares euédricos a subeuédricos isolados, ou formando agregados microcristalinos. Pode estar distribuído pela matriz ou cristalizar nas bordas da tremolita/actinolita (Prancha 10/Foto F), estando, em ambos os casos, em paragênese com o anfibólio. Em alguns cristais de epídoto observa-se sobrecrescimento, sendo que, eventualmente, são visíveis as faces internas mal formadas e as externas bem desenvolvidas e vice-versa.

A clinozoizita ocorre como cristais anédricos finos a muito finos, podendo também cristalizar a partir do plagioclásio. Por vezes, pseudomorfos de plagioclásio inclusos no clinopiroxênio ou na tremolita/actinolita são formados essencialmente por clinozoizita.

Os cristais de clorita têm cores de interferência anômalas variando entre o marrom, o azul e o púrpura, sendo identificados como de cromo-peninita. A sua cristalização é preferencialmente tardi- $\mathrm{S}_{2}$ a partir da alteração retrometamórfica da tremolita/actinolita, ocorrendo em equilíbrio com albita, tremolita e epídoto, além de quartzo e, mais raramente, carbonato. Os cristais de biotita geralmente são maiores que os de clorita. Por vezes, ocorre em contato com a tremolita/actinolita ou como inclusões nesse anfibólio.

O quartzo está disperso na matriz, enquanto que o carbonato (calcita) cristaliza predominantemente em venulações tardias. Titanita compreende cristais subeuédricos que estão em associação paragenética com tremolita/actinolita e epídoto, ou constitui agregados microcristalinos em parte transformados para leucoxênio. Outras vezes, pode ser vista em contato com minerais opacos. Na região norte da área são freqüentes cristais de titanita substituídos por leucoxênio.

O mineral opaco pode apresentar forma tabular esquelética ou cúbica representando, respectivamente, possíveis cristais de ilmenita e de magnetita e/ou titanomagnetita. Por vezes, estão parcialmente alterados para leucoxênio. Localmente estão presentes como um dos minerais formados pela alteração metamórfica do clinopiroxênio.

Apatita consiste de finos cristais prismáticos euédricos. A cristalização de turmalina e de pirita parece estar relacionada à atuação de processos cataclásticos tardios que afetaram estas rochas. Alofana foi observada em uma amostra substituindo parcialmente os cristais de plagioclásio. Nesse caso, ocorre limonita associada. 
TABELA 5.22 - Relações de cristalização dos minerais nas rochas metabásicas do Grupo São Roque.

\begin{tabular}{|c|c|c|c|c|c|c|c|}
\hline Minerais & Reliquiar & Foliacão $S_{1}$ & $P o ́ s-S_{L}$ & Foliacão $\mathrm{S}_{2}$ & $P o ́ s-S_{2}$ & Foliacão $S_{3}$ & $P O ́ S-S_{3}$ \\
\hline Clinopx(diopsídio-augita) & $\cdots \cdots$ & & & & & & \\
\hline Trem./actinolita (porf.) & & 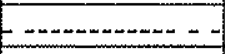 & & $\ldots-\ldots$ & & & \\
\hline Trem./actinolita (matriz) & & 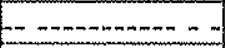 & $-m$ & 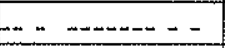 & & & \\
\hline Tremolita & & $-\cdots$ & $=$ & $\ldots-1$ & & & \\
\hline Plagioc. reliq. (Olig.-And.) & - - - - - & & & & & & \\
\hline Albita & & - - - & - & $\ldots \ldots$ & & & \\
\hline Epídoto & & $\ldots \ldots \ldots \ldots$ & $\cdots$ & 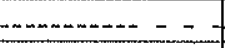 & $\cdots \cdots$ & & \\
\hline Clorita (peninita) & & - . - . - & $\ldots-\cdots$ & 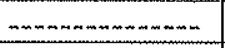 & & & \\
\hline Quartzo & $\ldots$ & $\ldots-n \ldots \ldots \ldots-\ldots$ & $\ldots$ & $\ldots \ldots-\ldots$ & $\cdots$ & $--?$ & \\
\hline Clinozoizita & & 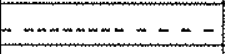 & $-\infty$ & $\cdots \cdots \cdots$ & & & \\
\hline Carbonato (calcita) & & $-\cdots$ & $\ldots$ & $\ldots \ldots \ldots \ldots$ & $\cdots-$ & $\ldots$ & \\
\hline Titanita & & 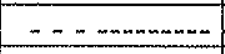 & $\ldots$ & $\ldots-\cdots$ & & & \\
\hline Mineral opaco & & $\ldots \ldots \ldots n$ & 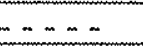 & $\ldots \ldots \ldots$ & & & \\
\hline Leucoxênio & & $\ldots \ldots$ & - & $\ldots \ldots \ldots$ & & $\ldots$ & \\
\hline Sulfeto (pirita) & $-n$ & $-?-$ & & $-\cdots$ & & & \\
\hline Apatita & & & & & - & & \\
\hline Biotita & & 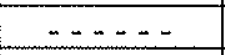 & & & & & \\
\hline Turmalina & & & & & - & & \\
\hline Rutilo & $-?-$ & & & & & & \\
\hline Fácies Metamórfica & & xisto-verde & & xisto-verde & & xisto-verde & \\
\hline
\end{tabular}

\subsubsection{Unidade Metacálcio-pelítica (NPSRpjcp)}

Devido à alteração que os metacálcio-pelitos apresentam, não foi possivel efetuar a descrição petrográfica dos afloramentos desta unidade visitados na Formação Pirapora do Bom Jesus. A descrição de um litotipo muito semelhante pode ser observada no item 5.2.4.2, referente aos metacálcio-pelitos da Formação Estrada dos Romeiros.

\subsubsection{Unidade Metacarbonática (NPSRpjed)}

O mesmo pode ser dito desta unidade. As descrições petrográficas se concentraram essencialmente nos litotipos da Unidade Metacarbonática da Formação Estrada dos Romeiros, descritas no item 5.2.4.3.

\subsubsection{Unidade Metavulcanoclástica (NPSRpjmv)}

\section{a) Rochas metavulcanoclásticas básicas}

Devido à forte alteração supérgena e à pequena área de exposição destas rochas, só foi possível coletar duas amostras frescas, sendo que uma delas pertence a uma intercalação que ocorre junto às rochas metabásicas de origem ígnea.

São rochas inequigranulares, de granulação muito fina a média, constituídas por fragmentos líticos e raros porfiroclastos de plagioclásio (até $1 \%$ ), dispersos em uma matriz muito fina a fina formada por plagioclásio $(\sim 50 \%)$, tremolita/actinolita $(\sim 30 \%)$, epídoto $(15 \%)$, titanita $(5 \%)$ e clorita $(3$ a $4 \%)$, além de goethita/limonita derivada da alteração supérgena. Petrograficamente, constituem epídototremolita/actinolita anfibolitos.

Diferenciam-se das rochas metabásicas de origem ígnea por apresentarem, às vezes, fragmentos 
arredondados a subarredondados de granulação mais grossa de rochas metabásicas e/ou com composições tendendo para metandesitos, assim como agregados arredondados formados principalmente por epídoto e clorita (Prancha 10/Foto G). Esses agregados podem representar fragmentos líticos metamorfizados, porém é mais sugestivo constituírem amígdalas derivadas, por alteração hidrotermal prévía e/ou por metamorfismo, de vesículas herdadas das rochas vulcanoclásticas. Também diferenciam-se dos anfibolitos de origem ígnea por serem mais ricos em epídoto, clorita e titanita, e por não apresentarem clinopiroxênio.

Nessas rochas predominam estrutura maciça e textura granoblástica. Localmente, observa-se a orientação dos diferentes minerais segundo o primeiro e o segundo eventos deformacionais. As relações de cristalização dos minerais segundo esses eventos podem ser observadas na TABELA 5.23.

Os fragmentos de rochas ígneas são formados principalmente por tremolita/actinolital \pm plagioclásio que, por vezes, exibem texturas blastofítica e blasto-subofítica (Prancha 10/Foto G). Os porfiroclastos de plagioclásio são ripiformes e podem atingir até $2,0 \mathrm{~mm}$, sendo localmente vistos prismas com o eixo $c$ muito alongado.

A matriz compreende principalmente plagioclásio e, subordinadamente, tremolita/actinolita. $\mathrm{O}$ plagioclásio apresenta-se fortemente recristalizado em grãos menores reequilibrados para albita. Alguns cristais maiores anédricos do anfibólio parecem ser $\sin -\mathrm{S}_{1}$, mas predominam cristais menores $\sin -\mathrm{S}_{2}$. Ambos exibem pleocroísmo variando entre verde muito pálido e verde-claro, sugestivos de composições mais próximas da tremolita/actinolita. Podem ser vistos cristais do anfibólio com formas aciculares e/ou fibrosas crescidos sobre os cristais maiores anédricos $\sin -\mathrm{S}_{1}$, sugerindo cristalização tardi- a pós $-\mathrm{S}_{2}$.

Raramente são observados cristais maiores de epídoto, prismáticos curtos e euédricos ou com forma granular, e que atingem até $0,3 \mathrm{~mm}$. Predominam, no entanto, finos cristais menores que $0,1 \mathrm{~mm}$. Localmente, em alguns cristais enédricos, recupera-se um núcleo anédrico que mostra uma borda de reação formada por leucoxênio, indicando a existência de cristais prévios à foliação $S_{1}$ que foram parcialmente destruídos.

A clorita constitui finos cristais subeuédricos predominantemente dispostos na foliação $S_{2}$, enquanto que a titanita ocorre leucoxenizada formando agregados cristalinos finos castanho-acinzentados.

TABELA 5.23 - Relações de cristalizą̧̃o dos minerais nas rochas metavulcanockásticas básicas do Grupo São Roque.

\begin{tabular}{|c|c|c|c|c|c|c|c|}
\hline Minerais & Reliquiar & Foliacão $S_{\ell}$ & Pós $s S_{L}$ & Foliação $S_{2}$ & Pós-S $S_{2}$ & Foliacão $S_{3}$ & $P O S-S_{3}$ \\
\hline Trem./Actinolita (porf.) & & $\ldots \ldots$ & & $\ldots \ldots$ & & & \\
\hline Trem./Actinolita (matriz) & & $\ldots$ & & $\ldots \ldots \ldots$ & - & & \\
\hline Plagioc. (Olig.-And.) & $\ldots \ldots$ & & & & & & \\
\hline Albita & & $\ldots \ldots$ & & $m-m-m-m-\infty$ & & & \\
\hline Epídoto & & $\ldots$ & - & $\cdots$ & - & & \\
\hline Clorita (peninita) & & $-?-$ & & - n.......... & & & \\
\hline Titanita & & $\ldots$ & & 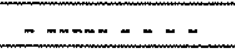 & & & \\
\hline Leucoxênio & & -- & & $\ldots$ & & & \\
\hline Fácies Metamórfica & & xisto-verde & & xisto-verde & & & \\
\hline
\end{tabular}




\subsubsection{Formação Boturuna}

\subsubsection{Unidade Metarenítica Feldspática (NPSRbtaf)}

Por serem muito semelhantes a estas rochas, os metarenitos feldspáticos da Unidade Metarenítica Feldspática da Formação Estrada dos Romeiros estão descritos conjuntamente neste item.

\section{a) Metarenitos feldspáticos e metarenitos com feldspato}

São rochas de granulação fina constituídas principalmente por quartzo (45 a 65\%), muscovita ( $5 \%$ até $45 \%$ ), biotita (ausente até 10\%), microclínio e plagioclásio (ambos somando ao redor de 5\% até raramente $15 \%$ ). Como minerais acessórios podem estar presentes epídoto, carbonato (raramente 10\%), mineral opaco, alanita, apatita, zircão e, raramente, turmalina, clorita e rutilo. Petrograficamente, correspondem a metarenitos feldspáticos ou a metarenitos com feldspato (Prancha 10/Foto $\mathrm{H}$ ). Em algumas amostras observa-se alternância de leitos que mostram pequenas variações quanto à sua granulação.

Predominam rochas com texturas granoblástica e granolepidoblástica, sendo que em exemplares com a última textura, o quartzo, os minerais micáceos e, subordinadamente, os feldspatos, estão preferencialmente orientados na foliação $S_{1}$ (Prancha 10/Foto $H$ ). O primeiro evento deformacional pode evoluir, localmente, para um evento protomilonítico. De forma muito subordinada, ocorrem minerais associados ao segundo evento deformacional, especialmente muscovita. As relações de cristalização entre os minerais e os eventos deformacionais podem ser vistas na TABELA 5.24.

Quando comparados aos metarcóseos e metarenitos arcoseanos presentes na Formação Morro Doce, os metarenitos feldspáticos e os metarenitos com feldspatos das formações Boturuna e Estrada dos Romeiros diferenciam-se por raramente apresentarem ou estarem ausentes os fragmentos líticos e os porfiroclastos de feldspatos, e por exibirem, na matriz, menor abundância de feldspatos, pequenas quantidades de biotita e de minerais opacos, enquanto que o quartzo é mais comum.

Essas rochas possuem cristais maiores de feldspato e de quartzo (menores que 1,0 mm), mas que não chegam a constituir porfiroclastos em função do tamanho dos outros constituintes minerais. Por vezes, esses cristais maiores preservam as formas detríticas originais, podendo também ser considerados como grãos reliquiares não totalmente metamorfizados e/ou reequilibrados.

Os cristais maiores de feldspatos constituem ate $5 \%$ do volume da rocha, predominando os com formas subarredondadas a arredondadas, enquanto que os clastos mais grossos de quartzo são menos comuns. Dentre os feldspatos predomina o plagioclásio, sendo que os cristais maiores podem eventualmente preservar a geminação múltipla e estarem pouco recristalizados, com composições variando entre andesina e oligoclásio.

Também observam-se cristais de plagioclásio que exibem um aspecto manchado, com geminação polissindética difusa e alteração parcial para muscovita. Predominam, no entanto, aqueles que se recristalizaram em grãos menores de albita. 
Ocorrem, de forma subordinada, cristais maiores de ortoclásio e de microclinio e, ocasionalmente, o plagioclásio ocorre em quantidades menores do que o ortoclásio. Em cristais maiores e nos raros porfiroclastos de ortoclásio observa-se, por vezes, textura pertítica.

O predomínio de formas arredondadas a subarredondadas desses feldspatos comparado ao aspecto anguloso dos porfiroclastos de feldspatos presentes nos metarcóseos e metarenitos arcoseanos da Formação Morro Doce sugere maior transporte em relação à área-fonte.

Os grãos maiores e alguns grânulos de quartzo, quando presentes, encontram-se geralmente recristalizados em grãos menores e, por vezes, estão alongados segundo a $S_{1}$. Raros agregados grossos formados por quartzo, plagioclásio e biotita sugerem ser relíquias de fragmentos líticos de composição granítica. Em uma amostra ocorrem agregados grossos formados por microclínio e quartzo e, em outra, observa-se um fragmento isolado de metarenito.

No restante da rocha predominam cristais de quartzo e feldspato com tamanhos que variam entre $0,4 \mathrm{~mm}$ e $0,7 \mathrm{~mm}$, enquanto que os minerais micáceos atingem até $0,25 \mathrm{~mm}$. O quartzo em geral tem formas granulares subangulosas a subarredondadas, predominando cristais com bordas retilíneas, sendo que alguns deles mostram extinção ondulante e estão com as bordas recristalizadas em cristais menores.

A maioria dos cristais menores de plagioclásio e de feldspato potássico recristalizaram em albita e microclínio $\sin -S_{1}$, mas ainda ocorrem cristais de plagioclásio com a geminação polissindética preservada representando clastos reliquiares não totalmente reequilibrados.

Dentre os minerais micáceos predomina a muscovita, que pode ser abundante em algumas amostras. Cristaliza em geral como cristais subeuédricos orientados sin- $S_{1}$ nos interstícios dos cristais de quartzo e feldspatos (Prancha 10/Foto H), ou está distribuída de forma aleatória pela rocha. Em alguns exemplares, a biotita pode estar presente em pouca quantidade. Ocorre na forma de cristais curtos subeuédricos a anédricos, com pleocró́smo variando do verde ao verde-acastanhado-claro, e dispõe-se predominantemente de forma aleatória.

O epídoto existente é fino e euédrico, e seus cristais por vezes podem substituir por completo os cristais maiores de feldspato. Dispõe-se ainda como agregados microcristalinos cristalizados a expensas da alanita.

Apesar de comumente anédricos, foram reconhecidas as formas cúbicas deformadas em alguns minerais opacos, sugerindo a presença de magnetita. Por vezes podem estar associados a finos cristais de clorita. Eventualmente, esse mineral micáceo também ocorre como cristais relativamente mais grossos.

Carbonato é um mineral acessório freqüente, sendo que em uma das amostras (VH 741a) ocupa até $10 \%$ do volume da rocha, cristalizando a partir do plagioclásio.

A alanita ocorre como grãos detríticos geralmente anédricos e parcialmente metamíticos, estando substituída por epídoto principalmente nas bordas. Por vezes, é possível reconstituir sua forma prismática.

Alguns cristais de zircão e de rutilo arredondados foram considerados detríticos, assím como outros cristais anédricos de apatita e de turmalina. Alguns desses cristais de zircão mostram-se 
parcialmente metamíticos.

No entanto, também foram observados cristais de zircão exibindo sobrecrescimento com faces euédricas, o que sugere ao menos recristalização parcial no primeiro evento deformacional. A turmalina também pode ocorrer como finos cristais euédricos cristalizados possivelmente nos estágios tardi- a pós$S_{1}$.

TABELA 5.24 - Relações de cristalização dos minerais nos metarenitos feldspáticos e metarenitos com feldspato.

\begin{tabular}{|c|c|c|c|c|c|c|c|}
\hline Minerais & Reliquiar & Foliacão $S_{t}$ & $P o ́ s-S_{L}$ & Foliação $S_{2}$ & $P o ́ s=S_{2}$ & Foliação $\left.S_{3}\right]$ & Pós- $S_{3}$ \\
\hline Quartzo & $\cdots$ & - & $\ldots$ & $\ldots$ & & & \\
\hline Plagioclásio (albita) & & $\ldots$ & & & & & \\
\hline FK (microclínio) & $\cdots$ & $\cdots$ & & & & & \\
\hline Biotita & & $\cdots \cdots$ & $\cdots$ & & & & \\
\hline Muscovita fina/sericita & & $-\ldots$ & $\cdots$ & $\ldots \ldots$ & & & \\
\hline Plag. Andesina/Olig. & $\cdots$ & & & & & & \\
\hline Ortoclásio & $\cdots$ & & & & & & \\
\hline Microclínio (porfiroclasto) & $\ldots$ & - ? & & & & & \\
\hline Pertitas & $\ldots$ & & & & & & \\
\hline Albita & & $\ldots$ & & & & & \\
\hline Quartzo & $\ldots$ & $\ldots \ldots$ & & $\ldots$ & & & \\
\hline Epídoto & & $-\ldots-$ & - & & & & \\
\hline Carbonato (calcita) & & $\cdots \cdots$ & & & & & \\
\hline Mineral opaco (magnetita) & - & $\cdots$ & & & & & \\
\hline Alanita & $\ldots$ & & & & & & \\
\hline Apatita & -- & & & & & & \\
\hline Clorita & & $\cdots$ & & & & & \\
\hline Turmalina & $\ldots$ & & - & & & & \\
\hline Rutilo & - & & & & & & \\
\hline Fácies Metamórfica & & xisto-verde & & xisto-verde & & & \\
\hline
\end{tabular}

\section{b) Metabásicas shoshoniticas}

São rochas de granulação fina a muito fina compostas principalmente por quantidades variáveis de biotita (50 até 90\%) e de quartzo (traço ou variando de 30 a 80\%). Como minerais acessórios observam-se plagioclásio e feldspato potássico (somando < 10\%), mineral opaco (traço até $7 \%$ ), muscovita (traço até $2 \%$ ), epídoto (até $1 \%$ ), além de clinozoizita, alanita, zircão, turmalina e apatita. Os exemplares mais ricos em biotita (90\%) possuem pequenas quantidades de quartzo (4\%). Petrograficamente, correspondem a biotita xistos finos.

A foliação $S_{1}$ foi em grande parte destruída, mas é possível recuperar arcos poligonais formados por cristais de biotita $\sin -S_{1}$ ou pequenas lentes formadas por cristais relativamente mais grossos de biotita, quartzo e muscovita sin- $S_{1}$.

A granulação fina parece resultado da cominuição gerada pela superposição do evento deformacional $S_{2}$, evento esse que pode evoluir para uma foliação milonítica $S_{m}$ e ao qual, por vezes, associam-se as foliações $S_{s}$ e $S_{c}$. A sobreposição do evento milonítico também pode ser caracterizada pela transposição de venulações tardi-S $S_{1}$ contendo quartzo essencial por cristais de biotita $S_{2} / S_{m}$.

Scgundo a $S_{3}$ observa-se cristalização incipiente de muscovita e quartzo. Predomina a textura lepidoblástica dada pela orientação da biotita. As relações de cristalização dos minerais com as diferentes 
foliações metamórficas podem ser visualizadas na TABELA 5.25.

Nessas rochas é característica a presença de aglomerados arredondados ou alongados segundo a $S_{2}$, constituídos em essência por quartzo \pm biotita e que foram interpretados como amígdalas preenchiclas por esses minerais. A biotita pode estar distribuída de forma aleatória ou estar concentrada no centro, circundada por uma espécie de corona formada pelos cristais de quartzo (Prancha 11/Foto A). Essas feições são raras ou constituem até $15 \%$ do volume da rocha e, quando mais abundantes, costumam também ser maiores. As amígdalas medem até $3,0 \mathrm{~mm}$, e ao seu redor podem ocorrer sombras de pressão nas rochas milonitizadas. Nesses casos, observam-se aglomerados de cristais de até $7,0 \mathrm{~mm}$.

São rochas inequigranulares, com os cristais mais finos tendo menos de $0,1 \mathrm{~mm}$, enquanto que os maiores podem atingir até $0,5 \mathrm{~mm}$.

Em amostras frescas, a biotita é pleocróica do castanho ao verde, estando principalmente orientada segundo a $S_{2}$. Amostras intemperizadas exibem agregados finos avermelhados de goethita/limonita associados a esse mineral micáceo.

O quartzo, de modo geral, tem formas irregulares tendendo a angulosas, sendo os contatos entre seus cristais preferencialmente suturados mas, não raro, mostram-se granulares e com contatos retilíneos a poligonizados. Nas rochas afetadas pela $S_{m}$ pode-se observar estiramento dos cristais de quartzo segundo essa foliação. Adicionalmente, ocorrem pequenos arranjos com formas sigmoidais formadas por quartzo ou pequenas lentes amendoadas ricas em quartzo, por vezes seccionadas, e que parecem corresponder a antigas amígdalas deformadas segundo a foliação $S_{\mathrm{m}}$

O plagioclásio encontra-se reequilibrado para albita. Raros cristais de feldspato potássico se destacam por serem maiores e euédricos e mostrarem relíquias da geminação em grade, sendo que encontram-se em parte alterados para sericita. enquanto que alguns cristais mais finos ocorrem não geminados

O mineral opaco ocorre disseminado como cristais anédricos ou que exibem forma cúbica. Em geral, estão orientados segundo a $S_{m}$. Os cúbicos foram caracterizados como de magnetita.

A muscovita é rara, comumente associada à foliação $S_{2}$. Também pode estar disseminada ou dispor-se perpendicularmente à $S_{m}$, sendo caracterizada como $\sin \sim S_{3}$.

Alanita, quando observada, em geral é anédrica e sugere ser reliquiar. Ocasionalmente está bem preservada com forma tendendo à prismática. Foi observada também no interior de uma amígdala. Epídoto cristaliza a partir da borda da alanita ou pode estar disseminado pela amostra. Só ocasionalmente ocorre clinozoizita nessas rochas.

O zircão, apesar de raro, ocorre ora como cristais normais ora como cristais parcialmente metamíticos. Alguns dos normais são prismáticos e euédricos, porém a maioria dos cristais metamíticos e outros normais têm forma arredondada, sugerindo também a ocorrência de cristais reliquiares. A apatita e a turmalina são ocasionais em algumas lentes quartzosas. 
TABELA 5.25 - Relações de cristalização dos minerais nas rochas metabásicas shoshoníticas do Grupo São Roque.

\begin{tabular}{|c|c|c|c|c|c|c|c|}
\hline Minerais & Reliquiar & Foliação $S_{\perp}$ & Pós-S, & Foliacão $S_{2}$ & Pós-S & Foliacão $S_{3}$ & $P O ́ s-S_{3}$ \\
\hline Biotita & & $\ldots \ldots \ldots$ & $\cdots$ & 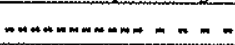 & & & \\
\hline Quartzo & & $\cdots \cdots$ & $=$ & $\ldots \ldots$ & & $\cdots$ & \\
\hline Plagioclásio (albita) & & $\ldots$ & & $\cdots$ & & & \\
\hline Feldspato potássico & 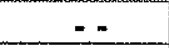 & $\ldots \ldots \ldots$ & & 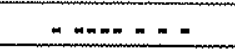 & & & \\
\hline Muscovita & & $\ldots \ldots$ & & 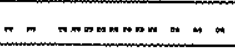 & & $=m-\infty$ & \\
\hline Epídoto & & $-?-$ & & $\ldots$ & & & \\
\hline Clinozoizita & & $\ldots$ & - & $\cdots \cdots$ & & & \\
\hline Mineral opaco (magnetita) & & $\ldots$ & & $\ldots \ldots$ & - & & \\
\hline Zircâo & $\cdots$ & $\cdots$ & & & & & \\
\hline Apatita & & $\cdots$ & - & . & $\ldots$ & & \\
\hline Turmalina & & & & $\ldots$ & -. & & \\
\hline Alanita & $\cdots$ & & & & & & \\
\hline Sericita & & & & & & $\cdots$ & 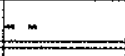 \\
\hline Fácies Metamórfica & & xisto-verde & & xisto-verde & & xisto verde & \\
\hline
\end{tabular}

\subsubsection{Unidade quartzítica (NPSRbtqz)}

Por serem muito semelhantes, são descritos em conjunto neste item os quartzitos e metapsamitos que ocorrem tanto na Formação Boturuna como aqueles da unidade NPSRerpm da Formação Estrada dos Romeiros.

\section{a) Quartzitos e metarenitos}

São rochas de granulação muito fina a média, compostas principalmente por quartzo ( 85 até 98\%) e muscovita/sericita (traço até 15\%). Como minerais acessórios, podem estar presentes mineral opaco, zircão, biotita, turmalina e rutilo. Correspondem, petrograficamente, a quartzitos e metarenitos, termos adotados, respectivamente, devido ao maior e ao menor grau de recristalização observado.

O primeiro evento deformacional é marcado preferencialmente pela orientação e estiramento do quartzo e da muscovita sin- $S_{1}$ (Prancha 11/Foto B), enquanto que a foliação $S_{2}$ é localmente responsável por ondular a foliação anterior, apresentando incipiente cristalização de quartzo e de muscovita. As relações de cristalização dos minerais com as foliações metamórficas são exibidas na TABELA 5.26.

Nessas rochas os cristais de quartzo podem não estar orientados, observando-se então a textura granoblástica, ou ocorrem orientados principalmente segundo a $S_{1}$. Em alguns exemplares ou porções dos mesmos ricas em muscovita pode-se observar tanto textura granolepidoblástica como lepidoblástica, sendo que, nesse último caso, os cristais de quartzo $\sin -S_{1}$ encontram-se comumente orientados e estirados segundo a foliação.

Os cristais de quartzo medem predominantemente entre 0,05 e $0,6 \mathrm{~mm}$, sendo raros os grânulos com pouco mais de $2,0 \mathrm{~mm}$. Os cristais de quartzo menores têm formas subangulosas a subarredondadas. Alguns grãos recristalizados segundo a $S_{1}$ estão estirados e mostram extinção ondulante; outros podem ter sofrido forte cominuição, configurando textura semelhante à mortar. Normalmente esses cristais exibem bordas irregulares a lobadas (Prancha 11/Foto B).

Na Formação Boturuna, no morro homônimo, os quartzitos e metarenitos por vezes portam raros grânulos de quartzo dispersos pela matriz, sendo muito ocasionalmente observados finos leitos onde há 
presença de biotita e de fragmentos líticos de arenito fino rico em mineral opaco.

A muscovita é fina e cristaliza entre os cristais granulares de quartzo. Biotita verde-clara cristaliza localmente, estando associada a cristais de muscovita e de quartzo.

São vistos tanto cristais de zircão arredondados, denotando possível origem detrítica, como cristais prismáticos e zonados que sugerem recristalização metamórfica. É muito raro encontrar grãos arredondados de turmalina detrítica.

O mineral opaco tem forma octaédrica, tratando-se provavelmente de magnetita. Por vezes está intemperizado para limonita, que pode formar uma carapaça que envolve os grãos de quartzo recristalizados. Rutilo foi caracterizado na região do Várzea do Souza em quartzitos da Formação Estrada dos Romeiros, sendo possivelmente detrítico.

TABELA 5.26 - Relações de cristalização dos minerais segundo as diferentes foliações metamórficas nos quartzitos e metarenitos das formação Boturuna e Estrada dos Romeiros.

\begin{tabular}{|c|c|c|c|c|c|c|c|}
\hline Minerais & Reliquiar & Foliação $S_{L}$ & $P \hat{o s}-S_{l}$ & Foliacão $S_{2}$ & $P o ́ s-S_{2}$ & Foliacão $S_{3}$ & Pós-S \\
\hline Quartzo & $\ldots$ & $-\ldots \ldots$ & $\ldots$ & $\ldots \ldots$ & & & \\
\hline Muscovita/sericita & & $\ldots \ldots \ldots$ & $\ldots$ & $\ldots .$. & & & \\
\hline Biotita & & $\cdots$ & & & & & \\
\hline Zircão & $\cdots$ & 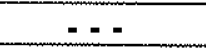 & & & & & \\
\hline Mineral opaco (magnetita) & $\cdots$ & $=0$ & & & & & \\
\hline Turmalina & $\cdots$ & & & & & & \\
\hline Rutilo & $m$ & & & & & & \\
\hline Limonita/goethita & & & & $\rightarrow$ & & & \\
\hline Fácies Metamórfica & & xisto-verde & & xisto-verde & & & \\
\hline
\end{tabular}

\subsubsection{Formação Estrada dos Romeiros}

\subsubsection{Unidade Metarrítmica (NPSRerpm)}

Estão descritos em conjunto os metarritmitos desta unidade e aqueles que ocorrem intercalados na Unidade Metacálcio-Pelítica desta formação (NPSRercp), além dos que constituem a Unidade Metarrítmica da Formação Piragibu (NPSRpgmr).

\section{a) Metarritmitos}

Estas rochas mostram caracteristicamente a intercalação de leitos de metassiltitos e metarenitos finos a grossos (Prancha 11/ Foto C) com filitos e quartzo filitos (Prancha 11/Foto D), sendo que, por vezes, também ocorrem leitos de metaconglomerados interpostos. A espessura desses leitos em seç̧ões delgadas varia de milimétrica até centimétrica, mas em campo são observadas interposições de espessura até decamétrica.

Nos leitos filíticos predomina a muscovita/sericita (até 90\%) sobre o quartzo (até 30\%), enquanto que nos metassiltitos e metarenitos ocorre o inverso, predominando amplamente o quartzo (até 95\%) sobre a muscovita/sericita (5 até 30\%). Nestas rochas também podem ocorrer, de forma subordinada, mineral opaco (traço, raramente até $15 \%$ ), clorita, turmalina, zircão e epídoto. Raramente são observados clastos de quartzo e fragmentos líticos de veio de quartzo e de quartzito/metarenito fino.

Os metarritmitos exibem estrutura laminada a bandada. Nas rochas onde a deformação e a 
recristalização foram menos intensas podem ser recuperadas feições sedimentares, como finos leitos de minerais opacos que refletem o acamamento original e efeitos de pressão de carga exercidos por clastos maiores depositados sobre delgados leitos de granulação mais fina e que podem indicar topo e base (Prancha 11/Foto C).

O principal evento deformacional também está representado por uma foliação $S_{1}$ que exibe forte cristalização dos minerais micáceos, enquanto que a foliação $S_{2}$, menos comum, pode ser responsável por uma ondulação suave da $S_{1}$, compreender uma clivagem de crenulação penetrativa, gerar um bandeamento diferenciado (Prancha 11/Foto D) ou, localmente, evoluir para uma foliação milonítica $S_{\mathrm{tw}}$. As relações de cristalização dos minerais com os eventos deformacionais podem ser observadas na TABELA 5.27.

Nos leitos de metassiltitos e metarenitos finos a grossos predomina a textura granoblástica e, nos filitos, a textura lepidoblástica, sendo que nessas últimas rochas pode ser observada a orientação dos minerais micáceos e, por vezes, dos cristais de quartzo, predominantemente segundo a $S_{1}$. Nas rochas mais quartzosas e que encontram-se intensamente foliadas ou afetadas pela $S_{m}$ também podem ser vistos, com certa freqüência, a orientação ou mesmo o estiramento dos cristais de quartzo $\sin -S_{1} / S_{m}$.

O tamanho dos clastos de quartzo e dos fragmentos líticos de veio de quartzo e de quartzito/metarenito fino varia de $0,2 \mathrm{~mm}$ até $1,0 \mathrm{~mm}$, podendo eventualmente atingir até $3,0 \mathrm{~mm}$. Entre os menores predominam formas que tendem a angulosas, enquanto que nos maiores são mais comuns as subarredondadas, correspondendo, provavelmente, às formas como foram sedimentados. Em um leito de metarenito conglomerático são observados fragmentos dispersos de quartzito com até $3,0 \mathrm{~mm}$ constituídos por cristais de quartzo que exibem contato poligonizado (CJ 169).

Em algumas rochas mais foliadas pode ocorrer uma intensa percolação de óxidos/hidróxidos de ferro que envolvem os clastos ou fragmentos líticos.

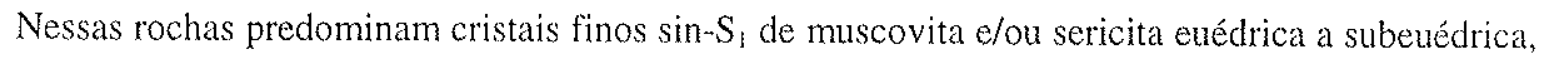
e são observadas em alguns leitos pequenas quantidades de clorita fina $\sin -S_{1}$. Subordinadamente, podem ocorrer minerais micáceos $\sin -\mathrm{S}_{2}$, distribuídos de forma oblíqua ou perpendicular à foliação principal, sendo que nas rochas onde o segundo evento deformacional foi mais intenso, ainda é possível recuperar os cristais de clorita e de muscovita $\sin -S_{1}$ formando arcos poligonais. Ocasionalmente, ocorrem cristais de muscovita e de clorita mais grossos, e que por vezes estão distribuídos de forma aleatória pela amostra, sugerindo cristalização pós- $S_{1}$. Outros encontram-se rotacionados preferencialmente pela foliação $S_{1}$ e podem exibir kink bands, tendo sido interpretados como relíquias detríticas.

O quartzo dos metassiltitos predomina na forma de grãos recristalizados que exibem contatos retilíneos ou poligonizados. Em alguns leitos quartzosos dos metarritmitos observam-se clastos de quartzo de mais ou menos $1,0 \mathrm{~mm}$ dispersos em uma matriz muito fina formada principalmente por quartzo \pm sericita. Esses clastos em geral têm formas arredondadas a subarredondadas (Prancha 11/ Foto C).

Nos filitos ou nas rochas onde o quartzo ocorre subordinado em relação aos minerais micáceos, $o$ 
mineral é observado como grãos dispersos recristalizados que podem mostrar uma incipiente orientação ou estar estirados segundo a foliação $S_{1}$. Nas rochas afetadas pela foliação milonítica por vezes são reconhecidas feições sigmoidais constituídas principalmente por finos cristais de quartzo alongados, feições essas derivadas das foliações $S_{s}$ e $S_{c}$. Remobilizações tardias do quartzo que ocorreram no primeiro e segundo eventos deformacionais produziram venulações que cortam preferencialmente os leitos quartzosos, sendo raras ou ausentes nos leitos micáceos.

O mineral opaco é reconhecido, na maioria das vezes, na forma de cristais finos e euédricos de hábito cúbico, considerados como de magnetita. Podem estar aleatoriamente distribuídos pela amostra ou, eventualmente, quando mais abundantes, chegam a constituir finos leitos que marcam o acamamento original. Raramente são vistos orientados segundo a $S_{1}$ e/ou $S_{2}$, o que sugere recristalizações tardi- a pós$\mathrm{S}_{1}$ e/ou tardi a pós- $\mathrm{S}_{2}$. A borda vermelha de alguns cristais indica transformação para limonita devido à alteração supérgena.

Coexistem cristais euédricos e anédricos de turmalina, sendo sugerida para os últimos origem detrítica, enquanto que os primeiros parecem resultar de recristalização no final do primeiro evento deformacional. Epídoto é muito raro, tem forma euedral, sugerindo cristalização tardi- a pós- $S_{1}$.

Em uma amostra de metarritmito intercalado na unidade quartzítica do Morro do Boturuna ocorrem cristais euédricos de zircão com núcleos detríticos arredondados, sugerindo recristalização e sobrecrescimento das bordas que se relacionam, possivelmente, aos estágios tardi- e pós $S_{1}$.

TABELA 5.27 - Relações de cristalização dos minerais com as foliações nos metarritmitos nas unidades Metarrítmica e Metacálcio-pelítica da Formaçăo Estrada dos Romeiros e na Unidade Metarrítmica da Formação Piragibu.

\begin{tabular}{|c|c|c|c|c|c|c|c|}
\hline Minerais & Reliquiar & Foliacão $S_{L}$ & $P o s-S_{\perp}$ & Foliacão $S_{2}$ & Pós.. $S_{2}$ & Foliação $S_{3}$ & Pós-S $S_{3}$ \\
\hline Muscovita mais grossa & $--?$ & & $\cdots \cdots$ & & & & \\
\hline Muscovita fina / Sericita & & 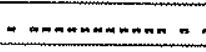 & & $m \cdots \cdots$ & & & \\
\hline Quartzo & $\cdots$ & $\ldots \ldots \ldots$ & $\ldots$ & $\cdots \ldots$ & $\ldots$ & & \\
\hline Clorita & & $\cdots \cdots \cdots$ & $\cdots$ & $\ldots \cdots$ & & & \\
\hline Mineral opaco (magnetita) & $\cdots$ & $\cdots$ & $\cdots$ & & $-m$ & & \\
\hline Zircão & $\cdots$ & $m$ & $\ldots$ & & & & \\
\hline Turmalina & $\cdots$ & $\ldots$ & $\cdots$ & & & & \\
\hline Epídoto & & $\cdots$ & $n$ & & & & \\
\hline Fácies Metamórfica & & xisto-verde & & xisto-verde & & & \\
\hline
\end{tabular}

\section{b) Metarenitos}

São rochas inequigranulares formadas por porfiroclastos de quartzo e de plagioclásio que podem constituir até $10 \%$ do volume da rocha, e por raros porfiroblastos de muscovita e de clorita dispersos em matriz rica em quartzo (60 a 65\%), com muscovita (20 a $25 \%$ ) e clorita $(\sim 10 \%)$ subordinadas, e onde também podem ocorrer mineral opaco e epídoto como traços (Prancha 11/Foto E).

Nessas rochas são comuns a estruturas maciça e a que exibe uma incipiente orientação, a última marcada pela isorientação dos minerais micáceos segundo a foliação $S_{1}$ dispostos de forma subordinada entre os cristais granulares de quartzo, produzindo uma textura lepidogranoblástica. Segundo a $S_{2}$ observam-se pouca blastese e reorientação dos porfiroclastos. As relações de cristalização dos minerais 
com as respectivas foliações metamórficas estão na TABELA 5.28.

Os clastos de quartzo e de feldspatos têm diversos tamanhos, a maioria deles variando entre $0,2 \mathrm{e}$ $0,6 \mathrm{~mm}$. Os maiores chegam a constituir porfiroclastos (Prancha 11/ Foto $\mathbf{E}$ ) que encontram-se orientados segundo a $S_{1}$ ou estão rotacionados pela $S_{2}$, ou ainda podem se distribuir de forma aleatória pela rocha.

Predominam porfiroclastos de quartzo angulosos a subangulosos com moderada extinção ondulante (Prancha 11/ Foto E). Alguns aglomerados formados por diversos cristais de quartzo sugerem tratar-se de fragmentos líticos de antigos veios de quartzo. Os porfiroclastos de plagioclásio são mais raros, exibindo comumente formas subeuédricas, sendo que alguns preservam parcial ou totalmente a geminação múltipla. Localmente, a borda pode estar recristalizada em grãos menores não geminados e com relevo menor que o do quartzo, o que sugere reequilíbrio para albita.

Raramente ocorrem porfiroblastos etuédricos de clorita e de muscovita, distribuídos de forma aleatória pela amostra, o que parece indicar cristalização tardi- a pós-S $S_{1}$.

Os minerais da matriz em geral são menores que $0,1 \mathrm{~mm}$, sendo que o quartzo está recristalizado e parcialmente orientado na foliação $S_{1}$. A muscovita ocorre preferencialmente orientada como finos cristais subeuédricos a euédricos $\sin -S_{1}$, podendo cristalizar entre os grãos de quartzo, enquanto que a clorita constitui cristais verdes mais finos do que os de muscovita e que, em geral, encontram-se menos orientados. Observam-se pequenos cristais de mineral opaco subeuedral e com forma cúbica, tratando-se de magnetita. Eventualmente, ocorrem finíssimos cristais enédricos de epídoto cristalizados provavelmente nos estágios tardi- a pós-S.

TABEl_A 5.28 - Relações de cristalização dos minerais segundo as foliaçôes metamorficas nos metarenitos da Unidade Metarrítmica da Formação Estrada dos Romeiros.

\begin{tabular}{|c|c|c|c|c|c|c|c|}
\hline Minerais & Reliquiar & Foliacão $S_{l}$ & $P o ́ s-S_{1}$ & Foliacão $S_{2}$ & $P o ́ s-S_{2}$ & Foliacão $S_{3}$ & $P o ́ s-S_{3}$ \\
\hline Muscovita porfiroblástica & & & $\ldots$. & & & & \\
\hline Muscovita fina/Sericita & & $m-\cdots \cdots \cdots$ & & $\cdots$ & & & \\
\hline Quartzo & $=-m$ & 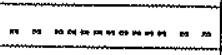 & $\sim$ & $\ldots$ & & & \\
\hline Clorita & & $\cdots \cdots \cdots$ & $=-$ & $-\cdots$ & & & \\
\hline Plagioclásio (albita reequil) & $m \cdots$ & $\ldots$ & & & & & \\
\hline Mineral opaco (magnetita) & $\ldots \ldots$ & $\ldots$ & & & & & \\
\hline Epídoto & & $\ldots$ & 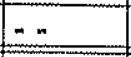 & & & & \\
\hline Fácies Metamórfica & & xisto-verde & & xisto-yerde & & & \\
\hline
\end{tabular}

\section{c) Metaconglomerados}

Apenas duas amostras frescas foram obtidas deste litotipo. São rochas compostas principalmente por fragmentos líticos $(\sim 90 \%)$, sendo mais comuns os de quartzitos, de metarenitos finos a muito finos, de filito, de quartzo-de-veio, além de clastos angulosos de quartzo, de quartzo-de-veio e raros grânulos de quartzo subarredondados. Os fragmentos líticos e os clastos predominam sobre uma matriz muito fina constituída por quartzo recristalizado, muscovita e/ou sericita, que somados atingem ao redor de $10 \%$ do volume da rocha. São caracterizados como metaconglomerados clasto-suportados (Prancha 11/Foto F).

O tamanho dos fragmentos varia de grãos grossos até grânulos que têm ao redor de $3,0 \mathrm{~mm}$. 
Em alguns dos fragmentos líticos de metarenitos e de filito podem-se observar cristais de quartzo e de minerais micáceos orientados segundo uma foliação prévia a $S_{1}$. Os cristais de muscovita/sericita e de quartzo da matriz cristalizam no pouco espaço existente entre os fragmentos líticos, estando orientados principalmente segundo a foliação principal $S_{1}$. As relações de cristalização dos minerais com as foliações metamórficas podem ser observadas na TABELA 5.29.

Localmente, a foliação $S_{1}$ pode tornar-se mais intensa ou mesmo evoluir para uma foliação milonítica $S_{m}$. Neste caso, alguns dos fragmentos líticos ocorrem orientados segundo a $S_{m}$.

TABELA 5.29 - Relações de cristalização dos minerais nos metaconglomerados da Unidade Metarrítmica da Formação Estrada dos Romeiros.

\begin{tabular}{|c|c|c|c|c|c|c|c|}
\hline Minerais & Reliquiar & Foliacão $S_{\lambda}$ & Pós- $S_{\perp}$ & Foliacão $S_{2}$ & Pós-S $S_{2}$ & Foliacão $S_{3}$ & $P o ́ S-S_{3}$ \\
\hline Muscovita fina / Sericita & & $\ldots \ldots$ & & & & & \\
\hline Quartzo & & $\ldots$ & & & & & \\
\hline Fragmentos de filito & $\ldots .$. & & & & & & \\
\hline Fragmentos de quartzito & $\cdots$ & & & & & & \\
\hline Fragmentos de metarenitos & $\cdots \cdots$ & & & & & & \\
\hline Grânulos de quartzo & $\cdots \cdots$ & & & & & & \\
\hline Fácies Metamórfica & & xisto-verde & & xisto-verde & & & \\
\hline
\end{tabular}

\subsubsection{Unidade Metacálcio-Pelítica (NPSRercd)}

\section{a) Metacálcio-pelitos}

Devido à forte alteração intempérica que afeta o litotipo desta unidade e da Unidade Metacálciopelítica da Formação Pirapora do Bom Jesus, apenas uma amostra permitiu a análise petrográfica.

Nessa amostra observa-se alternância de lâminas e bandas. Nos leitos de granulação mais fina a rocha é formada principalmente por carbonato + muscovita \pm quartzo, sendo difícil estimar o volume de cada um desses minerais pelo fato de a granulação ser menor que $0,01 \mathrm{~mm}$, com raros cristais de quartzo atingindo $0,02 \mathrm{~mm}$. Nesses leitos predomina a textura granoblástica.

Os leitos de granulação relativamente mais grossa são constituídos principalmente por flogopita ( 35 a $55 \%$ ), e ocorrem de forma subordinada quartzo (10 a $25 \%)$, sericita $(\sim 15 \%)$ e carbonato (5 e $10 \%)$. Nesses leitos predomina a textura lepidoblástica, sendo que os cristais de flogopita podem atingir até 0,3 $\mathrm{mm}$, ocorrendo essencialmente orientados segundo a $\mathrm{S}_{1} / \mathrm{S}_{0}$. Localmente, observam-se lâminas formadas essencialmente por quartzo, e pode ocorrer, ocasionalmente, grafita associada.

Por vezes, observam-se cristais de um mineral opaco identificados como pirita. Encontram-se parcialmente limonitizados devido à alteração intempérica e, localmente, pode ocorrer associada a percolação de óxidos e hidróxidos de ferro.

As relações de cristalização dos minerais com as foliações metamórficas estão na TABELA 5.30.

\subsubsection{Unidade Metacarbonática (NPSRercd)}

\section{a) Rochas carbonáticas}

Pela semelhança dos litotipos, são descritas em conjunto as rochas carbonáticas presentes nas formações Pirapora do Bom Jesus e Estrada dos Romeiros. 
São rochas constituídas principalmente por carbonato, que ocupa mais de $90 \%$ do conteúdo podendo atingir até $98 \%$ do volume da rocha. Como minerais acessórios por vezes são identificados quartzo, flogopita, grafita, clorita, sericita/muscovita fina e pirita porfiroblástica (Prancha 11/Foto G).

A granulação dessas rochas é muito fina, em geral menor que $0,05 \mathrm{~mm}$. Em algumas amostras predomina a textura granoblástica, enquanto que em outras a orientação preferencial dos minerais segundo o primeiro evento deformacional confere à rocha uma estrutura laminada (Prancha 11/Foto G). Localmente, o primeiro evento deformacional pode evoluir para uma foliação milonítica $S_{m}$.

O carbonato recristaliza essencialmente na $S_{1}$. Nas amostras afetadas pelo evento milonítico $S_{\mathrm{m}}$, os cristais de carbonato mostram formas amendoadas $\sin -S_{m}$ e os cristais de quartzo estão estirados segundo essa foliação, podendo, localmente, ocorrer pequenas lentes constituídas essencialmente por quartzo. As relações de cristalização dos minerais com as foliações encontram-se na TABELA 5.31.

Em algumas amostras o carbonato está remobilizado em finos veios e venulações provavelmente pós $S_{2}$, onde cristaliza principalmente carbonato \pm quartzo e ocorrem cristais de carbonato que atingem 2,5 mm. Nessas remobilizações predominam contatos poligonizados entre os cristais de carbonato, e os de quartzo também podem ocorrer em forma de fita.

Os cristais de quartzo mais grossos em geral preservam suas características clásticas, que se refletem em suas formas arredondadas a subarredondadas. Grafita, muscovita fina/sericita e flogopita cristalizam essencialmente na $S_{1}$. Alguns cristais de sericita podem exibir um fraco pleocroísmo variável do incolor ao verde-claro pálido. Também são observados cristais incolores de clorita que indicam composições magnesianas. Raros cristais maiores, euédricos, e de hábito cúbico, medindo até $0,5 \mathrm{~mm}$, foram identificados como pirita. Encontram-se parcialmente limonitizados.

TABELA 5.30 - Relações de cristalização dos minerais com as foliações metamórficas nos metacálcio-pelitos das formações Pirapora do Bom Jesus e Estrada dos Romeiros.

\begin{tabular}{|c|c|c|c|c|c|c|c|}
\hline Minerais & Reliquiar & Foliacão $S_{\perp}$ & $P o ́ s m S_{I}$ & Foliacão $S_{2}$ & $P o ́ s-S_{2}$ & Foliacão $S_{3}$ & Pós-S $S_{3}$ \\
\hline Carbonato & & $\ldots \ldots$ & $\cdots$ & $\ldots$ & & & \\
\hline Quartzo & $\ldots$ & $\cdots \cdots$ & & $\cdots$ & & & \\
\hline Muscovita fina/Sericita & & $\cdots \cdots$ & & $\ldots$ & & & \\
\hline Flogopita & & $\ldots \ldots$ & $\cdots$ & & & & \\
\hline Grafita & & $\cdots$ & & & & & \\
\hline Pirita & & - & $\cdots$ & & & & \\
\hline Fácies Metamórfica & & xisto-verde & & xisto-verde & & & \\
\hline
\end{tabular}

TABELA 5.31 - Relações de cristalização dos minerais com as foliações metamórficas nas rochas carbonáticas das formacões Pirapora do Bom Jesus e Estrada dos Romeiros.

\begin{tabular}{|c|c|c|c|c|c|c|c|}
\hline Minerais & Reliquiar & Foliação $S_{L}$ & Pós $=S_{L}$ & Foliacão $S_{2}$ & Pós- $S_{2}$ & Foliacão $S_{3}$ & Pós-S $S_{3}$ \\
\hline Carbonato & & - & -- & $\ldots \ldots$ & $\ldots$ & & \\
\hline Quartzo & $\cdots$ & $\cdots \cdots$ & & $\ldots$ & & & \\
\hline Muscovita fina / Sericita & & $\ldots \ldots$ & & $\ldots$ & & & \\
\hline Flogopita & & $\ldots$ & $=-$ & & & & \\
\hline Grafita & & $\ldots$ & & & & & \\
\hline Clorita & & $\ldots$ & & & & & \\
\hline Pirita & & - & $\ldots$ & & & & \\
\hline Fácies Metamórfica & & xisto-verde & & xisto-verde & & & \\
\hline
\end{tabular}




\subsubsection{Formação Piragibu}

\subsubsection{Unidade metapelítica (NPSRpgmp)}

Por sua semelhança petrográfica, são também considerados neste item os filitos que ocorrem na Unidade Metapelítica da Formação Estrada dos Romeiros.

\section{a) Filitos}

São rochas de granulação fina constituídas predominantemente por muscovita fina/sericita ( 35 até $90 \%$ ), enquanto que o quartzo geralmente ocorre de forma subordinada (entre 15 e $35 \%$, por vezes até $60 \%$ ). Também podem estar presentes clorita (ausente até $70 \%$, em alguns leitos restritos), biotita, mineral opaco (traço até $2 \%$ ), grafita, carbonato, zircão, epídoto e turmalina. A granulação é fina a muito fina, menor que $0,1 \mathrm{~mm}$, comumente menor que $0,05 \mathrm{~mm}$.

Os fillitos têm uma estrutura que varia de laminada a bandada, que geralmente representa ou o acamamento original preservado ou um bandeamento composicional $S_{1} / S_{0}$ gerado no primeiro evento deformacional. São comuns as intercalações de finos leitos ricos em muscovita/sericita com aqueles mais pobres nesse mineral, e também podem ser observados finos leitos intercalados constituídos quase exclusivamente por quartzo. Por vezes, ocorrem leitos ricos em grafita.

A foliação principal corresponde à $S_{1}$, que se dispõe paralela ou oblíqua ao acamamento. Uma clivagem de crenulação $S_{2}$ pode se sobrepor à foliação $S_{1}$ e produzir, eventualmente, arcos poligonais formados pelos minerais micáceos da foliação prévia. Por vezes ocorrem, em algumas amostras, finos leitos quartzosos dobrados intrafolialmente e isolados no interior da $S_{2}$. Ocasionalmente, as foliações $S_{1} e$ $S_{2}$ podem estar afetadas por uma clivagem de fratura $S_{3}$. As relações de cristalização dos minerais com as foliações encontram-se na TABELA 5.32.

Localmente, o segundo evento deformacional também pode evoluir para um evento milonítico $S_{\mathrm{m}}$, ocorrendo associadas, em alguns exemplares, intensas recristalização e transposição, onde as estruturas originais e o bandeamento $S_{1} / S_{0}$ podem ser totalmente obliterados, transformando as rochas em filonitos.

Nos filitos mais preservados podem ocorrer a textura lepidoblástica, marcada pela forte orientação dos minerais micáceos essenciais $\sin -S_{1}$ e pela presença de quartzo muito subordinado e estirado, e a granolepidoblástica, em lâminas e bandas onde o quartzo torna-se relativamente mais comum e tem forma predominantemente granular, estando pouco orientado. A textura granoblástica é observada nos leitos formados essencialmente por quartzo.

Eventualmente, ocorrem cristais maiores e anédricos de muscovita e de biotita, cujas formas sugerem tratar-se de cristais detríticos. Predominam, no entanto, cristais finos de muscovita/sericita. Nas amostras afetadas pela $S_{\mathrm{m}}$ não é raro observar muscovita/sericita amoldando-se aos grãos de quartzo, que podem estar estirados.

Clorita $\sin -S_{1}$ cristaliza em pequenas quantidades em alguns leitos finos ou pode constituir o mineral mais abundante em outros, ao passo que o carbonato forma agregados maiores que parecem correspondem a grãos detríticos relativamente mais grossos que foram recristalizados. 
O mineral opaco por vezes concentra-se em finos leitos que refletem o acamamento original, podendo ou não estar orientado na $S_{1}$. Ocasionalmente, quando constitui cristais muito finos, torna-se difícil clistinguí-lo da grafita. Transforma-se parcial ou totalmente em agregados microgranulares de limonita/goethita, devido à alteração intempérica.

Ocorrem finos cristais anédricos de zircão e de turmalina detríticos, sendo que raros cristais euédricos de turmalina e de epídoto parecem ter sido cristalizados tardi- a pós- $S_{1}$.

Venulações tardias cortam as foliações, sendo responsáveis essencialmente pela remobilização e cristalização de quartzo granular ou com forma fitada ao qual associam-se, subordinadamente, cristais de magnetita ou de sulfeto. Microfalhas tardias provocam rejeitos milimétricos em alguns leitos.

TABELA 5.32 - Relações de cristalização dos minerais com as foliações metamórficas nos filitos das unidades metapelíticas das formações Piragibu e Estrada dos Romeiros.

\begin{tabular}{|c|c|c|c|c|c|c|c|}
\hline Minerais & Reliquiar & Foliacão $S_{\iota}$ & Pós-S, & Foliacâo $S_{2}$ & $P o ́ s-S_{2}$ & Foliacão $S_{3}$ & $P o ́ s-S_{3}$ \\
\hline Muscovita mais grossa & $\cdots$ & & & & & & \\
\hline Muscovita fina/Sericita & & - & $\cdots$ & $\cdots \cdots \cdots$ & & $\cdots$ & \\
\hline Quartzo & $\cdots$ & 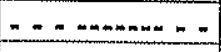 & $\ldots$ & $\cdots \cdots \cdots$ & $\cdots$ & $\cdots$ & \\
\hline Clorita & & $\ldots \ldots$ & & $n+?$ & & & \\
\hline Biotita mais grossa & $\ldots$ & & & & & & \\
\hline Grafita & & $m \cdots+1$ & & $\cdots$ & & $\cdots$ ? & \\
\hline Carbonato & $\cdots$ & $\cdots$ & $=$ & $\cdots$ & & & \\
\hline Mineral opaco (magnetita) & $\cdots$ & $\cdots \cdots$ & & & & & \\
\hline Zircão & $\cdots$ & & & & & & \\
\hline Turmalina & $-\cdots$ & - & - & & & & \\
\hline Epídoto & & - - - & $\ldots$ & & & & \\
\hline Sulfeto (pirita) & & & & & - ? & $\cdots$ & $-?$ \\
\hline Fácies Metamórfica & & xistonverde & & xisto-verde & & xisto-verde & \\
\hline
\end{tabular}

\section{b) Ardósias}

Estas rochas são formadas por raros porfiroclastos de muscovita, cristais detríticos de biotita e cristais maiores de clorita, dispersos em uma matriz de granulação muito fina, em geral menor que 0,05 $\mathrm{mm}$, que tem como principais minerais clorita $(\sim 45 \%)$, quartzo (30 a $35 \%)$, sericita (até $20 \%$ ), mineral opaco (3-5\%) e biotita (menos de 1\%). Petrograficamente, correspondem a ardósias.

Os porfiroclastos de muscovita podem medir até $0,5 \mathrm{~mm}$, e por vezes exibem sombra de pressão nas suas extremidades (Prancha 11/Foto H). Ocasionalmente, ocorrem relíquias detríticas de biotita com até $0,3 \mathrm{~mm}$ na forma de cristais alongados anédricos, assim como cristais maiores de clorita $\sin -\mathrm{S}_{1}$.

Em certas lâminas de granulação relativamente mais grossa, os minerais micáceos e o quartzo estão preferencialmente orientados segundo a foliação $S_{1}$, que dispõe-se obliquamente ao acamamento, sendo que alguns desses finíssimos cristais de quartzo estão estirados. Há também pouca cristalização de minerais no segundo evento deformacional, por vezes sendo descritos muscovita e quartzo $\sin -S_{2}$. As relações de cristalização dos minerais com as diferentes foliações podem ser vistas na TABELA 5.33.

A clorita pode concentrar-se em leitos que, em geral, são mais ricos em mineral opaco detrítico. 
TABELA 5.33 - Relações de cristalização dos minerais com as folią̧ões metamórficas nas ardósias da Unidade Metapelítica da Formação Piragibu.

\begin{tabular}{|c|c|c|c|c|c|c|c|}
\hline Minerais & Reliquiar & Foliacão $S_{L}$ & Pós-S $S_{1}$ & Foliacão $S_{2}$ & $P o ́ s-S_{2}$ & Foliacâao $S_{3}$ & Pós-S \\
\hline Quartzo & $\cdots$ & - ................. & & $\ldots$ & & & \\
\hline Clorita & & $\ldots \ldots$ & & & & & \\
\hline Sericita & & $\cdots n n$ & & $n \ldots$ & & & \\
\hline Muscovita & $\ldots$ & & & & & & \\
\hline Biotita & $\cdots$ & & & & & & \\
\hline Mineral opaco (magnetita) & $\cdots$ & $\cdots$ & & & & & \\
\hline Fácies Metamórfica & & xisto-verde & & xisto-verde & & & \\
\hline
\end{tabular}




\section{CAPÍTULO VI}

\section{METAMORFISMO}

A discussão do metamorfismo dos grupos Serra do Itaberaba e São Roque tem por base as paragêneses observadas nos metabasitos e metapelitos e alguns metapsamitos, litotipos que podem guardar informações importantes sobre o tema além de estarem expostos em grandes áreas e/ou em diversas das regiōes onde esses grupos afloram.

As demais rochas não serão abordadas devido à quantidade relativamente pequena de amostras estudadas, além do fato de serem suficientes para a caracterização do grau e tipo de metamorfismo a análise dos litotipos acima considerados. As reações utilizadas para a discussão do capítulo foram, em grande parte, consultadas em JULIANI (1993).

\subsection{Grupo Serra do Itaberaba}

\subsubsection{Rochas metabásicas e rochas metavulcanoclásticas básicas}

Foram analisadas de forma conjunta as rochas metabásicas descritas como hornblendahornblenda/actinolita anfibolitos, hornblenda anfibolitos, hornblenda xistos e granada hornblenda anfibolitos, e as rochas metavulcanoclásticas mais grossas, incluindo metabrechas e metatufos básicos, por exibirem paragêneses bastante semelhantes. As relações de cristalização dos minerais dessas rochas e suas respectivas foliações metamórficas podem ser consultadas nas TABELAS 5.1, 5.2 e 5.3.

As associações minerais mais comuns observadas nessas rochas nas foliações $S_{1}$ e $S_{2}$ são:

hornblenda + plagioclásio cálcico \pm ilmenita \pm clinozoizita \pm quartzo

hornblenda \pm plagioclásio cálcico \pm granada \pm ilmenita \pm quartzo

hornblenda \pm plagioclásio cálcico \pm diopsídio \pm ilmenita \pm quartzo

No retrometamorfismo associado às foliações $S_{3}$ e $S_{4}$ que se desenvolvem principalmente nas bordas dos minerais das paragêneses anteriores observam-se as assembléias:

hornblenda + plagioclásio sódico \pm actinolita \pm ilmenita \pm titanita \pm quartzo

actinolita + albita \pm titanita \pm clorita \pm epídoto \pm clinozoisita \pm quartzo \pm calcita

$O$ anfibólio das foliações $S_{1}$ e $S_{2}$ presente é sempre uma hornblenda com variações para hornblenda actinolítica e o plagioclásio tem composição variando entre oligoclásio e labradorita com predomínio de termos andesínicos, indicando condições metamórficas características da fácies anfibolito.

O anfibólio na região do Stock Granítico Tico-Tico em geral é verde-escuro e homogêneo, mas não são raros os cristais associados à $S_{1}$ e à $S_{2}$ que estão zonados e apresentam núcleos de hornblenda com pleocroísmo mais forte e finas bordas de tendência mais actinolítica, textura que sugere gradativo retrometamorfismo sobre rochas que alcançaram o pico térmico com equilíbrio de fases. Núcleos mais 
fortemente pleocróicos estão comumente associados ao primeiro evento metamórfico.

Em outras amostras da mesma região e em direção à porção sul da área também foram observados cristais de anfibólio com núcleos mais actinolíticos envolvidos por uma fase intermediária de hornblenda que grada para bordas de actinolita. Tal textura sugere falta de equilíbrio durante o desenvolvimento da foliação $S_{l}$, com o anfibólio não tendo sido totalmente reequilibrado para hornblenda de mais aita temperatura que o envolve, e que, posteriormente, sofreu retrometamorfismo nas bordas associado às foliações $S_{2}, S_{3}$ e $S_{4}$.

O plagioclásio também se apresenta zonado e tende a ser mais cálcico no núcleo e mais sódico nas bordas, chegando até composições de albita. Mais raramente ocorrem cristais com núcleos menos cálcicos que, provavelmente, estavam em equilíbrio com núcleos de hornblenda menos pleocróica.

YARDLEX (1994) descreve que na transição da fácies xisto-verde para a fácies anfibolito há um decréscimo em abundância de actinolita, clorita e epídoto, além do desaparecimento da albita, ao passo que ocorre um aumento dos teores de hornblenda e de plagioclásio mais cálcico gerados a partir de reações contínuas, tais como:

- 3 clorita +12 epídoto (rico em $\mathrm{Al})+4$ quartzo $=10$ hornblenda tschermakítica +4 anortita $+2 \mathrm{H}_{2} \mathrm{O}$;

- albita + actinolita = hornblenda edenítica + quartzo;

- actinolita +7 clorita +28 quartzo +24 epídoto $=25$ hornb. tschermakítica $+44 \mathrm{H}_{2} \mathrm{O}$

A clinozoizita também pode constituir um dos reagentes comuns para o desenvolvimento de um anfibólio de mais alto grau através da reação:

- actinolita +7 clorita +24 clinozoizita +28 quartzo $=25$ tschermakita $+44 \mathrm{H}_{2} \mathrm{O}$

SPEAR (1995) cita, entre outras, algumas reações comuns na zona de transição da fácies xistoverde para anfibolito:

- tremolita + clorita + epídoto $=$ tschermakita $+\mathrm{H}_{2} \mathrm{O}$

- zoizita + quartzo $=$ anortita $+\mathrm{H}_{2} \mathrm{O}$

O componente anortita produzido em algumas das reações acima mistura-se com a albita préexistente gerando um plagioclásio mais cálcico. Uma das mudanças mais significativas na transição entre essas fácies, além do aparecimento do oligoclásio, trata-se da remoção da clorita e da substituição da actinolita por um anfibólio rico em Al. O limite superior da estabilidade da clorita ocorre a temperaturas de $550^{\circ} \mathrm{C}$, podendo apresentar variações de mais ou menos $30^{\circ} \mathrm{C}$ em função da composição total dos metabasitos e da fugacidade de $\mathrm{O}_{2}$.

SPEAR (1995) admite não ser incomum a coexistência de oligoclásio e albita na mesma rocha na zona de transição xisto-verde para anfibolito. JULIANI (1993) observou que entre os cristais de plagioclásio metamórfico dos metabasitos do Grupo Serra do Itaberaba, na região homônima, predominam amplamente aqueles com conteúdo de $\mathrm{An}>20$. 
Composições semelhantes também são observadas com maior frequência na região aqui abordada, com o oligoclásio sempre acima de $A n_{17}$, o que, de acordo com WINKLER (1977), indica condições de grau médio, mais severas que as atingidas na fácies epídoto-anfibolito, e que também as condições de coexistência de dois plagioclásios (albita e oligoclásio) admitidas por SPEAR (1995) para a zona de transiçăo foram ultrapassadas.

Tanto o epídoto como a clinozoizita não são comuns ou estão ausentes nas paragêneses associadas às foliações $S_{1}$ e $S_{2}$ nos metabasitos próximos do Stock Granítico Tico-Tico. Contudo, são relativamente mais frequientes na foliação $S_{2}$ na porção sul da área, nas redondezas dos maciços graníticos Cantareira, Itaqui e São Roque, indicando que as paragêneses a ela associadas encontram-se melhor reequilibradas em grau metamórfico um pouco mais baixo.

A ausência de clorita nas rochas metabásicas e metavulcanoclásticas básicas e a presença, mesmo mais rara, de epídoto e de clinozoizita observados na região sul nos estágios tardi- e pós-S $S_{2}$ também indicam as condições mínimas do metamorfismo progressivo da $S_{1}$, pois a ausência de clorita define temperaturas superiores a $550^{\circ} \mathrm{C}$ e a presença de clinozoisita indica pressões relativamente altas, acima de 3,6 Kbar, segundo as paragêneses observadas nos metabasitos, mas certamente acima de 5 Kbar, se considerada a presença de cianita nos metapelitos encaixantes. JULIANI (1993) admite que a temperatura mínima para a formação do oligoclásio é de $550^{\circ} \mathrm{C} \pm 50^{\circ} \mathrm{C}$ para pressões ao redor de $6 \mathrm{~Kb}$.

Em direção e nos arredores do Stock Granítico Tico-Tico associam-se às foliações $S_{1}$ e $S_{2}$ deformações, às vezes intensas. A primeira delas, de identificação mais difícil, foi responsável pela cristalização predominante de hornblenda em arranjo nematoblástico. É comum observar a recristalização e o desenvolvimento de dobras, às vezes intrafoliais, associados à $S_{2}$. Essas podem estar relacionadas à evolução da foliação $S_{2}$ para uma foliação milonítica. Os cristais de anfibólio desta região cristalizados na $\mathrm{S}_{2}$ são homogêneos e verde-escuros, indicando as condições metamórficas mais rígidas, fato também confirmado pela presença eventual de granada e de diopsídio.

A granada é zonada e possui relações texturais indicativas de cristalização mais efetiva nos estágios tardi- e pós- $S_{2}$, além de um provável desenvolvimento no primeiro evento metamórfico. deformacional. A sua presença indica que, ao menos localmente, os anfibolitos atingiram condições de fácies anfibolito alto, ou da subfácies almandina-anfibolito. O clinopiroxênio (diopsídio) observado na mesma região, a sudoeste do stock, indica um grau ainda um pouco mais elevado.

Os cristais ocasionais de diopsídio descritos em contato com hornblenda $S_{2}$ estão parcialmente destruídos e transformados em epídoto e leucoxênio associados à $S_{3}$ e à $S_{4}$, o que indica sua instabilidade nos eventos retrometamórficos. Por ser raro e instável e exibir relação com a hornblenda $S_{2}$ aparentemente também de desequilíbrio, o diopsídio representa, possivelmente, restos da foliação $S_{1}$, o que indica que no segundo evento deformacional as condições para sua cristalização podem não ter sido mantidas. A presença do diopsídio indica que a temperatura máxima da $S_{1}$ foi superior a $730^{\circ} \mathrm{C}$ e inferior a $800^{\circ} \mathrm{C}$, em condições báricas barrowianas, devido à ausência de ortopiroxênio. 
Deve também ser considerada a relativa abundância de mineral opaco nos anfibolitos que afloram próximos do stock, notadamente a ilmenita, em detrimento da titanita, mais comum de ocorrer em rochas que atingem até as condições de fácies epídotowanfibolito.

Relacionados ao evento $S_{2}$, os anfibólios dos litotipos básicos que ocorrem mais próximos dos maciços granitóides Cantareira, Itaqui e São Roque na porção sul da área estão tipicamente manchados, com um núcleo verde, que sugere composição mais actinolítica, e borda verde-escura indicando composição de hornblenda.

GOMES (1971, 1973b) e GOMES et al. (1972) consideraram estas texturas nos metabasitos do Jaraguá como resultantes do efeito de metamorfismo termal do Maciço Granítico Cantareira, que aflora em contato. JULIANI (1993) sugere que texturas semelhantes dos metabasitos a NE da cidade de São Paulo representem relíquias de um evento anterior preservado devido às alterações relativamente rápidas das condições de P e T, mas relacionadas ao metamorfismo regional com minerais em condições de metaestabilidade, o que teria impedido o equilíbrio em graus mais elevados ou mais baixos.

Aparentemente, trata-se também de texturas de meta-estabilidade nas proximidades dos maciços granitóides na região sul, porém em grande parte associadas à $S_{2}$. A presença de epídoto associado com esses cristais manchados de anfibólio pode sugerir que as condições de estabilidade em fácies epídotoanfibolito predominaram.

Duas outras texturas de desequilíbrio estão presentes nos anfibolitos. A primeira delas foi observada notadamente a sul do Stock Granítico Tico-Tico e a norte-noroeste do Maciço Granitóide Itaqui. É dada por pequenas bordas de hornblenda no anfibólio associado com reequilíbrio do plagiociásio de composições mais sódicas ou intermediárias para composições de andesina cálcica, o que parece indicar que essas rochas foram também afetadas pelo metamorfismo de contato dessas intrusões.

Nestas rochas ocorrem comumente quartzo, turmalina e biotita associada, provavelmente formada por metassomatismo potássico produzido pelos fluidos derivados das rochas graníticas, corforme reportado por WINCHESTER (1972, in JULIANI 1993) segundo a reação:

\section{- 2 hornblenda +2 microclina $=$ biotita +4 anortita +4 quartzo}

Eventualmente, também foram observados alguns cristais de cummingtonita associados com a hornblenda e cristalizados nos estágios tardi- e pós- $S_{2}$. MIYASHIRO (1968) reporta que o desenvolvimento do mineral pode ocorrer em condições de fácies anfibolito a partir do consumo de hornblenda tschermakítica e de quartzo, conforme a reação:

\section{- 7 tschermakita +10 quartzo $=3$ cummingtonita +14 anortita}

Contudo, YARDLEY (1994) comenta que em metabasitos afetados por baixa pressão ou por metamorfismo de contato é comum o desenvolvimento de anfibólios pobres em $\mathrm{Ca}$, notadamente a cummingtonita, caracterizando fácies hornblenda-hornfels. As relações texturais e a associação com turmalina nas rochas metavulcanoclásticas básicas que afloram muito próximas do Maciço Granítico Itaqui parecem sugerir relação local com um evento termal pós-S $S_{2}$. 
A segunda textura é dada por um forte reequilíbrio local dos minerais, com o anfibólio tendendo à actinolita e o plagioclásio à albita, provavelmente relacionado ao metamorfismo dinâmico vinculado às zonas de empurrão que colocaram o Grupo São Roque sobre o Grupo Serra do Itaberaba, e que também podem ocorrer nas partes internas dos grupos.

Recristalizações isorientadas dos minerais associados à foliação $S_{3}$, por vezes plano-axial a dobras abertas desenhadas pelos anfibólios, foram também verificadas. Porém, neste caso, predomina a actinolita (e tremolita) como anfibólio característico que, associada à cristalização de clorita e dos minerais do grupo do epídoto, ao desenvolvimento da albita, à presença mais comum de quartzo, titanita e leucoxênio e, localmente, de carbonato, denotam condições de fácies xistomverde.

Nas TABELAS 5.1, 5.2 e 5.3, nota-se que as condições do retrometamorfismo associadas à foliação $S_{4}$ são semelhantes àquelas da $S_{3}$ mas não tão intensas, como pode ser constatado pela cristalização e desenvolvimento menos efetivo dos minerais retrometamórficos.

Este conjunto de rochas apresenta-se metamorfizado de modo muito semelhante aos metabasitos do Grupo Serra do Itaberaba da região homônima (JULIANI, 1993), sendo possível aplicar os mesmos diagramas de fases, como pode ser visto na FIGURA 6.1.

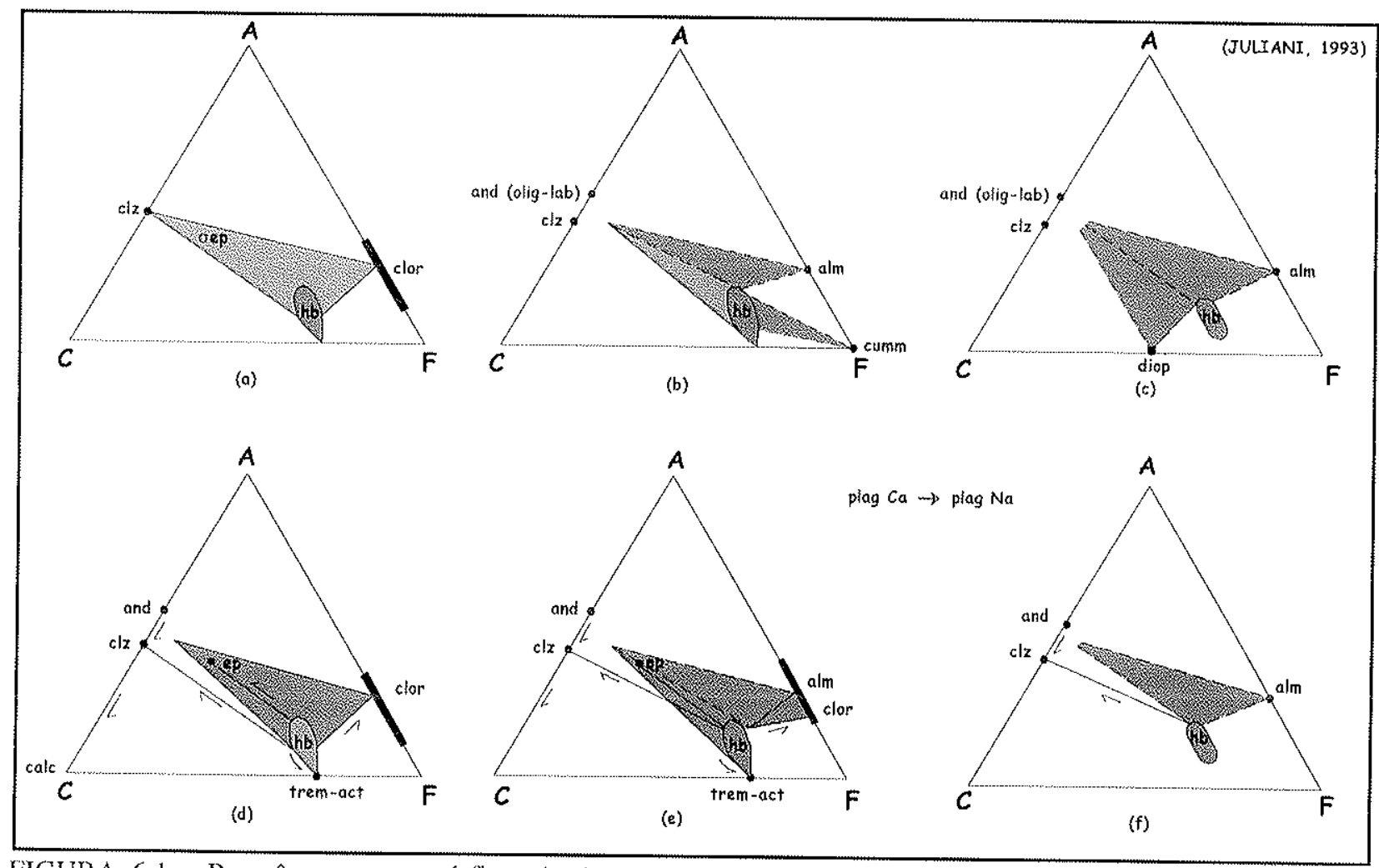
FIGURA 6.1 - Paragêneses metamórficas (a-c) e retrometamórficas (d-f) dos metabasitos do Grupo Serra do
ltaberaba.

De modo geral e de acordo com o exposto acima, pode ser considerado que na maioria das amostras de anfibolitos estudadas ocorre um declínio das condições metamórficas entre o 
desenvolvimento da primeira e da segunda foliações, e dessa com relação às demais, chegando à fácies xisto-verde durante o retrometamorfismo.

Comparações entre a porção sul da área, nas proximidades dos maciços granitóides Cantareira, Itaqui e São Roque, e os arredores do Stock Granítico Tico-Tico permitem afirmar que, nos dois primeiros eventos deformacionais e de região para região, são comuns as diferenças texturais e mineralógicas, como já constatado por JULIANI (1993) na região da Serra do Itaberaba, o que indica variações apreciáveis nas condições do metamorfismo.

De forma geral, as condições de $\mathrm{P}$ e $\mathrm{T}$ registradas nas foliações $S_{1}$ e $S_{2}$ indicam o amplo predomínio da fácies anfibolito, sendo observadas variações locais na região sul até a fácies epídotoanfibolito, enquanto que próximo ao Stock Granítico Tico-Tico são atingidas, também localmente, grau anfibolito alto (subfácies almandina-anfibolito) ou mesmo condições um pouco mais drásticas no primeiro evento, denunciadas pela presença de diopsídio.

\subsubsection{Metapelitos e metapsamitos das formações Morro da Pedra Preta e Pirucaia}

São discutidas a seguir as principais assembléias minerais que caracterizam esses litotipos segundo o aumento do grau metamórfico.

\subsubsection{Xistos finos rítmicos}

Estas rochas ocorrem na transição entre os metassedimentos tufíticos da Unidade Metavulcanoclástica e a Unidade dos Xistos Pelíticos da Formação Morro da Pedra Preta. As relações de cristalização dos minerais com as respectivas foliações podem ser observadas na TABELA 5.7.

A assembléia mineral identificada nesse conjunto é:

biotita + quartzo + muscovita + grafita \pm epídoto \pm turmalina \pm mineral opaco \pm andaluzita

Essas rochas se assemelham, em parte, àquelas de mais baixo grau descritas por JULIANI (1993) na Formação Morro da Pedra Preta na região nordeste da cidade de São Paulo, mas nas rochas aqui estudadas foi identificada andaluzita cristalizada nos estágios tardi- e, possivelmente, pós- $S_{1}$ (Prancha 7/Foto A).

Uma das possíveis reações para a cristalização da andaluzita seria a partir da quebra da pirofilita em condições de fácies xisto-verde (MIYASHIRO 1973) ou de início da fácies anfibolito sob pressões suficientemente baixas para não cristalizar cianita (JULIANI 1993). A ausência de clorita e a observação comum de biotita sugere que a cristalização da andaluzita e do mineral micáceo pode ter ocorrido, em grande parte, pelo consumo da clorita através da reação:

- 3 clorita +7 muscovita + quartzo $=13 \mathrm{Al}_{2} \mathrm{SiO}_{3}+7$ biotita $+18 \mathrm{H}_{2} \mathrm{O}$

A associação paragenética dessas rochas poderia ser relacionada à fácies xisto-verde, porém ocorrem próximas de metatufos básicos finos com hornblenda e plagioclásio de composição andesinaoligoclásio e intercalam se com xistos finos que contêm estaurolita, implicando terem sido metamorfizadas em condições de fácies anfibolito. A ausência de inclusões de minerais opacos na 
andaluzita reforça esta dedução (DEER et al. 1992) e indica o desenvolvimento no limite superior de sua estabilidade.

A razão da falta de minerais índices de grau médio deve ser então explicada pela composição química da rocha, possivelmente pouco aluminosa ou com alta razão $\mathrm{MgO} / \mathrm{FeO}$. A variação no teor de biotita nessas rochas, presente como traço até fase amplamente predominante sobre a muscovita e o quartzo, parece indicar fortes gradações das composições químicas originais neste litotipo.

Conforme observado por CHINNER (1960), a cristalização de biotita e de granada deve-se, em grande parte, ao quimismo original, reportando que rochas com alta taxa de oxidação tendem a dificultar a cristalização de biotita e de granada e facilitar o desenvolvimento de muscovita e dos óxidos de ferro.

A presença comum de biotita e a ausência de granada, porém, sugerem que essa última tenha sido consumida segundo a reação:

- almandina + muscovita $=2$ andaluzita + biotita + quartzo

Essa reação responde, em parte, à presença comum de biotita e de restos de andaluzita observados nestes litotipos, desenvolvidas na foliação $S_{1}$.

A frequiência com que se observa muscovita $\sin -S_{1}$ associada à biotita $\sin -S_{1}$ sugere que esses minerais micáceos podem representar os produtos de reações onde a clorita, que poderia ter se cristalizado ainda no início do metamorfismo progressivo, fosse consumida como, dentre outras, através das reações:

- 8 fengita + clorita $=5$ muscovita +3 biotita +7 quartzo $+\mathrm{H}_{2} \mathrm{O}$

- microclina + clorita $=$ biotita + muscovita $+\mathrm{H}_{2} \mathrm{O}$

A presença de epídoto em uma das amostras pode ter envolvido a reação:

- muscovita + stilpnomelano = biotita (rica em ferro ) + epídoto

Associada à foliação $S_{2}$ ocorre a cristalização mais intensa de biotita, muscovita e do quartzo, e substituição da andaluzita por muscovita fina/sericita. No terceiro evento metamórfico, notado apenas pelo menor crescimento dos minerais, não houve grandes variações das condições físicas.

\subsubsection{Xistos finos com biotita e/ou magnetita porfiroblásticas}

Estes xistos estão dispostos no topo da Formação Morro da Pedra Preta e afloram na região das fazendas Itayhe e Tamboré. Exibem porfiroblastos de magnetita e de biotita isolados ou em agregados. As relações de cristalização dos minerais com as respectivas foliações metamórficas podem ser consultadas na TABELA 5.10 .

A associação mineral típica observada nestas rochas é:

quartzo + biotita + muscovita + magnetita \pm turmalina \pm estaurolita \pm grafita

Dada a presença comum da magnetita parcialmente consumida e de biotita cristalizada na mesma foliação, uma possível reação para a cristalização do mineral micáceo, conforme reporta GANGULY 
(1972, in JULIANI 1993) é:

- muscovita + magnetita $=$ biotita $+\mathrm{O}_{2}$

A estaurolita nestes litotipos cristalizou-se no final do primeiro evento metamórfico e, mais efetivamente, nos estágios tardi- e pós-S $S_{2}$. CARNEIRO (1983) descreve apenas biotita nessas rochas e argumenta que sua cristalização como agregados estaria associada ao desenvolvimento da foliação $S_{2}$.

Contudo, os agregados porfiroblásticos de biotita+magnetita e os porfiroblastos de biotita exibem comumente sombras de pressão que associam-se à forte orientação da foliação $S_{2}$. Adicionalmente, em amostras do mesmo litotipo que aflora a sudoeste do Maciço Granitóide Itaqui, nota-se claramente que os porfiroblastos de biotita também se cristalizaram de forma estática no final do primeiro evento e estão estirados e/ou transpostos nos flancos inversos de dobras rompidas geradas na foliação $S_{2}$, o que indica terem sido cristalizados em um estágio prévio, possivelmente tardi- a pós- $\mathrm{S}_{1}$,

A ausência de clorita (excetuando cristais retrometamórficos) e a não observação de granada podem indicar que esses minerais foram consumidos para o desenvolvimento da estaurolita, além da cristalização parcial da magnetita e da biotita nos estágios tardios do primeiro evento deformacional e/ou pós-S.

A cristalização da granada depende sobremodo da composição química da rocha, segundo ATHERTON (1964). Em rochas ricas em $\mathrm{SiO}_{2}$ e pobres em $\mathrm{Al}_{2} \mathrm{O}_{3}$ a granada não se desenvolve, permanecendo estáveis assembléias com quartzo + biotita + clorita (muscovita). Altas $\mathrm{fO}_{2}$ podem também inibir a cristalização da granada (CHINNER 1961). Estas rochas apresentam magnetita em relativa abundância, o que sugere uma taxa de oxidação bastante elevada que pode ter impedido o seu desenvolvimento.

Algumas possíveis reações para geração da biotita e da estaurolita, além da magnetita, seriam:

- clorita + muscovita + almandina $=$ estaurolita + biotita + quartzo $+\mathrm{H}_{2} \mathrm{O}$

- 54 almandina $+6 \mathrm{H}_{2} \mathrm{O}+23 \mathrm{O}_{2}=12$ estaurolita +46 magnetita +111 quartzo

Alternativamente, alguns minerais ainda presentes podem ter sido parcialmente consumidos para a geração da estaurolita, como através da reação:

- muscovita + magnetita $=$ estaurolita + quartzo $+\mathrm{K}_{2} \mathrm{O}+\mathrm{H}_{2} \mathrm{O}$

A presença de estaurolita indica que foram atingidas condições de fácies anfibolito (TURNER 1981) e define para esses metapelitos o grau médio de WINKLER (1977).

No segundo evento deformacional, as condições de $\mathrm{P}$ e $\mathrm{T}$ parecem não ter sofrido modificações acentuadas. Nota-se a cristalização de estaurolita nos estágios tardi- e pós-- $S_{2}$, a presença mais comum de muscovita, além da biotita.

À foliação $S_{3}$, retrometamórfica, associa-se recristalização local do quartzo, de muscovita e de magnetita fina e clorita, indicando condições compatíveis com a fácies xisto-verde. 


\subsubsection{Biotita-estaurolita xistos com granada}

Esses litotipos ocorrem principalmente a sul-sudoeste do Stock Granítico Tico-Tico, na Unidade dos Xistos Pelíticos da Formação Morro da Pedra Preta, na forma de um pacote mais ou menos contínuo.

A assembléia mineral típica observada nessas rochas é dada por:

estaurolita + biotita + quartzo \pm muscovita \pm granada \pm turmalina \pm mineral opaco

Esses xistos com frequiência estão sobrepostos aos metassedimentos tufíticos, e gradam e se intercalam com os xistos pelíticos com aglomerados grossos de fibrolita. As relações de cristalização dos minerais nos biotita-estaurolita xistos com granada e suas respectivas foliações metamórficas podem ser consultadas na TABELA 5.8 .

A análise petrográfica ressalta a presença de matriz marcada por conspícua foliação $S_{2}$ e que, comumente, pode evoluir para uma $S_{m}$. Superpostos a essa orientação observam-se porfiroblastos de biotita, granada e, principalmente, de estaurolita, além da muscovita mais rara.

A cristalização da granada ocorreu nos estágios tardios e posteriores às deformações $S_{1}$ e $S_{2}$. A ausência de clorita relacionada ao metamorfismo progressivo nessas rochas sugere seu consumo para produzir a granada já no primeiro evento metamórfico, através das reações:

- clorita +4 quartzo $=$ almandina $+8 \mathrm{H}_{2} \mathrm{O}$

- clorita + biotita $1+$ quartzo = granada almadina + biotita $2+\mathrm{H}_{2} \mathrm{O}$

A falta ou o pequeno volume de muscovita no primeiro evento deformacional sugere que, caso esse mineral tenha se cristalizado, pode também ter sido consumido em reações como:

- clorita + muscovita + quartzo $=$ almandina + biotita $+\mathrm{H}_{2} \mathrm{O}$

- clorita + muscovita $=$ granada + biotita + quartzo $+\mathrm{H}_{2} \mathrm{O}$

Os cristais de granada exibem com freqüência alterações intempéricas limoníticas, o que sugere que sua composição esteja mais próxima do membro almandina. HSU (1968) determinou que a espessartita pura se desenvolve a $385^{\circ} \mathrm{C} / 1 \mathrm{~Kb}$ e a $415^{\circ} \mathrm{C} / 3 \mathrm{~Kb}$, enquanto que almandina pura cristaliza a $525^{\circ} \mathrm{C} / 1 \mathrm{~Kb}$ e a $550^{\circ} \mathrm{C} / 3 \mathrm{~Kb}$.

Segundo JULIANI (1993), as granadas almandínicas geradas no limite da fácies xisto-verde para a fácies anfibolito são bastante pequenas e ricas em $\mathrm{MnO}$, o que parece não corresponder ao observado nestes xistos, pois mostram-se relativamente grandes e isentas das alterações manganesíferas típicas. Acrescenta-se o fato de ocorrerem bem formadas, sugerindo estabilidade nas mesmas foliações em que estão presentes os cristais de estaurolita.

A abundância de estaurolita nestes litotipos pode indicar uma zona de grau metamórfico um pouco mais baixo (zona da estaurolita) quando comparados aos xistos com silimanita/fibrolita com os quais intercalam-se, ou ainda, influência térmica de rochas graníticas.

YARDLEY (1994) sugere que esse mineral tem seu crescimento facilitado em rochas pelíticas ricas em Al e pobres em Ca, e só raramente se desenvolve em outros litotipos. Nos pelitos aluminosos a 
estaurolita é produzida, em geral, a partir da quebra do cloritóide. Contudo, a ausência de grãos reliquiares de cloritóide na forma de inclusões na estaurolita ou ainda na granada nesses xistos de aspecto maciço sugere que essas rochas têm composições impróprias para o desenvolvimento do cloritóide sendo, provavelmente, relativamente pobres em aluminio.

SPEAR (1995) destaca que o primeiro aparecimento de estaurolita em paragênese com biotita e granada em pelitos com baixo teor de alumínio está ligado à reação:

- granada + clorita $=$ estaurolita + biotita $+\mathrm{H}_{2} \mathrm{O}$

Essa reação pode levar ao desaparecimento da clorita e, através das reações abaixo, podem também ter sido consumidas a muscovita e a granada para a cristalização de estaurolita:

- clorita + muscovita $=$ estaurolita + biotita + quartzo $+\mathrm{H}_{2} \mathrm{O}$

- granada + muscovita + clorita $=$ estaurolita + biotita + quartzo $+\mathrm{H}_{2} \mathrm{O}$

Segundo HOSCHEK (1969), a primeira reação acima balanceada:

49 clorita +151 muscovita $=44$ estaurolita +151 biotita +360 quartzo $+696 \mathrm{H}_{2} \mathrm{O}$, ocorre a $\mathrm{P}_{\mathrm{T}}=4 \mathrm{~Kb} \mathrm{a} \mathrm{T}=540 \pm 15^{\circ} \mathrm{C}$ e a $\mathrm{P}_{\mathrm{T}}=7 \mathrm{~Kb}$ a $\mathrm{T}=565 \pm 15^{\circ} \mathrm{C}$, condições essas que devem ser consiceradas como mínimas à formação das paragêneses com estaurolita e granada da $\mathrm{S}_{2}$.

A ausência de polimorfos de $\mathrm{Al}_{2} \mathrm{SiO}_{5}$, principalmente a fibrolita, comum em afloramentos próximos, e a presença de muscovita em relações paragenéticas estáveis com a biotita, o quartzo e a estaurolita pode ser devida à composição da rocha, menos alumínico e com menor razão FeO/MgO, que impede a cristalização dos polimorfos antes da quebra da estaurolita. Contudo, como as paragêneses estão em texturas de retro- ou re-metamorfismo da $S_{1}$, uma vez que concentram-se na $S_{2}$, caso tenha havido silimanita nas paragêneses de mais alto grau da $S_{1}$, ela poderia ter sido consumida segundo a reação:

- $98 \mathrm{Al}_{2} \mathrm{SiO}_{5}+8$ biotita $+20 \mathrm{H}_{2} \mathrm{O}=10$ estaurolita +8 muscovita +15 quartzo

Essa reação ocorre em temperaturas inferiores a $540 \pm 15^{\circ} \mathrm{C}$ a $\mathrm{P}=2,0 \mathrm{Kbar}$ e a $675 \pm 15^{\circ} \mathrm{C}$ a P $=$ 5,5 Kbar.

Levando em consideração a ausência de clorita e de muscovita no primeiro evento deformacional, a não observação de polimorfos de $\mathrm{Al}_{2} \mathrm{SiO}_{5}$ e a presença comum de granada bem desenvolvida, o que indica, segundo JULLANI (1993), pressões superiores a $3 \mathrm{~Kb}$, é possível afirmar que esses xistos foram submetidos a temperaturas entre $540-675^{\circ} \mathrm{C}$ para faixas de pressões de 4 a $7 \mathrm{~Kb}$, ou até $8 \mathrm{~Kb}$, segundo o campo da estabilidade da estaurolita.

Pequenos cristais prismáticos de estaurolita sem inclusões e envolvidos por poiquiloblastos do mesmo mineral foram caracterizados como desenvolvidos, possivelmente, nos estágios tardi-e pós-S. Os poiquiloblastos com inclusões de quartzo orientadas e por vezes onduladas, indicam que a cristalização de estaurolita, ao menos nesses litotipos, também está relacionada ao estágio tardio da foliação $S_{2}$.

Contudo, poiquiloblastos que crescem superpostos à matriz milonítica $S_{2}$ com bordas euédricas e muitas vezes sem inclusões indicam desenvolvimento pós- $S_{2}$, muito provavelmente gerado por efeito de 
metamorfismo de contato da intrusão granítica do Stock Tíco-Tico.

COUTINHO (1972) observou a presença de estaurolita poiquiloblástica em parte gerada por metamorfismo de contato, contudo destacou que no metamorfismo regional onde a silimanita estivesse presente a estaurolita não ocorreria. Seriam apenas vistos em coexistência devido a um rápido aquecimento que teria elevado subitamente o gradiente termal e produzido a aproximação ou mesmo a mistura das isógradas desses minerais junto ao Stock Granítico Tico-Tico.

Relacionado à foliação $S_{3}$ retrometamórfica pode ser observado desenvolvimento de biotita e, mais comumente, de muscovita, e a recristalização do quartzo, sugerindo condições de fácies xisto-verde.

\subsubsection{Xistos com cianita e/ou silimanita/fibrolita}

Estas rochas de composição mais pelítica com aglomerados de fibrolita da Unidade Metapelítica da Formação Morro da Pedra Preta afloram preferencialmente entre o Pico do Jaraguá e os arredores do Stock Granítico Tico-Tico e em direção ao Maciço Granitóide Cantareira. As amostras estudadas dos xistos quartzosos da Formação Pirucaia ocorrem, de forma geral, próximas do Stock Granítico Tico-Tico.

As relações de cristalização dos minerais em ambos os litotipos e as respectivas foliações metamórficas podem ser consultadas nas TABELAS 5.9 e 5.18 .

As assembléias minerais mais frequientes observadas nestas rochas podem ser agrupadas em:

biotita + quartzo + muscovita + fibrolita \pm turmalina \pm mineral opaco \pm granada \pm cianita \pm silimanita \pm cordierita ( \pm plagioclásio \pm estaurolita \pm feldspato potássico?)

A cianita está presente em microlitons $S_{1}$ preservados na $S_{2}$ nos xistos quartzosos pouco afetados pela milonitização e, de forma mais rara, nos xistos pelíticos com aglomerados de fibrolita. Segundo MIYASHIRO (1973), a cianita se desenvolve no início da fácies anfibolito em condições de pressão relativamente elevada, o que indica que as condições báricas para o primeiro evento deformacional foram de pressão intermediária, sendo o metamorfismo caracterizado como do tipo barrowiano, pela primeira vez reconhecido na região norte-noroeste da cidade de São Paulo.

Uma das possíveis reações para a cristalização do polimorfo de $\mathrm{Al}_{2} \mathrm{SiO}_{5}$ é dada por:

- 3 clorita +7 muscovita + quartzo $=13$ cianita +7 biotita $+18 \mathrm{H}_{2} \mathrm{O}$

A ausência de clorita e a ocorrência muito rara de estaurolita nestas rochas no primeiro evento deformacional sugere que o desenvolvimento da cianita, caso tenha sido mais efetivo na $S_{1}$, também pode ter ocorrido a partir da quebra daqueles minerais, conforme as reações discutidas em JULIANI (1993):

- 6 estaurolita +4 muscovita +7 quartzo $=4$ biotita +31 cianita $+3 \mathrm{H}_{2} \mathrm{O}$

- $\quad$ estaurolita + clorita $=$ cianita + biotita

Comentando trabalhos de GANGULY (1968, 1969 e 1972), JULIANI (1993) destaca que a falta de estaurolita em rochas da região da Serra do Itaberaba, bastantes semelhantes às aqui descritas, poderia ser explicada pelo quimismo da rocha, pela $\mathrm{PO}_{2}$, mas também por sua quebra em rochas relativamente 
ricas em cianita e granada.

A presença mais frequiente da granada nos xistos quartzosos pode indicar que a sua cristalização também resulta da reação que teve como produto a cianita:

\section{- 6 estaurolita +11 quartzo $=4$ almandina +23 cianita $+3 \mathrm{H}_{2} \mathrm{O}$}

A existência de uma possível inclusão de rutilo em um dos cristais de cianita sugere que, neste evento deformacional, as condições de pressão podem ter sido ainda um pouco mais elevadas. BOHLEN et al. (1983) separam os granada-cianita xistos de pressão mais alta, que contêm rutilo, das variedades de pressão mais baixa, que apresentam ilmenita.

Em algumas amostras dos xistos pelíticos dos arredores do Stock Granítico Tíco-Tico são observados raros cristais relativamente grossos de andaluzita associados aos estágios tardi- e pós- $S_{1}$. Segundo JULIANI (1993), a presença ocasional desse polimorfo pode indicar condiçóes de metaestabilidade ou variações locais da pressão. Andaluzita contendo $\mathrm{Fe}^{3+}$ e $\mathrm{Mn}^{3++}$ pode ter seu campo de estabilidade estendido por mais de $200^{\circ} \mathrm{C}$, estando presente até na zona da silimanita. COUTINHO (1972), contudo, as considera associadas aos efeitos do metamorfismo termal daquele stock.

A silimanita prismática ou granular também foi observada raramente em relíquias da foliação $S_{1}$ não totalmente transposta pela foliação $S_{2} / S_{m}$ e, ainda, como restos de cristais envolvidos pelos aglomerados grossos de fibrolita $S_{2}$. A presença desse polimorfo nos xistos pelíticos e nos xistos quartzosos marca a zona da silimanita nessas rochas. As reações para o seu desenvolvimento podem ser as mesmas que apresentam como produto a cianita. Entretanto, na evolução do metamorfismo progressivo e no conseqüente aumento do grau metamórfico na foliação $S_{1}$, a silimanita também pode ter sido derivada da inversão direta da cianita segundo a reação:

- cianita = silimanita

Ainda associado à foliação $S_{1}$ pode-se notar, localmente, o desenvolvimento de fibrolita. Mas a cristalização intensa de fibrolita ocorre no segundo evento deformacional, evidenciando que as condições de P e T alcançadas por estas rochas durante a $S_{2}$ foram predominantemente de fácies anfibolito na zona da silimanita.

Nas rochas onde os aglomerados grossos de fibrolita são comuns quase sempre a estaurolita não é vista, o que pode sugerir, conforme comentado anteriormente, que esse mineral não se desenvolveu tanto, devido, por exemplo, às composições químicas impróprias das rochas. A fibrolita, nesse caso, é observada com freqüência em crescimento epitáxico com a biotita nos xistos pelíticos. CHINNER (1961, 1966) reporta que no aumento do grau metamórfico a biotita pode funcionar como um agente nucleador para a fibrolita, devido à disposição dos seus arranjos atômicos.

Contudo, junto aos porfiroblastos de fibrolita eventualmente são recuperados restos de cristais de cianita e de silimanita prismática do primeiro evento deformacional, confirmando que os porfiroblastos de fibrolita, ao menos em parte, originaram-se a partir da transformação desses minerais.

Não é raro reconhecer pseudomorfos de cianita nos aglomerados grossos de fibrolita, 
identificados pelo arranjo das clivagens reliquiares agora desenhadas por minúsculos minerais opacos, situação essa também reportada por JULIANI (1993) na região da Serra do Itaberaba.

A milonitização intensa $S_{2} / S_{m}$ deve ter contribuído em muito para a destruição da cianita, se esse polimorfo por ventura ainda estivesse estável no início desse evento, considerando que o desenvolvimento da fibrolita foi mais efetivo. Segundo JULIANI (1993), o forte stress afeta a estabilidade da cianita e aumenta a possibilidade do reequilíbrio metamórfico.

A geração de fïbrolita associada às micas por meio de forte ação metassomática tem sido considerada por vários autores, que admitem que os fluidos são próprios da atividade metamórfica ou ainda podem pertencer às intrusões graníticas.

A cristalização principal da fibrolita se dá no início do segundo evento deformacional, estando disposta estirada e orientada na $S_{2}$, podendo cortar e/ou cristalizar na borda dos agregados porfiroblásticos de muscovita $S_{1}$. Seus cristais estão dobrados e deformados pelo evento $S_{3}$, o que torna a vinculação com os eventos retrometamórficos pouco provável.

Por outro lado, as intrusôes graníticas dos arredores dos xistos pelíticos e dos xistos quartzosos são claramente pós- $S_{2}$, o que descarta a hipótese de cristalização tardia vinculada aos fluidos gerados nas intrusões.

Ao abordar o assunto, JULIANI (1993) comenta que a intensa mobilização de alumínio, potássio e hidrogênio pode gerar reequilíbrios locais, e que, de forma geral, a percolação desses fluidos atua em zonas mais foliadas ou fraturadas ao longo de determinadas foliações metamórficas, o que pode ser aventado para explicar, em parte, a forma de ocorrência dos aglomerados grossos de fibrolita descritos acima. Segundo o autor, esses fluidos gerados durante a progradação do metamorfismo poderiam ter exercido significativo efeito na fibrolitização da cianita e, principalmente, da silimanita.

Assim, as texturas foram interpretadas como geradas por forte ação de fluidos metassomáticos $\operatorname{com} \mathrm{K}^{+*}$ e $\mathrm{Al}^{2+}$ associados às zonas de cisalhamento e/ou flancos inversos de dobras da $\mathrm{S}_{2}$.

A presença muito eventual de estaurolita como restos de cristais consumidos nestes litotipos indica que as condiçôes de estabilidade do mineral foram ultrapassadas intensamente ou por longos períodos.

Utilizando reações de diversos autores, JULIANI (1993) reportou que a instabilidade dos cristais de estaurolita ou seu quase desaparecimento, dando origem a polimorfos de $\mathrm{Al}_{2} \mathrm{SiO}_{5}$ em rochas bastante semelhantes às aqui comentadas, poderia ocorrer segundo as seguintes reações, dentre outras:

- 6 estaurolita +3 quartzo $+2 \mathrm{O}_{2}=27 \mathrm{Al}_{2} \mathrm{SiO}_{5}+4$ magnetita $+3 \mathrm{H}_{2} \mathrm{O}$

- 18 estaurolita +19 biotita +52 quartzo $=31 \mathrm{Al}_{2} \mathrm{SiO}_{5}+19$ muscovita $+9 \mathrm{H}_{2} \mathrm{O}$

CARMICHAEL (1970) determinou que a quebra da estaurolita na zona da silimanita pode ocorrer pela reação:

- $\quad$ estaurolita + muscovita + quartzo $=$ silimanita + almandina + biotita $+\mathrm{H}_{2} \mathrm{O}$

Reconhecida ocasionalmente, porém com mais frequiência nos xistos quartzosos, a estaurolita 
encontra-se quase completamente transformada e envolvida por cristais de muscovita em agregados porfiroblásticos, sugerindo que, ao menos em parte, esses agregados e, talvez, a muscovita porfiroblástica que ocorrem nos xistos quartzosos e principalmente nos xistos pelíticos, podem ser derivados da transformação da estaurolita $S_{1}$, ainda antes do evento deformacional $S_{2}$.

JULIANI (1993) considera que a sericitização que afeta alguns cristais de estaroulita pode relacionar-se aos processos metassomáticos devidos à percolação de fluidos ricos em $\mathrm{H}^{* *}$ e $\mathrm{K}^{+}$presentes nos eventos de retrometamorfismo. Entretanto, citando GUIDOTTI (1968), destaca também a possibilidade da transformação ter se dado durante a progradação do metamorfïsmo, já na zona da silimanita, com a dissolução da estaurolita e o desenvolvimento de mica branca, situação mais plausível segundo as relações texturais observadas.

A cordierita, quando ocorre, substitui quase inteiramente alguns porfiroblastos de fibrolita ou de estaurolita, ou cristaliza sobre a matriz milonítica como cristais maiores ou porfiroblastos distribuídos sem orientação. Algumas possíveis reações que têm cordierita como produto são:

\section{- 2 estaurolita +7 quartzo $=2$ cordierita $+\mathrm{Al}_{2} \mathrm{SiO}_{5}+\mathrm{H}_{2} \mathrm{O}$}

\section{- 10 estaurolita +10 magnetita +84 quartzo $=27$ cordierita $+6 \mathrm{H}_{2} \mathrm{O}+5 \mathrm{O}_{2}$}

Devido aos raros cristais observados, a cristalização do mineral associada ao final da foliação $S_{2}$ foi caracterizada com maior segurança em algumas amostras dos xistos pelíticos, enquanto que nos xistos quartzosos não fica claro se ocorre apenas no final do primeiro evento ou também $\sin / t a r d i-S_{2}$. A cristalização de cordierita pode estar vinculada ao desenvolvimento da $S_{2}$ devido a uma descompressão aproximadamente isotérmica, provavelmente associada à intrusão de granitos tardios a este evento.

A presença mais freqüente de fibrolita (e silimanita), granada, biotita, minerais opacos, além de alguns cristais de cordierita nesses litotipos, parece indicar, segundo JULIANI (1993), que essas fases podem ter sido geradas pela quebra da estaurolita. Considerando ainda a ocorrencia de cianita e discutindo dentre outras, as reações expostas acima e os dados de BASKHAR RAO \& JOHANNES (1979, in JULIANI 1993), estimou que as condições de metamorfismo às quais rochas muito semelhantes foram submetidas são de temperatura ao redor de $620^{\circ} \mathrm{C}$ e pressões variando entre 5 e $6 \mathrm{~Kb}$.

A presença muito rara de feldspato potássico nos xistos pelíticos, não satisfatoriamente confirmada devido à granulação muito fina do mineral, e ainda, de plagioclásio nessas rochas, pode indicar condiçōes de mais alto grau metamórfico. A eventual ocorrência de ortoclásio, se confirmada, pode indicar que o conjunto atingiu a segunda isógrada da silimanita, parte superior da fácies anfibolito (subfácies almandina-anfibolito), em acordo com as paragêneses descritas nos metabasitos que afloram na mesma região.

A cristalização da cordierita após o desenvolvimento da silimanita e a presença de cianita $S_{1}$ présilimanita $S_{1}$ sugerem que ao final do primeiro evento metamórfico regional houve acentuada queda da pressão, uma vez que a cordierita, nesta paragênese pelítica, não poderia ser magnesiana o suficiente para cristalizar-se em pressões elevadas. No primeiro evento deformacional, essa queda de pressão é possível 
de ter ocorrido logo após a inversão da cianita para silimanita. Este padrão evolutivo do metamorfismo é o mesmo verificado na Serra do Itaberaba (JULIANI 1993).

A cristalizaçẫo de porfiroblastos de muscovita e, eventualmente, de biotita, no final dos eventos metamórficos, em regimes estáticos ou não, tem sido atribuída a processos metassomáticos originados pela percolação de fluidos por infiltração ou por difusão iônica nos litotipos, vinculados às intrusões graníticas e/ou aos eventos retrometamórficos. A maioria dos agregados porfiroblásticos de muscovita dos xistos pelíticos estão freqüentemente estirados na foliação $S_{2}$, podem exibir sombras de pressão e, não raro, são truncados e/ou cortados por cristais menores de biotita e de muscovita claramente relacionados à foliação milonítica $S_{2}$, indicando que esses agregados porfiroblásticos cristalizaram previamente.

Quanto à biotita, seus cristais maiores estão frequientemente associados ao evento deformacional $S_{1}$, como pode ser observado nos xistos pelíticos com aglomerados grossos de fibrolita e nos xistos quartzosos, onde se recuperam lenticularizações em formas sigmóides muitas vezes isoladas pela foliação milonítica $\mathrm{S}_{2}$.

Na FIGURA 6.2 estão as principais paragêneses dos metapelitos do Grupo Serra do Itaberaba. Nas foliações retrometamórficas $S_{3}$ e $S_{4}$ são reconhecidas paragêneses típicas de fácies xisto-verde, com a presença de clorita, muscovita fina/sericita e recristalização do quartzo. Diferenciam-se pela cristalização mais efetiva dos minerais na $S_{3}$ e pela presença mais comum de biotita $S_{3}$ nos xistos quartzosos.

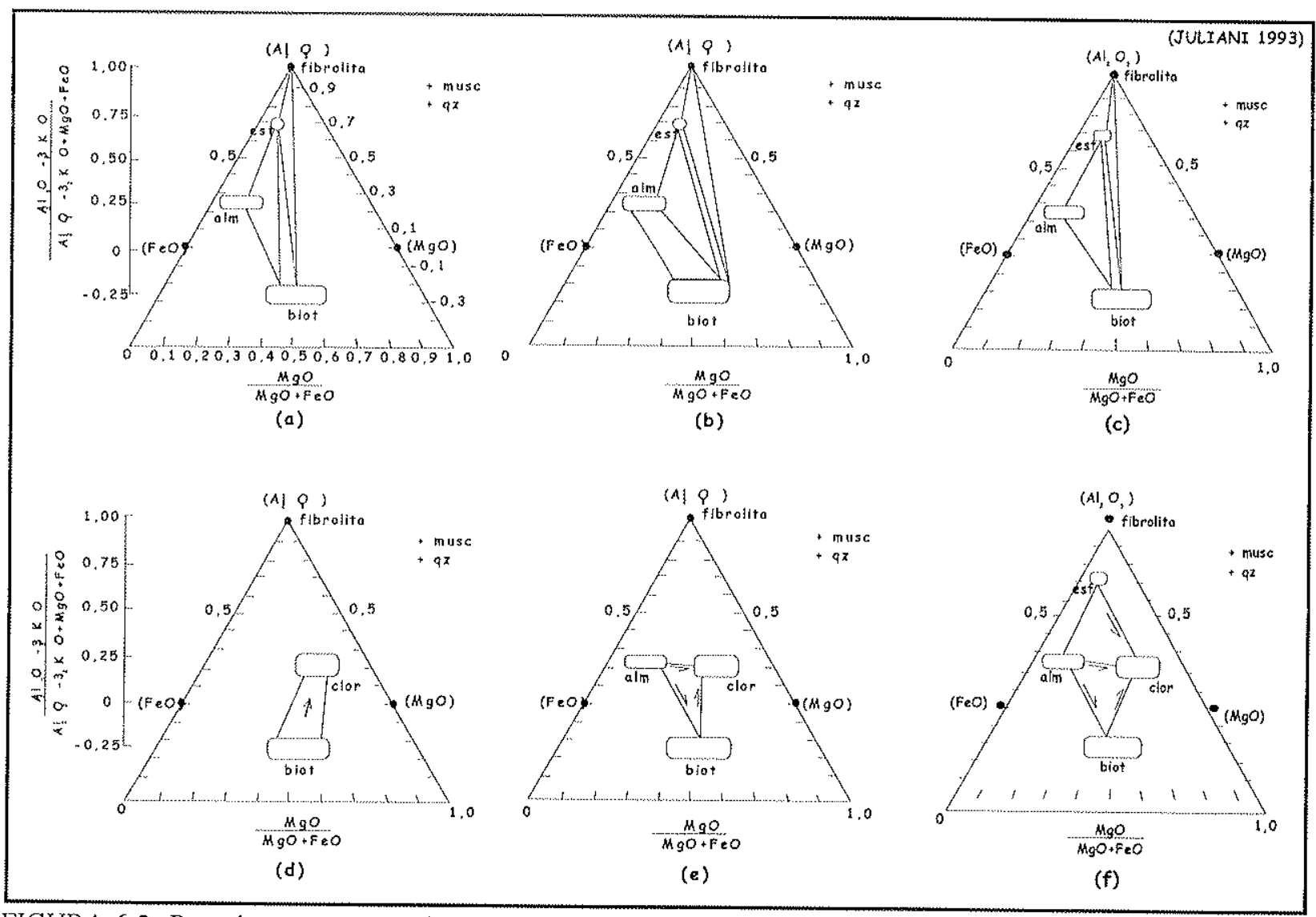

FIGURA 6.2- Paragêneses metamórficas $(a, b, c)$ e retrometamórficas $(d, e, f)$ dos metapelitos do Grupo Serra do Itaberaba. 


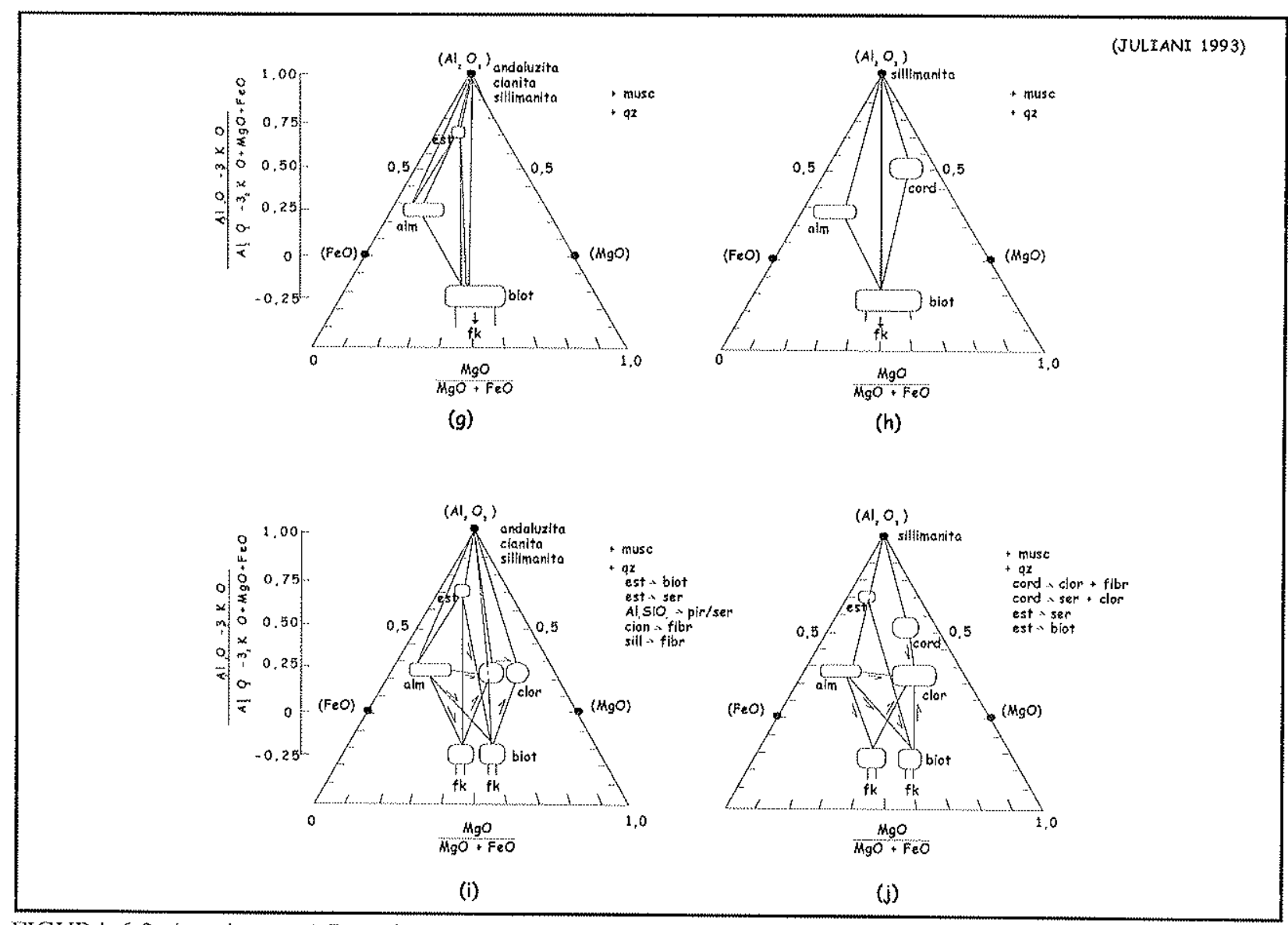

FIGURA 6.2- (continuação) Paragêneses metamórficas ( $\mathrm{g}$ e h) e retrometamórficas (i e j) dos metapelitos do Grupo Serra do laberaba.

\subsection{Grupo São Roque}

\subsubsection{Metabasitos das formações Pirapora do Bom Jesus, Estrada dos Romeiros e Piragibu}

São aqui discutidas as paragêneses minerais das rochas metabásicas distribuidas entre ats formações citadas acima. Também são comentadas as peculiaridades e as possíveis variações de grau metamórfico que ocorrem entre essas rochas nestas formações. Ainda foram utilizadas para avaliar o metamorfismo as rochas metavulcanoclásticas da Formação Pirapora do Bom Jesus.

As relações de cristalização dos minerais nessas rochas e suas respectivas foliações metamórficas podem ser consultadas nas TABELAS 5.22 e 5.23. A assembléia mineral observada nos metabasitos (e nas rochas metavulcanoclásticas básicas) do Grupo São Roque é dada por:

actinolita (tremolita) + clorita + plagioclásio sódico + epídoto \pm quartzo \pm calcita \pm clinozoizita \pm titanita \pm minerais opacos \pm leucoxênio

Essa associação é típica da zona albita-actinolita-clorita (WINKLER 1977) ou da fácies xistoverde (MIYASHIRO 1973). As condições de baixo grau metamórfico às quais estas rochas foram submetidas também podem ser evidenciadas pela presença de cristais ígneos reliquiares de clinopiroxênio (diopsídio-augita) e de plagioclásio que preservam a composição de oligoclásio a andesina. 
A ocorrência de actinolita e a ausência de pumpellyita sugere que temperaturas de ao menos $300^{\circ} \mathrm{C}$ foram alcançadas, ultrapassando o limite inferior da fácies xisto-verde. Segundo MIYASHIRO (1973), a quebra da pumpellyita e o aparecimento da actinolita se dá a $310^{\circ} \mathrm{C}$ e a $5,5 \mathrm{~kb}$, segundo a reação:

- 41 pumpellyita +2 clorita +47 quartzo $=71$ clinozoisita +11 actinolita $+109 \mathrm{H}_{2} \mathrm{O}$

De acordo com SPEAR (1995) o aquecimento progressivo nos metabasitos gera actinolita via uma complexa reação (não balanceada) que envolve:

- clorita (com baixo $\mathrm{Al})+$ carbonato (calcita, dolomita ou ankerita) + óxidos = actinolita + + zoisita $+\mathrm{CO}_{2}+\mathrm{H}_{2} \mathrm{O}$

A actinolita foi também cristalizada em franjas diretamente a partir do clinopiroxênio ígneo, por hidratação, semelhante aos processos de uralitização, o que pode indicar, conforme YARDLEY (1994), que o metamorfismo de baixo grau não foi estritamente progressivo, pelo fato do anfibólio não se desenvolver em torno de minerais metamórficos prévios. Essa textura é comum nos metabasitos das formações Estrada dos Romeiros e Piragibu nos arredores de Cajamar-Jordanésia, onde o grau metamórfico parece ser ainda mais baixo.

ZEN (1961) assinalou que o metamorfismo às vezes parece iniciar-se diretamente nas associações da fácies xisto-verde a partir de minerais primários, sem o desenvolvimento da fácies zeólita.

A fácies zeólita é típica de metamorfismo oceânico, o que pode sugerir, conforme comentado nas descrições da geologia, que parte das rochas da região de Cajamar sejam intrusivas e não vulcânicas. Entretanto, as zeólitas podem não se cristalizar sob pressão parcial de $\mathrm{CO}_{2}$, mesmo pequena (THOMPSON 1971), o que poderia explicar as texturas verificadas em parte dos metabasitos, já que essas rochas estão quase sempre associadas a sedimentos carbonáticos.

SPEAR (1995) reporta que o aparecimento e estabilidade da actinolita envolve a $\mathrm{PCO}_{2}$ além das condições de P e T. Elevadas $\mathrm{PCO}_{2}$ contribuem para a estabilidade da clorita e carbonato ao invés de actinolita e epídoto. O predomínio de actinolita e epídoto nos metabasitos do Grupo São Roque sugere que nessas rochas atuaram baixas pressões de $\mathrm{CO}_{2}$ e que as temperaturas foram suficientemente altas para o aparecimento de actinolita.

O plagioclásio sódico metamórfico relacionado ao evento $S_{1}$ é essencialmente uma albita. Localmente, observam-se cristais de oligoclásio com a geminação mal preservada. Esses podem, entretanto, representar reequilíbrios parciais dos cristais ígneos.

A presença comum de clorita estável na foliação $S_{1}$ sugere que o plagioclásio com essa composição seja reliquiar, pois LIOU et al. (1974) destacam que a clorita inicia sua desestabilização a partir de $475^{\circ} \mathrm{C}$ e, simultaneamente, se estabelece o começo da transformação da albita para termos de composição mais cálcica, através da reação:

- epídoto + clorita + quartzo $=$ actinolita + anortita $+\mathrm{H}_{2} \mathrm{O}$

Nessas condições poderia coexistir com a albita $S_{1}$ o oligoclásio metamórfico. Tal situação seria 
possível se o componente anortita produzido pela reação acima ou ainda pela reação:

\section{- $\quad$ epídoto + quartzo $=$ anortita $+\mathrm{H}_{2} \mathrm{O}$}

dissolvesse parte dos cristais pré-existentes de albita, resultando em cristais de oligoclásio.

SPEAR (1995) reporta que o cristalização do oligoclásio é um bom indicador do início da zona de transição para fácies anfibolito. Neste caso, associados a esse plagioclásio coexistiriam, caracteristicamente, dois anfibólios cálcicos em contato mútuo, actinolita e hornblenda, como pode ser observado na FIGURA 6.3. Nessas condições, o epídoto tenderia a desaparecer durante a produção do anfibólio e do plagioclásio mais cálcico.

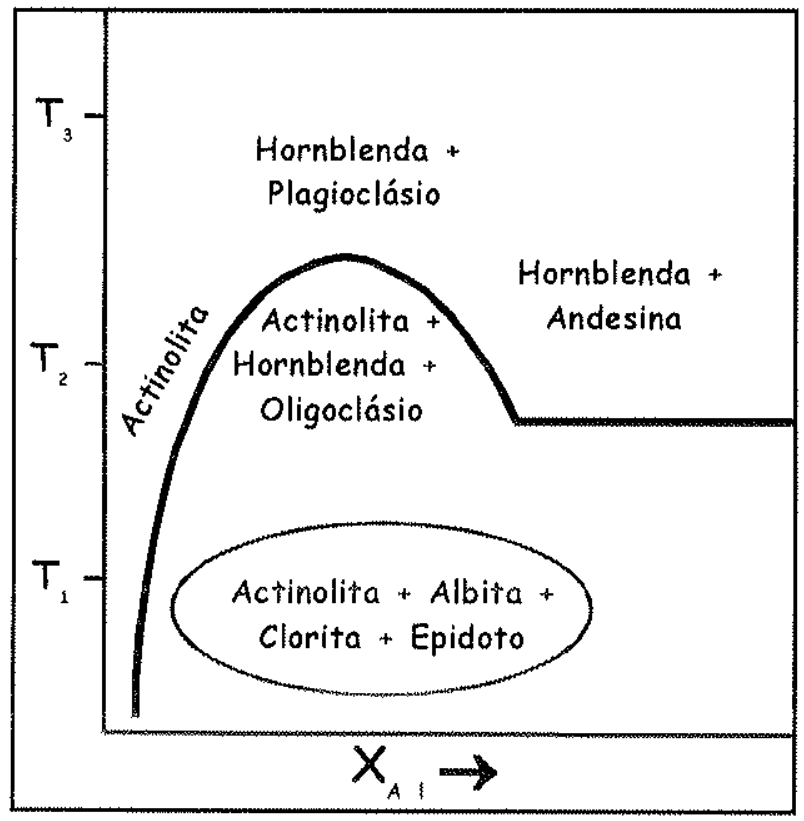

FIGURA 6.3 - Onde $T_{1}$ (fácies xisto-verde), $\mathrm{T}_{2}$ (zona de transição) e $\mathrm{T}_{3}$ (fácies anfibolito).
Contudo, a ausência de oligoclásio metamórfico, a relativa abundância de clorita $S_{1}$ estável e a presença comum de epídoto em paragênese com actinolita nessa foliação sugerem que as condições de metamorfismo foram relativamente suaves, possivelmente bem próximas do campo delimitado com a elípse na FIGURA 6.3, e que de modo geral, não devem ter sido ultrapassados os $475^{\circ} \mathrm{C}$ durante a $S_{1}$ nos metabasitos do Grupo São Roque.

A presença mais abundante de clinozoisita associada ao primeiro evento e a cristalização mais intensa de clorita e de epídoto a partir dos minerais metamórficos, como pode ser observado na TABELA $5.22 \mathrm{e}$, em parte, nas rochas metavulcanoclásticas básicas na TABELA 5.23, indicam que durante o desenvolvimento da $S_{2}$ as condições físicas do metamorfismo foram mais brandas, caracterizando retrometamorfismo.

Essas paragêneses podem ser visualizadas na FIGURA 6.4.

Cabe ainda ressaltar que nas rochas metabásicas da Unidade Metabasítica da Formação Pirapora do Bom Jesus a presença de cristais reliquiares de clinopiroxênio de modo geral é muito mais rara, em particular no corpo metabasítico de Pirapora do Bom Jesus, quando comparadas às rochas metabásicas que ocorrem nas formações Estrada dos Romeiros e Piragibu, onde o leucoxênio é mais frequiente, a titanita tende a ser fina e mal formada e os minerais opacos são mais raros.

Estas informações reforçam a hipótese de que no Grupo São Roque, na região estudada, o grau metamórfico é ainda mais fraco ou mesmo incipiente nas proximidades de Cajamar-Jordanésia.

As associações metamórficas observadas nos metabasitos são típicas de fácies xisto-verde, em consonância com as assembléias verificadas nos metapelitos do Grupo. 


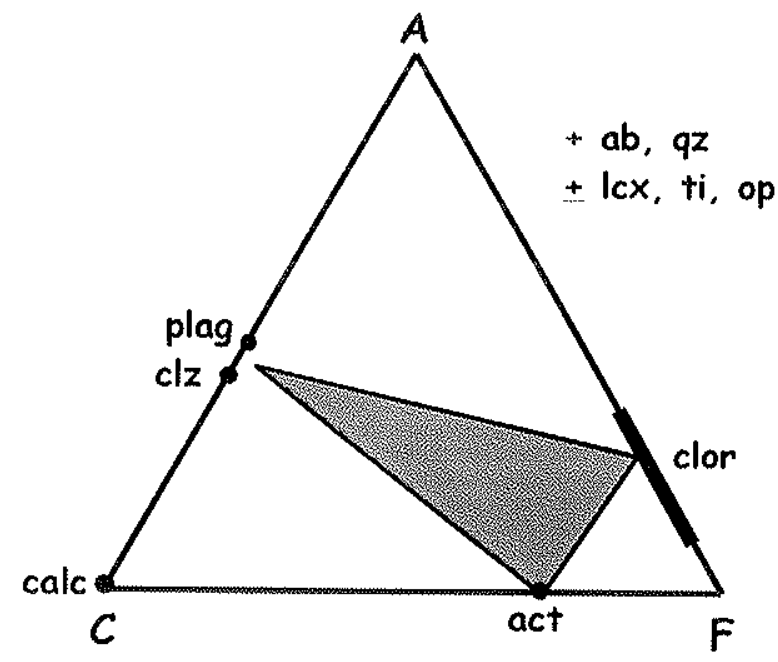

(a)

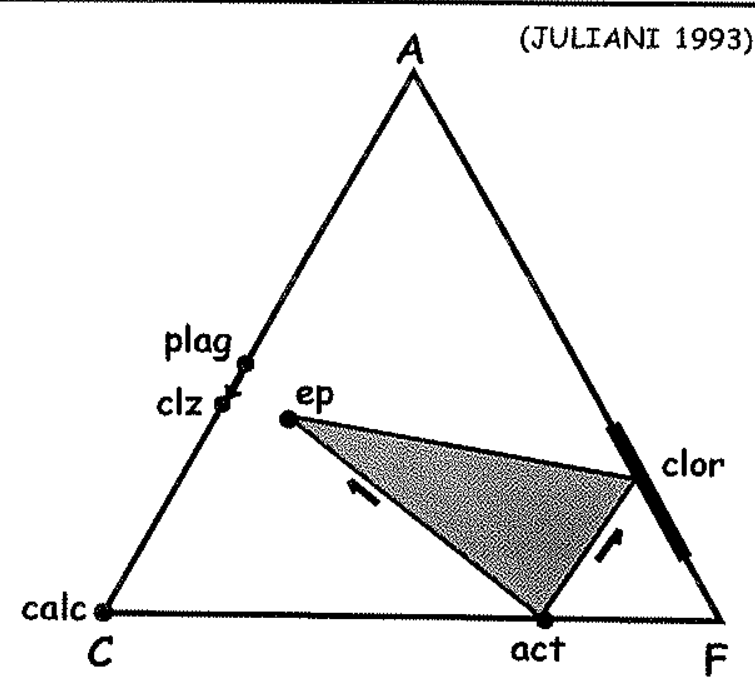

(b)

FIGURA 6.4 - Paragêneses metamórficas (a) e retrometamórficas (b) dos metabasitos do Grupo São Roque.

\subsubsection{Metapsamitos das formações Morro Doce e Boturuna}

São discutidas a seguir as paragêneses observadas nos metarcóseos, metarenitos arcoseanos, metagrauvacas e na matriz dos metaconglomerados da Formação Morro Doce, posicionados na base do Grupo São Roque, e as que ocorrem nos metarenitos feldspáticos e nos quartzitos micáceos da Formação Boturuna.

As relações de cristalização dos minerais nessas rochas e suas respectivas foliações metamórfïcas podem ser observadas nas TABELAS 5.19, 5.20, 5.21, 5.24 e 5.26.

A associação mais comum encontrada nessas rochas é:

quartzo + biotita + muscovita + feldspato potássico + albita \pm magnetita \pm epídoto \pm clorita

Segundo MATHER (1970), a biotita se desenvolve primeiramente em grauvacas com feldspato potássico detrítico que propriamente nos metapelitos, onde vão se cristalizar a temperaturas mais elevadas, razão pela qual estes litotipos não podem ser considerados como pertencentes à zona da biotita. Reforça ainda mais esta conclusão o fato das camadas de fílitos intercaladas possuírem apenas muscovita/sericita e clorita, o que os posiciona claramente na zona da clorita

O aparecimento da biotita depende largamente da composição química do sedimento (JULIANI 1993). Sua cristalização pode inclusive ocorrer em certas tochas no início do metamorfismo (MIYASHIRO 1973).

Seu desenvolvimento, dessa forma, pode ter ocorrido nessas rochas segundo a reação:

- feldspato potássico + clorita = biotita + muscovita + quartzo $+\mathrm{H}_{2} \mathrm{O}$

Nos litotipos da Formação Morro Doce e nos metarenitos feldspáticos da Formação Boturuna também está presente a calcita e, considerando a ocorrência comum de epídoto na $S_{1}$, como pode ser observado nas TABELAS 5.19, 5.20 e 5.21, o sedimento original deveria ser relativamente rico em 
carbonato mais magnesiano. Desta forma, outra possibilidade para o surgimento da biotita nessas rochas seria por descarbonatização, conforme a reação:

- 3 dolomita (ou ankerita) $+\mathrm{K}$-feldspato $+\mathrm{H}_{2} \mathrm{O}=$ biotita +3 calcita $+7 \mathrm{CO}_{2}$

A presença de clorita muito subordinada nestes litotipos sugere que boa parte tenha sido consumida na reação anterior que também envolve o feldspato potássico como reagente. Contudo, localmente, a presença de clorita em paragênese estável com a biotita na $S_{1}$ pode ser interpretada como devida a um evento metamórfico de pressão mais baixa, não barrowiano, como observado por JULIANI (1993) na região da Serra do Itaberaba.

O feldspato potássico detrítico foi recristalizado nas bordas para microclínio, indicando tamperaturas baixas. Entretanto, o microclínio fino da matriz pode ter também se desenvolvido conforme a reação:

- 6 fengita $=3$ muscovita + biotita $+2 \mathrm{~K}$-feldspato +3 quartzo $+\mathrm{H}_{2} \mathrm{O}$

O plagioclásio da matriz encontra-se em grande parte reequilibrado para albita, que pode permanecer estável até a zona da granada YARDLEY (1994).

\subsubsection{Metapelitos e metarritmitos das formações Estrada dos Romeiros e Piragibu}

Nas formações Estrada dos Romeiros e Piragibu os litotipos comumente têm granulação fina a muito fina e são frequientes as estruturas sedimentares preservadas. As relações de cristalização dos minerais e as respectivas foliações metamórficas podem ser consultadas nas TABELAS 5.27, 5.32 e 5.33.

A associação mineral mais freqüente observada nestas rochas é:

quartzo + clorita + sericita/muscovita \pm mineral opaco \pm epídoto \pm carbonato \pm grafita

Assim como observado nos metarcóseos, a presença de carbonato e/ou epídoto na associação deriva, muito provavelmente, da mistura de sedimentos carbonáticos nos metapelitos.

Os grãos de plagioclásio identificados em metarenitos da unidade metarrítmica da Formação Estrada dos Romeiros são detríticos e albíticos. Apresentam reequilíbrio metamórfico associado à $S_{1}$, mas não se descarta a hipótese de ocorrerem composições reliquiares preservadas.

A clorita presente nas foliações $S_{1}$ e $S_{2}$ pode ser derivada da reação:

- 10 fengita $+26 \mathrm{SiO}_{2}=$ clorita +4 pirofilita +10 feldspato potássico $+\mathrm{H}_{2} \mathrm{O}$

Devido à granulação muito fina, não foi possível distinguir petrograficamente a pirofilita da fengita dentre os cristais de sericita. YARDLEY (1994) considera que a sericita associada à clorita em condições metamórficas de epizona em geral é uma fengita, mas reporta a coexistência local de fengita + paragonita + pirofilita.

Segundo SPEAR (1995) a assembléia clorita + K-feldspato é estável em condições de pressão intermediária na zona da clorita para qualquer relação $\mathrm{Fe} / \mathrm{Mg}$, ao passo que pelitos relativamente ricos em ferro e com alto conteúdo de $\mathrm{Al}$ podem possuir pirofilita + Fe-clorita + muscovita + quartzo.

Nos pelitos com baixo $\mathrm{Al}$ a paragênese esperada é muscovita + clorita + K-feldspato + quartzo, e 
as condições mínimas a partir dessa assembléia para o aparecimento da biotita têm início a $350^{\circ} \mathrm{C}$ e $2 \mathrm{~Kb}$, condições essas que não foram alcançadas, dada a ausência de biotita metamórfica.

Cristais mais grossos de biotita e de muscovita identificados nos metapelitos e metarritmitos são detríticos.

Com base nos comentátios acima, pode-se dizer que o metamorfismo nos metapelitos e metarritmitos do Grupo São Roque durante o primeiro evento deformacional é de fácies xisto-verde e restrito à zona da clorita.

Os minerais associados à clivagem de crenulação $S_{2}$ de alguns exemplares não indicam mudanças significativas das condições físicas no evento retrometamórfico. Nas unidades do topo são observadas cristalização e recristalização de quartzo, de sericita/muscovita fina e, eventualmente, de clorita.

Nas rochas da Formação Morro Doce, a biotita cristalizou mais raramente e, assim como a biotita $S_{1}$, foi parcialmente substituída por clorita. As relações metamórficas e retrometamórficas dos metapelitos, metarritmitos e rochas com K-feldspato detrítico podem ser observadas na figura 6.5 .

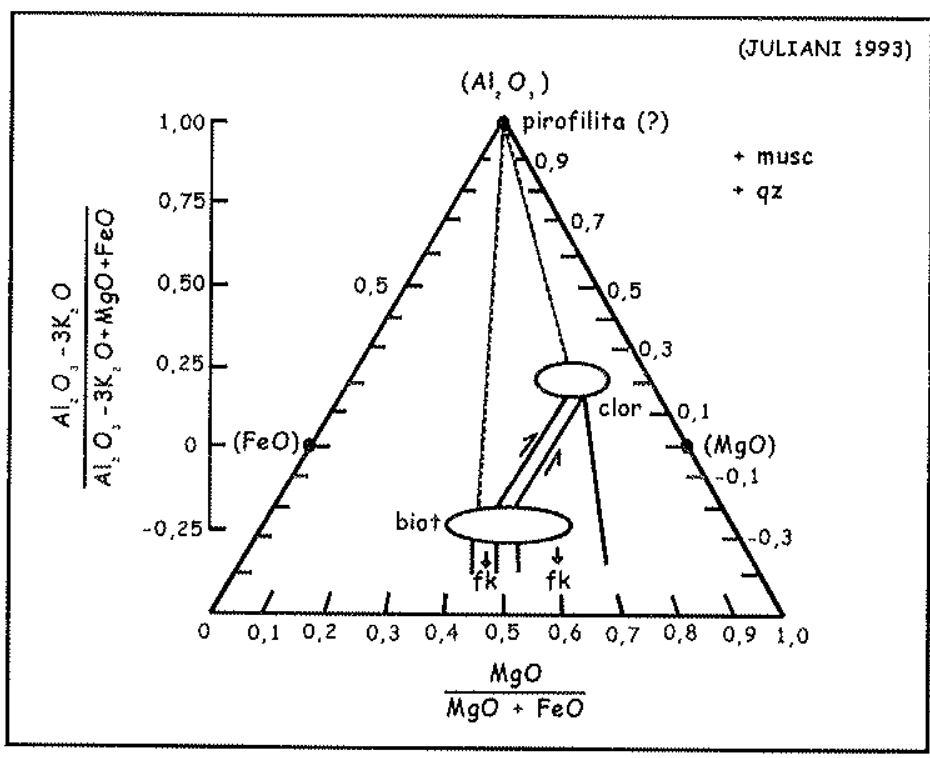

Figura 6.5 - Paragêneses metamórficas e retrometamórficas dos metapelitos, metarritmitos e rochas com K-feldspato detrítico (metarcóseos, metarenitos feldspáticos, matriz dos metaconglomerados) do Grupo São Roque.

\subsection{Síntese do metamorfismo dos grupos Serra do Itaberaba e São Roque}

No Grupo Serra do Itaberaba predominaram condições de fácies anfibolito na $S_{1}$, atingindo localmente fácies anfibolito alto (subfácies almandina anfibolito), com a cristalização de cordierita após a silimanita, e possivelmente, ortoclásio nos metapelitos, e de almandina e diopsídio nos anfibolitos. A presença de cianita sin- $S_{1}$ caracteriza o metamorfismo como de pressão intermediária, do tipo barrowiano.

$\mathrm{Na}_{2}$ as paragêneses indicam que o grau metamórfico foi muito semelhante, com xistos com forte cristalização de fibrolita marcando a zona da silimanita. Localmente, parece ter sido atingida, também, a zona da cordierita. Contudo, a ausência de cianita indica que as condições de pressão não se mantiveram, situação essa muito semelhante à observada na região da Serra do Itaberaba onde, após a inversão da 
cianita para silimanita, ainda na $S_{1}$, JULIANI (1993) reconheceu acentuada queda de pressão, e caracterizou condições de pressão um pouco mais baixa para a $\mathrm{S}_{2}$.

As rochas metabásicas e as rochas metavulcanoclásticas básicas com texturas de metaestabilidade que ocorrem nas proximidades dos maciços graníticos refletem condições de fácies epídotoanfibolito locais na foliação $S_{2}$, com tendência de reequilíbrio ou que se reequilibraram para fáceis anfibolito no mesmo evento, como visto pelas bordas verde-escuras dos cristais manchados de anfibólio, que denunciam composição de hornblenda e condições de grau médio. Xistos pelíticos associados contêm estaurolita $\sin -\mathrm{S}_{2} \mathrm{e}$ indicam que essas condições foram atingidas.

As foliações $S_{3}$ e $S_{4}$, retrometamórficas, apresentam cristalização de muscovita, clorita e quartzo, além da biotita subordinada, compatíveis com a fácies xisto-verde, mais efetiva nos metapelitos (e nos metapsamitos). Nos anfibolitos, em geral, nota-se o predomínio de actinolita (tremolita), albita, quartzo, epídoto, clinozoisita, clorita e calcita, além da titanita mais comum que o mineral opaco, indicando condições de pressão e temperatura de grau fraco. Localmente, em anfibolitos próximos do Stock Granítico do Tico-Tico, observam-se cristais de homblenda e de homblenda-actinolita associados à foliação $S_{3}$, que podem sugerir condições um pouco mais drásticas nesse evento retrometamórfico.

Nas rochas metabásicas do Grupo São Roque observa-se, na $S_{1}$, epídoto (e clinozoisita) em paragênese com actinolita-tremolita e albita, relativa abundância de clorita e de quartzo, além da ausência de oligoclásio metamórfico, o que indica condições de metamorfismo de fácies xisto-verde ou de grau fraco, sendo que não foram ultrapassadas temperaturas ao redor de $475^{\circ} \mathrm{C}$ nessas rochas da Formação Pirapora do Bom Jesus.

Nas rochas metabásicas das formações Estrada dos Romeiros e Piragibu a frequiente ocorrência do clinopiroxênio ígneo reliquiar e de leucoxênio associado com titanita pouco desenvolvida indicam que as as condições metamórficas foram ainda mais brandas.

$\mathrm{Na}$ foliação $S_{2}$, retrometamórfica, ocorre cristalização mais efetiva de epídoto, clorita, calcita e leucoxênio, além da tremolita, em condições próximas de pressão e de temperatura.

Nos metapsamitos do Grupo São Roque a clorita, em relação paragenética estável com biotita, sugere que o metamorfismo é de pressão mais baixa que do tipo barrowiano. A cristalização de biotita nessas rochas onde o K-feldspato é comum não permite definir a zona da biotita e os filitos intercalados contendo apenas muscovita/sericita e clorita, indicam ter sido atingida tão somente a zona da clorita.

Nos metapelitos e metarritmitos das formações Estrada dos Romeiros e Piragibu o grau metamórfico também alcançou apenas a zona da clorita. As condições de pressão e temperatura associadas à foliação $S_{2}$ não apresentam mudanças significativas, como observado pelas cristalizações menos efetivas da biotita na Formação Morro Doce e da sericita nas formações Estrada dos Romeiros e Piragibu. 


\section{CAPÍTULO VII}

\section{CONSIDERAÇÕES FINAIS}

- O levantamento bibliográfico sobre as rochas granitóides que ocorrem na região possibilitou a compilação dos dados geológicos básicos, principalmente quanto à faciologia desses corpos. Uma síntese dos conhecimentos dessas rochas que afloram na área pesquisada é apresentada nos capítulos II (Trabalhos Anteriores) e IV (Geologia e Litoestratigrafia). O resultado dessa compilação também está disponível no mapa geológico (Anexo II), através da apresentação das diversas fácies litológicas/petrográficas individualizadas.

- No extremo noroeste da área aflora o Complexo Itapira (PaleoProterozóico) com quartzitos a norte, e gnaisses na porção meridional milonitizados e tectonicamente imbricados com o Stock Granítico Guaxatuba/Pica-Pau. Os gnaisses do Complexo e o Stock não foram individualizados devido ao intenso imbricamento e à escala de mapa adotada, e esses limitam-se através das zonas de cisalhamento ItuJundiuvira e Moreiras com rochas do Grupo São Roque.

- A região sul está ocupada pelo Complexo Embú (Mesoproterozóico) que é intrudido pela Fácies Ibiúna do Maciço Granitóide Ibiúna. No Maciço, a norte, rochas da Fácies Itapevi estão em contato tectônico com litotipos do Grupo Serra do Itaberaba e com fácies dos maciços granitóides Itaqui e São Roque através da Zona de Cisalhamento Taxaquara.

\section{LTTOESTRATIGRAFIA DOS GRUPOS SERRA DO ITABERABA E SÃO ROQUE}

- Os estudos geológicos nas rochas supracrustais a NW da cidade de São Paulo permitiu observar a existência de duas unidades litoestratigráficas com histórias deposicionais e evolutivas distintas: o Grupo Serra do Itaberaba, originado no Mesoproterozóico, de característica essencialmente vulcano-sedimentar, e o Grupo São Roque (Neoproterozóico), também com contribuições vulcânicas, porém predominantemente constituído por seqüências metassedimentares.

- A sequiência metavulcano-sedimentar tem ampla correlação com o Grupo Serra do Itaberaba que aflora a NE da cidade de São Paulo, sendo possível utilizar as formações definidas por JULIANI (1993). A noroeste da cidade de São Paulo, o Grupo Serra do Itaberaba é constituído pela:

- Formacão Morro da Pedra Preta, caracterizada como basal e vulcano-sedimentar e subdividida em:

- Unidade Metabásica, onde predominam anfibolitos e anfibólio xistos contendo hornblenda/actinolita e plagioclásio (andesina a labradorita) com granada anfibolitos e anfibolitos com diopsídio raros, sendo reconhecidas na região estruturas tipo pillow lavas em rochas de mais alto grau metamórfico. Ocorrem ainda rochas metavulcanoclásticas básicas, metassedimentos tufíticos, rochas calciossilicáticas, xistos pelíticos variados, às vezes grafitosos, e metapelitos calcíferos.

- Unidade Metavulcanoclástica, aflora em grande extensão da área, apresentando amplo predomínio 
dos metassedimentos tufíticos e contendo intercalações de metabrechas e metatufos básicos, além de metapelitos com contribuição tufítica, xistos pelíticos variados, metapelitos grafitosos, ferromanganesíferos e calcíferos, metabasitos, rochas calciossilicáticas, rochas metavulcanoclásticas quartzo-. andesíticas a riolíticas, metachert, turmalinitos e metarriólitos. Foram também reconhecidos metassedimentos silto-arenosos rítmicos, por vezes com leitos microconglomeráticos, que correspondem a possíveis metaturbiditos, não descritos na Serra do Itaberaba.

- Unidade Calciossilicática, constituída em essência por rochas calciossilicáticas e por metassedimentos tufíticos, metatufos básicos, plagioclásio-biotita-quartzo xistos com biotita porfiroblástica, metapelitos manganesíferos, calcíferos e grafitosos, além de diopsídio mármore com tremolita, xistos granatíferos, flogopita xistos com epídoto e metachert subordinados

- Unidade dos Xistos Pelíticos, também de grande distribuição na área, representada por xistos diversos que podem conter fibrolita, granada e, mais raramente, estaurolita, andaluzita, silimanita, cianita e cordierita, além de agregados porfiroblásticos de muscovita+quartzo+biotita ou de muscovita. Na base da unidade ocorrem metapelitos com contribuição tufítica e biotita-estaurolita xistos com granada. Para o topo estão presentes xistos com biotita e magnetita porfiroblásticas. Metassedimentos tufíticos, xistos quartzosos com leitos conglomeráticos ou näo, rochas metabásicas e metavulcanoclásticas básicas, xistos turmaliníticos e grafitosos e metapelitos calcíferos encontram-se intercalados de forma subordinada. Leitos de turmalinitos, rochas meta-intermediárias e metarriólitos são raros.

- Unidade de Formação Ferrífera, onde leitos de metachert e ferríferos estão intercalados com metassedimentos tufíticos ricos em turmalina, turmalinito, xistos grafitosos com pirita e xistos com estaurolita e granada.

- Unidade Metapelítica Grafitosa, constituída em grande parte por xistos grafitosos que gradam e interdigitam-se com xistos pelíticos com grafita ou estaurolita e têm contato brusco com metabasitos/anfibolitos. Os xistos grafitosos contêm pirita disseminada e intercalações de leitos quartzosos e muscovíticos, às vezes com andaluzita. Intercalam-se ainda formações ferríferas, turmalina xistos, turmalinitos e metapelitos com contribuições manganesíferas.

- Na Formação Morro da Pedra Preta os metabasitos são subordinados enquanto que as rochas metavulcanoclásticas básicas, em particular os metassedimentos tufíticos, predominam, o que aliado à presença de extensos pacotes de xistos pelíticos indica que o ambiente deposicional do Grupo Serra do Itaberaba nesta região é relativamente mais proximal ao continente, distinguindo-se do ambiente de MORB dos metabasitos e metapelitos da Formação Morro da Pedra Preta na Serra do Itaberaba.

- A presença de diversos corpos de xistos grafitosos, de metacherts e de formações ferríferas, ainda que de pequeno porte, além de leitos de turmalinitos intercalados nos metassedimentos tufíticos e nos xistos pelíticos e grafitosos denota que ocorreu expressiva atividade vulcano-exalativa.

- As rochas laminadas a bandadas alteradas e de cores variegadas que ocorrem na Rodovia Anhangüera 
na região sudeste da área representam uma seqüência de rochas metavulcanoclásticas básicas com amplo predomínio de metassedimentos tufíticos, e não rochas calciossilicáticas decompostas, conforme reportado por CARNEIRO (1983). Corpos relativamente extensos de rochas calciossilicáticas são bem mais raros nessa região, contudo puderam ser individualizados na Unidade Calciossilicática.

- Nesses metassedimentos tufíticos e nas zonas de cisalhamento de empurrão associadas estão concentradas as principais mineralizaçóes de ouro da região (MARTIN 1998a).

- Os xistos com fibrolita comumente milonitizados e com paragêneses de fácies anfibolito médio a superior constituem uma janela estrutural relacionada aos efeitos das zonas de cisalhamento de empurrão somados ao alçamento provocado pela colocação do Stock Granítico do Tico-Tico.

- Litotipos das unidades Metavulcanoclástica e dos Xistos Pelíticos da região sudeste estão frequientemente milonitizados devido às zonas de cisalhamento de empurrão que, em geral, apresentam transporte tectônico para NNW, e foram responsáveis por inversôes estratigráficas na Formação Morro da Pedra Preta, que colocaram, localmente, a sequiência metavulcanoclástica sobre os xistos.

- Formacão Nhangucu, manganesífera e carbonática, depositada em bacia de retro-arco, ocorre geralmente sobreposta à Unidade Metavulcanoclástica da Formação Morro da Pedra Preta através de intercalações bruscas bem marcadas entre metapelitos manganesíferos e calcíferos e os metassedimentos tufíticos sotopostos. Contatos gradacionais subordinados apresentam contribuições manganesíferas cada vez mais expressivas nos metassedimentos tufíticos. A Formação Nhanguçu foi subdividida em:

- Unidade dos Metassedimentos Manganesíferos, representada predominantemente por metassedimentos manganesíferos onde intercalam-se com freqüência metapelitos calcíteros que geralmente apresentam intercalações e gradações para rochas carbonáticas. Metassedimentos grafitosos e tufíticos, metapelitos com contribuição tufítica, rochas calciossilicáticas com escapolita e anfibolitos estão presentes de forma subordinada.

- Unidade das Rochas Carbonáticas, que contém rochas carbonáticas laminadas a bandadas ou de tendência maciça, onde predominam termos dolomíticos e estão presentes tipos calcíticos. Essas rochas podem ter ou não tremolita e/ou diopsídio. Litotipos intercalados subordinadamentes são, com maior frequiência, metapelitos calcíferos e metassedimentos manganesíferos.

- Formacão Pirucaia, constituída por sedimentos litorâneos de base de talude continental, está sobreposta à Unidade dos Xistos Pelíticos da Formação Morro da Pedra Preta através de contato transicional. É composta pela:

- Unidade dos Xistos Quartzosos, onde predominam xistos quartzosos e muscovita-biotita quartzitos com grânulos de quartzo dispersos. Podem conter granada, fibrolita ou estaurolita, além de raros cristais de cianita, silimanita e cordierita. Ocorrem intercalados muscovita-biotitamquartzo xistos e, mais raramente, xistos conglomeráticos oligomíticos e quartzitos puros. Na base da unidade estão presentes 
interposições comuns de xistos pelíticos.

- Diferencia-se da Formação Pirucaia de JULIANI (1993) por serem raros os quartzitos quase puros. A NW da cidade de São Paulo os xistos quartzosos foram mapeados essencialmente nos arredores do Stock Granítico Tico-Tico e para nordeste, indicando que deposição clástica mais grossa do Grupo Serra do Itaberaba ocorre nessa região. A Formação Pirucaia pode ser correlacionada aos xistos quartzosos da Unidade Inferior do Grupo São Roque (DANTAS 1990).

- O Grupo São Roque constitui na região uma entidade geotectônica brasiliana posicionada de forma discordante, através de zonas de cavalgamento, sobre o Grupo Serra do Itaberaba. Foram parcialmente identificadas no Grupo São Roque as formações propostas por HASUI et al. (1976) e BERGMANN (1988) com algumas redefiniç̧̃es. Durante este trabalho também foi proposta uma nova formação para o Grupo, de caráter basal. As formações reconhecidas para o Grupo São Roque a NW da cidade de São Paulo, da base para o topo são:

- Formacão Morro Doce, individualizada por JULIANI et al. (1999), está representada por lentes de metaconglomerados, metarcóseos e metarenitos feldspáticos depositados em ambiente de leques aluviais. Zonas de cisalhamento de empurrão ocorrem no contato tectônico com a Unidade Metavulcanoclástica do Grupo Serra do Itaberaba. Compreende, na região sudeste da área a base do Grupo São Roque. A formação foi subdividida em:

- Unidade Metarcoseana, que ocorre em contato tectônico com os metassedimentos tufíticos do Grupo Serra do Itaberaba. É constituída por metarcóseos com clastos de feldspato potássico, plagioclásio, quartzo, quartzito, e raros de granitóides. Gradam para subarcóseos e estão intercalados com lentes subordinadas de metaconglomerados, quartzitos e metarenitos feldspáticos, metarenitos finos, metagrauvacas e filitos.

- Unidade Metaconglomerática, aparentemente sobreposta à unidade anterior, É constituída por metaconglomerados com seixos e calhaus de granitóides, dentre outros, e clastos de feldspato potássico e de plagioclásio às vezes euédricos. Seixos mais raros de xistos, de rochas metabásicas e de rochas de tendência andesítica parecem indicar contribuição proveniente do Grupo Serra do Itaberaba para a bacia São Roque. Metarcóseos, metarenitos feldspáticos ou não e filitos estão subordinados.

- O reconhecimento de passagens graduais entre o suposto metarriodacito (CARNEIRO 1983) e corpos de metaconglomerado na região do Morro do Polvilho, e a presença de estruturas sedimentares e fragmentos clásticos de rochas graníticas idênticos aos encontrados nos metarcóseos do Morro Doce clurante o desenvolvimento desse trabalho, permitiram definir que o "metarriodacito" é, em verdade, um metarcóseo com intercalações de metaconglomerado (JULIANI et al. 1997a).

A análise petrográfica revelou a semelhança dos porfiroclastos de plagioclásio e de feldspato potássico nos supostos metarriodacitos, nos metarcóseos e na matriz dos metaconglomerados, muitas vezes com 
suas faces preservadas, indicando origem comum e proximidade da área fonte.

- Formacão Pirapora do Bom Jesus, que corresponde em grande parte à Formação Pirapora (BERGMANN 1988), apresentando característica vulcanossedimentar. É também basal, sendo cronocorrelata à Formação Morro Doce. Contudo, deve constituir ilhas oceânicas do início da deposição do Grupo São Roque, como sugerido por JULIANI (1993). A Formação Pirapora do Bom Jesus foi subdividida em:

- Unidade Metabasítica, que contém rochas metabásicas com actinolita e albita, com relíquias ocasionais de clinopiroxênio ígneo e estrutura tipo pillow-lavas. Intercalam-se, subordinadamente, metatufos básicos, filitos manganesíferos, metacálcio-pelitos com leitos de rochas carbonáticas, metassedimento tufítico com leitos de rocha metabásica amigdaloidal, rocha meta-ultrabásica e camadas de itabirito.

- Unidade Metacálcio-Pelítica, onde ocorrem metacálcio-pelitos laminados a bandados até maciços com sericita, clorita e carbonato, além de grafita, quartzo, óxidos e hidróxidos de manganês e níveis sulfetados. Intercalam-se filitos sericítico, grafitoso e manganesífero, além de leitos carbonáticos, níveis restritos de metachert e quartzitos ferruginosos.

- Unidade Metacarbonática, que geralmente está em contato transicional com a unidade anterior. Contém rochas carbonáticas calcíticas e dolomíticas bandadas e laminadas, além de tipos maciços. Estruturas estromatolíticas podem estar presentes localmente. Metacálcio-pelitos e metassedimentos manganesíferos são subordinados.

- Unidade Metavulcanoclástica, constituída predominantemente por metabrechas e metatufos básicos com actinolita e albita, e onde intercalam-se rochas metabásicas finas, metassedimentos tufíticos, metapelitos e metarritmitos.

- Formação Boturuna, ocupa posição litoestratigráfica intermediária no Grupo São Roque, apresentando na região do Pico do Jaraguá, metarenitos feldspáticos em contato transicional com os metarcóseos da Formação Morro Doce. Sobrepostos, os metarenitos feldspáticos gradam em posição normal para os quartzitos. No Morro do Boturuna os metarenitos feldspáticos formam corpos delgados na base e os quartzitos predominam para o topo. A formação representa, possivelmente, retrabalhamento em ambiente litorâneo, talvez com dunas associadas.

- Os metarcóseos da Formação Boturuna (BERGMANN 1988) foram em grande parte reinterpretados como metarenitos feldspáticos. Esses, na região de Pirapora do Bom Jesus, estão sobrepostos aos metarritmitos da Formação Estrada dos Romeiros, indicando que os metarenitos feldspáticos também podem ser cronocorrelatos ou ter sido depositados, ao menos em parte, após os metarritmitos.

- Na porção sudeste da área, a transição em contato normal com litotipos da Formação Morro Doce aliada à presença dos metarenitos feldspáticos abundantes com metarcóseos comuns e quartzitos mais 
raros indica deposição da Formação Boturuna mais próxima à área fonte e/ou ainda com influência de leques aluviais. Nessa região, os litotipos dessa formação, redefinida, são correlacionáveis às rochas da porção superior do pacote de metapsamitos impuros de CARNEIRO (1983). A Formação Boturuna foi subdividida em:

- Unidade Metarenítica Feldspática, formada por metarenitos feldspáticos finos a grossos com raros fragmentos de feldspatos. Metarcóseos, metarenitos, metarritmitos, filitos sericíticos, quartzitos por vezes micáceos e metaconglomerados são subordinados. Localmente ocorrem intercalações de rocha metavulcânica básica amigdaloidal rica em biotita, rocha metabásica, rocha metavulcânica intermediária a ácida amigdaloidal e metagrauvaca.

- Unidade Quartzítica, composta preferencialmente por quartzitos finos a grossos com grânulos de quartzo. Metarenitos feldspáticos, metarcóseos, metaconglomerados oligomíticos matriz-suportados, quartzitos micáceos, xistos com biotita, metarritmitos e filitos sericíticos compõem os litotipos subordinados. A ocorrência de rocha metasubvulcânica intermediária a ácida no topo da Formação Boturuna indica que essa atividade vulcânica foi mais extensa do que o antes admitido (BERGMANN 1988). A Unidade Quartzítica também deve ser correlacionada à Formação Boturuna de HACKSPACHER et al. (1992a, b), porém sobreposta à Formação Pirapora do Bom Jesus.

- Formacão Estrada dos Romeiros, redefinida, pode ser correlacionada ao Membro Arenoso da Formação Estrada dos Romeiros (BERGMANN 1988). O caráter relativamente mais grosso dos depósitos da região de Pirapora do Bom Jesus comparado aos metassedimentos rítmicos mais finos que predominam no sentido de Cajamar sustentam a hipótese de que litotipos das formaçŏes Estrada dos Romeiros e Piragibu representam apenas diferentes fácies de ambiente deposicional (JULIANI \& BELJAVSKIS 1995). Constitui a gradação da Formação Boturuna, com litotipos rítmicos depositados em base de talude, possivelmente como turbiditos proximais grossos. Reinterpretada, a formação é constituída preferencialmente pela:

- Unidade Metarrítmica, onde predominam metarritmitos bandados e laminados compostos por metarenitos maciços finos a médios com grânulos e pequenos seixos de quartzo, metassiltitos e quartzo filitos, que ocorrem intercalados com filitos sericíticos em contato brusco. Subordinadamente estão presentes metacálciopelitos por vezes com leitos grafitosos, metarenitos com feldspatos, metaconglomerados, metarenitos grossos e quartzitos. Pacotes de filitos sericíticos intercalam-se comumente e rochas metavulcanoclásticas básicas estão presentes muito ocasionalmente.

Outras unidades menores foram individualizadas nesta Formação, quais sejam:

- Unidade Metarenítica Feldspática, com metarenitos feldspáticos contendo raros fragmentos de feldspatos, além de metarcóseos, metarenitos e metarritmitos subordinados; Unidade Metacálciopelítica, onde predominam metacálcio-pelitos que estão intercalados com metarritmitos mais finos e 
filitos, e que gradam com frequiência para rochas carbonáticas. Metapelitos manganesiferos, rochas calciossilicáticas, metarenitos feldspáticos e metagrauvacas constituem litotipos mais raros; Unidade Metacarbonática, composta por rochas carbonáticas calcíticas por vezes grafitosas e litotipos dolomíticos subordinados, além de rochas calciossilicáticas, quartzitos, metacálcio-pelitos, metarritmitos e filitos sericíticos mais raros; Unidade Metapsamítica, formada por metarenitos e quartzitos finos a grossos, com quartzitos conglomeráticos ocasionais e subordinados, sendo que os litotipos predominantes transicionam por vezes para metarritmitos constituídos por metarenitos finos e metassiltitos; Unidade Metabasítica, onde ocorrem rochas metabásicas com actinolita, albita, clinopiroxênio ígneo reliquiar comum e textura blastofítica intercaladas com metarritmitos e, de modo subordinado, com metabrecha e metatufos básicos e com metassedimentos tufíticos; Unidade Metapelítica, constituída em geral por filitos laminados a bandados intercalados com metarritmitos e, subordinadamente, com rochas metavuleanoclásticas básicas.

- Formacão Piragibu, parcialmente redefinida, ocupa o topo do Grupo São Roque, podendo ser correlacionada com os metassedimentos de caráter flyschóide da Formação Piragibu (HASUI et al. 1976), com os filitos da Formação Boturuna (HASUI et al. 1976), com o Membro Pelítico da Formação Estrada dos Romeiros (BERGMANN 1988), com os filitos laminados da unidade dos metassedimentos detríticos com predomínio de metapelitos (CARNEIRO 1983) da região de Cajamar-Jordanésia, além dos filitos bandados do Pacote Superior do Grupo São Roque (DANTAS 1990).

- A Formação Piragibu deve ser considerada uma variação dos depósitos de base de talude, estando representada por sedimentos finos distais quando comparados à Formação Estrada dos Romeiros. Está constituída na área em grande parte pela:

- Unidade Metapelítica, que contém extensos pacotes de filitos sericíticos laminados a bandados e outros filitos menos frequientes ricos em clorita. Filitos mais argilosos também estão presentes e contêm leitos grafitosos, ocorrendo corpos menores de ardósia com biotita e/ou muscovita detríticas. Subordinadamente ocorrem intercalações de metarritmitos e de filitos grafitosos, e por vezes gradações para metacálcio-pelitos. Rochas metabásicas e metassedimentos tufíticos são restritos. Também foram individualizados pacotes menos espessos onde predominam outros litotipos, quais sejam:

- Unidade Metarrítmica onde ocorrem metarritmitos variados e intercalações subordinadas de filitos sericíticos; Unidade Metabasítica, com pequenos corpos de rochas metabásicas contendo actinolita, albita, clinopiroxênio reliquiar e com texturas blastofítica e blasto-subofítica; Unidade Metavulcanoclástica, com metassedimentos tufíticos, além de rochas metabásicas e filitos sericíticos presentes de forma subordinada. 


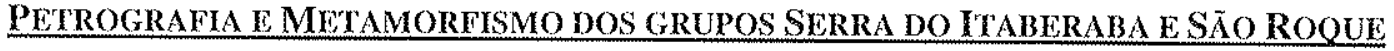

- A análise petrográfica dos diversos litotipos e o estudo do metamorfismo das rochas metabásicas, dos metapelitos e de alguns metapsamitos permitiram indentificar dois conjuntos de rochas afetados por graus metamórficos e deformações distintas, correlacionáveis com os grupos Serra do Itaberaba e São Roque. Não foi observada gradação do metamorfismo como ressaltado em estudos anteriores efetuados na região, sendo constatado o seguinte:

- No Grupo Serra do Itaberaba os litotipos têm paragêneses de grau médio com predomínio, durante at $S_{1}$, de condições de fácies anfibolito, atingindo localmente fácies anfibolito superior (subfácies almandina-anfibolito). A presença neste evento de cianita $\sin -S_{1}$ transformada em silimanita na sua evolução progressiva nos metapelitos indica metamorfismo de pressão intermediária, em regime Barrowiano.

- Durante a $S_{2}$ o metamorfismo foi semelhante e se desenvolveu em geral na fácies anfibolito. Contudo, a ausência de cianita mostra que as condições báricas não se mantiveram, sendo caracterizado metamorfismo intermediário de pressão relativamente mais baixa quando comparado à $S_{1}$.

- Localmente predominaram condições de fácies epídoto-anfibolito na foliação $S_{2}$ como observado pelas texturas de desequilíbrio dos anfibólios, mas com tendência de reequilíbrio para fáceis anfibolito ainda nessa foliação.

- As foliações $S_{3}$ e $S_{4}$ apresentam paragêneses compatíveis com a fácies xisto-verde, com a presença mais comum de clorita e epídoto nas rochas metabásicas indicando o retrometamorfismo. Anfibolitos dos arredores do Stock Granítico do Tico-Tico podem desenvolver hornblenda-actinolita na folią̧̃o $S_{3}$, refletindo condições de $\mathrm{P}$ e $\mathrm{T}$ um pouco mais severas.

- No Grupo São Roque as rochas metabásicas da Formação Pirapora do Bom Jesus têm paragêneses típicas da fácies xisto-verde de MIYASHIRO (1973) ou da zona da albita-actinolita-clorita de WINKLER (1977), enquanto que nas rochas metabásicas das formações Estrada dos Romeiros e Piragibu a presença constante de clinopiroxênio ígneo reliquiar indica que as condições foram ainda mais brandas. $\mathrm{Na}$ foliação $S_{2}$ as condições de pressão e de temperatura se mantiveram próximas às da $S_{1}$, mas a cristalização mais intensa de epidoto e clorita permitiram caracterizar retrometamorfismo.

- Nos metapsamitos deste grupo, a presença de biotita em paragênese estável com a clorita sugere metamorfismo de pressão mais baixa que o barrowiano, mas não define a zona da biotita por se desenvolver apenas em litotipos relativamente ricos em feldspato potássico, caracterizando assim a zona da clorita.

- Nos metapelitos e metarritmitos das formações Estrada dos Romeiros e Piragibu o grau metamórfico támbém alcançou apenas a zona da clorita.

- Na foliação $S_{2}$ não há mudanças significativas no metamorfismo, ocorrendo cristalizações menos intensas da biotita na Formação Morro Doce e da sericita nas formações Estrada dos Romeiros e Piragibu. 


\section{CAPÍTULO VIII}

\section{REFERÊNCIAS BIBLIOGRÁFICAS}

ALMEIDA, F.F.M.de \& HASUI, Y. 1984. O Pré-Cambriano do Brasil. São Paulo, Edgard Bliicher. 378p.

ALMEIDA, G.R.; MOYA, L.S. 1986. Projeto Jordanésia - Relatório Final, Grupo I, PRÓ-MINÉRIO IGCE/UNESP, 94p.

ALMEIDA, F.F.M.de; AMARAL, G.; CORDANI, U.G.; KAWASHITA, K. 1973. The precambrian evolution of the South American cratonic margin south of Amazon River. In: NAIRN, A.E.M.; STEHLI, F.G., eds. The Ocean Basin and Margins. New York, Plenum, 1:411-446.

ALMEIDA, F.F.M. de; CARNEIRO, C.D.R.; BISTRICHI, C.A.; CAMPANHA, G.A. da C.; CAMPANHA; V.A.; PRESSINOTTI, P.C. 1995. Folha Geológica São Paulo (SF.23-Y-C), escala 1:250 000. In: SIMPÓSIO DE GEOLOGIA DO SUDESTE, 4, Águas de São Pedro, SP. Boletim de Resumos. SBG/NSP-NRJ/ES. 1995. p. 112.

ALMEIDA, F.F.M.de; HASUI, Y.; BRITO NEVES, B.B. 1976. The Upper Precambrian of South America, Boletim $I G-U S P,(7): 45-80$.

ALMEIDA, F.F.M.de; HASUI, Y.; PONÇANO, W.L.; DANTAS, A.S.L.; CARNEIRO, C.D.R.; MELO, M.S. de, BISTRICHI, C.A. 1981. Mapa Geológico do Estado de Säo Paulo - Nota Explicativa. São Paulo, IPT, v. (Monografias, 6). (Escala $1: 500.000$ ),

ANDRADE, F.R.D. 1993. Complexo Granitóide São Roque, petrografia, litoquímica e tipologia de zircão. Rio Claro, 156p. (Dissertação - Mestrado) - Instituto de Geociências e Ciências Exatas, Universidade Estadual Paulista.

ANDRADE, F.R.D. de; ARTUR, A.C.; WERNICK, E. 1994. Caracterização faciológica do Complexo Granitóide São Roque, SP. Geociencais, 13(1): 185-212.

ATENCIO, D. \& HYPOLTTO, R. 1994. Fosfatos e silicatos secundários de urânio de Perus, São Paulo. Revista Brasileira de Geociências, 24(1): 43-51.

ATHERTON, M.P. 1964. The garnet isograd in pelitic rocks and its relation to metamorphic facies. The Americun Mineralogist, 49(9/10): 1331-1349.

AZEVEDO, D. T. de. 1997. Os Turmalina Granitos de Perus, SP: Aspectos Geológicos e Petrográficos. São Paulo, 96 p. (Dissertação - Mestrado) - Instituto de Geociências, Universidade de São Paulo.

BATISTA, J. J. 1991. O Significado Tectônico das Rochas Metabásicas do Bloco São Roque. In: SIMPÓsIo NACIONAL DE ESTUDOS TECTÔNICOS, 3, Rio Claro, 1991. Boletim. Rio Claro, SBG/NSP, p. 60-61.

BATISTA, J.J.; GALIPI, D.B.; NARDY, A.J.R. 1991. Dados litogeoquímicos de metabasitos do Bloco São Roquc. In: CONGRESSO BRASILEIRO DE GEOQUÍMICA, 3, e CONGRESSO DE GEOQUÍMICA DOS PAÍSES DE Língua PORTUGUeSA, 1, São Paulo, 1991. Resumos. São Paulo, SBGq/SGP-GG, v.1, p. 176-180.

BERGMANN, M. 1988. Caracterização estratigráfica e estrutural da sequiência vulcano-sedimentar do Grupo Sâo Roque na região de Pirapora do Bom Jesus, Estado de São Paulo. São Paulo, 155p. (Dissertação - Mestrado) Instituto de Geociências, Universidade de São Paulo.

BERGMANN, M. 1991. Litoestratigrafia e paleoambiente do Grupo São Roque na região de Pirapora do Bom Jesus, SP. Boletim IG-USP: Publicação Especial, n. 9, p.107-109. / Apresentado a 1. Jornadas Científicas, São Patulo, 1991 - Resumos /.

BERGMANN, M.1992. Litoestratigrafia e palcoambiente do Grupo São Roque na região de Sinclinório de Pirapora, SP - Revisão. In: CONGRESSO BRASILEIRO DE GEOLOGIA, 37, São Paulo, 1992. Boletim. São Paulo, $S B G$, v. 1, p. 282-283.

BERGMANN, M. \& FAIRCHILD, T.R. 1985. Estromatólitos do Grupo São Roque, Proterozóico Superior, Região de Pirapora do Bom Jesus, Estado de São Paulo. Anais da Academia Brasileira de Ciências, 57(1): 116-117. 
BERGMANN, M. \& FAIRCHLD, T.R. 1986. Estromatólitos do Grupo São Roque: uma hipótese paleogeográlica. In: CONGRESSO BRASILEIRO DE GEOLOGIA, 34, Goiânia, 1986. Boletim de Resumos. Goiânia, SBG, p. 79.

BERGMANN, M. \& McREATH, I. 1992. Rochas vulcânicas do Grupo São Roque, na região do Morro Boturuna em São Paulo. Boletim IG-USP: Publicação Especial, n. 12, p.19-21. / Apresentado a 2. Jornadas Científicas, São Paulo, 1992 - Resumos /.

BETTENCOURT, J.S. \& WERNICK, E. 1976. Contribuiç̧ão à geoquímica do Sr das rochas calcárias dos grupos São Roclue e Açungui (SP,PR). In: CONGRESSO BRASIlEIRO DE GEOLOGIA, 29, Ouro Preto, 1976. Anais. Ouro Preto, SBG, v.1, p. 171-187.

BHASKAR RAO, B. \& JOHANNES, W. 1979. Further data on the stability of staurolite + quartz and related assemblages. Neues Jahrbuch fü Mineralogie Monatshefte, 10: 437-447. BISTRICHI, C.A. 1982. Geologia do Sinclinório de Pirapora, SP. São Paulo, 92p. (Dissertação - Mestrado)
Instituto de Geociências, Universidade de São Paulo.

BISTRICHI, C.A.; CARNEIRO, C.D.R.; DANTAS, A.S.L.; PONÇANO, W.L.; CAMPANHA, G.A. da C.; NAGATA, N.; ALMEIDA, M.A.; STEIN, D.P.; MELO, M.S. de; CREMONINI, O.A. 1981. Mapa Geológico do Estado de São Paulo. São Paulo, XPT/PRÓ-MINÉRIO, v. 2 (Monograftas, 6). (Escala $1: 500.000$ ).

BOHLEN, S.R.; WALL, V.J.; BEOTTCHER, A.L. 1983. Experimental investigations and geological applications of equilibria in the system $\mathrm{FeO}-\mathrm{TiO}_{2}-\mathrm{Al}_{2} \mathrm{O}_{3}-\mathrm{SiO}_{2}-\mathrm{SiO}_{2}$. American Mineralogist, 68, 1049-1058.

BORRAIDAILE, G.J.; BAYLY, M.B.; POWELL, C.McA., eds. 1982. Atlas of deformational and metamorphic: rock fabrics. Berlin-Heidelberg, Springer-Verlag. $551 \mathrm{p}$.

CAMPANHA, G. A. da C.; SADOWSKI, G. R. 1998. Cinturão Ribeira: Tectônica e questões pendentes sobre sua evolução, In: CONGRESSO BRASILEIRO DE GEOLOGIA, 40, Belo Horizonte, 1998. Anais. Belo Horizonte, SBG, p. 17.

CAMPOS NETO, M.da C. \& BASEI, M.A.S. 1983a. Evolução estrutural brasiliana do nordeste de São Paulo: dobramentos superpostos e esboço estratigráfico e tectônico. In: SIMPÓSIO REGIONAL DE GEOLOGIA, 4, São Paulo, 1983. Atas. São Paulo, SBG-NSP, p. 61-78.

CAMPOS NETO, M.da C. \& BASEl, M.A.S. 1983b. A importância dos falhamentos transcorrentes na configuração do Pré-Cambriano entre São José dos Campos e Amparo (SP). In: SIMPÓSIO REGIONAL DE GEOLOGIA, 4, São Paulo, 1983. Atas. São Paulo, SBG-NSP, p. 79-90.

CAMPOS NETO, M.C. \& CABY, R. 1999. Neoproterozoic high-pressure metamorphism and tectonic constraint from the nappe system south of the São Francisco Craton, southeast Brazil. Precambrian Research, 97: 3-26.

CAMPOS NETO, M.C. da \& FIGUERREDO, M.C.H. de. 1992. A orogenia Rio Doce. In: CONGRESSO BRASILEIRO DE GEOLOGIA, 37, São Paulo, SP, 1992. Boletim. São Paulo, SBG, v. 1, p. 276-277.

CAMPOS NETO, M. da C. \& FIGUEIREDO, M.C.H. de. 1995a. Sistemas orogennicos do Ciclo Brasiliano no sudeste brasileiro. Anais da Academia Brasileira de Ciências, 67(4): 526.

CAMPOS NETO, M. da C. \& FIGUEIREDO, M.C.H. de. 1995b. The Rio Doce orogeny, Southeastern Brasil. J. South Amer. Earth Sci. 8(2): 143-162.

CAMPOS NETO, M.da C. \& BASEl, M.A.S.; ALVES, F.R.; VASCONCELOS, A.C. de. 1984. A Napppe de Cavalgamento de Socorro (SP MG). In: CONGRESSO BRASILEIRO DE GEOLOGIA, 33, Rio de Janeiro, 1984. Anais. Rio de Janeiro, SBG, v, 4, p. 1809-1822. CARMICHAEL, D.M. 1970. Intersecting isograds in the Whestone Lake area, Ontario. Journal of Petrology, 11(1):
147-181.

CARNEIRO, C.D.R. 1983. Análise estrutural do Grupo São Roque na faixa entre o Pico do Jaraguá e a Serra dos Cristais, SP. São Paulo, 155p. (Tese - Doutoramento) - Instituto de Geociências, Universidade de São Paulo.

CARNEIRO, C.D.R.; COUTINHO, J.M.V.; SUEMITSU, A.; RODRIGUES, E. de P. 1984a. Relaçöes geométricás e temporais de eventos magmáticos no Grupo São Roque a partir da descoberta de rochas metavulcânicas e da 
aplicação de critérios estruturais. In: CONGRESSO BRASLLEIRO DE GEOLOGIA, 33, Rio de Janeiro, 1984. Anais. Rio de Janeiro, SBG, v. 7, p. 3196-3211.

CARNEIRO, C.D.R.; HASUI, Y.; DANTAS, A.S.L. 1984b. Contribuição ao estudo da litoestratigrafia do Grupo São Roque na Faixa Jaraguá-Cristais - SP. In: CONGRESSO BRASHLEIRO DE GEOLOGIA, 33, Rio de Janeiro, 1984. Anais. Rio de Janeiro, SBG, v. 7, p. 3212-3226.

CAVALCANTE, J.C. \& KAEFER, L.Q. 1974. Geologia da Folha Santos (parcial). In: CONGRESSO BRASILEIRO DE GEOLOGIA, 28, Porto Alegre, 1974. Anais, Porto Alegre, SBG, v. 4, p. 227.245.

CAVALCANTE, J.C.; CUNHA, H.C. da S.; CHIEREGATI, L.A.; KAEFER, L.Q.; ROCHA, J.M.da; DAITX, E.C; COUTINHO, M.G. da N.; YAMAMOTO, K.; DRUMOND, J.B.V; ROSA; D.B.; RAMALHO, R. 1979. Projeto Sapucá, Estados de São Paulo, Rio de Janeiro e Minas Gerais; relatório final de geologia. Brasília, DNPM/CPRM, Superintendência Regional de São Paulo. 229p.il. (DNPM. Série Geologia, 5. Seç̧ão Geoogia Básica, 2)

CHINNER, G.A. 1960. Pelitic gneisses with varying ferrous/ferric ratios from Glen Clova, Angus, Scotland. Joumal of Petrology, I(2): 178-217.

CHINNER, G.A. 1961. The origin of sillimanite in Glen Clova, Angus. Joumal of Petrology, 2(3): 312-323.

CHINNER, G.A. 1966. The significance of the aluminium silicates in metamorphism. Earth Science Reviews, 2 : $111-126$.

CORDANI, U.G. \& BITTENCOURT, I. 1967a. Determinações de idade potássionargônio em rochas do Grupo Açungui. In: CONGRESSO BRASILEIRO DE GEOLOGIA, 21, Curitiba, 1967. Anais. Curitiba, SBG, p. 218 233.

CORDANI, U.G. \& BITTENCOURT, 1. 1967b. Estudo geocronológico no Grupo Açungui. Boletim Paranaense de Geociências, n. 26, p.58-59. / Apresentado a 21. Congresso Brasileiro de Geologia, Curitiba, 1967.

CORDANI, U.G. \&. KAWASHITA, K. 1971. Estudo geocronológico pelo método Rb/Sr de rochas graníticas intrusivas no Grupo Açungui. In: CONGRESSO BRASILEIRO DE GEOLOGIA, 25, São Paulo, 1971. Anais. São Paulo, SBG, v.1, p. $105-110$.

CORDANI, U.G. \& TEIXEIRA, W. 1979. Comentários sobre as determinações geocronológicas existentes para as regiōes das folhas Rio de Janeiro, Vitória e Iguape. In: SCHOBBENHAUS FILHO, C, coord. Carta geológica do Brasil ao milionésimo, folhas Rio de Janeiro (SF-23), Vitória (SF-24) e Iguape (SG-23). Brasília, MME/DNPM, p. 175-207.

CORDANI, U.G.; GOMES, C.B. \& GIRARDI, V.A.V. 1963. Rochas cálcio-silicatadas da região de Perus, SP. Anais da Academia Brasileira de Ciências, 35: 361-372.

COUTINHO, J.M.V. 1950. Petrologia da região de São Roque, São Paulo. São Paulo, 15lp. (Tese Doutoramento) Faculdade de Filosofia, Ciências e Letras, Universidade de São Paulo.

COUTINHO, J.M.V. 1953. Petrologia da região de São Roque, São Paulo. Boletim da Faculdade de Filosofia, Ciências e Letras-USP (159): 1 87. (Mineralogia, 11).

COUTINHO, J.M.V. 1955. Sobre os metaconglomerados dos arredores de São Paulo. Eng. Min. Metal, 21(121): $15-16$.

COUTINHO, J.M.V. 1968a. O Grupo Açungui nas vizinhanças da capital de São Paulo. In: CONGRESSO BRASILEIRO DE GEOLOGIA, 22, Belo Horizonte, 1968. Boletim de Resumos. Belo Horizonte, SBG, p. 8485.

COUTINHO, J.M.V. 1968b. Série facial de metamorfismo na região do município de São Paulo. In: CONGRESSO BRASILEIRO DE GEOLOGIA, 22, Belo Horizonte, 1968. Boletim de Resumos. Belo Horizonte, SBG, p.2.

COUTINHO, J.M.V. 1971. Estado atual do conhecimento do Pré-Cambriano Superior sul-brasileiro; uma sintese. In: CONGRESSO BRASHLEIRO DE GEOLOGIA, 25, São Paulo, 1971. Anais. São Paulo, SBG, v.1, 83.92. 
COUTINHO, J.M.V. 1972. Petrologia do Pré-Cambriano em São Paulo e arredores. Boletim do IG USP, 3:5-99.

COUTINHO, J.M.V. \& TAKEDA, F.K. 1955. Metaconglomerados e rochas associadas no município de São paulo. Bol. Fac. Fil. Ciênc. e Letr. USP, 186: 5-47. (Mineralogia, 13).

COUTINHO, J.M.V.; RODRIGUES, E.de P.; SUEMOTSU, A; JULIANI, C.; BELJAVSKIS, P.; PEROSA, P. de T.Y. 1982. Geologia e petrologia da seqüencia vulcano-sedimentar do Grupo São Roque na Serra de Itaberaba - SP. In: CONGRESSO BRASILEIRO DE GEOLOGIA, 32, Salvador, 1982. Anais. Salvador, SBG, v. 2, p. 624-640.

DANTAS, A.S.L. 1990. Geologia da faixa São Roque e intrusivas associadas na região entre São Paulo e Mairiporâ, Norte de São Paulo - SP. São Paulo, 199p. (Dissertação - Mestrado) - Instituto de Geociências, Universidade de São Paulo.

DANTAS, A.S.L. 1992. Geologia, estruturas e evolução tectônica da Faixa São Roque na região entre São Paulo e Mairiporã (SP). In: CONGRESSO BRASILEIRO DE GEOLOGIA, 37, São Paulo, 1992. Boletim. São Paulo, $\mathrm{SBG}$, v. 2, p. 132-133.

DANTAS, E.L.; HACKSPACHER, P.C.; GODOY.A.M.; SATO, K.; PIMENTEL, M.; OLIVEIRA, M.A.F de.; FETTER, A. 1999. Characterization of the generating sources of continental crust of the Ribeira Bell through isotope of $\mathrm{Nd}$ in the state of São paulo, SE of Brazil. In: SIMPÓSIO SUDAMERICANO DE GEOLOGIA ISOTOPICA, 2, Cordoba. 1999. Actas. Cordoba, SEGEMAR, p. 192-195.

DEER, W.A.; HOWIE, R.A. \& ZUSSMAN, J. 1992. An introduction to the rock-forming minerals. 2 ed. Harlow, Longman Scientific \& Technical. 696p.

EBERT, H. 1967. A estrutura pré-cambriana do sudoeste de Minas Gerais e áreas adjascentes. Boletim Paranatense de Geociências, n. 26, p.42-45. / Apresentado a 21. Congresso Brasileiro de Geologia, Curitiba, 1967. Programa, Resumos e Roteiros das Excursões/.

EBERT, H. 1968. Ocorrências da fácies granulítica no sul de Minas Gerais e áreas adjascentes, em depedência da estrutura orogênica: hipóteses sobre sua origem. Anais da Academia Brasileira de Ciências, 40: 215-229. Suplemento.

EBERT, H. 1971. Os Paraíbides entre São João Del Rei, Minas Gerais e Itapira, Săo Paulo e a bifurcação entre Paraíbides e Araxádes. In: CONGRESSO BRASILEIRO DE GEOLOGIA, 25, São Paulo, 1971. Boletim Especial: Resumos das Comunicaçóes. SBG, São Paulo, $\mathrm{n}^{2} 1$, p. 177.178.

EBERT, H.D.; HASUI, Y,; COSTA, J. B. S. 1991. O caráter transpressivo do Cinturão Transcorrente Rio Parába do Sul. In: SIMPÓSIO NACIONAL DE ESTUDOS TECTÔNICOS, 3, Rio Claro, 1991. Boletim. SBG/NSP, Rio Claro, p. 139-141.

EBERT, H. D.; HASUI, Y.; SARTORATO, G.; ALMEIDA, S.H.; COSTA, J. B. S. 1993 a. Arcabouço estrutural e tectônica transpressiva das faixas móveis das bordas sul e sudeste do cráton do São Francisco e da sintaxe de Guaxupé. In: SIMPÓSIO NACIONAL DE ESTUDOS TECTÔNICOS, 4, Belo Horizonte, 1993. Bolefint. Belo Horizonte, SBG/NMG, p.166-171.

EBERT, H. D.; NEVES, M. A.; HASUI, Y.; LOPES, J. A.; GUERRA, M. 1995. Compartimentação Crustal e Evolução Cinemática da Província Mantiqueira Através de Modelagem Física. In: SIMPÓSIO NACIONAL. DE ESTUDOS TECTONNICOS, 5, Gramado, 1995. Boletim. Gramado, SBG/NRS, p. 26-28.

EBERT, H.D.; NEVES, M.A.; HASUI, Y.; SZATMARI, P.; AIRES, J.R. 1993b. Evolução dos cinturões de cisalhamento entre os blocos São Paulo, Vitória e Brasília através da tectônica colisional oblíqua: uma modelagem tisica. In: SIMPÓSIO NACIONAL DE ESTUDOS TECTÔNICOS, 4, Belo Horizonte, 1993. Boletim. Belo Horizonte, SBG/NMG, p. 254-258.

EMPRESA METROPOLITANA DE PLANEYAMENTO DA GRANDE SÃO PAULO (EMPLASA). 1980. Mapa Geológico da Grande São Paulo. São Paulo, EMPLASA (2 Folhas). (Escala 1: 100.000).

ENDO, l. \& MACHADO, R. 1993. Sistema de cisalhamento transatântico: um modelo tectônico transpressional para o Neoproterozóico do Brasil oriental. In: SIMPÓSIO NACIONAL DE ESTUDOS TECTÔNICOS, 4, Belo Horizonte, 1993. Boletim. Belo Horizonte, SBG/NMG, p. 356-359.

FtRREIRA, C. J. 1991. Geologia, petrografia e tipologia de zircão da Suíte Intrusiva Itaqui, Barueri (SP). Rio Claro, 253p. (Dissertação - Mestrado) - Instituto de Geociências e Ciências Exatas, Universidade Estadual Paulista. 
FERREIRA, C. J. 1996. Geoquímica e análise dá deformação do Complexo Itaqui, SP: Evolução de granitos cálcioalcalinos poli-intrusivos. Rio Claro, 272p. (Tese - Doutorado) -- Instituto de Geociências e Ciências Exatas, Universidade Estadual Paulista.

FERREIRA, C. J. \& WERNICK, E. 1995. Gradientes de deformação magmática do Granito Poli-Intrusivo Itaqui (SP) com base na razão axial de enclaves. In: SIMPÓSIO NACIONAL DE ESTUDOS TECTONICOS, 5 , 1995, Gramado. Boletim. Gramado, SBG, p. 189-190.

FERREIRA, C.J. \& WERNICK, E. 1996. Quantificação de enclaves magmáticos máticos do Granito Itaqui, SP e implicações petrológicas e estruturais. Anais da Academia Brasileira de Ciências, 68(4); 598 - 599.

FERREIRA, C. J. \& WERNICK, E. 1997a. Tectônica de Emplacement Durante a Evolução de Zonas de Cisalhamentos Transpressivos: Complexo Itaqui, SP. In: SIMPÓSIO DE GEOLOGIA DO SUDESTE, 5 , Penedo-latiaia, 1997. Atas. Penedo-Itatiaia, RJ. SBG/NSP-RJ/ES, ABGE/NRJ, p. 175-176.

FERREIRA, C. J.; WERNICK, E. 1997b. Evolução Magmática de Granitóides Poli-Intrusivos Associados com Zonas de Cisalhamento: Complexo Itaqui, SP. In: SIMPÓSIO DE GEOLOGIA DO SUDESTE, 5, Penedo.Itatiaia, 1997. Atas. SBG/NSP-RJ/ES, ABGE/NRJ, p. 147-149.

FIGUEIREDO, M. C. H. de; CAMPOS NETO, M. da C. 1994. O arco magmático cálcio-alcalino de alto potássio da microplaca Apiaí-Guaxupé. In: CONGRESSO BRASILEIRO DE GEOLOGIA, 38, Balneário Camboriú, 1994. Boletim. Balneário Camboriú, SBG, v. 1, p. 620-621.

FIGUEIREDO, M.C.H.; BERGMANN, M.; PENALVA, F.; TASSINARI,C.C.G. 1982. Ocorrência de pillow-lavas no Grupo São Roque, Estado de São Paulo. Revista Ciências da Terra, (2): 6-8.

FRASCA, M. H. B. de O.; COUTINHO, J. M. V. 1998. Geoquímica de rochas carbonáticas pré-cambrianas dos grupos Açungui e São Roque, SP. In: CONGRESSO BRASILEIRO DE GEOLOGLA, 40, Belo Horizonte, 1998. Anais. Belo Horizonte, SBG, p. 469.

FRASCÁ, M.H.B. de \& HACHIRO, J. 1996. Composições isotópicas de carbono e oxigênio de rochas metacarbonáticas dos grupos Açungui c São Roque, SP. In: CONGRESSO BRASHLEIRO DE GEOLOGIA, 39, Salvador, 1996. Anais. Salvador, SBG, v. 6, p. 551 - 553.

GALEMBECK, T. M. B.; WERNICK, E. 1998. Tipos de plutons rapakivi na província Itu, SP. In: CONGRESSO BRASILEIRO DE GEOLOGL, 40, Belo Horizonte, 1998. Anais. Belo Horizonte, SBG, p. 519.

GANGUL,Y, J. 1968. Analysis of the stabilities of chloritoid and staurolite and some equilibria in the system feO$\mathrm{Al}_{2} \mathrm{O}_{3}-\mathrm{SiO}_{2}-\mathrm{H}_{2} \mathrm{O}-\mathrm{O}_{2}$. American Joumal of Science, 266(4): 277-298.

GANGULY, J. 1969. Chloritoid stability and related parageneses: theory, experiments, and applications. American Joumal of Science, 267(8): 910-944. GANGULY, J. 1972. Staurolite stability and related parageneses: theory, experiments and applications. Journal of
Petrology, 13(2):335-365.

GARCIA, M. da G. M. 1996. Análise Cinemática do Setor de Junção entre as Zonas de Cisalhamento Direcionais São Bento do Sapucaí, Sertãozinho e Jundiuvira, nas imediafões de Piracaia - SP. São Paulo, 104p. (Dissertação - Mestrado) - Instituto de Geociênctas, Universidade de São Paulo.

GARCIA, M. da G. M. \& CAMPOS NETO, M. da C. 1996. Evidencias de inversäo cinemática em zonás de cisalhamento direcionais na Faixa Ribeira, região de Piracaia - SP. In: CONGRESSO BRASILEIRO DE GEOLOGIA, 39, Salvador, 1996. Anais. Salvador, SBG, v.1, p. 442 - 443.

GODOY, A. M.; HACKSPACHER, P. C.; OLIVEIRA, M. A. F. de. 1996a. Geologia da Região de Sorocaba - SP. Geociências, 15: 89-110. Número Especial.

GODOY, A. M.; HACKSPACHER, P. C.; OLIVEIRA, M. A. F. de ; CASTRO, J. C. de. 1994. Geologia das folhas Sorocaba, Brigadeiro Tobias e Sananduva, SP, em escala 1:25 000. In: CONGRESSO BRASILEIRO DE GEOLOGIA, 38, Balneário Camboriú, 1994. Boletim. Baneário Camboriú, SBG, v. 2, p. 97-98.

GODOY, A. M.; OLIVEIRA, M. A. F. de; HACKSPACHER, P. C. 1996b. Geoquímica das Rochas Granitódes da Folha São Roque - SP. Geociências, 15: 67-88. Número Especial.

GOMES, C.de B. 1962. Contribuição ao conhecimento dos anfibolitos da região do Jaraguá, S.P. Boletim da Sociedade Brasileira de Geologia, 11(1): 57.78 . 
GOMES, C. de B. 1972. Chemical changes in plagioclases and their bearing on the petrologic history of na amphibolite body. American Mineralogist, 57(11-12): 1860-1870.

GOMES, C.de B. 1973. Nota sobre os minerais opacos dos anfibolitos do Jaraguá, S.P. Anais da Academia Brasileira de Ciências, 45(1): 103-107.

GOMES, C.de B; OOSTERWYCK-GASTUCHE, M.C.van \& DUTRA, C.V. 1972. Anfibólios do corpo anlïbolítico do Jaraguá, S.P. Revista Brasileira de Geociências, 2(4) :236-259.

GOMES, C.de B.; SANTINI, P.; DUTRA, C.V. 1964. Petrochemistry of a precambrian amphibolite from the Jaraguá area, São Paulo, Brazil. Journal of Geology, 72(5):664-680.

GUIDOT'Tl, C.V. 1968. Prograde muscovite pseudomorphs after staurolite in the Rangeley-Oquossoc areas, Maine. The American Mineralogist, 53(7/8): 1368-1376.

HACKSPACHER, P.C., coord. 1988. Geologia das quadriculas Cabreava e Moreiros (escala 1:25.000). In: Projeto Cabreúva. Rio Claro, UNESP-IGCE/PRÓ-MINÉRIO, 2v. (Relatório Finat).

HACKSPACHER, P.C. 1994. Tectônica transtensivaltranspressiva e alojamento de rochas plutônicas, à exemplo da folha Cabreúva (SP) 1:50000. Rio Claro, 203 p. (Tese Livre - Docência) - Instituto de Geociências e Ciências Exatas, Universidade Estadual Paulista.

HACKSPACHER, P.C.; GODOY, A. M.; OLIVEIRA, M. A. F. de. 1991. Estrutura e tectônica do cinturão de cisalhamento de cavalgamento/transcorrência do Sudeste brasileiro-Excursão 2. In: SIMPÓSIO NACIONAL. DE ESTUDOS TECTÔNICOS, 3, Rio Claro, 1991. Boletim. Rio Claro, SBG/NSP, p. 223-230.

HACKSPACHER, P.C.; GODOY, A.M.; OLIVEIRA, M.A.F de. 1992a.Geologia da metade oeste da Folha de Cabreúva, São Paulo, Brasil. Geociêncais, 11(2): 9-39.

HACKSPACHER, P.C.; GODOY, A.M.; OLIVEIRA, M.A.F de, 1992b. Geologia da Folha Pirapora, SP, em 1:25000. In: CONGRESSO BRASILEIRO DE GEOLOGIA, 37, São Paulo, 1992. Boletim. São Paulo, SBG, v 2, p. $127-128$.

HACKSPACHER, P.C.; GODOY, A.M.; Ol.JVEIRA, M.A.F. 1993a. Evolução crustal do Bloco São Roque, ná região sudeste do Estado de São Paulo. Revista Brasileira de Geociências, 23(3): 260-264.

HACKSPACHER, P. C.; GODOY, A. M.; OLIVEIRA, M. A. F. de. 1994. Geologia da Folha Cabreúva - SP, 1:50.000, SP. In: CONGRESSO BRASILEIRO DE GEOLOGIA, 38, Balneário Camboriú, 1994. Boletim. Balneário Camboriú, $S B G$, v. 2, p. 79-81.

HACKSPACHER, P.C.; GODOY, A.M.; OLIVEIRA, M.A.F.de. 1996. Geologia da Folha Cabreúva - SP, 1:50.000, Geociências, 15: 111-131. Número Especial.

HACKSPACHER, P. C.; GODOY, A. M; OLIVEIRA, M. A. F. de; KRUHL, J. 1998. Evolução geológica precambriana do sudeste do estado de São Paulo, região de São Roque. In: CONGRESSO BRASILEIRO DE GEOLOGIA, 40, Belo Horizonte, 1998. Anais. Belo Horizonte, SBG, p. 26.

HACKSPACHER, P.C.; GODOY, M.L.S; SANTOS, É.L. 1993b. Petrotrama de quattzo e feldspato ao longo da Zona de Cisalhamento Jundiuvira, Cabreúva (SP). Geociêncais, 12(1): 141-153.

HACKSPACHER, P. C.; OLIVEIRA, M. A. F. de; GODOY, A. M. 1992c. Geologia dos Grupos Serra do Itaberaba São Roque na Folha Cábreúva-SP, 1:50.000. In: CONGRESSO BRASILEIRO DE GEOLOGIA, 37, São Paulo, 1992. Boletim. São Paulo, SBG, v. 2, p. 124-125.

HACKSPACHER, P.C.; OLIVEIRA, M.A.F. de; GODOX, A.M.; VAlERIANO, C. de M. 1989. A geologia dos Grupos Itapira e São Roque na região de Cabreúva: uma revisão. In: SIMPÓSIO DE GEOLOGIA DO SUDESTE, 1, Rio de Janeiro, 1989. Boletim de Resumos. Rio de Janeiro, SBG/NRJ-SP, p. 93-94.

HACKSPACHER, P.C.; DANTAS, E.L.; GODOY, A.M.; OLIVEIRA, M.A.F. de; FETTER, A.; VAN SCHMUS, W.R. 1999. Considerations about the evoution of the Riberia Belt in the São Paulo state - Brazil, from U/Pb geochronology in metavolcanic rocks of the São Roque Group. In: SIMPÓSIO SUDAMERICANO DE GEOLOGIA ISOTOPICA, 2, Cordoba. 1999. Actas. Cordoba, SEGEMAR, p. 310-313.

HASUI, Y. 1973. Tectônica da área das folhas de São Roque e Pilar do Sul. São Paulo, 190p. (Tese Livre Docência) - Instituto de Geociências, Universidade de São Paulo. 
HASUI, Y.1975a. Evolução polifásica do Precambriano a oeste de São Paulo. Boletim do IG/USP, (6):95-108.

HASUI, Y. 1975b. Geologia da Folha São Roque. Boletim do IG/USP, (6): 157-183.

HASUI Y. \& HAMA, M. 1970. Idades potássio-argônio de rochas pré-cambrianas da região de São Paulo -- Jundiaí --. Sorocaba. In: CONGRESSO BRASILEIRO DE GEOLOGIA, 24, Brasília, 1970. Resumo das Comunicaf̧oes. Brasília, SBG, Boletim especial (1):75-76.

HASUI, Y. \& HAMA, M. 1972. Geocronologia do Grupo São Roque pelo método potássio-argônio. Revista Brasileira de Geociências, 2(1):18-24.

HASUI, Y. \& SADOWSKI, G.R. 1976. Evolução geologica do Precambriano na região sudeste do Estado de São paulo. Revista Brasileira de Geociências, 6(3):182-200.

HASUI, Y.; SADOWSKI, G.R.; CARNEIRO, C.D.R. 1976. Considerações sobre a estratiguafia do Pré-Cambriano na região de São Paulo. Boetim do. IG/USP, (7):107-112.

HASUI, Y.; ALMEIDA, F.M.M.; BRITO NEVES, B.B, 1978a. As estruturas brasilianas. In: CONGRESSO BRASILEIRO DE GEOLOGLA, 30, Recife, 1978. Anais. Recife, SBG, v.6, p. 2423-2437.

HASUI, Y.; CARNEIRO, C.D.R.; BISTRICHI, C.A. 1978b. Os granitos e granitóides da região de dobramentos sudeste nos estados de São Paulo e paraná. In: CONGRESSO BRASILEIRO DE GEOLOGIA, 30, Recife, 1978. Anais, Recife, SBG, v.6, p. 2594-2608.

HASUI, Y.; CARNEIRO, C.D.R.; COIMBRA, A.M. 1975. The Ribeira Folded Belt. Revista Brasileira de Geociências, 5(4):257-266.

HASUI, Y.; DANTAS, A.S.L.; CARNEIRO, C.D.R.; BISTRICHI, C.A. 1981. O embasamento Pré-Cambriano e Eopaleoźico em São Paulo. In: ALMEIDA, F.F.M. de; HASUI, Y.; PONÇANO, W.L.; DANTAS, A.S.L.; CARNEIRO, C.D.R.; MELO, M.S. de; BISTRICHI, C. A . Mapa Geológico do Éstado de Säo Paulo, p. 12. 45. (Escala $1: 500.000)$.

HASUI, Y; HARALY, N.L.E; COSTA, J.B.S. 1993. Megaestruturação pré-cambriana do teritório brasileiro baseada em dados geotísicos e geológicos. Geociêncais, 12(1): 7-31.

HASUI, Y.; HARALYI, N.L. E.; GALLI, V.A.; MIOTO, J.A. 1991 . Estruturação pré-cambriana do Estado de São Paulo com base en dados geofísicos. In: SIMPÓSIO NACIONAL DE ESTUDOS TECTONICOS, 3, Rio Claro, 1991. Boletim. Rio Claro, SBG/NSP, p. 137-138.

HASU, Y; PENALVA, F; HENNIES, W. "T. 1969. Geologia do Grupo São Roque. In: CONGRESSO BRASILEIRO DE GEOLOGIA, 23, Salvador, 1969. Anais. Salvador, SBG, p. 101-134. HASUI, Y.; TOGNON, A.A.; SOARES, L.; CSORDAS, S.M. 1978c. Geologia e tectônica da Serra do Japi.
Boletim do IG/USP, (9):17-24.

HENNIES, W.T,; HASU, Y.; PENALVA, F. 1967. O falhamento transcorrente de Taxaquara. In: CONGRESSO BRASILEIRO DE GEOLOGIA, 21, Curitiba, 1967. Anais. Curitiba, SBG, p. 159-168.

HIGGINS, M.W. 1971. Cataclastic rocks. Washington, US Geological Survey, Professional Paper (687), 97p.

HOSCHEK, G. 1969. The stability of staurolite and chloritoid and their significance in metamorphism of pelitic rocks. Contributions to Mineralogy and Petrology, 22: 208-232.

HSU, L.C. 1968. Selected phase relationships in the system Al-Mn-Fe-Si-O-H: a model for garnet equilibriat. Jounal of Petrology, 9:40-83.

INSTYTUTO GEOGRÁFICO E GEOLÓGICO. 1947. Carta geológica de São Paulo (Brasil). São Paulo, IGG. (Escala $1: 1.000 .000)$. INSTTTUTO GEOGRÁfICO E GEOLÓGICO. 1963. Carta geológica de São Paulo (Brasil). São Paulo, IGG.
(Escala $1: 1.000 .000$ ). 
JANASI, V. de A. \& ULBRICH, H.H.G.J. 1991. Late Ptoterozoic granitoid magmatism in the State of São Paulo, Southeastern Brazil. Precambrian Research, 51:351-374.

JANASI, V. de A.; ULBRICH, H. P. G. J.; LEITE, R. J. 1994. Diversidade do magmatismo granítico tardibrasiliano na região de Piedade, SP: Aspectos petrográficos e geoquímicos. In: CONGRESSO BRASILEIRO DE GEOLOGIA, 38, Balneário Camboriú, 1994. Boletim. Balneário Camboriú, SBG, v. 1, p. 131-133.

JANASI, V. A.; VASCONCELLOS, A.C.B.C.; VLACH, S.R.F.; MOTIDOME, M. J. 1990. Granitódes da regiắo entre as cidade de São Palulo e Piedade (SP): faciologia e contexto tectônico. In: CONGRESSO BRASILEIRO DE GEOLOGIA, 36, Natal, 1990. Anais. Natal, SBG, v. 4, p. 1925-1935.

JULIANl, C. 1992. O embasamento pré-cambriano da Bacia de São Paulo. In: PROBLEMAS GEOLÓGICOS E GEOTÉCNICOS NA REGIÃO METROPOLITANA DE SÃO PAULO, São Paulo, 1992. Aias. São Paulo, ABAS-ABGE-SBG/NSP, p.3-20.

JULIANI, C. 1993. Geologia, petrogênese e aspectos metalogenéticos dos grupos Serra do Itaberaba e São Roque nat região das serras do ltaberaba e Pedra Branca, NE da cidade de São Paulo, SP. São Paulo, 2v. (Tese Doutorado) - Instituto de Geociências, Universidade de São Paulo.

JULIANI, C. 1994. Metamorlismo dos grupos Serra do Itaberaba e São Roque na região da Serra do Itaberaba, entre Guarulhos e Santa Isabel - SP. In: CONGRESSO BRASILEIRO DE GEOLOGIA, 38, Balneário Camboriú, 1994. Boletim. Balneário Camboriú, SBG, v. 3, p. 82-83.

JULIANI, C. 1997. Geologia da região das Serras do Itaberaba e da Pedra Branca, entre Guarulhos e Santa Isabel (SP). Anais da Academia Brasileira de Ciências, 69(3): 440-44l.

JULLANI, C. \& BELJAVSKIS, P. 1983. Geologia e evolução geológico-estrutural preliminar do Grupo São Roque na região da Serra de Itaberaba (SP). In: SIMPÓSIO REGIONAL DE GEOLOGIA, 4, São Paulo, 1983. Atas. São Paulo, SBG-NSP, p. 113-126.

IULIANI, C. \& BELJAVSKIS, P. 1995. Revisão da litoestratigrafiada Faixa São Roque/Serra do Itaberaba (SP). Revista do Instituto Geológico, 16(1/2): 33-58.

IULIANI, C; BELJAVSKIS, P; SCHORSCHER, H.D. 1986. Petrogênese do vulcanismo e aspectos metalogenéticos associados: Grupo Serra do laberaba na regiño do São Roque - SP. In: CONGRESSO BRASILEIRO DE GEOLOGIA, 34, Goiânia, 1986. Anais. Goianta, SBG, v. 2, p. 730-743.

JULIANI, C.; MARTIN, M.A.; CLARIMUNDO, S. de J. 1997a. Os metarcóseos do Morro do Polvilho: implicações para a geocronologia e para evolução crustal dos grupos Sera do Itaberaba e São Roque (SP). Anais da Academia Brasileira de Ciências, $69(3): 441$.

JULIANI, C.; MARTIN, M. A. B.; McREATH, I.; PÉREZ,AGUILAR, A.; CLARIMUNDO, S. de J.; CHIARINI, A. P.; FERNANDES, F. 1998. A evolução dos grupos Serra do taberaba e São Roque a nordeste e noroeste da cidade de São Paulo (SP). In CONGRESSO BRASILEIRO DE GEOLOGIA, 40, Belo Horizonte, 1998. Anais. Belo Horizonte, $\mathrm{SBG}, \mathrm{p} .12$.

JULIANI, C.; PÉREZ AGUILAR, A.; MARTIN, M.A.B. 1996a. Ocorrencia de anfibolitos com cummingtonita/antofilita, marunditos e turmalinitos em sequências metavulcano-sedimentares de grau médio e sua implicação como guia de prospecção de ouro e metais de base. In: CONGRESSO BRASILEIRO DE GEOLOGIA, 39, Salvador, 1996. Anais. Salvador, SBG, v.3, p.111-113.

JULIANI, C.; PÉREZ AGUILAR, A.; MARTIN, M.A. 1997b. Geotermobarometria e evolução metamórfica P.T-t do Grupo Serra do Itaberaba (SP). Anais da Academia Brasileira de Ciências, 69)(3): 441 - 442.

JULIANI, C.; PÉREZ AGUILAR, A.; MARTIN, M.A.B.; BELJAVSKIS, P. 1995. Ocorrência e petrogratia dos meta-riólitos da Formação Nhanguçu - Grupo Serra do Itaberaba (SP). In: SIMPÓSIO DE GEOLOGIA DO SUDESTE, 4, Águas de São Pedro. Boletim de Resumos. SBG/NSP-NRJ/ES, p. 137.

JULIANI, C.; PÉREZ AGUILAR, A.; MARTIN, M.A.B.; BELJAVSKIS, P. 1996b. Ocorrência e petrografia dos metarriólitos da Formação Nhanguçu - Grupo Serra do Itaberaba (SP). Revista Brasileira de Geociencias,
26(2): $113-116$. 
JULIANI, C; SCHORSCHER, H.D.; PÉREZ AGUILAR, A. 1994. Corundum-margarite schists ("Marundites") in the precambrian Serra do Itaberada Group, São Paulo, Brazil: Geological relationships and petrogenesis. Ancis da Academia Brasileira de Ciências, 66(4): 498.

JULIANI, C.; MARTIN, M.A.B.; CLARIMUNDO, S.de J.; MCREATH, L; PERTERSEN Jr., K.J. 1999. Geologia dos grupos Serra do Itaberaba e São Roque entre o Píco do Jaraguá e Araçarigüama, São Paulo. In: SIMPÓSTO DE GEOLOGIA DO SUDESTE, 6, Águas de São Pedro, Boletim de Resumos. SBG/NSP ARJ/ES, p. 26.

KINOSHITA, H. 1976. Aplicabilidade do método ${ }^{40}$ Ar ${ }^{30}$ Ar em rocha policíclicas. São Paulo, 63p. (Dissertação-Mestrado) - Instituto de Geociências, Universidade de São Paulo.

KNECHT, T, 1943. Staurolita da Série de São Roque no município da capital. Boletim do Instituto Geográfico e Geologico, 1(2): 165-167.

KNECHT, T. 1944a. Relatório sobre minério de ferro nos arredores do morro do Vacanga, no município de Parnaíba. Boletim do Instituto Geográfico e Geológico, 2(2): 118-128.

KNECH'T, T. 1944b. Silimanita no Km 20 da via Anhanguera. Boletim do Instituto Geográfico e Geologico, 2(2): $129-131$.

KNECHT, T. 1950. Ocorrências minerais do estado de São Paulo. Volume 1: Municípios de São Pauto, Santana do Parnaíba, Barueri, Franco da Rocha, Guarulhos, Mogi das Cruzes, Suzano e Poá. Instituto Geográfico e Geológico, p. 1-145.

LAZZARI, M. de L. 1987. O metabasito de Pirapora do Bom Jesus, SP. São Paulo, 96p. (Dissertação - Mestrado) Institutto de Geociências, Universidade de São Paulo.

LEFEVRE, V.; BARBOSA, A .F.; WOHLERS, A.; ALMEIDA, F.F.M. de; MELCHER, G.C; FELICÍSSIMO JR., J.; GUIMARÃES, J.E.P.; SETZER, J; PAOLIELLO, P.C.; FREITAS, R. O. de; MEZZALIRA, S.; PETRI, S.; KNECHT, T'. 1963. Mapa Geológico do Estado de São Paulo (Brasil). São Paulo, Instituto Geográfico e Geológico. (Escala 1: 1.000.000).

LEITE, R.J. 1997. Geologia, petrografia e geoquímica dos granitóides da região de Piedade, SP. São Paulo, 138p. (Dissertação - Mestrado) - Instituto de Geociências, Universidade de São Paulo.

LEITE, R. J.; JANASI, V. de A.; ULBRICH, H. H. G. J. 1997. Geologia, Petrografia e Geoquímica dos Granitódes da Região de Piedade, SP. In: SIMPÓSIO DE GEOLOGIA DO SUDESTE, 5, 1997, Penedo-Itatiaia. Atas. Penedo-Itatiaia, SBG/NRJ/ES/SP, ABGE/NRJ. p. 156-158.

LIOU, J.G.; KUNIYOSHI, S.; ITO, K. 1974. Experimental studies of the phase relations between greenschist and amphibolite in a basalt system. American Journal of Science, 274: 613-632.

MACHADO, R. 1997. Litogeoquimica e tectônica dos granitóides neoproterozóicos do Cinturão Paraiba do Sul no Estado do Rio de Janeiro. São Paulo, 215p. (Tese - Livre Docência) - Instituto de Geociências, Universidade de Săo Paulo.

MACHADO, R.; ENDO, I. 1993a. O Cinturão de Cisalhamento Atlântico: um exemplo de tectônica transpressional neoproterozóica. In: SIMPÓSIO NACIONAL DE ESTUUDOS TECTÔNICOS, 4, Belo Horizonte, 1993. Boletim. Belo Horizonte, SBG/NMG, p. 188-191.

MACHADO, R.; ENDO, I. 1993b. A megaestrutura em flor positiva do vale do Rio Parába do Sul no Rio de Janeiro e suas implicą̧ôes tectônicas regionais. In: SIMPÓSIO DE GEOLOGIA DO SUDESTE, 3, Rio de Janeiro. Atas. Rio de Janeiro, SBG/NRJ-SP, p. 208-213.

MACHADO, R.; ENDO, 1. 1994. Superposição cinemática brasiliana no Cinturão de Cisalhamento Atlântico e na Cunha de Guaxupé. In: CONGRESSO BRASILEIRO DE GEOLOGIA, 38, Balneário Camboriú, 1994. Boletim. Balneátio Camboriú, SBG, v. 1, p. 269-270.

MACKENZIE, W.S.; GUILFORD, C. 1980. Atlas of rock-forming minerals in thin section. Harlow, Longman. 98p.

MACKENZIE, W.S.; DONALDSON, C.H.; GULLFORD, C. 1991. Atlas of igneous rocks and their textures. Harlow, Longman. 148p. 
MARINI, O.J.; TREIN, E. \& FUCK, R.A..1967. o Grupo Açungui no Estado do Paraná. In: BIGARELLA, J.J.; SALAMUNI, R. \& PINTO, V.M., eds. Geologia do pré-Devoniano e intrusivas subsequentes da porção oriental do Estado do Paraná. Boletim Paranaense de Geociências (23 a 25): 43-103.

MARTIN, M. A. B.; JULIANI, C. 1994. Geologia, petrografia e gênese dos marunditos (margaritancoríndon xistos). In: CONGRESSO BRASILEIRO DE GEOLOGIA, 38, Balneário Camboriú, 1994. Boletim. Balneário Camboriú, SBG, v. 3, p. 77-78

MARTIN, M. A. B.; JULlANI, C.; Cl.ARIMUNDO, S. de J. 1998a. Metavulcanoclásticas básicas e mineralizações auríferas associadas à zona de cisalhamento: Formação Morro da Pedra Preta, Grupo Serra do Itáberaba a NW da cidade de São Paulo, SP. In: CONGRESSO BRASILEIRO DE GEOLOGIA, 40, Belo Horizonte, 1998. Anais. Belo Horizonte, SBG, p. 147.

MARTIN, M. A. B.; JULIANI, C.; CLARIMUNDO, S. de J. 1998b. Metarriólito nas formações Morro da Pedra Preta e Nhanguçu (Grupo Serra do Itaberaba), na região de Santana do Parnaíba-Barueri, SP. In: CONGRESSO BRASLEIRO DE GEOLOGIA, 40, Belo Horizonte, 1998. Anais. Belo Horizonte, SBG, p. 479.

MATHER, J.D. 1970. The biotite isograd and lower greenschist facies in the Dalradian rocks of Scotland. Joumal of Petrology, 11:253-275.

MIYASHIRO, A. 1968. Metamorphism of mafic rocks. In: HESS, H.H. \& POLDERVAART, A., eds. Basalts: the Poldervaart treatise on rocks of basaltic composition. New York, Interscience Publishers, v. 2, p. 799.834.

MIYASHIRO, A. 1973. Metamorphism and metamorphic belts. London, George Allen \& Unwin. 492p.

MORAES REGO, L.F. de .1930. A geologia do petróleo no Estado de São Paulo. Boletim do Serviço Geológico e Mineralógico, (46): $71-76$.

MORAES REGO, L.F. de. 1932. O ouro em São Paulo. Boletim do Instituto de Engenharia, 16(82): $178-181$.

MORAES REGO L.F. de. 1933. Contribuição ao estudo das formações pré-devoneanas de S. Paulo. Boletim do Instituto Astronômico e Geographico, $43 \mathrm{p}$.

MORAIS, S.M. \& CAMPOS NETO, M. da C. 1996. Integração geologica da Folha Santos/Bara de Santos (SF-23Y-D). In: CONGRESSO BRASUleIRO DE GEOLOGIA, 39, Salvador, 1996. Anais. Salvador, SBG, v.1, p.
106.108.

MORAIS, S. M.; SACHS, L. L. B.; DEHLFR, N. M.; RODRIGUES, J. B.; DELGADO, I. de M. 1998. O arcabouço tectônico do Pré-Cambriano da região leste do estado de São Paulo e sul de Minas Gerais. In: CONGRESSO BRASILEIRO DE GEOLOGIA, 40, Belo Horizonte, 1998. Anais. Belo Horizonte, SBG, p. 411.

MORALES, N.; PERES, J. P.; MORAIS, S. M.; ARTUR, A. C. 1995a. Indicadores cinemáticos do granitóide Itapeti - SP. In: SIMPÓSIO DE GEOLOGIA DO SUDESTE, 4, Águas de São Pedro. Boletin de Resumos. SBG/NSP-NRJ/ES, p. 115.

MORALES, N.; PERES, J. P.; MORAIS, S. M.; ARTUR, A. C. 1995b. Características Transtensivas da Zona de Cisalhamento Taxaquara, Exemplificadas Pelas Rochas Granitóides da Região de Mogi clas Cruzes, SP. In: SIMPÓSIO NACIONAL DE ESTUdOS TECTÔNICOS, 5, Gramado, 1995. Boletim. Gramado, SBG/NRS, p.
200-201.

NASCIMENTO, D.B. do; RUEGGER, R. - 1986 - Projeto Jordanésia - Relatório Final, Grupo VII, PRO-MINÉRIO - IGCE/UNESP, $101 \mathrm{p}$.

ODMAN, O.H. 1955. A pre-cambrian conglomerate with pebbles of deep-seated rocks near São Paulo; Brazil Mineraçäo e Metalurgia, 21(121): 32.

OLIVEIRA, E.P. de 1916. Geologia do Estado do Paraná. Boletim do Ministério da Agricultura, 5(1):6-143.

OLIVEIRA,E.P. de. 1925. Analyses de calcareos. Boletim do Servigo Geológico e Mineralógico, (10): 1-45.

OLIVEIRA, M. A. F. de; GODOY, A. M.; HACKSPACHER, P. C.; MORENO, M. M. T. 1994. Novos dados geoquímicos para rochas antibolíticas do Grupo São Roque nas regiões de Cabretiva e Sorocaba - SP. In: CONGRESSO BRASILEIRO DE GEOLOGIA, 38, Balneário Camboúú, 1994. Boletim. Balneário Camboriú $S B G$, v. 3, p. 165-166. 
OLIVEIRA, M. A. F. de; GODOY, A. M.; ZANARDO, A.; ARTUR, A. C.; HACKSPACHER, P. C. MORALES, N. 1992a. Geologia da Folha São Roque - SP. In: CONGRESSO BRASILEIRO DE GEOLOGIA, 37, São Paulo, 1992. Boletim. São Paulo, SBG, v. 2, p. 126-127.

OLIVEIRA, M. A. F. de; GODOY, A. M.; ZANARDO, A.; HACKSPACHER, P. C. 1998. Monticellita e periclásio em horntels cálcio-silicáticos no contato do Maciço Granítico São Francisco, SP. In: CONGRESSO BRASILEIRO DE GEOLOGIA, 40, Belo Horizonte, 1998. Anais. Belo Horizonte, SBG, p. 479.

OLIVEIRA, M. A. F. de.; HACKSPACHER, P. C.; GODOY, A. M. 1992b. Geologia da Folha Japi em 1:25000. In: CONGRESSO BRASILEIRO DE GEOLOGIA, 37, São Paulo, 1992. Boletim. São Paulo, SBG, v. 2, p. 129. 130.

PAOLIELLO, P.C. 1964. Pré-Cambriano Superior (Grupo São Roque). In: Geologia do Estado de São Paulo. Boletim do lnstituto Geográfico e Geológico (41): 37-44.

PASSCHIER, C.W. \& TROUW, R.A.J. 1996. Microtectonics. Berlin, Springer. 289p.

PENALVA, F.; HASUI, Y. 1970. A intrusão granítica dos morros Grande e do T'ico-Tico, município de Caieiras, SP. Anais da Academia Brasileira de Ciências, 42(4):725-730.

PÉREZ-AGUILAR, A. 1996. Geologia, petrografia e gênese dos granada-cordierita-cummingtonita/antofilita anfibolitos e rochas associadas do Grupo Serra do ltaberaba, SP. São Paulo, 168 p. (Dissertação - Mestrado) - Instituto de Geociências, Universidade de São Paulo.

PÉREZ-AGUILAR, A.; JULIANI, C. 1994. Petrografia de granada-cordierita-cummingtonita anfibolitos da serta do Itaberaba. In: CONGRESSO BRASILEIRO DE GEOLOGLA, 38, Balneário Camboriú, 1994. Boletim. Balneário Camboriú, SBG, v. 3, p. 98-99.

PEREZ-AGUILAR, A.; JULIANI, C.; MARTIN, M.A.B. 1996. Caracterização petrográfica de zonas de alteração hidrotermal progressiva prémetamórifea no Grupo Serra do Itaberaba, SP. In: CONGRESSO BRASILEIRO DE GEOLOGIA, 39, Salvador, 1996. Anciss. Salvador, SBG, v.2, p. 22-24.

RAGATKY, D. 1997. Contribuição à geoquímica e geocronologia do Domínio São Roque e da Nappe de Emparräo Socomo-Guaxupé na região de Igaratá e Piracaia, SP. São Paulo, 130 p. (Tese - Doutorado) Instituto de Geociências, Universidade de São Paulo.

RICCOMINI, C. 1989. O rift continental do sudeste do Brasil. São Paulo, 256p. (Fese - Doutorado) - Instituto de Geociências, Universidade de São Paulo.

SACHS, L.L.B. \& CAMPOS NETO, M. da C. 1996. Integração geológica da Folha São Paulo 1:250.000) (SF.23-YC). In: CONGRESSO BRASILEIRO DE GEOLOGIA, 39, Salvador, 1996. Anais. Salvador, SBG, v.1, p. 68. 70 .

SADOWSKI, G.R. 1974. Tectônica da Serra de Cubatĩo, SP. São Paulo, 159 p. (Tese - Doutorado) - Instituto de Geociências, Universidade de São Paulo.

SANTORO, E. 1984. Geologia da Folha Cabreúva, SP. São Paulo, 114p. (Dissertação - Mestrado) - Instituto de Geociências, Universidade de São Paulo.

SANTORO, E. 1986. Organização estrutural do Crupo São Roque ná Folha Cabreúva - SP. In: CONGRESSO BRASILEIRO DE GEOLOGIA, 34, Goiânia, 1986. Anais. Goiânia, SBG, v. 2, p. 891 -904.

SANTORO, E.; CARNEIRO, C.D.R.; OLIVEIRA, M.C.B. de; HACHIRO, J. - 1988 - Estrutura geológica da região de Cajamar-Jordanésia, SP. Revista Brasileira de Geociências, 18(3):353-361.

SANTORO, E.; RAGATKY, D.; TUPINAMBÁ, M. 1997. Domínio Alóctone da Faixa Ribeira na Serra da Mantiqueira, SP. In; SIMPÓSIO DE GEOLOGIA DO SUDESTE, 5, 1997, Penedo-Itatiaia. Atas. PenedoItatiaia, SBG/NRJ/ES/SP, AGBE/NRJ, p. 129-130.

SARAGIOTTO, J.A.R.; JULIANI, C; BELJAVSKIS, P.; PEROSA, P. de T.Y.; ZAINE, J.E. 1984. projeto Ouro Tapera Grande - Pesquisa de detalhe. São Paulo, IPT/PRÓ-MINÉRIO, 2V. São Paulo, IPT'. (Relatório 20.719). 
SCHOBBENHAUS FILHO, C.; CAMPOS, D. de A.; DERZE, G.R.; ASMUS, H.E. 1984. Geologia do Brasil. Texto Explicativo do mapa geológico do Brasil e da área oceânica adjascente, incluindo os depósitos minerais - Escala l:2500000. Brasília, DNPM/DGM, 501p.

SILVA, P.C. F da. 1997a. Ambientes de sedimentąão e tectônica do Grupo São Roque na região entre pilar do Sul e Votorantim, SP. São Paulo, 127p. (Dissertação … Mestrado) -... Instituto de Geociências, Universidade de São Paulo.

SLLVA, P. C. F. da. 1997b. Consideraçóes sobre a tectônica rúptil na região entre Votorantim e Salto de Pirapora, SP. In: SIMPÓSIO NACIONAL DE ESTUDOS TECTÔNICOS, 6, 1997, Pirenópolis. Anais. Pirenópolis, SBG/Núcleo Brasília, p. 139-142.

SILVA, P. C. F. da. 1998. Tectônica rúptil da região entre Pilar do Sul e Votorantim, SP. Revista Brasileira de Geociências, $28(4): 485-494$.

SOARES, P.C. 1988. Tectônica colisional en torno do bloco Paraná, Brasil. In: CONGRESSO LATINOAMERICANO DE GEOLOGIA, 7, Belém, 1988. Anais. Belém, SBG, p.63-79.

SOARES, P. C.; ROSTIROLLA, S. P. 1997. Tectônica de escape tardicolisional nos cinturões Ribeira e Dom Feliciano. In: SIMPÓSIO NACIONAL DE ESTUDOS TECTÔNICOS, 6, 1997, Pirenópolis. Anais. Pirenópolis, SBG/Núcleo Brasília, p. 65-67.

SOUZA, S.C.A. de. 1997. Anfibolitos ortoderivados do Complexo Itapira e do Bloco Säo Rogue nas Folhas Cabreúva, Sorocaba, Itu e São Roque (SP): Petrografia, litoquímica, química mineral e termobarometria. São Paulo, 137 p. (Dissertação - Mestrado) - Instituto de Geociências e Ciências Exatas, Universidade Estadual Paulista.

SOUZA, S. C. A. de \& OLIVEIRA, M. A. F de. 1997. Anfibolitos Ortoderivados do Complexo Itapira e do Bloco São Roque nas Folhas de Cabreúva, Sorocaba, Itu e São Roque (SP). 1:50.000. In: SIMPÓSIO DE GEOLOGIA DO SUDESTE, 5, 1997, Penedo-Itatiaia. Atas. Penedo-Itatiaia, SBG/NSP-RJ/ES, ABGE/NRJ, p. $100-102$.

SOUZA, S. C. A. de; OLIVEIRA, M. A. F. de. 1998. Petrografia do corpo anfibolítico de Hermida (SP). $/ n$ : CONGRESSO BRASUEIRO DE GEOLOGIA, 40, Belo Horizonte, 1998. Anais. Belo Horizonte, SBG, p. 487.

SOUZA, S.C.A.; OLIVEIRA, M.A.F. de; ZANARDO, A. 1996a. Petrogratia do Complexo Itapha: Folhas Águas de Lindóla (SP/MG) e Cabreúva (SP). In: CONGRESSO BRASILEIRO DE GEOLOGIA, 39, Salvador, 1996. Anais. Salvador, SBG, v.2, p.131-133.

SOUZA, S.C.A.; OLIVEIRA, M.A.F. de; ZANARDO, A.; HACKSPACHER, P.C.; GODOY, A.M. 1996. Influência do Granito São Roque no metamorfismo de rochas básicas do Grupo São Roque na Folha Cabreúva (SP). In: CONGRESSO BRASILEIRO DE GEOLOGIA, 39, Salvador, 1996. Anais. Salvador, SBG, v.2,
p.134-135.

SPEAR, F.S. 1995. Metamorphic phase equilibria and pressure-temperature-time. Mineralogical Society of America, Monograph Series. Michigan, BookCrafters Inc., 799p.

TASSINARI, C.C.G. \& SATO, K. 1996. Idades de formação de crosta continental na parte sudeste do Estado de São Paulo, com base em dados Sm-Nd. In: CONGRESSO BRASILEIRO DE GEOLOGIA, 39, Salvador,
1996. Anais. Salvador, SBG, v.6, p. 489-492.

TASSINARI, C.C.G.; KAWASHITA, K.; KIKUCHI, R.K.P. de. 1985. Estudo geocronológico nos metaconglomerados do Grupo São Roque, no Estado de São Paulo. In: SIMPÓSIO REGIONAL DE GEOLOGIA, 5, São Paulo, 1985. Atas. São Paulo, SBG-NSP, v.1, p. $201-208$.

TASSINARY, C.C.G.; KAWASHITA, K.; VAN SCHMUSS, R.; TAYLOR, P.N. 1988. A idade das rochas e dos eventos metamórficos da região sudeste do Estado de São Paulo. In: CONGRESSO BRASILEIRO DE GEOLOGIA, 35, Belém, 1988. Anais. Belém, SBG, v. 6, p. 2840-2853.

TEUPPENHAYN, J. P.; WERNICK, E.; SÖLLNER, F.; WEBER-DIEFENBACH, K. 1995. Relação temporal entre - Granodiorito Cantareira e o Granito Perus, SP. In: SIMPÓSIO DE GEOLOGIA DO SUDESTE, 4, Águas de São Pedro, 1995. Boletim de Resumos. Águas de São Pedro, SBG/NSP-NRJ/ES, p. 142. 
THOMPSON, A.B. 1971. $\mathrm{PCO}_{2}$ in low grade metamotphic: zeolite, carbonate, clay mineral, prehnite relations in the system $\mathrm{CaO}-\mathrm{Al}_{2} \mathrm{O}_{3}-\mathrm{CO}_{2}-\mathrm{H}_{2} \mathrm{O}$. Contributions to Mineralogy and Petrology, 33:145-161.

TRÖGER, W.E. 1979. Optical determination of rock-froming minerals. Part I - Determinative tables. Stuttgart, E. Schweizebart'sche Verlagsbuchhandlung (Nagele u. Obermiller), $194 \mathrm{p}$.

TURNBR, F.J. 1981. Metamorphic petrology. 2. ed. New York, MacGraw-Hill. 524p.

VAN SCHMUS, W.R.; 'TASSINARI, C.C.G.; CORDANI, U.G. 1986. Estudo geocronológico da parte inferior do Grupo São Roque. In: CONGRESSO BRASILEIRO DE GEOLOGIA, 34, Goiânia, 1986 Anais Goiânia, SBG, v. 3, p. 1399-1406.

VIEIRA, S.R.S.S.; COUTINHO, J.M.V.; ALVES, F.R. 1992. Considerações sobre o metamorfismo das rochas da região de Embu-Guaçu - Parelheiros, SP. Revista Brasileira de Geociências, 22(1): 82-92.

WERNICK, E. 1997. Idade da tectônica de colocação do magmatismo granitóide brasiliano do estado de São paulo e de áreas adjascentes do estado de Minas Gerais, SE Brasil. In: SIMPÓSIO NACIONAL DE ESTUDOS TECTÔNICOS, 6, 1997, Purenópolis. Anais. Pirenópolis, SBG/Núcleo Brasília, p. $104-106$.

WERNICK, E. 1998a. Estágios de magmatismo granitóide no Cinturão Ribeira (Ciclo Brasiliano), In: CONGRESSO BRASILEIRO DE GEOLOGIA, 40, Belo Horizonte, 1998. Anais. Belo Horizonte, SBG, p. 22.

WERNICK, E. 1998b. Feições do magmatismo granitóide no Cinturão Transpressivo Ribeira (Ciclo Brasiliano). In: CONGRESSO BRASILEIRO DE GEOLOGIA, 40, Belo Horizonte, 1998. Anais. Belo Horizonte, SBG, p. 28.

WERNICK, E. 1998c. Sistema magmático pluriserial 590: caracterização e implicações geodinâmicas. In CONGRESSO BRASILEIRO DE GEOLOGIA, 40, Belo Horizonte, 1998. Anais. Belo Horizonte, SBG, p. 46.

WERNICK, E. 1998d. The pluriserial Ribeira magmatic system 590, SE/S Brazil and Uruguay. Revista Brasileira de Geociências, 28(4): 459-466.

WERNICK, E..; FERREIRA, C. J. 1991. Estruturas, Arquitetura e Evolução do Complexo Granitóide de Itaqui, SP. In: SIMPÓSIO NACIONAL DE ESTUDOS TECTÔNICOS, 3, Rio Claro, 1991. Rio Claro. Boletim. Rio Claro, SBG/NSP, p. 62-63.

WERNICK, E. \& FERREIRA, C.J. 1993. Fstruturas, arquitetura e evolução do Complexo Granitóide laqui (SP).
Geociencis,

WERNICK, E. \& GALEMBECK, T.M.B. 1986. Caracterização do plutonismo granitóide do Ciclo Brasiliano no Estado de São Paulo através do método da tipologia do zircão. In: CONGRESSO BRASILEIRO DE GEOLOGIA, 34, Goiânia, 1986. Anais. Goiânia, SBG, v.3, p. 1369-1382.

WERNICK, E. \& TEUPPENHAYN, J.P. 1996. Origem e evolução do magma crustal "Pirituba" nos arredores de São Paulo, SP, SE Brasil. In: CONGRESSO BRASILEIRO DE GEOLOGIA, 39, Salvador, 1996. Anais. Salvador, SBG, v.6, p. 459-461.

WERNICK, E; TÖPFNER, C. 1997. Idades do Magmatismo Granitóide Brasiliano nos Estados de São Paulo e Minas Gerais: Implicações na Caracterização Temporal da Evolução do Cinturão Ribeira. In: SIMPÓSIO DE GEOLOGIA DO SUDESTE, 5, 1997, Penedo-Itatiaia. Atas. Penedo-Itatiaia, SBG/NRJ/ES/SP, ABGE/NRJ, p.159-161.

WERNICK, E.; FERREIRA, C. J.; HÖRMANN, P. K. 1994a. Fracionamento magmático em câmaras coletoras: uma abordagem através dos ciclos magmáticos do Complexo Granitóde Itaqui, SP. In: CONGRESSO BRASILEIRO DE GEOLOGIA, 38, Balneário Camboriú, 1994. Boletim. Balneário Camboriú, SBG, v. 1, p.
$141-143$.

WERNICK, E; FERREIRA, C.J.; HÖRMANN, P.K.; DUTRA, C.V. 1993a. Elementos terras raras no Complexo Granitóde Itaqui (Estado de São Paulo): Evolução e aspectos físicos de magmas granitóides. Revista Brasileira de Geociências, 23(2): 147-157.

WERNICK, E.; FERREIRA, C. J.; TEUPPENHAYN, J. P. 1995. Elementos terras raras e tipologia de zircão de granitos crustais e cálcio-alcalinos entre as falhas Jundiuvira e Taxaquara, SP. In: SIMPÓSIO DE GEOLOGIA DO SUDESTE, 4, Águas de São Pedro. Boletim de Resumos. Águas de São Pedro, SBG/NSP-NRJ/ES, p. 141.

WERNICK, E.; GALEMBECK, T. M. B.; HÖRMANN, P. K.; FERREIRA, C. J. 1994b. Fracionamento magmático por fluxo e compressão em magmas granitóides nos complexos São Roque e Itu, SP: aspectos geoquímicos. In: 
CONGRESSO BRASLEERO DE GEOLOGIA, 38, Balneário Camboriú, 1994. Boletim. Balneário Camboriú, SBG, v. 1, p. 143-144.

WERNICK, E.; HÖRMANN, P.K.; ARTUR, A.C.; FERREIRA, C.J.; GALEMBECK, T.M.B.; GODOY, A.M.; ANDRADE, F.R.D. 1993b. Fases, impulsos e ciclos magmáticos em complexos granitóides associados com falhas trancorrentes, SP. Revista Brasileira de Geociências, 23(3): 248-259.

WERNICK, E.; NARDY, A.J.R.; WEBER-DIEFEMBACH, K. 1992. Estudo comparativo de enclaves de distintas séries granitóides. Geociêncais, 11(2): 121-146.

WINKLER, H.G.F. 1977. Petrogênese das rochas metamórficas. Porto Alegre, Editora Edgard Blücher. 254p. (Traduzido por BURGER Jr., C., revisado por FREITAS, R.O. de).

YARDLEX, B.W.D. 1994. Introdução à petrologia metamórfica. Brasília, Editora Universidade de Brasília, 340p. (Traduzido por R.A FUCK).

YARDLEY, B.W.D.; MACKENZIE, W.S.; GULLFORD, C. 1990. Atlas os metamorphic rocks and their textures. London, Logman, 120p.

ZEN, E-an. 1961. The zeolite facies: an interpretation. American Journal of Science, 259: 401-409. 
ANEXO I 


\section{LEGENDA - PRANCHA 01}

Foto A - Gnaisses do Complexo Itapira predominando porçōes xistosas com bandas graníticas brancas e anfibolítica ocre subordinadas. Notar bandas dobradas e por vezes rompidas no centro da foto, devido às falhas associadas à Zona da Cisalhamento de Itú-Jundiuvira. Banda anfibolítica com 6 cm de espessura. Afloramento do ponto MV 1036.

Foto $\mathbf{B}$ - Xistos feldspáticos alterados e milonitizados do Complexo Embu apresentando intercalações graníticas derivadas da fusão parcial dos metassedimentos. A falha que desloca os litotipos associa-se ao sistema tardio de falhas conjugadas de direções NNW-SSE e NW-SE. Afloramento do ponto JA 996.

Foto $\mathrm{C}$ - Leito de xisto conglomerático que ocorre intercalado com xistos arenosos e pelíticos com fibrolita sobrepostos a um corpo anfibolítico. Observar a riqueza de grânulos e pequenos seixos arredondados predominando os de quartzo de veio. Escala dada pela ponta da lapiseira.

Foto D - Metassedimentos tufíticos miloníticos da Formação Morro da Pedra Preta, intercalando lâminas e bandas roxo, vinho e vermelhas e brancas mais raras, afetados por falhas inversas associadas às zonas de cisalhamento de empurrão.

Foto $\mathbf{E}$ - Milonito dos metassedimentos tufíticos na encosta nordeste do Pico do Jaraguá (PJ 1199). São laminados a variegados e com contribuição de material manganesífero indicado pela porções verdes-ocráceas. Notar foliação milonítica ondulada com sigmóides associados indicando transporte tectônico para N-NE marcado pela ponta da lapiseira.

Foto F - Metapelitos que ocorrem intercalado aos metassedimentos tufíticos observado a SSE do Morro do Boturuna (CV 956). Estão representados por xistos finos róseo-claros de estrutura laminada a bandada. Notar a foliação milonítica S2 oblíqua ao bandamento e algumas falhas posteriores de rejeito centimétrico.

Foto $\mathbf{G}$-... Metarriolito associado com metapelitos calcíferos e metassedimentos manganesíferos ocráceos que ocorrem no topo da Unidade Metavulcanoclástica da Formação Morro da Pedra Preta no afloramento do ponto BA 840 . Altura do afloramento $\sim 5 \mathrm{~m}$. À esquerda o metarriolito está concordante com a foliação $S 2$ dos metassedimentos e, para a direita, observa-se um provável xenólito.

Foto $\mathbf{H}$ - Intercalações de bandas de rochas calciossilicáticas ocre-amarelada a marrom com aspecto manchado dado pela percolação de manganês e leitos pretos com até $1 \mathrm{~cm}$ ricos em metapelitos manganesíferos e bandas mais largas e com cores mais vivas das rochas anfibolíticas. 
PRANCHA 01
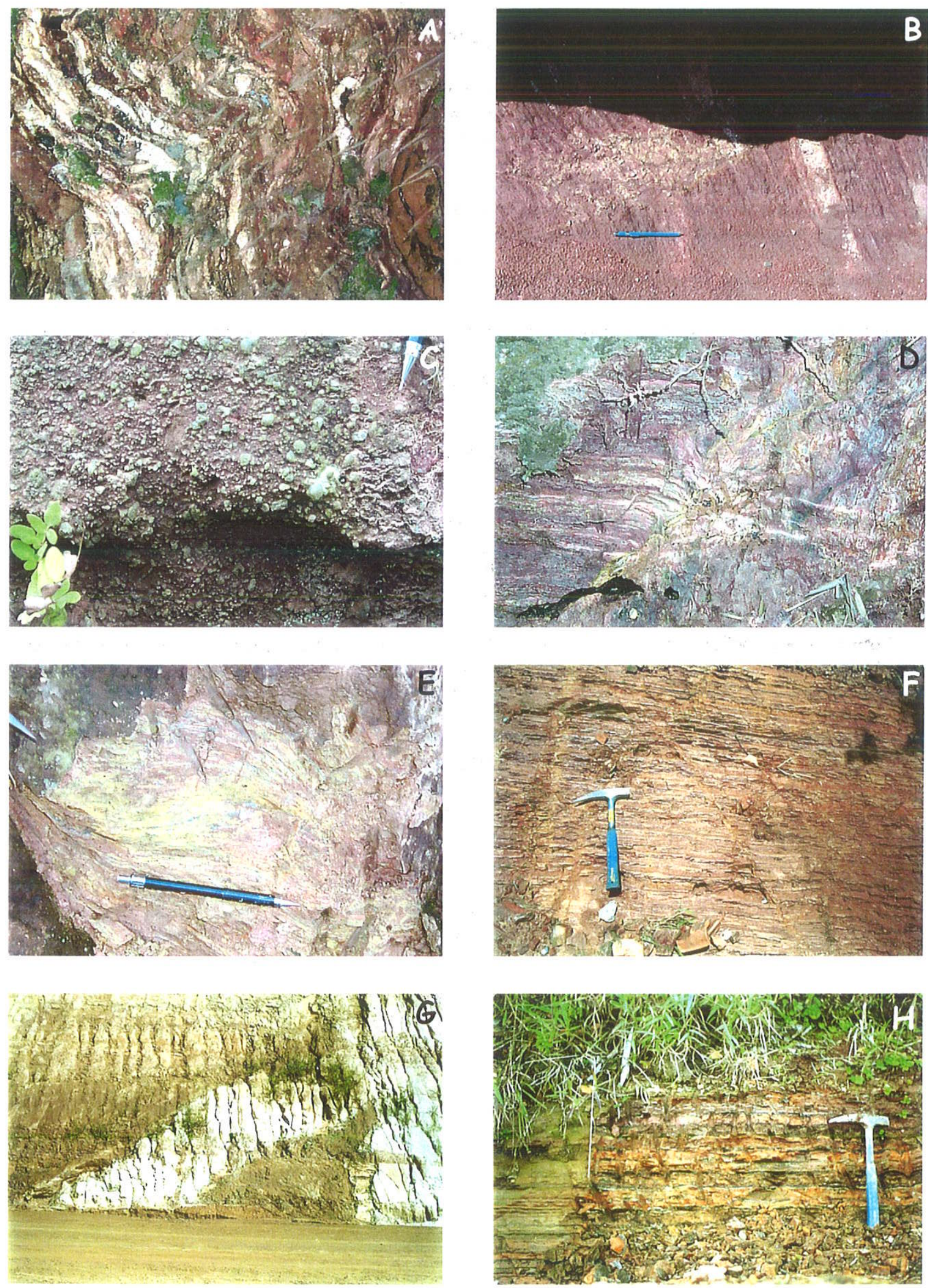


\section{LEGENDA - PRANCHA 02}

Foto A - Xistos pelíticos porfiroblásticos com intercalações de bandas ricas em fibrolita branca orientada segundo a foliação $S 2$ com mergulho subvertical e outras bandasonde a fibrolita está quase ausente. À esquerda, pacote maciço de xistos mais arenosos.

Foto B - Xistos pelíticos milonitizados do Grupo Serra do Itaberaba do ponto JD 961 próximo do contato com o Grupo São Roque, sendo observados veios de quartzo estirados e os pares $S-C$ que mostram uma foliação milonítica associada com zonas de cisalhamento de empurrão.

Foto C - Xistos pelíticos finos da Formação Morro da Pedra Preta ricos em porfiroblastos de estaurolita orientada segundo a foliação S2. Afloramento do ponto BA 844A.

Foto D - Metassedimentos grafitosos laminados a bandados cinza da Formação Morro da Pedra Preta contendo intercalações de leitos brancos mais siltosos e outros esverdeados sugerindo contribuição de sedimentos manganesíferos.

Foto $\mathbf{E}$ - Metassedimentos manganesíferos com estrutura laminada a finamente bandada intercalndo leitos ocre-claros e outros marrons. Afloramento do ponto CV 955.

Foto F - Metassedimentos manganesíferos bandados a laminados intercalando finas laminações amarelo-ocráceas de rocha calciossilicática exibindo dobras fechadas e paralelizando nos flancos a foliação S2 com o bandamento S1/SO. Afloramento do ponto BT 963.

Foto $\mathbf{G}$ - Rochas carbonáticas do ponto PJ 879 exibindo estrutura laminada a bandada, com bandas castanho flogopíticas e esverdeadas com tremolita. Leitos mais claros em essência carbonáticos e mais escuros podem apresentar minerais opacos disseminados.

Foto H - Porções mais finas dos xistos quartzosos da Formação Pirucaia com porções pouco milonitizadas exibindo os grânulos de quartzo arredondados no centro da fotografia. Afloramento do ponto PJ 944. 


\section{PRANCHA 02}
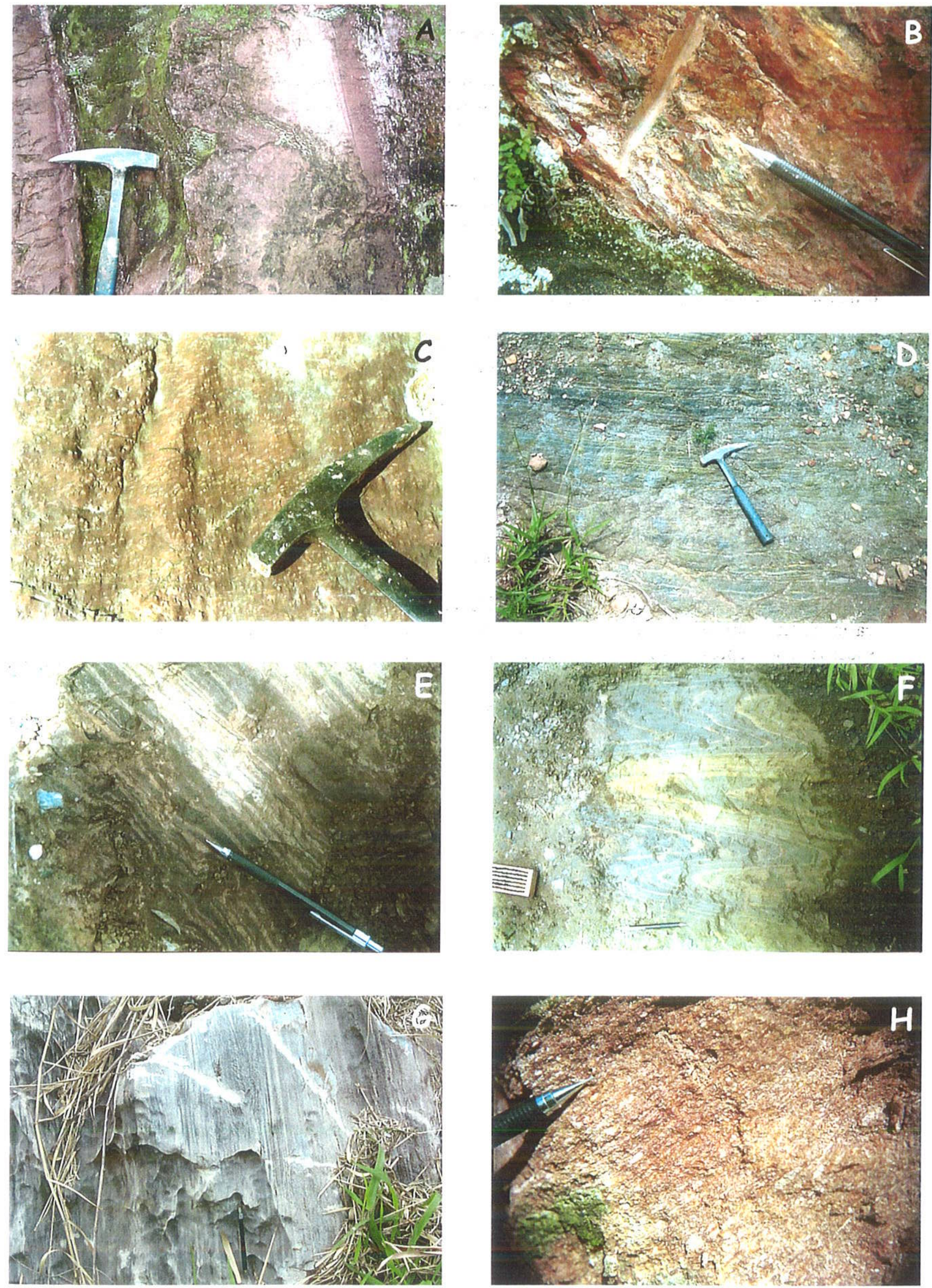


\section{LEGENDA - PRANCHA 03}

Foto A - Metarcóseos com porfuroclastos de feldspatos da Formação Morro Doce no Morro do Polvilho (BT 104) contendo intercalações de bandas com até $3,0 \mathrm{~cm}$ de espessura de metarenitos finos cinza-esverdeados escuros.

Foto B - Metaconglomerados milonitizados da Formação Morro Doce na região do Morro do Polvilho, no ponto BT 105 , predominando seixos e calhaus de rochas granitóides e de quartzitos estirados pela foliação milonítica de alto ângulo. Matriz cinza-escura rica em biotita e magnetita. Topo do afloramento para direita.

Foto C - Metabasitos da Formação Pirapora do Bom Jesus com estrutura tipo pillow lava parcialmente destruída por cisalhamento de baixo ângulo encaixado na descontinuidade do material interpillows. Afloramento do ponto RP 1225.

Foto D - Rochas carbonáticas da Formação Pirapora do Bom Jesus contendo malaquita supérgena disseminada derivada da alteração de calcopirita. Afloramento VL 1063. Topo do afloramento para direita.

Foto E - Quartzitos da Formação Boturuna com estratificação cruzada tangencial na base e com veios de quartzo remolizados nos estratos. Topo em posição normal apontado pelo cabo do martelo. Afloramento do ponto CV 830.

Foto F - Quartzitos da base do Morro do Boturuna com estratificações plano-paralelas sobrepostas às estratificações cruzadas tipo espinha-de-peixe. Afloramento do ponto VL 785.

Foto $\mathbf{G}$ - Nível do metapsamito grosso da Formação Boturuna contendo seixos angulosos de rocha filítica representando possíveis gretas de ressecação retrabalhadas ou nível de canibalismo com destruição de estratos argilosos. Afloramento do ponto CV $827 \mathrm{~B}$.

Foto H - Metaconglomerado da Unidade Metarrítmica da Formação da Estrada dos Romeiros apresentando matriz arenosa fina e exibindo seixos e calhaus angulosos de quartzo de veio e de metassedimentos manganesíferos marrom-escuros. Afloramento do ponto RP 1241. 


\section{PRANCHA 03}
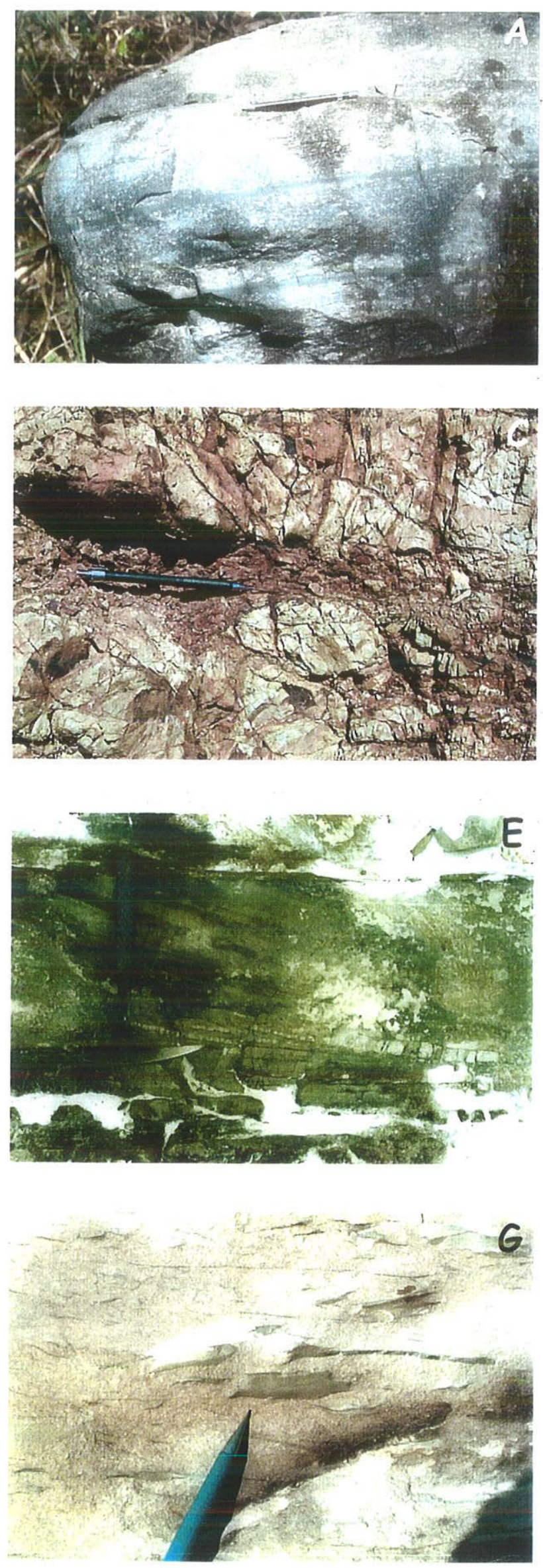
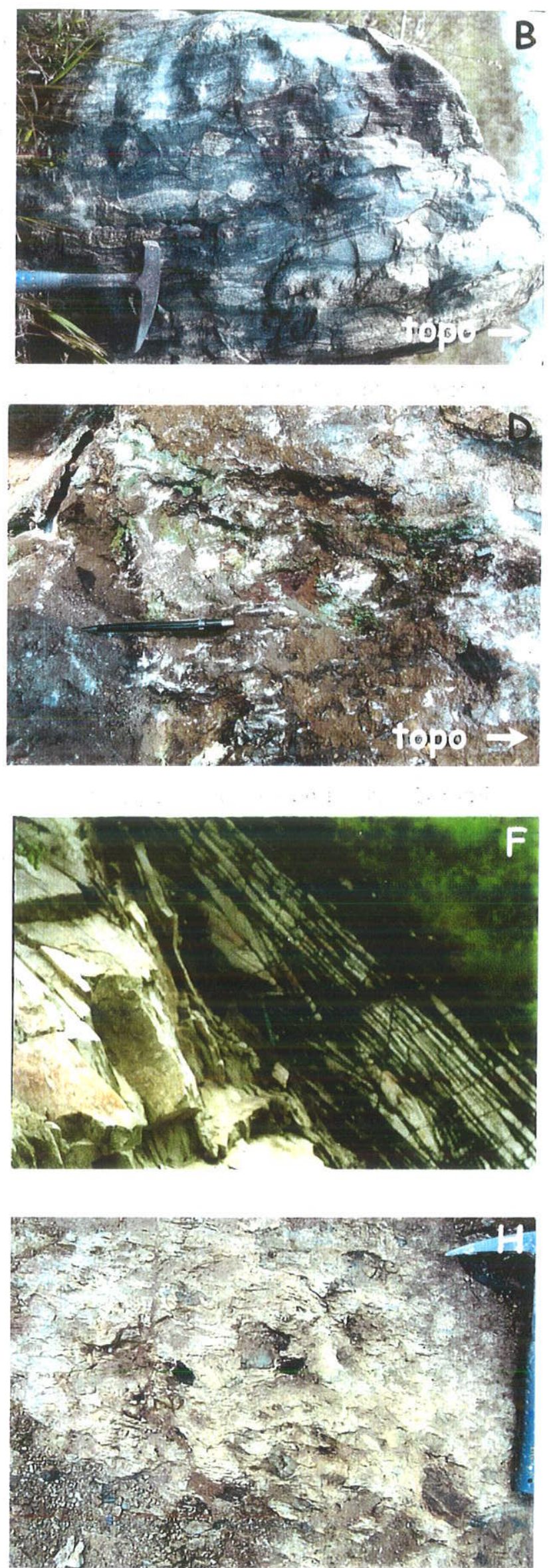


\section{LEGENDA - PRANCHA 04}

Foto A - Filitos com estrutura laminada a bandada da Unidade Metapelítica da Formação Piragibu com intercalações de leitos com até $1,5 \mathrm{~cm}$ escuros e grafitosos. Notar clivagem de fratura paralela à lapiseira com filmes mais escuros dado pela alteração de clorita. Afloramento do ponto CV 954.

Foto $\mathbf{B}$ - Filitos bandados alterados ricos em clorita da Formação Piragibu com bandas de espessura decimétrica roxas e porções mais decompostas ocre-esverdeadas. Afloramento VL 1078.

Foto $\mathbf{C}$ - Aspecto geral da fácies mais comum dos maciços granitóides que ocorrem na área. Amostra do Granodiorito Barueri dos arredores de Santana do Parnaíba. Ponto SP 826A.

Foto D - Metarcóseos da base do Morro Doce milonitizados e associados às zonas de cisalhamento de empurrão de baixo a médio ângulo relacionadas à colocação do Grupo São Roque sobre o Grupo Serra do Itaberaba.

Foto E - Xistos pelíticos da Formação Morro da Pedra Preta com dobras recumbentes e falhas de médio ângulo com venulações de quartzo associadas ao cisalhamento de empurrão. Ponto BT 569.

Foto F - Milonitos do Maciço Granitóide Itaqui afetado pela Zona de Cisalhamento Taxaquara. Notar o mergulho suvertical e as estruturas $\mathrm{S}-\mathrm{C}$, mais comuns na porção inferior esquerda da foto. Afloramento do ponto JA 997.

Foto G - Ultramilonitos da Fácies Itapevi do Maciço Granitóide Ibiúna exibindo foliação milonítica de baixo ângulo posterior a foliação milonítica associada à transcorrência, Ponto JA 995.

Foto H - Sedimentos terciários correlatos às formações Resende e São Paulo expostos na altura do $\mathrm{km} 34$ da Rodovia dos Bandeirantes. Notar as flhas associadas que colocam lado a lado um pacote arenoso e outro de argilitos. Afloramento do ponto CB 1146. 


\section{PRANCHA 04}
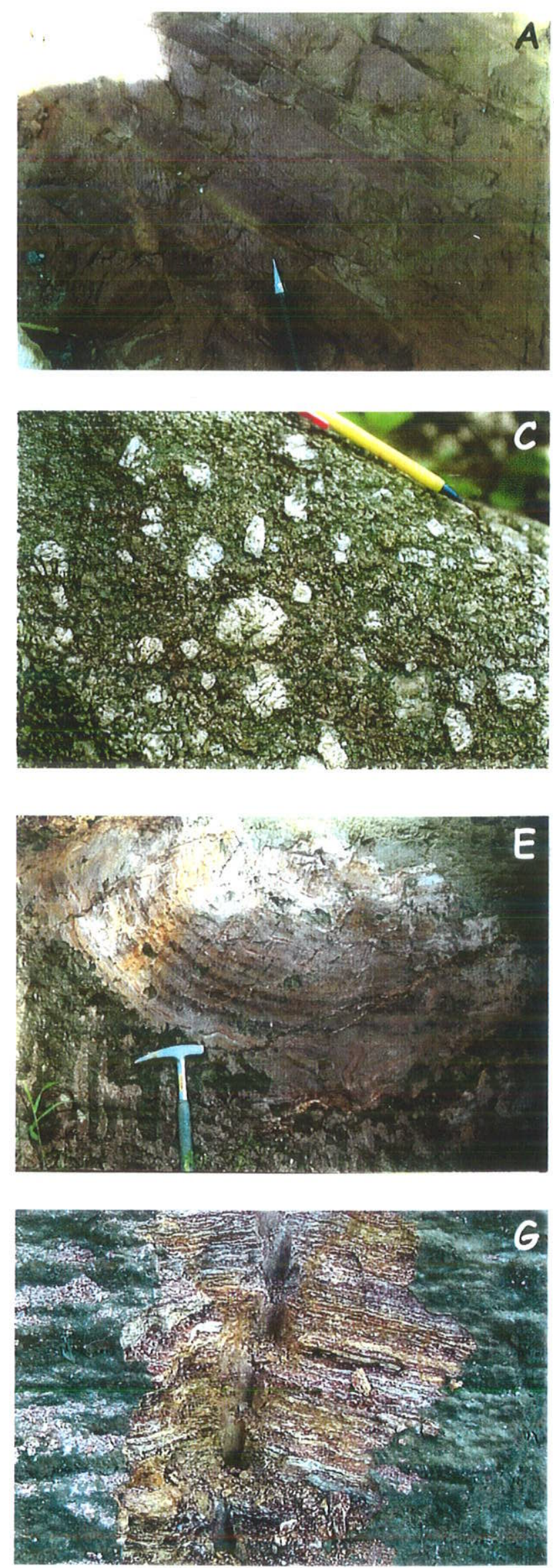
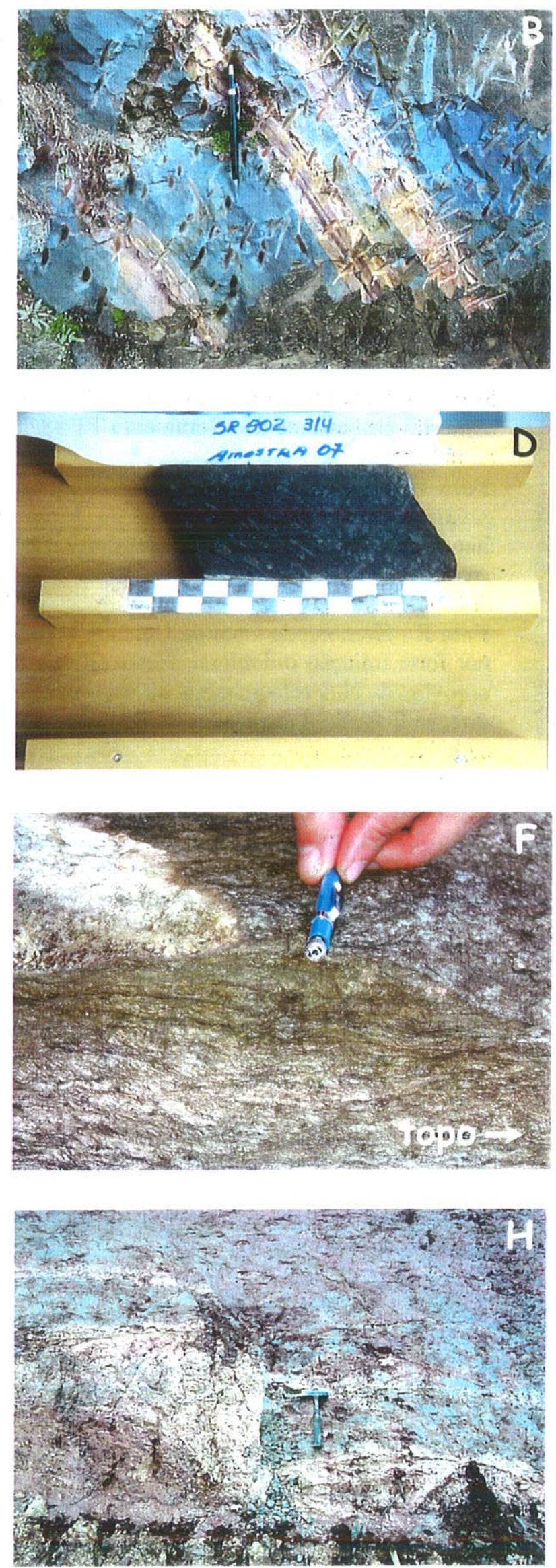


\section{LEGENDA - PRANCHA 05}

Foto A - Textura blastofítica em hornblenda anfibolitos da Formação Morro da Pedra Preta (GSI). Observar inclusões de cristais de plagioclásio nos porfiroblastos de hornblenda com a forma reliquiar ígnea preservada, mas recristalizados em grãos menores. Com analisador. Lado maior $\sim 2,8 \mathrm{~mm}$. Amostra do afloramento PP 19.

Foto B - Hornblenda-homblenda/actinolita anfibolito pouco foliado da Formação Morro da Pedra Preta (GSI). Notar porfiroblasto de anfibólio com núcleo verde-claro (hornblenda-actinolita) e borda verde-escura (hornblenda). Sem analisador. Lado maior 1, $4 \mathrm{~mm}$. Amostra do afloramento SP 643B, próximo ao Maçico Granitóide Itaqui.

Foto C - Hornblenda anfibolito da Formação Morro da Pedra Preta (GSI). Observar possível recristalização de hornblenda sin- $\mathrm{S}_{1}$ em aglomerados de cristais menores de hornblenda sin- $\mathrm{S}_{2}$. Notar subordinadamente a presença de biotita, ilmenita e titanita. Sem analisador. Lado maior $\sim 5.5 \mathrm{~mm}$. Amostra proveniente do afloramento TT 88 .

Foto D - Hornblenda-hornblenda/actinolita anfibolito da Formação Morro da Pedra Preta (GSI) próximo do Maciço Granitóide Itaqui. Notar granulação relativamente mais grossa e textura reliquiar intergranular (gabróica), onde estão preservados cristais de plagioclásio tabulares e geminados. Com analisador. Lado maior $\sim 2,8 \mathrm{~mm}$. Amostra do afloramento CV 766 .

Foto E - Hornblenda xisto da Unidade Metabásica da Formação Morro da Pedra Preta (GSI), afetado por forte foliação milonítica. Notar cristais de homblenda $\sin -S_{\text {\& }}$ um pouco maiores com disposição aproximada N-S rotacionados ou transpostos por cristais menores de hornblenda $\mathrm{S}_{2} / \mathrm{S}_{\mathrm{m}}$ orientados na direção E-W. Sem analisador. Lado maior 5,5 mm. Amostra do afloramento PP 142.

Foto F - Granada hornblenda anfibolitoda Formação Morro da Pedra Preta (GSI), onde são vistos cristais subeuédricos de granada sin- a pós- $S_{2}$ em equilíbrio com hornblenda. Amostra proveniente do ponto TT 79, próximo do contato com o Stock Granítico Tico-Tico. Notar núcleos poiquiloblásticos na granada com inclusões de ilmenita, quartzo e plagioclásio e bordas maciças associadas ao reequilíbrio pós- $\mathrm{S}_{2}$. Sem analisador. Lado maior $\sim 2,8 \mathrm{~mm}$.

Foto G - Hornblenda anfibolito da Formação Morro da Pedra Preta (GSI). À direita, observar porfiroblasto de diopsídio $S_{1}$ instável e uma matriz composta por hornblenda $S_{2}$ e cristais menores recristalizados de plagioclásio $S_{2}$. Com analisador. Lado maior $\sim 2,8 \mathrm{~mm}$. Amostra do afloramento $\mathrm{PP}$ 927, a sudoeste do Stock Granítico Tico-Tico.

Foto H - Hornblenda anfibolito da Formação Morro da Pedra Preta (GSI) dos arredores do Stock Granítico Tico-Tico. No centro, cristal de hornblenda $S_{1}$ (em secção basal) parcialmente envolvido por hornblenda $\sin -\mathrm{S}_{2}$ orientada segundo essa foliação. Matriz composta essencialmente por cristais de plagioclásio menores e recristalizados. Sem analisador. Lado maior $\sim 2,8 \mathrm{~mm}$. Amostra do afloramento PP 514B. 


\section{PRANCHA 05}
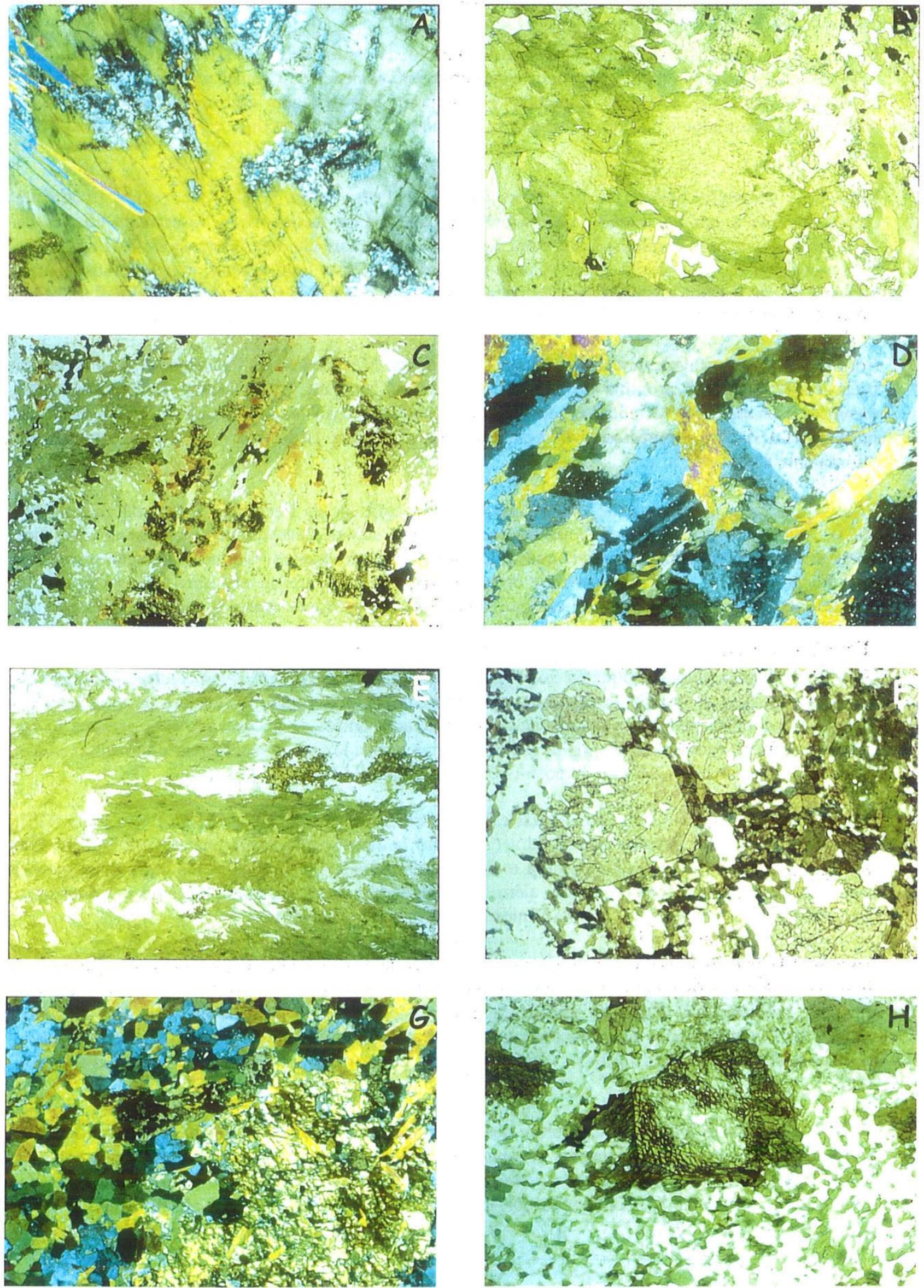


\section{LEGENDA - PRANCHA 06}

Foto A - Hornblenda anfibolito da Formação Morro da Pedra Preta (GSI) afetado pela foliação milonítica $S_{n}$. Notar bandamento composicional com intercalações de lâminas e finas bandas ricas em hornblenda orientada e outras contendo plagioclásio recristalizado em cristais menores. Sem analisador. Lado maior 5,5 mm. Amostra do afloramento TT 568, próximo do Stock Granítico TicoTico.

Foto B -... Metatufo básico da Formação Morro da Pedra Preta (GSI), que petrograficamente correspondente a um hornblenda xisto Observar bandamento metamórfico $\mathrm{S}_{2} \mathrm{com}$ os cristais de hormblenda orientados paralelos à estrutura $S_{1} / S_{0}$. Estrutura marcada pela intercalação de finos leitos com variações da granulação e do volume de homblenda, ora com cristais mais grossos e mais comuns, ora mais finos e mais raros. Com analisador. Lado maior $\sim 2,8 \mathrm{~mm}$. Amostra do afloramento PP 572.

Foto C - Rocha metavulcanoclástica básica (da Unidade Metabásica) da Formação Morro da Pedra Preta (GSI) localizada próxima do Maciço Granitóide Cantareira. Notar cristais de hornblenda $S_{2}$ menores e fortemente orientados associados à milonitização que transpõe porfiroblastos de hornblenda-actinolita $S_{1}$ (núcleos verde-claros). Sem analisador. Lado maior 1,4 mm. Amostra do afloramento PJ 879.

Foto D - Clorita xisto presente nos metassedimentos tufíticos da Formação Morro da Pedra Preta (GSI). Notar que a clorita pouco pleocróica a incolor sugere composição magnesiana. Presença relativamente abundante de minerais opacos e raros cristais de quartzo. Observar foliação milonítica com feições tipo s-c onde finos cristais orientados de clorita $S_{2}$ transpõem uma foliação prévia $S_{1}$ constituída por cristais maiores de clorita. Sem analisadores. Lado maior $\sim 0,7 \mathrm{~mm}$. Amostra do afloramento SP 645

Foto E - Rochas calciossilicática da Formação Morro da Pedra Preta (GSI). No centro e à esquerda o amplo predomínio de cristais de tremolita-actinolita orientados segundo a $S_{2}$, além de um fino leito onde concentram-se cristais granulares de clinopiroxênio e outros de microclínio com geminação em grade. $\grave{A}$ direita, predomina flogopita $\sin -\mathrm{S}_{2}$ e leitos formados na essência por clinozoizita. Com analisador, Lado maior 2,8 mm. Amostra do afloramento SP 620 .

Foto $\mathbf{F}$ - Aspecto mais comum das rochas calciossilicáticas da Formação Morro da Pedra Preta (GSI) com intercalações de lâmina verde-escura (à direita) composta principalmente por biotita, mineral opaco e quartzo, com epídoto, tremolita e allanita subordinados, e lâmina verde-clara (à esquerda) contendo actinolita, epídoto e quartzo, além de hornblenda prismática, clinopiroxênio e clinozoizita. Sem analisador. Lado maior 5,5 mm. Amostra do afloramento PJ 109.

Foto G - Rocha calciossilicática da Formação Morro da Pedra Preta (GSI). No centro ocorre um quartzo-flogopita xisto orientado segundo a foliação $S_{2}$ e estão presentes plagioclásio, clinozoizita e allanita subordinados. Notar na parte inferior, forte cristalização de diopsídio, titanita e cristais maiores de flogopita, todos de tendência granular e pouco orientados, sugerindo possível sobreposição de metamorfismo de contato pós- $\mathrm{S}_{2}$. Com analisador. Lado maior 5,5 mm. Amostra do ponto CV 761 .

Foto H - Muscovita-biotita xisto presente nos xistos finos a muito fïnos da Formação Morro da Pedra Preta (GSI). Observar o bandamento metamórfico $S_{2}$ marcado pela forte orientação dos cristais de biotita e pelos leitos ricos em quartzo dobrados intrafolialmente $\left(S_{2}\right.$ paralelo a $\left.S_{1} / S_{0}\right)$, posteriormente crenulados pela foliação $S_{3}$. Com analisador. Lado maior $\sim 5,5 \mathrm{~mm}$. Amostra do afloramento $P$ P 575 . 


\section{PRANCHA 06}
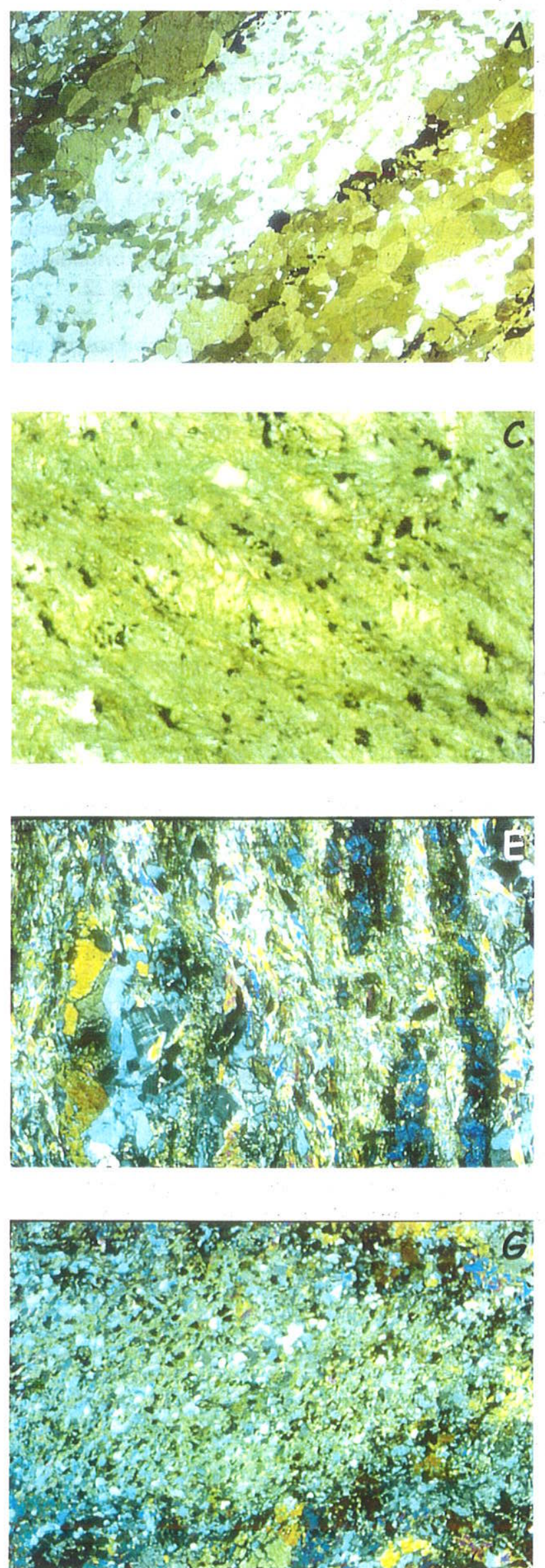

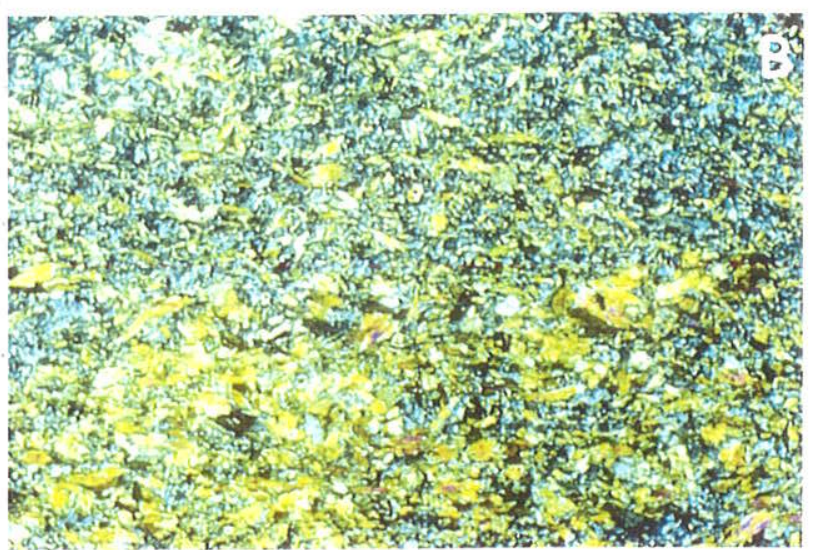

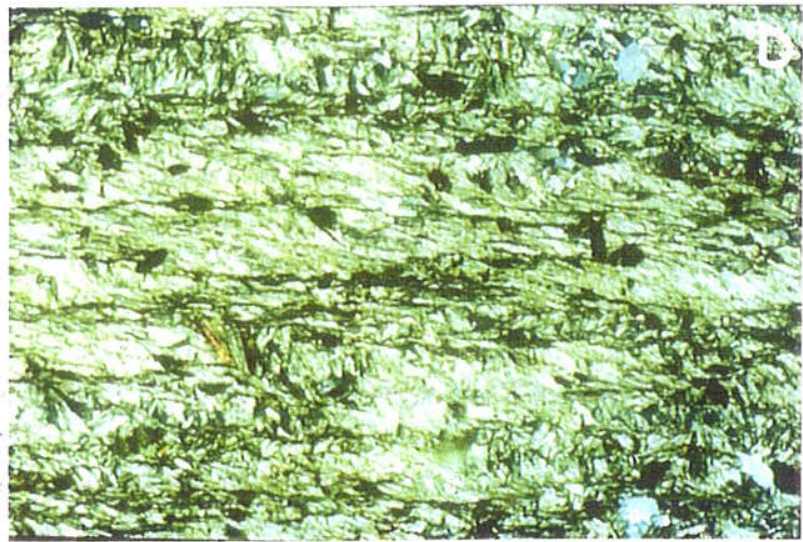
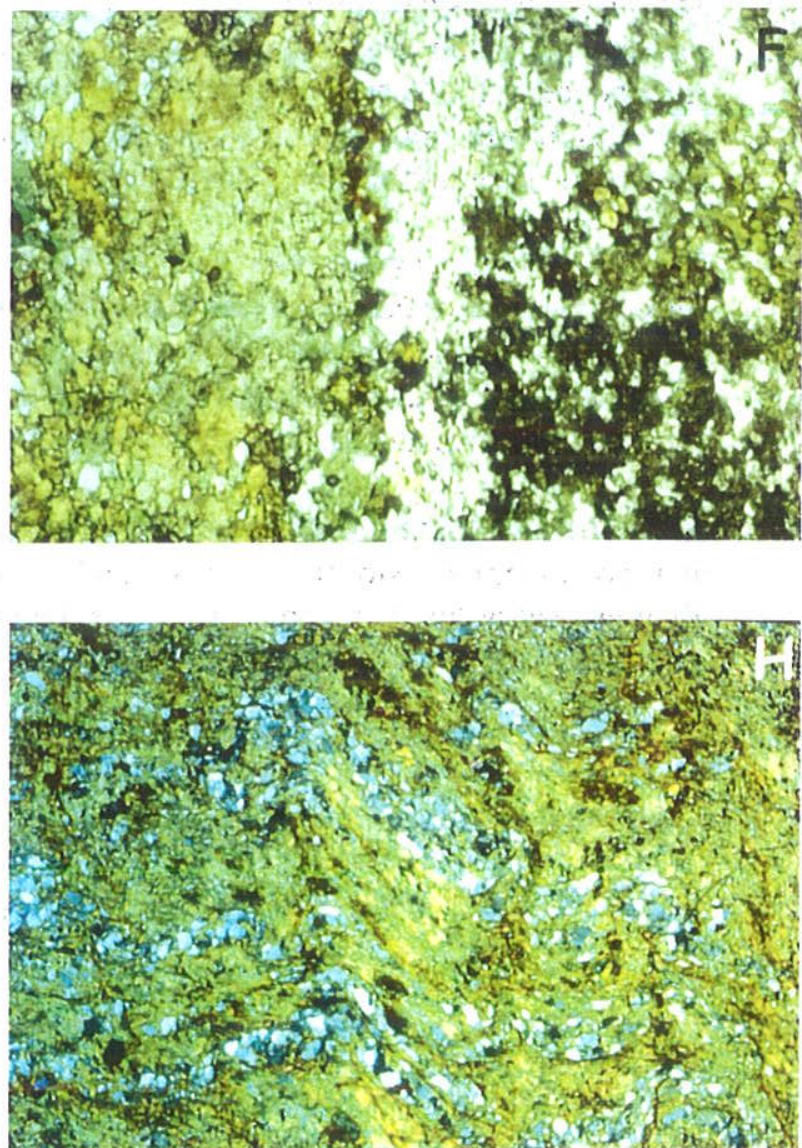


\section{LEGENDA - PRANCHA 07}

Foto A - Porfiroblasto instável de andaluzita sin- $S_{\text {, }}$ presente nos muscovita-biotita xistos (xistos finos rítmicos) da Formação Morro da Pedra Preta (GSI). Notar que o porfiroblasto está cortado e transformado nas bordas para cristais de sericita/muscovita fina orientados segundo a foliação $S_{2} / S_{m}$. Com analisador. Lado maior $\sim 1,4 \mathrm{~mm}$. Amostra do afloramento BT 691 .

Foto B - Biotitanestaurolita xisto com granada da Formação Morro da Pedra Preta (GSI). Notar os poiquiloblastos de granada e de estaurolita com inclusões orientadas sugerindo crescimento preferencial tardi- a pós- $S_{2}$, dispersos em uma matriz rica em quartzo e minerais micáceos orientados segundo a foliação $\mathrm{S}_{2} / \mathrm{S}_{\mathrm{m}}$. Sem analisador. Lado maior $\sim 5,5 \mathrm{~mm}$. Amostra do afloramento PP 22 .

Foto $C$ - Aspecto comum da foliação $S_{2} / S_{m}$ dos biotita-muscovita xistos com agregados grossos de fibrolita da Formação Morro da Pedra Preta (GSI). Observar pares Ss e Sc, formas sigmoidais e forte cristalização de fibrolita segundo a $S_{\mathrm{m}}$. Nos cristais de quartzo predominam bordas retilíneas devido à dissolução e recristalização. Com analisador. Lado maior $\sim 2,8 \mathrm{~mm}$. Amostra do afloramento PP 509 .

Foto $D$ - Aspecto geral da clivagem de crenulação $S_{3}$ que afeta a foliação $S_{2} / S_{m}$ dos biotita-muscovita xistos com agregados grossos de fibrolita da Formação Morro da Pedra Preta (GSI), gerando dobras fechadas onde podem ser vistos arcos poligonais formados pelos minerais micáceos. Na porção inferior direita, observar porfiroblasto de fibrolita contido na foliação $\mathrm{S}_{2}$. Com analisador. Lado maior $\sim 5,5 \mathrm{~mm}$. Amostra do afloramento 'TT 85.

Foto $\mathbf{E}$ - Aglomerados grossos de fibrolita sin- $S_{2}$ presentes em xistos pelíticos da Formação Morro da Pedra Preta (GSl). A fibrolita exibe hábito fibrorradiado a acicular e pode ser observado o crescimento epitáxico com biotita. Na porção inferior direita ocorrem cristais prismáticos finos de sillimanita caracterizados como $\sin -\mathrm{S}_{1}$. Sem analisador. Lado maior 1,4 mm. Amostra do afloramento PP 540 .

Foto $\mathbf{F}$ - Biotita-muscovita xisto com porfiroblastos de biotita e magnetita da Formação Morro da Pedra Preta (GSI). Na porção centro-esquerda, observa-se porfiroblasto de biotita sin-S, $S_{1}$ e, na região superior direita, ocorre um agregado porfiroblástico de biotita e magnetita, ambos exibindo sombra de pressão, devido à sobreposição da xistosidade $S_{2}$ marcada pela matriz rica em quartzo e muscovita orientados. Sem analisador. Lado maior 5,5 mm. Amostra do ponto BT 717.

Foto G - Grafita-muscovita xisto da Formação Morro da Pedra Preta (GSD). Notar que o quartzo concentra-se em finos veios (metachert?) onde tem granulação relativamente mais grossa. Observar a orientação dos minerais micáceos segundo a foliação $S_{2}$ que está dobrada pela clivagem de crenulação $\mathrm{S}_{3}$ gerando até dobras fechadas. Sem analisador. Lado maior $\sim 2,8 \mathrm{~mm}$. Amostra coletada em uma intercalação junto aos metassedimentos tufíticos no afloramento PP $570 \mathrm{~B}$.

Foto H - Turmalinito da Formação Morro da Pedra Preta (GSI). Detalhe de um leito essencialmente turmalinítico onde a turmalina apresenta-se zonada em secção basal exibindo o centro verde e borda verde-acastanhada ou verde-escura. Cristais de quartzo e de mineral opaco estão presentes muito subordinadamente. Com analisador. Lado maior 2,8 mm. Amostra do afloramento PP 94 . 


\section{PRANCHA 07}
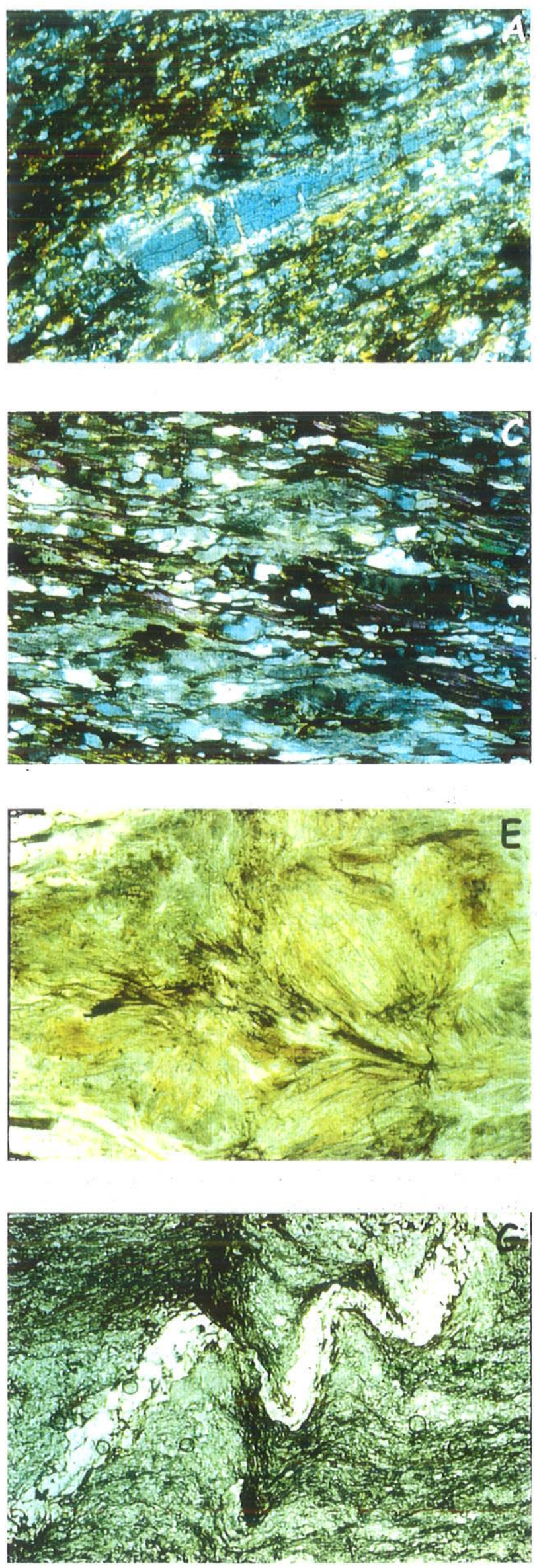
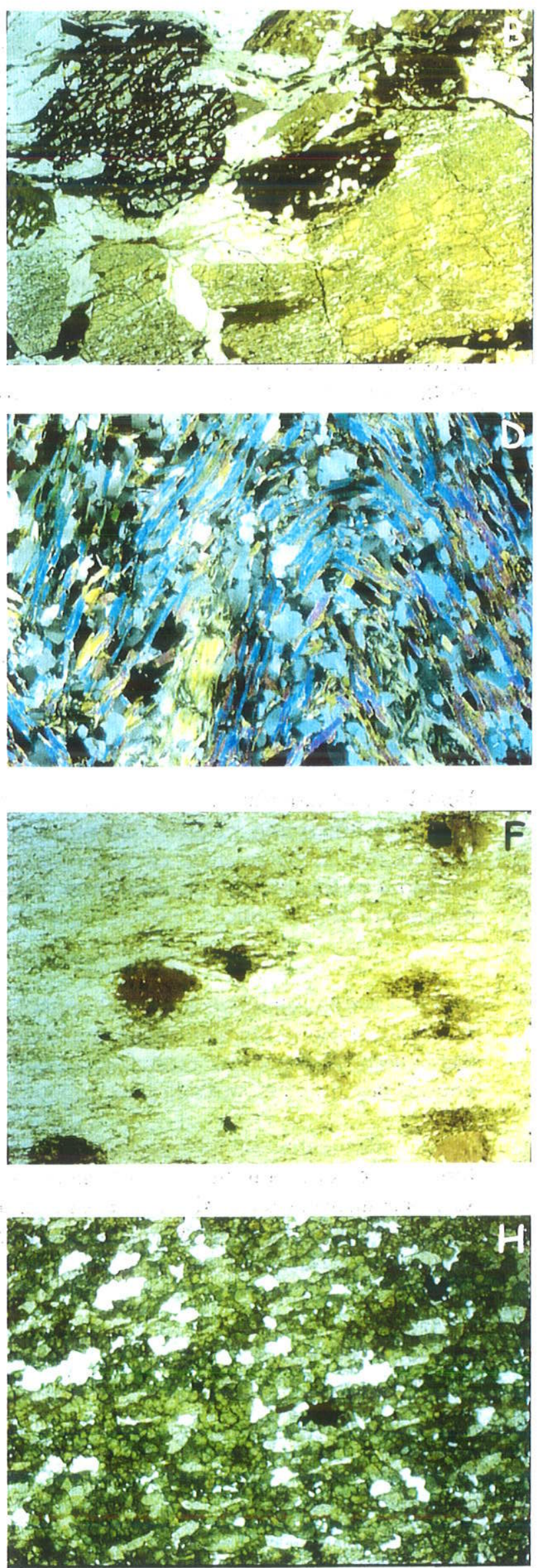


\section{LEGENDA - PRANCHA 08}

Foto A - Biotita-turmalina xisto intercalado nos metassedimentos tufíticos e xistos pelíticos da Formação Morro da Pedra Preta (GSl). Nas porções superior e inferior observam-se leitos formados essencialmente por turmalina e biotita com quartzo subordinado. No leito central a turmalina se associa essencialmente ao quartzo. Sem analisador. Lado maior $~ 5,5 \mathrm{~mm}$. Amostra do afloramento PP 593.

Foto B - Metarriólito da Formação Morro da Pedra Preta (GSI). Observar fenocristais reliquiares de quartzo bipiramidais com faces retilíneas e/ou corroídas e preenchidas por matriz quartzo-micácea. Alguns fenocristais estão recristalizados e se nota a extinção ondulante. A matriz, fina a muito fína, é composta por quartzo, feldspato potássico e plagioclásio recristalizados, além de minerais micáceos orientados segundo a foliação $S_{1}$. Com analisador. Lado maior 5,5 mm. Amostra do ponto SP 643A.

Foto C - Metarriólito da Formação Morro da Pedra Preta (GSI) exibindo fenocristais de fedspato. O maior deles mostra uma textura granofírica devido ao intercrescimento de feldspato potássico e quartzo, indicando uma origem subvulcânica. Com analisador. Lado maior 5,5 mm. Amostra do ponto CV 818.

Foto D - Metapelito calcífero da Formação Nhanguçu (GSI), formado principalmente por muscovita, flogopita, grafita \pm carbonato. Pode-se notar que os cristais de quartzo ocorrem subordinados e estão alongados segundo a foliação $S_{2}$. Na porção superior direita são vistos finos cristais de carbonato concentrados com os de quartzo. Sobrepõe-se à $S_{2}$ uma clivagem de crenulação $S_{3}$. Com analisador. Lado maior 2,8 mm. Amostra do afloramento SP 484 .

Foto E - Metapelito calcífero da Formação Nhanguçu (GSI) rico em carbonato. Observam-se intercalações de leitos ricos em carbonato $\sin -S_{2}$ e outros ricos em quartzo e flogopita também orientados na foliação $S_{2}$. Sem analisador. Lado maior $\sim 2,8 \mathrm{~mm}$. Amostra da região central da área do afloramento SP 647 coletada em uma intercalação junto às rochas carbonáticas.

Foto $\mathbf{F}$ - Rocha calciossilicática da Formação Nhanguçu (GSI). Notar na porção superior a presença de cristais de escapolita (com cores de interferência amarelo e cinza), gerados a partir da alteração do plagioclásio. Nas porçöes central e inferior ocorrem cristais de tremolita e de diopsídio (cor de interferência cinza). Com analisador. Lado maior 2,8 mm. Amostra do afloramento SP 632.

Foto G - Tremolita mármore da base da Formação Nhanguçu (GSI). Observar porfíroblastos de tremolita com forma tendendo a fibrorradiada dispersos em matriz carbonática. Com analisador. Lado maior 5,5 mm. Amostra coletada em um corpo lenticular imbricado tectonicamente na Unidade Metabásica da Formação Morro da Pedra Preta (GSI) no afloramento PJ 879.

Foto H - Aspecto geral dos xistos quartzosos da Formação Pirucaia (GSI) formados principalmente por quartzo e biotita. Notar a presença de grãos e grânulos de quartzo com as formas clásticas preservadas porém recristalizados. A orientação da rocha é dada pela isorientação dos cristais mais finos de biotita da foliação $S_{2}$. Com analisador. Lado maior $~ 5,5 \mathrm{~mm}$. Amostra do afloramento TT $881 \mathrm{~B}$. 
PRANCHA 08
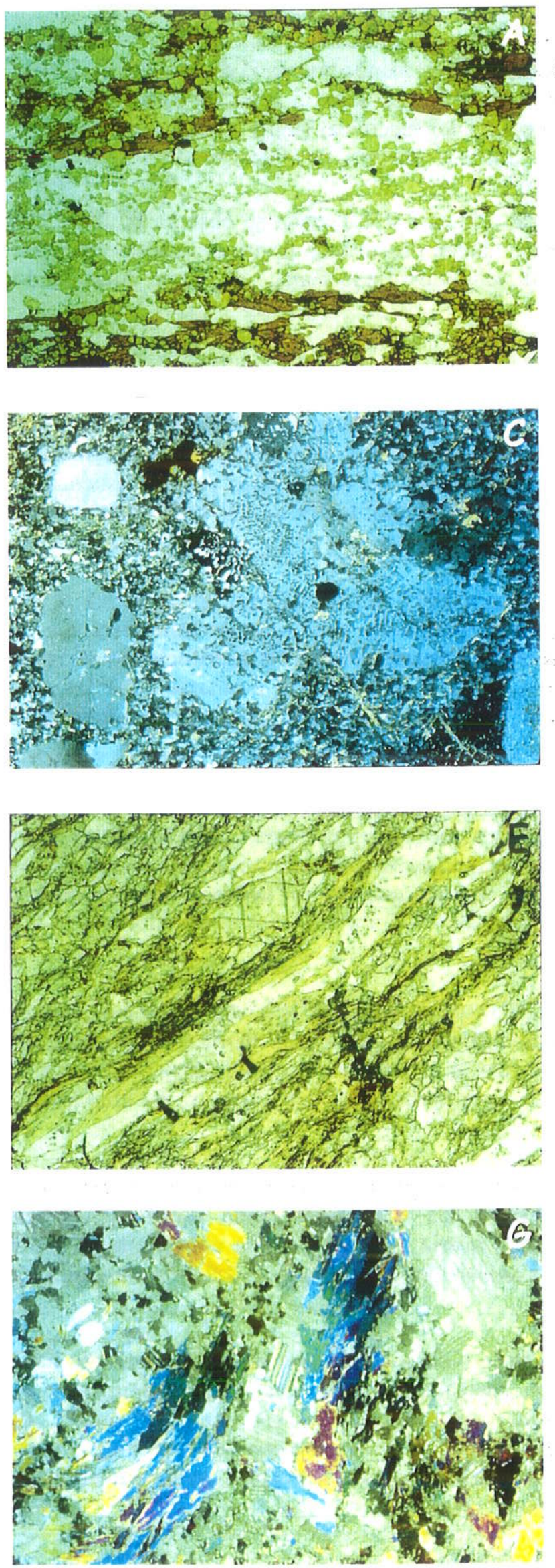
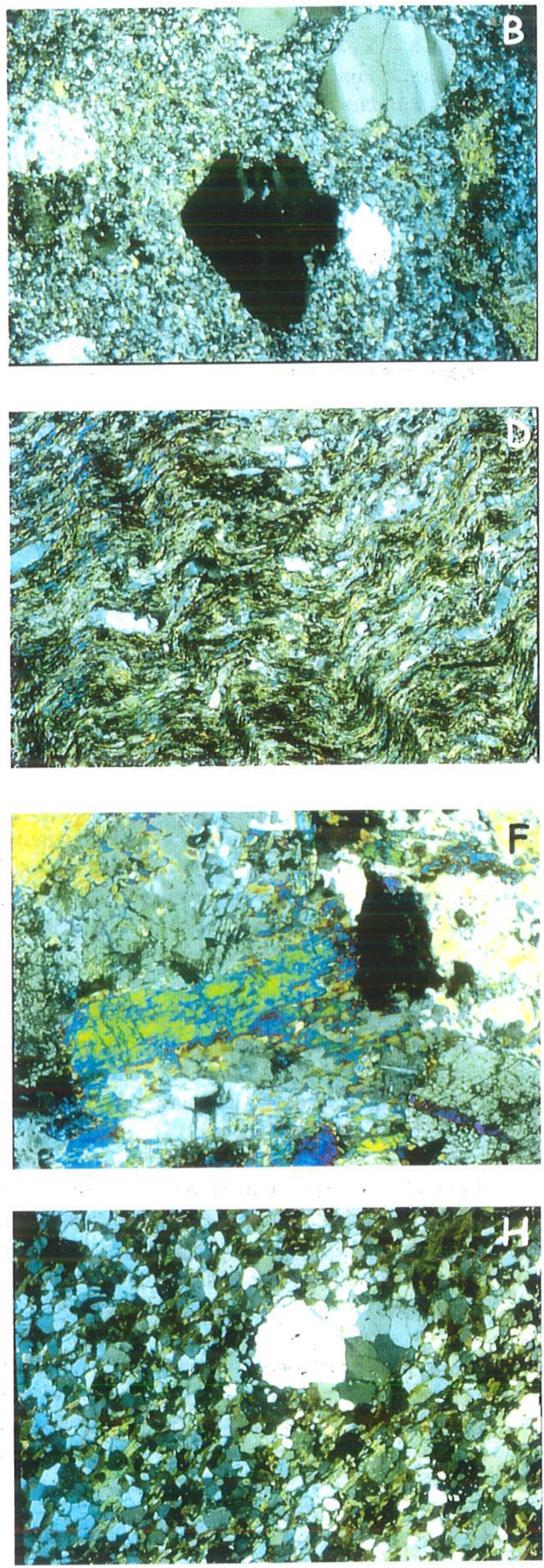


\section{LEGENDA - PRANCHA 09}

Foto A - Xisto quartzoso da Formação Pirucaia (GSI) formado por quartzo, biotita e muscovita. Notar na porção centro-inferior a foliação $S_{1}$ reconhecida pelo arranjo menos orientado dos cristais de biotita e de quartzo que também säo maiores. Na região superior predomina a foliação $S_{2} / S_{m}$ que, mais intensa, trunca os cristais prévios e propicia a cristalização de muscovita, biotita e quartzo mais finos e fortemente orientados. Sem analisador. Lado maior 1,4 mm. Amostra do afloramento TT' 526.

Foto B - Detalhe dos xistos quartzosos da Formação Pirucaia (GSI), onde se observa biotita e um cristal euédrico de cianita, ambos sin- $S_{1}$. Notar que a cianita possui uma provável inclusão de rutilo róseo no centro e de mineral opaco na borda. Sem analisador. Lado maior $\sim 0,7 \mathrm{~mm}$. Amostra do ponto TT $881 \mathrm{~B}$.

Foto C - Metarcóseo da Formação Morro Doce (GSR). Notar no centro porfiroclasto de plagioclásio com a geminação múltipla preservada e fraturado pela foliação $S_{\mathrm{m}}$. À direita, porfiroclasto de feldspato potássico com faces retas indicando pouco transporte. Observar matriz intensamente recristalizada pela foliação milonítica $S_{1} / S_{m}$, onde predominam muscovita e biotita, além do quartzo e plagioclásio subordinados. Cristais maiores de biotita estão presentes junto ao plagioclásio porfiroclástico. São vistos ainda alguns clastos de quartzo. Com analisador. Lado maior 5,5 mm. Amostra do afloramento PJ 17D (região do Morro Doce).

Foto D - Metarcóseo da Formação Morro Doce (GSR). Notar porfiroclastos euédricos de plagioclásio com a geminação múltipla preservada e fraturados pela foliação milonítica $\mathrm{S}_{\mathrm{m}}$. $\mathrm{A}$ esquerda, observa-se outro porfiroclasto de plagioclásio subarredondado. Os porfiroclastos ocorrem dispersos em uma matriz fina a muito fina rica em biotita com muscovita e quartzo subordinados, orientados segundo a foliação $S_{1} / S_{\mathfrak{m}}$. Com analisador. Lado maior $~ 5,5 \mathrm{~mm}$. Amostra do afloramento PJ 17D (região do Morro Doce).

Foto E - Metarcóseo da Formação Morro Doce (GSR) com porfiroclasto de feldspato potássico na porção superior parcialmente recristalizado em cristais menores nas bordas, mas sendo possível reconhecer a forma reliquiar. No centro, outro porfiroclasto exibe faces euédricas. Os porfiroclastos estão dispersos em uma matriz fina formada por biotita, quartzo (e feldspato recristalizado), muscovita, magnetita e epidoto. Com analisador. Lado maior $\sim 5,5 \mathrm{~mm}$. Amostra do afloramento BT 104 (região do Morro do Polvilho).

Foto F - Metarcóseo da Formação Morro Doce (GSR) com porfiroclasto subeuédrico de feldspato (à esquerda) e com fragmento lítico de granitóide (à direita), dispersos em uma matriz fina parcialmente preservada da milonitização, constituída por quartzo e feldspatos recristalizados, com biotita, muscovita e epidoto subordinados. Com analisador. Lado maior 5,5 $\mathrm{mm}$. Amostra do afloramento BT 100 (regiäo do Morro do Polvilho).

Foto G - Metaconglomerado da Formação Morro Doce (GSR). Obervar, à direita, um fragmento lítico de granitóide com cristais de feldspato semelhantes aos observados como porfiroclastos nos metarcóseos. Notar na porção inferior-esquerda que a matriz é rica em biotita e ocorrem dispersos pequenos clastos de feldspato e de quartzo. Com analisador. Lado maior $\sim 2,8 \mathrm{~mm}$. Amostra do afloramento BT 105 (região do Morro do Polvilho).

Foto H - Metaconglomerado da Formação Morro Doce (GSR). Notar no centro um fragmento lítico de rocha meta-intermediária, provavelmente um metandesito, rico em cristais ripiformes de plagioclásio. $\mathrm{Na}$ borda do fragmento há forte cristalização de epidoto. $\mathrm{Na}$ matriz do metaconglomerado, à direita, observam-se clastos euédricos de feldspato potássico e de plagioclásio. Com analisador. Lado maior $\sim 5,5 \mathrm{~mm}$. Amostra da base do Morro Doce (Túnel do Rodoanel, altura do $\mathrm{km} 22,5$ da Rodovia Anhangüera). 


\section{PRANCHA 09}
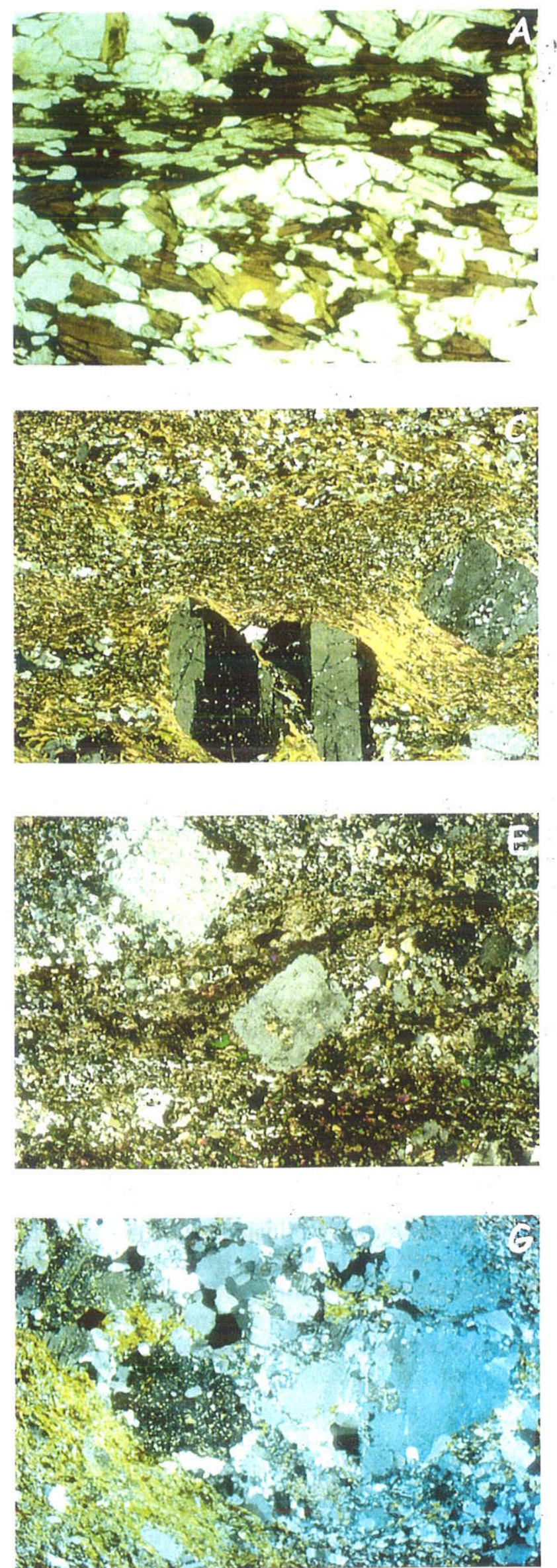

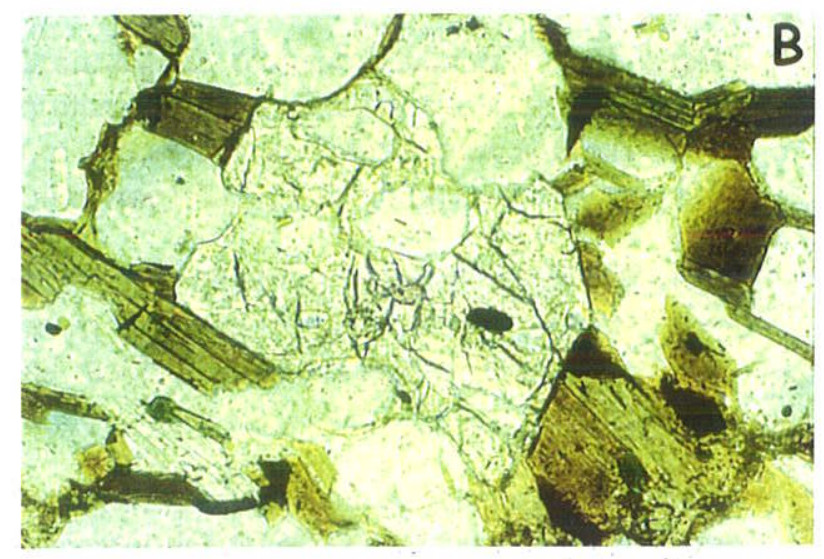

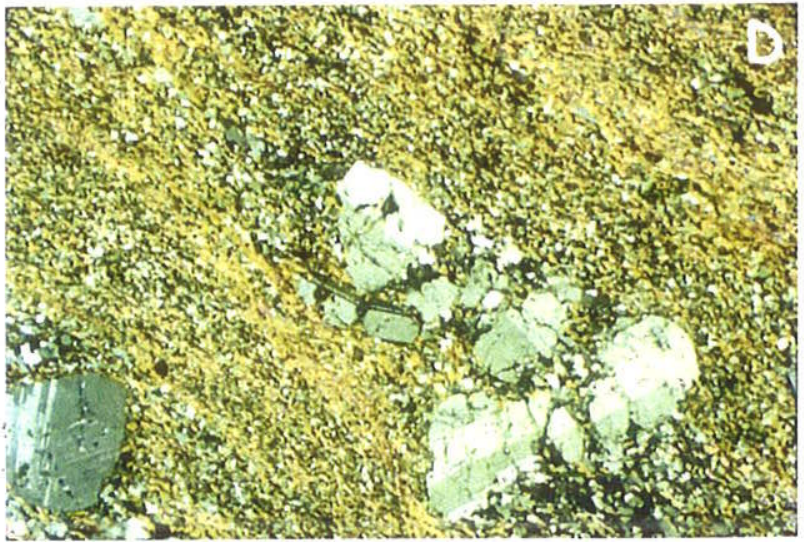
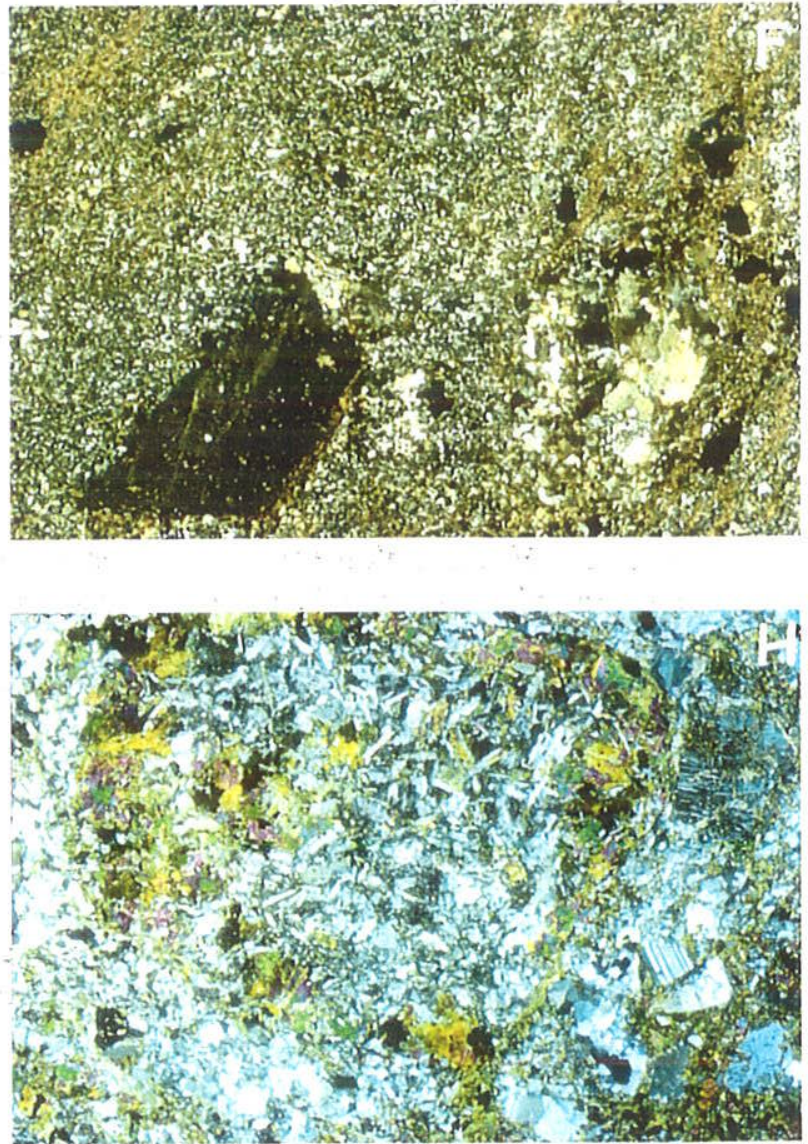


\section{LEGENDA - PRANCHA 10}

Foto A - Metaconglomerado da Formação Morro Doce (GSR) com porfiroclastos euédricos a subeuédricos de plagioclásio e de feldspato potássico, semelhantes àqueles presentes nos metarcóseos e metarenitos arcoseanos das regiōes dos morros Doce e do Polvilho. Com analisador. Lado maior $5,5 \mathrm{~mm}$. Amostra do ponto PJ 17A (região do Morro Doce).

Foto B - Clinopiroxênio-tremolita/actinolita da Formação Pirapora do Bom Jesus (GSR). Observar os cristais ripiformes de plagioclásio com geminação simples inclusos em fenocristal de clinopiroxênio denotando uma textura blastofítica. Com analisador. Lado maior $\sim 2,8 \mathrm{~mm}$. Amostra do ponto RP 894A.

Foto $\mathrm{C}$ - Aspecto comum dos tremolita/actinolita-clinopiroxênio anfibolitos das formações Estrada dos Romeiros e Piragibu (GSR). Observar restos instáveis de cristais de clinopiroxênio castanho-claro dispersos em matriz fina constituída principalmente por agregados de cristais de epidoto e titanita. Sem analisador. Lado maior 2,8 mm. Amostra do afloramento CJ 285 (Formação Estrada dos Romeiros).

Foto D - Tremolita/actinolita anfibolito da Formação Estrada dos Romeiros (GSR). Observar porfiroblastos subeuédricos a anédricos de tremolita-actinolita com as extremidades esfiapadas. $\AA$ direita ocorrem cristais de plagioclásio com a forma tabular reliquiar e outros de epidoto granular. $\mathrm{Na}$ porção superior podem ser vistos cristais anédricos de titanita parcialmente leucoxenizada. Sem analisador. Lado maior $\sim 2,8 \mathrm{~mm}$. Amostra do afloramento JD 152.

Foto E - Tremolita/actinolita anfibolito da Formação Estrada dos Romeiros (GSR) contendo porfiroblastos de tremolita/actinolita $S_{1}$ parcialmente alterados para clorita retrometamórfica $S_{2}$. Observar à direita, cristais de plagioclásio não mais geminados inclusos nos porfiroblastos que estão reequilibrados para albita. Com analisador. Lado maior $\sim 1,4 \mathrm{~mm}$. Amostra do afloramento CV 01 .

Foto F - Tremolita/actinolita anfibolito com epidoto da Formação Pirapora do Bom Jesus (GSR) e que também ocorre nas Formações Estrada dos Romeiros e Piragibu. Observar a estrutura maciça e a textura blastosubofítica com cristais de plagioclásio ripiformes preservados. Notar a alteração dos cristais anédricos de tremolita/actinolita para epidoto granular no centro e à direita, e a presença de titanita anédrica. Sem analisador. Lado maior $\sim 5,5 \mathrm{~mm}$. Amostra do afloramento VS 412.

Foto $\mathrm{G}$ - Tremolita/actinolita anfibolito (rocha metavulcanoclástica básica) da Formação Pirapora do Bom Jesus (GSR). No centro nota-se um fragmento de rocha (possivelmente intermediária) contendo prismas ripiformes de plagioclásio, em meio a uma matriz de granulação fina rica em cristais de tremolita-actinolita. À direita, ocorre um agregado constituído por clorita e com epidoto no centro, representando possível amígdala recristalizada. Sem analisador. Lado maior $\sim 2,8 \mathrm{~mm}$. Amostra do afloramento VS 373.

Foto H - Metarenito feldspático da Formação Boturuna (GSR) formado principalmente por quartzo, feldspato e muscovita. Observar os grãos de quartzo e de feldspato recristalizados e um pouco orientados segundo a foliação $S_{1}$ (de direção NNE-SSW na foto) que também marca a isorientação dos cristais de muscovita. Os clastos de feldspato (cor de interferência cinza) são mais angulosos e concentram-se à esquerda e, um deles, preserva a geminação em grade. Com analisador. Lado maior 2,8 mm. Amostra do afloramento CV 773. 


\section{PRANCHA 10}
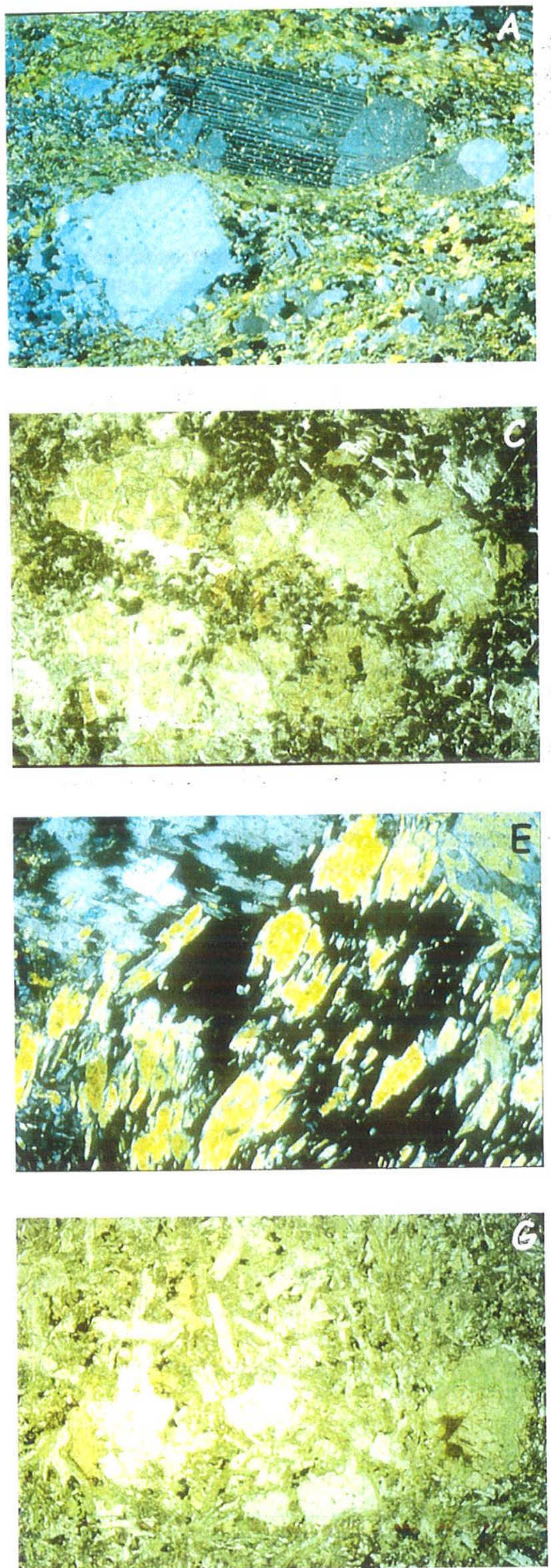
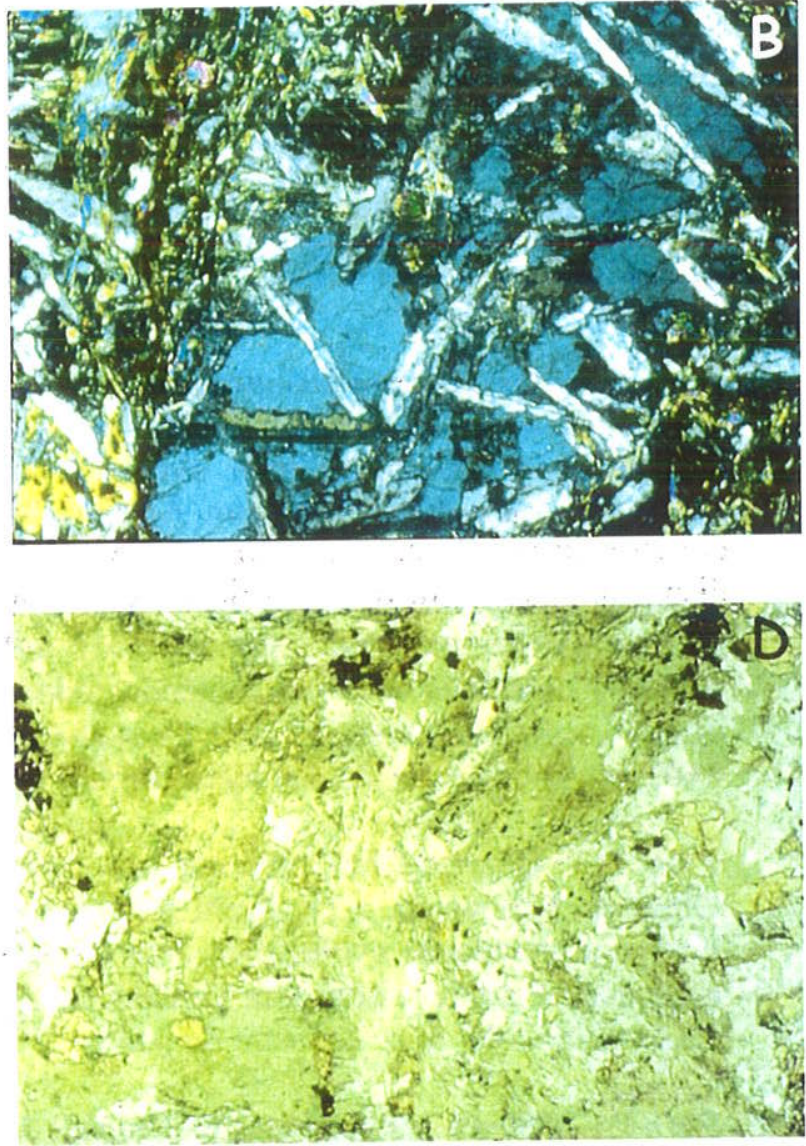

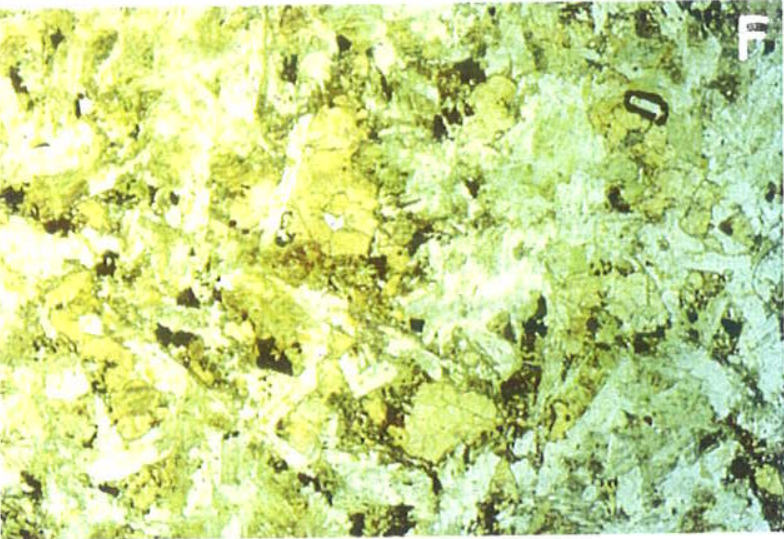

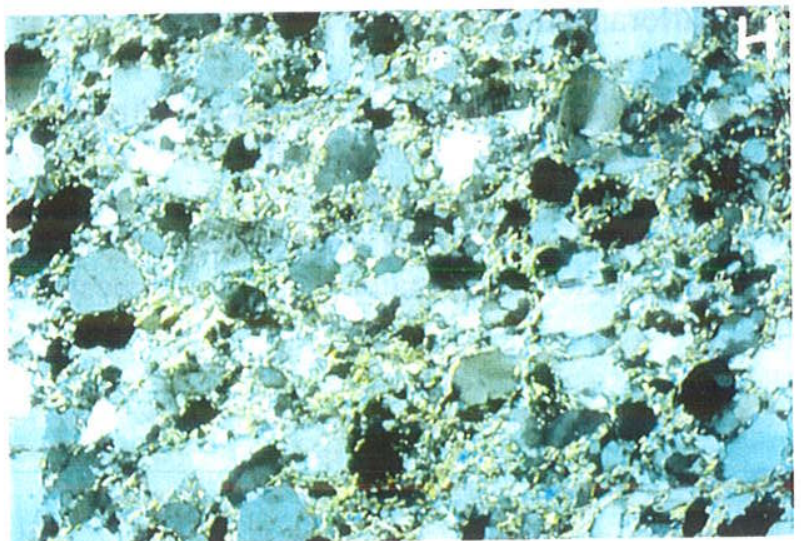




\section{LEGENDA - PRANCHA 11}

Foto A - Rocha metabásica shoshonítica da Formação Boturuna (GSR). Petrograficamente corresponde a um biotita xisto. Observar aglomerados arredondados (amígdalas) ora preenchidos por quartzo (centro) ora formando uma espécie de corona com quartzo na borda e um núcleo rico em biotita (esquerda). Notar que a amígdala à direita encontra-se adelgaçada pelas foliações $S_{1} / S_{2}$ superpostas. Com analisador. Lado maior $~ 5,5 \mathrm{~mm}$. Amostra do afloramento PJ 920B (WSW do Pico do Jaraguá).

Foto B - Aspecto geral dos quartzitos das formações Boturuna e Estrada dos Romeiros (GSR). Notar a estrutura orientada pela foliação $S_{\mathrm{m}}$ que gerou nos cristais de quartzo, recristalização e estiramento. Clastos mais grossos exibem extinçăo ondulante e podem apresentar cominuição local. Com analisador. Lado maior 2,8 mm. Amostra do afloramento VS 376.

Foto C - Aspecto geral dos metarritmitos da Formação Estrada dos Romeiros (GSR). Observar a intercalação de leitos ricos em sericita e que contém quartzo fino subordinado (porções superior e inferior) com leito arenoso contendo grãos arredondados de quartzo e uma matriz composta por quartzo, sericita e mineral opaco. Com analisador. Lado maior $~ 5,5 \mathrm{~mm}$. Amostra do afloramento CJ 169, de uma intercalação dos metarritmitos na Unidade Metapelítica da Formação Piragibu.

Foto D - Quartzo-filito presente nos metarritmitos da Formação Estrada dos Romeiros (GSR). Observar à esquerda, a clivagem de crenulação (de direção N-S) ortogonal à foliação $\mathrm{S}_{1}$.(E-W) A direita, a crenulação evolui para uma foliação de transposição $S_{\mathrm{m}}$ com o início da formação de um bandamento diferenciado com lâminas ricas em quartzo e outras ricas em sericita. Com analisador. Lado maior $\sim 0.7 \mathrm{~mm}$. Amostra do ponto CJ 274 .

Foto $\mathbf{E}$ - Metarenitos presentes na Unidade Metarritmítica da Formação Estrada dos Romeiros (GSR). Observar a estrutura pouco orientada marcada pelo predomínio de cristais de quartzo com muscovita fina/sericita subordinada. Na parte superior ocorrem raros porfiroclastos de feldspato; no centro e a noroeste podem ser vistos porfiroblastos de clorita (cor de interferência anômala cinza-azulado escura). Com analisador. Lado maior 2,8 $\mathrm{mm}$. Amostra do afloramento CJ 162 .

Foto F - Metaconglomerado da Unidade Metarrítmica da Formação Estrada dos Romeiros (GSR). Observar a estrutura clasto-suportada com fragmentos de rocha filítica (centro), de metarenito (à direita), de metarenito muito fino (à esquerda, no topo e na base) e de quartzito fino (à esquerda), além de grãos angulosos de quartzo. Matriz composta essencialmente por sericita e quartzo muito fino. Com analisador. Lado maior 5,5 mm. Amostra do afloramento JD 153.

Foto $\mathbf{G}$ - Rocha metacarbonática da Formação Estrada dos Romeiros (GSR), formada essencialmente por carbonato com sericita e minerais opacos muito subordinados. Observar a foliação $\mathrm{S}_{1}$ (direção NESW na foto) dada pela isorientação dos cristais de calcita e do mineral micáceo. Alguns porfiroblastos euédricos de pirita indicam crescimento pós-S. $S_{1}$. Com analisador. Lado maior $\sim 2,8 \mathrm{~mm}$. Amostra do afloramento VS $916 \mathrm{D}$, próximo do contato das unidades Metacarbonática e Metacálcio-pelítica.

Foto $\mathbf{H}$ - Ardósia da Formação Piragibu (GSR) com matriz rica em cristais de clorita orientados segundo a foliação $S_{1}$ (NNE-WSW na foto). Notar a presença de grãos de biotita detrítica marrom rotacionados pela foliação $S_{1}$ e em parte reequilibrados para clorita sin- $S_{1}$. $\grave{A}$ direita, porfiroclasto maior de muscovita com sombra de pressão parcialmente reequilibrado para clorita $\sin -\mathrm{S}_{1}$. Sem analisador. Lado maior 1,4 mm. Amostra do afloramento ID 20 . 
PRANCHA 11
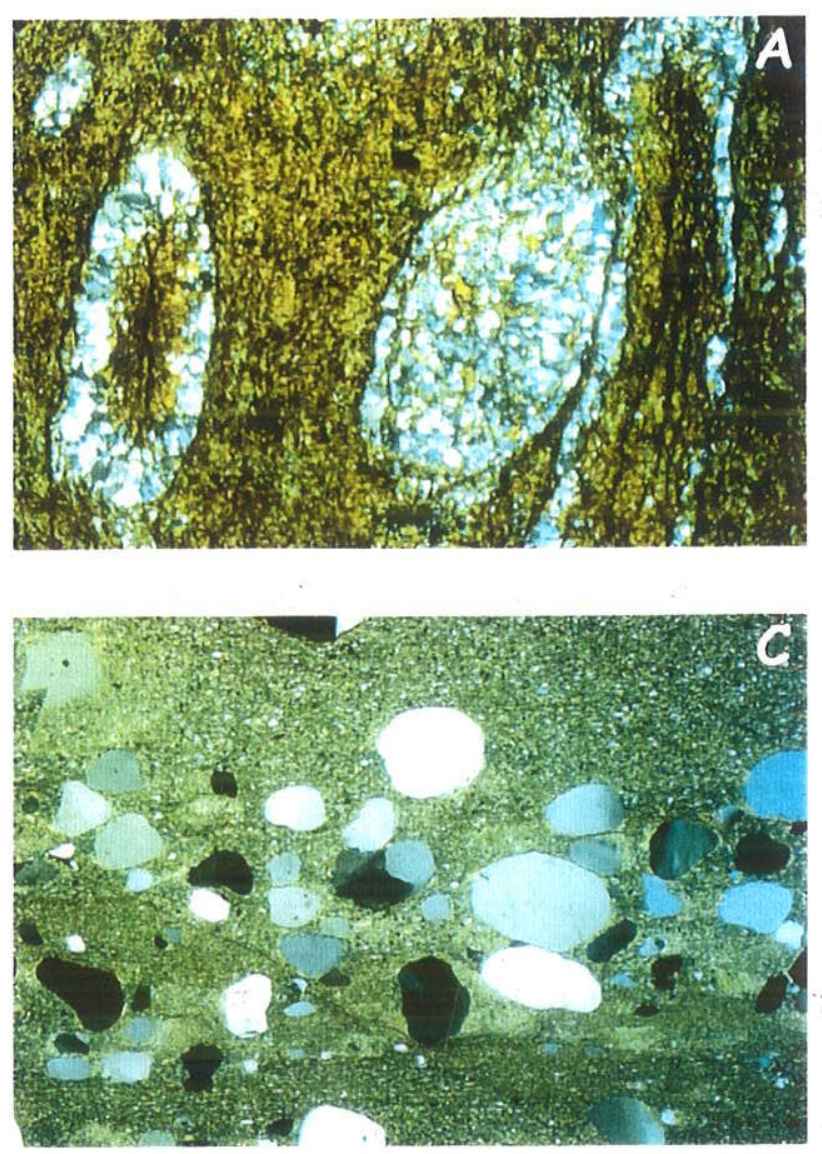

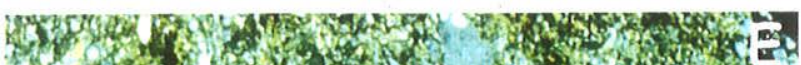

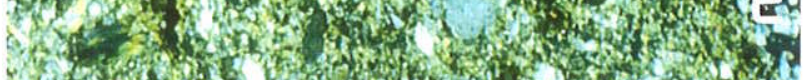

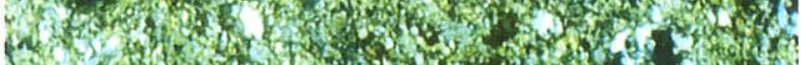

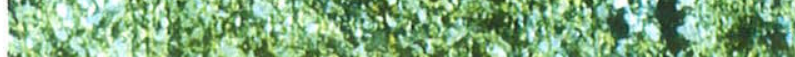
7.6.

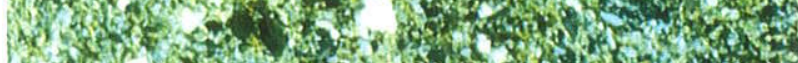

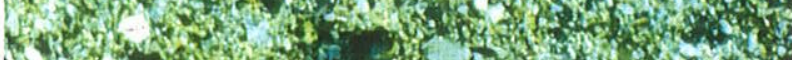

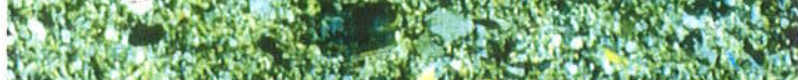

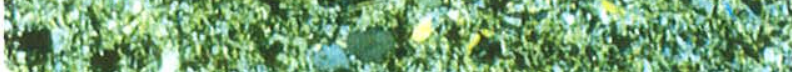

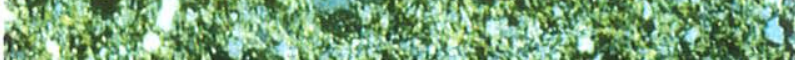

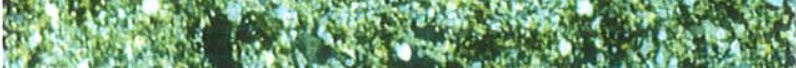

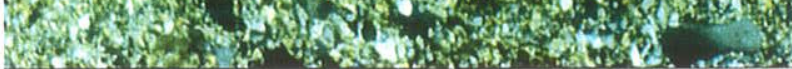

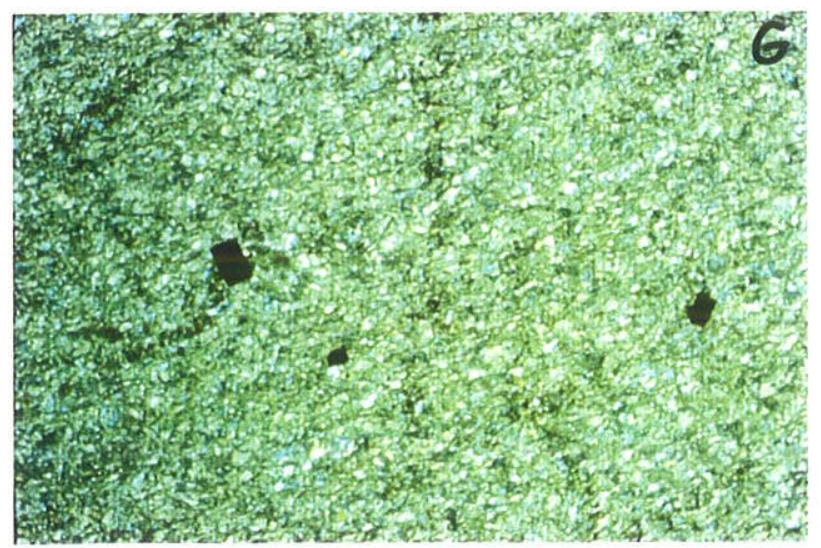

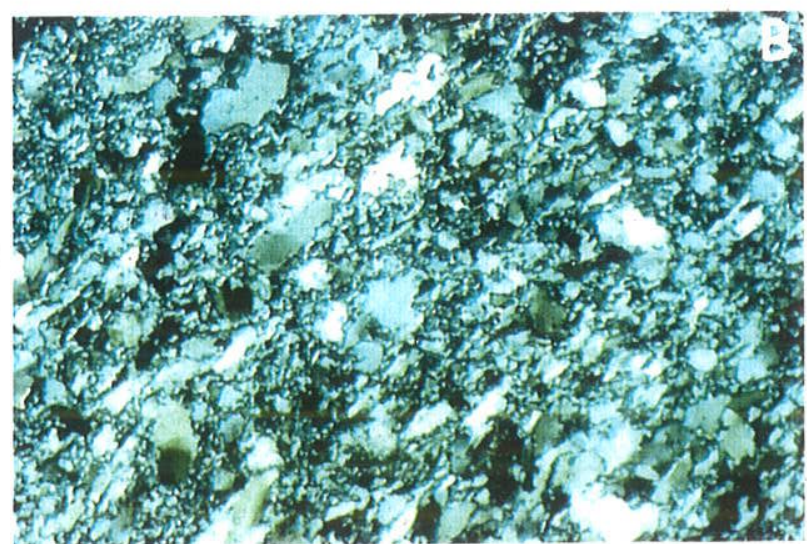

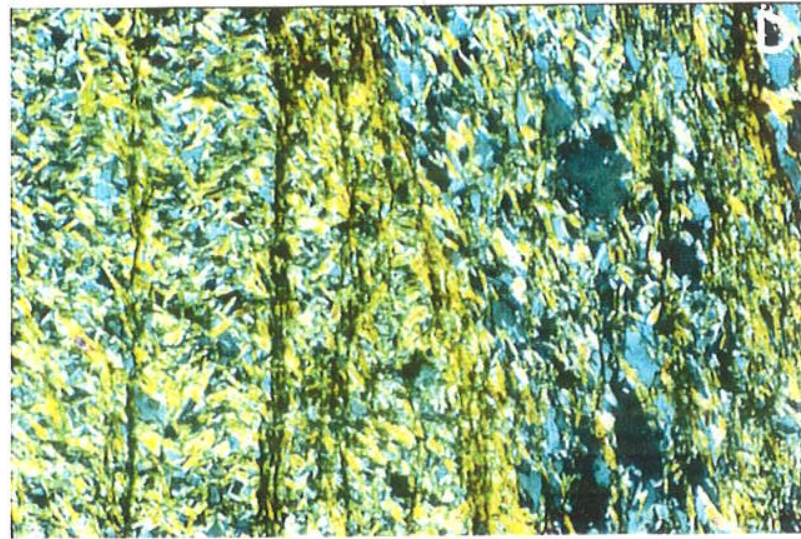
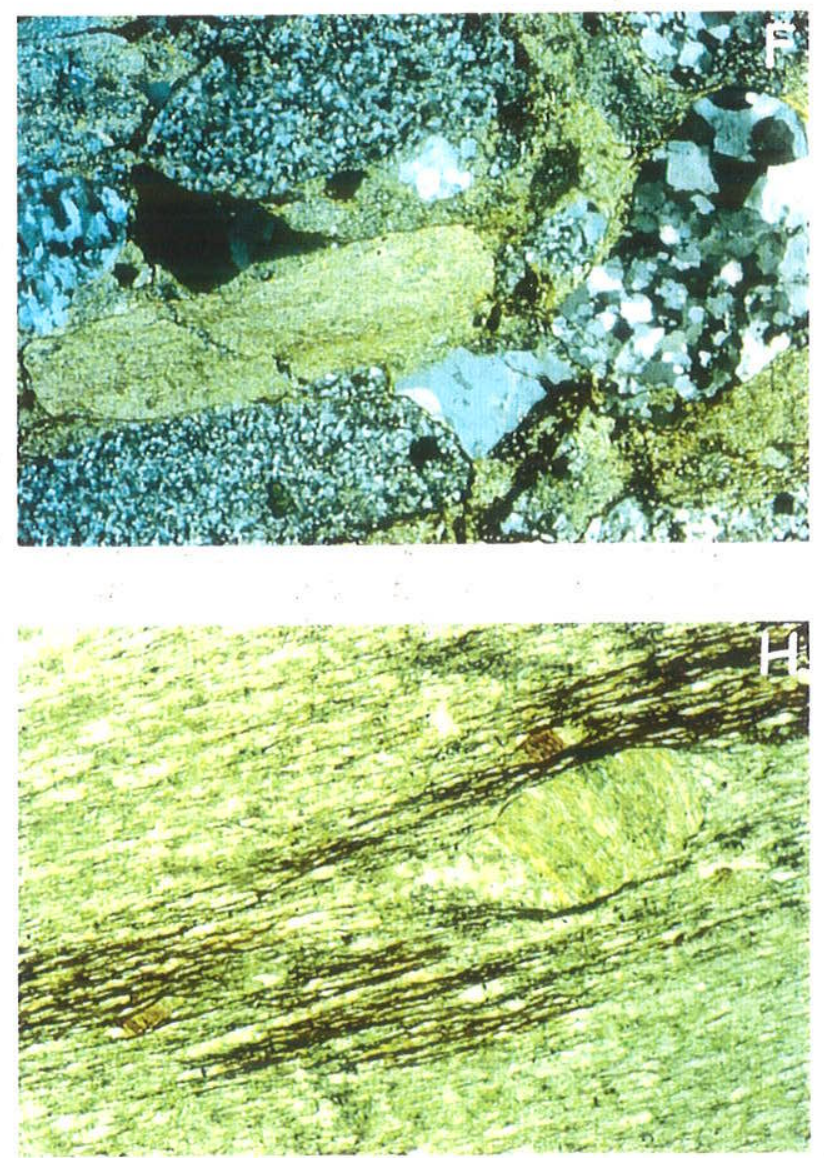


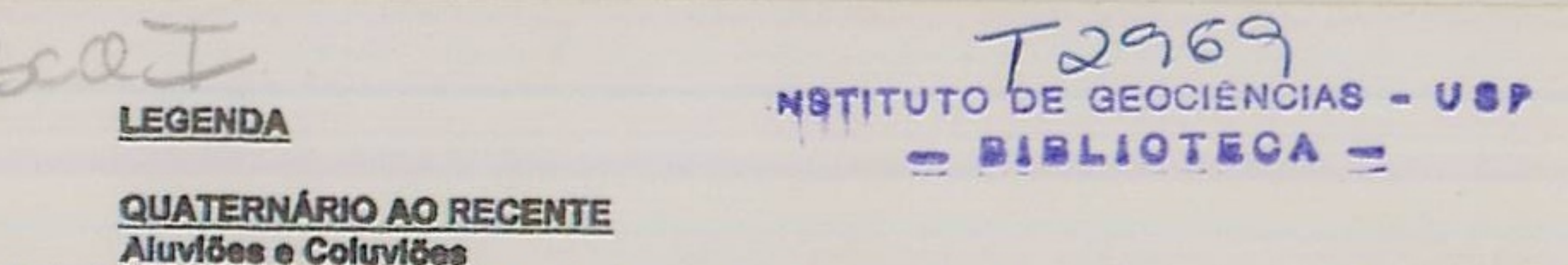

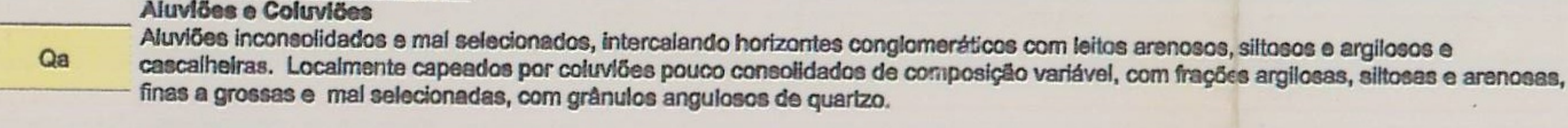

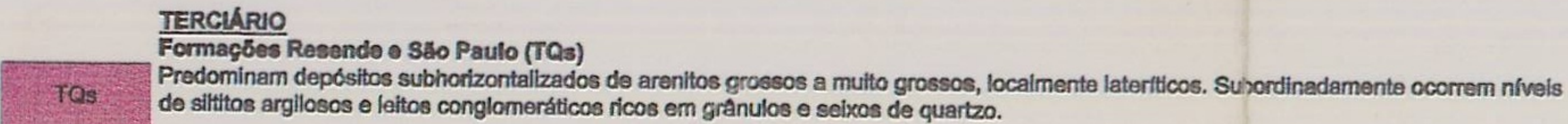

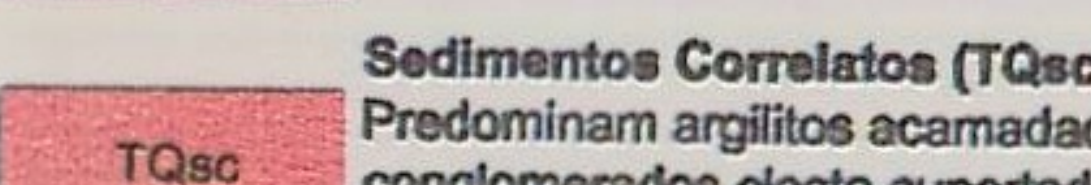

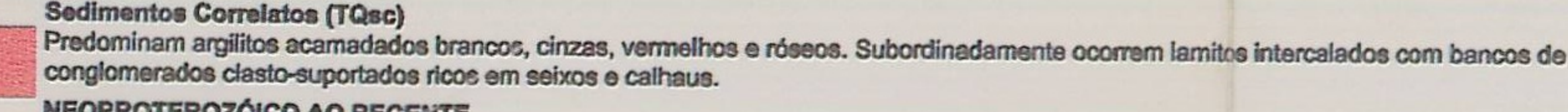
NEOPROTEROZOCOCOAORECEMTE

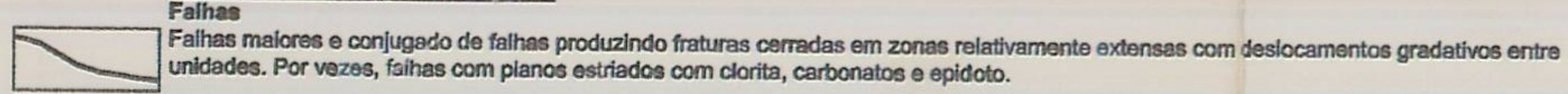

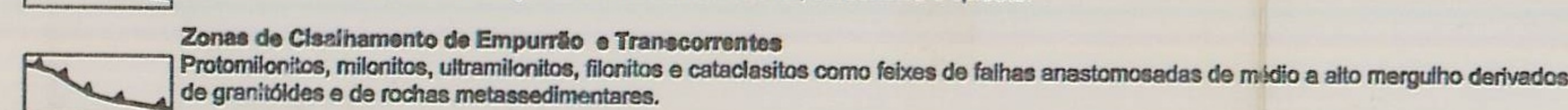

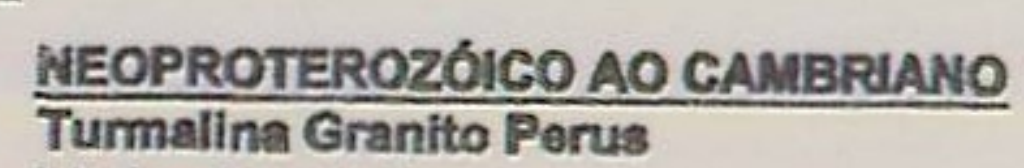

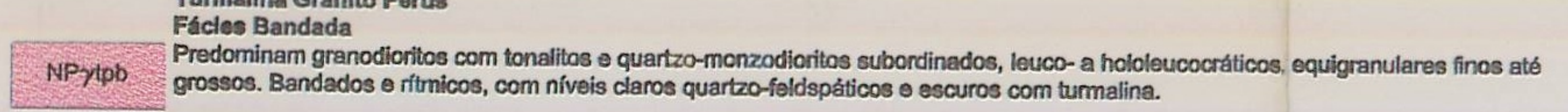

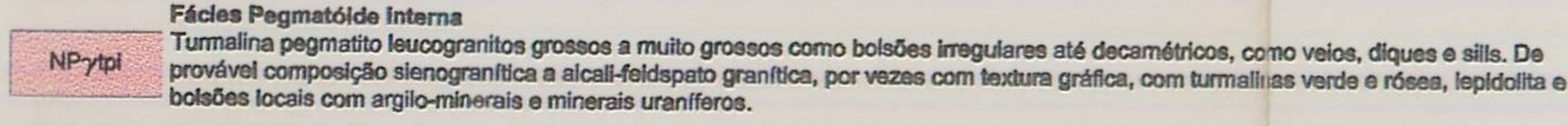

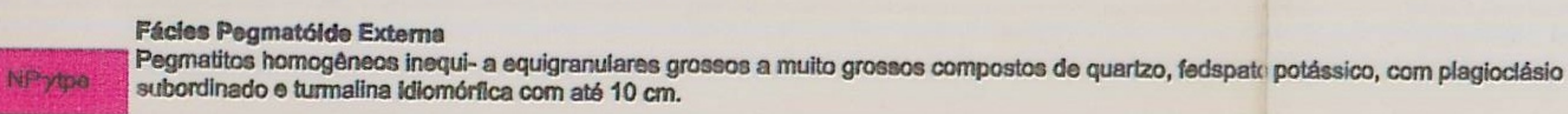

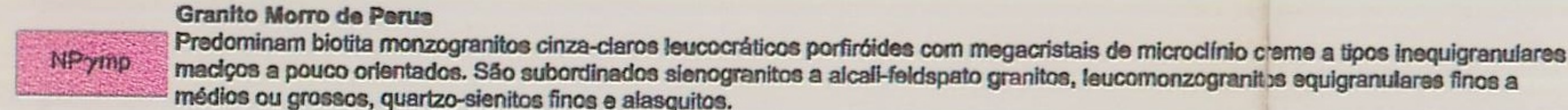
Stock Brantitico Jugueri

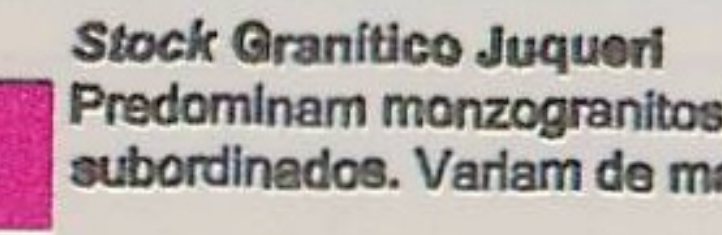

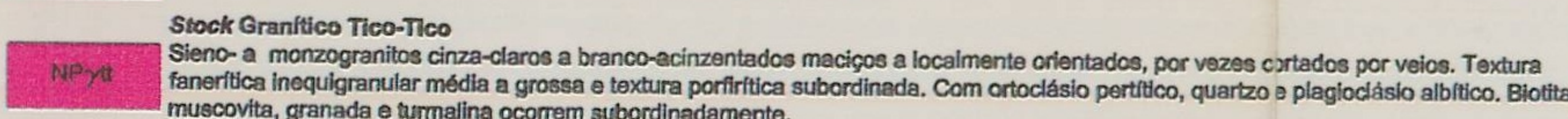

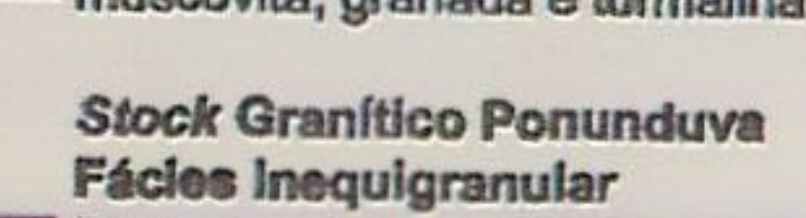

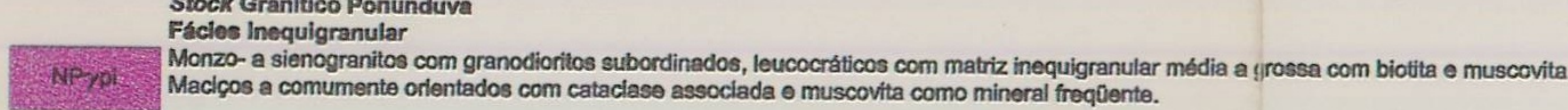

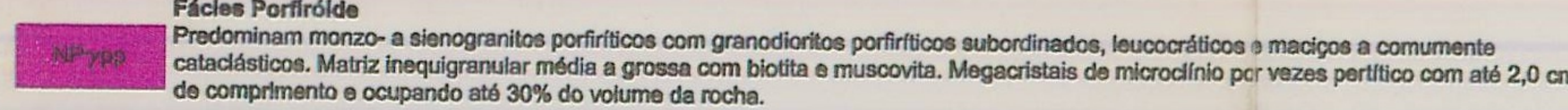

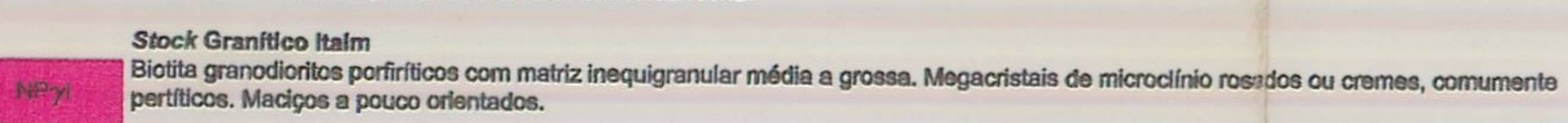

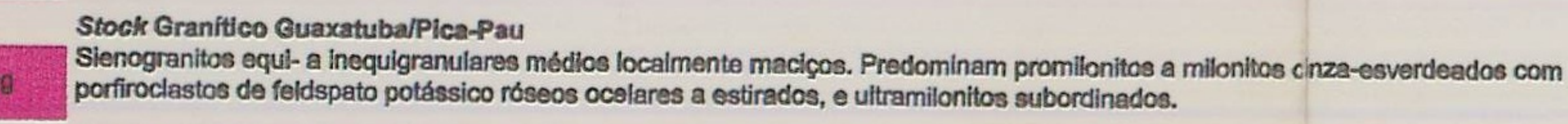

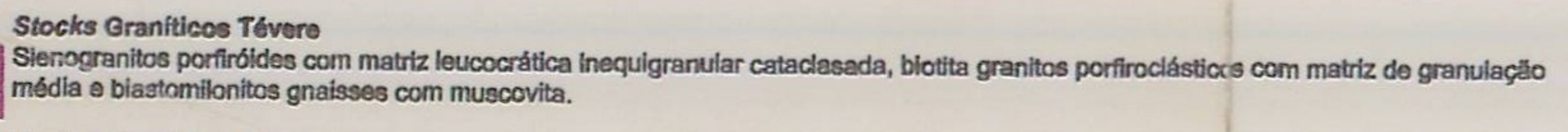

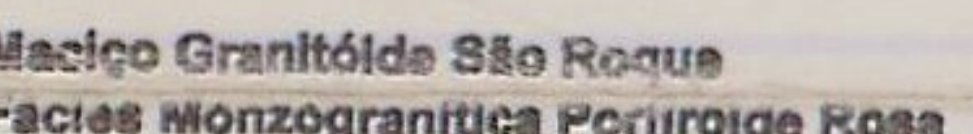

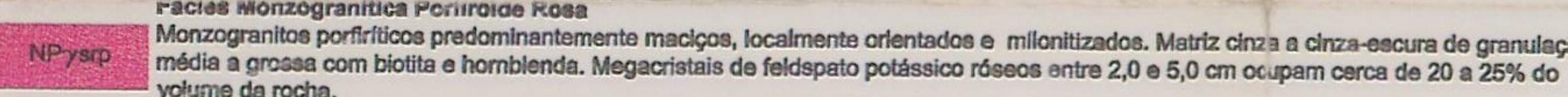

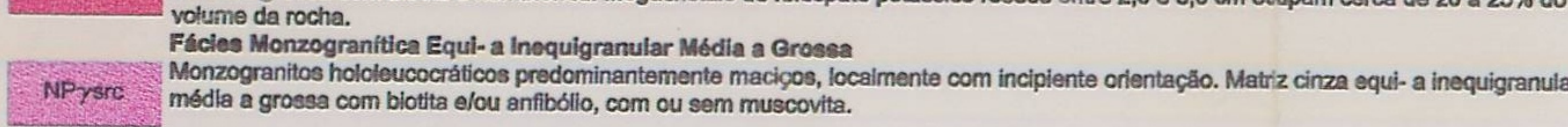

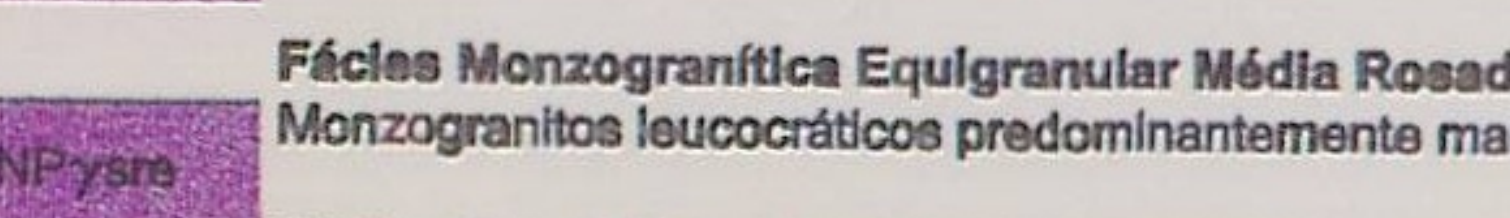

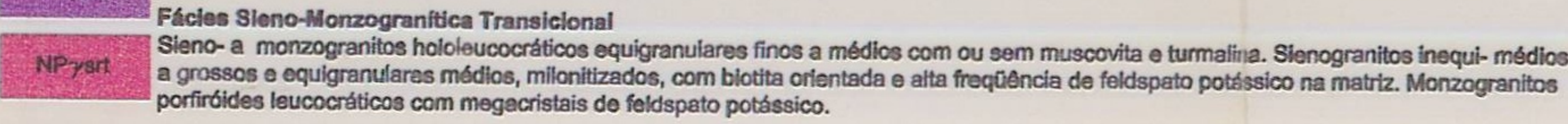

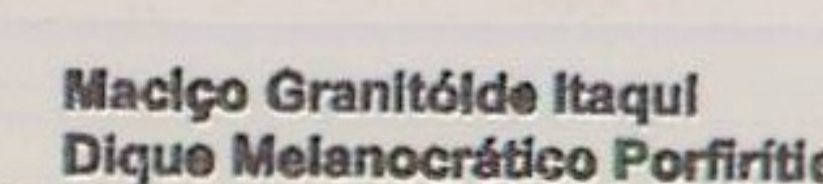

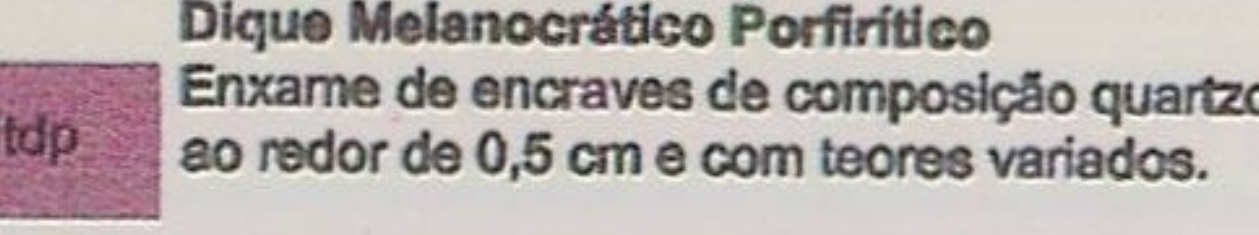

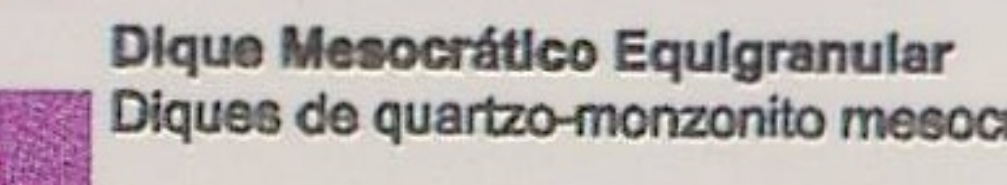

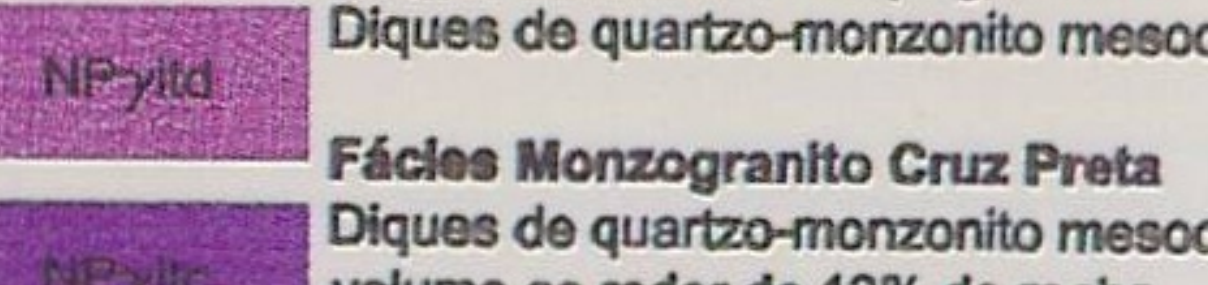

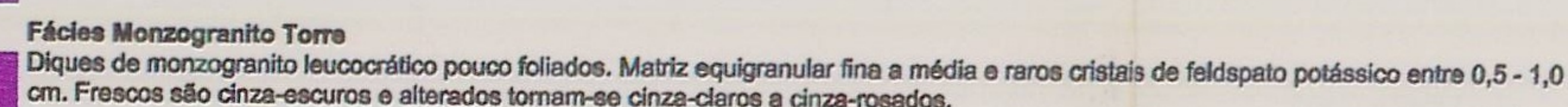

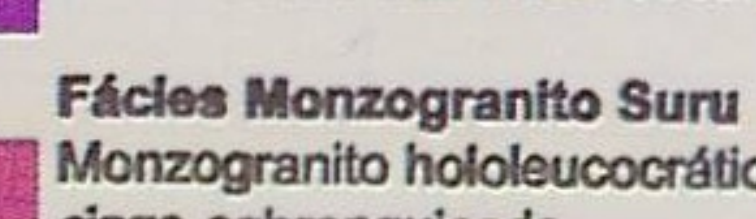

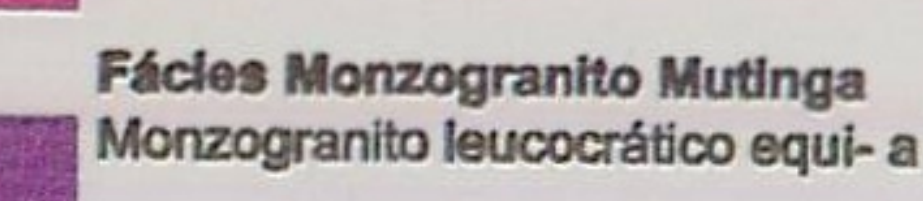

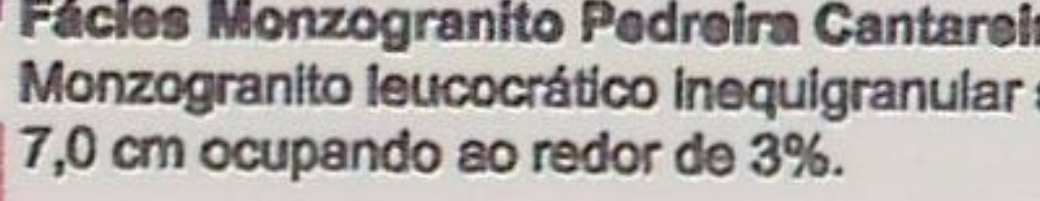

NPYItP

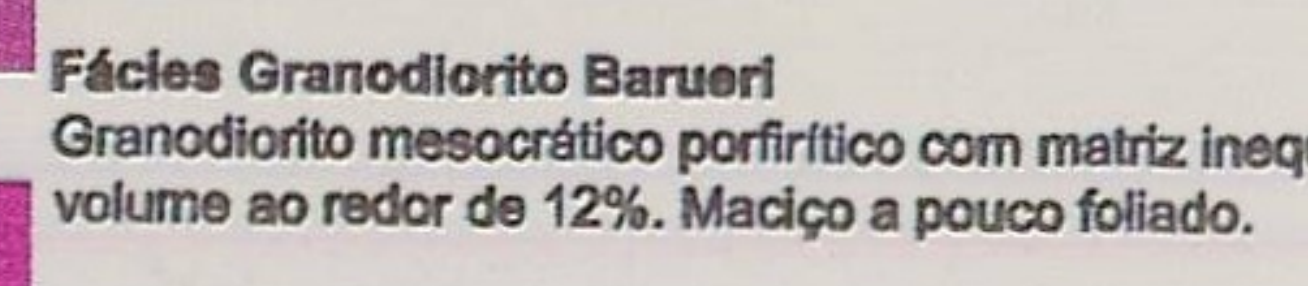

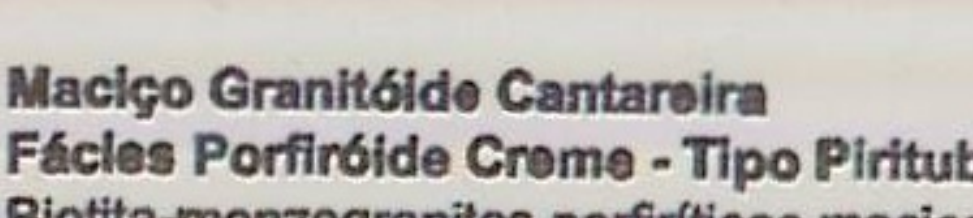

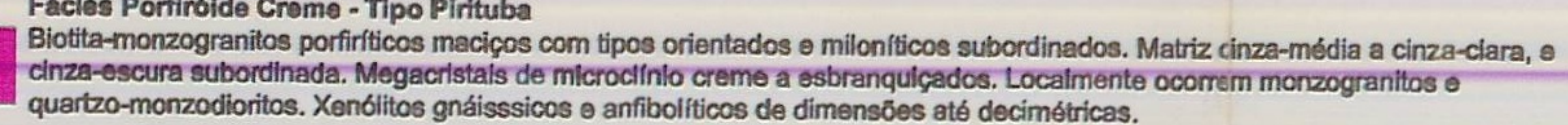

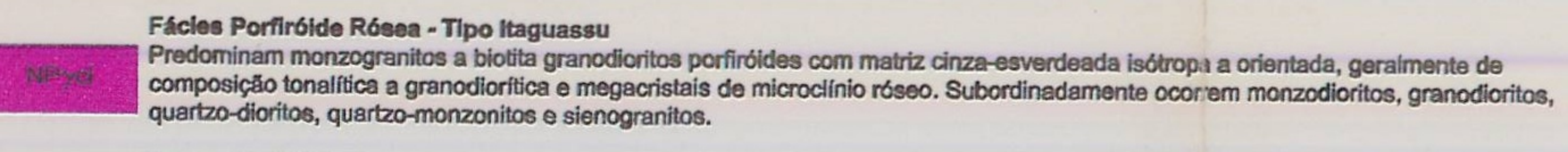

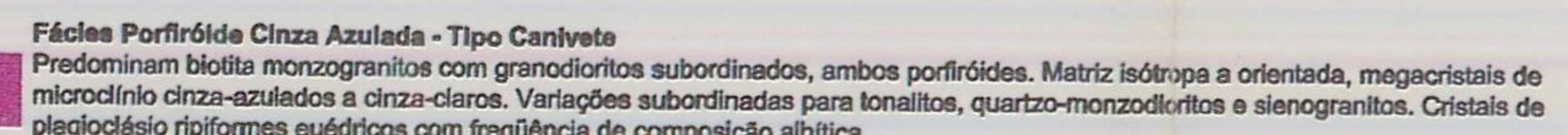

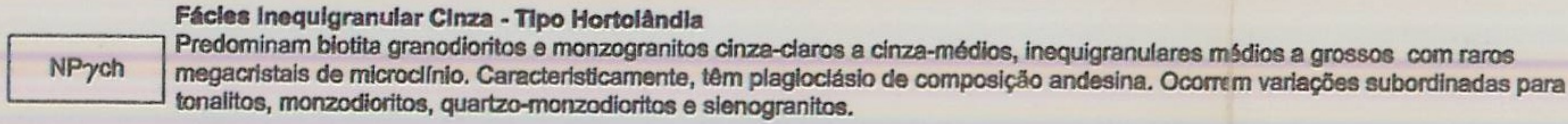

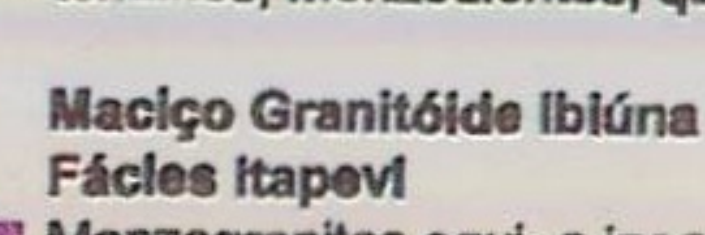

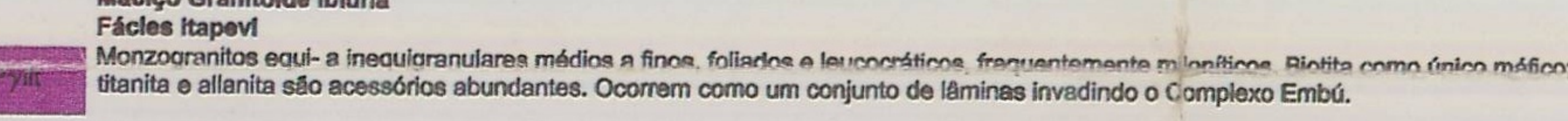

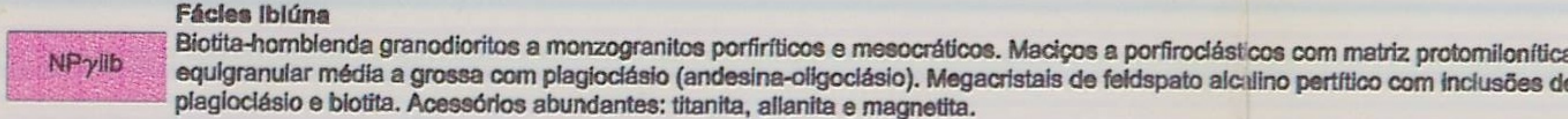

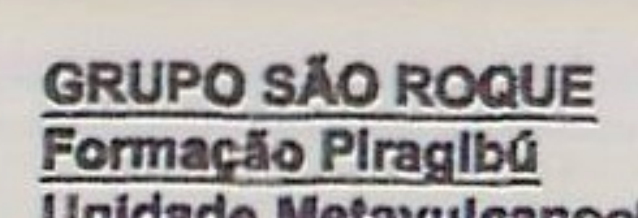

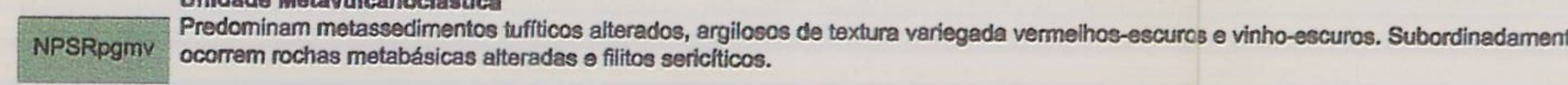

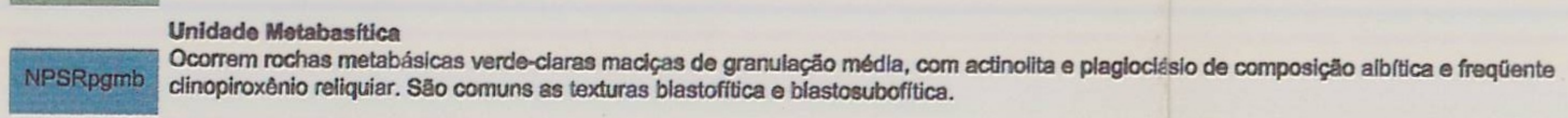

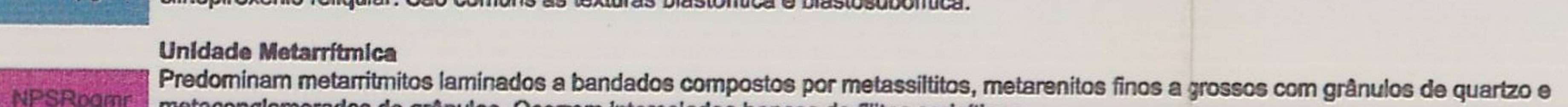

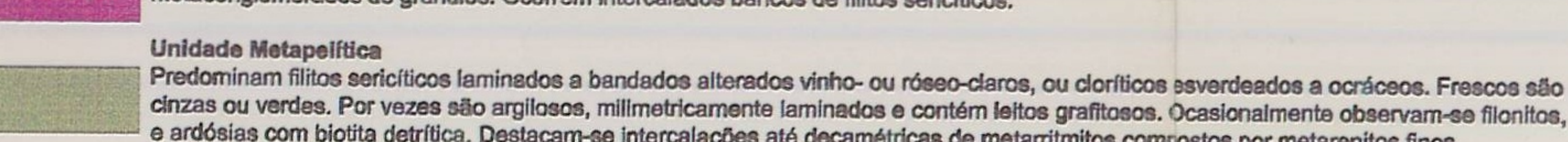

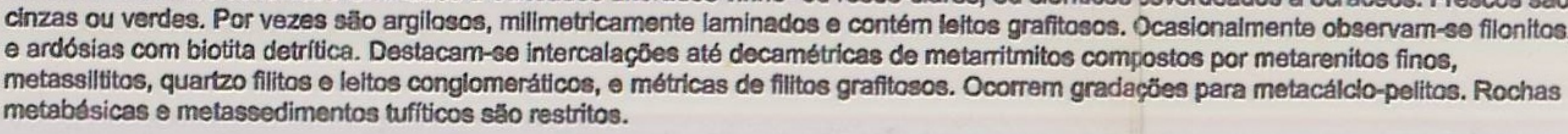

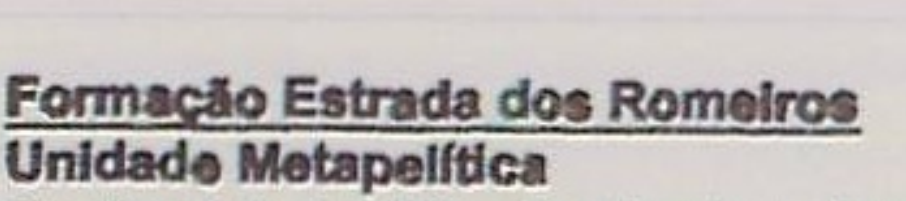

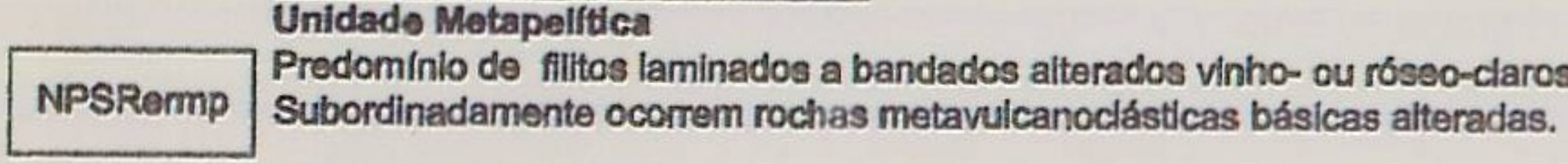

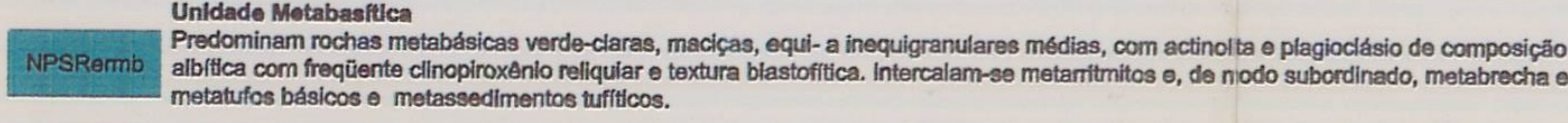

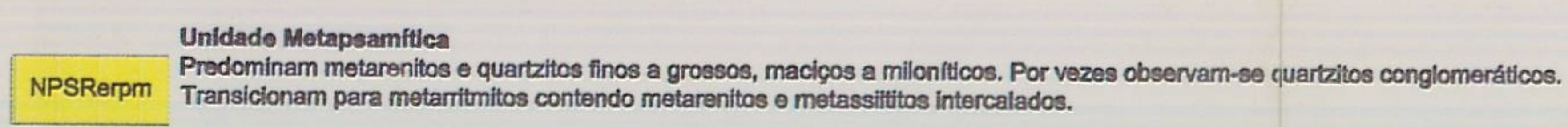

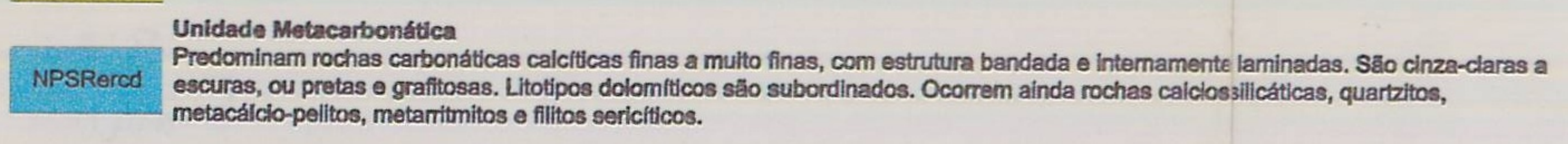

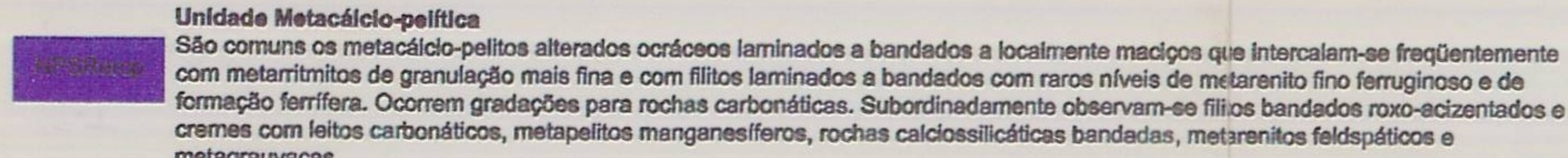

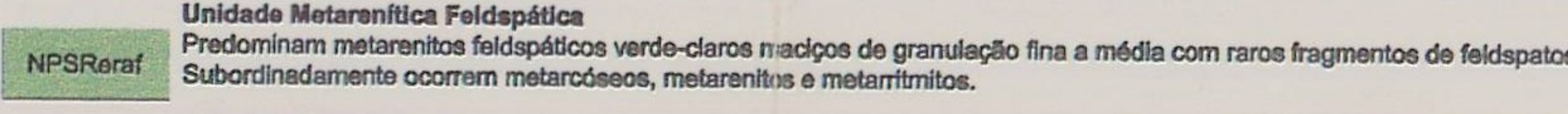

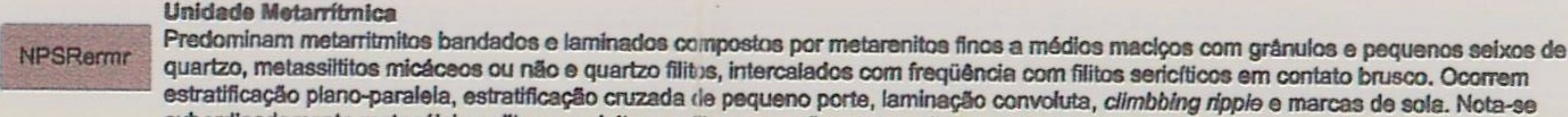

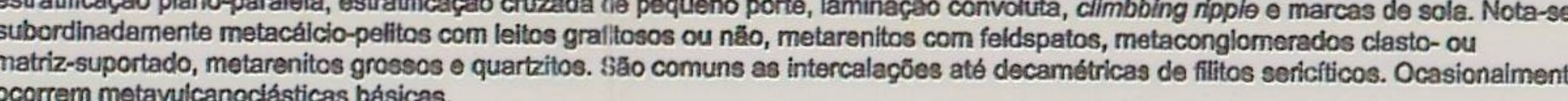

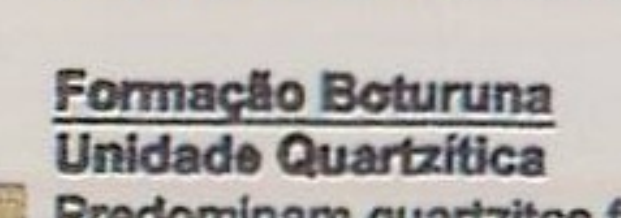

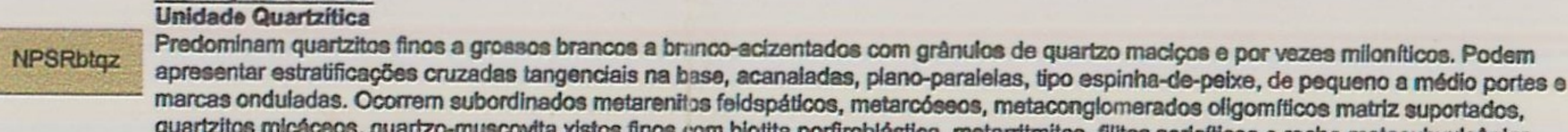

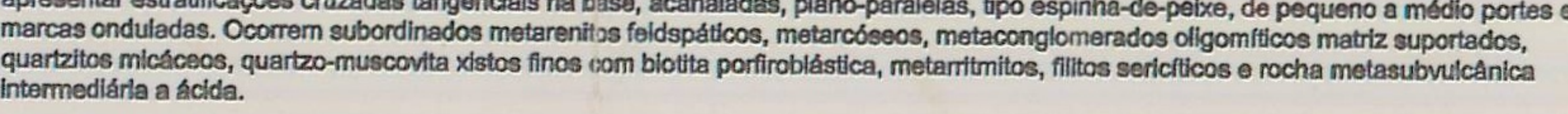

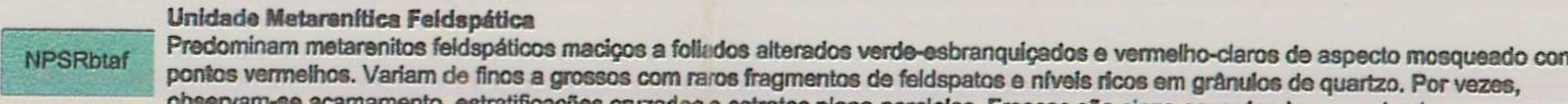

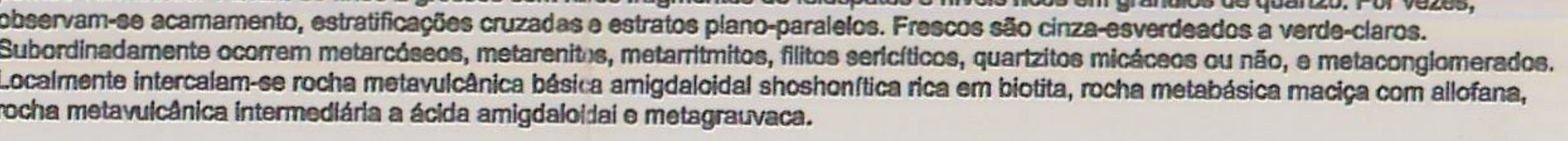

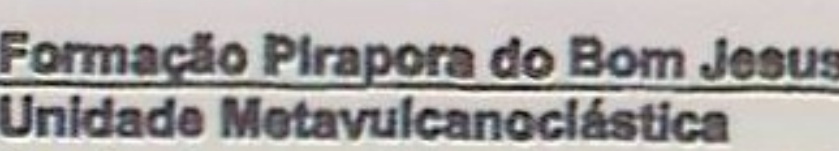

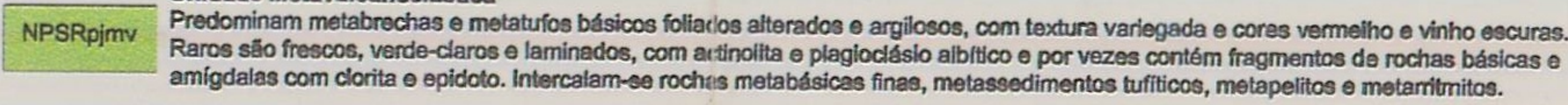

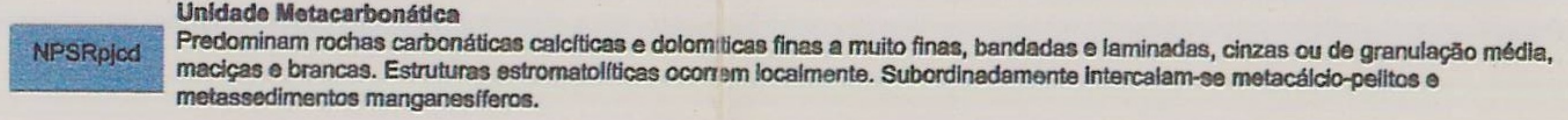

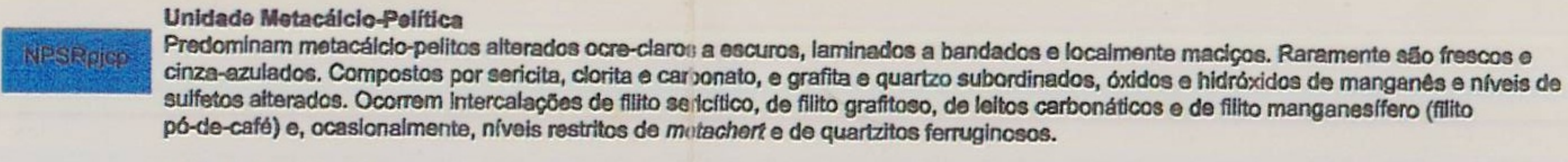

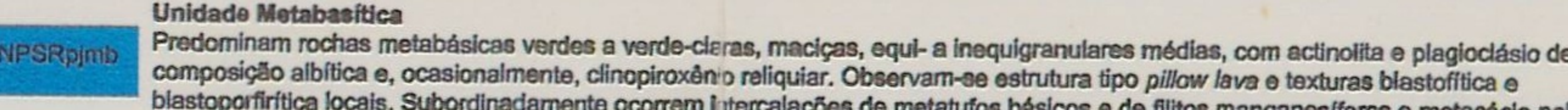

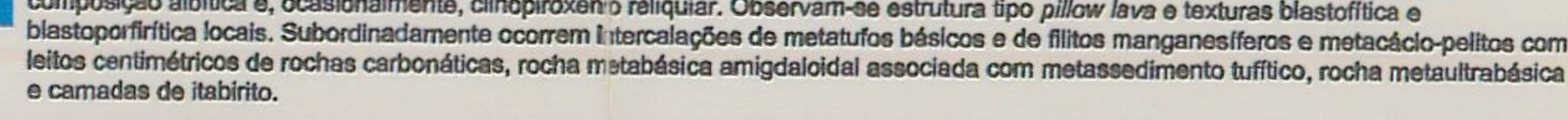

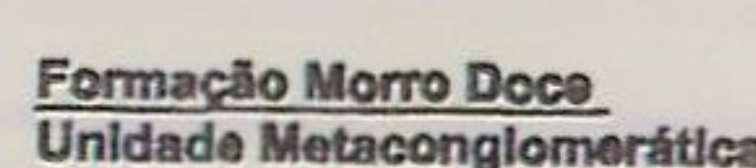

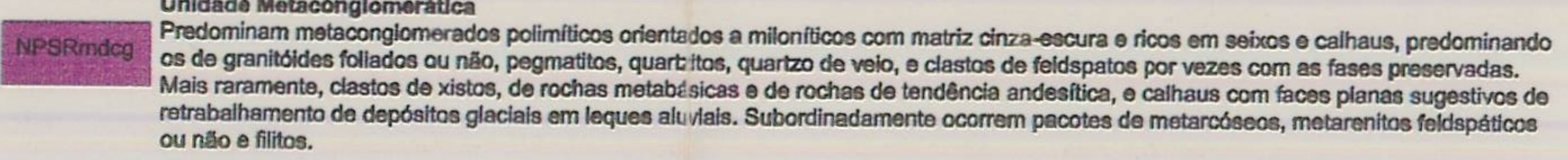

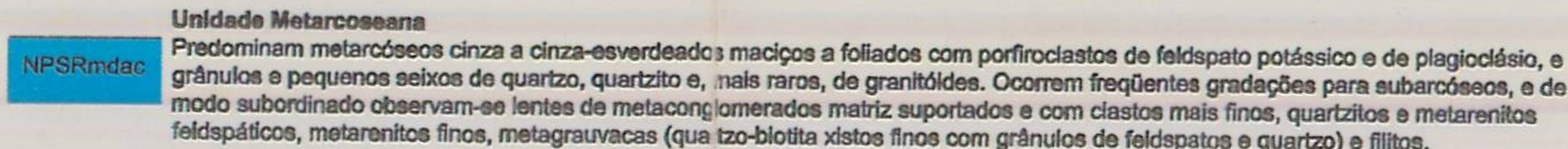
MESOPBOTEROZZOCOCO

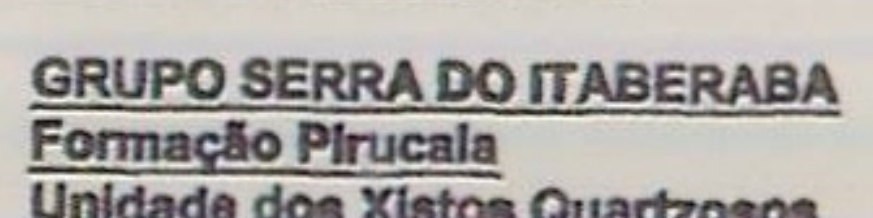

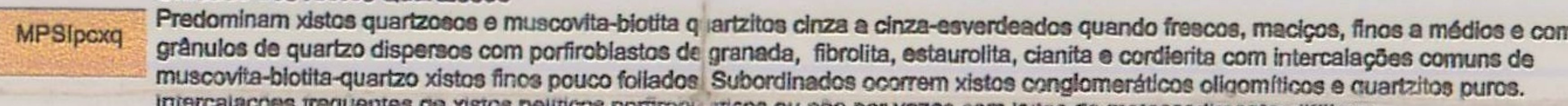

\section{Formacto Nhanayuey}

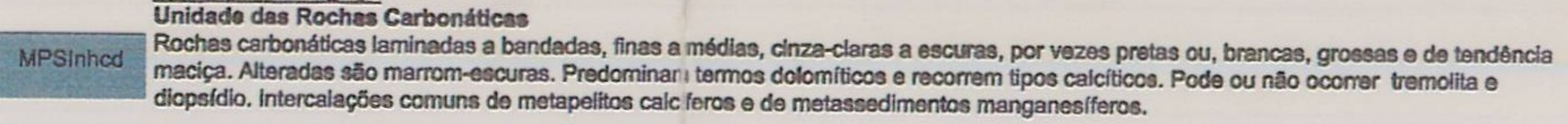

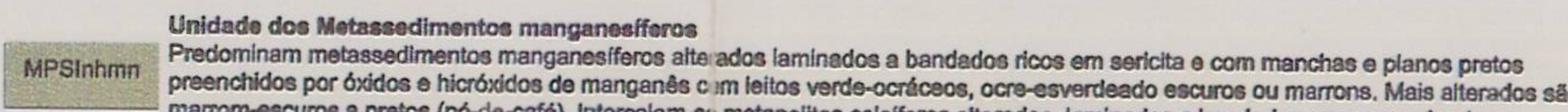

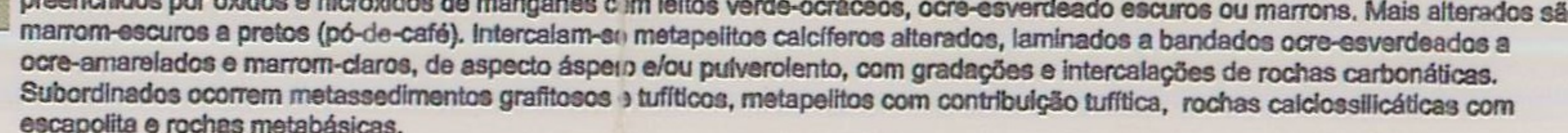

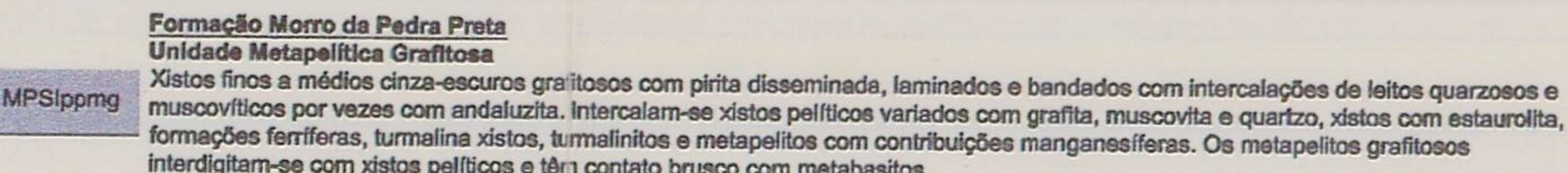

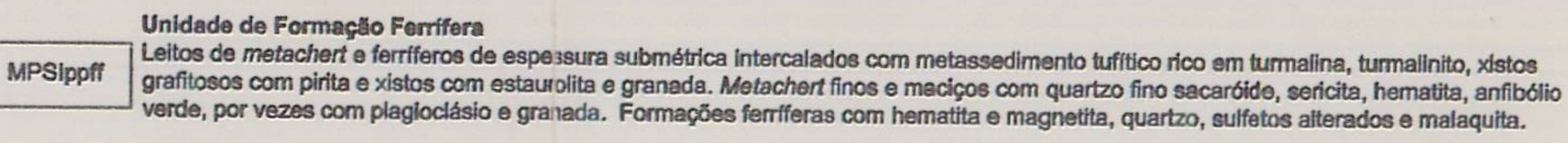

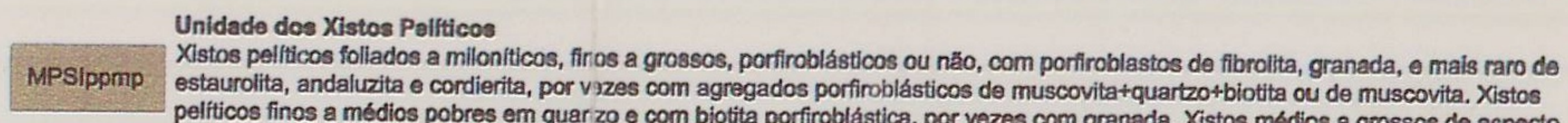

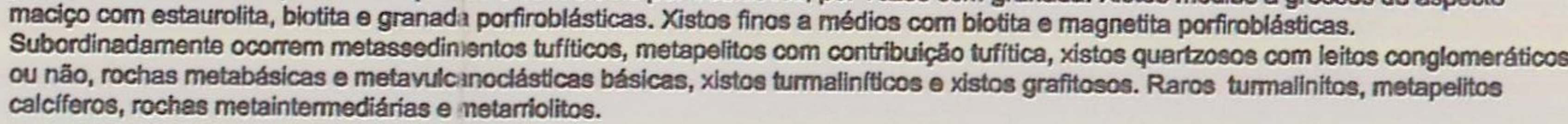

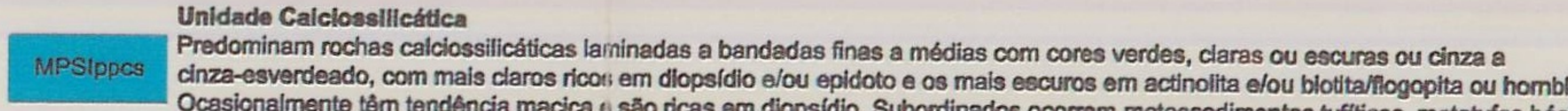

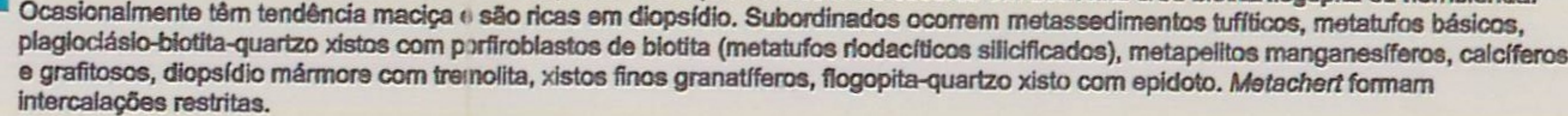

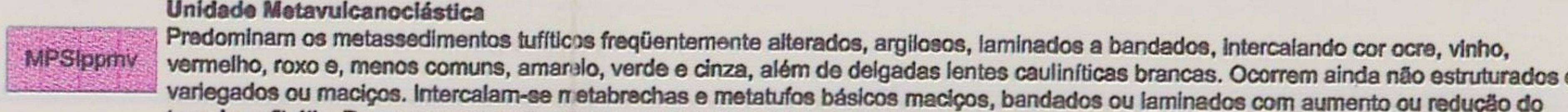

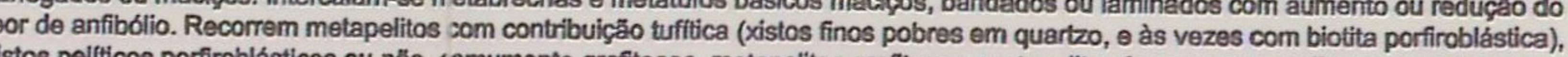

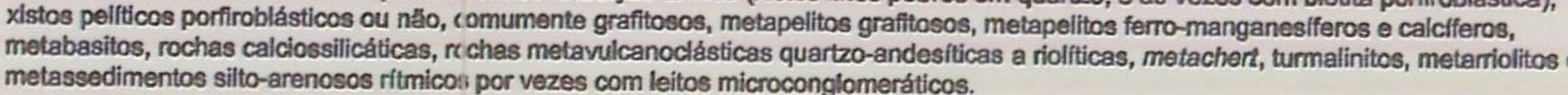

slopmb

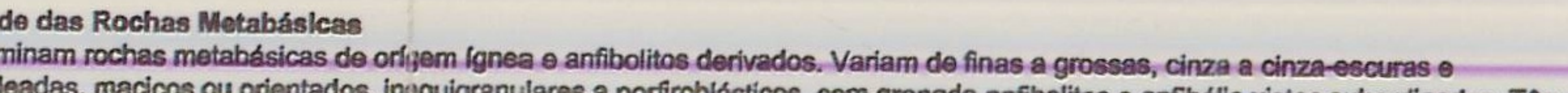

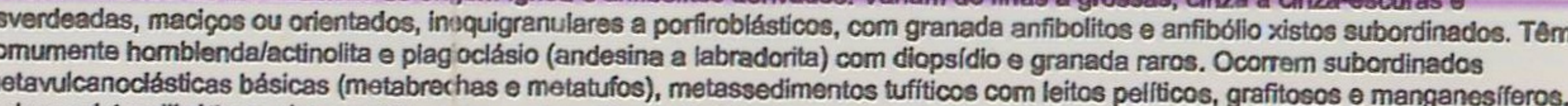

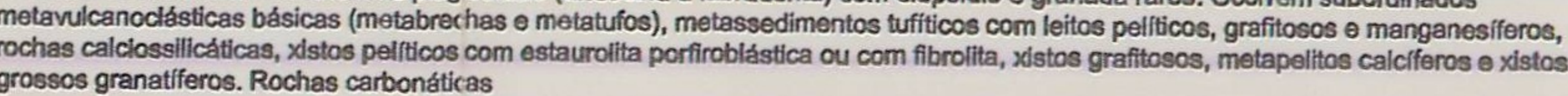

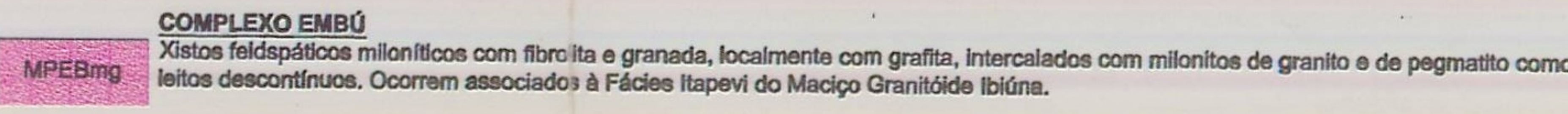
PALEOPROTEROZOICO

COMPLEXOTAPIRA

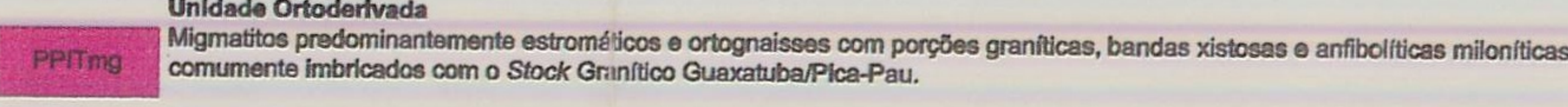

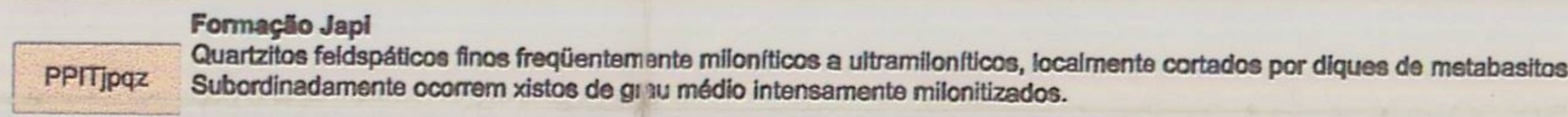


ANEXO II 


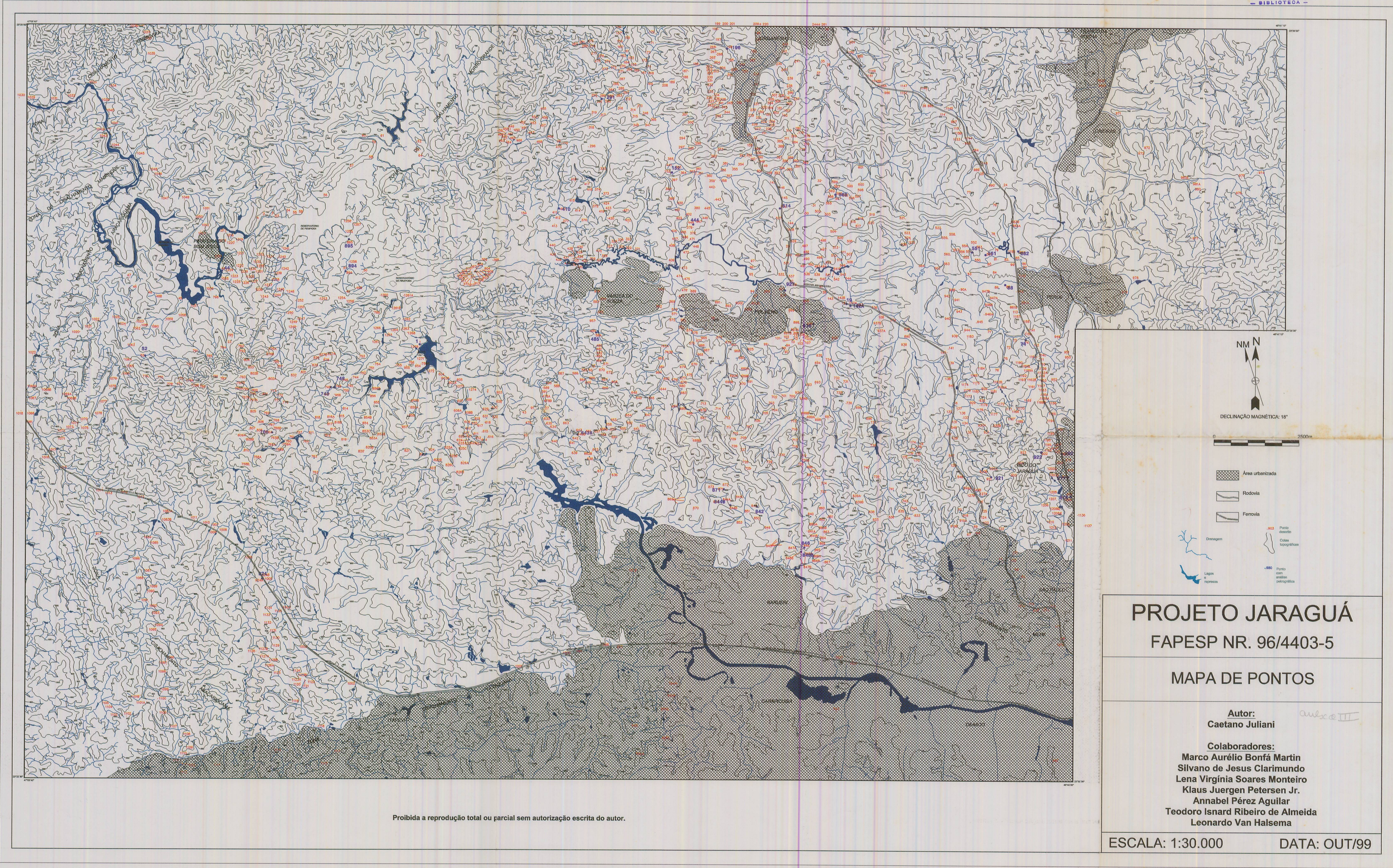

